ANL-7411 Supplement 4 Mathematics and Computers

\author{
ARGONNE NATIONAL LABORATORY \\ 9700 South Cass Avenue \\ Argonne, Illinois 60439
}

\title{
ARGONNE CODE CENTER: \\ COMPILATION OF PROGRAM ABSTRACTS
}

by

M. K. Butler, Marianne Legan,

L. Ranzini, and William J. Snow

\section{Applied Mathematics Division}

\begin{abstract}
LEGAL NOTICE
This report was prepared as an account of work sponsored by the United States Government. Neither

the United States nor the United States Atomic Energy

Commission, nor any of their employees, nor any of

their contractors, subcontractors, or their employees,

makes any warranty, express or implied, or assumes any

legal liability or responsibility for the accuracy, com-

pleteness or usefulness of any information, apparatus,

product or process disclosed, or represents that its use

would not infringe privately owned rights.
\end{abstract}

May 1970 


\section{DISCLAIMER}

This report was prepared as an account of work sponsored by an agency of the United States Government. Neither the United States Government nor any agency Thereof, nor any of their employees, makes any warranty, express or implied, or assumes any legal liability or responsibility for the accuracy, completeness, or usefulness of any information, apparatus, product, or process disclosed, or represents that its use would not infringe privately owned rights. Reference herein to any specific commercial product, process, or service by trade name, trademark, manufacturer, or otherwise does not necessarily constitute or imply its endorsement, recommendation, or favoring by the United States Government or any agency thereof. The views and opinions of authors expressed herein do not necessarily state or reflect those of the United States Government or any agency thereof. 


\section{DISCLAIMER}

Portions of this document may be illegible in electronic image products. Images are produced from the best available original document. 
-

- 


\section{ANL - 7411 SUPPLEMENT 4}

This publication is the fourth supplement to and revision of ANL-7411 issued in January 1968. Supplement 1 was issued in October 1968, supplement 2 in April 1969, and supplement 3 in November 1969. Supplemental and replacement pages contained in this publication are as follows:

\begin{tabular}{|c|c|c|}
\hline $\begin{array}{l}\text { PAGES TO BE } \\
\text { INSERTED } \\
\end{array}$ & $\begin{array}{l}\text { PAGES TO BE } \\
\text { REMOVED }\end{array}$ & COMMENT \\
\hline $1-8.2$ & $1-8.2$ & $\begin{array}{l}\text { Revised cover, title page and table } \\
\text { of contents }\end{array}$ \\
\hline $345-348$ & $345-348$ & Reactor Code Abstract 247 revised \\
\hline $379-380$ & $379-380$ & Reactor Code Abstract 263 revised \\
\hline $451-458$ & $451-458$ & $\begin{array}{l}\text { Reactor Code Abstracts } 298 \text { and } 299 \\
\text { revised }\end{array}$ \\
\hline $509-510.2$ & $509-510$ & Reactor Code Abstract 325 revised \\
\hline $635-813$ & $635-751$ & $\begin{array}{l}\text { Reactor Code Abstracts } 385 \text { through } \\
410 \text { added; Section VI Library } \\
\text { Programs by Classification revised; } \\
\text { Section VII KWIC Index revised; } \\
\text { References replaced }\end{array}$ \\
\hline
\end{tabular}


8

-

8 
TABLE OF CONTENTS

$\underline{\text { Page }}$

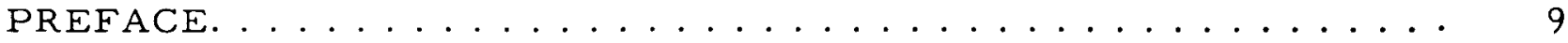

I. HISTORY AND ACKNOWLEDGMENTS ................ 10

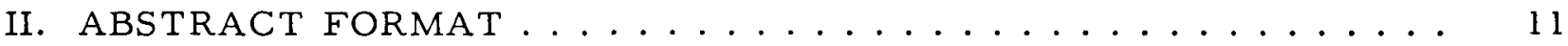

III. RECOMMENDED PROGRAM PACKAGE CONTENTS. . . . . . . . . . 14

A. Card and/or Tape Material.................... 14

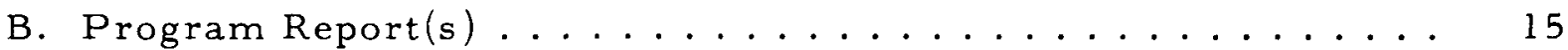

C. Installation Environment Report. ............... 16

IV. PROGRAM CLASSIFICATION GUIDE AND THESAURUS . . . . . . 17

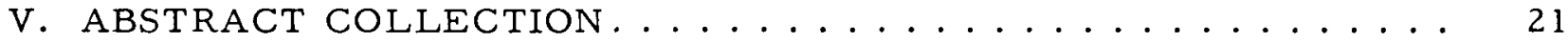

No.

KWIC TITLE INSTALLATION MACH LANG PACKAGE CAT

7 FIRN, 2-D FEW-GP 54 APPROXIMATION RZ GEOMETRY

9 FIRE5, 1-D AGE-DIFFUSION SLAB CYLINDER SPHERE

14 HAFEVER, HAUSER-FESHBACH INELASTIC SCATTERING

18 2DXY, 2-D MULTI-GP SN APPROXIMATION XY GEOM

28 FOG, I-D FEW-GP DIFFUSION SLAB CYLINDER SPHERE AI

28 FOG, 1-D FEW-GP DIFFUSION SLAB CYLINDER SPHERE CDC

28 FOG, 1-D FEW-GP DIFFUSION SLAB CYLINDER SPHERE BC

29 AIMG, I-D MULTI-GP DIFFUSION SLAB CYL SPHERE

29 AIM6, 1-D MULTI-GP DIFFUSION SLAB CYL SPHERE

30 PERT, 1-D PERTURBATION FOR AIM AND FOG CODES

30 PERT, 1-D PERTURBATION FOR AIM AND FOG CODES

30 PERT, 1-D PERTURBATION FOR AIM AND FOG CODES

32 WHIRLAWAY, 3-D 2-GROUP DIFFUSION XYI GEOMETRY

32 WHIRLAWAY, 3-D 2-GROUP DIFFUSION XYZ GEOMETRY

33 GAMI, FAST NEUTRON SPECTRUM X-SECTION CALC

33 GAMI, FAST NEUTRON SPECTRUM X-SECTION CALC

33 GAM1. FAST NEUTRON SPECTRUM X-SECTION CALC

39 EOUIPOISE3, 2-D 2-GROUP DIFFUSION SLAB CYL

40 2OGRAND, 2-D FEW-GROUP DIFFUSION SLAB CYLINDER

40 20GR AND, 2-D FEW-GROUP DIFFUSION SLAR CYLINDER

41 ZUT, RESOLVED REGION RESONANCE INTEGRAL CALC

42 TUZ, UNRESOLVED REGION RESONANCE INTEGRAL CALC GGA

R 43 CURFIT, CURVE FITTING EXPERIMENTAL DATA POINTS

45 GRACEL, GAMMA-RAY ATTENUATION SLAB GEOMETRY

45 GRACEI, GAMMA-RAY ATTENUATION SLAB GEOMETRY

46 GRACE2, GAMMA-RAY ATTENUATION CYL SPHERE GEOM

46 GRACE2, GAMMA-RAY ATTENUATION CYL SPHERE GEOM

47 CLOUD, GAMMA-RAY DOSE RATE FROM A CLOUD

47 CLOUD, GAMMA-RAY DOSE RATE FROM A CLOUD

47 CLOUD, GAMMA-RAY DOSE RATE FROM A CLOUD

48 FUGUE, STEADY-STATE TEMPERATURE VOID FRACTION

50 TEMPEST2, THERMAL NEUTRON SPECTRUM $X$-SECTIONS

50 TEMPEST2, THERMAL NFUTRON SPECTRUM $X$-SECTIONS

50 TEMPEST2. THERMAL NEUTRON SPECTRUM $X$-SECTIONS

51 FORM, FAST NEUTRON SPECTRUM X-SECTION CALC

51 FORM, FAST NEUTRON SPECTRUM X-SECTION CALC

52 SAIL, 1-D 1-GP SN APPROXIMATION SLAB GEOMETRY

52 SAIL, 1-D 1-GP SN APPROXIMATION SLAB GEOMETRY

5354 CVL CELL CODE, 1-D L-GP S4 APPROXIMATION

5354 CYL CELL CODE, I-D 1-GP S4 APPRDXIMATION

CDC

AI $7090 \mathrm{F2}$

CDC $1604 \mathrm{~F}_{63}$

BHSC $360 \mathrm{F4}$

ORNL 7090 F2

CDC 1604 F63

GGA $7090 \mathrm{F2}$

CDC 1604 F63

ANL $3600 \quad F 63$

ORNL 7090 F2

ORNL $7090 \mathrm{F2}$

1604 F63

7090 F+FAP RSB

$7090 \mathrm{~F}+F A P$ RSB

KAPL $6600 \mathrm{~F}+A S C$

AI $7090 \mathrm{F2}$

CDC $1604 F 63$

AI $7090 \mathrm{F2}$

CDC $1604 \quad F 63$

AI $\quad 7090 \mathrm{F2}$

CDC $\quad 1604 \quad F 63$

DP $\quad 360 \mathrm{F4}$

AI $7090 \mathrm{F2}$

AI $7090 \mathrm{~F}+F A P$

CDC $1604 \mathrm{FG}_{3}$

BHSC $360 \mathrm{~F} 4$

AI $7090 \mathrm{F2}$

CDC $1604 \quad F 63$

AI $7090 \mathrm{F2}$

COC 1604 F63

AI $\quad 7090 \mathrm{F2}$

RS $C$

RS $C \quad 23$

RS $L T C$

26

28

30

30

30

32

32

34

34

34

36

36

38

38

38

40

42

42

44

46

47.1

48

48

50

50

52

52

52 
TABLE OF CONTENTS

$\underline{\text { Page }}$

No.

KWIC TITLE

INSTALLATION MACH LANG

55 AIMFIRE, URANIUM FUEL CYCLE COST ANALYSIS 56 SUMMIT, CRYSTALLINE SC,ATTERING KERNEL CALC 58 SIZZLE, 1-D MULTIGROUP DIFFUSION DEPLETION 58 SIZZLE, 1-D MULTIGRDUP DIFFUSION DEPLETION 58 SIZZLE, 1-D MULTIGROUP DIFFUSION DEPLETION 59 MIST, 1-D FEW-GP SN DUUBLE SN APPROX SLAB GEOM 62 LASL LEAST SQUARES, GENERAL CURVE FITTING 75 GE-HAPD-S13, I-D MULTI-GP DOUBLE SN APPROX

$R$ 80 SOR2, STRESS ANALYSIS SHELLS OF REVOLUTION 87 EQU I POI SE 3A, 2-D 2-GP DIFFUSION CYLINDER SLAB 87 EQUIPOISE3A, 2-D 2-GP DIFFUSION CYLINOER SLAB 89 ARES2, RESONANCE INTEGRAL X-SECTION CALC 89 ARES2, RESONANCE INTEGRAL X-SECTION CALC 91 FARSEIA, DOSE RATE FROM SNAP SHIELD LEAKAGE 99 DDB, 2-D FEW-GP DIFFUSION BURNUP RZ GEOMETRY 102 AXI, COUPLED NFUTRONIC S-HYDRODYNAMICS SPHERE 103 CRAM, 1-D AND 2-D MULTI-GP DIFFUSION PROGRAM 103 CRAM, 1-D AND 2-D MULTI-GP OIFFUSION PROGRAM 108 BAM, S4 CYL CELL CODE AND TEMPEST COMBINATION 109 4RESTRAINT PIPE STRESS, MAXIMUM MOMENT CALC

110 SCARF2, SCATTER. FROM RADIATOR FINS SNAP GEOM 111 SCAR 1, SCATTER FROM A RING SNAP GEOMETRY

112 CROCK, SPACE POWER PLANT DESIGN OPTIMIZATION 113 ZOT, GROUP-COLLAPSING OF MULTI-GP X-SECTIONS 114 SHOCK, SPACE POWER PLANT DESIGN OPTIMIZATION 117 FEVER, 1-D FEW-GP DIFFUSION DEPLETION PROGRAM 118 ULCER, 1-D MULTI-GP DIFFUSION SLAB CYL SPHERE 119 QUICKIE, INFINITE MEDIUM SPECTRUM X-SECTIONS 120 FAIM, 1-D MULTI-GP DIFFUSION SLAB CYL SPHERE 120 FAIM, 1-D MULTI-GP DIFFUSION SLAB CYL SPHERE 120 FAIMOS, 1-D MULTI-GP DIFFUSION SLAB CYL SPHERE 121 AIREK3, SPACE-INDEPENDENT KINETICS W/FEEDBACK 121 AIREK3, SPACE-INDEPENDENT KINETICS W/FEEDBACK 121 AIREK3, SPACE-INDEPENDENT KINETICS W/FEEDBACK 122 SNAPKIN5/5A, 1-REGION KINETICS SNAP GEOMETRY 123 LIPRECANI, MC NEUTRON PENETRATION CALCULATION 129 CONEC, COUPLED NEUTRONICS-HYORODYNAMICS SPHERE 132 W-DSN, 1-D MULII-GP SN APPROX SLAB CYL SPHERE 133 WED, W-OSN OUTPUT TAPE EDIT REACTION RATES 134 NUCY, SOLUTION OF NUCLIDE CHAIN EQUATIONS 135 TRAFICORPORATION, TRANSFER FUNCTION SYNTHESIS 136 HERESY1, LATTICE PARAMETERS HETERCGENEOUS CALC 141 RATRAP, DOSE RATE CALCULATION SNAP GEOMETRY 142 MORTIMER, DOSE RATE CALCULATION SNAP GEOMETRY 143 MAC, SHIELD OFSIGN MULTIGROUP SLAR GEOMETRY 143 MAC, SHIELD DESIGN MULTIGROUP SLAB GEOMETRY 144 DTF, 1-D MULTIGROUP OISCRETE ORDINATE CALC 145 WEAK EXPLOSION, COUPLED NEUTRON-HYDROOYNAMICS 146 NPRFCCP, FUEL CYCLE COSTS PERFORMANCE DATA 147 AILMOE, X-SECTION CALC ELASTIC SCAT RESONANCES 147 AILMOE, X-SECTION CALC ELASTIC SCAT RESONANCES 148 TOPIC, 1-D FEW-GP SN APPROXIMATION CYLINDER 148 TOPIC, 1-D FEW-GP SN APPROXIMATION CYLINDER 149 TYCHE3, MONTE CARLO SLOWING-DOWN DENSITY CALC 150 DANCOFF JR, MODERATOR SPACE CHORD DIST FUNCT 151 DTF2, 1-D MULTI-GP DISCRETE ORDINATE CALC 151 ANISN, I-D MULTI-GP DISCRETE ORDINATF CALC 152 ARGUS, TRANSIENT TEMPERATURE CALC CYLINDER 153 HATCHET, COUPLED NEUTR UNICS-HYDRDDYNAMICS COOE 154 CROC90, ML-1 FLUID FLOW EXPERIMENT ANALYSIS 155 PTHI, BLOWDOWN PRESSURE TEMPERATURE HISTORY 156 EXTERMINATOR2, 2-D MUL TI-GP DIFFUSION PROGRAM 156 EXTERMINATOR, 2-D MULTI-GP DIFFUSION PROGRAM 156 EXTERMINATOR2, 2-D MULTI-GP DIFFUSION PROGRAM

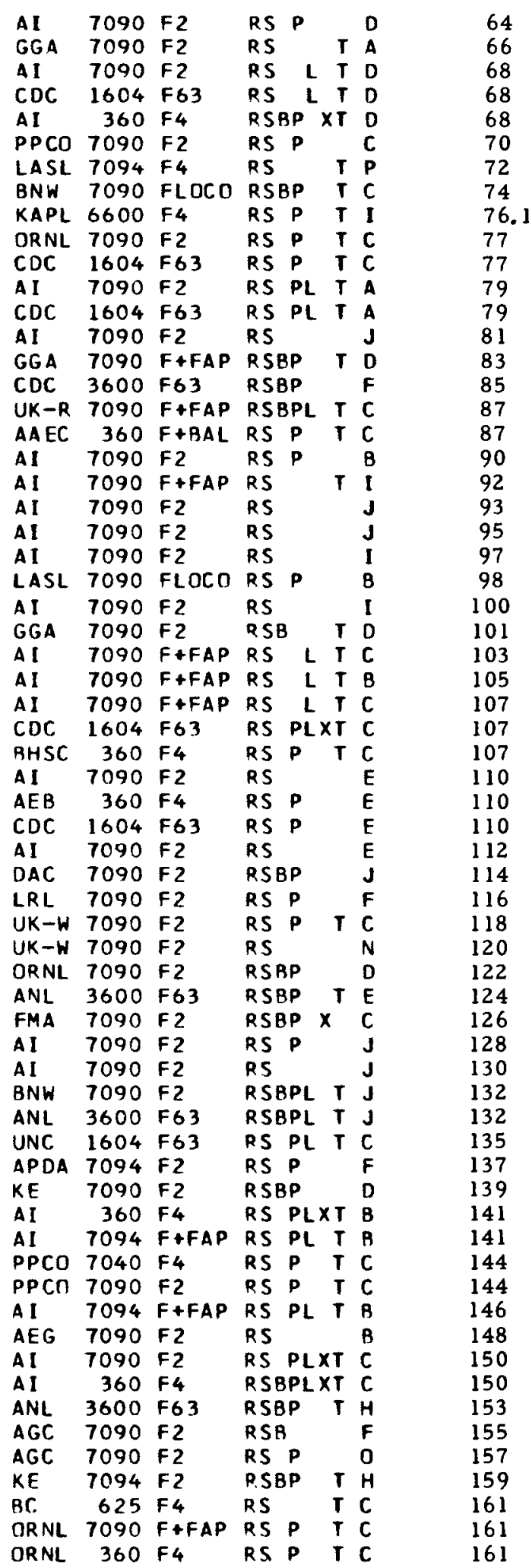


TABLE OF CONTENTS

$\underline{\text { Page }}$

No.

KWIC TITLE

INSTALLATION MACH LANG PACKAGE CAT

159 MOMUS, X-SECTION LIBRARY UTILITY PROGRAM

160 SOPHIST1/2/5, MULTI-GP TRANSFER COEFFICIENTS

161 FORTRAN TDC, 2-D MULTI-GP SN APPROXIMATION RZ

162 GRAVE, GROUP-AVERAGING X-SECTIONS PARAMETERS

163 AIROS, SPACE-INDEPENDENT KINETICS W/FEEDBACK

164 BURP 1, DETECTOR EFFICIENCY POINT SOURCE

165 BURP2, DETECTOR EFFICIENCY DISK SOURCE

166 BURP 3, DETECTOR EFFICIENCY POINT SOURCE

167 FLARE, 3-D REACTIVITY AND POWER DISTRIBUTION

167 FLARE, 3-D REACTIVITY AND POWER DISTRIBUTION

168 R102, SPACE-INDEPENDENT INVERSE KINETICS CALC

168 R 102, SPACE-INDEPENDENT INVERSE KINETICS CALC

169 BURP4, GAMMA-RAY PHOTOFRACTION SOLIO CRYSTAL

170 BURP5, GAMMA-RAY PHOTOFRACTION WELL CRYSTAL

171 NEARREX, COMPOUND NUCLEUS X-SECTIDN CALC

172 R153, PARAMETRIC SIIE REQUIREMENT STUDY

172 AISITE2, PARAMETRIC SITE REQUIREMENT STUDY

172 AISITE2, PARAMETRIC SITE REQUIREMENT STUDY

173 2DF, 2-D MULTI-GP DI SCRETE ORDINATE CODE

174 FORE2, FAST REACTOR EXCURSION CALCULATIONS

174 FORE, FAST REACTOR EXCURSION CALCULATIONS

174 FORE2, FAST REACTOR EXCUR SION CALCULATIONS

176 RAPTURE, RESONANCE INTEGRAL X-SECTION CALC

177 DOPIE, RESOLVED RESONANCE X-SECTION CALC

178 SPARTA, SPATIALLY-AVERAGED DOPPLER EFFECTS

179 I SOTOPES, MAXIMUM YIELD FROM REACTION OR DECAY

180 I SOCRUNCH, REACTION DECAY CHAIN ANALYSIS

180 I SOCRUNCH, REACTION DECAY CHAIN ANALYSIS

181 XLIBIT, X-SECTION LIBRARY UTILITY ROUTINE

182 AXFLU, HEAT TRANSFER MOLTEN FUEL TUBE BUNDLES

183 AXTHRM, HEAT TRANSFER SOLID FUEL TUBE BUNDLES

184 THERMOS (ANL), THERMAL SPECTRUM X-SECTION CALC

185 GAMTEC2, MULTI-GP CONSTANT CALC 0 TO 10 MEV

185 GAMTEC2, MULTI-GP CONSTANT CALC O TO 10 MEV

185 GAMTEC2, MULTI-GP CONSTANT CALC 0 TO 10 MEV

186 LAG, ASSEMBLER FOR FLOCO2 INSTRUCTION SET

187 PIP, CENTRIFUGAL PUMP IMPELLER DESIGN STUDY

188 CMPXMAT, TRANSFER FUNCTION EVALUATION

189 SNC, CALCULATION OF SN CONSTANTS FOR DSN TDC

190 WOPEXPRT, REACTOR WEIGHT OPTIMIZATION STUDY

191 AX-TNT, COUPLED NEUTRONICS-HYDROOYNAMICS SPH

192 20XYL, 3-D MULTI-GP FLUX SYNTHESIS PROGRAM CYL

193 CSP2A, SN X-SECTION LIBRARY TAPE PREPARATION

194 CSPI, SN X-SECTION LIBRARY TAPE PREPARATION

195 FMC-N, FMC-G, MC NEUTRON, GAMMA-RAY HISTORIES

195 FMC-N, MONTE CARLO CALC NEUTRON HISTORIES

196 CURI E, DOSE, THUNDERHEAD, EXTERNAL + INTERNAL DOSE

197 SHOE, SHIELD WEIGHT OPTIMIZATION DOSE CALC A

198 HEATING2, TRANSIENT STEADY-STATE HEAT TRANSFER A

199 TDP, 2-D PERTURBATION TDC OR 2OXY FLUX INPUT

200 SATURATED BLOWDOWN2, BLOWDOWN ANALYSIS LOFT

201 EPITHERMOS, SPECTRUM AND X-SECTION CALCULATION

202 MCS, MONTE CARLO NEUTRON PENETRATION STUDY

203 COMBCO, COMBINED B-W MULTI-LEVEL CONVOLUTION

204 AGN-GAM, FAST SPECTRUM MULTI-GP CONSTANT CALC

205 BLOOST5, POINT-KINETICS WITH 2-D HEAT TRANSFER

206 UNPACK, RETRIEVAL FROM SCISRS X-SECTION TAPE

207 CROSSPLOT, SC 4020 PLOTS FROM X-SECTION TAPES

208 TRIXI, RESONANCE INTEGRAL X-SECTION CALC

209 DTF 4, 1-D MULTI-GP DISCRETE ORDINATE PROGRAM

209 DTF 4, 1-D MULTI-GP DISCRETE ORDINATE PROGRAM

209 DTF4, 1-D MULTI-GP DISCRETE ORDINATE PROGRAM

209 DTF 4, 1-D MULTI-GP DISCRETE DRDINATE PROGRAM

209 DTF4, 1-D MULTI-GP DISCRETE OROINATE PROGRAM

AI 7094 F+FAP RS L T M

165

$\begin{array}{llllll} & 7090 & \text { F+FAP RS P } & \text { T } & B & 167\end{array}$

PH 1604 F63 RS P T C $\quad 169$

AI 7094 F+FAP RS PL T B 172

AI 7094 F+MAP RS P T E 174

UM TO90 MAD RSB 00177

UM 7090 MAD RSB 00179

UM 7090 MAD $\quad$ RSB 00182

$\begin{array}{llllll}\text { NED } & 635 & \mathrm{~F} 4 & \text { RS P } & \text { T } & 185\end{array}$

$\begin{array}{llllll}\text { CDC } & 3600 & \text { F63 } & \text { RSBP } & \text { T } & \\ \end{array}$

ANL 3600 F63 RSBP $\quad$ E $\quad 187$

WANL 7094 F4 $\quad$ RS $\quad$ E $\quad 187$

UM TO90 MAD RSB 001

UM 7090 MAD $\quad$ RSB $\quad 0 \quad 192$

ANL 3600 F63 RSBP A 194

ANL 3600 F63 RSBP T G 196

AI 7094 F+FAP RS P T G 196

AI 360 F4 $\quad$ RS P T G 196

198

200

200

200

203

205

207

209

211

211

213

215

217

219

221

221

221

223

225

227

229

230

232

235

237

239

241

241

244

246

248

250

252

254

256

258

260

262

264

266

268

LASL $6600 \mathrm{~F} 4 \quad$ RS P T C $\quad 270$

BC $625 \mathrm{FH}_{4}$ RS P T C 270

ANL $360 \mathrm{F4} \quad$ RS P $T$ T 270

LASL $7030 \mathrm{F4} \quad$ RS P T C $\quad 270$

$\begin{array}{llllll}\text { LER } 7094 & F 4 & \text { RS } P & T C & \end{array}$ 
TABLE OF CONTENTS

Page

No. KWIC TITLE

INSTALLATI ON MACH LANG

PACKAGE CAT

210 DTX, EFFECTIVE X-SECTION CALC FROM DSN DUTPUT 211 MGDSN, 1-D MULTI-GP SN APPROX SLAB CYL SPHERE 212 VARI-QUIR, TIME-DEP 2-D MULTI-GP DIFFUSION 212 VARI-QUIR, TIME-DEP 2-D MULTI-GP DIFFUSION 213 RIFF-RAFF, RESONANCE INTEGRAL CALC 2-REG CELL 214 MISH-MASH, RESONANCE INTEGRAL CALC HOMOGENEOUS 215 CHAD, LEGENDRE COEF CALC FOR ANGULAR OIST DATA 216 FASDOP, X-SECTIONS FROM B-W RESONANCE DATA 217 LEGCOEF3, LEGENDRE COEF CALC FOR ANGULAR DIST 218 GAVER, ENERGY INTERVAL X-SECTION AVERAGING 219 GAROL, RESONANCE OVERLAP AND LATTICE EFFECTS 219 GAROL, RESONANCE OVERLAP AND LATTICE EFFECTS 220 GASP2, 1-D FEW-GP DIFFUSION POHER DIST SEARCH 221 RELOAD-FEVER, I-D FEH-GP DIFFUSION DEPLETION

222 GAMBLF4, 2-D MULTI-GP DIFFUSION $X Y$ RZ GEOMETRY 222 GAMBLE5, 2-D MULTI-GP OIFFUSION XY RZ GEOMETRY 223 REVISED-GAD, FUEL CYCLE ANALYSIS W/REFUEL ING 224 WAMPUM, FUEL CYCLE COSTS PERFORMANCE STUDY 225 TEMCO, 1-D FEW-GP DIFFUSION TEMP COEF CALC 226 OPUS, PDWER PLANT PERFDRMANCE AND PRICE STUDY 227 STMGEN, STEAM GENERATOR DESIGN CRITERIA COSTS 228 PRECON, HTGR CONTAINMENT PRESSURE POST RUPTURE 229 ELBOW, FUEL ELEMENT STRESS ANALYSIS STUDY

231 RAD2, HTGR FISSION PRODUCT ACTIVITY DIST STUDY

232 GAZELLES, GAS-CONLED CORE THERMAL DESIGN STUDY 233 CORE, CORE CONFIGURATION FUEL TEMPERATURE CODE
234 DPC, DATA PREPARATION FOR 2-D DESIGN PROGRAMS 235 GAMMA-P, PRODUCTION X-SFCTIONS FOR GAMMA-RAYS 236 DFSR, DATA FILE SERVICE ROUTINES ENDF TAPES 237 BOUNCE, FLUX DIST IN MULTI-PIN FUEL ELEMENT 238 EXT, X-SECTIDNS FROM B-W RESONANCE PARAMETERS 239 CPS, SC 4020 PLOTS FROM SCISRS X-SECTION TAPES 240 ASSAULT, 2-D MULTI-GP DIFFUSION DEPLETION CODE 241 HFN, 1-D MULTI-GP DIFFUSION SLAB CYL SPHERE 242 RATH, 2- OR 3-D HEAT CONDUCTION LUMPED MASS 242 RATH, 2- OR 3-D HEAT CONDUCTION LUMPED MASS 243 AGN-SIGMA, CALC OF MULTI-GP TRANSFER MATRICES 244 CYCLOPSI, THERMOOYNAMIC CYCLE ANALYSIS

246 FLOW-MDDEL, MULTI-CHANNEL 2-D 2-PHASE FLOW

247 FLANGE 1, SCATTERING LAW X-SECTION CALCULATION

247 FLANGEI, SCATTERING LAW X-SECTION CALCULATION

248 COINC, COINCIDENCE COUNTING DATA REDUCTION

249 LASER, SPECTRUM CALC WITH BURNUP CYL LATTICE

250 SAFE-PCRS, STRESS ANALYSIS AXISYMMETRIC LOAD

251 SAFE-AXISYM, STRESS ANALYSIS AXISYMMETRIC LOAD

252 SAFE-PLANE, PLANE STRESS ANALYSIS, 2-D BDDIES

253 SAFE-SHELL, STRESS ANALYSIS THIN SHELLS

254 2PLUS, NON-SPHERICAL OPTICAL MODEL X-SECTIONS

254 2PLUS, NON-SPHERICAL DPTICAL MODEL X-SFCTIONS

255 R101, SPACE-INDEPENDENT KINETICS KEX OPTIONS

255 R101, SPACE-INDFPENDENT KINETICS KEX OPTIONS

256 MANTA, STEAOY-STATE THERMAL-HYDRAULIC ANALYSIS

257 REAX, RESOLVED RESONANCE EPITHERMAL X-SECTIONS

258 EXPN, ANALYSIS OF PULSED NEUTRON SOURCE DATA

259 MUSCAT, VIEW FACTOR SHIELDING CODE CAVITY GEOM

260 GARGOYLE, FUEL CYCLE ANALYSIS PARTIAL REFUEL

261 GADOSE, DOSET, HTGR ACCIDENT ANALYSIS DOSE CALC

262 MACHI, 1-D MULTI-GP DIFFUSION SLAB CYL SPHERE

262 MACHI, 1-D MULTI-GP DIFFUSION SLAB CYL SPHERE

263 GASKET, THERMAL SCATTERING LAW CALCULATION

264 VARI-QUIR3, 2-D MULTI-GP DIFFUSION XY RZ RTH

265 RSAC, RADIOLOGICAL SAFETY ANALYSIS PROGRAM

R266 CYGRO2, STRESS ANALYSIS CYL FUEL ELEMENT

R267 WATER, STEAM TABLES $14.5-14,500$ PSIA 32-472DEGF

$\begin{array}{lrl}\text { PW } & 1604 & \text { LAGI } \\ \text { PW } & 1604 & \text { LAGI } \\ \text { WANL } & 6600 & \text { F4 } \\ \text { UMCC } & 360 & \text { F4 } \\ \text { ANL } & 3600 & \text { F36 } \\ \text { ANL } & 3600 & \text { F36 } \\ \text { AI } & 7094 & \text { F+MAP } \\ \text { GGA } & 7044 & \text { F4 } \\ \text { GGA } & 7044 & \text { F4 } \\ \text { GGA } & 7044 & \text { F4 }\end{array}$

GGA 7044 F+MAP

LER

GGA

GGA

GGA

GGA

GGA

GGA

GGA

GGA

GGA

GGA

GGA

GGA

GGA

GASL

GEC 7094 F4

BNL 7090 F+FAP

AGC $7090 \mathrm{F2}$

WANL 7094 F2

WANL $7094 \mathrm{FZ}$

ORNL $7090 \mathrm{~F}+F A P$

BNW $1107 \mathrm{F4}$

LASL 7094 FAP

LASL 7030 F4

AGC $7090 \mathrm{F2}$

AI $7094 \mathrm{F2}$

AI 7094 F2

GGA 7044 F4

GGA 1108 F5

ANL 3600 F63

WAPD 7094 F+MAP

GGA $7044 \quad F 4$

GGA $7044 F 4$

GGA $1108 \quad F 4$

GGA $1108 \quad \mathrm{~F} 4$

ANL $3600 \quad F 63$

AI $7094 \mathrm{F2}$

WANL $7094 \mathrm{~F}_{4}$

ANL 3600 F63

NED

NED

NED

GGA

GGA

PURD 6500 F4

ANL 3600 F36

GGA $1108 \quad F 4$

WANL $7094 F 4$

PPCO 7040 F+MAP

BAPL $6600 \mathrm{FH}_{4}$

BAPL $6600 \mathrm{~F} 4$
RS P N $\quad 273$

RS P C $\quad 275$

RS P T C $\quad 277$

$\begin{array}{llll}P S & P & T & C\end{array}$

RSBP XT B 279

RSBP A $\quad 281$

283

285

287

289

291

291

293

295

297

297

299

301

303

305

307

309

311

315

317

319

321

323

325

327

329

331

333

336

338

338

340

342

344

346

346

348

350

353

355

357

359

361

361

363

363

365

367

369

371

373

375

377

377

379

381

383

385

387 
TABLE OF CONTENTS

Page

No.

KWIC TITLE

INSTALLATION MACH LANG

268 TRANS-FUGUE 1 , TRANSIFNT FLOW AND HEAT TRANSFER AI 7094 F2 269 DTF-AURN, 1-D MULTI-GP DTF 4 WITH OEPLETION LASL $7030 \mathrm{FH}$

270 CAESAR4,LIBLST, 1-D MULTI-GP DIFFUSION + LIB AI 360 F4 271 CLIP, FORM OR THREDES LIRRARY UTILITY ROUTINE

R272 FIGR.O, LSBR FUEL SWELLING TEMPERATURE STUDY 273 THREDES, 1-D FEW-GP DIFFUSION DISIGN SYSTEM R274 WIGL2, 1-D 2-GP SPACE-TIME DIFFUSION 3-GEOM R274 WIGL2, 1-D 2-GP SPACE-TIMF CIFFUSION 3-GEOM R275 PDQ7, 1,2 OR 3-D TEW-GP DIFFUSION DEPLETION R275 PDQ7, 1,2 OR 3-D FFW-GP DIFFUSION DEPLETION

276 AVOID, ANNULAR VOID X-SECTION CALCULATION

277 HAMMER, CRITICAL EXOERIMENT ANALYSIS SYSTEM

277 HAMMEP, CRIIICAL EXPERIMENT ANALYSIS SYSTEM

278 WATER-HAMMER, LIOUID BLOWDOWN ANALYSIS LOFT

278 WHAM, LIQUID-FILLED PIPING SYSTEM ANALYSIS

279 LECPAPD, SPECTRA CALCULATION WITH DEPLETION

AI $\quad 360 \quad F 4$

BAPL $6600 \quad F 4$

A I $\quad 360 \quad F 4$

GGA 1108 F4

BAPL $6600 \quad F 4$

IAM 360 F4

BAPL $6600 F+A S C$

GEC $625 \mathrm{FH}_{4}$

$B N L-D P \quad 360 \quad F 4$

$B N L-D P 7090$ F2

UGA $360 \quad F 4$

KE $\quad 3600 \quad F 36$

WAPD 360 F4

R280 MO807, 2-D DIFFUSION ABSOPPTION REMOVAL X-SECS BAPL 6600 F4

281 RABBLE, WLIB,FLAT, RESCNANCE ABSORPTION, CELL ANL $3600 \mathrm{~F} 36$

R282 SEALSHELL2, SHELL STRESS ANALYSIS AXISYM LOAD BAPL 6600 F4

R283 MO552, DYNAMIC ANALYSIS LINEAR ELASTIC SYSTEMS

R284 M0555,ACT1, LOSS-CF-COOLANT ACCIDENT ANALYSIS

R285 RESQ2, RESQ0, DHF1, RESONANCE INTEGRAL HEX CELL

R286 HOT2, 2-D TRANSIENT HEAT CONDUCTION PROGRAM

287 BISYN, 2-D MULTI-GP DIFFUSION SYNTHFSIS CALC.

BAPL $6600 \quad F 4$

BAPL $6600 \mathrm{F4}$

BAPL $6600 \mathrm{F4}$

BAPL 6600 F4

NED $\quad 635 \quad F 4$

288 SNARG-1D, 1-D MULTI-GP DISCRETE ORDINATE CALC ANL 3600 F36

289 GAKER, INELASTIC SCAT X-SECTION CALC MODERATOR GGA 1108 F4

290 GASA, STABILITY ANALYSIS REACTOR KINETICS EQNS GGA 1108 F4

291 HEXSCAT, ELASTIC SCAT X-SECTIONS HEX LATTICE

292 PSEUDO, STATISTICAL RF SONANICE PARAMETER CALC

293 MARS, 2-D EXCURSICN CALCULATION R- $Z$ GEOMETRY

R294 MOB99, HOH, STEAM TABLES $14.5-2538$ PSIA

R294 MO899,HOH, STEAM TABLFS $14.5-2538$ PSIA

R295 FLASH2, LOSS-OF-COOLANT ACCIDFNT ANALYSIS

296 GRDWRK, GRID GENERATION FOR SAFE PROGRAMS

297 CONTEMPT, LOSS-OF-COOLANT ACCIDENT ANALYSIS

GGA 1108 F4

GGA $1108 F_{4}$

APDA $7094 \quad F 4$

ANL $1604 \quad \mathrm{FG} 3$

BAPL $6600 \quad F 4$

BAPL $6600 \quad F 4$

GGA 1108 F4

PPCO 7040 F+MAP

298 GGC4. MULTI-GP $X-S E C T I O N S$ FAST THFRMAL SPECTRA
298 GGC4, MUL TII-GP $X$ X-SECTIONS FAST THERMAL SPECTRA

R299 LION, 3-D TEMPERATURE IISTRIBUTION PROGRAM

300 SAFE-CREEP, VISCOELASTIC ANALYSIS CONCRETE

GGA $1109 F 4$

GGA $6600 \quad F 4$

KAPL $6600 F+A S C$

301 FREVAPG, HTGR METALLIC FISSION PRODUCT RELEASE

302 GAFFE, EQUILIBRIUM FUFL CYCLE CALCULATION

GGA 1108 F4

GGA $1108 \quad F 4$

303 BLOOST6, COMBINED KINETICS 2-D HEAT TRANSFER

GGA 1108 F4

GGA 1108 F4

304 PERT4, 2-D PERTURBATION XY RZ RTHETA GEOMETRY BNW 1108 F4

305 STRIP, RESOLVEO RESONANCE INTEGRAL CALCULATION BW

BW $2000 F 4$

306 FCC 4, FUNDAMENTAL MODF FAST REACTOR X-SEC CALC BNW $1108 \mathrm{~F} 4$

307 HWOCR-SAFE, 2-D MONTE CAFLO CFLL CALCULATION

308 JUPITOR 1, COUPLED-CHANNEL X-SEC EVALUATION

309 TSN, SPATIALLY-UEPENDENT REACTOR KINETICS

AI $\quad 360 \quad F 4$

ORNL $1604 \mathrm{~F}_{63}$

AI $\quad 7094 \quad F 4$

309 TSN, SPATIALLY-DEPENIENT REACTOR KINETICS

AI $\quad 360 \quad F 4$

310 GAKIN, 1-D MULTIGROUP TIME-DEPENDENT DIFFUSION GGA $1108 \mathrm{~F}$

311 BURNUP, HEAVY ELEMENT ISOTOPIC BURNUP ANALYSIS GEV 635 F4

312 IDSN, 2-D MULTIGROUP DISCRETE ORDINATE PROGRAM LER 7090 F+MAP

313 CINDER,MO102, POINT DEPLETION FISSION PRODUCT BAPL 6600 F4

314 NAP, NEUTRON-INDUCED GAMMA-RAY RADIOACTIVITY IITR 7094 F4

315 WIREX, COMPUTER-PRODUCED WIRING LISTS UHTREX

LASL 7090 F2

316 GAF, GAR, SPECTRA AND GROUP-AVERAGED X-SEC CALC GGA 1108 F4

317 GAPOTKIN, SPACE-INDEPENDFNT REACTOR KINETICS GGA 1108 F4

318 FEVERT, 1-D MULTIGROUP DIFFUSION AND DEPLETION GGA 1108 F4

319 GASP7, 1-D BURNUP POWER DISTRIBUTION SEARCH GGA 1108 F4

320 TEMCO7, TFMPERATURE COEFFICIENT CALCULATION GGA 1108 F4

321 EXPALS, LEAST SQUARES EXPONENTIAL DECAY CURVES LRL 7094 F2

322 ISOSEARCH, ISOTOPE PRODUCTION FLUX, X-SEC CALC ORNL 1604 F63

322 ISOSEARCH, ISOTOPE ORODUCTION FLUX, X-SEC CALC ORNL $360 \mathrm{F4}$

323 MUFFLE, FISSILE NUCLIDE X-SECTION EVALUATION

ORNL $7090 \quad F 4$

PACKAGE CAT

RS P T G

RS P T D

PSBPLXT C

RSB L I $M$

RS P XT H

RSBP T K

RS P T F

RS P XT F

RS $P \quad T \quad D$

RS $P X T \quad D$

RS $P$ B

RS PLXT $B$

RS PLXT $B$

RS $P \quad G$

PSBP G

RS PLXT $B$

RS $X T A$

RSAP $X T \quad B$

RS $P \quad X T$ I

RS $P X T$ I

RS $P X T \quad G$

RS $P X T \quad B$

RS $P X T H$

RS PL T C

RS $P$ T C

RS $P$

RS $\mathbf{P}$

RS

RS P

RS $P$

RS $P$ XT

RS $P X T G$

RS $P \quad L$

RS $P \quad T G$

RS PLXT $B$

DS $L T B$

RS $P$ T

RS $P$ I

RS $P$

$S$

T D

RS P TE

RS P

RS

RS $P$ T

RS $P X T \quad B$

RS $P \quad T A$

RS $P$ T F

RS P T F

RS $P$ T

RS $P T O$

QS P T C

RS $P$

RSBPLXT D

RS $P$

RS $P X T \quad B$

RS $P$

RS $P$

RS $P$

RS $P$

RS $P$

RS $P$

RS $P$

RSBP

T D

I C

T $\mathrm{C}$

P

D

D

389

391

393

396

398

400

402

402

405

405

407

409

409

411

411

413

415

417

419

421

423

425

427

429

432

434

436

438

440

442

444

444

446

448

450

452

452

456

458

460

462

464

466

468

470

472

474

476

476

478

480

482

484

486

488

490

493

495

497

499

501

503

503 
TABLE OF CONTENTS

Page

No.

KWIC TITLE

INSTALLAT ION MACH LANG

PACKAGE CAT

324 FRANTIC, LEAST SQUARES FIT SUM DF EXPONENTIALS MIT 7090 F2

$32520 B, 2-D$ MULTIGROUP DIFFUSION AND DEPLETION

$3252 D B, 2-D$ MULIIGROUP DIFFUSION ANO DEPLETION

BNW $1108 \mathrm{F4}$

$32520 B, 2-D$ MULIIGROUP DIFFUSION ANO DEPLETION

326 AIROS2A, SIMULATION OF RFACTOR DYNAMICS

R327 DAFT1, LEAST SQUARES FIT FISSILE NUCLIDE DATA

328 NURLOC,-1.0, LOSS-OF-COOLANT THERMAL ANALYSIS

R329 M0457,PIPE. ELASTIC STRESS OF PIPING SYSTEM

330 ECCSAI, LOSS-OF-COCLANT + EMERGENCY COOLING

R331 FLOT1, M0219, PWR FLOW TRANSIENT ANALYSIS

LASL $6600 \mathrm{F4}$

ANL $3600 \quad F 4$

AI $\quad 360 \mathrm{~F}+\mathrm{BAL}$

BAPL $6600 \mathrm{FH}_{4}$

$\mathrm{BCL} \quad 6400 \quad \mathrm{F4}$

BAPL $6600 \quad F 4$

$B C L \quad 6400 \quad F_{4}$

BAPL $6600 \quad F 4$

332 SAFE-3D, 3-D COMPOSITE STRUCTURE STRESS STUDY

GGA $1108 \quad F 4$

333 TOAD, PROCESSING OF ANALYZER GAMMA-RAY SPECTRA GGA 1108 F4

334 PEGGY, ELASTIC SCATTERING PHASE-SHIFT ANALYSIS

335 RAMES, PARTICLE WAVE FUNCTION RADIAL INTEGRALS

R336 PDQ5, 2-D FEW-GROUP DIFFUSION AND DEPLETION

ORNL 1604 F63

ORNL 1604 F63

R337 STEM. MATRIX GENERATITN FOR A SYSTEM OF RFAMS

R338 TWIGGLE, 2-D 2-GP SPACE-TIME DIFFUSION

IBM $360 \mathrm{~F}+\mathrm{BAL}$

KAPL $6600 \quad F 4$

ANL $360 \mathrm{F4}$

R338 TWIGL, 2-D 2-GP SPACE-TIME DIFFUSION FEEDBACK

339 GAUGE, 2-D FEW-GP HEX GEOM DIFFUSION DEPLETION

340 POWERCO, NUCLEAR STATION ELECTRICITY COSTS

BAPL $6600 \mathrm{~F}_{4}$

341 GANDY, UNRESOLVED RESONANCE X-SECTION CALC

$\begin{array}{lll}\text { GGA } & 1108 & \mathrm{FA}_{4} \\ \text { ORNL } & 1604 & \mathrm{FG}^{3}\end{array}$

GGA $1108 \quad F 4$

BAPL $6600 \mathrm{F4}$

R343 MO756, LETO, 1-D SL AB GAMMA-RAY TRANSPORT

R344 GEM, FIGENVALUE PROßLEM FDR VIBRATING SYSTEMS

345 GAND, GAFGAR X-SECTION LIBPARY PREPARATION

346 THTE, 3-D TRANSIENT HEAT TRANSFER PROGRAM

BAPL $6600 \quad F 4$

KAPL $6600 \quad F_{4}$

GGA $1109 F_{4}$

GEC $635 \mathrm{~F}+\mathrm{GMP}$

RS $P$ P

RS $P$ T $D$

RS $P$ T $D$

RSBP T D

RS :P T T

RS P XT P

RS P $T$ T

RS $P X T$ I

RS $P$ T G

RS P XT H

RS $P$ T $I$

RS P T 0

RS P

RS $P$

RS P

PS P

RS $P$ I

RS P XT F

RS $P$ T $D$

RS $P$ D

RS $P \quad A$

RS XT C

RS $P$ P $X T$ T

RS $P$ T I

RS P T L

347 CODILLI, LEAST SQUARES ANALYSIS RESONANCE DATA

R348 TOPS, TRANSIENT THERMODYNAMICS OF PRESSURI ZERS

349 TOODEE, 2-D TIME-DEPENDFNT HEAT CONDIJCTION

350 ETOF, ENDF/8 TO MC * 2 DATA CONVERSION

351 ECSIL. EXPERIMENTAL NEUTRON DATA LIBRARY

R352 RAUMZFIT, 1-D TIME-DEPENDENT DIFFUSION CALC

353 SWELL2, FUEL ELEMENT LIFETIME ANALYSIS

354 CINCAS, NUCLEAR FUEL CYCLE COST AND ECONOMICS

355 MC* *2, ENDF MULTIGROUP X-SFCTION CALCULATION

356 ZPR-III ASSEMRLY 48 GAFGAR ENDF/B DATA TAPES

357 SUPORAN, REACTOR CORE SIJPPIRT STRESS ANALYSIS

358 TWOTRAN, 2-D MULTI-GP TRANSPORT COIDE $X-Y$ GEOM

358 TWOTRAN, 2-D MULTI-GP TRANSPORT CODE $X-Y$ GEOM

R359 PUNI, UNRESOLVFD RESINANCE INTEGRALS $X-S E C S$

UILL $360 \mathrm{FH}_{4}$

RS P A

BAPL 6602 F4 RS P XT H

PPCO 7044 F+MAP RS P TH

APDA 3600 ASAF4 RS P T M

LRL 7094 F2 RS PL T M

KAPL $6600 \quad F 4$

ANL $3600 \mathrm{~F} 36$

COMM $360 \quad F 4$

ANL 3600 F36

GGA 1108 BIN

ANL $3600 \quad F 36$

ANL $360 \mathrm{FH}_{4}$

LASL $1109 \mathrm{FH}_{4}$

BAPL $6600 \mathrm{~F}_{4}$

360 TOR, THERMAL SCATTERING CRYSTALLINE MATERIALS LASL 6600 F4

361 GLEN, GROUP CONSTANT CALC FROM TOR DUTPUT DATA

362 WELWING, MATERIAL BUCKLING CYL FUFL ELEMENTS

$\begin{array}{lrr}\text { LASL } & 6600 & \mathrm{F4} \\ \text { AEB } & 360 & \mathrm{F4}\end{array}$

RS P F

RSBP I

RS P T D

RS P T P

R $\quad L \quad T \quad Z$

RS $P$ P $T$

RS P I C

RS $P$ T

RS $P$ X $X T$

$\begin{array}{llll}\text { RS } & P & T & A \\ \text { RS } & P & \text { T } & \text { B }\end{array}$

$S$ P

363 BLAST, REACTOP, KINETICS TEMPERATURE DIST STUDY

R364 SNEO, NONLINEAR ALGFBPAIC EQN SOLN CURVE PLOT

365 BOW2, DEFLECTICN CALCULATION PARALLEL BEAMS

AER $360 \mathrm{FH}$

RS $P$

KAPL 6600 F+ASC. RS P

366 CHEMLOC2, CTRE HEATING CLADDING-STEAM REACTION

367 I SOGEN, RADIONUCLIDE GENERATION AND DECAY

ANL 3600 F36

ANL $3600 F 36$

368 FLANGE2, ENDF/B THEPMAL SCATTERING DATA PROC

BNW

$1108 \mathrm{F5}$

369 RELAP2, REACTOR BLOWDOWN - EXCURSION ANALYSIS

370 GAKIT, 1-D MULTIGP KINETICS WITH TEMP FEEDBACK
371 NOWIG, 1-D 2-GP KINETICS TEMPERATURE FEEDBACK

372 RAPFU, FUEL CYCLE PARAMETERS FAST BREEDERS

R373 BL47, DRAFTING TOOL TO PLOT PLANE STRUCTURES

INC

$360 F 4$

$7044 F_{4}$

GGA $1108 \mathrm{FH}^{2}$

BAPL $6600 \quad F 4$

APO $635 \mathrm{FH}_{4}$

BAPL $6600 \mathrm{~F}_{4}$

BNW $1109 \mathrm{F4}$

375 SCORE2, SCISRS ENDF/B GRAPHIC X-SEC EVALUATION

376 AVERAGE, UNRESOLVED REGION AVERAGE $X$-SFC CALC

376 AVERAGE, UNRESULVED REGION AVERAGE $X$-SEC CALC

377 SIGPLOT, RESOLVED MULTILEVEL B-W $X$-SEC CALC

377 SIGPLOT, RESOLVEO MULTILEVEL B-W X-SEC CALC

R378 TUBE, U-TUBE HEAT EXCHANGER STRESS ANALYSIS

379 SAFE-2D, PLANE + AXISYMMETRIC STRESS ANALYSIS

380 GATT, 3-O FEW-GP DIFFUSION CALC HEX-Z MESH

AI $360 \mathrm{~F}+\mathrm{BAL}$

BNL $6600 \mathrm{F4}$

BNL $7094 \quad F 4$

BNL $6600 \mathrm{F4}$

BNL $7094 \mathrm{F4}$

KAPL 6600 F4

GGA $1109 \mathrm{F4}$

GGA $1108 \mathrm{FH}^{2}$

381 LYNNE, WOODS-SAXON POTENTIAL SHAPE CALCULATION

ORNL $7090 \mathrm{~F} 2$

RSRP

RSBPL T

RS P T A

RS P T G

RS P T F

P.S P XT F

RS $P$ D

RS P XT L

RS P XT $B$

RS $L \quad T M$

RS P A

$\begin{array}{lll}\text { RS } & P & A \\ \text { RS } & P\end{array}$

R.S $P$ A

RS $P$

R.S $P$

RS P

RS
507

509

509

509

511

514

516

518

520

522

524

526

528

530

531

532

535

535

538

541

543

546

548

550

552

554

556

558

560

562

564

567

569

571

573

575

578

580

581

582

584

586

588

590

592

594

596

598

600

602

604

607

609

611

613

615

617

617

619

619

621

623

625

627 
TABLE OF CONTENTS

No.

KWIC TITLE

INSTALLATION MACH LANG

PACKAGE CAT

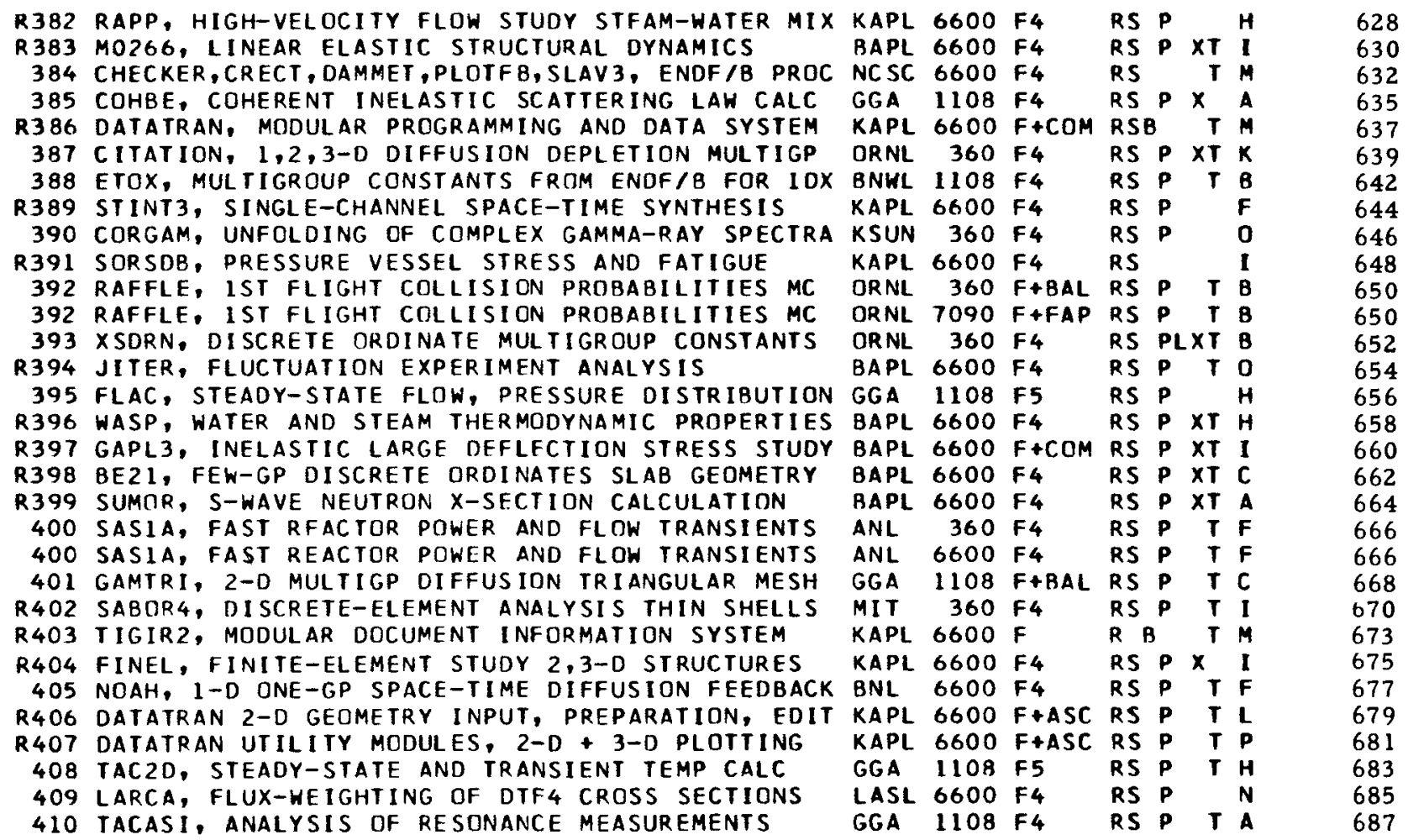

VI. LIBRARY PROGRAMS BY CLASSIFICATION . . . . . . . . . .

A. Cross-section and Resonance-integral Calculations . . . . . .

B. Spectrum Calculations, Generation of Group Constants, Lattice and Cell Problems . . . . . . . . . . . . . . . . .

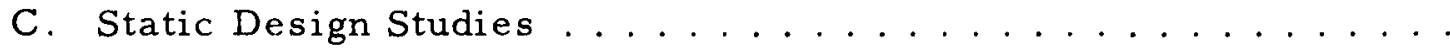

D. Depletion, Fuel Management, Cost Analysis, and Reactor Economics ........................

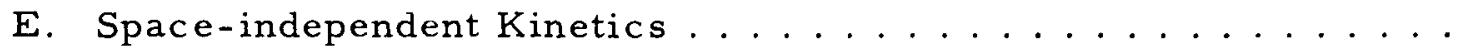

F. Space-Time Kinetics, Coupled Neutronics-Hydrodynamics Thermodynamics, and Excursion Simulations . . . . . . . . .

G. Radiological Safety, Hazard and Accident Analysis.........

H. Steady-state and Transient Heat Transfer ............ 
I. Deformation and Stress Distribution Computations, Structural Analysis and Engineering Design Studies . . . . . . . . 741

J. Gamma Heating and Shield Design Problems. . . . . . . . . . . 747

K. Total Systems Analysis. .................. 750

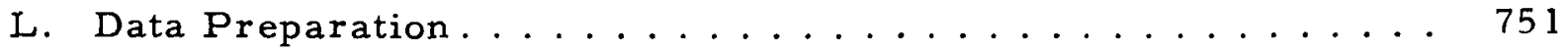

M. Data Management. . . . . . . . . . . . . . 753

N. Subsidiary Calculations. . . . . . . . . . . . . 756

O. Experimental Data Processing . . . . . . . . . . . 757

P. General Mathematical and Computing System Routines . . . . . 760

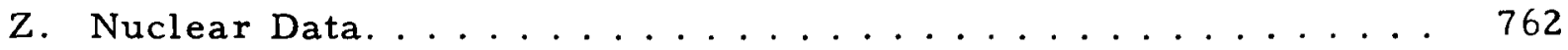

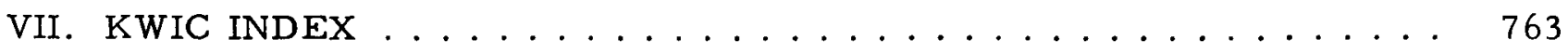

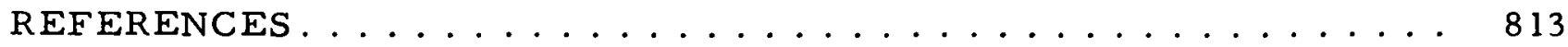


14. ANY CTHEP PROGPAMMING DR OPERATING INFORMATION OR RESTRICTIONS IF AN SC-4020 GPAPHICAL DISPLAY DEVICE IS AVAILABLE, THE DUMMY SUBRCUTINE AICRT3 SHOULD BE RFPLACED BY THE FORTRAN II AICRT3 SUBROUTINE AND THE NAA-SC-4C20 SUBRDUTINE PACKAGE WHICH ARE AVAILABLE THROUGH -

$$
\begin{aligned}
& \text { UAIDE LIBRARIAN } \\
& \text { C/O STROMBERG-CARLSON } \\
& \text { P. O. BOX } 2449 \\
& \text { SAN DIEGO, CAL IFORNIA }
\end{aligned}
$$

15. NAME AND ESTARLISHMENT OF AUTHOR -

R. F. BERLAND

MATHEMATICAL AND CMMPUTING SCIENCES GROUP ATOMICS INTERNATIONAL

P. ก. BCX 309

CANOGA PARK, CALIFORNIA 91304

16. MATERIAL AVAILABLE -

SOURCE DECK (366 CARDS)

SAMPLE PROBLEM (36 CARDS)

REFERENCE REPORTS

17. CATEGCRY - H

KEYWCRDS - 2-DIMENSIONAL, FLUIO FLOW, CODLANTS DISTRIBUTIONS, GRAPHS 
1. NAME TR DESIgNATION OF PROGRAM - FLANGE1

2. COMPUTER FIR WHICH PROGPAM IS DFSIGNED AND OTHERS UPON WHICH IT IS OPERARLF - UNIVAC 1108

3. NATURE DF PHYSICAL PRTBLEM SOLVED - FLANGE1 COMPUTES NEUTRON SCATTERING KERNELS FOP A LARGF CLASS OF MODERATORS. NEUTRON SCATTERING KERNELS ARE OBTAINED FROM THE SCATTERING LAW COMPUTED BY THE CODE GASKET. FLANGEI ALLOWS THE CALCULATION OF DOUBLE DIFFERENTIAL CROSS SECTIONS, ANGULAR CROSS SECTIONS, TOTAL CROSS SECTIONS, AND LEGENDRE MOMENTS OF THE SCATTERING KERNEL. THE SHORT COLLISION TIME APPROXIMATION IS USED FOR ENERGY TRANSFERS LARGER THAN THE NAXIMUM PROVIDED RY GASKET.

4. METHCD CF SCLUTION -

5. RESTRICTIONS ON THE CCMPLEXITY OF THE PROBLEM -

6. TYPICAL RUNNING TIME - 3 MINUTES ARE REQUIRED ON THF UNIVACIIO8.

7. UNUSUAL fEATURES DF THE PROGRAM -

8. Relatfo and aUXILIARY pPOGRAMS - GASKET (ACC ABSTRACT 263)

9. STATLS - ABSTQACT FIFST DISTRIBUTED APRIL 1967. IBM7044 VEPSION SUBMITTED JUNE 1966, DELETED SEPTEMBER 1969 . UNIVACIIC8 VFRSION SUBMITTED SEPTEMBER 1969.

10. REFERENCES - H. C. HCNECK AND Y. П. NALIBOFF, APPENDIX E INTEGRAL NEUTRON THERMALIZATION ANNUAL SUMMARY REPORT OCTOBER 1964 THROUGH SEPTFMBER 1965, GA-6824, MARCH 1965.

G. M. BCRGCNOVI, NEUTRON SCATTERING KERNELS CALCULATIGNS AT EPITHEQMAL ENERGIES, GA-9950, MARCH $17,1970$.

11. MACHINE REQUIREMENTS - 32K MEMORY, 2 MAGNETIC TAPES, ONE SCRATCH UNIT

12. PROGRAMMING language USED - FORTRAN V

13. OPERATING SYSTEM OR MONITOR UNDER WHICH PROGRAM IS EXECUTED EXEC II.

14. ANY CTHER PROGRAMMING DR OPERATING INFDRMATION OR RESTRICTIONS -

15. NAME AND ESTABLISHMENT CF AUTHOR -

G. M. BCRGCNOVI

GULF GENERAL ATOMIC INCORPORATED

P. O. BOX 608

SAN DIEGO, CALIFORNIA 92112 
16. MATERIAL AVAILABLE -

SOURCE DECK (869 (AROS)

SAMPLE DROBLEM 15 (ARDS)

REFEPENCF REPORTS

17. CATLGCRY - A

KFYWRRDS - SCATTEPING LAW, CRMSS SECTIONS, ANGULAR DISTPIBUTION

8. RELATED AND AUXILIARY PRCGRAMS - AN AUXILIARY CODE, FLANGE IACC ABSTPACT 247I, IS USED TO GENERATE CROSS SECTION INFORMATION FROM THE SCATTERING LAW.

9. STATUS - ABSTRACT FIPST DISTRIBUTED NPRIL 1967. UNIVAC 1108 VERSIUN SUBMITTED DECEMBER 1966, REPLACED BY LATER VERSION SEPTEMRER 1969. 
1. NAME OR DESIGNATION GF PROGRAM - COINC ICOMPUTER CODE FDR REDUCTION OF COINCIDENCE COUNTING DATA)

10. REFERENCES - J. U. KCPPEL, J. R. TRIPLETT, AND Y. D. NALIBOFF, GASKET, A UNIFIED CODF FOR THERMAL NEUTRON SCATTERING, GA-7417 REVISFD, MARCH $10,1967$. GASKET UPDATE NOTE, GGA NOTE.

11. MACHINE REQUIREMENTS - 32K MACHINE WITH ABOUT 26K AVAILABLE FOR THE PROGRAM AND ONE SCRATCH UNIT (DRUM, DISK, OR TAPE)

12. Programming language used - fortran iv

13. DPEPATING SYSTEM OR MINITOR UNDER WHICH PROGRAM IS EXECUTED EXEC II (UNIVAC1108) AND CHIPPEWA (CDC6600).

14. ANY CTHER PROGRAMMING OR CPERATING INFORMATION OR RESTRICTIONS -

15. NAME AND ESTABLISHMFNT OF AUTHORS PROGRAM J. U. KOPPEL, J. R. TRIPLETT, AND Y. D. NALIBOFF ABSTRACT O. H. HOUSTON GULF GENERAL ATOMIC INCORPORATED P. O. BCX 608 SAN DIEGO, CALIFORNIA 92112

16. MATFRIAL AVAILABLE -

SOURCE DECK (1108-1385 CARDS)

SAMPLE PRCBLEM (1108-61 CARDS)

REFERENCE REPORT AND NOTE

17. CATEGCRY - A

KEYWORDS - SCATTEPING LAW, INCOHERENT APPROXIMATION, MODERATORS 
6. TYPICAL RUNNING TIME - ON THE IBM7040 APPROXIMATELY 0.32 SECOND PEP TIME ADVANCEMENT IS REQUIRED FOR A PROBLEM USING 90 MESH POINTS FOR HEAT STRUCTURES.

7. UNUSUAL fEATURES OF THE PROGRAM -

8. RELATFD AND AUXILIARY PROGRAMS -

9. STATLS - ABSTPACT FIRST DISTRIBUTED DECEMBER 1967. I BM7O40 VERSION SUBMITTED SEPTEMBER 1967.

10. REFERFNCE - L. C. RICHARDSON, L. J. FINNEGAN, R. J. WAGNER, AND J. M. WAAGF, CONTEMPT, A CCMPUTER PROGRAM FOR PREDICTING THE CONTAINMFNT PRESSURE-TEMPERATURE RESPONSE TO A LOSS-OF-COOLANT ACCIDENT, IDO-17220, JUNE 1967 .

11. MACHINE REQUIREMENTS - 32K MEMORY

12. PRGgRAMMING LANGUAgeS USED - FDRTRAN IV AND MAP (DECIMAL INPUT, DATE, AND CLOCKING QDUTINES)

13. OPERATING SYSTFM OR MCNITOR UNOER WHICH PROGRAM IS EXECUTED I BSYS.

14. ANY CTHER PROGRAMMING OR OPERATING INFORMATION OR RESTRICTIONS -

15. NANE AND ESTABLISHMENT OF AUTHCRS -

L. C. RICHARDSON, L. J. FINNEGAN, R. J. WAGNER, AND J. M. WAAGE

ATOMIC ENERGY DIVISION

PHILLIPS PETROLEUM CDMPANY

P. C. BOX 2067

IDAHO FALLS, IDAHO $\$ 3401$

16. MATfFial aVAILABle - MAGNETIC taPE TRANSMItTAL

SNURCE DECK (7040-2154 CARDS)

SAMPLE PROBLEM (7040-58 CARDS)

RFFERENCE REPORT

17. CATEGORY - G

KEYWORDS - ACCIDENTS, TEMPERATURE DISTRIBUTION, PRESSURE DISTRIBUTION, CONTAINMENT, COOLANTS, WATER, LIQUIDS, VAPORS, LEAKAGE, HEAT TRANSFER 
1. NAME OR DESIGNATION OF PROGRAM - GGC4

2. COMPUTER FOP WHICH PROGRAM IS DESIGNED AND OTHERS UPON WHICH IT IS OPERABLE - UNIVAC 1108, CDC6600

3. NATURE GF PHYSICAL PRDBLEM SOLVED - THE GGC4 PROGRAM SOLVES THE MULTIGRCUP SPECTRUM EOUATIONS WITH SPATIAL DEPENDENCE REPRESENTED BY A SINGLE POSITIVE INPUT BUCKLING. BROAD GROUP CROSS SECTIONS (SHIELDED OR UNSHICLDED) ARE PREPARFD FOR DIFFUSION AND TRANSPORT CODES 3Y AVERAGING, WITH THE CALCULATED SPECTRA OVER INPUT-DESIGNATED ENERGY LIMITS. THE CCDE IS DIVIDED INTO THREE MAIN PARTS. A FAST (GAM) SECTICN WHICH COVERS THE ENERGY RANGE FRCM 14.9 MEV TO 0.414 EV, A THERMAL (GATHER) SECTION WHICH COVERS THE ENERGY RANGE FROM $C$ TO 2.38 EV, ANC A COMBINING (COMBO) SECTION WHICH COMBINES FAST AND THERMAL CROSS SECTIONS INTD SINGLE SETS. BASIC NUCLFAR DATA FOR THE FAST SECTION WHICH CONSISTS OF FINE GROUPAVERAGED CROSS SECTICNS AND RESONANCE PARAMETERS IS READ OFF A DATA TAPF. THE FINE GROUP ABSORPTION AND FISSIDN CROSS SECTIONS MAY BE ADJUSTED BY PERFCRMING A RESONANCE INTEGRAL CALCULATION. UTILIZING A FISSICN SOURCE AND AN INPUT BUCKLING, THE CODE SOLVFS THE P1, B1, B2, OR B3 APPRCXIMATINN TO DBTAIN THE ENFRGY-DEPENDENT FAST SPECTRUM. TWO CR SIX SPATIAL MOMENTS OF THE SPECTRUM IDUE TO A PLANE SOURCE) MAY ALSO BE EVALUATED. INSTEAD OF PERFORMING A SPECTRUM CALCULATION, THE USER MAY ENTER THE LEGENDRE COMPONENTS OF THE ANGULAR FLUX DIRECTLY. FOR AS MANY INPUT-DESIGNATED BROAD GROUP STRUCTURES AS DESIRED, THE CODE CALCULATES AND SAVES (FDR THE COMBINING SECTION) SPECTRUM-WEIGHTED AVERAGES OF MICROSCOPIC AND MACRISCOPIC CROSS SECTIONS AND TRANSFER ARRAYS. SLOWING DOWN SOURCES ARE CALCULATED AND SAVED FOR USE IN THE LOWER ENERGY RANGE. GIVEN BASIC NUCLEAR DATA, THE THERMAL SECTION OF GGC4 DETERMINES A THERMAL SPECTRUM BY EITHER READING IT AS INPUT, BY CALCULATING A MAXWELLIAN SPECTRUM FOR A GIVEN TEMPERATURE, OR BY AN ITERATIVE SOLUTION OF THE P3, BO, P1, DR BI EQUATIONS FOR AN INPUT BUCKLING. TIME MOMENTS OF THE TIME AND ENERGY-DEPENDENT DIFFUSION EQUATIONS ARE CALCULATED (AS AN OPTION) USING THE INPUT BUCKLING TO REPRESENT LEAKAGE. BROAD GROUP CROSS SECTIDNS ARE PREPARED BY AVERAGING FINE GRDUP CROSS SECTIONS OVER THE CALCULATEC SPECTRA. BRCAD GROUP STRUCTURES ARE READ AS INPUT. THE COMRINING SECTION OF GGC4 TAKES THF BROAD GROUP-AVERAGED CROSS SECTIONS FROM THE FAST AND THERMAL PORTIONS OF GGC4 AND FORMS MULTIGRDUP CROSS SECTION TABLES. THESE TABLES ARE PREPARED IN STANDARD FORMATS FOR TRANSPORT OR DIFFUSION THEORY CALCULATIONS. IN ADOITION, IT IS POSSIBLE TO USE THE COMBINING SECTION TO PRODUCE MIXTURES NOT USED IN THE SPECTRUM CALCULATION OR TO COMBINE THE RESULTS OF DIFFERENT FAST AND THERMAL SECTION CALCULATIONS AND SO ON. THESE DPTINNS ARE DESCRIBED IN REFERENCE 2.

4. METHOD OF SOLUTION - IN THE FAST SECTION EITHER THE PI OR THE B1, B2, OR B3 APPROXIMATION IS MADE TO THE TRANSPORT EQUATION USING THE POSITIVE, ENERGY-INDEPENDENT BUCKLING. IN EACH APPROXIMATION LEGENDRE MOMENTS DF THE ANGULAR FLUX ARE COMPUTED BY DIRECT NUMER ICAL INTEGRATION CF THE SLOWING DOWN EQUATIONS. IN THE RESD- 
4. METHOD OF SOLUTION (CONTINUED)

NANCE CALCULATIONS, DOPPLER BROADFNED (AT AN [NPUT TEMPERATURE) ABSORPTION AND SCATTERING CROSS SECTIONS ARE USED. THE RESONANCE TREATMENT ALLOWS UP TO TWO ADMIXED MODERATORS IN AN ABSORBER LUMP IMBEDEED IN A SUPDOUNDING MODERATOR. THE ABSORBER IN THE LUMP IS TREATED BY USING IITHFR THE NARROW RESONANCE APPROXIMATION, THE NARROW RESONANCE INFINITE MASS APPROXIMATION, DR A SOLUTION DF THE SLOWING DOWN INTEGRAL EQUATIONS TO DETERMINE THE COLLISION DENSITY THROUGH THE RESONANCF. THE ADMIXED MODERATDRS ARE TRFATED BY USING EITHER AN ASYMPTOTIC FORM OF, OR AN INTEGRAL EQUATION SOLUTION FOR, THE COLLISION DENSITY. IN THE RESONANCE CALCULATION EITHFR STANDARD GEOMETRY COLLISION PROBABILIIIES ARE USFD OR TABLES OF COLLISION PRORARILITIES ARE ENTERED. DANCOFF CORRECTIONS CAN ALSO BE MADE. IN THE REGION OF UNRESOLVEO RESONANCES, RESONANCE ABSORPTION IS CALCULATED BY USING PORTER-THOMAS DISTRIBUTIONS, BUT CNLY S-WAVE NEUTRONS ARE CONSIDERED. IN THE THERMAL SECTION EITHER THE $3 C, 81$, PO, OR PI APPROXIMATION TO THE TRANSPORT FQUATIDN IS MADE, AND IN ALL OPTIONS LEGENDRE MOMENTS OF THF ANGULAR FLUX ARE COMPUTED. A TRAPEZOIDAL ENERGY INTEGRATION MESH IS USED, AND THE RFSULTING EQUATIONS ARE SOLVED ITERATIVELY BY USING A SOURCE-NORMALIZED, OVER-RELAXED, GAUSSIAN TECHNIQUE. AVERAGES OVER BROAD GROUPS ARE PERFIRMED BY SIMPLE NUMERICAL INTEGRATION. THE RESULTS OBTAINED IN THE FAST AND THERMAL SECTIONS ARE STORED ON SPECIAL TAPES. THESE TAPFS MAY CONTAIN RESULTS FOR A NUMBER OF PRORLEMS, EACH PROBLEM INCLUDING FINE GROUP CROSS SFCTION DATA FOR A NUMBER OF NUCLIDES. IF THE PROBLEM NUMBFR IS SPFCIFIED ON THESE TAPES, AND A DESIRED LIST OF NUCLIDES IS GIVEN, THE COMBINING CODE WILL PUNCH MICROSCOPIC CROSS SECTIONS FOR THE REQUESTED LIST OF NUCLIDES. THE PROGRAM ALSO TREATS MIXTURES. GIVEN THE ATOMIC DENSITIES OF THE NUCLIDES IN A MIXTURE. THF CODE WILL PUNCH MACROSCOPIC CROSS SECTIONS.

5. RESTRICTIONS ON THE COMPLEXITY OF THE PROBLEM - MAXIMA OF 99 FAST GROUPS

101 THERMAL FINE GROUPS

99 FAST BROAD GROUPS

50 THERMAL BROAD GROUPS

50 BROAD GROUPS IN THE COMBINING SECTION

100 RESONANCES PFR NUCLIDE

2 MODERATORS ADMIXED WITH A RESONANCE ABSORBER

305 ENTRIES IN THE ESCAPE PROBABILITY TABLE FOR CYLINDRICAL GEOMETRIES

505 ENTRIES IN THE ESCAPE PROBABILITY TABLE FOR SLAB GEOMETRIES A SINGLE AND POSITIVE VALUE FOR THE BUCKLING (B* 2 ) MUST BE SUPPLIED.

6. TYPICAL RUNNING TIME - A B I CALCULATION IN THE FAST SECTION FDR 3 NUCLIDES AND 6 BRDAD GROUPS TAKES APPROXIMATELY 4 MINUTES ON THE UNIVAC 1108 IF A RESONANCE CALCULATION $(1 / 2$ MINUTE) IS PERFORMED FOR ONE NUCLIDE. THE THERMAL CALCULATION FOR 3 BROAD GRTUPS REQUIRES APPROXIMATELY 2 MINUTES, WHICH INCLUDE ABOUT 7 SECONDS FOR THE I TERATIVE PROCEDURE. TO PUNCH STANDARD DIFFUSION AND STANOARD TRANSPORT CROSS SECTIONS FOR THIS PROBLEM REQUIRES 2 SECONDS . 
$\begin{array}{llll}\text { REACTOR CODE ABSTRACT } 298 & -3- & 05 / 70\end{array}$

7. UNUSUAL FEATURES OF THE PROGRAM - THERF IS AN OPTION IN GGC4 WHICH MAKES IT POSSIRLE TO SHURTEN THE PUNCHING PROCESS FOR LARGE TWODIMENSIONAL TRANSFFR ARRAYS. THIS CAN BE DONE BY SPECIFYING A MAXINUM NUMBER IIF DFSIRED UPSCATTERING AND DOWNSCATTFRING TERMS.

8. RELATFD AND AUXILIARY PROGRAMS - GGC 4 IS A REVISION OF THE EARLIER PRCGRAM, GGC3. TC PREPARE, HANDLE, AND UPDATE THE BASIC CROSS SECTION TAPES WHICH ARE USED AS INPUT FOR GGC4, THE FOLLOWING CODES ARE UTILIZED - MAKE, MST, PRINT, MIXER, WTFG, MGT3, SPRINT, COMRIN, AND DOP.

9. STATUS - ABSTRACT FIRST DISTRIBUTED DECEMBER 1967. UNIVAC 1108 VFRSION OF GGC3 SUBMITTED SEPTEMBER 1967, DELETED JUNE 1963.

UNIVACIIOR VERSION OF GGC4 SUBMITTED JUNE 1968, REPLACED RY LATER VERSICN JULY 1969. CDC6600 VERSION SUBMITTED OCTOBER 1969.

10. REFERENCES - J. ADIR AND K. D. LATHROP, THEORY OF METHODS USED IN GGC-4 MULTIGROUP CRISS SECTION CODE, GA-9021, OCTOBER 1,1968 . J. ADIR, S. S. CLARK, R. FROEHLICH, AND L. J. TODT, USERS AND PROGRAMMERS MANUAL FOR GGC-3 MULTIGROUP CROSS SECTION CODE, PARTS 1 AND 2 , GA-7157, JULY 1967.

M. K. DRAKE, DESCRIPTION OF AUXILIARY CODES USED IN THE PREPARATION OF DATA FUR THE GGC-3 CODE, GA-7158, AUGUST 1967. BCDCON, GA NOTE.

MCDIFICATIONS TO IMPLEMENT THE UNIVAC 1108 VERSION OF THE GGC-4 PROGRAM TO THE CDC 6600 COMPUTER, WANL NOTF.

11. MACHINE REQUIREMENTS - 64K MEMORY WITH 11 TAPE UNITS ISOME OF WHICH MAY BE DRUM AREASI ON THE UNIVAC1108.

12. PROGRAMMING LANGUAGE USED - FDRTRAN IV

13. OPERATING SYSTEM OR MENITOR UNDER WHICH PROGRAM IS EXECUTED UNIVAC EXEC II, GAX29.

14. ANY OTHER PROGRAMMING OR OPERATING INFORMATION OR RESTRICTIONS THERE IS NO RESTRICTION ON THE NUMBER OF PROBLEMS THAT CAN BE RUN CONSECUTIVELY IN EACH SECTION, NOR IS THERE A RESTRICTION ON THE NUMRER OF NUCLIDES PER PROBLEM. WITHOUT USING THE NEW OPTIONS, GGC4 CAN ALSO BE RUN WITH THE GGC3 INPUT INSTRUCTIONS. THE CDC6600 VERSION IS DRGANIZED INTO FOUR OVERLAYS. WITH THE BUFFER LENGTHS SET TO 1030 IOCTAL), THE LARGEST OVERLAY REQUIRES 165,000 (OCTAL) LOCATIONS. IT SHOULD BE POSSIBLE TO REDUCF THIS REQUIREMENT BY A MORE EFFICIENT USE OF THE COMMON AREA.

15. NAME AND ESTABLISHMENT OF AUTHORS 1108 AUTHOR

J. $A D I R$

PRESENT CONTACT

D. R. MATHEWS 
15. NAME AND ESTARLISHMENT CF AUTHOR(S) (CONTINUED)

GULF GENERAL ATOMIC INCORPORATED

P. D. BOX 608

SAN DIEGO, CALIFORNIA 92112

6600 AUTHOR

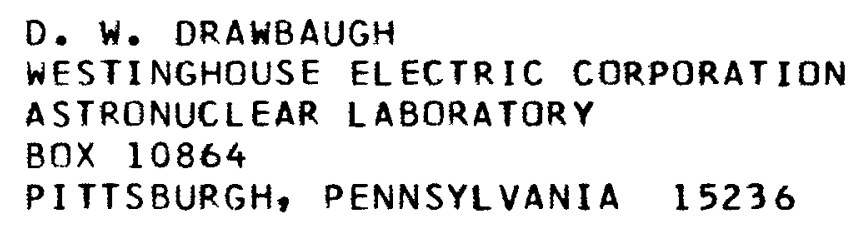

16. Material aVAILABLE - MAgNetic tAPE transmittal (4 TAPES) SOURCE DECKS IGGC 4 1108-11,567 CARDS, WTFG 1646 CARDS, MAKE 1033 CARDS, MST 463 CARDS, PRINT 769 CARDS, MIXER 500 CARDS, MGT 3251 CARDS, SPRINT 334 CARDS, COMBIN 479 CARDS, DOP 927 CARDS, GGC4 660011,504 (ARDS)

SAMPLE PROBLEMS (GGC4 1108-38 CARDS, 6600-38 CARDS)

FAST DATA TAPE 160 NUCLIDES - TAPE 2 - 1108-2772 BINARY RECORDS, 6600-1703 BINARY RECORDSI)

FAST DATA TAPE 1151 NUCLIDES - TAPE 3 - 1108-7362 BINARY RECORDS, 6600-4436 BINARY RECORDSI

THERMAL DATA TAPE 1222 NUCLIDES - TAPE 4 - 1108-2854 BINARY RECORDS, 6600-1539 BINARY RECORDSI

REFERENCE REPORTS AND NOTES

17. CATEGORY - B

KEYWORDS - MULTIGROUP CROSS SECTIONS, AVERAGES, FAST, THERMAL, SPECTRA, DOPPLER BROADENING, DANCOFF CORRECTION, ANGULAR DISTRIBUTION, RESONANCE PARAMETERS, MAKE CODES, MST CODES, PRINT CODES, MIXER CDDES, WTFG CODES, MGT3 CODES, SPRINT CODES, COMBIN CODES, DOP CODES 
1. NAME OR DESIGNATION OF PROGRAM - LION

2. COMPUTER FOR WHICH PROGRAM IS DESIGNED AND OTHERS UPON WHICH IT IS OPERABLE - CDC6600

3. NATURE OF PHYSICAL PROBLEM SOLVED - LION IS A DIGITAL COMPUTER PROGRAM WHICH WILL SOLVE THREE-DIMENSIONAL TRANSIENT AND STEADYSTATE TEMPERATURE DISTRIBUTION PROBLEMS. THE INPUT CONSISTS OF GEOMETRY, PHYSICAL PROPERTIES, BOUNDARY CONDITIONS, INTERNAL HEAT GENERATION RATES, AND COOLANT FLOW RATES AS A FUNCTION OF TIME. IN ADDITION TO SOLVING PROBLEMS OF HEAT CONDUCTION IN A STRUCTURE. LION CAN HANDLE FORCED CONVECTION, FREE CONVECTION, AND RADIATION OR A COMBINATION OF THESE AT THE SURFACE OF THE STRUCTURE. THE OUTPUT CONSISTS OF COMPLETE NODAL TEMPERATURE DISTRIBUTIONS ALONG WITH SURFACE FLUXES AND HEAT TRANSFER COEFFICIENTS. AN OPTION IS INCLUDED IN THE PROGRAM FOR DETERMINING THE MEAN TEMPERATURE IN ANY SPECIFIED SECTION OF THE STRUCTURE.

4. METHOD OF SOLUTION - THE MODELING IS BASED ON THE CONCEPT OF NODAL POINTS CONNECTED BY ONE-DIMENSIONAL THERMAL CONDUCTANCE EQUATIONS IN AS MANY AS SIX LIPECTIONS SIMULTANEOUSLY. THE EXPLICIT, OR FIRST FORWARD DIFFERENCE METHOD, IS THEN USED TO DBTAIN THE SOLUTIONS TO THESE EQUATIONS FOR THE THREE-DIMENSIONAL FIELD. THE TEMPERATURE CHANGE FOR A SURFACE NODE IS CALCULATED BY APPLYING THE OHMS LAW ANALOGY FOR HEAT FLOW TO A NODE WITH NO CAPACITANCE.

5. RESTRICTIONS ON THE COMPLEXITY OF THE PROBLEM $11 * D 1+22 * D 2+20 * 03+61 * D 4+15 * D 5$ LESS THAN OR EQUAL TO 21000 VARI ABLE NUMBER OF SURFACE CONNECTIONS (D1)

VAR I ABLE NUMBER OF INTERNAL NODES (02)

VARI ABLE NUMBER OF SURFACE NODES (D3)

VAR IABLE NUMBER OF BOUNDARY NODES (D4)

VARI ABLE NUMBER OF COOLANT NODES (DS)

15 MATERIALS

$7 *$ D2 INTERNAL CONNECTIONS

12 CODLANT CHANNELS (EACH WITH 4 SIDES MAXIMUM)

75 PRINTOUTS

7 INTERNAL CONNECTIONS PER INTERNAL NODE

6 SURFACE CONNECTIONS PER SURFACE NODE

30 MEANS AND DIFFERENCES SETS

100 NDDES PER SET (WITHOUT EQUIVALENT LINEAR)

50 NODES PER SET (WITH EQUIVALENT LINEAR)

6 TYPES OF MEANS AND DIFFERENCES SETS

5 GRAPHS

6 CURVES PER GRAPH

13 TYPES OF QUANTITIES GRAPHABLE

4 SUB-CODLED NUCLEATE BOILING REGIONS

6. TYPICAL RUNNING TIME - THE APPROXIMATE RUNNING TIME ON THE CDC6600 IS 1 MINUTE PER 10 NODES FOR A STEADY-STATE PROBLEM AND 1.5 MINUTES PER 10 NODES FOR A TRANSIENT PROBLEM. 
7. UNUSUAL FEATURES OF THE PROGRAM - SUBCOOLED NUCLEATE BOILING MAY BE CONSIDERED. HOWEVER, THIS CONSIDERATION IS LIMITEO TO WATER.

8. RELATED AND AUXILIARY PROGRAMS - LION SUPERCEDES EARLIER IBMTO4 AND PHILCO 2000 PRCGRAMS CALLED TIGER.

9. STATUS - ABSTRACT FIPST DISTRIBUTED DECEMBER 1967. CDC6600 VERSION SUBMITTED OCTOBER 1967, REPLACED BY MODIFIED VERSION AUGUST 1968 , REPLACED BY MODIFIED VERSICN JANUARY 1970.

10. REFERENCES - J.R. SCHMID, G. L. LECHLITER, AND W. W. FISCHER, LION TEMPERATURE DISTRIBUTIONS FOR ARBITRARY SHAPES AND COMPLICATED BOUNDARY CONDITIONS, KAPL-M-6532 (EC-57), JULY 27, 1966. W. W. FISCHER, LION TALES A USERS MANUAL FOR THE LION THERMAL-STRUCTURAL EVALUATION CODE, KAPL-M-6533 (EC-58), JULY $31,1967$. JUNE 28,1968 . E. J. BINNEY, ADDENDUM TO LION REPORT, KAPL-M-6532, R. J. CULLEN, 6600 CALCOMP PLOTTER ROUTINES, KAPL NOTE, JULY $25,1966$. E. J. BINNEY, ADDITIONS TO LION CODE, KAPL NOTE, SEPTEMBER $30,1969$. LION4 INPUT DESCRIPTION, SPECIAL NOTE, AND LIMITS, KAPL NOTE, DECEMBER $30,1969$. ACC PRDGRAMMING NOTE 70-27, MAY 1970.

11. MACHINE REQUIREMENTS - THE PLOTTER ROUTINE APPLE IS USED TO PRODUCE THE INPUT REQUIRED BY THE ASSOCIATED CALCOMP PLOTTFR FOR GRAPHICAL CUTPUT.

12. PROGRAMMING LANGUAGES USED - FORTRAN IV AND ASCENT

13. OPERATING SYSTEM OR MONITOR UNDER WHICH PROGRAM IS EXECUTED SCOPE (CDC6600).

14. ANY OTHER PROGRAMMING OR OPERATING INFORMATION OR RESTRICTIONS BECAUSE OF THE LAPGE SIZE OF THE LION PROGRAM IT WAS NECESSARY TO SEGMENT THE PROGRAM.

15. NAME AND ESTABLISHMENT OF AUTHOR -

E. J. BINNEY

KNOLLS ATOMIC POWER LABORATORY

GENERAL ELECTRIC COMPANY

BOX 1072

SCHENECTADY, NEW YORK 12301

16. MATERIAL AVAILABLE - RESTRICTED DISTRIBUTION

MAGNETIC TAPE TRANSMITTAL

SOURCE DECK (4064 CARDS)

SAMPLE PROBLEM (158 CARDS)

REFERENCE RFPORTS, ADDENDUM, NOTES 
457.1

REACTOR CODE ABSTRACT 299

$-3-$

$05 / 70$

17. CATEGORY - H

KEYWORDS - TEMPERATURE DISTRIBUTION, FLUID FLOW, THERMAL, 3-DIMENSIONAL, HEAT TRANSFER, LIQUIDS, VAPORS 
457.2

9

๑ 
1. NAME OR DESIGNATION CF PROGRAM - SAFE-CREEP

2. COMPUIER FOR WHICH PROGRAM IS DESIGNED AND OTHERS UPON WHICH IT IS OPERABLE - UNIVAC 1108

3. NATURE OF PHYSICAL PROBLEM SOLVED - SAFE-CREEP PERFORMS A VISCOELASTIC ANALYSIS OF PLANE OR AXISYMMETRIC COMPOSITE CONCRETE STRUCTURES WITH AGE- AND TEMPERATURE-DEPENDENT CREEP DATA.

4. METHOD OF SOLUTION - THE PROGRAM USES THE FINITE ELEMENT METHOD WHICH REDUCES THE PROBLEM TO THE SOLUTION OF A SYSTEM OF COUPLED INTEGRAL EQUATIONS. THE METHOD OF SOLUTION IS ITERATIVE ON THE SPACE VARIABLE AND UTILIZES THE TRAPEZOIDAL RULE INTEGRATION FOR THE TIME VARIABLE.

5. RESTRICTIONS ON THE COMPLEXITY OF THE PROBLEM - MAXIMA OF 350 NODES

750 ELEMENTS

60 TIME INCREMENTS

6. TYPICAL RUNNING TIME - 90 MINUTES ARE REQUIRED FOR A FULL-CAPACITY PROBLEM.

7. UNUSUAL FEATURES OF THE PROGRAM -

8. RELATED AND AUXILIARY PRDGRAMS - GROWRK (ACC ABSTRACT 296 ), SAFE-PCRS (ACC ABSTRACT 250), SAFE-PLANE (ACC ABSTRACT 252), SAFE-SHELL (ACC ABSTRACT 253)

9. STATUS - ABSTRACT FIRST DISTRIBUTED CECEMBER 1967. UNIVACIIO8 VERSION SUBMITTED OCTOBER 1967.

10. REFERENCES - $Y$. RASHID AND W. ROCKENHAUSER, PRESSURE VESSEL ANALYSIS BY FINITE ELEMENT TECHNIQUE, GA-7810, 1967.

R. D. BROWN, PRIPERTIES OF CONCRETE IN REACTOR VESSELS, PAPER NO. 13, CONFERENCE ON PRESTRESSED CONCRETE PRESSURE VESSELS, LONDUN, MARCH 13-17, 1967.

F. J. DE ARRIAGA AND Y.R. RASHID, SAFE-CREEP, A COMPUTER PROGRAM FOR THE VISCOELASTIC ANALYSIS OF AXISYMMETRIC AND PLANE CONCRETE STRUCTURES, A USERS MANUAL, GA-8111, JULY $31,1967$.

11. MACHINE REQUIREMENTS - 65K MEMORY AND 13 TAPES

12. PROGRAMMING LANGUAGE USED - FORTRAN IV

13. OPERATING SYSTEM OR MONITOR UNDER WHICH PROGRAM IS EXECUTED -

14. ANY CTHER PROGRAMMING OR DPERATING INFORMATION OR RESTRICTIONS CALL TICKER REFFRS TO AN 1108 SYSTEM ROUTINE FDR LOGGING JOB TIME USED. A SUBSTITUTE ROUTINE WILL BE REQUIRED FOR USE OF THIS PROGRAM ON ANOTHER MACHINE. 
1. NAME OR DESIGNATION OF PROGRAM - 2DR

2. COMPUTER FOR WHICH PROGRAM IS DESIGNED AND OTHERS UPON WHICH IT IS DPERARLE - UNIVAC 1108, CDC 6600,3600

3. NATURE OF PHYSICAL PROBLEM SOLVED - 2DB IS A FLEXIBLE, TWO-DIMENSIDNAL ( $X-Y, R-Z$, R-THFTA, HEX GEOMETRY) DIFFUSION CODE FOR USE IN FAST REACTOR ANALYSES. THE CDDE CAN BE USED TO -

(A) COMPUTE FUEL BURNUP USING A FLEXIBLE MATERIAL SHUFFLING SCHEME,

(B) PERFORM CRITICALITY SEARCHES ON TIME ABSORPTION (ALPHA), MATERIAL CONCENTRATIONS, AND REGION DIMENSIONS USING A REGULAR OR ADJOINT MCDEL. CRITICALITY SEARCHES CAN BE PERFORMED DURING BURNUP TO COMPENSATE FOR FUEL DEPLETION,

(C) COMPUTE FLUX DISTRIBUTIONS FOR AN ARBITRARY EXTRANEOUS SOURCE.

4. METHCD OF SOLUTION - STANDARD SOURCE-ITERATION TECHNIQUES ARE USED. GRDUP REBALANCING AND SUCCESSIVE OVERRELAXATION WITH LINE INVERSION ARE USED TO ACCELERATE CONVERGENCE. MATERIAL BURNUP IS BY REACTOR ZONE. THE BURNUP RATE IS DETERMINED BY THE ZONE AND ENERGY (GROUP) AVERAGED CROSS SECTIONS WHICH ARE RECOMPUTED AFTER EACH TIME-STEP. THE ISOTOPIC CHAINS, WHICH CAN CONTAIN ANY NUMBER OF ISOTOPES, ARE FORMED BY THE USER. THE CODE DOES NOT CONTAIN BUILT-IN OR INTERNAL CHAINS.

5. RESTRICTIONS ON THE CCMPLEXITY OF THE PROBLEM - SINCE VARIABLE DIMENSIONING IS EMPLCYED, NO SIMPLE BOUNDS CAN BE STATED. THE CURRENT 1108 VERSION, HOWEVER, IS NOMINALLY RESTRICTED TO 50 ENERGY GROUPS IN A $65 \mathrm{~K}$ MEMORY. IN THE 6600 VERSION THE POWER FRACTION, AVERAGE BURNUP RATE, AND BREEDING RATIO CALCULATIONS ARE LIMITED TO REACTORS WITH A MAXIMUM OF 50 ZONES.

6. TYPICAL RUNNING TIME - A KEFF CALCULATION WITH A $30 \times 30$ MESH AND FOUR ENERGY GROUPS REQUIRES APPROXIMATELY ONE MINUTE. A TYPICAL BURNUP CALCULATION REQUIRES ROUGHLY TWICE THE MACHINE TIME OF A KEFF CALCULATION. THE SAMPLE PROBLEM REQUIRES ABOUT 3 MINUTES ON THE CDC3600.

7. UNUSUAL FEATURES OF THE PROGRAM - THE INPUT DATA ARE ARRANGED SO THE CODE CAN BE EASILY USED FOR KEFF AND SEARCH CALCULATIONS WITHDUT BURDENING THE USER WITH BURNUP PARAMETERS.

8. RELATED AND AUXILIARY PROGRAMS - THE INPUT DATA IE.G., CROSS SECTIONS, FLUX DUMPS, GEOMETRY, AND COMPOSITION SPECIFICATIONS) ARE COMPATIBLE WITH THE LOS ALAMOS ONE- AND TWO-DIMENSIONAL TRANSPORT CODES, DTF4 (ACC ABSTRACT 209) AND 2DF, AND THE BATTELLE.PERTURBATION CODE, PERT4 (ACC ABSTRACT 304). ALL FOUR CODES USE THE SAME INPUT MODULE. THE LOGICAL FLOW OF 2DB IS PATTERNED AFTER THE 2DF CODE. 
REACTOR CODE ABSTRACT 325

$05 / 70$

9. STATUS - ABSTRACT FIRST DISTRIBUTED JUNE 1968. UNIVAC 1108 VERSION SUBMITTED FEBRUARY 1968, REVISED APRIL 1969.

CDC 6600 VERSION SUBMITTED FEBRUARY 1969.

CDC 3600 VERSION SUBMITTED FEBRUARY 1970.

10. REFERFNCES - W. W. LITTLE, JR. AND R. W. HARDIE, 2DB, A TWODIMENSIUNAL DIFFUSION-BURNUP CODE FOR FAST REACTOR ANALYSIS, BNWL-640, JANUARY 1968, ADDENDUM AND ERRATA, APRIL 12, 1968.

W. W. LITTLE, JR. AND R. W. HARDIE, 2DB USERS MANUAL

- REVISION 1, BNWL-R31, REV. 1, FEBRUARY 1969.

T. J. HIRONS AND R. D. ODELL, CDC-6600 VERSION DF

2DB, A TWO-DIMENSIONAL DIFFUSION-BURNUP CODE FOR FAST REACTOR

ANALYSES, LASL NOTE K-1-L-776, FEBRUARY 5, 1969.

K. D. LATHPOP, DTF-IV, A FORTRAN-IV PROGRAM FOR SOLV-

ING THE MULTIGRDUP TRANSPORT EQUATION WITH ANISOTROPIC SCATTER ING, LA-3373, JULY 15, 1965.

2DF, A TWO-DIMENSIDNAL TRANSPORT CODE FROM THE LOS ALAMOS SCIENTIFIC LABORATORY (UNPUBL ISHED).

R. W. HARDIE AND W. W. LITTLE, JR., PERT-IV, A TWODIMENSIONAL PERTURBATION CODE IN FORTRAN-IV, BNWL-409, APRIL 1967.

11. MACHINE REQUIREMFNTS - 65K MEMORY AND THREE PERIPHERAL STORAGE DEVICES

12. PROGRAMMING LANGUAGE USED - FORTRAN IV

13. OPERATING SYSTEM UR MONITOR UNDER WHICH PROGRAM IS EXECUTED -

14. ANY CTHER PROGRAMMING OR OPERATING INFORMATION OR RESTRICTIONS -

15. NAME AND ESTABLISHMENT OF AUTHORS -

1108

W. W. LITTLE, JR. AND R. W. HARDIE

BATTELLE-NORTHWEST LABORATORY

P. O. BOX 999

RICHLAND, WASHINGTON 99352

6600 T. J. HIRONS AND R. D. ODELL

UNIVERSITY OF CAL IFORNIA

LOS ALAMOS SCIENTIFIC LABORATORY

P. D. BOX 1663

LOS ALAMOS, NEW MEXICO 87544

3600 M. LEGAN

ARGONNE CODE CENTER

ARGONNE NATIONAL LABORATORY

9700 SDUTH CASS AVENUE

ARGONNE, ILLINOIS 60439

16. MATERIAL AVAILABLE - MAGNETIC TAPE TRANSMITTAL

SOURCE DECKS $(1108-2425$ CARDS, 6600-3110 CARDS, 3600-3074

(ARDS)

BINARY DECK $(3600-1496$ CARDS) 
16. MATERIAL AVAILABLE (CONTINUED) SAMPLE PROBLEMS (1108-63 CARDS, 6600-169 CARDS, 3600-63 (ARDS) REFERENCE REPORTS, BNWL-640 AND BNWL-831, AND LASL NOTE

17. CATEGORY - D

KEYWORDS - 2-DIMENSIONAL, MULTIGROUP, REACTIVITY, CRITICALITY SEARCHES, DEPLETION, DIFFUSION EQUATIONS, $X-Y, R-Z$, R-THETA GEOMETRIES, DTF4 CODES, PERT 4 CODES 
510.2

$\bullet$

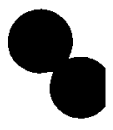


REACTOR CODE ABSTRACT $385 \quad 05 / 70$

1. NAME OR DESIGNATION OF PROGRAM - COHAE/PREP

2. COMPUITER FIR WHICH PROGRAM IS DESIGNED AND OTHFRS UPON WHICH IT IS OPERABLF - UNIVACIIOB

3. NATUFE TF DHYSICAL PROBLEM SOLVED - THF PROGRAMS, PRFP and COHBE CALCULATE THF COHERFNT ONF-PHONON SCATTER ING LAW FOR POLYCRYSTALLINE BFRYLLIUM, USING AN I SOTROPIC DEBYE-WALLER FACTOR AS AN APPROXIMATION FOR BFRYLLIUM. THE DEBYF-WALLFR FACTOR W IS CONSISTENT WITH THE DEFINITION FXP**(-2*W*ALPHA) IN THE SCATTERING LAW.

4. MFTHOD DF SOLUTION - THE FREQUFNCIES AND THE PILARITATION VECTORS FOR AN IRREDUCIBLE SRILLOUIN ZTNE ARE OBTAINED USING THF SLUTSKY AND GARLAND FRRM DF THE DYNAMICAL MATR IX WITH FORCE CONSTANTS DETFRMINFD RY SCHMUNK. FT AL. THESE VALUES FOR A COARSE MESH ARE WR ITTEN ON MAGNFTIC TAPF. THE CODE THFN COMPUTES THE SCATTERING LAW BY SUMMING DVER RECIPROCAL LATTICE VECTORS, THE NUMRER OF WHICH DEPFNDS ON ALPHA MAX. FOR EACH RECIPROCAL LATTICE VECTOR THE STRUCTURE FACTORS APE COMPUTEN FOR ALL POINTS TF THE CDARSE MESH, AND THE CONTRIBUTION TO THE SCATTFRING LAW IS CALCULATED FOR EACH POINT ON A FINE MESH BY LINEAR INTERPOLATION OF THF STRUCTURE FACTORS. THE CONTRIBUTIONS ARE STIRED IN A REGION DELTA ALPHA, DELTA RETA AROUND THF APPROPRIATE ALPHA, BETA TO GIVE THE SCATTERING LAW S(ALPHA, BETA) AS A DOURLE HISTOGRAM.

5. RESTRICTIONS ON THE COMPLEXITY OF THE PRORLEM - MAXIMA TF 90 ALPHA GRTUPS

40 BETA GRTUPS

6. TYPICAL RUNNing tIME - the maximum VAlue of alpha at which the SCATTERING LAW IS COMPUTED DETERMINES COMPUTATION TIME, WHICH INCREASES APPROXIMATELY AS ALPHA TO THE $3 / 2$ POWER. A TYPICAL PROBLEM MAY REQUTRF 30 MINUTES.

7. UNUSUAL FEATURES DF THE PROGRAM - COHBE REDUCES MESH SIZE DEPENDENCE OF RESULTS, ASSTCIATED WITH COHERENT SCATTERING LAW CALCULATIONS.

8. RELATEN AND AUXILIARY PROGRAMS - PREP PREPARES THE MAGNETIC TAPE WITH THE FREOIIENCIES AND PRLARIZATION VECTORS FOR BFRYLLIUM. COHBF WRITES THE SCATTERING LAW ON A MAGNETIC TAPE SUITABLF FOR INPUT TO THE FLANGE CODE (ACC ABSTRAT,T 247).

9. STATUS - ABSTRACT FIRST DISTRIBUTED MAY 1970. UNIVAC 1108 VERSION SUBMITTED AUGUST 1969.

10. REFERENCE - G. M. BDRGONOV I, COHERENT SCATTERING LAW FOR PDLYCRYSTALLINE BERYLLIUM, GA-9364, MAY 16, 1969.

11. MACHINE REQUIREMENTS - 45K MFMORY AND? MAGNFTIC TAPFS 
REACTOR CONE ABSTRACT $385 \quad-2-\quad 05 / 70$

12. PRTGRAMMING LANGUAGF USED - FORTRAN IV

13. DPERATING SYSTFM OR MONITIR UNDER WHICH PROGRAM IS EXECUTED EXEC II.

14. ANY OTHER PROGRAMMING OR OPERATING INFORMATION OR RESTRICTIONS -

15. NAME AND ESTABLISHMFNT OF AUTHOR -

G. M. BORGONOVI

GULF GENERAL ATOMIC INCORPORATED

P. O. BOX 608

SAN DIEGO, CALIFORNIA 92112

16. MATERIAL AVAILABLE -

SUURCE DECKS (CNHRE 1108-230 CARDS, PREP 1108-319 CARDS)

SAMPLF PRORLEMS (COHBE 1108-37 CARDS, PREP 1108-3 CARDS)

REFERFNCE RFPORT

17. CATEGORY - A

KEYWORDS - INELASTIC SCATTERING, CRYSTALS, BE, SCATTERING LAH, CROSS SECTIONS 
RFACTOR CODDE ABSTRACT 386

$05 / 70$

1. NAME OR DESIGNATION OF PROGRAM - DATATRAN

2. COMPUTER FDR WHICH PROGRAM IS DESIGNED AND DTHERS UPDN WHICH IT IS OPFRABLF - CDC,6600

3. NATURF IF PHYSICAL PROBLEM SOLVED - DATATRAN SUPPLIFS A LINKAGE SYSTEM FCR MODULARIZED PROGRAMS, ENABLES A HIERARCHICAL NAMING, TECHNIQUE, AND SIMPLIFIES HANDLING OF STRUCTURED DATA LISTS.

4. METHOD OF SULUTION - A DRECOMPILER SCANS THE DATATRAN job DECK, REPLACING DATATRAN STATEMENTS WITH FORTRAN SUBROUTINE CALLS. $\triangle$ SFT OF SUBROUT INFS TO INTERPRET THESE CALLS IS THEN LOADFD WITH THE JOB AS PART OF THE BASE GVERLAY.

5. RESTRICTIONS ON THF COMPLFXITY OF THE PROBLEM - MODULES ARF LIMITEN TO 5OK OCTAL WORDS. DATA LISTS ARE LIMITFD ONLY RY DISK CAPACITY, BUT DATATRAN OPERATIONS MAY BECOME INEFFICIENT WHEN DFALING WITH MIRF THAN SEVERAL HUNDRED THOUSAND WORDS TF DATA.

6. TYPICAL RUNNING TIME - 30 SECONDS ARE REQUIRED FOR THF PRECOMPILER AND SFTTING UP TO RUN THE FIRST MODULE.

7. UNUSUAL TEATURES OF THF PROGRAM - DATATRAN ALLOWS ANY PATH THROUGH A SERIES OF PROGRAMS (BY SIMPLE KALL STATEMENTS), TRANSFERS BLOCKS DF DATA FROM PROGRAM TO PROGRAM SIMPLY BY NAME ASSIGNMENT, ALLOWS A HIFRARCHICAL STRUT,TURF TD BLOCKS OF DATA WHEREBY THE NAME ALONE CAN RT: USFD TO MANIPULATE ALL DR ONLY A SELECTED PORTION DF THE DATA, ALLNWS EASF IN SAVING AND RFTRIEVING BLOCKS OF DATA, IN PARTICULAR, RETRIEVAL SEARCHING AT LOW FIELD LENGTH. DATATRAN MOST BENEFITS THAT CLLASS OF PRDRLEMS WHERE INTERFACING IS IMPORTANT AMONG MANY COMPUTER PROGRAMS IN A COMPLEX DESIGN PROCESS. DATATRAN ALLOWS VERY GFNERAL AND FLEXIBLE WAYS OF PREPARIN, INPUT.

8. RELATED AND AUXILIARY PROGRAMS - DATATRAN USFS THF KAPL DATAPDOL DISK FILE SYSTFM AND ITS RELATFD PP PROGRAMS. DATATRAN INCLUDES A NUMBER OF UTILITY ROUTINES.

9. STATUS - ARSTPACT FIRST DISTRIBUTED MAY 1970. CDC 6600 VFR.SION SUBMITTED JULY 1969.

10. REFERFNCES - W. F. SCHILLING AND H. J. KOPP, DATATRAN MODULAR PROGRAMMING SYSTEM FOR A DIGITAL COMPUTER, KAPL-M-6997L, JULY 1 , 1968 .

J. D. MORRIS AND H. J. KOPP, DESCRIPTION OF THE FIRTRAN PROGRAM NTSCAN, KAPL-M-7036L, DECEMBER 16, 1968.

W. E. SCHILLING, DATATRAN SYSTEM NOTICE, SUGGESTED LOADING AND TFSTING PROCEDURES, AND EXPLANATORY NOTFS APPLICABLE TO INCORPMRATION TF MATATRAN SYSTFM, APRIL $30,1969$.

F. E. KAZMIERCZAK, DATAPOOL A DATA STORAGE AND RETRIFVAL SUBROUTINF, JANUARY 23, 1969. 
11. MACHINE RFQUIREMENTS - MINIMUM REQUIREMENTS ARE A 65,536 CFNTRAL MEMORY AND AT LEAST HALF OF ONE CDC6638 DISK WHICH CAN BE DEDICATEN TO DATATRAN.

12. PROGRAMMING LANGUAGFS USFD - FORTRAN IV AND COMPASS

13. OPERATING SYSTEM TR MONITOR UNDER WHICH PROGRAM IS FXECUTED MATATRAN TPERATES UNDER SCOPE 3.1.X. THE DPERATING SYSTEM MUST ALLOW AT LEAST 144, OOก OCTAL FIFLD LENGTH FOR A DATATRAN JOA.

14. ANY CTHER PROGRAMMING OR OPERATING INFORMAT ION OR RESTR ICTIDNS THE PRESENT VFRSION OF DATATRAN REQUIRES SOME MODIFICATION TO THE SCOPF IPERATING SYSTFM. DATATRAN MAKES USE OF THE KAPL DATAPOOL. THIS IN TURN REQUIRFS DEDICATED DISKS IDR PORTIONS OF A DISK UNITI. MMOIFICATION OF THE STACK PRDCESSOR AND/OR MONITOR PROGRAMS IS THUS RFQUIRFO. A VERSIDN OF DATATRAN IS AVAILABLE WITHMUT THFSE RESTRICTIONS RUT IT REQUIRES THAT A LARGE AMOUNT OF ECS BF MADF AVAILARLF TO IT. THE SIZE OF PROBLEMS THAT CAN BE RUN WITH THIS VFRSIDN OF MATATRAN IS CONSIDERABLY SMALLFR THAN WITH THE DISK VERSION.

15. NAME AND ESTARLISHMENT OF AUTHCRS -

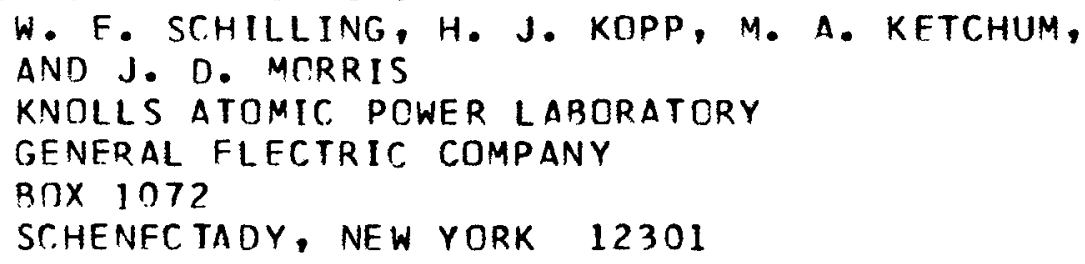

16. MATFRIAL AVAILABLE - MAGNETIC TAPE TRANSMITTAL FILE I TATATRAN FDITSYM FORMAT (213 BINARY RECHRDS)

FILE 2 MODIFICATIONS TO DATATRAN (276 CARDS) REFERENCE RFPORTS AND NOTES

17. CATEGORY - M

KEYWORNS - PROGRAMMING LANGUAGES, DATA PROCESSING 
1. NAME OR DESIGNATION OF PROGRAM - CITATION

2. COMPUTER FOR WHICH PROGRAM IS DESIGNEN AND OTHERS UPON WHICH IT IS OPFRABLE - I3M360

3. NATURE OF PHYSICAL PRDBLEM SOLVED - CITATION IS DESIGNED TD ATTACK THE RFACTOR CORE DEPLETION AND DYNAMICS PROBLEMS IN A GENERAL SENSE. A VARIFTY OF MATHFMATICAL FORMULATIONS IS AVAILABLE TO CHOOSF FROM - FDR EXAMPLE, THF GENERAL NEUTRON-FLUX-EIGENVALUE PRIBLEM MAY BF SOLVED IN ONE-, TWO- OR THREE-DIMENSIONAL GEOMETRY WITH ARBITRARY SCATTERING IN THE DISCRETE-ENERGY, FINITEDIFFERENCE DIFFUSION-THEORY FORMULATION. CERTAIN OTHER FORMULATIONS ARE BEING ADDED AND STILL OTHERS WILL BE INCORPDRATED. NOW THF PROGRAM WILL SULVE EIGENVALUE PROBLEMS WITHIN A FINITEDIFFERENCF REPRESENTATION DF THE DIFFUSION THEORY APPROXIMATION TO NEUTRON TRANSPORT IN MULTIGRCUP FORM WITH ARBITRARY SCATTERING. THE EIGENVALUE PROBLEM MAY INVOL VE THE DETERMINATION OF THE EFFFCTIVE MULTIPLICATION FACTOR, OR BE A DIRECT CRITICALITY SEARCH ON BUCKLINF, ON $1 / V$ ABSORBER, OR ON THE CONCENTRATIONS OF SPECIFIED NUCLIDES WHICH MAY INCLUDE FUEL. THE ADJOINT PRORLEM MAY BE SOLVFD AND PERTURBATION CALCULATIONS PERFORMED. UP TO THREE GEOMFTRIC DIMENSIONS MAY BE CONSIDERED INCLUDING $X-Y-Z$, R-THETA-Z, AND HFXAGONAL-Z CDORDINATF SYSTEMS.

4. METHOD OF SOLUTION - EXPLICIT, FINITF-DIFFERENCE APPROXIMATIONS IN SPACE AND TIME HAVE BEEN GIVEN PREFERENCE ALTHOUGH CERTAIN OTHER TEC.HNIQUFS ARE BEING INCORPORATED. THE NEUTRON-FLUX-EIGENVALUE PRCBLEMS ARE SOLVFD BY DIRECT ITERATION TO DETERMINE THE MULTIPLICATION FACTOR OR THE NUCLIDE DENSITIES REQUIRED FOR A CRITICAL SYSTEM.

5. RFSTRICTIONS ON THE COMPLEXITY OF THE PROBLEM - CITATION HAS BEEN DES IGNED TO ATTACK PROBLEMS WHICH CAN BE RUN IN A RFASONABLE AMOUNT OF TIMF. STORAGF OF DATA IS ALLOCATED DYNAMICALLY TO GIVE THE USER FLEXIBILITY IN DIMENSIONING. TYPICALLY, A FINITEDIFFERENCE DIFFUSION PROBLFM COULD HAVE 200 DEPLETING ZONES, 10,000 NUCLIDE DENSITIES AND 30,000 SPACE-ENERGY POINT FLUX VALUES WITH ALL FQUATION CONSTANTS FOR THE ITERATIVE EIGENVALUE PROBLEM AVAILABLE IN STORAGE, OR 60,000 SPACE-ENERGY POINT FLUX VALUES WITH I/O.

6. TYPICAL RUNNING TIME - THE TWO-DIMENSIDNAL FINITE-DIFFERENCF DIFFUSION THEORY EIGENVALUE PROBLEMS ITERATE AT A RATE OF ABOUT 0.1 MILLISECOND PER POINT PER ITERATION WITH ALTERNATING-DIRECTION LINE RELAXATION (TWO SWEFPS PER ITERATION) WITH B-BYTE WDRDS ON THE IBM360/91 (0.5 ON THE 360/75). SINCE ABOUT 30 ITERATIONS ARE REQUIRED FOR EACH SUCCEEDING EIGENVALUE PROBLEM, MACHINE TIME FOR A DEPLETION OR DYNAMICS PROBLEM IS ABOUT .003 SECOND PER POINT PER TIMF-STEP. THIS TIME SHOULD BE MULTIPLIED BY THE NUMBER OF TIMES EACH STEP IS TO BE REPEATED (BY THE NUMBER OF TIMES EIGENVALUE PRDBLEMS ARE REPEATEDI. MACHINE TIME FOR MOST AUXILIARY CALCULATIONS IS USUALLY INSIGNIFICANT. FOR A REPRESENTATIVE FAST 
6. TYPICAL RUNNING TIME (CONT INUED)

RREEDFR DEPLETION PROBLFM, 68 PERCENT OF THE MACHINE CPU TIME HAS SPFNT IN SILVING EIGENVALUE PROBLEMS.

7. UNUSUAL FEATURES OF THE PRMGRAM - CITATION IS CONS IDERED UNUSUAL IN THAT IT SHOULD BE RELATIVELY EASY TO MODIFY THE CONTENTS OR TO ADD RDUT INES . FFFECT IVE TECHNIQUES ARE INCORPORATED TO DF TERMINE A CRITICAL SYSTEM. MORE THAN ONE SET OF MICROSCOPIC CROSS SECTIONS MAY BE USED IN A SYSTEM AND NUCLIDE BEHAVIOR CAN BE FOLLOWED ON A SUB-ZONF SCALF WITHIN DEPLETION REGIONS. THE DATA REQUIRED FOR NUCLIIDF CHAIN RELATIONSHIPS, FOR DELAYED NEUTRONS AND FDR CALCULATING THE CAPTURF GAMMA SOURCE CAN BE SUPPLIED ON THE MICROSCOPIC CROSS SECTION TAPE ALLOWING AUTOMATION RF MANY TYPES OF CALCULATIONS. THE USER HAS FLFXIBLE CONTROL OVER THE ROUTF DF A CALCULATION AS WELL AS OF THE EDIT OF RESULTS.

8. RELATFD AND AUXILIARY PRCGRAMS - THE MICROSCOPIC CROSS SECTION TAPE. FIR THIS PROGRAM MAY BE GENERATED BY VARIOUS CODES, BUT XSDRN IACC ABSTRACT 393 I IS DESIGNED SPECIFICALLY FOR THIS PURPOSE.

9. STATUS - AASTRACT FIRST DISTRIBUTED MAY 1970. IBM 360 VER SION SURMITTED JULY 1969, REVISED JANUARY 1970, REVISED APRIL 1970.

10. RFFERENCFS - T. B. FOWLFR AND D. R. VONDY, NUCLEAR REACTOR CORE ANALYSIS CODF CITATION, ORNL-TM-2496, JULY 1969.

N. M. GREFNE AND C. W. CRAVEN, JR.. XSDRN, A DISCRETE CRIINATES SPECTRAL AVERAGING CODE, ORNL-TM-2500, JULY 1969.

11. MACHINE REQUIREMENTS - IBM 360/91 OR EQUIVALENT WITH AT LEAST 128,000 4-BYTE WORDS OF DIRECTLY-ADDRESSABLE CORF STORAGE, 8 1/0 DEVICES, EXCLUDING INPUT AND OUTPUT DEVICES AND SYSTEM REQUIREMENTS.

12. PRDgRAMMING LANGUAge USED - Fortran IV

13. DPERATING SYSTEM OR MONITOR UNDER WHICH PROGRAM IS EXECUTED OS/360.

14. ANY OTHER PROGRAMMING OR IPERATING INFORMATION OR RESTRICTIONS NOW CITATION CONTAINS ABOUT 15,000 SOURCE STATEMENTS, AND WITHOUT OVERLAY, STORAGF FOR THE CODE INSTRUCTIONS WOULD APPROACH 100,000 4-RYTE WTRDS.

15. NAME AND ESTABLI SHMENT OF AUTHORS -

T. B. FOWLER AND D. R. VONDY

DAK RIDGE NAT IONAL LABTRATORY

P. D. BOX Y

OAK RIDGE, TENNESSE 37830

16. MATERIAL AVAILABLF - MAGNETIC TAPE TRANSMITTAL SOURCE DECKS ICITATION 14,902 CARDS, CROSS-SECTION WRITER 1891 (ARDS ) 
641

RFACTOR CODE ABSTRACT 387

$-3-$

$05 / 70$

16. MATERIAL AVAILABLF (CONTINUFO)

SAMPLE ORIBLEMS (CITATION 111 CARDS, CROSS-SECTION WRITER 344 (ARกS)

REFFRENCE RFPחRT, ORNL-TM-2496

17. CATEGTRY - $K$

KEYWOROS - 1-IIMENSIONAL, ?-DIMFNS IONAL, 3-DIMENS IONAL, MULTIGROUP, DIFFUSINN, CRITICALITY SEARCHES, BUCKLING, $X-Y-Z, R-T H E T A$, HEXAGONAL, XSDRN CODES 
1. NAME DR DES IGNATION OF PROGRAM - ETOX

2. COMPUTER FOR WHICH PROGRAM IS DESIGNED AND OTHERS UPON WHICH IT IS OPERABLE - UNIVAC 1109

3. NATURF OF PHYSICAL PRDBLEM SOLVED - ETOX (ENDF/B TO IDX) CALCULATES MULTIGROUP CONSTANTS FOR NUCLEAR REACTOR CALCULATIONS USING DATA FROM THE EVALUATED NUT,LEAR DATA FILE (ENDF/B). THE CODE IS DES IGNED TO COMPUTE AND PUNCH -

(A) INFINITE TILUTE CROSS SECT IONS,

(B) TEMPERATURE DEPENDENT SELF-SHIELDING FACTORS FOR ARBITRARY VALUES OF MICROSCOPIC SIGMAO (TOTAL CROSS SECTION PER ATOM) IN THE RUSSIAN (BONDARENKO) FORMAT, AND

(C) INELASTIC SCATTERING PROBABILITY MATRICES.

4. METHOD OF SMLUTION - MICROSCOPIC CROSS SECTION VALUES ARE CONSTRUCTED AS SPECIFIED BY THF ENDF/B. GROUP CONSTANTS ARE DBTAINED BY INTEGRATING THE MICROSCOPIC DATA OVER GROUP INTERVALS USING THE FLUX WEIGHTING SCHEME

PHI (U) IS PROPORTIONAL TO 1/SIGMAT(U), SIGMAT(U)=N(J)*MICROSOPIC SIGMAT(J)+N(J) *MICROSCOPIC SIGMAO.

INTEGRATION METHODS USED I NCLUDE ROMBERG, GAUSSIAN QUADRATURE, NPOINT, SIMPSCN AND TRAPEZIIDAL. THE CODE ALLOWS AS INPUT ARBITRARY SETS OF VALUES OF GROUP ENERGIES, TEMPERATURES, AND MICROSCOPIC SIGMAO, S.

5. RESTRICTIDNS ON THE COMPLEXITY CF THE PROBLEM -

6. TYPICAL RUNNING TIMF - 26-GROUP DATA FOR A REPRESENTATIVE SET OF 14 ISOTDPES REQUIRES ABDUT 28 MINUTES.

7. UNUSUAL fEATURES TF THE PROGRAM -

8. RELATEO AND AUXILIARY PROGRAMS - THE FORMAT OF THE INPUT DATA IS COMPATIRLE WITH THE ENDF/B DATA TAPE. THE FORMAT OF THE OUTPUT IS COMPATIBLE FDR INPUT TO THE COMPUTER CODE 1 DX (ACC ABSTRACT 374 ), A MULTIPURPOSE DIFFUSION CODF FOR GENERATING CROSS SECTIONS TO BE USFD IN FAST REACTOR ANALYSIS.

9. STATUS - ABSTRACT FIRST DISTRIBUTED MAY 1970. UNIVACIIOB VERSIDN SUBMITTED JULY 1969, REVISED APRIL 1970.

10. REFERENCES - R. E. SCHENTER, J. L. BAKER, AND R. B. KIDMAN, ETOX, A CODE TO CALCULATE GROUP CONSTANTS FOR NUCLEAR REACTOR CALCULATINNS, BNWL-1OO?, MAY 1969.

CARD INPUT INSTRUCTIONS AND DPERATING INSTRUCTIONS, BNWL NOTE.

H. C. HONECK, ENDF/B, SPECIFICATION FDR AN EVALUATED NUCLEAR DATA FILE FOR RFACTOR APPL ICATIONS, BNL-50066 (T-46), MAY 1966, RFVISED JULY 1967.

R. W. HARDIE AND H. W. LITTLE, JR., IDX, A ONE- 
10. RFFERENCES (CONTINUED)

DIMENSIONAL DIFFUSION CODE FRR GENERATING EFFECTIVE NUCLEAR CROSS SECT INNS, BNWL-954, MARCH 1969.

I. I. BINDARENKC (ECITOR), GROUP CONSTANTS FOR

NUCLEAR REACTIR CALCULATIONS, CONSULTANTS BUREAU, NEW YORK, 1964.

W. ROMPFRG, VEREINFACHTE NIJMER ISCHE INTEGRATION, DET. KONG. NORSKE VIDENSKABFR SFLSKAB FORHANDLINGFR, BAND 29, NR. 7, 1955.

M. ALBRAMOW ITZ AND I. A. STEGUN (EDITORS), HANDBDOK OF MATHEMATICAL FUNR,TIONS, DCVER PUBLICATIONS, INC., P. $916,1965$. D. M. OSHEA, B. J. TOPPEL, AND A. L. RAGO, MC* $* 2, A$ CODE TO CALCULATE MULTIGRMUP CRISS SECTIONS, ANL-7318, JUNE 1967.

11. MACHINE REQUIREMENTS - 65K MEMDRY, 3 TAPE UNITS, AND RANDOM ACCESS DRUM STRRAGF

12. PRDGPAMMING LANGUAGE USED - FORTRAN IV

13. DPERATING SYSTEM OR MONITOR UNDER WHICH PRDGRAM IS EXECUTED -

14. ANY OTHER PRIGRAMMING TR OPERATING INFORMATION OR RESTRICTIONS ETOX USES RANDOM DRUM STORAGE TO MAKE MAXIMUM USE DF CORE.

15. NAME AND ESTABL ISHMENT OF AUTHDRS -
$R$. E. SCHENTER AND J. L. BAKER
PHYSICS AND ENGINEERING DIVISION
R. B. KIDMAN
FFTF REACTOR PHYSICS ANO OPERATIONS
BATTELLE MEMORIAL INSTITUTE
PACIFIC NOR THWEST LABORATORY
RICHL AND, WASHINGTON 99352

16. MATERIAL AVAILABLE - MAGNetic tAPE transmittal

SOURCE DFCK (5139 CARDS)

SAMPLE PRORLEM (72 CAROS)

REFFRENCE RFPORT, BNWL-1002, AND BNWL NOTE

17. CATEGORY - B

KEYWORDS - GROUP CONSTANTS, INELASTIC SCATTERING, FAST REACTORS, TEMPERATURE, INPUT DATA, ENDF/B, IDX CODES 
1. NAMF TR DESIGNATION TF PROGPAM - STINT3

2. COMPUTER FDR WHICH PROGRAM IS DESIGNED AND OTHFRS UPON WHICH IT IS OPFRABLE - CDC.6500

3. NATURE TF PHYSICAL PRDBLFM SCLVFD - STINT3 SOLVES STATIC IEIGENVALUF, AND TIME-DEDFNDENT SYSTEMS TF R.OUPLFD, ONE-DIMENSIONAL, DIFFUSION TYPE FQUATIONS IN SLAB GEOMFTRY AND IS PRIMARILY INTENDED FOR SOLVING SINGLE-CHANNEL, FLUX-SYNTHES IS EQUATIDNS. THE CONF PROVIDES FOR CONTROL ROD MOTION AND TFMPFRATURE FEEOBACK.

4. METHOD RF SOLUTION - THF SYSTEM OF DIFFERENCE EQUAT IONS IS SOLVED BY THE FDRWARD-ELIMINATION, BACKWARD-SURSTITUTION METHOD.

5. RESTRICTIONS ON THE COMPLEXITY CF THF PROBLEM - MAXIMA OF -

6 FQUATIONS IGR NUPS * MODESI

5) AXIAL MFSH INTERVALS

6 DELAYFD NEUTRTN GROUPS

40 CONTROL RON AND TEMPERATURE FEEDRACK CHANNELS

6. TYPICAL RUNNING TIMF - 3 SFCCNDS PER TIME-STEP ARE REQUIRED FOR THF LARGFST POSSIBLE PRDBLEM.

7. UNUSUAL FTATURFS OF THF PROGRAM -

(A) EVERY TRANSIENT CALCULATION IS AUTOMATICALLY PRECEDFD BY AN FISENVALUF PROBLEM TO ESTABLISH CRITICAL INITIAL CONDITIONS. THE CRITICAL POWER DISTRIBUTION IS USED TO CALCULATE AN INITIAL TEMPERATURE DISTRIBUTION.

(8) THF CONE CALCULATES THERMAL FEEDBACK USING A SIMPLE DPENLOOP THERMALHYDRAULIC MODEL.

(C) STINT3 CAN ALSO BF USFD FOR ONE-DIMENSIONAL, FEW-GRDUP TRANSIFNT CALCULATIONS.

8. RELATED AND AUXILIARY PROGRAMS -

9. STATUS - ARSTRACT FIRST DISTRIBUTED MAY 1970. CDC6600 VEPSION SUBMITTED JULY 1969.

10. RFFERFNCE - C. H. AMAMS, R. A. RYOIN, AND W. M. STACEY, JR., STINT - SINGLF-CHANNEL, SPACE-TIME SYNTHESIS CODES FOR MULTIDI MFNSIMNAL NFUTRON DIFFUSION PROBLEMS, KAPL-3449, MAY 1969.

11. MACHINE REQUIREMENTS - 64K MEMORY

12. PRDGRAMMING LANGUAGF USED - FORTRAN IV

13. OPFRATING SYSTEM OR MONITOR UNDER WHICH PROGRAM IS FXECUTED SCNPE 3.1 .

14. ANY CTHER PROGRAMMING OR OPERATING INFORMATICN OR RESTRICTIONS STINT3 SNLVES THE SYNTHESIS EQUATIONS ONLY. THF TASK OF GENERATING THF SYNTHFSIS EXPANSION FUNCTIONS AND PERFORMING THE RERUIRFD 
14. ANY DTHER INF PRMATI ON OR RESTRICTIONS (CONT INUED)

INTEGRALS MUST BF DONE FLSEWHERE. THF SOLE FUNCTION OF ONE OF THE SUBROUTINES, INVFRT, IS TO INVERT A MATRIX. IN THE PROCESS IT CALLS A SYSTEM INVERSION SUBROUTINE, F4MAIN, WHICH IS NOT GFNERALLY AVAILABLF OUTSIDE OF KAPL. THE USER WILL HAVE TO SUPPLY AN EQUI VALFNT INVERSION RMUTINF.

15. NAME AND FSTABLISHMENT DF AUTHORS -

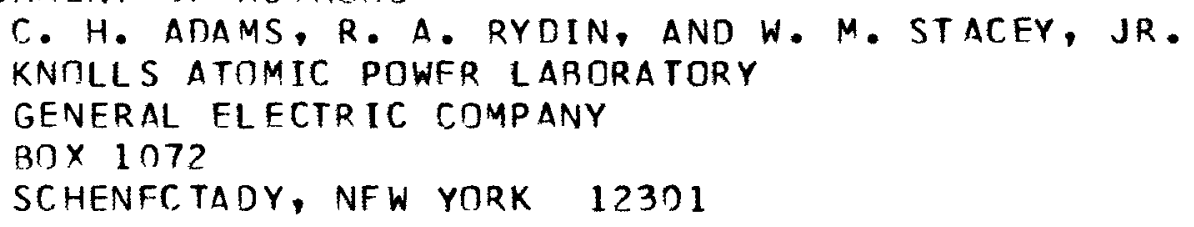

16. MATERIAL AVAILARLF - RESTRICTED DISTRIBUTION SOURCE DECK (1296 CARDS $)$

17. CATEGRRY - F

KEYWOPDS - KINETICS, SYNTHESIS, SPACE-TIME, DIFFUSION FQUAT IONS, FFFDBACK, CONTROL RODS, TEMPERATURE DISTRIBUTION, 1-DIMENS I ONAL, 3-DIMENS IONAL 
1. NAME DR DESIGNATIDN OF PRDGRAM - CORGAM

2. COMPLTFR FOR WHITH DROGRAM IS DESIGNED AND OTHERS UPON WHICH IT IS NPERARLF - IRM 360/50

3. NATURE TF PHYSICAL PRCBLEM SCLVED - A CORRELATION ALGOR ITHM IS CODFD TO ALLNW THE UNFILDING OF COMPLEX GAMMA-RAY SPECTRA TYPICALLY COLLECTFD IN A NEUTRON ACTIVATION ANALYSIS PROCEDURE. CORGAM 11 ) WILL COMDENSATF FOR ELECTRONIC SHIFTS IN THE DATA, (2) WILL CORRECT FOR BACKGRDUND, (3) WILL NORMALIZE THF DATA TO A FIXED NFUTRON FLUX LEVEL, (4) ALLDWS A CHOICE OF WEIGHTING FACTORS, AND (5) ALLOWS A CHOICF OF METHODS FOR CALCULATION OF STANDARD DEVIATINNS. THF CODF REQUIRES A MATRIX OF REFERENCE GAMMARAY SPECTRA. THESE SPFC.TRA CAN BE IN A RAW-DATA FORM. ALL OF THE MONIFICATIONS AVATL ABLF TO THE COMPLEX GAMMA-RAY SPFCTRA ARE AVAILABLF TO THE REFERENCE GAMMA-RAY SPECTRA. IN ADDITION, A DECAY CORRECTION IS AVAILARLE FOR THE REFERENCE GAMMA-RAY SPECTRA. ONLY THE REFERENCE GAMMA-RAY SPFCTQA THAT HAVE INTENSITY CDEFFICIFNTS WHICH ARE SIGNIFICANT AT A PRESCRIBFD LEVEL OF SIGNIFICANCE ARF RETAINED IN THE FINAL SOLUTION. THE INTERMEDIATE SOLUTIONS, I.F., THOSE SOLUTIONS THAT CONTA IN REFERENCE GAMMA-RAY SPECTRA WHICH HAVE NONSIGNIFICANT INTENSITY CNEFFICIENTS AT THE PRESCRIBFD LEVFL, ARE PRINTFO DUT. THEREFIRE, SEVFRAL SOLUTIONS ARE IMBEDDED IN THE FINAL SOLUTICN.

4. MFTHOD OF SOLUTION - A BACKWARD ELIMINATION LEAST-SQUARES METHOD IS EMPLTYER. THE FLIMINATION CRITERION IS ONE IN WHICH THE STUDENTS T VALUE OF EACH INTENSITY IS COMPARED TO A T VALUE AT A PRESCRIRED LEVEL TF SIGNIFICANCE. THE CALCULATION OF THE STANDARD DEVIATION FOR FACH INTENSITY COEFFICIFNT ACCOUNTS FOR RANDIMNESS IN BOTH THE COMPLFX AND REFFRENCE GAMMA-RAY SPECTRA.

5. RESTRICTIONS ON THE COMPLFXITY OF THE PROBLEM - CURRENTLY THE PROGRAM IS RESTRICTED TO A PRDBLEM OF 400 CHANNELS AND 15 REFERENCF. SPECTRA. THERF WOULD BE NO DIFFICULTY IN EXPANDING THIS TO AS MANY AS 4096 CHANNFLS. HOWEVER, THE NUMBER OF REFERENCE SPECTRA IS LIMITED AY THE ACCURACY DESIRFD IN THE INVERSION PROCEDURE. THE INVERSIDN PROSRAM CURRENTLY BFING USED WOULD SUFFER (FROM THE ACCURACY STANDPOINTI IF THF NUMBER OF REFERENCE SPECTRA WERE GREATFR THAN 25 .

6. TYPICAL RUNNING TIME - A TYPICAL ANALYSIS, INVDLVING 256 CHANNELS AND 14 REFFRENCF SPECTRA AND USING REFERENCE SPEC TRA WHICH WERE SUI TABLY ALIGNFD, RFQUIRES LESS THAN I MINUTE DF EXECUTIDN TIME.

7. UNUSUAL FEATURES DF THE PRDGRAM - CORGAM IS A NOVEL METHOD OF UNFOLDING COMPLEX GAMMA-RAY SPECTRA BECAUSE THE VARIANCE CALCULATIONS INCLUNE CONTRIBUTICNS FROM BOTH THF COMPLEX AND REFFRENCE SPECTRA. ALSO, ONLY REFERFNCE SPECTRA THAT HAVE INTENSITY COEFFICIENTS WHICH ARE SIGNIFICANT AT A PRFSELECTED LEVEL ARE RETAINED IN THE FINAL SOLUTION. THE INTERMEDIATE RESULTS CAN BE PRINTFD, AND THE LEVEL OF SIGNIFICANCE OF EACH OF THE INTENSITY COEFFICIFNTS CAN BE OBSERVED. 
3. RELATFD AND AUXILIARY PROGRAMS -

9. STATUS - ABSTRACT FIRST DISTRIBUTED MAY 1970. IBM 360 VERSION SURMITTED JULY 1969.

10. REFERENCES - N. D. FCKHOFF, OPTIMAL NEUTRON ACT IVATION ANALYSIS, TID-24581, 1968 .

$$
\text { N. D. FCKHOFF, CORGAM - AN OPERATORS MANUAL, KSU }
$$

REPORT, JULY 7, 1969.

N. R. DRAPER AND H. SMITH, APPLIED REGRESSION ANALYSIS, JOHN WILEY AND SDNS, INC., 1966.

M. H. YOUNG AND N. S. SINGHAL, GAMMA-RAY SPECTRAL

UNFOLDING BY THE STEPWISE STATISTICAL METHOD, NUCLEAR INSTRUMENTS AND METHODS, VOL. 45, P. $287,1966$.

J. I. TROMBKA AND R. L. SCHMADEBECK, A METHOD FOR THE ANALYSIS OF PULSE-HEIGHT SPECTRA CONTAINING GAIN SHIFT AND ZERODRIFT COMPENSATION, TRANSACTIONS OF THE AMERICAN NUCLEAR SOCIETY, VOL. 10, P. 33, JUNE 1967.

R. M. PARR AND H. F. LUCAS, JR., A RIGOROUS LEASTSQUARES ANALYSIS OF COMPLEX GAMMA-RAY SPECTRA WITH PARTIAL COMPENSATION FOR INSTRIJMENTAL INSTABILITY, IEEE TRANSACTIONS NUCLEAR SCIENCE, NS-11, P. 349, JUNE 1964.

G. D. OKELLEY, ED., APPLICATIONS DF COMPUTERS TO NUCLEAR AND RADIOCHFMISTRY, GATL INBURG CONFERENCE, NAS-NS-3107, 1963.

11. MACHINE REQUIREMENTS -

12. PRogramming language uSED - fortran iV leVel g

13. OPERATING SYSTFM OR MONITOR UNDER HHICH PROGRAM IS EXFCUTED OS/ 360 .

14. $A N Y$ OTHER PROGRAMMING OR DPERATING INFORMATION OR RESTRICTIONS DISK STORAGE IS REQUIRED.

15. NAME AND ESTABLI SHMENT OF AUTHCR -

N. D. ECKHOFF

DEPARTMFNT OF NUCLEAR ENGINEER ING

KANSAS STATE UNIVERSITY

MANHATTAN, KANSAS 66502

16. MATERIAL AVAILABLE -

SOURCE RECK (1303 CARDS)

SAMPLE PROBLEM (558 CARDS)

REFERENCE REPORT, KSU REPORT

17. CATEGORY - 0

KEYWORDS - ACTIVATION, DATA PROCESSING, LEAST SQUARES, GAMMA RADIATION SPECTRA 
1. NAME DR TESIgNATION DF PROJRAM - STRSDB

2. COMPUTER FOR WHICH PRIGRAM IS DESIGNED AND OTHERS UPON WHICH IT IS DPFRARLF - CDC.660ก

3. NATURE OF PHYSICAL PRORLEM SOLVED - SORSDB WAS WRITTEN TO CALCULATE THE STRESS INTENSITIFS AND FATIGUE USAGE FACTORS FOR PRESSURF VESSFLS (STRUT.TURAL MFMBERS) IN ACCORDANCF WITH THE ASME CODE, NUCLEAR VESSFLS, SECTION 3. THF INPUT REQUIRES THE BASIT. MEMRRANF AND RFNIING STRESSES GENFRATED RY THE SOR 2 CODE (ACC. ABSTRAT, BOI TR ANY ATAPTABLE SHELL PROGRAM. THE MUTPUT INCLUDES STRFSS DIFFERFNCES, STRFSS INTENSITIFS, AND FATIGUE USAGE FACTORS.

4. METHON OF SOLUTION - THE PRICEDURES OF PARAGRAPHS N414 AND N415.2 DF THE ASMF CODE ARF USED TO CALCULATE PRIMARY AND SECONIARY STRESSFS, STRF SS DIFFFRFNCES AND STRESS INTENSITIES FOR COMPARISON WITH ALLOWED VALUES. CALCULATIONS ARF BASFD ON A SET OF UNIT LOAD INPUT CASES FOP A FIXED GEOMETRY.

5. RFSTRICTIONS ON THE COMPLFXITY CF THE PRORLEM - AS MANY AS 100 POINTS DN THF VESSFL MAY RE EVALUATED FOR A MAXIMUM OF 15 DPERATING CONDITIONS $\triangle N D$ SO FATIGUE CYCLFS.

6. TYPICAL RUNNING TIME - 10 SECONDS TO 1 MINUTE ARE REQUIRED, DFPFNDING, ON PRORLEM SIZF.

7. UNUSUAL fFATURFS DF THE PROGRAM -

8. RELATED ANO AUXILIARY PROGRAMS - SOR2.

9. STATUS - ABSTRACT FIRST DI STRIBUTED MAY 1970. CIC66ON VERSION SUBMITTED JULY 1969.

10. REFERENCFS - F. C. TARLSON AND R. E. DORSON, SORSDR, A COMPUTER PROGRAM FOR THE STRFSS AND FATIGUE FVALUATION OF SHELLS OF REVOLUTION, KAPL-M-6729, APRIL 1969. J. A. MIRABAL AND D. G. DIGHT, SOR-II - A PROGRAM TO PERFCRM STRFSS ANALYSIS OF SHELLS DF REVILUTION, KAPL-M-229?, SEPTFMBER $15,1963$. R. L. FAGAN, PUNCHED CARD FROM SOR-2 FOR SORSDR, KE-ZAP-2393, JUNE 2ก, 1969.

11. MACHINE REQUIRFMFNTS -

12. PROGRAMMING LANGUAGF USFC - FORTRAN IV

13. OPERATING SYSTFM DR MONITOR UNDER WHICH PROGRAM IS EXFCUTED 14. ANY CTHFR PROGRAMMING OR IPERATING INFCRMATICN DR RESTRICTIONS 15. NAMF AND ESTARLISHMENT OF AUTHORS - 
649

RFACTOR CODE ABSTRACT 3?1

$-2-$

$05 / 70$

15. NAMF AND ESTARLISHMENT OF AUTHOR IS) (CONTINUFO) KNILLS ATOMIC POWER LABORATORY SFNERAL ELFCTRIC COMPANY

BDX $107 ?$

SCHENECTADY, NFW YORK 12301

16. MATERIAL AVAILABLF - RFSTRICTFD DISTRIBUTION SNIIRC, DECK (SO9 CARDSI

REFFRFNCE RFPORT, KAPL-M-6729

17. CATFGORY - 1

KEYWORDS - STRESSES, SHFLLS, STRUCTURAL ANALYSIS, SDR CODES, FATIGUE ANALYSIS 
1. NAME OR DESIGNATION OF PROGRAM - RAFFLE

2. COMPUTER FOR WHICH PROGRAM IS DESIGNED AND OTHERS UPON WHICH IT IS OPERABLE - IBM7090,360/75

3. NATURE DF PHYSICAL PROBLEM SOLVED - RAFFLE CALCULATES NEUTRON FIRST FLIGHT COLLISION PROBABILITIES FOR A WIDF VARIETY OF THREEDIMENSIONAL CELL GEDMETRY CONFIGURATIONS. THE OUTER BOUNDARIES OF THE CFLL CROSS SECTION MAY BE CIRCULAR, SQUARE, OR HEXAGONAL. THE CELL MAY C.ONTAIN ANNULAR REGIONS AND/OR CLUSTERS OF RODS.

4. METHOD OF SOLUTION - EACH AXIAL SUBDIVISION OF EACH REGION AND ROD IS CHARACTERI ZED BY A NUMBER WHICH DESIGNATES ITS MATERIAL, AND THEREBY THE NUCLEAR TOTAL CROSS SECTION. THE MONTE CARLO METHOD IS USED, IN WHICH NEUTRON HISTDRIES ARE STARTED AT RANDOM WITHIN MATERIAL NUMBER I AND CONTINUED UNTIL A COLLISION OR ESCAPE CCCURS. IF DESIREN, SUCCFSSIVE CASES MAY BE RUN IN WHICH THE HISTORIES ARE STARTED IN ANY MATERIAL OF THE CELL MERELY BY RENUMBER ING THE MATERIALS.

5. RESTRICTIONS ON THE COMPLEXITY CF THE PRORLEM - MAXIMA OF 20 REGIONS

10 DIFFERFNT TYPES OF RODS (DIFFERING IN EITHER GEOMETRY DR MATER IALSI

50 RODS PER REGION

20 SUBREGIONS PER ROD

12 REGIONS WITH RODS IONLY THE FIRST 12 REGIONS COUNTING FROM THE C.ELL CENTFRI

8 MATERIALS

6. TYPICAL RUNNING TIME - SIMPLE GEOMETRIES MAY REQUIRE 10 MINUTES FOR A CASE CONSISTING OF 25,000 HISTORIES ON THE IBM7090 OR 2 MINUTFS FOR THE SAME CASF ON THE IBM360. PROBLEMS IN WHICH THE SOURCE REGION IS A SMALL FRACTION OF THE TOTAL OR THE MEAN FREE PATHS ARE LONG COMPARED TO THE DIMENSIONS OF THE REGIONS MAY TAKE SEVERAL TIMES AS LONG.

7. UNUSUAL FEATURES OF THE PROGRAM -

8. RELATED AND AUXILIARY PROGRAMS - MUCH OF THE BASIC INFORMATION AND SOME PARTS OF THE CODE ITSELF ARE TAKEN FROM THE MORE GENERAL MONTE CARLO CODE, NSR.

9. STATUS - ABSTRACT FIRST DISTRIBUTED MAY 1970. IBMTD90 VERSION SUBMITTED DCTOBER 1969. IBM360 VERSION SUBMITTED OCTOBER 1969.

10. REFERENCES - 0 . W. HERMANN AND R. S. CARLSMITH, RAFFLE, A MONTE CARLD CDDE FOR CALCULATION OF FIRST FLIGHT COLLISION PROBABILITIES, ORNL-TM-1699, DFCEMBER 1966.

D. C. IRVING, R. M. FREESTONE, JR., AND F. B. K. KAM, 05R, A GENERAL-PURPOSE MONTE CARLD NEUTRON TRANSPORT CODE, ORNL-3622, FEBRUARY 1965. 
651

REACTOR CODE ABSTRACT 392

$-2-$

$05 / 70$

11. MACHINE REQUIREMENTS -

12. PRTGRAMMING LANGUAGES USFD - (IBM7090) FORTRAN II 195 PERCENT) AND FAD 15 PERCENT), ([ RM360) FORTRAN IV 197 PERCENT) AND BAL 13 PER(.NT)

13. OPERATING SYSTEM OR MONI TOR UNDER WHICH PROGRAM IS EXECUTED -

14. ANY CTHER PROGRAMMING OR OPERATING INFORMATION OR RESTRICTIONS ASSEMBLY LANGUAGE IS USED FOR THE RANDOM NUMBER GENERATION RUTINES.

15. NAME AND ESTABLISHMENT OF AUTHORS -

O. W. HERMANN AND R. S. CARL SMITH

DAK RIDGE NAT IONAL LABORATORY

DAK RIDGE, TENNESSEE 37830

16. MATERIAL AVAILABLE - MAGNFTIC TAPE TRANSMITTAL SNURCE DECKS (7090-3384 CARDS, 360-3294 (ARDS) SAMPLE PROBLEMS $17090-28$ CARDS, 360-31 CARDS 1 REFERENCE REPORT, ORNL-TM-1699

17. CATFGRRY - R

KEYWORDS - CELL CALCULATION, LEAKAGE, MONTE CARLO METHOD, latICES, OS CODES 
1. NAME DR DESIGAATION OF PROGRAM - XSDRN

2. COMPUTER FOR WHIC.H PROGRAM IS DESIGNED AND OTHERS UPON WHICH IT IS OPERARLE - IBM360/65 CR HIGHFR

3. NATURE OF PHYSICAL PRDBLFM SOLVED - XSORN USES THF NORDHEIM INTFGRAL TREATMENT, NARRTW RESONANCF, OR INFINITF MASS APPROXIMATION TO OROCFSS RFSUNANCE DATA CN A MASTER CROSS SECTION LIBRARY AND THUS TRTAIN MICROSCOPIC FINF-GRTUP CROSS SECTIONS FOR A LARGF NUMBER OF NUT,LIDFS. THF CODE WILL THEN USF THESE CROSS SFCTIONS IN AN INIEPFNDENT CALCULATICN TC SOLVE FRR FLUXFS, FIGFNVALUES, CRITICAL DIMFNSIONS, FTC., USING DISCRETE MRDINATES, DIFFUSIDN, OR AN INFINITE MFDIUM THECRY CALCULATION. THE FINE-GROUP FLUXES THUS DRTAINED CAN THFN BE USED TO COLLAPSE THE FINE-GROUP CROSS SECTION DATA TO A MORE TENARLE BROAD-GROUP STRUCTURE FOR USE IN SEVERAL INDFPFNDENT COMOUTFQ CODES.

4. METHCD TF SOLUTION - THE PRINCIPAL CALCULATIONS PERFDRMFD BY XSDRN (RFSTNANCE CALC.ILATION ANI FLUX CALCULATION) BOTH FMPLOY NUMFR ICAL FINITE-DIFFERENCE TFC.HNIOUES. FOR THE RESONANCE CALCULATION, THIS INVILVES A SIMPSONS INTFGRAT ION TO SOLVF FOR THE COLLISION DENSITY IN THE RFSINANCE RANGF. THF FLUX CALCULATIONS FMPLOY A MULTIGROUP FNFRGY STRUCTURE, AN ARRITRARY SPATIAL STRUCTURE AND A MECHANICAL ANGIJLAR QUADRATURF, ALL OF WHICH MUST RE USED IN THE VARIOUS INTEGRATIIN AND DIFFERENSING SCHEMES IN THE CODE.

5. RESTRICTIONS ON THE COMPLFXITY CF THE PRORLEM - THF PRINCIPAL RESTRICTION IS THF AVAILABILITY OF ADEQUATF CORE STDRAGE TO BUILD REQUIRED ARRAYS. THF CODF IS FLEXIBLY DIMFNSIONED WHICH MEANS THAT ARRAY SIZES ARF SET FOR THF PARTICULAR PRORLEM AT EXECUTION TIMF. (PRDVISIONS ARE ALSO AVAILABLE FOR STORING CFRTAIN LARGE DATA ARRAYS CUT OF CIRRE, IF NEED BE.I

6. TYPICAL RUNNING TIYF - TYPICAL RE SINANCE CALCULATIONS HAVE BEEN RUN ON THF IBM360/75 IN FROM ONF-HALF TO ONE MINUTE PER NUCLIDF. A TYPICAL FLUX CALCULATION 154 P3, 25 SPACE POINTS, 123 ENFRGY GROUPS, CYLINDER, K-CALCULATION, REDUCE CROSS SECTIONS, 4 RESDNANCE NUCLIDESI GENERALLY RUNS IN 11 TO 12 MINUTES. A FIXED SDURCE CALCULATION FOR THF SAME SYSTEM WOULD TAKE APPROXIMATELY THE SAMF TIME.

7. UNUSUAL FFATURES DF THF PRTGRAM - THE FLEXIBLE DIMENSIONING SCHEME FMPLOYED BY XSDRN ALLOWS DNE TO MAKE OPTIMAL USE OF CORE STORAGE. A UNIQUF METHOD OF STORING CRDSS SECTIONS IS EMPLOYEO TO EL IMINATE INPUT OF UNNECESSARY TRANSFER CROSS SECTIONS.

8. RELATED AND AUXILIARY PRGGRAMS - THE MASTER LIBRARY TAPE FOR XSDRN IS PRDDUCED RY XLACS. CRDSS SECTION TAPES CAN BE GENFRATED FOR ANISN (ACC ABSTRACT 151), DIT, CITATION (ACC ABSTRACT 387), ROD, OR THE FXTERMINATOR2 (ACC ABSTRACT 156 ) CODES. 
9. STATUS - ABSTRACT FIRST DISTRIBUTED MAY 1970. IRM36O VERSION SUBMITTED NOVEMRER 1969.

10. RFFERFNCFS - N. M. GRFENE AND C. W. CRAVEN, JR \& XSDRN, A DISCRETE TRDINATES SPECTRAL AVERAGING CODE, ORNL-TM-2500, JULY 1969, AND ERRATA. N. M. GREENE, XLACS, CRISS SECTION PRODUCTION PACKAGE FDR XSDRN, CTC REPORT (TC RE PUBLISHED). DESTRIPTION RF XSDRN TAPF CONTENTS, ACC NOTE, MAY 1970 .

11. MACHINE RFQUIREMFNTS - ON THE IBM3SO/65 APPROXIMATELY 9OK WORDS OF DIRFCTLY ADDRESSABLE CORE STORAGE MUST BE AVAILARLE FOR THE PROGRAM. THE VARINUS CALCULATIONAL OPTIONS REQUIRE FROM 4 TO 13 INPUT/OUTPUT DEVICES, DEPENDING ON THE PROBLEM. AT LEAST ONE DIRECT-ACCESS NEVICE IS REQUIRED.

12. PROGRAMMING LANGUAGE USFT - FORTRAN IV

13. OPERATING SYSTEM OR MONITOR UNDFR WHICH PROGRAM IS EXFCUTED DS/360.

14. ANY CTHER PROGRAMMING OR DPERATING INFORMATION OR RESTRICTIONS XSDRN IS PRESENTLY USED IN A FOUR-LEVEL DVERLAY STRUCTURE CONSISTING CF 14 SEPARATE LINKS. SUBROUTINE TA MUST RE COMPILED WITH THE FORTRAN G COMPILER.

15. NAMF AND ESTARLISHMFNT TF AUTHCRS -

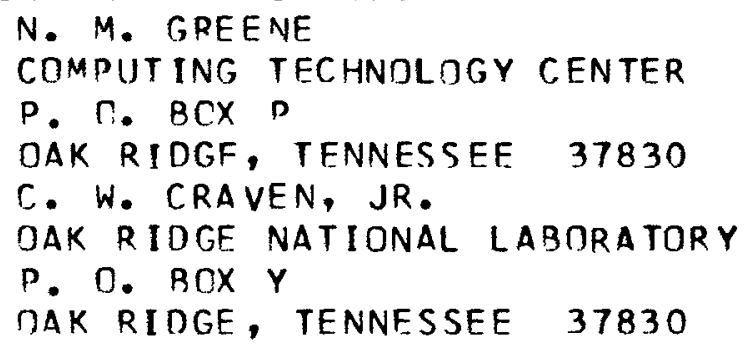

16. MATFRIAL AVAILABLF - MAGNETIC TAPF TRANSMITTAL (2 TAPES) SCURCE DECKS SAMPLF PRORLEM MASTER CROSS SECTION LIBRARY (TAPE 2 ) REFERENCF REPORT, ORNL-TM-2500, ERRATA, AND NOTE

17. CATEGORY - B

KEYWCRDS - GROUP CONSTANTS, CFLL CALCULATION, TRANSPORT THEORY, MULTIGRMUP, 1-DIMFNSIONAL, SN METHOD, RFSONANCE, SLARS, CYLINDERS, SPHERES, FLUX DISTRIRUTION, ANGULAR DISTRIRUTION, XLACS CODES, ANISN CODES, DOT CODES, CITATION CODES, RCD CODES, EXTERMINATOR2 CODES 
1. NAME tR designation of PROGRAM - JITER

2. COMPUTFR FOR WHICH PROGRAM IS DESIGNEN AND OTHFRS UPON WHICH IT IS DPERABLF - CDC GSOO

3. NATURE OF PHYSICAL PROBLFM SOLVED - JITER COMPUTES THE FOLLOWING QUANTITIFS MEASURED IN REACTOR FLUCTUATION EXPERIMENTS - THE DISPERSION PARAMETER Y, THE MODIFIED COEFFICIENT OF CORRELATION MCC, THE FREQUENCY DEPENDENT PART OF THE POWER SPECTRAL DENSITY PSD, AND THE CRISS POWER SPECTRAL DENSITY CPSD.

4. METHOD DF SOLUTION - THE COMPUTATION IS DONE AS AN FXPANSION IN TERMS DF THE DECAYING MODES OF A ONE-DIMENSIONAL, FEW-GRDUP KINETICS MODEL.

5. RESTRICTIONS ON THE COMPLEXITY OF THE PROBLEM - THE KINETICS MODEL MAY HAVE AS MANY AS 4 ENERGY GROUPS AND UP TO 6 GROUPS OF DELAYED NFUTRONS. HALF THE REACTOR CORE CAN BE DESCRIBED WITH UP TO 300 SPATIAL MESH POINTS AND AS MANY AS 5 DIFFERENT MATERIALS DISTRIBUTED IN AT MOST 50 SPATIAL REGIONS. A TOTAL DF 10 MODES CAN BE USED IN THF EXPANSIONS.

6. TYPICAL RUNNING TIMF - 30 SECDNDS ARE REQUIRED WITH 8 MODES.

7. UNUSUAL FEATURES OF THE PROGRAM - ANY ORDER SPHERICAL HARMONICS TRANSPORT APPROXIMATION CAN BE USED FOR THE MODES SO LONG AS TIME DERIVATIVES ARE IGNORFO IN ALL BUT ONE PO EQUATION.

8. RELATED AND AUXILIARY PROGRAMS - MODES CAN BE PRODUCED WITH BE21 (ACC ABSTRACT 398 ) TR MULE.

9. STATUS - ABSTRACT FIRST DISTRIBUTED MAY 1970. CDC6600 VERSION SUBMITTED AUGUST 1969.

10. REFERENCES - M. NATELSON AND D. R. HARRIS, JITER, A FORTRAN IV PROGRAM FOR THE COMPUTATION, FROM ONE-DIMENSIONAL MODAL KINETICS MODELS, OF STATISTICAL PARAMETERS MEASURED IN REACTOR FLUCTUATION EXPERIMENTS, WAPD-TM-877, JUNE 1969.

C. J. PFEIFER, CDC-6600 FORTRAN PROGRAMMING - BFTTIS ENVIRONMFNTAL REPIRT, WAPD-TM-668, JANUARY 1967.

11. MACHINE REQUIREMENTS - 120,000 (DCTAL) MEMORY LOCATIONS

12. PROGRAMMING LANGUAGE USED - FORTRAN IV

13. DPERATING SYSTEM OR MONITOR UNDER WHICH PROGRAM IS EXECUTED -

14. ANY CTHER PROGRAMMING OR OPERATING INFORMATION OR RESTRICTIONS -

15. NAME AND ESTABLISHMENT OF AUTHORS -

M. NATELSON AND D. R. HARRIS

BETTIS ATOMIC POWER LABORATORY 
15. NAME AND FSTABL ISHMFNT OF AUTHOR (S) (CDNTINUED)

WESTINGHOUSE ELECTRIC CORPORATION

P. O. BOX 79

WFST MIFFLIN, PENNSYLVANIA 15122

16. MATERIAL AVAILABLE - RESTRICTED DISTRIRUTION

MAGNETIC, TAPE TRANSMITTAL

SOURCE DECK (435 CARDS)

SAMPLE PROBLEM (961 CARDS)

BETTIS ENVIRONMENTAL ROUTINES $(21,123$ CARDS $)$

REFERENCF REPORTS

17. CATEGORY - 0

KEYWORDS - POWER SPECTRA, DATA PROCESSING, CORRELATION COEFFICIENTS, STATISTICS, I-DIMENSIONAL, KINETICS 
1. NAME OR DESIGNATION OF PRTGRAM - FLAC

2. COMPIJTFR FOR WHICH DROSRAM IS DESIGNFT AND OTHERS UPON WHICH IT IS DPFRARLE - UNIVAC 1108

3. nature tf physical problem solvfo - the flow analysis cone flac CALCULATES THF STEACY-STATF FLDW AND PRESSURF DISTRIBUTION IN AN ARRI IRARY NETWORK. THF PRIGRAM INCLUDES THE POSSIRILITY OF HFAT ADDITION AND MASS ADDITION IN ANY PORTION OF THE NFTWORK.

4. MFTHOT OF SOLUTION - THF FQUATICNS THAT ARE SOLVFO ARE THE ONEDIMENSIONAL MOMFNTUM EQUATION FOR INCOMPRESSIBLE FLOW IN A DUCT AND THE CCNSERVATION FQUAT IONS FOR FLOW AND ENERCY AT EACH NODE. DENSITY RHANGFS DUE TD HEAT ADDITION ARE INCLUDED ACCORDING TO THE DERFFCT CAS LAW. THE METHOD FOR SOLVING THE SET OF ALGEBRAIC EQUATIONS IS A VARIATICN OF THE POINT RELAXATION TECHNIQUE.

5. RFSTRITTIINS ON THF COMPLFXITY OF THF PROBLEM - THE FLAC PRIGRAM DOES NOT CONSIDER TWO-PHASE FLOW OR OPEN-CHANNEL FLOW, AS IN HYDRAUL ICS.

6. TYPICAL RUNNING TIME - APPROXIMATELY 30 SFCONDS ARE REQUIRED FOR A PROBLFM CONSISTINF, TF ITO BRANCHES.

7. UNUSUAL features or the PROGRAM -

8. RFLATED AND AUXILIARY PROGRAMS -

9. STATUS - ABSTRACT FIRST DISTRIBUTED MAY 1970. UNIVACI173 VERSION SURMITTEO AUGUST 1969.

10. RFFFRENCF - G. J. MALEK, DEVELOPMENT TF THE FLOW ANALYS IS CODE FLAC, GA-9482, JUNE 1969.

11. MACHINE REQUIPFMENTS - THE COMPUTER STORAGE REQUIRFMENTS FOR FLAC ARE FLEXIBL.F, AND THE SIZF OF THE VARIDUS ARRAYS CAN BE ADJUSTED TO SUIT ANY PROBLEM. WITH ALL ARRAYS SET TO THEIR MAXIMUM, A PRORLEM CDNSISTING TF 1500 RRANCHFS AND 700 NODES RFQUIRES APPROXIMATELY 50,02N STMRAGE LOCATIONS.

12. PRTGRAMMINS, LANGUAT,F USFD - FORTRAN V

13. DPERATING SYSTEM OR MONITOR UNDER WHICH PROGRAM IS EXECUTEO EXEC. II .

14. $A N Y$ OTHFR PROGRAMMING OR OPERATING INFORMATION OR RFSTRICTIONS FOR LARGE PRORLEMS, AUXILIARY DATA TAPES CAN BE USFD TO STORF INPUT INFORMATION AND RESULTS FROM THE LAST ITERATION. THESE DATA TAPFS CAN BE USED TO RESTART THE PROBLEM IN CASE OF NO CONVFRGENCF. 
657

REACTOR CODE ABSTRACT 395

$-?-$

$05 / 70$

15. NAME AND ESTABLISHMENT OF AUTHOR G. J. MALEK

GULF GFNFRAL ATOMIC INCORPORATED

P. $\mathrm{B}$. BOX 608

SAN DIEGO, CALIFORNIA 92112

16. MATERIAL AVAILABLE SOURCE DECK

SAMPLE PROBLEM

REFERENCE REPORT

17. CATEGORY - H

KEYWORDS - FLUID FLOW, TEMPERATURE DISTRIBUTION, PRESSURE DISTRRUIN, GASES, HEAT CONDUCTION, HTGR REACTORS 
1. NAME OR DES IGNATION OF PROGRAM - WASP

2. COMPUTER FOR WHICH PROGRAM IS DESIGNED AND OTHERS UPON WHICH IT IS OPERABLE - CDC6600

3. NATURE OF PHYSICAL PROBLEM SOLVED - WASP USES A UNIQUE METHOD TO QUICKLY CALCULATE VARIOUS HATER AND STEAM PHYSICAL PROPERTIES OVER AN EXTREMELY WIDE RANGE.

4. METHCD OF SOLUTION - WASP STORFS SATURATION LINE PROPERTIES AND DER IVATIVES OF INTERNAL ENERGY, ENTHALPY, AND TEMPERATURE WITH RESPECT TO PRFSSIJRE ALDNG CONSTANT DENSITY LINES IN THE SINGLEPHASE REGIONS, AND USES LINEAR INTERPOLATION TO LOCATE EQUILIBRIUM THERMODYNAMIC POINTS.

5. RESTRICTIONS ON THF COMPLEXITY OF THE PROBLEM - WASP WILL TREAT ANY POSITIVE PRESSURE, ENERGY, ENTHALPY, OR TEMPERATURE, AND ANY DENSITY LESS THAN 71.0 POUNDS PER CUBIC FOOT.

6. TYPICAL RUNNING TIME - 0.3 TC 0.4 MILLISECONDS PER CALL ARE REQUIRED.

7. UNUSUAL FEATURES OF THE PRDGRAM -

8. RELATED AND AUXILIARY PROGRAMS - THE NUMER ICAL ME THODS USED WERE DRIGINALLY DEVELOPED FOR USE IN THE FLASH2 (ACC ABSTRACT 295 ) COMPUTER PROGRAM.

9. STATUS - ABSTRACT FIRST DISTRIBUTED MAY 1970. CDC6600 VERSION SUBMITTED AUGUST 1969.

10. REFERFNCES - J. H. MURPHY AND J. A. REDFIELD, WASP - A PROGRAM TO GENERATE WATER AND STEAM THERMODYNAMIC PROPERTIES, WAPD-TM-839, OCTOBER 1968.

J. A. REDFIELD, J.H. MURPHY, AND V. C. DAVIS, FLASH-2, A FORTRAN-IV PROGRAM FOR THE DIGITAL SIMULATION OF A MULTINODE REACTOR PLANT DURING LOSS OF COOLANT, WAPD-TM-666, APRIL 1967.

11. MACHINE REQUIREMENTS - LESS THAN 1000 (DECIMAL) CENTRAL MEMORY LOCATIONS

12. PROGRAMMING LANGUAGE USED - FORTRAN IV

13. OPERATING SYSTEM OR MONITOR UNDER HHICH PROGRAM IS EXECUTED -

14. ANY OTHER PROGRAMMING OR OPERATING INFORMATION OR RESTRICTIONS -

15. NAME AND ESTABLISHMENT OF AUTHORS -

J. H. MURPHY AND J. A. REDF IELD

BETTIS ATOMIC POWER LABORATORY

WESTINGHOUSE ELECTRIC CORPORATION 
659

REACTOR CODE ABSTRACT 396

$-2-$

$05 / 70$

15. NAME AND FSTABLISHMENT OF AUTHCR(S) (CONT INUED)

$$
\text { P. } \mathrm{C} \text {. BOX } 79
$$

WEST MIFFLIN, PENNSYLVANIA 15122

16. MATERIAL AVAILABLE - RESTRICTED DISTRIRUTION SOURCE DECK (446 CARDS)

SAMPLE PROBLEM $(15$ CARDS $)$

REFERENCE REPORT, WAPD-TM-839

17. CATEGORY - H

KEYWORDS - THERMODYNAMICS, WATER, PRESSURE, TEMPERATURE, LIQUIDS, VAPORS 
1. NAMF DR DESIGNATIDN TF PROGRAM - GAPL3

2. CDMPUTER FOR WHICH PROGRAM IS DESIGNED AND OTHERS UPON WHICH IT IS OPERABLF - COCGGOO

3. NATUPE OF PHYSICAL PROBLEM SOLVED - GAPL3 DETERMINES THE INELASTIC, LARGE-DEFLFCTION BEHAVIOR OF THIN PLATES OR AXIALLY SYMMETRIC SHELLS WITH PRESSURF LOADING AND DEFLECTION RESTRAINTS.

4. METHOD OF SOLUTION - THF DFFORNATION OF THE BODY IS DESCRIPED BY A SET OF PARAMFTERS ZETAIII. THE STRAINS ARE FOUND IN TFRMS DF THE ZETAIII BY GECMETRIC RELATIONS, AND THE STRESSES ARE FOUND IN TFRMS DF THE STRAINS RY MATERIAL PROPERTY RELATIONS. THF PRINCIPLE CF VIRTUAI WORK IS USFO TO SET UD SIMUL TANEOUS EQUATIONS WHICH MAY BF SOLVED FOR THE ZFTAIII. THE SOLUTION IS ITERATED UNTIL THE STRESSES AND STRAINS DO NOT CHANGE APPRECIABLY.

5. RESTRICTIONS TN THE COMPLEXITY CF THE PRORLEM - THF THICKNESS OF THE PLATF OR SHELL SHDULD FALL WITHIN THE LIMITS OF THIN SHELL THECRY.

6. TYPICAL RUNNING TIME - A SMALL ELASTIC PROBLFM WILL TAKE LESS THAN a minUte. A LARGE PLASTIC DNF CAN REQUiRE DVER 10 MINUTES.

7. UNUSUAL FEATURES OF THE PRDGRAM - GAPL 3 IS QUITE VERSATILF AND MAY BE APPLIED TO MOST THIN PLATE OR AXIALLY SYMMETRIC SHELL PROBLEMS. IT IS PARTICULARLY APPROPRIATE WHEN NONLINEAR MATFRIAL OR GEOMETRIC EFFFCTS ARE IMPORTANT. AMONG ITS DISTINGUISHING FEATURES ARE -

(1) LARGE-DEFLECTION THEORY IS USED,

(?) FITHFR DEFORMATION THEORY OR I NCREMENTAL THEORY MAY BE SPECIFIED,

(3) ELASTIC-PLASTIC MATERIAL PROPERTIES ARE USED,

(4) ALMOST ANY ROUNDARY CONDITIONS MAY BE CONSIDERED,

(5) THE RIGID DEFLECTION RESTRAINT MAY TAKE ANY SHAPE AND ORIENTATION, AND

(6) BODIES haVING a VARIABle thICKNESS maY BE ANALYZED.

8. RELATFD AND AUXILIARY PROGRAMS - GAPL3 IS AN EXTENSIVE MODIFICATION OF GAPL 1 AND GAPL2 TO PERMIT THE SOLUTION OF A BRDAD CLASS OF PRORLEMS.

9. STATUS - ABSTRACT FIRST DISTRIBUTED MAY 1970. CDC6600 VFRSION SUBMITTFD AUGUST 1969.

10. REFERENCES - A. L. THURMAN, GAPL-3, A COMPUTER PROGRAM FOR THE INELASTIC LARGE-DFFLECTIDN STRESS ANALYSIS OF A THIN PLATE OR AXIALLY SYMMETRIC SHELL WITH PRESSURE LOADING AND DEFLECTION RESTRAINTS, WAPD-TM-791, JUNE 1969.

C. M. FR IEDRI CH, W. H. GUILINGER, A. E. SUMNFR, JR . GAPL-1, A COMPUTFR PROGRAM FOR THE PLASTIC STRESS ANALYSIS DF A HOR IZONTAL PLATE WITH PRESSURE LOADING ABOVE AND DEFLECTION 
10. REFFRFNCFS (CONTINUFD)

RESTRAINTS RELOW, WAPD-TM-731, (TO BF ISSUED).

C. J. DFEIFFR, CDC-6600 FORTRAN PRIGRAMMING - BETIIS ENVIRONMFNTAL REPIRT, WAPD-TM-668, DECEMBER 1966.

11. MACHINE REQUIREMFNTS - MINIMUM CORE STORAGE OF 100,000 (DCTAL) WDRDS, A PRINTFR, AN ON-LINE PUNCH, AND A PLOTTER

12. PROGRAMMING LANGUAGES USED - FDRTRAN IV AND ASSEMBLY LANGUAGE

13. OPERATINT, SYSTFM OR MONITOR UNDER WHICH PROGRAM IS EXECUTED SCOPF.

14. ANY CTHER PROGRAMMING CR DPERATING INFCRMATION OR RESTRICTIDNS -

15. NAMF AND ESTARLISHMENT OF AUTHOR -

$$
\begin{aligned}
& \text { A. L. THURMAN } \\
& \text { RETTIS ATOMIC POWER LABORATRRY } \\
& \text { WESTINGHOUSE ELECTRIC CORPORATION } \\
& \text { P. O. BCX } 79 \\
& \text { WFST MIFFLIN, PENNSYLVANIA } 15122
\end{aligned}
$$

16. MATERIAL AVAILABLE - RESTRICTED DISTRIBUTION

MAGNETIC TAPE TRANSMITTAL

SOURCE DECK (3416 CARDS)

SAMPLE PRORLEM (2P CARDS)

BETTIS ENVIRONMENTAL ROUTINES $(21,123$ CARDS)

RFFERENCE REPORTS, WAPD-TM-791 AND WAPD-TM-668

17. CATEGCRY - I

KFYWORDS - STRUCTURAL ANALYSIS, STRESSFS, PLATFS, SHELLS, PRESSURE 
1. NAME OR DFSIGNATIINN DF PROGRAM - BE21

2. COMPUTER FOR WHICH PROGRAM IS DESIGNED AND OTHERS UPON WHICH IT IS OPERABLF - CDCGGOO

3. NATURE OF PHYSICAL PRORLFM SCLVED - BE2I SOLVES THE FFW-GROUP DISCRETF DRDINATFS EQUATIONS IN SLAB GEOMETRY. EITHER HOMOGENEOUS OR INHOMOGENFOUS PROBLEMS CAN BE SOLVEO.

4. METHOD OF SOLUTION - AUXILIARY VARIABLES ARE INTRODUCED THAT PERMIT THE INHOMOGENEDUS EQUATIONS TO BE SOL VED BY DIRFCT INVERSION. THE METHOD IS STABLF WITH RESPECT TC RCUNDOFF ERRORS . HOMDGENEDUS PROBLFMS ARE SOLVED BY USING THE SAME INVERSION MFTHOD TO FVALUATE THE CRITICAL DETERMINANT. CRITICALITY IS OBTAINED BY SEARCHING FOR SUITABLE RTOTS TF THE CRITICAL DETERMINANT WITH INVERSE INTERPOLATION. AN EXACT SPATIAL DIFFERENCING SCHEME IS INCLUDED.

5. RESTRICTIONS TN THE COMPLEXITY OF THE PROBLEM - THE MAXIMUM NUMBER OF ORDINATES IS 60 WHICH MAY BE DIVIDED ARBI TRARILY AMONG THE GROUPS SURJECT TO THE RESTRICTION THAT THE ORDINATE SCHEMES RE SYMMETRIC ABOUT, BUT NOT INCLUDE, MU=0 IN FACH GROUP. THE CORRESPONDING GROUP NUMBER LIMIT IS $30 \mathrm{WITH} \mathrm{TWO} \mathrm{ORDINATES} \mathrm{PER} \mathrm{GROUP.}$ OTHER LIMITATIONS INCLUDE -

20 COMPOSITIONS

5n REGINNS

50 SOURCE RFGIONS

6. TYPICAL RUNNING TIME - LESS THAN DNE MINUTE IS REQUIRED FOR A 10 DRTINATE FIGENVALUE PRORLEM.

7. UNUSIJAL FEATURES DF THE PRTGRAM - BE2I HAS AN INTERNAL LIBRARY OF GAUSS-LEGENDRE ORDINATE SCHEMES THAT PERMIT EITHER PN OR DPN APPROXIMATION. THE HOMDGENEOUS SOLUTICN WILL FIND ANY EIGENFUNCTION OF THE SYSTEM WITH EQUAL FACILITY.

8. RELATED AND AUXILIARY PROGRAMS -

9. STATUS - ABSTRACT FIRST DISTRIBUTED MAY 1970. CDC6600 VERSIDN SUBMITTED AUGUST 1969.

10. REFERENCES - E. SCHMINT, BEZI - A FEW-GROUP TRANSPORT PROGRAM IN FORTRAN IV, WAPD-TM-781, MAY 1968.

C. J. PFFIFFR, CDC-6600 FORTRAN PROGRAMMING - BETTIS ENVIRONMENTAL REPORT, WAPD-TM-668, JANUARY 1967.

11. MACHINE REQUIREMENTS - 140,000 (OCTAL) LOCATIONS OF FAST MEMORY AND 2 SCRATCH TAPES

12. PROGRAMMING LANGUAGE USFD - FORTRAN IV

13. OPERATING SYSTEM OR MONITOR UNDER WHICH PROGRAM IS EXECUTED SCOPE 3.1. 
663

REACTOR CODE ABSTRACT 398

$-2-$

$05 / 70$

14. ANY CTHER PROGRAMMING OR OPERATING INFORMATION OR RESTRICTIONS -

15. NAME AND ESTABLISHMENT OF AUTHOR -

$$
\text { E. SCHMIDT }
$$

BETTI ATOMIC POWER LABORATORY

WESTINGHOUSE ELECTRIC CORPORATION

P. C. BOX 79

WEST MIFFLIN, PENNSYLVANIA 15122

16. MATFRIAL AVAILABLE - RESTRICTED DISTRIBUTION MAGNETIC TAPE TRANSMITTAL

SOURCE DECK $(2185$ CARDS )

SAMPLE PROBLEM $(11$ CARDS I

BETTI ENVIRONMENTAL ROUTINES $(21,123$ CARDS)

REFERENCE REPORTS

17. CATEGORY - C

KEYWORDS - FEW-GROUP, TRANSPORT THEORY, SLAB GEOMETRY, PL METHOD 
1. NAME DR DESIGNATION OF PROSRAM - SUMORIMOP71)

2. COMPUTER FUR WHICH PPOGRAM IS DESIGNFD AND OTHERS UPMN WHICH IT IS RPFRARLE - CDTKGOO

3. NATURE TF PHYSICAL PRORLFM SOLVED - SUMDR CALCULATES S-WAVF NEUTRON CROSS SECTIONS AT SELECTFD ENERGIES. THE CROSS SECTIONS ARE CALCULATED IN THREE APPROXIMATIONS TO R-MATRIX THECRY - THE REICH AND NDORF APPRIXIMATION, THE FESHBACH, PORTER, AND WEISSKDPF APPROXIMATION, ANO THE SUMS OF SINGLE-LEVEL FORMULAF APPROXIMATION. THESE CALCULATFO CROSS SECTIONS OR, AL TERNATIVELY, INPUT LISTS OF CRISS SECTIONS, ARF DCPPLER BRCACENFD USING FXACT CALCULATION FIR TARGET NUCLEI IN MAXWELLIAN MOTION. CALCULATED CROSS SFCTIONS CR CROSS SFCTIONS DIVIDFO RY NEUTRON ENERGY CAN BE INTFGRATED BETWEEN ARBITRARY ENERGY LIMITS.

4. METHCD OF SOLUTION - DOPPLER BRCADENING IS CARRIED OUT BY A TRAPEZOIDAL INTEGRATION TVFR NEIGHRORING CROSS SECTIONS WEIGHTED BY THE SCLBRIG KFRNFL.

5. RESTRICTIONS ON THE COMPLEXITY OF THF PROBLEM - LEVFL-LEVFL INTFRFERENCF IS NOT DERMITTFD IN FISSION CHANNELS. SUMOR TREATS S-WAVE CHANNFLS ONLY, AND POTENTIAL CROSS SECTION IS APPROXIMATED AS INDEPENDFNT DF ENERGY.

6. TYPICAL RUNNING TIMF - A PRCBLEM WHICH CALCULATES ARSORPTIDN, FISSION, SCATTERING, AND TOTAL CROSS SECTIONS FROM 5 RFSONANCE ENERGIFS AT 50 ENERGIES RUNS APPROXIMATFLY 10 SFCONDS.

7. UNUSUAL. FEATURES OF THE PROGRAM -

8. RELATED AND AUXILIARY PROGRAMS -

9. STATUS - ARSTRACT FIRST DISTRIBUTED MAY 1970. COC66OD VERSION SURMITTED AUGUST 1969.

10. REFERENCES - D. R. HARRIS AND C. R. NOLL, SUMOR (MOP71), A FORTRAN IV PRDGRAM FOR THE CDC-6600 FOR NEUTRON RESONANCF CROSS SFCTIONS INCLUNING LEVFL-LEVEL INTERFERENCE AND EXACT DOPPLER BROADENING, WAPD-TM-810, JULY 1969.

D. R. HARRIS AND C. B. NOLL, SUMOR, A FORTRAN-IV PROGRAM FOR THF PHILCO-2OON FDR NEUTRON RESONANCE CROSS SECTIONS INCLUDING, LFVFL-LEVEL INTFRFERENCE AND EXACT DOPPLER BROADENING, WAPD-TM-519, NOVFMBER 1967.

C. J. PFEIFER, CDC-6600 FORTRAN PROGRAMMING - BETTIS ENVIRONMENTAL REPORT, WAPD-TM-668, JANUARY 1967.

11. NACHINE REQUIREMENTS - SUMOR REQUIRES APPROXIMATELY 135,000 (OCTAL) CENTRAL MEMTRY LOCATIONS. THE NUMBER OF CENTRAL MEMORY WORDS COULD BF DECREASED BY DECREASING THE DIMENSICNS OF THE OUTPUT CROSS SECTIONS. ALSO, ONE INPUT AND AT LEAST THREE OUTPUT DEVICES ARE RFQUIRFN. 
665

REACTOR CONE ABSTRACT 399

$-2-$

$05 / 70$

12. PROgRAMMING language USEC - FORTRAN IV

13. TPERATING SYSTEM DR MONITOR UNDER WHICH PROGRAM IS EXECUTED SC PF 3.1 .

14. ANY CTHER PROGRAMMING OR MPERATING INFORMATION OR RESTRICTIONS -

15. NAME AND ESTABLISHMFNT OF AUTHCRS -

$D$. R. HARP IS AND $C$. R. NULL

RFTTIS ATOMIC POWER LABORATORY

WE STINGHOUSE ELECTRIC CORPORATION

P. O. BOX 79

WEST MIFFLIN, PENNSYLVANIA 15122

16. MATERIAL AVAILABLE - RESTRICTFD DISTRIRUTION

MAGNETIC, TAPE TRANSMITTAL

SOURCE DECK $(154)$ CARDS $)$

SAMPLE PROBLFM (?1 CARDS)

METIS ENVIRONMENTAL ROUTINES $(21,123$ CARDS $)$

REFERENCE REPORTS

17. CATEGORY - A

KEYWORDS - EPOS SECTIONS, DOPPLER BROADENING, MULTILEVEL, ELASTIC SCATTERING, CAPTURE, FISSION 
1. NAME OR DESIGNATION OF PROGRAM - SASIA

2. COMPUTFR FOR WHICH PRDGRAM IS DESIGNED AND OTHERS UPON WHICH IT IS OPERABLF - CDC6600, IBM360/75

3. NATURE OF PHYSICAL PROBLEM SOLVFD - SASIA IS USED FOR THE ANALYSIS OF FAST REACTOR POWER AND FLOW TRANSIENTS. THE PROGRAM CONSISTS OF FOUR DRIVER PROGRAMS FACH CALLED BY THE MAIN PROGRAM. THESE DRIVERS HANDLF THE AREAS OF 11 INPUT/OUTPUT, WITH DIAGNOSTICS, (2) STEADY-STATE INITIALIZATION, TO DEFINE THE CORE OPERATING CONDITICNS BEFORE THE INITIATION OF THE TRANSIENT, (3) THE TRANSIENT PORTION, AND (4) THE DISASSEMBLY (WEAK EXPLOSION) ANALYSIS.

4. METHCD DF SOLUTION -

5. RESTRICTIONS ON THE COMPLEXITY OF THE PROBLEM - MAXIMA OF 20 AXIAL HEAT TRANSFER NDDES IN A FUEL PIN, IN THE UPPER BL ANKET, AND IN THE LOWER BLANKET

6 DELAY GRDUPS

60 REGIONS USED TO DESCRIBE THE CORE

200 AXIAL SEGMENTS IN THE COOLANT CHANNEL

15 RADIAL TEMPERATURES IN THE FUEL

6. TYPICAL RUNNING TIMF - 5 MINUTES ARE REQUIRED ON THE IBM360/75.

7. UNUSUal fEATURES DF THE PROgRAM -

8. RELATED ANI AUXILIARY PROGRAMS - THE BASIC METHOD OF ANALYSIS USED IN THE WFAK EXPLOSION MODULE IS A MODIFIED VERSION OF THE MARS CODF (ACC ABSTRACT 293 ).

9. STATUS - ABSTRACT FIRST DISTRIBUTFD MAY 1970. CDC6600 VERSION SUBMITTED SEPTEMBER 1969. IBM360 VERSION SUBMITTED SEPTEMBER 1969.

10. REFERENCES - A. K. AGRAWAL, J. C. CARTER, G. J. FISCHER, T. J. HEAMES, D. R. MACFARLANE, N. A. MCNEAL, W. T. SHA, C. $K$. SANA THANAN, AND C. K. YOUNGDAHL, SASIA, A COMPUTER CODE FOR THE ANALYSIS OF FAST REACTOR POWER AND FLOW TRANSIENTS, ANL-7607, AUGUST 1969.

$$
\text { SASIA DICTIONARY. }
$$

11. MACHINE REQUIREMENTS - 410K BYTES DN THE IBM360/75 (WITHOUT OVERLAYS) AND APPROXIMATELY $300 K$ BYTES ON THE IBM360/75 (WITH OVERLAYSI

12. Programming language USED - Fortran IV

13. OPERATING SYSTEM OR MONI TOR UNDER WHICH PROGRAM IS EXECUTED SCOPE (CDC6600) AND OS/360 (IBM360). 
667

REACTOR CODE ABSTRACT 400

$-2-$

$05 / 70$

14. ANY OTHER PROGRAMMING OR OPERATING INFORMATION OR RESTRICTIONS PRED IS A FUNCTION SUBPROGRAM WHICH GIVES EITHER THE REACTIVITY OR POWER VERSUS TIME INPUT DEPENDING ON THE OPTION CHOSEN FIR A POWER TRANSIENT. THIS IS AN ARBITRARY FUNCTION WHICH MUST BE STECIFIED RY THE USER.

15. NAMF AND ESTARLISHMENT OF AUTHOR -

T. J. HERMES

APPLIED PHYSICS DIVISOR

AR GONNA NATIONAL LABORATORY

9700 SOUTH CIS AVENUE

$\triangle R G O N N F$, ILLINOIS 60439

16. Material available - magnet IC tape transmittal SOURCF DECKS (6600-8568 CARDS, 360-8590 (ARDS)

SAMPLF PRORLFMS (6600-198 CARDS, 360-198 CARDS)

REFERFNCF REPORT AND DICTIONARY

17. CATEGTRY - F

KEYWORDS - FAST REACTORS, POWER TRANSIENTS, EXCURSIONS, HEAT TRANSFER, REACTIVITY, MARS CODES 
1. NAME OR DESIGNATION OF PROGRAM - GAMTRI

2. COMPUTER FOR WHICH PROGRAM IS DESIGNED AND OTHERS UPTN WHICH IT IS OPERABLF - UNIVACI108

3. NATURF TF PHYSICAL PROBLEM SOLVED - THE HOMOGENFOUS TWO-DIMENSIONAL MULTIGROIP DIFFUSION THEORY EQUATIONS WITH ARBITRARY GROUPTO-GROUP SCATTERING AND ARRITRARY FISSICN TRANSFER ARE SDLVED FOR HETFRTGENFIUS ASSEMRLIES IN (UNIFORM MESHI TRIANGULAR GEOMETRY. HOMOSENF OUS LOSARITHMIC BOUNCARY CONDITIONS ARF USFD AT THF OUTER SURFACE TF NON-DIFFUSION RFGIONS. THF RFSULTS INCLUDE THE GROUP AND PCINT-DEPENDENT NEUTRON FLUXES, THF POWER DISTRIBUTION, THE NEUTRON MULTIPLICATION FACTCR, AND A DFTAILED NFUTRON BALANCF.

4. METHCO OF SOLUTION - THF MULTIGRCUP DIFFUSION THFORY EQUATIONS ARE APPR NXIMATED RY 7-POINT DIFFERFNCF EOUATIONS FOR THF UNIFORM TRIANGULAR NESH GRID. THF SYSTEM OF DIFFERENCE FQUATIONS IS SOLVED RY AN EXTENSION DF THE PCWER METHDD TO FIND THE FIGENVECTOR INFUTRON FLUX) AND THE FIGFNVALUF (K-EFFECTIVE). SUCCFSSIVE LINE OVFRRFLAXATION IS APOLIFD IN A SPECIAL FORM IEXPONENTIAL OVERRELAXATIONI THAT GIUARANTEES THE NCN-NFGATIVITY OF THE NEUTRON FLUX. COARSE MFSH REAALAVCING IS USED TO IMPROVE THE PREASYMPTOTIC CONVERGFNCE REHAVIOR. A VAPIATICN OF AITKENS METHOO IMPROVES THE ASYMPTITIC REHAVIOR, ASSUMING, ONLY CNE ERRCR MODF.

5. RESTRICTICNS ON THF COMPLFXITY CF THE PROBLEM - MAXIMA OF In FNERTY GRDUPS 22. กก๊ SPACE MFSH PIINTS 255 DIFFERENT MATFRI AL REGIONS

6. TYPICAL RIINNING TIMF - 5 TO GO MINUTFS ARE RFQUIRED.

7. UNUSUAL FFATURES OF THF PRDGRAM -

(A) THE COARSE MESH REBALANCING SCHEME INCREASES THE EFFECTIVE SCLUTION RANGE.

(B) SIMULTANEOUS PERFORMANCE OF COMPUTATION ANC DATA TRANSFER PROVIDE ITFRATIONS WITH VIRTUALLY NO DELAY CAUSED BY THE USE OF DRUM STDRAGE.

(C) EFFICIENT RESTART ABILITY AND ABILITY TO ACCEPT A TAPE FLUX GUFSS.

8. RELATED AND AUXILIARY PROGRAMS - gAMTRI IS A MAJOR REVISION OF GAMBIES (ACC ARSTRACT 222 ).

9. STATUS - ABSTRACT FIRST DISTRIBUTED MAY 1970. UNIVACIIOB VERSION SUBMITTED SEPTEMBER 1969.

10. RFFFRENTFS - J. P. DORSEY AND R. FROEHLICH, GAMTRI, A PROGRAM FOR THE SOLUTIDN DF THE MULTIGROUP NEUTRON-DIFFUSION EQUATIONS IN TRIANGULAR GEOMETRY WITH ARBITRARY GROUP SCATTERING, FOR THE UNIVAC$11 \cap 8$ COMPUTER, GA-9201, MAY 12, 1969, AND ERRATA. 
11. MACHINF RFQUIPEMTNTS - 55,536 WORDS TF CORE STDRAGE, 3 TAPE UNITS ON 1 DATA C.HANNFL, $1,572,864$ WORDS DF DRUM STDRAGF FROM 1 DATA C.HANNEL, AND A PERIPHERAL PRINTER-PUNCH.

12. PROGRAMMING LANGUACES USFD - FORTRAN IV 190 PERCENTI AND ASSEMBLY LANGUAGE $(10$ PFRCENT)

13. OPFRATING SYSTEM OR MGNITOR UNDER WHICH PROGRAM IS EXECUTEO FXEC II, GENERAL ATOMIC VERSION GAX 23.

14. ANY CTHER PROGRAMMING OR OPFRATING INFORMATION OR RESTR ICTIONS CTTS IS THF ASSEMBLY LANGUAGE RDUTINE USED FOR THF COMPREHENS IVE CHFCKING AND TRANSMITTING OF DATA INTO AND OUT OF CORE STIRAGE.

15. NAME AND ESTABLISHMENT DF AUTHORS -

J. P. DOR SEY AND R. FROEHLICH

GULF GFNERAL ATOMIC INCORPORATED

P. O. ROX 608

SAN DIEGO, CALIFORNIA 92112

16. MATERIAL AVAILABLF - MAS,NFTIC TAPE TRANSMITTAL

SOURCF DECK $(16,639$ (.ARDS)

SAMPLF PRORLEM (150 CARDS)

RFFERENCF REPORT AND ERRATA

17. CATFGORY - C

KEYWORDS - MULTIGROUP, DIFFUSION EQUATIONS, 2-DIMENSIONAL, TRIANGULAR GFOMETRIES, FLUX DISTRIBUTION, GAMBLE5 CIDES 
1. NAMF TR DESIGNATION OF PROGRAM - SABOR 4

2. COMPUTER FOR WHICH PROGRAM IS DFSIGNED AND OTHERS UPON WHICH IT IS OPERABLE - IRM360

3. NATURF DF PHYSICAL PRDBLFM SOLVED - SABOR4 IS A DISCRETE ELEMENT DISPLAC,EMENT PROGRAM FOR THE LINEAR-ELASTIC, STATIC, LOAD-DEFLECTION ANALYSIS OF MERI DIONALLY-CURVED, VARIABLE-THICKNESS, BRANCHED, THIN SHFLLS DF REVOLUTION WHICH MAY BE SUBJFCTED TO CONCENTRATED DR DISTRIBUTED EXTERNAL LOADING AND TO ISOTHERMAL OR NONUNIFORM TFMPERATURE CONDITINNS. THE PROGRAM CONSISTS OF FIVE PRIMARY SURPROGRAMS - HAL4, MELT4, LANCE4, MAINS4, AND SUMPLOT4. THREE OF THESE (HAL4, MELT4, AND LANCE4) PROCESS EXTERNAL-MECHANICAL-LTAD OR THERMAL-LOAD DATA TO DETERMINE THE GENERALIZED NODAL FORCES FOR EACH DISCRFTE ELEMFNT. MAINS4 COMPUTES THE DISCRETEELEMFNT STIFFNESS AND MASS MATRICES ANC FORMS THESE MATRICES FOR THE ASSFMBLFD STRUCTURE. SUMPLOT4 CALCULATES THE OTHER QUANTITIES CF INTFRFST, SUMS CCNTRIBUTIONS FROM VARIOUS LOADING HARMONICS, AND PREPARES RESULTS FDR CALCOMP PLOTTING.

4. METHON OF SOLUTION - IT IS ASSUMED THAT THE STRUCTURE IS A SHELL OF RFVILUTION WITH AXISYMMETRIC DISTRIBUTIONS DF THICKNESS AND MATERIAL PROPERTIFS SO THAT WHEN THE STRUCTURAL DEFORMATIONS ARE REPRESENTFO AS SUMS DF FOURIER CIRCUMFERENTIAL HARMONICS IN THETA, THF LDAD DEFLFCTION FQUATIONS OF EQUILIBRIUM SEPARATE INTO INDIVINUAL HARMONICS. THEN THE PROBLFM MAY BE SOLVED FOR EACH LOADING HARMDNIC SEPARATELY AND THE RESULTS SUMMED TO DBTAIN THE COMPLETE SOLUTION.

5. RESTRICTIONS ON THE COMPLEXITY CF THE PROBLEM HAL 4 MAXIMA -

150 ELEMENTS

IOn TABULATED F(THETA) POINTS

20 DIFFERENT HARMONIC.S ALLOWED FOR THE COMPLETE STRUCTURE MFLT4 MAXIMA -

150 ELFMENTS

72 THETA VALUES

25 THICKNESS STATIONS

19 HARMONICS IF THE DELTA-TIS, ZETA, THETA) OPTION IS BEING USED

26 HARMONICS IF THF DELTA-TIS, ZETA) OPTION IS BEING USED LANCF 4 MAXIMA -

150 ELEMENTS

29 S STATIONS FOR SIMPSON INTEGRATION ACROSS AN ELEMENT (THIS MUST BE AN ODD NUMRER)

MAINS 4 MAXIMA -

150 ELEMENTS

151 NODES

29 POINTS FOR THE SIMPSONS RULE INTEGRATION ACROSS AN ELEMENT

MAINS4 MINIMA -

O RADIUS AT DNLY DNE END OF AN ELEMENT 
5. RESTRICTIONS ON THE COMPLEXITY OF THE PROBLEM (CONTINUED)

2 ELEMENTS PER BRANCH

SUMPLOT4 MAXIMA -

159 FLEMENTS

37 THETA VALUES

11 THICKNESS STATIONS

175 ELEMENTS + NUMBER OF POLES

49 BR ANCHE S

175 PRINTS TO BE PLOTTED FOR A PARTICULAR FUNCTION AT ONE THETA-VALUE

175 NODES + BRANCHFS + INTERNAL DISCONTINUITIES

SUMPLOT4 MINIMA -

2 ELEMENTS PER BRANCH OR MAIN SHELL

6. TYPICAL RUNNING TIME -

7. UNUSUAL fEATURES DF the PROGRAM -

8. RELATFD AND AUXILIARY PROGRAMS -

9. STATUS - ABSTRACT FIRST DISTRIBUTED MAY 1970. IBM36D VFRSION SUBMITTED AUGUST 1969.

10. REFERFNCES - E. A. WITMER, E. W. MACK, T. H. H. PIAN, AND B. A. BERG, AN IMPROVED DI SCRETE-ELEMENT ANALYSIS AND PROGRAM FOR THE LINEAR-ELASTIC STATIC ANALYSIS OF MER IDIONALLY-CURVED, VARI $\triangle B L E-T H I C K N E S S$, BRANCHED THIN SHELLS OF REVOLUTION SUBJECTED TO GFNERAL EXTERNAL MECHANICAL AND THERMAL LOADS, PART 1 , ANALYSIS AND EVALUATION, SAMSO TR 68-310, PART 1, MARCH 1968.

F. W. MACK, B. A. BERG, AND E. A. WITMER, AN IMPRDVED CISCRETE-ELEMENT ANALYSIS AND PROGRAM FOR THE LINEAR-ELASTIC STATIC ANALYSIS OF MERIODIONALLY-CURVED, VARIABLE-THICKNESS, BRANCHED THIN SHELLS OF REVOLUTION SUBJECTED TO GENERAL EXTERNAL MECHANICAL AND THERMAL LOADS, PART 2, THE SABDR 4 PROGRAM, SAMSO TR 68-310, PART 2, MARCH 1968.

11. MACHINE REQUIREMENTS -

12. PROGRAMMING LANGUAGE USED - FORTRAN IV

13. OPERATING SYSTFM OR MONITOR UNDER HHICH PROGRAM IS EXECUTED OS/360.

14. ANY OTHER PROGRAMMING OR OPERATING INFORMATION OR RESTRICTIONS -

15. NAME AND ESTABLI SHMENT OF AUTHCRS -

E. A. WITMER, E. W. MACK, T. H. H. PIAN, AND B. A. BERG AEROELASTIC AND STRUCTURES RESEARCH LABORATORY DEPARTMENT OF AERONAUTICS AND ASTRONAUTICS MASSACHUSETTS INSTITUTE OF TECHNOLOGY CAMBRIDGE, MASSACHUSETTS 02139 
16. MATERTAL AVAILABLE - RESTRICTED DISTRIBUTION

MAGNETIC TAPE TRANSMITTAL

SCURCE DECK $(5635$ CARDS)

SAMPLE PROBLEM (619 (ARDS)

REFFRENCE REPORTS (MICROFICHE ONLY)

17. CATEGORY - I

KEYWURDS - FINITE-FLEMENT, MASS MATRICES, STRUCTURAL ANALYSIS, SHFLLS 
1. NAME TR DESIGNATIINN OF PROGRAM - TIGIR2

2. COMPUTER FOR WHICH PRIGRAM IS DESIGNED AND OTHERS UPON WHICH IT IS OPFRABLE - CDC6600

3. NATURE OF PHYSICAL PROBLEM SOLVED - TIGIR IS A MODULAR PROGRAM DESIGNED TO GENERATE AND MAINTAIN LIBRARIES OF DOCUMENT INFORMATION IABSTRACTS, BIRL IOGRAPHIC INFORMATION, INDEX TERMS, AND OTHER SIGNIFICANT INFORMATICN), TO RETRIFVE THE INFIRMAT ION SELECTIVELY, TO PRINT THE RFTRIEVED INFORMATICN IN VARIOUS OUTPUT FORMATS, AND TO GENERATE STATISTICS OF THE INFORMATION FILES.

4. METHRD OF SOLUTION - INFORMATION IS RETRIEVED ON A SELECTIVF BASIS. THE SELECTION PROCESS EMPLOYED IS ONE WHICH DETERMINES THE TRUTH VALUF OF A REQUEST FCR ANY GIVEN UNIT RECORD, WHERE A UNIT RECORD IS THE INFORMATION FILED FOR A DOCUMENT, AND THE REQUEST IS A BOOLEAN-LIKE EXPRFSSION WRITTEN IN THE LANGUAGE USED TO DESCRIBE THE DOCUMFNT.

5. RESTRICTIONS ON THE COMPLEXITY CF THE PROBLEM -

6. TYPICAL RUNNING TIME - ONE MINUTE OF CENTRAL PROCESSOR TIME IS REQUIRED TO SEARCH ABOUT 6000 DOCUMENT RECORDS ON TAPE.

7. UNUSUAL fEATURES DF THF PROGRAM -

8. RELATED AND AUXILIARY PROGRAMS - TIGIR2 PRESENTLY IS MADE UP OF THE FOLLOWING OVERLAY PROGRAMS - TIGIR, TIGIRI, LIBGEN, COMPILE, SEARCH, TIGEDIT, AND NOTIFY.

9. STATUS - ABSTRACT FIRST DISTRIBUTED MAY 1970. CDC 6600 VERSION SUBMITTED SEPTEMBER 1969.

10. RFFERENCES - J. L. COPFLAND, R. J. CULLEN, C. H. HUNTER, AND A. E. ZACKRISON, TIGIR, A DOCUMENT RETRIEVAL PROGRAM FOR THE CDC 6600 - USERS REFERENCE MANUAL, KAPL-M-6749, JULY 28, 1969. B. A. BRDWN, TIGIR, A DOCUMENT RETRIEVAL PROGRAM FOR THE CDC 6600 AND TIGSORT, ANOTHER TIGIR MDOULE TO PROVIDE SDRT CAPABILITY, KAPL-M-6749 ADDENDUM NO. 1, OCTOBER 1969.

11. MACHINE REQUIREMENTS -

12. PRDGRAMMING LANGUAGE USED - FORTRAN

13. DPERATING SYSTEM OR MONITOR UNDER WHICH PROGRAM IS EXECUTED SCOPE.

14. ANY CTHER PROGRAMMING OR OPERATING INFORMATION OR RESTRICTIONS SOME NON-STANDARD DPERATIONS SUCH AS BUFFER ASSIGNMENT AT EXECUTE TIME, RANDOM FILE GENERATION AND USE, AND SHIFTING, HAVE MADE MACHINE LANGUAGE SUBPROGRAMS NECESSARY. THE TIGIR 2 PROGRAM TAPE CONTAINS SEVEN BINARY FILFS, FACH BEING AN ABSDLUTE OVERLAY. THE 
RFACTCR CNDE ABSTRACT $403 \quad-2-\quad 05 / 70$

14. ANY OTHFR INFCRMATION OR RESTRICTIONS (CONTINUEC)

OVERLAY SCHEMF REQUIRES THAT THESE EXIST ON DISK WITH THE SPECIFIC INDIVIDUAL NAMES IN CRDFR - TIGIR, TIGIR 1, TIGIR 2, TIGIR 3, TIGIR 4, TIGIR 5, TISIR 6. THF SETUP DECK SETS UP THF DISK FILE AND LOADS THE BASE DVERLAY.

15. NAME AND ESTABLISHMFNT OF AUTHORS -

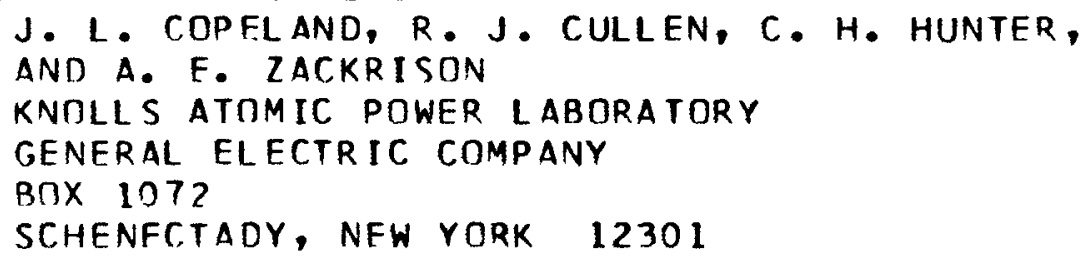

16. MATFRIAL AVAILABLE - RESTRICTFD DISTRIRUTION

MAGNETIC TAPE TRANSMITTAL

TIGIR 2 PROGRAM TAPE (BI NARY)

FILE 1 - TIGIR

FILF 2 - TIGIR 1

FILF 3 - TIGIR ? (LIBGEN)

FILE 4 - TIGIR 3 (COMP ILE)

FILF 5 - TIGIR 4 (SEARCH)

FILF 6 - TIGIR 5 (TIGEDIT)

FILF 7 - TIGIR 6 (NOTIFY)

SFTUP DECK (31 CARDS)

RFFERFNCE REPORT AND ADDENDUM

17. CATEGORY - $M$

KEYWORDS - LIBRARIES, MAINTENANCE, RETRIEVAL, DATA PROCESSING 
REACTOR CODE ABSTRACT $404 \quad 05 / 70$

1. NAME OR DESIGNATION OF PROGRAM - FINEL

2. COMPUTFR FOR WHICH PROGRAM IS DESIGNED AND OTHFRS UPON WHICH IT IS OPFRABLE - CDC6600

3. NATURF OF PHYSICAL PROBLEM SOLVED - FINEL IS A COLLECTION OF THREE PROGRAMS FOR THE CALCULATION DF THE ELASTIC AND PLASTIC BEHAVIOR DF STRUCTURES. THE STRUCTURFS ARE BUILT UP FROM PLATES AND BARS, WHICH CAN BF ARRANGED IN FITHER 2-DIMENSIINAL OR 3-DIMENSIONAL ASSENBLIES. THE PLATES CAN BE IN PLANE STRESS DR PLANE STRAIN. FINEL? HANDLES 2-D STRUCTURES ONLY. FINEL 3 CAN HANDLE BOTH 2- AND 3-D STRUCTURES, BUT IS SLOWER.

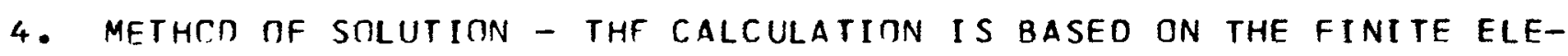
MENT APPROACH.

5. RESTRICTIONS ON THF COMPLEXITY OF THE PROBLEM FINFL? MAXI MA 2000 NODES $10 O \cap$ FLEMENTS

4 TYPES OF MATERIALS

10 DIFFERENT MATERIALS DF FACH TYPE

I IN GROUPS

500 FORCES TF ANY ONE TYPE (X, Y, OR SLANT)

FINEL 3 MAXIMA 500 RDUNDARY CONDITIONS OF ANY ONE TYPE

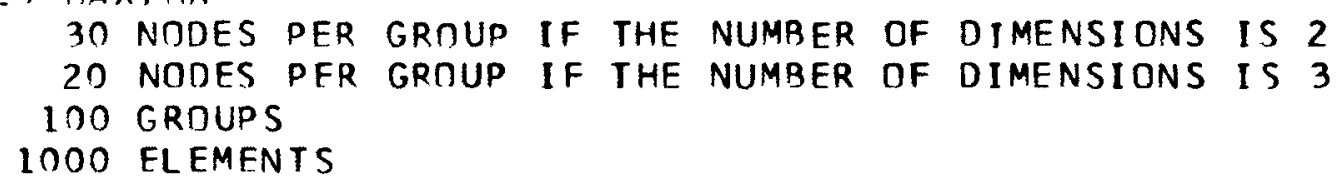

6. TYPICAL RUNNING TIMF - ON THE CDC6600 WITH THE CHIPPEWA OPERATING SYSTEM, FINEL 2 PLASTIC CALCULATIONS TAKE BETWEEN 1.2 AND 1.5 MINUTES PFR 100 NODES.

7. UNUSUAL fEATURES TF THE PROGRAM -

8. RFLATED AND AUXILIARY PROGRAMS - FINPUT IS AN AID FOR THE PREPARATION DF INPUT TO THE FINELS.

9. STATUS - ABSTRACT FIRST DISTRIBUTED MAY 1970. CDC 6600 VERSION SUBMITTED SEPTEMBER 1969.

10. REFERENCES - W. B. JOROAN, FINEL, A PROGRAM TO SOLVE ELASTIC STRUCTURES BY THE USE OF FINITE ELEMENTS, KAPL-M-6582, DECEMBER 1,1966 .

1. A. GRIEB, FINEL-2 INPUT PREPARATIDN AND ERROR CHECKS, KAPL NOTE, MARCH $13,1967$. L. A. GRIEB, FINEL INPUT DESCRIPTION ATTACHMENT, KAPL NOTE, APRIL $28,1967$. 
12. PROGRAMMING LANGUAGE USFD - FORTRAN IV

13. OPFRATING SYSTEM OR MONITOR UNDER WHICH PROGRAM IS EXECUTED CHIPPEWA.

14. ANY OTHER PRDGRAMMING OR TPERATING INFORMATION OR RESTRICTIONS -

15. NAME AND FSTABLISHMENT OF AUTHCRS -

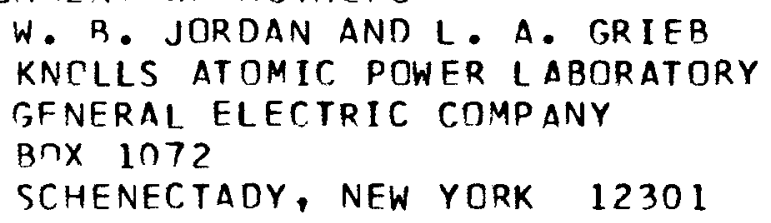

16. MATFRIAL AVAILABLF - RESTRICTED DISTRIBUTION

SOURCE DFCKS (FINEL 957 CARDS, FINPUT 211 CARDS)

SAMPLF PRORLEM (FINEL 34 CARDS)

REFERENCE REPIRT AND NOTFS

17. CATECORY - I

KEYWDRTS - 2-CIMFNS IONAL, 3-DIMENSIONAL, PLATFS, STRUCTURAL ANALYSIS, STRESSES, FINITE-ELEMENT, FINPUT CODES 
1. NAME oR DESIGNATION OF PROGRAM - NDAH

2. COMPUTER FOR WHICH PRDGRAM IS DESIGNED AND GTHERS UPON WHICH IT IS OPERABLE - CDC66ก0

3. NATURE OF PHYSICAL PRDBLFM SOLVED - NOAH SOLVES THE DNE-DIMENSIONAL, ONE-GROUP SPACE-TIME DIFFUSION EQUATION ACCOUNTING FOR THE EFFECTS TF FUFL, CLAD, AND CODLANT TEMPERATURES IDR BY CHANGING SUBR NUTINFS FUFL, COOLANT, AND SOLID MODERATOR TEMPERATURESI ON FISSION AND ARSIRDTION CROSS SECTIONS, ANO ON THE DIFFUSION C.OEFFICIENT AND THE TRANSVERSF BUCKLING. IT CAN ACCOUNT FOR THE EFFECTS DF XENON-IODINE FEEDRACK. IF DESIRED, IT WILL DETERMINE LONG-TIME XENDN-FLUX BEHAVINR ASSUMING THE TEMPERATURES TO BE IN QUASI-STATIS EQUILIRRIUM. NUMERDUS METHODS OF PERTURBATION ARE ALLOWED AND CONTROL DF THE TRANSIENT IS ALSO PROVIDED.

4. METHON OF SOLUTION - THF EQUILIBRIUM STATE IS DETERMINED ITERATIVELY BY AN IMPLICIT TWO PASS TECHNIQUE. THREE ACCELERATIDN METHODS ARF AVAILABLE - FIRST AND SECOND ORDER EXTRAPOLATION OF THE SOURCF AND A JUMP EXTRAPOLATION EVERY 13 ITERATIONS. POINTWISE FLUX CONVERGENCE IS REQUIRED. THE TRANSIFNT IS SOLVED BY BACKWARDS DIFFERFNCING OF TIME DERIVATIVES, AND COEFFICIENTS ARE EVALUATED AT THE PRECEDING TIME-STEP. ALL DEPENDENT VARIABLES (INCLUDING TEMPERATURES AND XENON) ARE EVALUATED ON THE SAME SPATIAL MESH. FIVE OUTPUT PRCCEDURFS ARE POSSIRLE.

5. RFSTRICTICNS ON THE COMPLFXITY OF THE PROBLEM - MAXIMA DF 6 GROUPS OF DELAYFD NFUTRONS

10 RFGIONS

$5 \cap 0$ SPACE POINTS

A NEW RFGION IS REQUIRED WHEN THE FEEDBACK FREF VALUE OF ANY OF THE PARAMETERS IS CHANGED FROM THE PRECEDING REgION VALUE.

6. TYPICAL RUNNING TIME - IF NS IS THE NUMBER OF SPACE POINTS AND NT THE NUMBER OF TIME-STEPS IONE STEADY-STATE I TERATION IS EQUIVALENT TC ONF TIME-STEPI, THEN THE RUNNING TIME IS $T=$ NS $\$ N T / 1500$ SFCONDS. FOR POINTWISE CDNVERGENCE TO $10 * *(-6)$ THE EQUILIBRIUM STATE IS TYPICALLY OBTAINED IN $? O$ TO 80 ITFRATIONS DEPENDING ON THE CHOICE DF ACCELERATION PARAMETERS.

7. UNUSUAL FEATURES OF THE PROGRAM - THE EQUILIBRIUM IS SOLVED BY ADDING A PSEUDO TIME DER IVATIVE WITH A RELATIVELY SMALL TIME CONSTANT. THE APPROACH TO EQUILIBRIUM IS RAPID BECAUSE THE PSEUDO TIME EIGENVALUE IS LARGF. THE JUMP EXTRAPOLATION TECHNIQUE TENDS TO FURTHER INCREASE THE RATE OF APPRDACH TO EQUILIBRIUM. PROVISION FDR READING IN AN ALREADY CALCULATED EQUILIBRIUM STATE IOR AN ARB ITRARY INITIAL FLUX AND TEMPERATURF DISTRIBUTIONI IS INCLUDED. RESTART IS POSSIBLE. PROVISION IS MADE FOR ADDITIONS TO THF PROGRAM BY THE USER IBY THIS WE MEAN A NUMBER OF INPUT LOCATIONS ARE NOT USED IN THE CURRENT CONFIGURATION BUT ARE ADDRESSABLE, HENCE, MAY RE USED IN USER-INITIATED SUBROUTINES WITHOUT CHANGING THE DIMENSION STATEMENTSI. 
8. RELATFD AND AUXILIARY PRCGRAMS -

9. STATUS - ABSTRACT FIRST DISTRIBUTED MAY 1970. CDC.6600 VERSION SUBMITTED SEPTEMBER 1969.

10. REFFRFNCE REPORT - G. S. LELLDUCHE, NOAH, A CODE FOR SOLVING THE ONE DIMENSIONAL SPACF-TIMF DIFFUSION EOUATION ACCOUNTING FOR THE EFFECTS OF TEMPERATURE AND XENON FEEDBACK, BNL-50157 (T-153). JANUARY 1969.

11. MACHINF REQUIREMENTS - 27K MEMTRY

12. PROgRAMMING language USEC - FCRTRAN IV

13. OPERATING SYSTEM OR MNNI TOR UNDER WHICH PROGRAM IS EXECUTED SCOPE 2 OR 3.

14. ANY OTHFR PROGRAMMING OR OPERATING INFORMATION OR RESTRICTIONS THE SOURCE DECK INCLUDES THE MAIN PRDGRAM AND 20 SUBROUTINES. THERE ARE TWO VERSION OF TEMPSS AND TEMPTR - TSSI AND TTR 1 FOR A FUEL-CLAD-COOLANT MIDEL AND TSS2 AND TTR2 FOR A FUEL-COOLANT-SOLID MODERATOR MODFL. THERE ARE TWO VERSION OF STABLE - STB I DOES NOT PERFORM ANY STARILIZATION WHILE STB2 DOES. THERE ARE FIGHT VERSIONS TF THE PERTURBATION SUBRDUTINE, PERT - PRTI FOR A TEST OF STABILITY IJNDFR A TEMPERATURE IMPULSE, PRT? FOR OSCILLATION OF INLET VALUE OF COOLANT TFMPERATURE, PRT 3 FOR A STEP CHANGE IN INLET CONLANT TEMPEQATURE, PRT 4 FOR A RAMP CHANGE IN INLET COOLANT TEMPFRATURF, PRT5 FOR SIMULATION OF AXIAL ROD BANK MOTION, PRT6 FOR A STEP CHANGE IN COOLANT VELOCITY, PRTT FOR A RAMP CHANGE IN COOLANT VELOCITY, AND PRTB FOR ALTERATION OF THE ABSORPTION CROSS SECTION BETWEEN ANY TWO POINTS.

15. NAME AND ESTABLISHEMENT OF AUTHOR -

G. S. LELLOUCHE

BRODKHAVEN NATIONAL LABORATORY

UPTDN, LONG ISLAND, NEW YORK 11973

16. MATFRIAL AVAILABLE - MAGNETIC TAPE tRANSMItTAL

STURCE DECK (2599 CAR.DS)

SAMPLE PROBLEM (75 CARDS)

REFERENCE REPORT

17. CATEGORY - F

KEYWORDS - ONE-GROUP, ONE-DIMENSIONAL, SPACE-TIME, DIFFUSION EQUATIONS, TFMPERATURE FEEDBACK, XENON FEFDBACK 
1. NAMF OR DESIGNATION OF PRIGRAM - DATATRAN 2-D GEOMFTRY INPUT

2. COMPUTER FOR WHICH PROGRAM IS DFSIGNED AND OTHERS UPON WHICH II IS OPERABLE - CDC 6600

3. NATURE OF PHYSICAL PRORLEM SOLVED - THIS SFRIES OF OATATRAN MODULES IS DESIGNED TI FACILITATE THE PREPARATION IF GEOMETRIC INPUT TO 2-DIMFNSIONAL FINITE DIFFERFNCE PROGRAMS FROM DATA READILY TRANSCRIBED FROM FNGINEFRING DRAWINGS AND TO CHECK AND EDIT THE INPUT DATA GFNERATED.

4. METHOD OF SOLUTION - THF MODULES CONSTRUCTED FOR THIS PURPOSE AND THEIR INOIVIDUAL FUNCTICNS ARE

GFO? - TO PRDCESS THE SPECIFICATION OF THF GEOMFTRY AS DRTAINED FROM THE ENGINEERING DRAWINGS IN UNITS OF INCHES OR CENTIMETERS AND DEFINE AND LABEL REGIONS.

PLOT20, PLOT21 - TO DRAW PLANE GEDMETRY PICTURES OF ALL REgIONS DEF INED IN THE GEOMETRY CONSTRUCTION USING MICROFILM, CALCOMP PLOTTER, GERBER DRAFTING MACHINE, DR PRINTFR.

MGEN - TO GENERATE THE 2-DIMENS IONAL 90 DEgREE MFSH DESCRIPTIONS RFQUIRED BY NOVA DIFFUSION THEORY CALCULATIINNS.

MAPI 20 - TO GENERATE A 2-CIMENSIONAL UNIFORMLY SPACED 120

DEGREE MESH DESCRIPTITN FRON REGION DEFINITIONS. BOUNDARIES ARE MAPPFD TO THE NFAREST MESH LINE.

PPLOT - TO GENERATF CONTOUR LINES FROM REGION DEFINITIONS. DUMPIT - TO EDIT THE OUTPUT OF GEO2 FOR CHECKING.

ORDELM - TO REORDER DATA FOR PPLOT.

5. RESTRICTIONS ON THE COMPLEXITY TF THE PROBLEM GEO2 - LIMITED TO PLANAR FIGURES COMPOSFD OF STRAIGHT-LINE SEGMENTS.

PLOT 20,21, MGEN, PPLOT - MAXIMUM OF 490 VERTICES FOR ANY REGION MAPI 20 - MAXIMUM OF 95 VFRTICES FDR ANY REGION

6. TYPICAL RUNNING TIME -

GEO2 - 15 SECONDS FOR A 325-REGION PROBLEM

PLOT20 - 20 SECONDS FOR A CALCOMP PLCT OF A 325-REGION PROBLEM 10 SECONDS FOR FILM PLOT DF A 325-REGION PROBLEM

MGEN - 30 SECONDS FIR A 300-REGION PROBLEM

PPLOT - 5 SECONDS FOR A 325-REGION PROBLEM

GEח2 AND MAP120 - 37 SECONDS FOR A 100-REGION PROBLEM

7. UNUSUal fEATURES OF tHe PROgRAM -

8. RELATED AND AUXILIARY PROGRAMS - PPLOT, PLOT20, PLOT21, DUMPIT, MGEN, MAP120, AND PLOT120 MAY BE RUN FOLLOWING GEO2 TO PREPARE AND CHECK 2-CIMENS IONAL INPUT. PLOT20 AND PLOT2l USE THE PLDTTING SURRCUTINES.

9. STATUS - ABSTRACT FIRST DISTRIBUTED MAY 1970. CDC6600 VERSION SUBMITTED JULY 1969. 
10. REFERENCES - R. H. BFAM AND H. J. KOPP, TWO-DIMENSIONAL GEOMETRY INPUT PROCESSING, KAPL-M-7040L, MAY 15, 1969.

W. E. SCHILLING AND H. J. KOPP, DATATRAN MODULAR PROGRAMMING SYSTEM, KAPL-M-6997L, JULY 1, 1968.

11. MACHINE REQUIPFMENTS - 51,200 WORDS TF HIGH-SPFFD MEMORY

12. PRTGRAMM ING LANGUAGFS USED - FORTRAN IV AND ASCENT

13. OPERATTNG, SYSTEM OR MONITOR UNDER WHICH PROGRAM IS EXECUTED SCOPF 3.1 .

14. ANY CTHER PROGRAMMING OR OPERATING INFCRMATION OR RESTRICTIONS THESF PROGRAMS OPERATE UNDER THE KAPL DATATRAN MODULAR PRTGRAMMING SYSTEM (ACC ARSTRACT 386).

15. NAME AND FSTABLISHMENT OF AUTHCRS -

$$
\begin{aligned}
& \text { R. H. BEAM AND H. J. KOPP } \\
& \text { KNCLLS ATOMIC POWER LAPORATORY } \\
& \text { GENERAL ELECTRIC COMPANY } \\
& \text { ROX } 1072 \\
& \text { SCHENFCTADY. NEW YORK } 12301
\end{aligned}
$$

16. MATFRIAL AVAILABLE - MAGNETIC TAPE TRANSMITTAL

SOURCE DECK WITH SAMPLF PRDBLEMS (9992 (ARDS)

REFFRFNCE REPORTS

FLOW CHARTS (MICROFICHE COPIES AVAILABLE UPON REQUFST)

17. CATEGORY - L

KEYWDRIS - INPUT DATA, DATA PROCESSING, GEOMETRIES, 2-DIMENSIONAL 
RFACTMR CODE ABSTRACT $407 \quad 05 / 70$

1. NAMF OR DESIGNATION OF PROGRAM - DATATRAN UTILITY MDDULES

2. COMPUTER FOR WHICH PROGRAM IS CESIGNED AND OTHERS UPDN WHICH IT IS OPERARLE - CDC 66กO

3. NATURE DF PHYSICAL PROBLEM SOLVED - PLOT2 WAS DESIGNED TO PROVIDE ROUTINE $X-Y$ PLOTS USING THF CALCOMP PLCTTER, MICROFILM UNIT, OR PRINTER AS THF DUTPUT DEVICE. PLOT3 WAS DESIGNED TO PREPARE CONTOUR, PERSPECTIVE, AND STERECGRAPHIC PLOTS FOR THE CALCOMP PLOTTER OR MICROFILM UNIT OF FUNCTIONS OF TWO VARIABLES.

4. MFTHCD OF SOLUTION - PI.OT3 IS AN ADAPTATION OF MOB83 DESCRIBED IN THE RFFERENCE REPORT, WAPD-TM-611.

5. RESTRICTIINS ON THE COMPLEXITY OF THE PRORLEM -

PLOT2 - A MAXIMUM OF 15 CURVES OR ORDINATE SCALES ALLOWED PER PLOT

PLOT 3 - A MAXIMUM OF 9000 POINTS PERMITTED

6. TYPICAL RUNNING TIME -

PLOT 2 - FOR TWO 135-POINT CURVES 5 SECDNDS ARE REQUIRED TO GENFRATE A MICROFILM FIGURE AND 8 SECONDS TO PREPARE CALCOMP DATA. FOR TWO FIGURES EACH WITH THREE 1024-PCINT CURVES 60 SECONDS WERE USED TO PREPARE CAL COMP DATA.

PLCT3 - 13 SECONDS WERE REQUIRED TO GENERATE A 300-POINT CALCOMP PLOT. FILM IS SEVFRAL TIMES FASTER.

7. UNUSUAL fEATURES OF THE PROGRAM -

8. RELATFD AND AUXILIARY PROGRAMS - PLOT3 IS AN ADAPTATION OF THE BETTIS PROGRAM MO883.

9. STATUS - ABSTRACT FIRST DISTRIBUTED MAY 1970. CDC6600 VERSION SUBMITTED JULY 1969.

10. REFERENCES - H. J. KOPP AND B. L. HENNIG, UTILITY PLOTTING MODULES FOR USE IN THF DATATRAN MODULAR SYSTEM, KAPL-M-7047L, MAY 1 , 1969.

W. E. SCHILLING AND H. J. KOPP, DATATRAN MODULAR PROGRAMMING SYSTEM, KAPL-M-6997L, JULY $1,1968$.

0. DILEONARDO, THE GRAPHICAL DISPLAY DF NUMERICAL DATA, WAPD-TM-611, APRIL 1966.

11. MACHINE REQUIREMENTS - 51,700 WORDS OF HIGH-SPEED MEMORY

12. PROGRAMMING LANGUAGES USED - FORTRAN IV AND ASCENT

13. OPERATING SYSTEM OR MONITOR UNDER WHICH PROGRAM IS EXECUTED SCOPE 3.1, SCDPE 3.2.

14. ANY CTHER PROGRAMMING OR OPERATING INFCRMATION OR RESTRICTIONS THESE PROGRAMS DPERATE UNDER THE KAPL DATATRAN MODULAR PROGRAMMING SYSTEM (ACC ABSTRACT 386). 
682

REACTOR CODE ABSTRACT 407

$-2-$

$05 / 70$

15. NAME AND ESTARLISHMENT OF AUTHORS -

R. L. HENNIG AND H. J. KOP

KNOLLS ATOMIC POWER LABORATORY

GENERAL ELECTRIC COMPANY

$B \cap \times 1072$

SCHENECTADY, NEW YORK 12301

16. MATERIAL AVAILABLE - MAGNETIC TAPE TRANSMITTAL SOURCE DECK WITH SAMPLF PROBLEMS (2810 CARDS)

REFERENCE REPORTS, KAPL-M-7047L AND KAPL-M-6997L.

17. CATEGORY - P

KEYWORDS - GRAPHS, DATA PROCESSING, 2-DIMENSIONAL, 3-DIMENSIONAL 
REACTDR CCDE ABSTRACT $408 \quad 05 / 70$

1. NAME DR DESIGNATICN OF PROGRAM - TAC?D

2. COMPUTER FIR WHICH PRTGRAM IS DESIGNED AND OTHFRS UPON WHICH IT IS DPFRABLF - INNIVACI108

3. NATURE DF PHYSICAL PRCBLEM SOLVFC - TAC2D IS DES IGNFD TO TREAT TRANSIENT, TWO-DIMENSIONAL HEAT TRANSFER PRORLEMS. STEADY-STATE PROBLEMS ARF TREATFO BY CONS IDER ING THE PROBLEM TO BE A TRANSIENT, STARTING WITH AN ASSUMFD TEMPFRATURE DISTRIBUT ION AND RUNNING UNT IL EQUIL IBRIUM CONDITIONS ARE ESTABLISHED. GEOMETRICALLY, RECTANGULAR $(X-Y)$, CYLINDRICAL $(R, Z)$, OR CIRCULAR (R, THETA) COORDINATFS MAY BF USED.

4. METHON DF SOLUTIINN - THE HEAT CONDUCTION EQUATION IS REPLACED BY AN EQUIVALENT SET OF LINEAR FINITE DIFFERENCE EQUATIONS. THIS SET OF EQUATIONS IS THEN SOLVED BY THE PEACEMAN-RACHFORD IMPLICIT ALTERNATING DIRECTION METHON.

5. RESTRICTINNS ON THE COMPLEXITY CF THE PROBLEM -

(A) THE GRID LINE SYSTFM MUST BE ORTHOGONAL IN THE RECTANGULAR, CYLINDRICAL, OR CIRCULAR COORDINATE SYSTEM. THEREFDRE, THE SIDES DF THE NODAL ELEMENTS MUST BE ORTHOGDNAL. THE ENTIRE PRDBLEM MLST BE BOUNDED BY FOUR GRID LINES IN CNE OF THE CNORDINATE SYSTEMS - DIFFICULTIES IN TREATING IRREGULAR BOUNDARIES CAN BF OVERCOME TO SOME EXTENT THROUGH THF USE OF MATFRIALS HAVING SPFCIALLY CHOSEN PROPERTIES.

(B) ALL RADIATION IS TREATED ONE-DIMENSIDNALLY.

(C) THERF ARE NO PROVISIONS FOR THERMAL FXPANSION OR CHANGE OF PHASE. SUCH SPFC.IAL HEAT TRANSFFR SITUAT IONS CDULD BE INCLUDEN BY EXTFNSIONS OF THE EXISTING PROGRAMMING.

6. TYPICAL RUNNING TIME -

7. UNUSUAL FEATURES TF THE PRTGRAM -

(A) THE GEOMFTRICAL INPUT IS SIMPLE.

(B) THE INPUT DF THERMAL PARAMETERS IS BY FORTRAN $V$ ARITHMETIC STATEMENT FUNCTIONS. MANY OF THE CALCULATION VARIABLES ITIME, LOCAL TEMPERATURE, LOCAL POSITION) ARE AVAILABLE FDR USE IN THESE FUNCTIONS.

(C) INTERNAL AND EXTERNAL FLOWING COOLANTS MAY BE USED.

(D) THERE MAY BF INTERNAL ANO EXTERNAL THERMAL RADIATION.

(F) THERE IS A WICE SELECTION OF OPTIONAL DUTPUT.

(G) THERE IS A SPECIAL OPTION WHICH MAY BE USED FOR OBTAINING STEADY-STATE RESULTS EFFICIENTLY.

8. RELATED AND AUXILIARY PROGRAMS - TAC3D, WHICH IS THREE-DIMENS IONAL AND HAS ALL THE FFATURES OF TAC2D DESCRIBED IN THIS ABSTRACT.

9. STATUS - ABSTRACT FIRST DISTRIBUTED MAY 1970. UNIVACI 108 VERSINN SUBMITTED OCTOBER 1969. 
10. RFFFRFNCFS - J.F. PFTFRSEN, TAC.2D, A GENERAL PURPOSE TWD-DIMENSICNAL HEAT TRANSFFR COMDUTFR CODE - USERS MANUAL, GA-8868, SFPTEMRFR 6,1969 S. S. CLARK AND J.F. PETFRSEN, TAC2D, A GENERAL PURPOST TWD-DIMENSIONAL HEAT TRANSFER COMPUTER CODE - MATHEMATICAL FORMULATIONS ANN PROKRAMMERS GUIDE, GA-9262, SFPTEMRER 1969. r. W. PEACEMAN AND H. H. RACHFORD, THF NUMERICAL SOLUTION OF PARAROLIS, AND ELLIPTIC DIFFERENTIAL EQUATIONS, I. SOC. INOUST. AODL. MATH., VIL.3, DP. 28-41, MARCH 1955.

J. F. PETERSEN, TAC3D, A GENERAL PURPOSE THREE-DIMENSIMNAL HEAT TRANSFER CODMPUTER CODE - USERS MANUAL, GA-9263, SFPTEMRER $1960^{\circ}$.

S. S. CLARK, J. V. DEL GFNE, AND J. F. PETERSEN, TAC.3D, A GFNERAL DIIRPISE THREE-DIMENSIONAL HEAT TRANSFER COMPUTER CONF - MATHEMATICAL FORMUL ATIONS AND PROGRAMMERS GUIDE, GA-9264, SEPTFMRER $196^{\circ}$.

11. NACHINE REQUIREMENTS - 65K UNIVACI108 DR EQUIVALENT. IN ADDITIDN TI INPUT/OUTPUT, A MAXIMUM OF FOUR AND A MINIMUM OF NO TAPFS ARE RFQUIRED DEPENIINS UPDN THE CODF OPTIONS BEING USED.

12. PROGPAMMING LANTUAGE USED - FORTRAN V

13. TPFR ATING SYSTEM OR MINITOR UNDER WHICH PROGRAM IS EXECUTED EXFC II .

14. ANY CTHFR PROGRAMMING OR DPERATING INFORMATION OR RESTRICTIONS IN SUBRTUTINES ERROR 2 AND STFADY, THE CALLS TO MERR CAUSE TERMIAATION OF THF PRORLEM WITH ERROR FLAG SETTING. ANY METHOD OF TERMINATING WHICH IS APPLICABLE TO THE SYSTEM BEING USFD COULD BE SUBSTITUTFD FRR THESF. TWO CALL MERR STATFMENTS.

15. NAME AND FSTABLI SHMFNT DF AUTHCRS -

J. F. PFTERSFN AND S. S. CLARK
GULF TENERAL ATOMIC INCORPORATED
P. O. BCX GOB
SAN DIEGO, CALIFORNIA 92112

16. MATERIAL AVAILABLE - MAGNETIC TAPE TRANSMITTAL SIURCE DECK (6511 CARחS)

SAMPLF DRTRLEM (289 CARDS)

REFERENCF REPORTS, GA-986\& AND GA-9262

17. CATFGOPY - H

KEYWOROS - HEAT TRANSFER, 2- IIMENSIONAL, COOLANTS, TEMPERATURE DISTRIBUTION 
1. NAMF OR DESIGNATION OF PROGRAM - LARCA

2. COMPUTFR FOR WHICH PROGRAM IS DESISNED AND OTHFRS UPON WHIC.H IT IS DPFRABLE - CNC6600

3. NATURF OF PHYSICAL PROBLEM SOLVED - MULTIGROUP CROSS SECTIONS ARF WEIGHTED BY THE FLUX IA THF APPRCPRIATE GROUPS AND REGIONS, AND CROSS SFCTIONS FOR THF ASSEMRLY ARE CCMPUTED AND PUNCHED IN DTF4 FORMAT. THF PRDGRAM ALSO COMPUTES THE INFINITF MEDIUM FLUX, REACTION RATES, AND THE INFINITE MULTIPLICATION FACTOR AND MATFRIAL BUC.KLING.

4. METHOD OF SOLUTION -

5. RESTRICTIONS ON THE COMPLEXITY OF THE PROBLEM - MAXIMA OF 25 GROUPS

13 REACTIONS PER GRDUP

2n ZONES

36 MATERIALS

6. TYPICAL RUNNING TIMF - 10 SECONDS ARE REQUIRED.

7. UNUSUAL fEATURES TF THE PROGRAM -

8. RELATED AND AUXILIARY PRCGRANS - INPUT AND DUTPUT CROSS SECTIONS ARF IN DTF4 (ACC $\triangle A S T R A C T$ 209) FORMAT. INPUT FLUXES ARF IN THE FORMAT OF 7 ONF FLUXFS PUNCHFC RY DTF4.

9. STATUS - ABSTRACT FIRST DISTRIBUTED MAY 1970. CDC $66 \cap N$ VERSION SURNITTED OCTOBER 1969.

10. REFERFNCES - R. C. ANDERSON, LARCA, A FORTRAN IV CDC-6GOO PROGRAM FOR CALCULATING FLUX-WEIGHTED CROSS SFCTIONS, LA-8373-MS, MARCH 29. 1968, AND ADDENDUM, OCTMAER $1,1969$.

11. MACHINE REQUIREMENTS - 63,00C (CCTAL) STIRAGE

12. PRDGRAMMING LANGUAGE USED - FCRTRAN IV

13. OPERATING SYSTFM OR MONITOR UNOER WHICH PROGRAM IS FXECUTFD SCOPE.

14. ANY OTHER PROGRAMMING OR OPERATING INFORMATICN OR RESTRICTIONS -

15. NAME AND ESTARLISHMFNT OF AUTHCR -

2. C. ANDFR SON

LOS ALAMOS SCIENTIFIC LABORATORY

P. O. BOX 1663

LOS ALAMOS, NEW MEXICD 87544

16. MATERIAL AVAILABLF STURCE DECK 
686

REACTCR CODE ARSTPACT 409

$-2-$

$05 / 70$

16. material aVAiLAsLe (CONTINUED) SAMPLE PRORLEMS RFFFRENCE REPIRT

17. CATEGORY - N KFYWORNS - CRISS SECTIRNS, AVERAGES, DATA PROCFSSING, DTF4 CODES 
1. NAME CR DESIGNATION OF PRDGRAM - TACASI

2. COMPUTFR FOR WHICH PROGRAM IS DESIGNED AND OTHERS UPON WHICH IT IS TPERABLF - UNIVAC 1108

3. NATURF OF PHYSICAL PROBLFM SOLVED - TACASI IS USED TO DETERMINF THE PARAMETERS DF A SINGLE NEUTRON RESONANCE. THE CODE ACCEPTS MEASURED VALUES OF C.APTURE AREAS, SELF-INDICATION AREAS, SELFINDICATION RATIOS AND TRANSMISSION ARFAS AND THEIR ASSOCIATED UNCERTAINTIES IN ANY COMBINATION AND DETERMINES BEST ESTIMATES OF THE NEUTRON AND RADIATIDN WIDTHS AND THEIR STANDARD DFVIATIONS.

4. METHOD DF SOLUTION - LEAST-SQUARES TECHNIQUES ARE USED. THE SOLUTION IS BY I TFRATION STARTING WITH GUESSED VALUES OF THE NEUTRON AND RADIATION WIDTHS. THE MULTIPLE SCATTERING CALCULATION EMPLOYS FITHER INFINITE SLAB OR RIGHT CIRCULAR CYLINDER GEOMETRY WITH THE REAM NORMAL TO THE FACE OF THE CYLINDER. IT IS ALSO POSSIBLE TO SELECT STATIONARY NUCLEUS (DOPPLER BROADENED) OR MOVING NUCLEUS (UNBRDADENED) MODF IN THE MULTIPLE SCATTERING CALCULATION. RUSSIAN ROULETTE AND IMPORTANCE SAMPLING TECHNI QUES ARE EMPLOYED TO REDUCF CDMPUTATION TIMF.

5. RESTRICTIONS ON THE COMPLEXITY OF THE PROBLEM - AS MANY AS 16 OBSFRVED QUANTITIES MAY BE INPUT AND AS MANY AS 24 SUBRESONANCES MAY RE INCLUDED.

6. TYPICAL RUNNING TIME - A TYPICAL PRCBLEM INVOLVING 3 OR 4 OBSFRVED QUANTITIES IN THE STATIONARY TARGET MODE CAN BE SOLVED IN ABOUT 1 MINUTF OF COMPUTING TIME IF THE GUESSES ARE REASONABLY ACCURATE.

7. UNUSUAL FEATURES OF THE PRIGRAM -

8. RELATED AND AUXILIARY PROGRAMS - SIGMA AND FLUSH ARE AUXILIARY CODES USFD TO PRFPARE TACASI INPUT. IF SIGMA AND FLUSH ARF NOT USED, IT WILL BE NECESSARY TO C.CNVERT CAPTURE AND SELF-INDICATION AREA DATA INTO CAPTURE PROBABILITIES AS A FUNCTION OF TIME-OFFL IGHT. THE CODE $P$ IS USFD TO DBTAIN A PRINTER PLOT OF THE EXPERIMENTAL DATA. HOWEVER, THE PLOT OF THE CALCULATED TIME HISTORY CAN STILL BE TATAINED. IF IT IS DESIRED TO PROCESS LARGE QUANTITIES OF DATA THROUGH TACASI, CONTACT THE AUTHOR DIRECTLY ABOUT DBTAINING THESE AUXILIARY CODES.

9. STATUS - ABSTRACT FIRST DISTRIBUTED MAY 1970. UNIVACI108 VERSION SUBMITTED OCTORER 1969.

10. REFERENCE - F. H. FROHNER, TACASI - A FORTRAN IV CODE FOR LEAST SQUARES AREA ANALYSIS OF NEUTRON RESONANCE DATA, GA-6906, AUGUST 4. 1966. TACASI VERSION 3, GGA NOTE. S. FRIESENHAHN, TACASI CPTIONS, GGA NOTE, FEBRUARY $7,1969$. 
10. REFERENCES (CONTINUED) 25. 1969 .

P CODE DESCRIPTION, GGA NOTE.

11. MAC.HINE RFQUIREMENTS - 65K MEMDRY

12. PROGRAMMING LANGUAGF USFD - FORTRAN IV

13. OPERATING SYSTFM OR MONITOR UNDER WHICH PROGRAM IS EXECUTED EXEC II .

14. ANY CTHFR PROGRAMMING OR TPERATING INFORMATION OR RESTRICTIONS -

15. NAMF AND FSTARLISHMENT OF AUTHCR -

S. FRIESENHAHN

GULF GENERAL ATOMIC INCORPORATED

P. O. BOX 608

SAN DIEGO, CAL IFORNIA 92112

16. MATFRIAL AVAILABLE - magnetic tape transmittal

SOURCF DFCK

SAMPLE PROBLEM

RFFERENCE RFPORT

17. CATFGORY - A

KEYWORDS - LFAST SQUARES, RESONANCE PARAMETERS, BREIT-WIGNER FCRMULA 
VI. LIBRARY PROGRAMS BY CLASSIFICATION 
690

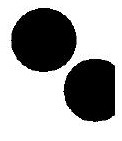

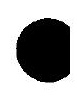

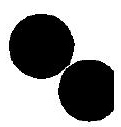


14 HAFEVER

HAFEVER CALCULATES THE ENERGY

EXCHANGE INELASTIC SCATTER ING CROSS SECTION ACCORDING TO THE HAUSER-FESHRACH THEDRY MCOIFIED TC INCLUDE THE EFFECT OF SPINORBIT COUPLING. THF CROSS SECTION IS INTEGRATED OVER ANGLE.

41 ZUT

GRALS FROM RESONANCE PARAMETERS FCR TURFS, COMPOSIIIIONS, AND GECMFTRIES
ZUT COMPUTES RESONANCE INTEA WIDE VARIETY OF TEMPERA-
42 TUZ

GRALS FOR TRIES FOR THE UNRESOLVEO RESONANCES.
TUZ COMPUTES RESONANCF INTEURES, COMPOSITIONS, AND GEOME-

\section{SUMMIT}

THE PROGRAM EVALUATFS THE DIFFERENTIAL ENERGY-TPANSFER CROSS SECTION FOR SCATTERING BY A CRYSTALLINE MODERATOR, UTILIZING THE SO-CALLED PHONON EXPANSION. THE SCATTER ING KERNEL FOR A 1-PHONON CHANGE IN ENERGY IS ADNED TO THAT FOR A 2-PHCNON ENERGY EXCHANGE, AND SO ON. THIS PROGRAM HAS BEEN USED TU DETERMINF SCATTERING MATRICFS FOR BERYLLIUM, GRAPHITE, AND DXYGEN.

SIGMA (F(O) TO FI/SIGMA $(O)=((I M+1) / M) * 2) * \operatorname{SORT}(E / E(O)) * 1 / 2$

THE INTEGRAL FROM -1 TO I CF SIGMAIE(O) TO E,COS(THETA))

D(CDS(THETA))

WHERE E(O) AND E APE THE INITIAL AND FINAL ENERGIES, THETA IS THE ANGLE OF SCATTERING, SIGMA(O) THE FREE-ATOM CROSS SECTION, AND M THE RATIO OF THE MASS OF THE SCATTEP ING NUCLEUS TO THAT OF

THE NEUTRON.

89 ARES2

ARES2 IS USED TO CALCULATE EFFECTIVE RESONANCE INTEGRALS AND MULTIGROUP CROSS SECTIONS FOR LUMPS AND MIXTURES USING RESONANCE PARAMETERS. IT COMBINES IN A SINGLE CODE, THE RESCLVFD, UNRESOLVED, AND $1 / \mathrm{V}$ PARTS OF THE CALCULATICN WHICH WERE PREVIOUSLY IN SEPARATE CODES. THE MULTIGROUP CROSS SECTIONS ARE PRINTED IN A FORM FOR USE IN MULTIGROUP REACTOR* CALCULATIONS. FOR EXAMPLE, THEY CAN BE INSERTED INTO THE AIMG (ACC ABSTRACT 29) OR FAIM (ACC ABSTRACT 120) LIBRARIES. THE ENERGY BREAKPOINTS ARE INPUT DATA AND A RESONANCE PARAMETER LIBRARY IS INCLUDED.

171 NEARREX

NEARREX COMPUTES NEUTRONINDUCED, AVERAGE FLUCTUATION IOR COMPOUND NUCLEUSI CROSS SECTIONS. PROVISION IS MADE FOR THE COMPUTATION OF COMPOUND ELASTIC AND INELASTIC NEUTRON CROSS SECTIONS, RADIATIVE CAPTURE AND FISSION CROSS SECTIONS, AS WELL AS OTHER PROCESSES, SUCH AS PRDTON EMISSICN. IT CAN ALSO BE USED TO COMPUTE PROTONINDUCED AVERAGE CROSS SECTIONS. 
176 RAPTURE

THIS CODE COMPUTFS

RESONANCE INTEGPAIS, AVERAGFS THEM TVER RESONANCE PARAMETRIC DISTRIBUTIONS, AND COMPUTES FISSION AND CAPTURE CROSS SECTIONS AS A FUNCTION OF FUFL TEMPERATURE AND OF POTENTIAL SCAITERING CROSS SECTION PER ABSORBER ISJTOPF.

177 DOPIE

DOPIE WAS DEVELOPED TO STUDY

THE EFFECTS OF -

(1) OVERLAP OF RESONANCES OF UNL IKE FUEL ISOTDPES SUCH AS U238 AND THE PLUTONIUY ISOTOPES, AND

(2) THE TEMPEPATUPE DEPENDENCE OF THE AVERAGE FLUX DVER AN ENEPGY INTERVAL CONTAINING RESONANCES IN THE CALCULATION OF THE DOPPLER COEFFICIENT.

DOPIE COMPUTES FLUX-AVERAGED CROSS SECTIONS OVER A GIVEN ENERGY RANGE UNDER THE FOLLOWING ASSUMPTION

(1) INTERFERENCE SCATTER ING CORRECTIONS WILL BE SMALL AND CAN BE IGNCRED.

(2) SCATTERED NEUTRONS ARE DISTRIBUTED UNIFORMLY OVER THE RANGE OF ENERGY DEGRADATION CONSTANT FOR EACH MATERIAL .

(3) ALL RESUNANCFS ARE RESOLVED OR CAN BE TREATED AS RESOLVFD.

(4) LEAKAGE IS INSIGNIFICANT, MAKING SIGMA R(J) = POTENTIAL SCATTER.ING.

203 COMBCO 140.02791

THE PROGRAM PERMITS COMPUT ING AND CONVOLUTING A CONBINATION CROSS SECTION CURVE COMPOSED OF THE CROSS SECTION CURVES OF A SAMPLE AND UP TO FOUR CONTAMINANTS.

208 TRIXI

TRIXI CALCULATES MULTIGRCUP, DCPPLER-BROADENED EFFECTIVE RESONANCE INTEGRALS AND CROSS SECTICNS AND THEIR TEMPERATURE COEFFICIENTS FOR A HETEROGENEOUS RESONANCE ABSTRBER. USING BASIC RESONANCE PARAMETERS, GEOMETRY AND CONCENTRATIONS, THE CODE COMBINES RESOLVED RESONANCE, UNPESOLVEO RFSONANCE, AND I/V AND NEGATIVE ENERGY RESCNANCE CALCULATICNS. FISS ILE ISOTOPE CALCULATION IS AVAILABLE. L $=1$ UNRESOLVED RESOINANCE CALCULATIONS ARE AVAILARLE FOR ISOTIPES OF ALL SPINS. EQUIVALENCE RELATIONSHIPS ARE CDDED FCR CYLINDERS, SPHERES, AND PLANES. INTERFERENCE BETWEEN RESCNANCF AND POTENTIAL SCATTERING AND ITS TEMPERATURE DFPENDENCE ARE AVAILABLE. THE NARROW-RESONANCE, INFINITEMASS, AND INTERMEDIATF REPRESENTATIONS OF SCATTER INGS WITH ABSORRER ATOMS ARE ALL AVAILASLE. THE ISOLATED SINGLE-LEVEL BREIT-WIGNER LINE SHAPE IS USED. 
214 MISH MASH

THE PROGRAM COMPUTES RESONANCE INTEGRALS FCR INFINITE HOMOGENEOUS MIXTURES FOR ABOVE THERMAL ENERGIES. THE MAJOR PHYSICAL APPROXIMATION IS THAT RESONANCFS ARF REDRESENTED BY THE SINGLE-LEVEL BREIT-WIGNER FORMULATION. IT IS ALSO ASSUMED THAT SCATTERING IS ELASTIC AND THAT A NONRESONANT MATERIAL HAS A CONSTANT SCATTERING CROSS SECTION.

215 CHAD

CHAD IS DESIGNED TO

FACILITATE ANALYSIS AND HANDL ING OF DIFFERENTIAL NEUTRON SCATTER ING DATA. IT PRODUCES LEGFNDRF SCATTERING COEFFICIENTS FRCM ANGULAR DISTPIBUTION DATA TABULATED IN MANY DIFFERENT FORMATS. IT CAN TRANSTCRM ANGULAR DATA INTO LEGENDRE SCATTERING COEFFIC IENTS IN EITHER THE LABORATORY OR THE CENTER-OF-MASS FRAME OF RFFERENCE. IT C.ALCULATES THE AVERAGE COSINE OF THF SCATTERING ANGLE IN THF LABORATORY SYSTEM AND THE AVERAGE LOGARITHMIC ENERGY DECREMENT PER ELASTIC COLLISION.

216 FASOOP

FASDDP EVALUATES POINTWISE, TEMPERATURE-DEPFNDENT CROSS SECTICNS FROM SINGLE-LEVEL BREITWIGNER RESONANCE PARAMETERS.

217 LFGCOEF $3 /$ GEOPGE

CALCULATES LEGENDRE EXPANSION COFFFICIENTS FDR THE ANGULAR DISTPIBUTION OF ELASTICALLY SCATTERED NEUTRONS.

238 EXT/XO

GIVFN A SET DF BREIT-WIGNER

RESONANCE PARAMETERS (ZERO TEMPERATURE) EXT CALCULATES THE EFFECTIVE DOPPLER-PRCADENED CROSS SECTIONS FOR ANY TEMPERATURE . THE EFFECTIVE CROSS SECTION WHEN MULTIPLIED BY THE TARGET DENSITY AND THE NEUTRON VELOCITY (LAB) GIVES THE REACTION RATE PER INC IDFNT NEUTRON. A MAXWELLIAN VELOCITY DISTRIBUTION IS ASSUMED FOR THE TARGET NUCLEI. THE ANALYSIS IS CARRIED DUT FOR SUFFICIENTLY LOW ENFRGIES SO THAT ONLY ZERO NEUTRON ANGULAR MOMENTA $(L=0)$ INTERACTIONS ARE IMPCRTANT. INTERFERFNCE BETWEEN LEVELS IS NEGLECTEC, HOWEVER, INTERFERENCE BETWEEN RESONANCE SCATTERING AND POTENTIAL SCATTERING IS INCLUDED. THERE ARE PROVISIONS FOR ADDING A CORRECTION CROSS SECTION OF THE FORM 1.0/SQRTIE) FOR LEVELS NOT EXPLICITLY CONSIDERED. ALSO THE CROSS SECTION IN THE WINGS OF A NEGATIVE ENERGY RESONANCE, CONSTANTI (SQRT(E) *(E-EO) *2) MAY BE ADDED. 
TERING KERNELS FOR A LARGE CLASS CF MODERATORS. NEUTRON SCATTERING KERNELS ARE OBTAINED FROM THE SCATTERING LAW COMPUTED BY THE CODE GASKET. FLANGEI ALLOWS THF CALCULATION DF DOUBLE DIFFEPFNTIAL CROSS SECTIONS, ANGULAR CROSS SECTIONS, TOTAL CROSS SECTIONS, AND LEGENDRE MCMENTS OF THE SCATTERING KERNEL. THE SHORT COLLISION TIME APPROXIMATICN IS USED FOR ENERGY TRANSFERS LARGER THAN THE MAXIMUM PROVIDED BY GASKET.

2542 PLUS

THE 2 PLUS CODE SOLVES THE PRDBLEM OF THE SCATTEPING OF CHARGED OR UNCHARGED NUCLEONS BY A NUCLEUS REPRESENTEC BY A DEFORMED NUCLFAR POTENTIAL. THE MODEL ASSUMES THAT THE TARGET NUCLEUS HAS A O+ GROUND STATE AND A $2+$ FIRST FXCITED LEVEL, AND THF INTERACTION POTENTIAL HAS A QUADRUPOLE DEFORMATION. A HAUSER-FESHBACH COMPOUND NUCLEUS CALCULATION HAS BEEN INCLUDED. THE OUTPUT CONTAINS TOTAL, POTENTIAL ELASTIC, PDTENTIAL INELASTIC $12+1$, REACTICN, AND COMPOUND NUCLEUS CROSS SECTIONS AS WELL AS ELASTIC AND INELASTIC ANGULAR DISTRIRUTIONS.

263 GASKET

GASKFT CALCULATES THE THERMAL NFUTRON SCATIERING LAW, S(ALPHA,BETA), FOR A LARGE CLASS OF MODERATCRS. PROVISICN HAS BEEN MADF IN GASKET FOR THE FOLLOWING DYNAMICAL MODES OF THE SCATTERER -

(1) FREE TRANSLATION (GAS).

(2) DIFFUSIVE GR EROWNIAN MOTION.

(3) HARMUNIC ISOTROPIC VIBRATIONS WITH CONTINUOUS FRFQUENCY SPECTRUM.

(4) HARMONIC ANISTROPIC VIBRATIONS WITH CONTINUOUS FREQUFNCY SPECTRUM (AS APPLIED FOR INSTANCE TO GRAPHITE).

(5) HARMONIC ISOTROPIC VIRRATIONS WITH DISCRETE FREQUENCY SPECTRUM.

289 GAKER

THE GAKER CODE EVALUATES THE INFLASTIC DOUBLE-DIFFERENT IAL NEUTRON SCATTERING CROSS SECTIONS FCR MODERATORS WITH PHONON SPECTRA WHICH CAN BF REPRESENTED AS SUMS OF DELTA-FUNCTIONS. IT IS BASED ON THE ORIGINAL MODEL FOR LIGHT WATER BY NELKIN, WHICH CONSISTFD RF A TRANSLATOR, A HINDERED ROTATOR (TREATED AS AN ISOIRGPIC OSCILLATOR), ANO SEVERAL VIBRATIONAL OSCILLATORS. THE CODE HAS BEEN MODIFIED SEVERAL TIMES TO INCLUDE MORE OSCILLATORS AND TO TREAT ANISOTROPIC EFFECTS. FINAL ENERGY-INTEGRATED CROSS SECTIONS ARE ALSO CALCULATED. STRUCTED FROM AVERAGE NUCLEAR PROPERTIES IN THE RESOLVED RESONANC REGION. 
305 STPIP

CAPTURE AND FISSION RESONANCF

INTEGRALS ARE CALCULATED BY A FAST METHOD IN THE RESTLVED RESTNANCE RANGE, TAKING FXPLICIT ACCDUNT OF OVERLAP AND INTERFERENCE BFTWEEN RESONANCES IN A MIXTURE OF RESONANCE ABSORBERS. THE RESONANCE INTEGRALS ARE CALCULATED NVEQ ARBITRARY FNERGY BANDS. OPTIONALLY, THF NEUTRCN FLUX AS A FUNCTION DF ENFRGY IN UNE GP TWO REGIONS MAY BE PRINTED DUT.

308 JUPITORI (JPI)

THIS IS A PROGRAM FNR PFRFGRMING CCUPLED-CHANNEL CALCULATIONS TO EVALUATE THE CROSS SECTIONS FOR THE SCATTEFING OF NUCLEAR PARTICLES BY VAPIOUS CCILLECTIVE NUCLFII.

323 MUFFLF

THIS PROGRAM COMPUTES THE NEUTPON CROSS SECTIONS FIR A FISSILE NUCLIDE IN WHICH TNE TO THRFE REACTIGN CHANNELS ARE OPEN FOR THF FISSIDN PROCESS. PRIVISION IS MADE FOR TWO INDEPENDENT SPIN STATES WITH INTERFERING LEVELS AS WELL AS A SET OF NON-INTERFEPING LEVELS. THE CROSS SECTIUNS ARF INTFGRATER OVER A SPFCIFIED GROUP STRUCTURE TO YIELD RESONANCE INTEGRALS.

334 PEGGY

PFGGY IS A LEAST SOUARES SEARCH PROIGRAM WHICH ANALYZES, IN TEPMS OF PHASE SHIFTS, THE ELASTIC SCATTERING UF SPIA ZERD AND SPIN ONE-HALF PARTICLFS BY SPIN ZERD NUCLEI. FEAL OR COMPLEX PHASE SHIFTS MAY BE USED WITH OR WITHOUT SPIN-URBIT C.CUPLING. DIFFEFENTIAL CROSS SECTION AND POLARIZATION ANGIII AP DISTPIBUTIONS MAY BE ANALYZED EITHER SEPARATELY OR SIMULTANEOUSLY.

335 RAMES

PAMES COMPUTES BOTH LOCAL AND NONLOCAL RAOIAL INTECFALS OF A VAPIFTY DF RADIAL UPERATORS USING SINGLE-PARTICLE WAVE FUNCTIONS WHICH ARE EIGENSTATES OF MOTION INN A WMCOS-SAXCN POTENTIAL WELL. THF MPERATORS CURRENTLY AVAILABLF ARE $P * N, N=0,1,2,3,4,5$ ANC THE DERIVATIVE WITH RESPECT TO X OF $1 /(E X P(X)+1)$ WHERE $X=(R-R(0)) / A(0)$.

341 GANDY

THF GANOY CODF EVALUATES TEMPERATURE-UFPENDENT FFFECTIVE NFUTRON CAPTURE, FISSION, AND SCATTER ING CROSS SECTICNS IN THE UNRESDL VED RESUNANCE REGION FRDM AVERAGL RESONANCE PARAMETERS. 
347 CODILLI

A LEAST SQUARES ANALYSIS OF NEUTRON RESONANCE DATA IS PERFORMFD USING THE MULTI-LEVEL EXPANSION. THE PROGRAM CAN HANDLE ONLY ONE SET OF CROSS SECTIONS AT A TIME. OPTIONS ARE PROVIDED FOR. THE ANALYSIS OF REACTION OR TOTAL CROSS SECTION DATA, AND FOR THE DIRECT HANDLING OF TRANSMISSION DATA. BY DPTION, ONE CAN INCLUDE THF MULTI-LEVEL INTERFERENCE DR PERFORM THE FIT IN TERMS OF SUPERIMPOSED SYMMETRIC BREIT-WIGNER LINES, WHILE THE POTENTIAL SCATTERING INTERFERENCE IS ALWAYS INCLUDED IN THE TRIAL FUNCTION FOR THE TOTAL CROSS SECTION. PROVISIONS ARE GIVEN FOR GAUSSIAN AND NON-GAUSSIAN RESOLUTION FUNCTIONS. IN THE LATTER CASE, MOOIFICATION OF ONE SUBRDUTINF ALLOWS FOR ADAPTATION TO ANY KIND OF EXPERIMENTAL CONDITIONS. THE RELEVANT CONVOLUTION INTEGRALS INVOLVING THF TRIAL FUINCTION ARE EVALUATED BY SIMPSON INTEGRATION WITH AN OPTIONAL NUMRER OF INTEGRATION STEPS. BESIDES THE PESONANCES TO BE FITTED, THE TRIAL FUNCTION CONTAINS AN OPTIONAL NUMBER OF RESONANCES HAVING KNOWN PARAMETERS, WHICH MAY REPRESENT RESONANCES EXTERNAL TO THE REGION BEING FITTED AS WELL AS RESONANCES WITHIN THE ENERGY INTERVAL OF INTEREST, THUS PERMITTING IMPURITY EFFECTS TO BE DESCRIBED, OR, IF NEEDED, SPIN STATFS SEPARATED.

359 PUN 1

PUN 1 EVALUATES UNRESOLVED

RADIATIVE CAPTURE INTEGRALS AND RELATED MULTIGRDUP CROSS SECTIONS. THE UNRESOLVED DISTRIBUTIONS MAY HAVE VARIDUS ORBITAL ANGULAR MOMENTUM QUANTUM NUMBERS AND THE EFFECTS OF DOPPLER BROADENING AND SELF-SHIELDING ARE INCLUDED.

360 TOR

THE TOR PRDGRAM CALCULATES THE SCATTERING LAW FOR A CRYSTALLINE MATERIAL IN THE INCOHERENT APPRCXIMATION, FROM THE PHONON FREQUENCY DISTRIBUTION AND A SPECIFIED TEMPERATURF. A PROPORTIONAL QUANTITY IS PUNCHED IN THE FORM OF A TABLE FOR INTERPOLATION OF THE DOUBLE DIFFERENTIAL CROSS SECTION. AS AN ALTERNATIVE, THE PROGRAM OBTAINS THE ANALDGDUS QUANTITIES FOR A MONATOMIC GAS.

368 FLANGE2

FLANGE2 TAKES CROSS SECTIONS, ANGULAR DISTRIBUTION, RESONANCE PARAMETER, AND SCATTERING LAW DATA FROM ENDF/B DATA TAPES AND PREPARES THERMAL MULTIGROUP CROSS SECTIONS AND SCATTERING MATRICES.

376 AVERAGE

AVERAGE CALCULATES AVERAGE SCATTERING, CAPTURE, AND FISSION CROSS SECTIONS FROM S- AND P-WAVE DATA OF THE UNRESOLVED PARAMETERS OF FILE 2 OF ENDF/B. 
377 SIGPLOT

SIGPLOT CALCULATES THE SCATTERING, CAPTURE, FISSION, AND TOTAL CROSS SECTIONS FROM RESOLVED RESONANCE PARAMETER DATA. SCATTERING CROSS SECTIONS MAY BE CALCULATED WITH OR WI THOUT LEVEL-LEVEL INTERFERENCE. PROVISION IS ALSO MADE TO NUMERICALLY DOPPLER-BROADEN ANY OF THE CROSS SECTICNS.

381 LYNNE LYNNE PERFORMS A MULTIPOLE EXPANSION OF THE WOODS-SAXON POTENTIAL. THE NUMBERS GENERATED ARF SUITABLE FOR MICROSCDPIC CALCULATIONS OF INELASTIC SCATTERING FROM NUCLEI WHICH USE A WOODS-SAXON INTERACTION RETWEEN THE PROJECTILE AND THE TARGET NUCLEONS. 
B. SPECTPUM CALCULATICNS, GENEFATION DF GROUP CONSTANTS, LATTICE AND CELL DFCBLFMS

33 GAML/REP/UPOATE

THIS PROGRAM COMPUTFS THE SLOHING-DLWN SPFTTOUM IN EITHEP THF PI OR THE BI APPROXIMATION USING GH GROUPS CF NEUTRRNS WITH A CONSTANT GROUP WIDTH DU $=0.25$, MULTIGROUP TCNSTANTS ART CALCULATED FOR UP TO 32 FAST GRDUPS.

50 TEMPFST?

TEMPEST2 IS A NEUTRON THERMALIIATION PPOGRAM RASED UPOA THE WIGNER-WILKINS APPDOXIMATION FOR LICHT MODEPATORS AN] THE WILKINS APPRDXIMATION FOR HFAVY MOOERATOFS. A MAXWHLLIAN CISTHIRUTICN MAY ALSO BE USED. THE MODEL USED MAY BF SELECTED AS A FUNCTION UF EVERGY. THE SECONO-CRDER DIFFEFENTIAL EQUATINIS ARE INTEGRATFD DIRECTLY RATHER THAN TRANSFORMFD TC THL PICCATI EGUATION. THE PROGRAM PROVIDES MICROSCOPIC AND NACRCSCCPIC CRISS SECTION AVERAGES DVER THE THERMAL NEUTRDN SPECTRUM.

51 FกRM

THE FORM, OR FORTRAN-MUFT, PRIGRAN IS A TOURIF? TRANSFORM SLOWING-DOWN CODE. A LIBRARY TAPE CONTAINING 54-GRCUP MICRCSCOPIC CROSS SFCTIONS, PFSONANCF PARAMFTERS, INELASTIC SCATTERING MATRICFS, AND SOURCF SPFCTRA IS USED TO GENFRATE A 54-GROUP FLUX SPECTRUM AND FEW-GRDUP CONSTANTS.

52 SAIL

THE MONOENERGETIC NFUTRDN

TRANSPTRT ECUATION IS SOLVED IJSING THF DISCRETE SN MFTHCD FOR A CRF-DIMFNSILNAL PLANE CELL. CELL PROPFRTIES ARF COMPUTED.

53 S4 CYLINDPICAL GETMETRY CFLL THIS PPOGRAM SOLVES THE TNEDIMENSIONAL NINIENERGETIC BULTZMANN FQUATION IN CYLINDRICAL GEOMETRY, USING THF S4 APPROXIMATION. IN ADDITION TO THE FLUX DISTRIRUTICN, CFLL-AVFRAGED PARAMFTFRS ARE COMPUTED.

109 BAM

BAM COMPUTES THFRMAL CONSTANTS, SPATIAL AND ENERGY OISTRIRIITIONS IN HETEROGENEDUS CYLINDR ICAL CFLLS RY ASSUMING SEPARABILITY OF SPACE AND ENFRGY IN THE BILTZMANN ERUATION.

$11320 T$

ZTT TAKES MULTIGROUN NEUTRON CRDSS SFCTION SFTS IN THF SN FOPMAT (SNG, DSN, ETC.) AND REDUCES THE NUMBER (F GRIUDS (CCLLAPSES) ACCORDING TO A GIVIN DR CNMPUTED MULTIGRRUP FLUX SPFCTRUM. AVEOAGE VELOCITIES FOR THE FEW-GROUP SET MAY EE GENERATED TN THE BASIS OF THE FLUXES AND VOLUMES FOR A GIVFN REACTLR CONFIGUFATION. 
LATTICE AND CELL PROBLEMS

119 QUICKIE

QUICKIE SOLVES THE NEUTRON SLOWING DOWN AND THERMALIZATIDN PRORLEM IN INFINITE MEDIA BY INVERTING A SET OF SIMULTANEOUS MULTIGROUP EQUATIONS. THE CODE USES THE ULCER (ACC ABSTRACT 118 ) LIBRARY TAPF AND IS IN EXCELLENT AGRFEMENT WITH ULCER FOR THCSE CASES WHERE BUCKLING IS KNOWN.

147 A ILMOE

AILMOE IS A MODIFIED FORM OF THE ANL ELMOE PRDGPAM. THE FOURIER TRANSFORM OF THE FAST NEUTRIN FLUX IS FOUND FOR A MIXIURF OF MODERATORS HEAVIER THAN HYDROGEN WITH THE MODERATOR SCATTERING LAW RIGOROUSLY ACCDUNTED FOR.

149 TYCHE3

TYCHE 3 IS A MONTE CARLO CODE DESIGNFD TO FIND THE SEC TND, FOURTH AND SIXTH MOMENTS OF THE NEUTRON SLOWING DOWN DENSITY DISTRIRUTIDN IN AN INFINITE HOMOGENEOUS MEDIUM. NEUTRON WEIGHTS ARE USED TO AVOID THE TERMINATION OF A HISTORY RY ABSOPPTION AND MINIMIZE THE RUNNING TIMF. PROVISIONS ARE MADF FOP RESTART TF NON-CONVERGED PROBLEMS, GRAPHICAL DISPLAYS OF THE MOMENTS AND AVERAGE FISSION ENERGY AS A FUNCTIDN DF THE NUMBER OF SETS OF HISTORIES AND CALCULATION OF THE CORRECTION TO FLUX MCMENTS.

150 DANCOFF JR .

THIS CODE EVALUATES MODERATOR SPACE CHORD DISTPIBUTION FUNCTIONS OF ZEROTH AND FIRST ORDER, PLUS THE IR LINEAR, SQUARE, LOGARITHMIC AND EXPONENTIAL MOMENTS, FOR REGULAR AND IRREGULAR LATTICES OF CYLINDRICAL FUEL RODS CLAD WITH MATERIAL OF NEGLIGIBLE TOTAL CROSS SECTION. OF PARTICULAR SIGNIFICANCE FOR REACTOR DESIGN CALCULATIONS IS THE EXPONENTIAL MOMENT. OR DANCDFF CORRECTION, WHICH CAN BF CALCULATED EXACTLY IN INFINITE SQUARF AND HEXAGONAL LATTICES, IN CLUMPED SQUARE LATTICES WITH STRAIGHT OR CRUCIFCRM WATER GAPS, OR IN CLUSTERS OF TWO, THREE, SFVFN, AND NINETEEN FUEL RODS.

160 SOPHIST

SOPHIST 1 CALCULATES TEMPFRATURE-DEPENDENT MULTIGPDUP ENERGY TRANSFER COEFFICIENTS FOR A MAXWELL GAS MODERATIP WITH ELASTIC, ISOTROPIC SCATTERING IN THE CENTER OF MASS SYSTEM. SOPHIST 2 CALCULATES TEMPERATURE-DEPENDENT MULTIGRCUP CROSS SECTIONS FOR A MAXWELL GAS. SOPHIST 5 CALCULATES MULTIGROUP ENERGY TRANSFER MATRICES FOR ANISTTROPIC ELASTIC SCATTFRING. 
R. SPFCTRUM CALCHLATITNS, GENEPATION OF GROUP CONSTANTS, LATTICE AND CFLL PFOBLLMS

162 GRAVE GRAVE IS THE PROGRAM TO FORM GROUP-AVERAGED CRUSS SECTICNS USING THE NEUTRON CROSS SECTION MASTER TAPE DEVELODER UNDEP THE ATOMICS INTERNATIONAL AUTOMATED CROSS SFCTICN PROGPAM. NINETEFN GROUP-AVFRAGED PARAMETERS ARE OBTAINABLE AS FILLCWS - SIGMA T, SIGMA EL, SIGMA N, SIGMA F, NUBAR, MUEAT, XIBAR, SIGMA IN, SIGMA N-ALPHA, SIGMA N-P, SIGMA N-2N, SIGMA A, SIGMA TP, SIGMA NON-FL, ALPHARAR, XI*SIGMA EL, NU* SIGMA F, MUBAR*SIGMA EL, ANC SIGMA R. THE SPLCTRUH IS CCNSTRUCTFD FROM A CUMBINATION DF FISSION, E* *-N, POWER SEPIES, MAXWELLIAN OR INPUT SPFCTRA.

173 SDAOTA AVERAGEO DOPPLFO CPEFFICIFNTS AND SPATIALLY-AVERAGED DOPPLER REACTIVITY CHANGES.
184 THERMOS (ANL VFPSION) LIKF THE ORIGINAL THFRMOS CUDF DFVELOPFI BY H. HONECK OF BROOKHAVEN NATIONAL LARLRATCRY COMPUTES THE SCALAR THERMAL NEUTRON SPECTPUM AS A FUNCTITN TF POSITION IN A LATTICE BY SOLVING THE INTEGRAL TRANSPUDT EQUATION WITH ISCTROPIC. SCATTERING. ONFDIMFNSILNAL SLAB UR CYLINDRICAL GEOMETRY MAY BE USED. AS OUTPUT THF CODF SUPPLIES FLIX-AVFRAGED VALUES OF SIGMA $A$, SIGMA F, NU SIGMA F, SIGMA S, ANIT, D FOR THE CELL CDMPOSITION AND THF VALUES OF SIGMA A, SIGMA F, NUS SIGMA F, SIGMA S, AND SIGMA TR FOR THE ISCTOPIC CUNSTITUFNTS.

185 GAMTEC2 GAMTEC2 GENERATES MULTIGROUP CONSTANTS IN THE ENEPGY PANGE FROM O TO 10 MEV FOR EITHER HOMMGFNECUS MIXTURFS CR HETEPOGENETUS ARRAYS CONSISTING CF CYLINDERIZED LATTICE CFLLS. THF THERMAL GROUP CONSTANTS ARE AVERAGED OVER EITHER (1) NIGNER-WILKINS LIGHT MODERATOR SPECTRUM, (2) WILKINS HEAVY MOLIERATOP SPECTRUM, OR (3) A MAXWELLIAN DISTRIBUTION. FCR HETEPOGENERUS ARRAYS THE SPATIAL THERMAL FLUX IS CALCULATED RY A MTNDENFFGETIC P3 APPROXIMATIDN. FOR EPITHFPMAL FNERGIFS, THE SLOWING-DOWN DISTRIBUTION IS DESCRIBED BY EITHEP A RI OR PI APPROXIMATION TO THE BOLTZMANN EQUATION. RESCNANCF ARSCRPTION AND FISSION ARE TREATEO BY THE ADLER-NORDHEIM METHOD. AN I MPROVED METHOC OVER THAT IN GAM-I FOR AVERAGING THE RESONANCE ABSIRPTICN CONTRIBUTION TO THE MULTIGROUP CONSTANTS IS INCLUDED. FUEL LUMPING FFFECTS ON THE FAST FISSION OF U238 AND TH232 APE TPEATED BY AN N-FLIGHT COLLISINN PROBABILITY TECHNIQUE. GROUP COINSTANTS ARE PUNCHED ON CARDS IN HFN (DIFFUSION CODE) AND DTF (SN TRANSPORT CODE) FORMATS. 
B. SPECTPUM CALCULATIONS, gENERATION DF GROUP CONSTANTS, LATTICE AND CELL PROBLEMS

195 FORTRAN FMC-N/FMC-G

THE FLEXIBLF MONTE CARLO PROGRAMS FMC-N ANI FMC-G WERE ORIGINALLY WRITTEN IN ASSEMBLY LANGUACSE FOR THE IRM704 RY GE-ANP. THESE PROGRAMS HAVE BEEN CCNVERTEO TO FURTRAN FOR THE CDC16O4R BY PRATT ANJ WHITNEY. THE PRCGRAMS APPLY MONTE CARLO NETHODS TO SIMULATE NEUTRON AND GAMMA RAY LIFE HISTORIES, RTSPECTIVELY, IN A SOURCE-SHIELD CONFIGURATION. AS THE NAMES IMPLY, THF CDDES ARE DESIGNED FOR FLEXIRILITY IN THE GFOMETRICAL, NATERIAL, NUCLEAR, ANO SOURCE DESCRIPTIONS OF SOURCE-SHIELD CONFIGURATIONS AND VARIANCE REDUCTION TECHNIQUES.

201 EPITHERMOS THE EPITHERMTS CODE IS A MODIFICATION IF THE THERMOS THEPMAL TRANSPORT THEORY CODE OF HONECK. THE ESSENTIAL DIFFERENCE BETWEEN THE CODES IS IN THE LIBRARY PREPARATION SUBROUTINE RASK. IHE EPITHERMOS CODE IS DESIGNED TO COMPUTE THE NEUTRON DENSITY ABOVE 0.7849 EV, THE MAXIMUM ENERGY DF THE IJSUAL THERMOS CALCULATION. EPITHERMOS COMPUTES THE SCALAR NEUTRON DENSITY AS A FUNCTION OF POSITION AND SPEED IN A ONE-DIMENSIONAL SLAB OP CYLINDRICAL SYSTEM. THE SCATTERING MUDEL IS ARBITRARY IN THE THERMAL RANGE AND THE BUILT-IN FREE GAS MDUFL IS USED IN THE EPITHERMAL RANGE.

202 MCS

THE MCS CODE DETERMINES THE SPATIAL DISTRIBUTION CF SOME NUCLEAR REACTION FOR A GIVEN NEUTRON SOURCE IN A GIVEN CONFIGURATION OF MATERIALS. THE MONTE CARLO ESTIMATE OF THE SOLUTION CONSISTS OF PICKING A SAMPLE OF NEUTRONS FROM THE GIVEN SOURCE AND FOLLOWING EACH NEUTRON THROUGH A SEQUENCE OF SURFACE CROSSINGS AND COLLISIONS UNTIL THE NEUTRON EITHEP ESCAPES OR IS NO LONGER DF INTEREST TO THE SOLUTION. THE DESIRED FLUX CR COLLISION DENSITY IS ACCUMULATED FOR EVERY NEUTRON OF THE SAMPLE, AND THF SAMPLF SIZE INCREASED UNTIL RESULTS OF SUFFICIENT STATISTICAL SIGNIFICANCE ARE OBTAINED. 
B. SPECTRUM CALCULATICNS, GENERATION JF GROUP CONSTANTS, LATTICE AND CELL PPOBLEMS

$204 \quad A G N-G A M$

AGN-GAM CALCULATES THE SUBGRDUP FLUXES AND CURRENT TERMS FROM A SOLUTION OF THE PI OR BI EQUATIONS. THE PI EQUATIONS INCORPORATE ROTH VOLUME AND SURFACE STURCES, ALLOWING SPECTPAL CALCULATIONS IN REFLECTOR REGIONS. DTHER SPFCTRAL OPTIONS ARE FLUX KNONN, CURRFNT TERM CALCULATED AND BOTH FLUX ANO CURRENT TFRMS KNOWN. THE AGE FOR THE MATEPIAL IS CBTAINED FROM A SECOND MOMENTS CALCULATION. THE 75 SURGRDUPS USED IN THE CALCULATIONS ARE ESTABL I SHED AS QUARTER LETHARGY GROUPS FROM 10 MEV TO 0.07EV. FLASTIC SCATTEPING MATRICES MAINTAIN THE ENERGYANGLE CORRELATION BY INCLUDING BOTH PO AND PI TERMS. ISOTROPIC SCATTER ING MATRICES ARE INCLUDED FOR INELASTIC AND $(N, 2 N)$ PROCESSES. THE METHOD CF ADLER, HINMAN AND NORDHEIM IS USED TO CALCULATE RESONANCF ABSCRPTION AND FISSION CROSS SECTIONS. MULTIGROUP CONSTANTS ARE GENERATED BY SPECTRAL AVERAGING OVER THE SUBGROUPS.

213 RIFF RAFF

THF PROGRAM COMPUTES RESONANCE INTEGRALS FCR ABSORBERS IN A RTO IN A TWD-REGION CIRCULARIZED CELL FOR ABOVE THERMAL ENERGIES. THE FLUX DISTRIBUTION IN THE CELL IS ALSO COMPUTED AND CAN BE PRINTFD. THE METHOD OF SOLUTION IS RASED UPON THE FOLLOWING ASSUMPTIONS - ISOTROPIC SCATTER ING IN THE LABURATORY SYSTEM, CCNSTANT TOTAL CROSS SECTION IN THE MODERATOR AND ISOTROPIC NEUTRON FLUXES ENTERING AND LEAVING THE RCD.

219 GAROL GAROL COMPUTES EFFECTIVE GROUP CROSS SECTIONS FOR THE RESOLVED RESTINANCES OF A MIXTURE OF ISOTOPES IN A TWO-REGION CELL. RASIC CROSS SECTIONS INCLUDE TEMPERATURE DEPENDENCE. THE PROGRAM ALLOWS A CHOICE OF GEOMETRIES AND CAN ACCEPT AN ARBITFARY TABLE OF ESCAPE PROBABILITIES. A DANCCFF CORPECTION MAY BE USED TO ACCOUNT FOR SHADDWING EFFECTS IN A TIGHT LATTICE, AND CROSS SECTIONS MAY BE $1 / \mathrm{V}$, CONSTANT, COMPUTED FRCM BREIT-WIGNER RESCNANCE PARAMETERS, OR GIVEN IN TABULAR FORM. THE MESH MAY BF CHISEN AT EQUAL ENERGY OR LETHARGY INTERVALS, PROPORTIONAL TO THE NEUTRDN VELOCITY, OR AS AN ARBITRAR TABLE OF VALUES.

235 GAMMA-P (NMP468) CRISS SECTIONS FOR THE PRODUCTION OF GAMMA RAYS BY NEUTRON RADIATIVE CAPTURE, BY NFUTRON INELASTIC SCATTERING, AND BY NEUTRON-INDUCED FISSIDNING ARE COMPUTED AS A FUNCTION OF NEUTRON LETHARGY GROUPS AND PHOTON ENERGY GROUPS. 
237 BOUNCE

THE BOUNCE CODE NETERMINES THE ONE-GROUP THERMAL NEUTRON FLUX DISTRIBUTION WITHIN THE PIN BUNDLE OF A MULTIPLE-PIN FUEL ELEMENT. ALL SCATTERING WITHIN THE PINS IS CONSIDFRED TO BE ISOTRDPIC. ELEMENTS WITH 6, 7, 12, 13, 18, AND 19 FUEL PINS, WHFRE FACH PIN IS CCMPCSFD OF A CENTRAL FUEL PELLET SURRDUNDED BY A CLADCING MATERIAL, MAY BE TREATED. THE C.ONLANT REGICN AROUNO THF PINS IS ASSUMFD TO CONTAIN A VOID.

\section{$243 \quad A G N-S I G M A$} ASN-SIGMA CALCULATES THF LEGENDRE COMPONENTS RF THE MULTIGPOUP TRANSFER MATRICES SIGMAIL,G TO G+NI FOR FAST NEUTRONS. REACTIONS CONSIDFRED ARE FLASTIC SCATTERING, INFLASTIC SCATTERING ILEVEL EXCITATION AND THE EVAPORATION MODELI, ANE THE FCLLOWING FIVE DECAY MODES FOR THE $(N, 2 N)$ RFACTION -- $A(N, N 1) A *(N 2)(A-1) * 3-A N D$ 4- BJOY PHASF SPACE MODEL, EVAPCRATICN MCDEL, AND THE CLUSTER MONFL, WHERE A IS THE RECOIL NUCLEUS. ALL NUCLEAR LEVELS INVOLVED IN THE TRANSITIONS ARE DISCRETE. THE CODE MAY ALSO BE USED TO CALCULATF GROUP AVFRAGFD CPOSS SECTICNS AS WELL AS TO MANIPULATE, F.G., ADD, MULTIPLY, ETC.. THE CUTPUT MATRICFS. THF NEUTRON SPECTRUM MAY BE A COMBINATICN GF FISSION AND I/F CR ARRITRARY INPUT DATA.

\section{LASER}

LASER IS BASED ON MODIFIED VERSIINS GF THE SLGWING-DTWN PROGRAM MUFT AND THE THERMALIZATION TPANSPORT THECRY PROGRAM THERMOS, AND PERFORMS A CALCULATION OF THE NFUTRON SPECTRUM IN A UNIFORM LATTICF MADE UP OF CYLINDRICAL RODS, CLAODING, AND SURROUNDING MODERATOR. THE THERMAL CUTOFF IN LASER IS 1.855 EV. THE PRCGPAM PERFCRMS A BURNUP CALCULATION FOR THE LATTICE. THE SPATIAL DISTRIBUTICN OF BURNUP WITHIN THE FUEL ROOS IS EXPLICITLY CALCULATED. THT PROGRAM WILL, AT OPTION, ACCOUAT FDR. ALL NON-LINEARITIES AND MUTUAL CONNECTIONS IN THE SYSTEN IF BURNUP EQUATIONS. THIS CALCULATION ACCOUNTS FOR THE VARIATICN CF THE NFUTRCN FLUX IN SPACE AND ENERGY DURING EACH TIMESTEP. A BUCKLING AND A RORON PUISON SEARCH (CRITICALITY SEARCH) ARE PROVIDED AS CFTIONS. CUUTPUT INCLUDES EDITS IN THE ENERGY RANGE ZERO LESS THAN GR EQUAL TO F LESS THAN OR EQUAL TO 0.625 EV:

257 REAX

REAX CALCULATES EPITHERMAL FLUX, ACTIVITIES AND CROSS SECTIONS AS A FUNCTION OF RADIUS AND ENERGY FUR A CONSTANT TEMPEFATURE FUEL ROD IMMERSFD IN A HOMOGENEOUS MEDIUM.

276 AVOID

DIFFUSION COEFFICIENT A CYLINDRICAL REACTOP VOID.
AVOID COMPUTES THE FQUIVALENT AND LOSS CRISS SECTION OF AN ANNULAR VOID IN AND THE RADIAL FLUX DISTPIBUTION IN THE 
B. SPECTRUM CALCULATIONS, GENERATION OF GROUP CONSTANTS, LATTICE AND C.ELL PROBLEMS

277 HAMMER/LITHE/HELP/LIBCON HAMMER PERFORMS INFINITE LATTICE, ONE-OIMENSIONAL CELL MULTIGROUP CALCULATIONS, FOLLOWED IOPTIONALLY) BY UNE-DIMENSICNAL, FEW-GRGUP, MULTIREGION REACTOR CALCULATIONS WITH NEUTRCN BALANCE EOITS.

279 LEOPARD/SPOTS

GENIZATION AND SPECTRUM GENERATION: FUEL DEPLETION OPTION.
LEOPARD IS A UNIT CELL HOMO(MUFT-SOFDCATE) PROGRAM WITH A
$280 \quad M 0807$ SIONAL FIXED-SOURCE DIFFUSION EQUATION FOR THE ABSORPTION AND REMOVAL MACROSCOPIC CROSS SECTIONS REQUIRED TO YIELD A SPECIFIED REACTIUN RATE DISTRIBUTION.
281 RABBLE/WLIB/FLAT CROSS SECTIONS FOR ABCV SINGLE-LEVEL RESONANCE PARAMETERS FOR INFINITE HOMOGENEOUS OR HETEROGENEOUS SYSTEMS.
285 RESQ2/RESQO/DRF1

RESQ2 CALCULATES THE RESONANCE INTEGRAL IN A TWO-DIMENSIONAL, HEXAGONAL SYSTEM CONSISTING OF FUEL, CLAD AND WATER WITH A REFLECTING BOUNDARY CONDITION.

291 HEXSCAT

HEXSCAT CALCULATES PO THROUGH P3 COMPONENTS OF THE POLYCRYSTALLINE COHERENT ELASTIC NEUTRDN SCATTERING CROSS SECTION PER NUCLEUS FOR A HEXAGONAL LATTICE. THE CODE AVERAGES POINT VALUES OVER INPUT GROUP BOUNDARIES TO GIVE SMOOTHED GROUP CROSS SECTIONS. 
SPFCTRUM CALCULATIONS, GENFRATION OF GRMUP CONSTANTS,

LATTICE AND CELL PROBLEMS

$298 \quad G G C 4$

THE GGC4 PRDGRAM SDLVES THE

MULTIGROUP SPECTPUM EQUATIONS WITH SPATIAL DEPENDENCE REPRESENTED BY A SINGLE POSITIVE INPUT BUCKLING B BROAD GROUP CROSS SECTIONS (SHIELDED CR UNSHIELDEDI ARE PREPARED FOR DIFFUSION AND TRANSPORT CODES RY AVERAGING WITH THE CALCULATED SPECTRA OVER INPUT-DESIGNATED ENERGY LIMITS. THE CODE IS DIVIDED INTO THREF MAIN PARTS. A FAST (GAM) SECTION WHICH COVERS THE ENERGY RANGE FRCM 14.9 MEV TO 0.414 EV, A THERMAL (GATHER) SECTION WHICH COVERS THF ENERGY RANGE FROM O TO 2.3\% EV, AND A CONBINING (COMBO) SECTION WHICH COMBINES FAST AND THERMAL CROSS SECTIDNS INTN SINGLE SETS. RASIC NUCLEAR DATA FOR THE FAST SECTION WHICH CONSISTS OF FINE GROUPAVERAGED CROSS SECTIONS AND RESINANCE PARAMETERS IS READ OFF A DATA TAPE. THE FINE GRDUP ABSOPPTION AND FISSION CROSS SECTIONS MAY BE ADJUSTED BY PERFORMING A RESONANCE INTEGRAL CALCULATION. UTILIZING A FISSION SOURCE AND AN INPUT BUCKLING, THE CODE SOLVES THE P1, B1, B2, DR B3 APPRCXIMATICN TO OBTAIN THE ENERGY-DEPENDENT FAST SPECTRUM. TWO OR SIX SPATIAL MOMENTS OF THE SPECTRUM IDUE TO A PLANE SCURCE) MAY ALSO BE EVALUATED. INSTEAD OF PERFORMING A SPECTRUM CALCULATION, THE USER MAY ENTER THE LEGENDRE COMPONENTS OF THE ANGULAR FLUX DIRECTLY. FOR AS MANY INPUT-DESIGNATED BROAD GROUP STRUCTURFS AS DESIPED, THE CODE CALCULATES AND SAVES (FOR THE COMBINING SECTICN) SPECTRUM-WF IGHTED AVERAGES OF MICROSCOPIC AND MACROSCOPIC CROSS SECTIONS AND TRANSFER ARRAYS. SLOWING DOWN SOURCES ARE CALCULATED AND SAVED FDR USE IN THE LOWER ENERGY RANGE. GIVEN BASIC NUCLEAR DATA, THE THERMAL SECTION OF GGC4 DETERMINES A THEPMAL SPECTRUM BY EITHER READING IT AS INPUT, BY CALCULATING A MAXKELLIAN SPECTRUM FOR A GIVEN TEMPERATURE, OR BY AN ITERATIVE SOLUTION OF THE P3, BO, P1, OR BI EQUATIONS FOR AN INPUT RUCKLING. TIME MOMENTS OF THE TIME AND ENERGY-DEPENDENT DIFFUSION EQUATIDNS ARE CALCULATED (AS AN OPTION) USING THE INPUT BUCKLING TO REPRESENT LEAKAGE. BROAD GROUP CROSS SECTIONS ARE PREPARED BY AVERAGING FINF GROUP CROSS SECTIONS OVER THE CALCULATED SPECTRA. BRDAD GROUP STRUCTURES ARE READ AS INPUT. THE COMBINING SECTION OF GGC4 TAKES THE BRDAD GROUP-AVERAGFD CROSS SECTIONS FROM THE FAST AND THERMAL PORTIONS OF GGC4 AND FORMS MULTIGROUP CROSS SECTION TABLES. THFSE TABLES ARE PREPARED IN STANDARD FORMATS FOR TRANSPORT OR DIFFUSION THEORY CALCULATIONS. IN ADDITION, IT IS POSSIBLE TO USF THE COMBINING SECTION TO PRODUCE MIXTURES NOT USFD IN THE SPECTRUM CALCULATION DR TO COMBINE THE RESULTS OF OIFFERENT TAST AND THERMAL SECTION CALCULATIONS AND SO ON. THESE OPTIONS ARE DESCRIBFD IN REFERENCE 2 .

306 FCC4

FCC4 IS A MULTIPURPOSE DATA MANIPULATION CODE FOR USE IN FAST REACTOR ANALYSIS. THE CODE CAN BE USED TO - (A) COMPUTE RESONANCE-SHIELDED CROSS SECTIONS USING DATA IN THE RUSSIAN FORMAT (SHIELDING FACTORS AND INFINITE-DILUTION CROSS SECTIUNS), (B) COMPUTE MULTIGROUP FUNDAMENTAL-MODE FLUX AND ADJOINT FLUX, (C) COMPUTE AND PUNCH GROUP-COLLAPSED MICROSCDPIC OR MACROSCOPIC CROSS SECTIONS IN THE DTF FORMAT, (D) COMPUTE FUEL BURNUP AT CONSTANT FLUX OR PCWER DENSITY. 
B. SPECTRUM CALCULATICNS, GENERATION DF group CONSTANTS, LATTICE AND CFLL PRCBLFMS

307 HWOCR-SAFE

HWOCR-SAFE IS A MONTE CARLO THERMAL REACTOP, ANALYSIS PRCGRAM DESIGNED FOR USE WITH PROPOSED HWCCR LATTICE CUNFICURATIONS. IT IS A BENCHMARK TOOL TO CHECK MULTIGRDUP DIFFUSION AND TRANSPRRT CALCULATIONS AND TO EVALUATE THF EFFECT CF THFIR USE OF GEOMETRIC APPROXIMATIONS.

316 GAFGAR/P3T/PROC/TAPCOP THE PROBLEM IS TO ORTAIN VERY DETAILED NEUTRON FLUX AND CURRENT DISTRIRUTIONS AS FUNCTIONS OF ENERGY CONSIDERING EXPLICITLY THE POSSIBLE OVERLAP EFFECTS BETWEEN RESCNANCES OF A PESONANCE ABSORBER AND OF MIXTURES OF RESONANC.E ABSCRPERS AND TO USE THESE DISTP IBUTIONS TO PREPARE GROUP-AVERAGED CRIISS SECTIONS AND TRANSFER ARRAYS FOR USE IN FAST REACTOR ANALYSFS.

$355 M C * 2$

MIJLTIGROUP CROSS

(FNDF) AND THESE NEUTRCINICS CODES
MC * *2 IS USED TO CALCULATE SECTIONS USING AN EVALUATED NUCLEAR DATA FILE CPISS SECTIONS ARE SUITABLE FOR DIRECT USE BY WITHOUT PERFORMING ANCILLARY CALCULATIONS.

361 GLEN

THE GLEN PROGRAM INTERPOLATES VALUES OF A FACTCR PFCPORTICNAL TO THE SCATTERING LAW FROM THE PUNCHFD DUTPUT OF THE TOR CCDE (ACC ABSTRACT 360). THE DIFFERENTIAL CROSS SECTION DETERMINED FROM THESE IS INTEGRATED DVER THE SCATTERING ANGLE TO CBTAIN COEFFICIENTS OF AN EXPANSION IN LEGENDRE PCLYNOMIALS OF THIS ANGLE FGR $\mathbf{L}=0,1,2,3$. INTEGRATICN GVEF FINAL ENERGIES YIELDS VALUES OF THE TOTAL SCATTERING CROSS SECTIIN AND TRANSPORT CROSS SECTION. FOR EACH OF A SERIES OF ISCTUPIC COMPOSITICNS (UP TO 10 COMPOSITIONS) THE GLEN CDDE CALCULATES THE DIFFUSION LENGTH AND VALUES OF THE FLUX-WEIGHTED GROUP AVERAGE MACROSCOPIC SCATTERING, ABSORPTION, FISSION, AND TRANSFER CRTSS SECTICNS.

362 WELWING

WELWING WAS DEVELOPED TO CALCULATE THE MATERIAL RUCKLING DF REACTOR SYSTEMS CONSISTING OF ANNULAR FUEL ELEMENTS IN HEAVY WATER AS MODERATOR FOR VARIOUS MODERATOR TO FUEL RATIOS. THE MODERATOR TO FUEL RATIO FOR THE MAXIMUM MATFRIAL RUCKL.ING FOR THE PARTICULAR SYSTEM IS SELECTED AUTOMATICALLY AND THE CORRESPONDING MATERIAL BUCKLING IS CALCULATED. 
SPECTRUM CALCULATIONS, GENERATICN TF GROUP CONSTANTS,

LATTICE AND CELL PPOBLEMS

$37410 X$

1DX IS A MULTIPURPOSF, ONF-

DIMENSIONAL DIFFUSION CCNE FOR GENFP.ATING CROSS SECTIONS TO BE USED IN FAST REACTIR ANALYSES. THE CODE IS DESIGNED TO -

(A) COMPUTE AND FUNCH RFSONANCE SHIELDED CROSS SECTIONS USING DATA IN THE PUSSIAN (SEF PEFERENCE 2 I FORMAT,

(B) COMPUTE AND PUNCH GROUP-CGLLAPSED MICROSCOPIS AND/BR MACROSCOPIC CROSS SECTIONS AVERAGED OVER THE SPECTRUM IN ANY SPECIFIED ZONE, AND

(C) COMPUTE KLFF AND PERFORM CRITICALITY SEARCHES ON TIME ARSURPTION, MATEF IAL CONCENTRATIONS, ZONE DIMFNSIONS, AND BUCKLING USING EITHER A FIUX OP AN ADJOINT MUDEL. 

AL SN APPROXIMATICN IN FINITE CYLINDRICAL GEOMETRY. IT IS A FORTRAN ADAPTATION IF THF LOS ALAMOS TDC PROGRAM WRITTEN BY BENGT CARLSTN AND CLARENCF LEE. FIRN IS LIMITFD TO A MAXINUM OF SIX GPRIJPS ANU THE S2, S4 OR SG APPROXIMATION.

- FIRF5

FIRES SOLVES THE ONE-DIMENSIONAL MULTIGROUP AGE-DIFFUSION ERUATIONS FOR SLAB ISYMMETRIC AND ASYUMETRICI, CYLINDEF, AND SPHERE GECMFTRIFS. AN EXTENSION OF THF ORIGINAL LOS ALAMOS FIRE PROGRAM WRITTEN RY F. W. BRINKLEY AND C. H. MILLS, IT CONTAINS A 34-GROUP LIBRARY OF 10 ELFMENTS. FIRES CAN $3 E$ USED FOR CELL CALCULATIONS WITH THE BOUNDARY CONNITION THAT THF CURRENT BE TERO ON THE OUTER B OUNDARY. THF EFFECTIVE CROSS SFCTIIVS ANO DIFFUSION COEFFICIFNTS FOR A HOMOGFNISED REGION CONSISTING OF ANY NUMBEP OF NEIGHBGRING RFGIONS CAN ALSO BE ORTAINFD. RUT CNLY FOR CYLINDR ICAL GEOMETRY. FIRES ALSO COMPUTES THF MACROSCOPIC FLUX-WEIGHTED CROSS SECTINNS FOR COLLAPSEN GROUPS IN EACH REGICN.

$182 \mathrm{DXY}$

THF 2DXY PROGRAM SOLVES THE HOMOGENFOUS OR INHOMOGENEOUS MULTIGROUP EQUATIONS IN $X-Y$ GEOMETRY, USING THF SN TRANSPORT FQUATION APPROXIMATION. VACUUM, SURFACE SOUPCE, OP REFLECTING BCUNDARY CONDITIONS ARE AVAILABLE AS OPTIONS. IN THE HOMCGENEGUS CASE THF USER MAY REQUEST THE COMPUTAIIIN IIF REACTIVITY, FFACTRR PERIOC, CRITICAL CONCENTRATIONS OF SOME COMPNSITICN, RR THE CRITICAL THICKNESS OF A ZONE.

\section{$28 \quad F O G$}

THE FOG PROGRAM SOLVES THE ONE-DIMENSIINAL FEW-GFOUP DIFFUSION EQUATIONS IN ANY OF THREE GEOMETRIES SLAB, CYLINOER, GR SPHERE. PROVISIONS ARE MADE FDR CALCULATING THE FLUX, THF ADJOINT FLUX, AND VARIOUS CRITICALITY SEARCHES AS WLLL AS A BUCKLING ITERATION AND AUTOMATIC TSCHEPYSCHEFF PILYNOMIAL COMPUTATION OF SOURCE EXTRAPOLATION FACTRRS.

\section{AIMS}

AIMG SOLVES THE ONE-DIMENSIONAL MULTIGRDUP DIFFUSIIN FQUATIONS UTILIZING A MICROSCOPIC CROSS SFCTICN LIRRARY. ANY OF THREE GEOMETRIES ARF AVAILABLE SLAB, CYLINDER UR SPHFRF. CRITICALITY SEARCHES ARE PRIVIDED INCLUDING A CONCENTRATICN SEARCH TN CNE OR TWO ELEMENTS. HOMOGENEOUS AND INHCMCOOFNEDUS PRCIRLEMS MAY RE SOLVED WITH A VARIETY CF RDUNDARY CONMITITN OPTICNS. 
30 PERT

PFRT IS A PERTURBATICN PPOGRAM DESIGNED FOR USE WITH THE AIMS AND FOG PROGRAMS. PUNCHED CARD OUTPUT FROM THESE COUES IS USED AS INPUT TO PERT. USING CROSS SECTION DATA, FLUXES, AND ADJOINT FLUXES, THE RELATIVF CHANGE IN KEFF CAN BE CALCULATED. CROSS SECTIONS MAY BE WEIGHTFD WITH THE ADJRINT FLUX ANDIOR DIRFCT FLUX. THE NEUTRON LIFETIMF FOR THE DELAY GROUPS MAY ALSC: BE DETERMINED.

32 NHIPLAWAY GROUP, THREL-DIMENSIGINAL, NEUTPON GEGMETRY.

39 EQUIPCISE 3 GRCUP, TWO-CIMENSIONAL, NEUTRCN DIFFUSION EQUATIONS IN CYLINDRICAL OR. SLAR GEOMETRY.

40 2OGRAND 2OGRAND SOLVES THE FEW-GRCUP, TWO-DIMENSICNAL. NEUTFON DIFFUSION EQUATIONS IN CYLINDRICAL OR SLAB GECMETRY.

59 MIST

MIST OBTAINS THE SCLUTION TO THE CNE-DIMENSIONAL BOLTZMANN EQUATIINN IN SLAB GEOMETPY. THE NUMERICAL APPROXIMATION USED IS A LINEAR ONE WHICH CAN RE DESCRIHED AS AN EXTENSICN AND GENERALIZATION OF THE SN APPROXIMATION. THE EQUATIONS ARE FORMULATED IN TERMS IF A DOUBLE SN APPROXINATICN. THE BOUNDARY CCNDITICNS FOR EACH GROUP MAY BF INDEPENDENTLY SPECIFIED AND PEPMIT VFRY GENERAL SPFCIFICATIONS WITH RESPECT TO-

(A) PERFER.T MIRROR RETLECTIEN OP SYMMETRY, BY INPUT OF MIRROR ALBEDDS,

(B) ANISUTRCPIC DIFFUSE STURCFS, BY INPUT OF LEGENDRF POLYNOMIAL CCEFFICIENTS UF TO LAMBDA $=9$, OR A SHOPT TARLE DESCRIBING A KNOWN ANGULAR OISTRIBUTION TF THE FLUX,

(C) ISOTROPIC. (LAMBERT SURFACE) REFLECTION.

ISOTROPIC VOLUME SOURCES IN EACH GROUP MAY ALSO BE INDEPFNDENTLY SPECIFIEN. THE SCATTERING FROM ONE GRDUP TO ANOTHER IS ASSUMED TO BE ISOTROPIC RUT THE SCATTERING FUNCTION WITHIN EACH GROUP CAN BE A SECCND-ORDFR LFGENDRE PCLYNOMIAL SERIES.

75 COF-HAPO-S13

PROGRAM S CONSTRUCTS BILINEARLY COUPLED TIMF-VARI ANT MULTIENERGY NFUTRDN-AND-PHOTON TRANSPORT AND NUCLIDE-TRANSMUTATION FIFLDS HAVING SLAB, CYLINORICAL, OR SPHERICAL SYMMETRY. ASSURANCE UF UNBIASED CONVERGENCE IS PROVIDFD BY USE OJF A DUAL ADJCINT-AND-FLUX LCOP CONSTRUCTEN IN PRECISE CORRESPONDENCE WITH THE PHYSICS OF SUCCESSIVE FFEE FLIGHTS. 
87 FQUIPIISE-3A

EQUIPOISE-3A SOLVES THE TWODINENSICNAL TWD-GROUP DIFFUSIIN EQUATIONS IN CYLINDRICAL OR SLAR GFONETRY. IT IS A SLIGHTLY PEVISFD VERSION OF EQUIPUISE3 IACC ARSTRACT 39I. IN ADOITION TO THE STANDARD OUTPUT, A PICTURE IS PRINTED OF THE MATEFIAL ARRANGEMENT IN THE REACTOR. IF THE AOJCINT FLUX CPTION IS USED, THE PROMPT NFUTRON LIFETIME IS CALCULATFU ANO PRINTED, $\checkmark$ ITH THE RFACTIVITY PER UNIT CHANGE IN EACH GROUP CONSTANT IN FACH REGICN DF THE REACTOR.

103 CRAM C.RAM IS A PRDGRAM TU SOLVE THF MULTIGRCIUP DIFFUSION ECUATICNS IN TWO-DIMENSIONS IR-Z, X-Y, OR RTHFTA GEONETRY), CP IN GNE-DIMENSION ISLAB, CYLINDRICAL, OR SPHERICAL (ECMETRY). NEUTPONS MAY SCATTER FROM ANY GR IUP TO ANY OTHER. REAL, ADJIIINT, AND SCUURE-TYPE PROBLEMS ARE ALL SOLVABLE. THE PRTGRAM WILL CCMPUTF THF K-FFFECTIVE OF THE SYSTEM OR ALTFRIATIVELY SEARCH FCR CRITICALITY BY MOVING SPATIAL BDUNDARIES, VARYING MATERIAL COMPOSITIMNS, OR VARYING TRANSVERSE BUCKLING.

118 ULCFR

ULCER IS A MULTIGROUP, ONEDIMINSIUNAL DIFFUSIIIN EQUATION CODF WITH UPSCATTER BASED ON FAIM (ACC NBSTRACT 1?O). ULCFR CIFFERS FROM FAIM IN THAT -

(A) UPSCATTEPING IS INCLUDED.

(B) DOWNSCATTEP TC ALL LCNER GROUPS,

(C) MICROSCOPIC CFOSS SFCTIONS $\triangle R E$ IN TAPE,

(D) PRDVISION FUP MULTIPLE FISSION SPFCTRA.

(E) KESTART DUMP,

(F) FEW-GPCIJP RFDUCTIUN, AND

(G) SPECTRUM COMPUTATION AND GRAPHICAL DISPLAY. 
120 FAIM/FAIMCS

FAIM IS A MUL TIGPOUP, DNEDIMENSIONAL DIFFUSION EQUATION PRTGRAM RASED ON AIMG (ACC ABSTRACT 291. THE PPINCIPAL FFATURES ARE -

(A) THREE GFCMETRIES,

(B) CALCULATION CF FLUXES AND MULTIPLICATION FACTOR,

(C) ONE-ITERATION PROBLEMS,

(D) CHOICE GF CINF DF FIVE SETS OF BOUNDARY CONDITIONS AT BOTH BOUNDARIES.

(E) CRITICALITY SEARCHES ON TRANSVERSE BUCKLING, HOMOGENEDUS POISON, CRITICAL RADIUS, ONE, TWO, OR THREF ELEMEVT CONCENTRATION, LOCATICN OF POISON REGION BDUNDARY, LOCATION OF A FUFL REGION ROUNDARY,

(F) ADJOINT FLUX CALCULATION, AND

(G) EXTENSIVE CATA EDIT.

FAIMOS IS A MUDIFIED VERSICN OF FAIM. THREE GENERAL MODIFICATIONS WERE MADE -

(A) THE MICROSCOPIC CROSS SECTION LIBRARY AND ITS ASSOCIATED SUBROUTINES WERE REMTVED. AS A RESULT, OPTIONS REQUIRING, THE USE OF MICRUSCCPIC CRTSS SECTIONS ARE NOT AVAILABLF.

(B) FAIM RAN AS A CHAIN JOB. OVERLAYS ARE NOT USED BY FAIMOS.

(C) THE PROGRAM LANGUAGF WAS CONVEPTED FROM FDRTRAN II TO FORTRAN IV(H). THIS MOUIFICATION MADE NECESSARY A MINOR CHANGE IN THE DATA INPUT FORMAT.

$132 W-D S N$ EQUATIONS IN CYLINDRICAL GECMETRY. REACTIVITY (KEFF) ONLY. BUT NO SURFACE SOURCES.
136 HERESY1/KERNEL

HERESY 1 CALCULATES THE REACTIVE ROD ABSDRPTIONS AND POWER DISTRIBUTION IN HETEROGENEOUS REACTORS HAVING TWO SPATIAL DIMENSIONS. HERESYI CAN BE USED FOR NONUNIFORM LATTICES, LATTICES WITH MANY TYPES OF FUEL AND CONTROL RODS, AND SPIKED ANI) SEFDED REACTORS. FISSIONS ARE ASSUMED TO OCCUR ONLY AT THFRMAL ENERGY. RESONANCE ABSORPTIONS ARE LUMPED INTO ONE EQUIVALENT RISONANCE. THE MODERATOR IS ASSUMED TO BE INFINITE IN THE RADIAL DIRFCTION, AND RODS ARE TREATED AS LINE SOURCES AND SINKS. THE RTD PARAMETERS ARF INDEPENDENT OF THE INTER-ROD SEPARATION DISTANCES. SLOWINI-DOWN KERNEL FUNCTIONS MAY BE OF ANY TYPE - AGE THEORY, TRANSPDRT THEQRY, OR EMPIRICAL. A SELF-CONSISTENT PROCEDUPE CAN BE USFD WHICH EFFECTIVELY CANCELS OUT ANY ERRORS IN THF KERNEL FUNCTIONS. 

EQUATION. THE PRCGRAM CAN DETERMINE THE REGULAR OR ADJOINT SOLUTICN FOR SLAB, CYLINDRICAL, OR SPHERICAL GEOMETRY. ISOTROPIC OR A FCRM OF LINFAR ANISOTROPIC SCATTER ING MAY BE CONSIDERED. VARIOUS BOUNDARY CONDITIONS ARE ALLOWED SO THAT CELLS OR TIME-DEPENDFNT SDLUTIONS MAY BE OBTAINED USING FINITE AS WELL AS INFINITE CONFIGURATICNS IN THE CASE OF SLABS OR CYLINDERS. THE PROGRAM ALSO CONTAINS A NUMBER OF SEARCH OPT IONS WHEREBY ONE CAN VARY DIMENSIONS CR CONCFNTRATIONS TO ARRIVE AT A PREDETERMINED EIGENVALUE. DISTRIBUTED OR SHELL SOURCES MAY BE SPECIFIED AT ANY POSITION WITHIN THE CONFIGURATION. AS OUTPUT THE PROGRAM SUPPLIES THE EIGENVALUE, ANGULAR FLUXES, TOTAL FLUXES, FISSION DISTRIBUTIONS, AND OTHER OUANTITIES. A LIBRARY OF CROSS SECTIONS IS AVAILABLE DN MAGNETIC TAPE. CROSS SECTIONS MAY BE READ FROM THIS LIBRARY TAPE ANDIOR FROM CARDS.

148 TOPIC

TOPIC SOLVES THE ONE-DIMENSIONAL BOLTZMANN EQUATION IN CYLINDRICAL GEOMETRY WITH UP TO SIX ENERGY GROUPS, 240 SPACE POINTS, 40 REGIONS, AND ANISOTROPIC (PI) SCATTERING.

THE BOUNDARY CONDITIONS FOR EACH GROUP CAN BE INDEPENDENTLY SPECIFIED AND THE FLEXIBILITY OF THE SPECIFICATIONS PERMIT a

(A) PERFECT MIRROR REFLECTION OR SYMMETRY,

(B) ISOTROPIC REFLECTION (LAMBERT SURFACE REFLECTION), AND

(C) ANISOTROPIC DIFFUSE SOURCES BY MEANS OF EITHER A PI LFGENDRE SERIFS OR A SHORT TABLE OF POINT VALUES FOR THE ANGULAR FLUX.

INDFPENDENT SPFCIFICATION OF ISOTROPIC FIXED VOLUME SOURCES FOR EACH GRDUP IS ALSO ALLOWEO.

AS IMPLIED, BOTH HOMOGENEOUS AND INHOMOGENEOUS PROBLEMS ARE SOLVED, AND FISSIONS CAN OCCUR IN EITHER TYPE OF PROBLEM.

151 DTF2/ANISN LINEAR ANISOTROPIC SCATTERING IS PEPMITTED BETWEEN ALL GROUPS AND A DIFFUSION SOLUTION MAY BE OBTAINED FOR ANY OR ALL GROUPS. HIGH-ORDER ANISDTRDPIC, SCATTERING PROBLEMS (PL) CAN BE RUN USING ANISN, THE 360 VERSION OF DTF2. WHITE/GREY BOUNDARY CONDITIONS ARE AVAILABLE, AND AN ALBEDO CAN BE SPECIFIED FOR EACH GROUP. A VOID STREAMING CORPECTION IS INCLUDED. A COMPLETE SHELL SOURCE DESCRIPTIDN BY GROUP, POSITION, AND ANGLE IS AVAILARLE. GRAPHICAL. DISPLAY (CRT) FEATURES ARE AVAILABLE WITH ANISN.

156 EXTERMINATOR/EXTERMINATOR2

THE MULTIGROUP, TWO-DIMENSIIONAL NEUTRON DIFFUSION EQUATIONS ARE SOLVED IN $X-Y, R-Z$, OR R-THETA GECMETRY. 
161 FORTRAN TDC

TDC SOLVES THE BOLTZMANN EQUATION IN MULTIGROUP FCRM FOR THE TRANSPORT OF NEUTRONS OR THE ADJOINT EQUAT ION IN FINITE (R,Z) CYLINDRICAL GEOMETRY BY THE DISCRETE SN METHOD. THE PROBLEM MAY BE HOMOGENENUS (NO SOURCES INDEPFNDENT OF FLUXESI OR INHOMOGENEOUS, BUT ALL SOURCES MUST BE ISOTROPIC. NEUTRON SCATTERING MUST ALSO BE ISOTROPIC. A HOMOGENEOUS PROBLEM MAY BE SOLVED FOR THE EIGENVALUE K-EFF OR THF EIGENVALUE ALPHA (TIME CONSTANT). ALTERNATIVELY, THE HOMOGENEOUS PROBLEM MAY BE SOLVED FOR THE SIZE (RADIUS, HEIGHT OR BOTH) OF THE SYSTEM CORRESPONDING TO A SPECIFIED K-EFF OR FOR THE ATOM CONCENTRATION OF SOME MATERIAL CORRESPONDING TO A SPECIFIED EIGENVALUE K-EFF OR ALPHA. FOR INHOMOGENEOUS PROBLEMS, THE IMPOSED SOURCE MAY BE AN ISOTROPIC VOLUME-DISTRIBUTED SOURCE OR AN ISOTROPIC SHELL SOURCE ON THE OUTER BOUNDARY.

167 FLARE

FLARE IS AN INEXPENSIVE CALCULATIONAL METHOD TO DETERMINE CORE REACTIVITY AND CORE POWER DISTRIRUTION. A SCOPING CALCULATION OF THIS TYPE IS VALUABLF IN APPRAISING THE PHYSICS CHARACTERISTICS OF PLANNED TFST MODES OF OPERATION SO THAT DETAILED ANALYSIS CAN BE RESERVED FOR THOSE CORE CALCULATIONS OF GREATER INTEREST FROM EITHER A TECHNICIAN DIR SAFETY STANDPOINT.

$1732 D F$

2DF IS A TWD-DIMENSIONAL

MULTIGRDUP PROGRAM WRITTEN IN FORTRAN FOR SOLVING THE NEUTRON TRANSPURT EQUATION USING THE SN METHOD. THE PROGRAM CAN DETERMINE THE REAL DR ADJOINT SOLUTION FOR $X-Y, R-Z$, OR R-THETA GEOMETRY. ISOTROPIC OR A FORM OF LINEAR ANISOTROPIC SCATTERING MAY RE CONSIDERED. VARIOUS BOUNDARY CONDITIONS ARE ALLOWED. THE PROGRAM ALSO CONTAINS A NUMBER OF SEARCH OPTIONS WHEREBY ONE CAN VARY DIMENSICNS OR CONCENTRATIONS TO ARRIVE AT A PREDETERMINED EIGENVALUE. A DISTRIBUTED SOURCE MAY BE SPECIFIED. A LIBRARY DF CROSS SECTIONS IS AVAILABLE ON MAGNETIC TAPE. CROSS SECTIONS MAY BE READ FROM THE LIBRARY TAPE AND/OR FROM CARDS.

$1922 D \times Y L$

THE 2DXY PROGRAM IACC ABSTRACT 18) HAS BEEN CONVERTED FROM FLOCO TO FORTRAN 63 FOR USE ON THE CDC 1604 WITH CHANGES TO PERMIT THE INCLUSION OF FIXED SOURCE TERMS FROM TDC - TERMS REPRESENTING THE EFFECTIVE NET LOSS PER UNIT VOLUME DUE TO AXIAL LEAKAGE. IN THIS MANNER, A THREF-DIMENSIONAL FLUX SYNTHESIS CODE IS ACHIEVED.

199 TDP TOP IS A TWO-DIMENSIONAL LINEAR PERTURBATION THEORY COOE WHICH CALCULATES REACTIVITY CDEFFICIENTS, PROMPT NEUTRCN LIFETIMES, AND EFFECTIVE DELAYED FRACTIONS USING FLUXES FROM TDC CYLINDRICAL $(P-Z)$ OR RECTANGULAR $(X-Y)$ GEOMETRY. 
BOLTZMANN EOUATION FOR PARTICLE TRANSPORT IS SOLVED FOR THE ENERGY SPACE, AND ANGULAR DEPENDENCE OF THE PARTICLE DISTRIBUTION IN DNEDIMEASIONAL SLABS, CYLINDERS, AND SPHERES. INDEPENDENT SOURCE OR EIGENVALUE (MULTIPLICATION, TIME-ABSORPTION, ELEMENT CONCENTRATION, ZONE THICKNESS OR SYSTEM DIMENSIONI PROBLEMS ARE SDLVED SUBJECT TH VACUUM, REFLECTIVF, OR PERIDDIC BOUNDARY CONDITIONS. A COMPLETE ENERGY-TRANSFER SCATTERING MATRIX IS ALLOWED FOR EACH LEGENDRE COMPONENT OF THE SCATTERING CROSS SECTION MATRICES.

211 MGDSN, MANY GROUP DSN MGDSN IS A MODIFICATION OF DSN, THE ONE-DIMFNSIONAL THEORY CODE DESIGNED TO ACC OMMODATE 100 GROUP ISOTROPIC MATERIAL CROSS SECTION DATA TAPES PREPARFD BY CSPI AND CSPZA.

212 VARI-QUIR THE TIME-DEPENDENT, MULTIGROUP, TWO-DIMENSIONAL NEUTPON DIFFUSION EQUATIONS ARE SOLVED IN $X-Y$ OR R-Z GEOMETRY.

\section{GASP2}

SOLVES FOR THE ONE-DIMENSI CNAL DISTRIBUTION DF FISSILE AND FERTILE MATERIALS IN A NUCLEAR REACTOR WHICH WILL YIELD ANY DESIREO POWER DISTRIBUTION AND APPROXIMATELY RETAIN THIS DESIRED POWER DISTRIBUTION DURING THE BURN-UP HISTORY OF THE REACTOR CURE. A POISON AND POISON DISTRIBUTION SEARCH FOR A DESIRED MULTIPLICATION AND MINIMUM POWER DISTRIBUTION PERTURBATION CAN ALSO BE PERFORMED.

\section{GAMBLE4/GAMBLE5}

THE HOMOGENEDUS TWO-DIMENS IONAL MULTIGROUP DIFFUSION THEORY EQUATIONS WITH ARBITRARY GROUP-TOGROUP SCATTERING AND ARBITRARY FISSION TRANSFER ARE SOLVED FOR HETEROGENEOUS ASSEMBLIES IN $X-Y$ AND $R-Z$ GEOMETRY. HOMOGENEOUS LOGARITHMIC BOUNDARY CONDITIONS ARE USFD AT THE DUTER SURFACE OF THE ASSEMBLY AND AT THE SURFACE OF NON-DIFFUSION REGIONS. THE RESULTS INCLUDE THE GROUP AND POINT DEPENDENT NEUTRON FLUXES, THE POWER DISTRIBUTION, THE NEUTRON MULTIPLICATION FACTOR (K-EFFECTIVE), AND A DETAILED NEUTRON BALANCE. 
$241 \mathrm{HFN}$

HFN SOLVES THE HOMOGENEOUS DR INHUMOGENEOUS ONE-DIMENSIUNAL MULTIGROUP DIFFUSION EQUATION FOR IT LGWEST EIGENVALUE AND THE CCRRESPCNDING DIRECT AND/OR ADJOINT EIGENVECTORS. INHOMCGENEOLS BOUNDARY CONDITIONS AND A FLEXIBLE SCATTER-TRANSFER MATRIX STRUCTURE ARF INCLUDED. OPTIONAL CALCULATIONS INCLUDE CRITICALITY SEARCHES, DETECTOR ACTIVATION TRAVEPSES, AND INTEGPALS FGE PERTURBATION THEORY ANALYSIS.

$262 \mathrm{MACHl}$

MACHI PERFORMS ONE-DIMENSIONAL MULTIGROUP DIFFUSICN SOLUTIONS AND ASSDCIATED CALCULATIONS, INCLUOING CFITICALITY SEARCHES, PERTURRATIUN, REACTION SUMMARY, BETA FFFECTIVE, GRGUP CCLLAPSING, AND POINTWISE REACTION RATES AND RATIOS. SEVERAL CARD DUMPS CF CONPUTED DATA ARE AVAILABLE ON CPTION.

264 VARI-QUIR3

THE STEADY-STATE, MULTIGR NUP, TWO-DIMENSICNAL NEUTRCN DIFFUSION EQUATIONS ARE SOLVED IN $X-Y$, $R-Z$, AND R-THETA GECMETRY.

\section{CAFSAR4/LIBLST}

CAESAR4 SOLVES THE DNEDIMENSICNAL, MULTIGROUP DIFFUSION EQUATIONS IN ANY DF THREE GEOMETRIES AND PROVIDES A WIDE CHOICE OF BOUNDARY CONDITIONS, CRITI CALITY SEARCHES, EDITS AND OTHER AUXILIARY COMPUTATIONS.

\section{BISYN}

BISYN SOLVES THE TWD-DIMENSIONAL MULTIGROUP NEUTRON DIFFUSION EQUATIONS IN $X-Y$ OR $R-Z$ GEOMETRY USING A NONITERATIVE SYNTHESIS METHOD. THIS APPROACH IS DESIGNED TO GREATLY REDUCE THF COMPUTER COST OF RUNNING TWO-DIMENSIONAL MULTIGROUP PRORLEMS AT THE RISK OF SOME LOSS IN ACCURACY OF THF DETAILED FLUX DISTPIRUTION. SOLVE THE ONE-DIMENSIONAL NEUTRON TRANSPORT EQUATIONS. SNARG-1D IS WRITTEN FOR THE SOLUTION OF ONE-DIMENSIONAL PROBLEMS USING THE ORDFR $N=2,4,6,9,12,16$, OR 32, AND APPLICABLE TO PLANE, CYLINDRICAL AND SPHERICAL GEOMETRIES. THE REAL OR ADJOINT SOLUTION MAY BE CALCULATED ANO HCMDGENEOUS OR INHDMOGENEOUS PROBLFMS MAY BE SOLVED. FOUR CRITICALITY SEARCH OPTIONS ARE PROVIDED FOR WHICH A FIXFD KEFF OP ALPHA, INVERSE PERIOO, VALUF MAY BE SPECIFIED RATHER THAN THE CRITICALITY VALUE, KEFF = 1 . EITHER OF TWO INHOMCGFNEDUS SOLUTIONS MAY BE DBTAINED ISHELL OR DISTRIBUTED SOURCF CALCULATIONSI. LINEAR ANISOTROPIC COMPONENTS OF BOTH THE SHELL SOURCE AND THE SCATTFRING CROSS SECTIONS MAY BE INCLUDED. FISSION SPECTRUM MATRICES ARE ALLOWED AS BOTH MATERIAL-DEPENDENT AND INCIDENT NEUTRON ENERGY-DEPENDENT FUNCTIONS. 
304 PERT4

PERT 4 COMPUTES REACTIVITY

COEFFICIENT TRAVFESTS IN $X-Y, R-Z$, OR R-THETA GEOMFTRY USING THF FIRST-ORLIFR PFRTURRATION ECUATIONS IN THE DIFFUSION APPROXIMATION. FLUX AND ADJOINT INPUT CAN BE TAKFN DIRECTLY FROM 2-D CALCULATIONS OP SYNTHESIZED FROM RADIAL AND AXIAL 1-D CALCULATIONS. THE CODE CAN ALSO BE USFD TR, COMPUTE ACTIVITY TRAVERSES FOR ANY CROSS SECTION RF ANY MATHPIAL, THE NEUTRUN GENERATION TIME, AND THE EFFECTIVE CELAYED NFUTRCN FRACTION.

312 TDSN

THE LINEAR, TIME-INDFPENDENT, BOLTZMANN EQUATIIN IS SCLVEO TOR THE ENERGY, SPACE, AND ANGULAR DEPENUENCE OF THF MELTRCN OISTRIRUTION IN ONE-DIMENSIONAL SLABS, CYLINCERS CF SPHFKES IR IN TWII-DIMFNSIONAL X-Y OR R-Z GEOMETRY. FIXFD SOURCE UO MULTIPLICATION FACTOR (ADJOINT OR FLUX) PRDBLEMS ARE SCLVFD SURJECT TI VACUUM, PLANE REFLFCTIVE, ISOTROPIC REFLECTIVE TR 190 UFGREE QCTATIONALLY SYMMETRIC BOUNDARY CONDITIONS. A COMPLTTF ENFRGY THANSFFP SCATTERING MATRIX IS ALLOWED FOR EACH LFGENDRE COMPININT OF SCATTERING CROSS SFCTION MATRICES THROUGH P1.

319 GASP7

GASP7 CALCULATES THE IINE-DIMENSIGINAL DISTPIBUTIOA OF FISSILE AND FFRTILE MATERIALS IN A NUCLEAR REACTIR WHICH WILL YIELD ANY DESIRED POWFR DISTRIBUTION DURING THF RURNUP HISTOFY OF THE FEACTOR CORE. A POISON AND POISON DISTRIRUTIONN SEAFCH FRR A DESIRED MULTIPLICATION AND MINIMUM PCWER DISTRIBUTION PFETUFBATION CAN ALSO BE PERFORMED.

32 TEMCUT

PFRATURE CUEFFITIENTS.

TEMCO7 COMPUTES REACTOR TEM-

$342 M \operatorname{MC} 48$

MO648 SOLVES THF ONE-DIMENSIONAL SLA3 TPANSPCNT PROBLEM WITH SLOWING DOWN FOR AN ARBITRARY SPATIAL EXTERNAL STURTE AND ARBITRARY SCATTERING.

35.3 TWUTRAN

PARTICLF TRANSPLRT PPOBLEMS IN $X-Y$ GEOMETRY. BOTH DIRECT AND ADJUINT, HONOSENECUS (KEFF OR PARAMETRIC EIGFNVALUE SEARCHES) INHOMOGENEOUS TIME-INDEPENDENT PROBLEMS ARE SOLVED SUBJECT TO VACUUM, REFLECTIVE, OR INPUT SPECIFICATION OF BOUNDARY FLUX CONDITIONS. ROTH ANISOTRCIPIC INHCMOGENEOUS PROBLEMS AND GENERAL ANISOTRCPIC SCATTERING PRCRLEMS ARE TREATED. 
380 GATT

FEW-GROUP NEU DETAILEO SPATIAL FLUX AND POWER DISTRIBUTION FOR REACTORS WITH HEXAGONAL CORE CONFIGUPATION. THF PROGRAM USES A UNIFORM TRIANGULAR MESH IN THE HIRIZCNTAL MESH PLANES AND ASSUMES A RELATIVELY SIMPLE REGION STRUCTUPE IN THE AXIAL DIRECTION. IT WAS DESIGNED TO REPRESENT THE SPECIAL PATCH-TYPE CORE STRUCTURE OF THE. HTGR REACTOR AS CLOSELY AS POSSIBLE. 
D. DEPLFTION, FUEL MANAGEMENT, COST ANALYSIS, AND

REACTOP ECONOMIC.S

55 AIMFIRE

THIS PROGRAM WAS DESIGNEO TO COMPARE THE COSTS CF VAPIOUS FUEL CYCLES. THE PRDGRAM CONTAINS A LIRRARY OF FAST ANL THERMAL MICROSCOPIC CROSS SECTICNS, DECAY CONSTANTS, AND FISSION YIELDS FOR 5C ISOTOPES. THE PRESENT VFRSION IS USED TO INVFSTIGATE THE ECONOMICS OF URANIUM FUEI. SYSTEMS.

58 SIZZLF

SIZZLE SOLVES THE ONE-DIMFNSIONAL, OR MULTIGROUP BUPNUP PROBLEM IN THE DIFFUSION THFORY APPRUXIMATION FOR FAST INTEPMEDIATE REACTORS. AFTER THF. INITIAL CALCULATION AT T=O, AVERAGF CROSS SECTIONS ARE COMPUTED FOR FURTHER CALCULATIONS USING ONE TO SIX ENERGY GROUPS. CRITICALITY MAY BE MAINTAINEN BY USE OF A CONCENTRATION SEARCH. THE CONCENTRATION OF THE VARIOUS ISOTOPES IS PERMITTED TO VARY ONLY FROM REGICN-TO-RFGION, CHAINIS INCLUDED ARE TH232, U238, AND A FISSION PRUDUCT POISON CHAIN.

99 DUO DIMENSILNAL BURNCUT (DDR) THE FIVE-GRUUP, TWO-DIMENSIONAL, NEUTRON DIFTUSITN FRUATIONS IN CYLINDRICAL GECMETRY ARE SOLVED WITH BUPNCUT OPTIONS AND CONTROL ROD SEARCH OPTIONS.

117 FEVER

FEVER PERFORMS ONE-DIMENSIONAL FEW-GROUP DFPLETION CALCULATIONS. OPTIONS ARE AVAILABLE TO AOJUST CONTROL POISONS IN VARIOUS REGIONS OF THE REACTOR, SELF-SHIELDING OF LUMPED PDISONS, AND TC CALCULATE HOT MAXIMUM AND COLO SHUT-DOWN MULTIPLICATION.

134 NUCY

THE CALCULATION OF NUCLIDF CONCENTRATICINS AT A PCINT IN A REACTOR AT SUCCESSIVF TIME INTERVALS, WITH EXPOSURE TO A TWO-GROUP NEUTRON FLUX. INFINITE SYSTEM CRITICALITY IS CALCULATED. 
DEPLETION, FUEL MANAGEMENT, COST ANALYSIS, AND REACTOR FCONOMICS

146 NPRFCCP

NUCLEAR FUEL CYCLE CASTS IN DOLLARS PER YEAR $(\$ / Y R)$, AND IN MILLS PER KILOWATT-HOUR (MILLS) KWHRI ARE COMPUTED AND TABULATED FOP. EACH REGION OF A MULTIREGION REACTOR CORE, ON THE BASIS OF AEC-LEASED NUCLEAR FUEL MATERIAL AND OF PRIVATELY-DWNED NUCLEAR FUEL MATERIAL. FUEL CYCLE COSTS ARE COMPUTED SEPARATELY FOR EACH REGION OR ZONE, FOR CORE DESIGNS OF ANY CONFIGUPATION CR COMBINATION OF MATERIAL DEPLETION DR ENRICHED URANIUM FUEL OR OTHER SPECIAL NUCLEAR MATERIAL. PRINTED OUTPUT OF THE PRUGRAM INCLUDES (A) DETAILED FUEL CYCLE COSTS FOR EACH ZONE IN TABULAR FORM, FOR AFC-LEASED AND PRIVATELY-OWNFD NUCLFAR FUEL MATERIAL, RESPECTIVFLY, (B) A SUMMARY TABULATION OF NUCLEAR FUEL COSTS.FOR ALL REGIONS OF THE COMPLETE CORE, INCLUDING FIXED CHARGES ON WORKING CAPITAL REQUIRED FOR CORE FABRICATION AND FDR NUCLEAR FUEL MATERIAL, (C) A SUMMARY TABULATION OF CERTAIN COMPUTED PERFORMANCE AND ECONOMIC DATA, VIZ., AVERAGE RESIDENCE TIME, ANNUAL FUFL THROUGHPUT, UNIT ELECTRICAL ENERGY YIELD, ANNUAL POWER GENERATION, AND CORE FABRICATION COSTS, AND IDI A TABULATION OF ALL INPUT DATA FOR ALL REGIONS. THE PRINTING, OF DATA DESCRIBED IN (A) AND (D) ABOVE IS OPTIONAL WITH PROGRAM USE.

179 I SOTOPES

THIS PROGRAM CAN RE USED TO CALCULATE FOR ANY NFUTRON FLUX THE OPTIMUM TIME DF IRRADIATION FOR MAXIMUM YIELD, THF SPECIFIC ACTIVITY OF THE PRODUCT ISOTOPE IN CURIES PER GRAM OF TARGET MATERIAL, AND THE COMBINED SPECIFIC ACTIVITY OF THE TARGET AND PRODUCT ISOTOPES. THE PRDDUCT ISOTCPE MAY BE PRODUCED BY ANY SIMPLE REACTION SUCH AS (N,GAMMA), (N,P), $(N, 2 N)$, ETC.. OR IT MAY BE PRODUCED BY DECAY OF A PARENT ISOTOPE.

180 ISOCRUNCH

ISOCRUNCH CAN BE USED TO COMPUTE THE AMOUNT OF EACH ISOTOPE IN A REACTION AND DECAY CHAIN FOP ANY SPECIFIED NEUTRON FLUX AND TIME, TO SUM THE CONTRIBUTIONS OF VARIOUS CHAINS TO THE SAME ISOTOPE, TO GRAPH ON AN ASSOCIATED ELECTROPLOTTER OR CALCOMP THE YIELD OF AN ISOTOPE VS. TIME FOR A GIVEN FLUX, AND TO FIND THE DPTIMUM TIME FOR MAXIMUM YIELD OF AN ISOTOPE IN A CHAIN. THE PROGRAM DOES NOT TAKE INTO ACCOUNT THE SELF-SHIELDING OF A TARGET IN A REACTOR DR THE DEPENDENCE OF REACTION CROSS SECTIONS ON NEUTRON ENERGY WHICH CAN BE HANDLED BY ADJUSTING THE INPUT DATA.

221 RELOAD FEVER

A FEW-GROUP, 1-D DEPLETION CALCULATION WHICH ALLOWS FUEL IN VARIOUS STAGES OF IRRADIATION TO BE HCMOGENIZED INTO THE SAME REGION FOR PURPOSES OF THE DIFFUSION CALCULATION BUT FOLLOWS THE DEPLETION OF EACH OF THE SUB-REGIONS SEPARATELY. THE CALCULATION MAY BE INTERRUPTED PERIODICALLY FOR REFUELING ONE OR MORE REGIONS. RECYCLING IS OPTIONAL AND THERE IS NO LIMIT TO THE NUMBER OF REFUEL INGS WHICH MAY BE PERFORMED. A CONTROL POISDN SEARCH IS AVAILABLE AND CONCENTRATION DEPENDENT SELF-SHIELDING FACTORS MAY BE APPLIED TO ONE LUMPED POISON. 
D. DEPLETION, FUEL MANAGEMENT, COST ANALYSIS, AND REACTOR ECONOMICS

223 REVISED GAD

THIS INFINITE-MEDIUM DEPLETION PROGRAM PFRFORMS FUEL CYCLF CALCULATIONS ON REACTORS EMPLOYING PARTIAL REFUELING. THE BURN-UP OF UP TO 12 DISCRETE FUEL COMPDSITIONS IREGIONS OR STAGES OF IRRADIATIONI MAY BE FOLLOWED SIMULTANETUSLY. THE RURN-UP CALCULATION MAY BE INTERRUPTED PERICDICALLY TO REMOVE THE CONTENTS AND TO REFUEL ONE OR MORE REGIONS. FUEL MAY BE PARTIALLY OR COMPLETELY RECYCLED.

224 WAMPUM

THIS PROGRAM CALCULATES FUEL CYCLE COSTS ON A DETAILED BASIS, USING RESULTS OF NUCLEAR DEPLETICN CALCULATIONS AND CERTAIN SPECIFIED ECONOMICS ASSUMPTIONS. THE PURPOSF IS TO PROVIDE A MEASURE OF PERFORMANCE FOR COMPARING OR OPTIMIZING FUEL CYCLES AND ASSOCIATED REACTOR CORE AND FUEL ELEMENT CHARACTERISTICS.

226 OPUS

THE CODE GENERATES A FLOW NETWORK EQUIVALENT TO A GAS-COOLED NUCLEAR POWER PLANT DF SPECIFIED ELECTRICAL NUTPUT (IN THE P.ANGE OF 100 TO $1000 \mathrm{MW}$ ) ACCORDING TO INPUT DATA AND PROGRAMMED RULES, PROCEEOS TO EVALUATE THF PLANT PERFORMANCE AND PRICE OF THE TURBOGENERATOR SET (ACCORDING TO GENERAL ELECTRIC PRICE DATA), AND PRINTS AS A RESULT A CODED LIST OF ALL PLANT COMPONENTS AND A DETAILED PERFORMANCE MAP.

227 STMGFN

STMGEN WILL BE USED IN A PLANT OPTIMIZATION PROGRAM. THIS CODE DETERMINES THE AREA DF EACH SECTION OF A STEAM GENERATOR REQUIRED TO SATISFY THE DESIGN CONDITIONS OF HEAT TRANSFER, PRESSURE DROP AND MAXIMUM TUBE TEMPERATURE CONSTRAINTS. THE COST OF THE GENERATOR IS COMPUTED AS A FUNCTION OF THE TOTAL HEAT TRANSFER AREA, THE NON-PRODUCTIVE TUBE LENGTH REQUIRED TO CONNECT THE HEADERS, PLUS THE COST OF THE HEADERS.

231 RAD2

THIS PROGRAM CALCULATES

THE FISSION PRODUCT ACTIVITY DISTRIBUTIONS IN A HIGH TEMPERATURE GAS-COOLED REACTIR SYSTEM.

240 ASSAULT

MULTIGROUP, TWO-DIMENSIONAL

REACTOR DEPLETION. GIVEN NUCLIDE CONCENTRATIONS AND MICROSCOPIC CROSS SECTIONS, THE STEADY-STATE MULTIREGION, MULTIGROUP DIFFUSION EQUATIONS ARE SOLVED IN ONE OR TWO DIMENSIONS OVER A FINITE-DIFFERENCE SYSTEM OF MESH POINTS. THE CALCULATED NEUTRON FLUXES ARE THEN USED TO DETERMINE NUCLIDE CONCENTRATIONS AFTER A SPECIFIED PERIOD OF EXPOSURE. THESE CALCULATIONS ARE REPEATED FOR A SPECIFIED NUMBER OF TIME-STEPS. 

RFACTOR ECONDMICS

260 GARGOYLE

GARGOYLE IS AN INFINITE MEDIUM DEPLETION CUDE FOR FUEL CYCLE CALCULATIONS ON REACTORS EMPLDYING PARTIAL REFUELING. THE PURNUP OF UP TO 12 OISCRETE FUEL COMPOSITIONS (REGIONS OR STAGES OF IRRADIATION) MAY BE FOLLOWED SIMULTANEDUSLY. THE RURNUP CALCULATION MAY BE INTERRUPTED PERIODICALLY TO REMOVE THE CONTENTS OF AND TO REFUEL ONE OR MORE REGIONS. FUEL MAY BE COMPLETELY OR PARTIALLY RECYCLED. A CONTROL PCI SON SFARCH MAY BE PERFORMED AT EACH TIME-STEP. FEED FUEL SEARCHES ARE PERMITTED AT THE END OF EACH BURNUP CYCLE BFFORE REFUFLING. CONCENTRATION DEPENCENT SELF-SHIELDING FACTORS MAY BE APPLIFD TO ANY NUCLIDE EXCEPT MODERATORS. THE NUCLIDE SCHEME EMPLOYED, ALTHOUGH NCT COMPLETELY GENERAL, IS FLEXIBLE.

269 DTF-BURN

DTF-BURN IS A DNE-DIMENSIONAL, MULTIGRCUP RURNUP CDDF RASED ON TRANSPORT THEORY. A DIFFERENT TYDE GF EIGENVALUE CALCULATION IMULTIPLICATION, PERIOD, NUCLIDE CONCENTRATION, ZTNE THICKNESS, OR SYSTEM DIMENSION) (AN BE PERFORMED AT THE BEGINNING OF EACH OF A SPECIFIED SET DF TIME-STEPS. THIS FEATURE PERMITS THE SIMULATICN, IN A SINGLE PROBLEM RUN, OF A SYSTEM IN WHICH VARICUS CONTROL METHODS ARE USFD AS A FUNCTION OF TIME. THE CONCENTRATION DF THE VARIOUS NUCLIDES IS PERMITTED TO VARY FROM REGION-TO-RFGION GR POINT-BY-POINT. NUCLIDES CONSIDERED ARE U235, U236, U238, NP239, PU239, PU240, PU241, PU242, AND FP. A PSEUDO FISSION PRODUCT PAIR.

\section{PDQ7}

PDQ7 SOLVES FEW-GROUP NEUTRON DIFFUSION-DEPLETION PROBLEMS IN ONE, TWD, AND THREE DIMENSIONS. ADJTINT SOLUTIONS ARE ALSO AVAILABLE AND TWO OVERLAPPING THERMAL GROUPS MAY BE USED IN ONE AND TWO-DIMENSIONAL PROBLFMS. EITHER PCINTWISF OR REGIONWISE DEPLETION MAY BE PERFORMED USING THE HARMCNY DEPLETION SYSTEM. THF GEOMETRY MAY BE RECTANGULAR, CYLINCRICAL, OR SPHERICAL IN ONE DIMENSION, RECTANGULAR, CYLINDRICAL, OR HFXAGONAL IN TWD DIMENSIONS, AND RECTANGULAR OR HEXAGONAL IN THREF DIMENSIONS. ALL GEOMETPIES PROVIDE FOR VARIABLE MESH SPACING IN ALL DIMENSIONS. ZERO FLUX, ZERO CURRENT, AND ROTATIONAL SYMMETRY BRUNDARY CONDITIGNS ARE AVAILABLE, AND BOUNDARY VALUE PRORLEMS MAY BE SOLVED BY SPECIFYING THE FLUX VALUES ON ONE OR MORE BOUNDARIES. 
D. DFPLFTION, FUEL MANAGEMFNT, COST ANALYSIS, AND PEACTOR FCONOMICS

3 CI FREVAPG THE FREVAP TYPE OF CODE FOR ESTIMATING THE RELEAST OF LONGER-LIVFD METALLIC FISSION PRDOUCTS FFCM HTGR FUEL ELEMEMTS HAS BEEN DEVELOPED TO TAKE INTO ACCOUNT THF COMPINEN ETFECTS OF THE RETENTION OF METALLIC FISSION PRODUCTS PYY FULL PARTICLES ANE THE FATHER STRNNG ABSORPTION DFF THESE FISSICN PRUDUCTS BY THE CRAPHITE OF THE FUEL ELEMENTS. RELEASE CALCU LATIINS ARE MALE TIN THE PASIS THAT THE LOSS OF FISSION PRODUCT NUCIIDES SUCH AS OF STFENTIUM, CFSIUM, AND BARIUM IS DETEPMINED BY THEIR FVAPIJRATI IN FRTIN THC GPAPHITE SURFACES AND THEIF TRANSPIRATICN INEUCED BY THE HLOWING. HFLIUM COOLANT. THE CODF IS DEVISED SQ THAT CHANGES (F FISSIGN RATE (FUEL ELEMENT POWEP), FUEL TEMPEQATURE, ARU GIAPHITH TEMPEPATURE MAY BE INCORPOPATEO INTO THE CALCULATIUN. TFMPIPATURE IS NUITF IMPORTANT IN DETERMINING RELEASF BECAUSE, IA GENERAL, BOTH RELEASE FROM FUEL FARTICLES AND LOSS RY [VAPOOATIIIA (TRANSPIRATICN) VARY EXPONFNTIALLY WITH THE RECIPRUCAL TH THE APSCLUTE TFMPERATURE.

302 GAFFE

A ZFRD-DIMENSIONAL CALCULATION OF FEFD FUEL RFQUIPEMENTS IS PFRFCRMED TO PRODUCF A SPECIFIED END DF CYCLF NULTIPLICATICN FACTOR FOF THF EQUILIBRIUM FUEL CYCLF, GIVFN FEED COMPRISITICN, LENGTH OF CYCLE AND REACTOR POWER. IT IS ALTERNATELY PISSIBLE TD COMPUTE CYCLE LFNGTH OR FEED ENRICHMENT. THF CNDE IS A SURVEY TONL WHICH ASSUMES PEPIODIC RFFUELING AND PEFMITS COMPLETF OR PARTIAL RFCYCLING OF MATERIALS. THE SEGREGATED FUEL CONCEPT CAN PF HANTLED WITHIN THE FRAMEWORK OF THE CALCULATION.

313 CINDEP $(N \mathrm{NG} 102)$

CINDER IS A FDUR-GRDUP, ONEPOINT DEPLETIION ANO FISSION PRODUCT PROGRAM BASED ON THE EVALUATION OF A GENEPAL ANALYTICAL SOLUTION OF NUCLIDES COUPLED IN ANY LINEAR SEQUFNCE OF RAOIOACTIVE DECAYS AND NEUTRON ABSORPTIONS IN A SPECIFIED NEUTRUN FLUX SPECTRUM. THE DESIRED DEPLETION AND FISSICN PRIDUCT CHAINS AND ALL PHYSICAL DATA ARE SPECIFIED BY THE PRCBLEM ORIGINATIIR. THE PROGRAM CIMPUTES INDIVIDUAL NUCLIDE NUMBER CFNSITIFS, ACTIVITIES, A. INE ENEPGY-GROUP DISINTEGRATION RATES, AND MACFUSCOPIC. ANC RAPNS/FISSIUN POISONS AT EACH TIME-STEP AS WFLL AS SELECTED SUMMARIFS OF THESE DATA.

314 NAP

NAP CALCULATES THF SPECTRUM AND SPATIAL DISTRIBUTION IN ONE DIMENSION OF ACTIVATION GAMMA RAYS FOLLCWING NEUTRDN IRRADIATICN. 
REACTUR ECONCMICS

318 FEVER 7

FEVERT PERFORMS A MULTIGRTUP, 1-DIMENSIONAL DEPLFTILN CALCULATICN WHICH ALLOWS FUEL IN VARIOUS STAGES OF IRRADIATIINN TO BE HOMOGENIZED INTO THE SAME REGION FOR PURPOSES OF THF DIFFISION CALCULATION BUT FOLLOWS THE DEPLETION DF EACH OF THE SUBREGIONS SEPARATELY. THE CALCULATION MAY BE INTERRUPTED PERIODICALLY FCR REFUELING ONE OR MORE REGIONS. RECYCLING IS OPTIONAL AND THERE IS NO LIMIT TD THE NUMBER OF REFUELINGS WHICH MAY PE PERFCRMED. A CONTROL POISON SEARCH IS AVAILABLE AND CONCENTRATION DEPENDENT SELF-SHIELDING FACTORS MAY BE APPLIFD TO A NUMBFP OF LUMPED POISONS.

322 I SRSEARCH THE PROGRAM WAS DFVELOPED TO CALCULATE THE UNKNOWN REACTION CROSS SECTION, FLUX VALUE, OR PRODUCT ACTIVITY IN AN ISOTIPE-PRODUCTION SCHEME CONSISTING OF TWM OR THREE NUCLIDES.

$3252 D B$ 2DB IS A FLEXIBLE, TWO-OIMENSICNAL (X-Y, R-Z, R-THETA, HEX GEOMETRY) DIFFUSION CODE FOR USE IN FAST REACTOR ANALYSES. THE CODE CAN BE USED TO -

(A) COMPUTE FUFL RURNUP USING A FLEXIBLE MATERIAL SHUFFLING SCHFME,

(B) PERFORM CRITIT.ALITY SFARCHES ON TIMF ABSORPTION (ALPHA), MATERIAL CONCENTRATIONS, AND REGION DIMENSIONS USING A REGULAR OR ADJDINT MCDEL. CRITICALITY SEARCHES CAN BE PERFORMED DURING BURNUP TO COMPENSATE FOR FUEL DEPLETION.

(C) COMPUTE FLUX DISTRIBUTIONS FOR AN ARBITRARY EXTRANEDUS SOURCE.

$336 \quad P D Q 5$ NEUTRON DIFFUSION EQUATIONS ARE SOLVED. UP TO FIVE GROUPS MAY BE USED WITH SCATTERING ALLOWED BETWEEN ADJACENT GRMUPS. IN ADDITION, DEPLETION PROBLEMS MAY SE SOLVED WITH PDQ5.
339 GAUGE NEUTRON DIFFUSION THEORY FQUATIONS FOR A UNIFORM TRIANGULAR MESH ARE SOLVED TO OBTAIN THE MULTIPLICATION FACTOR ANC THE SPATIAL FLUX AND POWER DISTRIBUTION OF REACTORS WITH HEXAGONAL CORE CONFIGURATION. COMPLETE PEACTOR LIFE HISTORIES WITH PARTIAL REFUFLLING AT A NUMBER OF RELOAD TIME POINTS CAN BE CALCULATED. AT EACH DISCRETE TIME POINT A CONTROL ROD SEARCH MAY BE PERFORMED TO MAINTAIN CRITICALITY AT ALL TIMES. THE DEPLETION SCHEME OF ALL BURNARLF NUCLIDES IS SPECIFIED BY THE USFR AT EXECUTION TIME. THREF MOUES OF OPERATION AFE POSSIFLE - $(1)$ STRAIGHT BURNUP CALCULATION, (2) CONTROL ROD CRITICALITY SEARCH, ALL IWING THE ADJUSTMENT OF A NUMAER UF CONTROL ROD BANKS ACCOROING TO A PRESCRIBEO ROD SEQUENCING SCHEME, AND (3) A SERIES OF STATIC CALCULATIONS WITH INSERTION OF RCDS INTO FIXED PRESCRIBED POSITIONS. 
C. DEPLETION, fuel management, cost analysis, ano REACTOR ECONCMICS

34.) POWERCO ELFCTRICITY PRTDUCED P.Y NUCLEAR EXFENSES SUCH AS INVFSTMENT AND AND TAXES ARE KNIWN. THF POWER THF PRIJJECT LIFE.
354 CINCAS

CINCAS IS A NUCLEAR FUEL CYCLF COST CODE WHICH MAY RE USEO FDR EITHER ENGINEERING ECONOMY PREDICTICNS OF FUEL CYCLE CUSTS CR FOR ACCOUNTING FORECASTING DF SUCH COSTS. FEATURES DF CINCAS INCLUDE -

(1) MONTHLY CALCULATION OF DOLLAR COSTS AND MASS INVENTORY ON A BATCH AND CASE BASIS FOR FACH MONTH OF A PERIDD WHICH IS USUALLY DEFINED AS (BUT NOT RESTRICTEN TO) REGINNING WITH THE DELIVFRY OF FIJEL TO THE REACTOR SITE AND ENDING WITH THE WITHDRAWAL OF FUEL FRTM THE REACTOR.

(2) A GFNEPAL FJRMULA FOR THF UNIT PQICE OF ENRICHED URANIUM WHICH ALLIWS FOR VARIABLF FFFD AND TAILS ENRICHMFNTS, COSTS C.F FEFD, CHEMICAL CONVERSIDN, SEPARATIVE WORK, AND LOSSES IN CONVERSION AND FARRICATION.

367 I SOGEN

I SOGEN CALCULATES RADIOISOTOPE GFNERATION AND IJFCAY, USING TWO-GROUP NEUTRON CROSS SECTIONS.

372 RAPFU

RAPFU CALCULATES EQUILIBRIUM

FUEL CYCLE ISOTCPICS IN FAST BREEDER REACTORS. THE RFCYCLED PLUTONIUM IS PERMITTED TO HAVE DIFFFRENT ISOTOPIC COMPOSITIONS IN TWD CIFFERENT CDRF ZONES, ANC SEVERAL RECYCLE SCHEMES ARE AVAILABLF AS OPTIONS. CIJTPUT DATA INCLUDES THE INITIAL, AVERAGF, AND DISCHARGFD FUEL ISCTUPIC CONCENTRATIONS FOR EACH REGION OF THE CCRF ZONES ANO THE BLANKETS, RREEDING RATIO, DOURLING TIME, AND (OPTIONALLY) FUEL COSTS CALCULATED USING SIMPLIFIED RELATIONSHIPS. 
121 AIKFK 3

AIREK3 FINDS THE NUMERICAL SIILUTION TU THE SPACE INCEPENDENT REACTOR KINETICS EQUATIONS BASFT DN THE NETHOU DIVELTPED BY F. P. COHEN. INPUT AND OUTPUT ARE SI $\because P L I F I E D$ AND THF PUWER, INVERSE DERIOD, FEEDBACKS, AND PRECUFSITRS ARE DISPLAYER GRAPHICALLY.

12? SNAPKIN5/SA.APKIN-SA SNAPKINS PROVIDES A DNE-REGIDN TINE-DEPFNOLNT CALCULATION OT POWER, ENERGY, TEMPERATURE, REACTIVITY, INVERSF PERICD, AND HYDROGEN LOSS IN A SNAP REACTOR AFTER A PFRTUREATICN FRON GIVEN INITIAL CONOITIONS. SNAPKIN-5A, IN ACOITION, WEIGHTS POWER, HEAT CAPACITY, AND REACIIVITY IMPORTANCE FCR TWENTY-FIVF GR FEWER REGIDNS.

135 TRAFICORPORATICN, COMPLEX TPA EXPERIMENTAL FREQUFNCY RESPONSE DATA CRTAINEO FROM A LINEAR DYNAMIC SYSTEM IS PRICESSED TO OBTAIN THE TRANSFEP FUNCTICN AS A RATIO OF TWO FREQUENCY-DEPENDENT POLYNOMIALS. THE TRANSFER FUNCTIDN MAY HAVE NON-MINIMUM PHASE.

163 AIPOS

AIROS SOLVES THE SPACE-INDEPENDENT REACTOR KINETICS EQUATIONS AND PROVIDES FOR THE DETERMINATION OF REACTIVITY RY SOLVING IN ADDITION THE DISCRETIZED EQUATIONS WHICH REPRESFNT THE SPATIAL HEAT AND MASS TRANSFER MONEL FRR SEVERAL FUEL CHANNELS. IN ADOITIUN, VARIATION OF THE FILM COEFFICIENT WITH FLOW IS ACCCUNTED FOP AS WELL AS THE PRCVISION FOR FLOW DECAY AND AFTERGLLW HEATING. SCRAMS CAN BE INITIATEO BY DELAYED SIGNALS FRCM INSTPUNENTS WHICH SFNSF. ANY QUANTITY CALCULATFU, E.G., POWER, INVFRSE PERIOD OR TEMPERATURF. GENFRALIZED FEEDBACK EQUATICNS ARF USFD TI PRCVIDE FLFXIBILITY IN THF MODFLS THAT REPRESENT MULTICHANNFL HEAT TPANSFFR INCLUDING CONDUCTION AND CONVECTION, ENERGY, PPESSURE AND OTHFR PHFNOMENON. THE REACTIVITY EQUATION IS ALSO GENERALIZED. THE REACTIVITY FEEDBACK COEFFICIENTS CAN BF CONSTANT OR VAPY AS THE SDUARE ROOT OR DECIPROCAL OF TEMPERATURE. FURTHEFMOPE ANY FEEDBACK VARIABLE CAN BE USED TD INITIATE A REACTIVITY SCRAM, EACH WITH A UNIQUE DELAY TIME.

168 INVERSE KINETICS (R102)

GIVEN THE SPACF-INDEPENDENT, ONE ENERGY GROUP PEACTOR KINETICS EQUATIONS AND THE INITIAL. CONDITICNS, THIS PROGRAM DETERMINFS THE TIME VARIATION OF REACTIVITY REQUIRED TC PRODUCE THE GIVEN INPUT OF FLUX-TIME DATA. 

DENT, ONE-ENERGY GROUP FEACTOR KINETICS EQUATIDNS TO DETERMINE THE TIME VARIATION OF NEUTRON DENSITY GIVEN SPECIFIED INITIAL CONDITIONS. ANY OF FOUR PROGRAMMED REPRESENTATIONS OF EXCESS REACTIVITY CAN BE SELECTEN.

290 GASA IGENERAL ATOMIC STABILIT GASA DETERMINES THE STABILITY OF ANY PHYSICAL SYSTEM WHOSE MOTICN IS DESCRIBABLE BY A SET OF FIRST-ORDER LINEAR DIFFERENTIAL EQUATIONS. IN PARTICULAR GASA EVALUATES THE STABILITY OF A REACTOR DESCRIBED BY THE LINEAR REACTOR KINETICS EQUATIONS WITH TEMPEFATURE FEEOBACK, AGAINST PERTURBATIONS ABOUT ANY CPERATING POWER LEVEL. THE PRDGRAM WILL ALSO CALCULATE AND PLOT THE TRANSFER FUNCTION BETWEEN ANY STATF VARIARLE OF THE SYSTEM AND A GIVEN EXTEPNAL FORCING FUNCTION ISUCH AS AN EXTERNAL REACTIVITY PERTURBATION) OR ANOTHER STATE VARIABLE OF THE SYSTEM.

303 BLOOST6

BLODST6 COMBINFS A REACTOR SPACE-INDEPENDENT KINETICS COUE WITH A TWO-DIMENSIONAL HEAT TRANSFER CODE, AND A TIME-DEPENDENT SPHERICAL GEOMETRY HEAT TRANSFER RDUTINE FOR FUEL PARTICLES. THE CDDE IS APPLICABLE TO PROBLEMS FOR WHICH THE SPACE-INDEPENDENT FORM OF THE REACTOR KINETICS EQUATION IS APPLICABLE.

317 GAPOTKIN GAPOTKIN IS A POINT KINETICS CMDE THAT SOLVES THE SPACE-INDEPENDENT KINETICS EQUATIONS FOR A VERY GENERAL FCRM OF THE REACTIVITY FUNCTION. 
326 AIRUS2A

AIROS?A SOLVES THE SPACF-INDEPENDFNT REACTOR KINFTICS F OUATIIINS AND DROVIDES FCR THE DETERMINATION OF REACTIVITY BY SCLVING IN AIDDITION THE DISCRETIZFN EQUAIICNS THAT REPRFSENT THF SPATIAL HEAT AND MASS TRANSFER MUDEL FLIF. SFVIRAL FUEL CHANNTLS. IN ADOITICN, VARIATION OF THF FILM CCEFFICIENT WITH FLOW IS ACCDUNTFO FOF ALONG WITH THE PROVISION FOR FLOW DFCAY AND AFTERGLIJW HEATING. SCRAMS CAN BE INITIATED BY BFLAYED SIGNALS FROM INSTRUAFATS THAT SENSF ANY QUANTITY CALCULATED, F.G.. PCIMER, INVERSF PEDIOD CD TEMPERATURE. GENFPALIZEO FEFDRACK EQUATIONS APE USED TO PRTVIDF FLEXIBILITY IN THE MONFLS THAT REDRESFNT MULTICHANNEL HEAT TRANSFFR INCLUDING CONDUCTION ANO CONVFCTION, ENEPCFY, PRESSUPF AND CTHER PHENOMENON SUCH AS FUEL MELTING, COOLANT BOILING AND VOIDING RUPN-OUT. THE REACTIVITY FQUATICN IS ALSD GFNERALIZED. THF REACTIVITY FEEDBACK CDEFFICIENTS CAN BE CCNSTANT OR VARY AS THE SQUARE RCOT OR RECIPROCAL DF TEMPERATURE. FURTHERMURE, ANY FEEDBACK VAPIAPLE CAN BF USED TO INITIATE A REACTIVITY SCPAM, EACH WITH $\triangle$ UNIQUE DELAY TIME. AN INPUT GFNERATCR COMPLTES THF CONDUCTICN AND CONVECTION COEFFICIENTS FCR AN $N X M$ NODAL. MULTICHANNEL SYSTEM USING BUILT-IN TABLES CF SDER,IFIC HEAT, DENSITY, CONDUCTIVITY ANO VISCOSITY FOR THE COMMON FUFL, STRUCTURE AND CCOLANT MATERIALS, AND PERFCPNS AN INITIAL TFMPERATURE CALCULATICN. THE FILM COEFFICIENTS MAY RE SPECIFIED OR CALCULATED USING LYONS EQUATION OR THE DITTUS-BNELTER FQUATION.

363 PLAST

STUDY ACCIOENT MULTIPLYING SYSTFMS. THE PROGRAMME COMPUTES THE TIME REHAVINUR OF THE THERMAL NEUTRON DENSITY AND THE SYSTEM TEMPERATURE FOLLCWING A STEP CHANGE IN FEACTIVITY. THE INTEGRATED THFRMAL NEUTRON DENSITY IS ALSO COMPUTEO, FRCM WHICH THE TOTAL NUMBER OF FISSIONS DURING AN FXCURSION MAY BE TRTAINED.

BLAST HAS BEEN DEVEL TPFD TC. AL AND SUBCRITICAL THERMAL

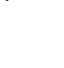


F. SPACF-TIME KINETICS, CDUPLED NEUTPUNICS-HYDRODYNAMICSTHERMDDYNAMICS, AND EXCURSIUN SIMULATIONS

$102 \quad A \times 1$

AXI PERFORMS A COUPLFD NEUTRONICS-HYDROUYNAMICS CALCULATION. GIVEN A SPHERICALLY SYMMETRIC, SUPERPROMPT CRITICAL SYSTEM, THE PROGRAM COMPUTES THF VARIATION IN TINE AND SPACE OF THF SPECIFIC ENERGY, TEMPERATURE, PRESSURE, DENSITY AND VELGCITY.

129 CONEC

CONEC IS A COUPLEO NEUTRONICELASTICITY CODE DESIGNED FLR APPLICATION TO PULSED FAST REACTOR SYSTEMS. IT IS A ONF-DIMENSIDNAL CALCULATION, CAPABLE OF DEALING WITH SOLID SPHERES OR SPHERICAL SHELLS. SPECIFICALLY, CONEC, CALCULATES THF ALPHA IJF A SYSTEM, THE TEMPERATURE DISTRIRUTION, THE RADIAL AND TANGENTIAL STRESS DISTRIBUTIONS, AND FROM THESE THE ACCELERATIONS, VELOCITIES, AND DISPLACEMENTS THROUGHOUT THE SYSTFM.

145 WEAK EXPLOSICN PRUGRAM

THIS PROGRAM PERFORMS A COUPLED NEUTRONICS-HYORUDYNAMICS CALCULATION FOR A SPHERICALLY SYMMETRIC REACTOR CTFE WITH A GIVEN COMPOSITION TO OBTAIN THE TIME-DEPENDENT ENFRGY RFLEASE THAT RESULTS FROM THE INSERTION DF REACTIVITY AT A GIVFN RATE. THE RASIC USE FOR THIS PROGRAM IS FOUND IN ANALYSIS OF FAST REACTOR CORE COLLAPSE ACCIDENTS.

153 HATCHET

HATCHET IS A MAJCR MODIFICATIINN OF THE AXI CIDE DESIGNED TO STUDY BURST CHARACTERISTICS IF A SUPERPRUMPT CRITICAL, CONCENTRIC SHELL, PULSED REACTOR. IT CDMPUTES SPECIFIC FNERGY, TEMPERATURE, PRESSURE, DENSITY AND VELUCITY VARIATIUNS AS A FUNCTION DF TIME AND SPACE. THF CODE ALSO COMa PUTES REACTIVITY AS A FUNC,TION OF INVERSE REACTOR PFRIOD, POWER, THE TOTAL AND KINETIC ENERGIES, AND THE PDSITION OF THE SHELLS WHICH COMPRISE THE SYSTEM. 
THFRMCOYNAMICS, AND EXCURSION SIMULATIONS

174 FOPE/FORE2

FORE CALCULATES REACTOR POWFR AND TEMPERATURES IIF FUEL, CCOLANT, CLAD, AND STRUCTURF AS FUNCTICNS IF TIME IN RESPLNSE TR A PROGRAMMED REACTIVITY INSERTION SPECIFIED AS A SERIES OF RAMPS. TEMPERATURE PROFILES ARE COMPUTED AT SPECIFIEC AXIAL PUSITIONS FOR AN AVFRAGE CHANNEL AND FOR THE PEAK PCWER (CFNTRAL) CHANNEL. THE HEAT OF FUSITIN ACCOMPANYING FUFL MELTINS IS TAKEN INTO ACCOCUNT. FEEDBACK REACTIVITY MECHANISMS THAT FESPCND TO CHANGES CF TEMPERATURES INCLUDE THE FUEL DCPPLFR EFFFCT AND THERMAL EXPANSTUN OF THE CORE IAND AXIAL BLANKET QR PEFLECTORI MATFRIALS. FCRE2 IS A COUPLEN THERMAL HYDRAULICS-PUINT KINETICS OIGITAL COMPUTER CODF DESIGNEO TO CALCULATE SIGNIFICANT REACTIIF PARAMETERS UNOER STEADY-STATE CONOITIONS, OP. AS FUNCTICNS UF TINE DURING TRANSICNTS. THE TRANSIENTS MAY RESULT FRCN A PRTGRAMMEC PEACTIVITY INSEPTION OR A POWER CHANGE. VAR IABLE INLET COOLANT FLOW RATE AND TEMPERATURF ARE CONSIDERED. THE CODE CALCULATES THE REACTRR POWER, THF INDIVIDUAL REACTIVITY FEEDBACKS, AND THE TEMPFFATURE OF COOLANT, CLADDING, FUFL, STRUCTURF, ANO ADDITIONAL MATFRIAL FOR UP TO SEVEN AXIAL POSITIONS IN THREE CHANNFL TYPES WHICH PEPRESENT RADIAL ZONES DF THE REACTOR. THE HEAT CF FUSIUN ACCOMPANYING FUEL MELTING, THE LIQUID MFTAL VOIDING REACTIVITY, AND THE SPATIAL AND THE TIME VARIATION OF THE FUEL CLADDING GAP COEFFICIENT DUE TO CHANGES IN GAP SIZF ARE CONSIDERFD.

101 AX-TNT
(A) THE COUPLED HYDRCOYNAMIC, THERMODYNAMIC AND NFUTRONIC
EQUATIONS WHICH OESCRIBE A SPHERICAL, SUPER-PRMMPT
CRITICAL REACTOR SYSTEM DURING AN EXCURSION,
THE COUPLED EOUATICNS OF MOTION, AND IDEAL GAS
EQUATION OF STATE FOR THE DETONATION OF A SPHERICAL
CHARGE IN A GAS.

274 NIGL2

WIGL? IS A DNE-DIMENSIONAL TWO-GPUUP SPACF-TIMF IIFFUSION THEORY PROGRAM WITH ZERO, DNF, OP SIX DFLAYED NEUTRON GROUPS. THE PROGRAM WILL TREAT SLAR, CYLINDRICAL, AND SPHERICAL GECMETRIES AND INCLUDES NON-BOILING HFAT TPANSFER. IT ACCOUNTS FUR XFNON FEEDBACK AND FEEDBACK EFFECTS DUF TO FUEL AND CUOLANT TEMPERATURE. CONTRDL RCD MOTION AND CONTROL SYSTEM FEEOBACK BASED ON TCTAL CORE POWER OR UUTLET COOLANT TEMPERATURE CAN BE SIMULATED. TRANSIENTS MAY BF EXCITEN BY PRESCRIBED CHANGES IN INLET COMLANT TEMPERATURF, CONLANT FLOW RATE, OR RCD POSITION. 
F. SPACE-TIMF KIVETICS, COUPLED NEUTRONICS-HYDRODYNAMICSTHERMCOYNAMICS, AND EXCURSION SIMULATIONS

293 MARS

MARS PERFORMS A COUPLED NEUTRONICS-HYDRODYNAMICS CALCULATIDN FCR A FINITE CYLINDER CORE WITH CONCENTRIC REGIONS OF DIFFERENT COMPOSITIONS AND CHARACTERISTICS TO OPTAIN THE TIME-DFPFUDFNT ENERGY RELEASE THAT RESULTS FROM THE INSERTION OF REACTIVITY ACCORDING TO A PRESCRIBED PROGRAM. THE BASIC USE FRR THIS PRUGRAM IS FOUND IN ANALYSIS OF FAST REACTOR CORE COLLAPSE ACCIDENTS. THE REACTIVITY CHANGES DUE TO MATFRIAL DISPLACEMENT IS DETEPMINED RY THE USE OF PERTURBATIDN THEORY AND THE PRESSURE GENERATION FOR THF HYORUDYNAMICS CALCULATION IS DETERMINED RY THE THE LISE GF AN EXPONENTIAL FURM FOR THE SATURATED VAPDR PRESSURE CURVE. THE DOPPLER EFFECT IS DETERMINED RY THE USE DF A FLEXIBLE T**(-N) FORM WHERE $N$ IS A PARAMETER THAT IS SPEC IFIFD AT THE TIME OF EXECUTION. THE EXTERNAL REACTIVITY INSEPTION CAN BE IN THE FUPM OF A STFP, A LINEAR RAMP OR A PARABOLIC RAMP, WITH A LIMIT ON THE AMDUNT OF REACTIVITY WHICH CAN BE INSEPTED BEING A DEFINABLF QUANTITY. TABULATEO VALUES OF THE POWFR AND MATERIAL WORTH OISIRIFUTIONS ARE ACCEPTED AS INPUT. THE CHARACTERISTICS OF EACH REGION (DENSITY, SPFCIFIC HEAT, DOPPLFR COEFFICIENT, FQUATION OF STATE, GEOMFTRIC LIMITSI ARE SPECIFIED INDEPENDFNTLY FOK EACH REGION TO PROVIDE FLEXIBILITY IN THF TREATMENT OF CORES OF UNUSUAL CCNFIGURATION. THE NEUTRON KINETICS CALCULATICNS ARE DONE WITH A PIINT PEACTOR MODEL AND DELAYED NEUTRUNS ARE USED.

309 TSN

THF TIME-DEPENDENT NEUTRON TRANSPORT EQUATION IS SOLVED. ENERGY DEPOSITION IS ALLOWED TO CAUSE VARIATION IN THE NEUTRON CROSS SECTIONS FOR THF CORE RFGION, IN THE CORE DENSITY, AND IN CORE HEIGHT. THE RESULT IS A KINETICS CALCULATION INCLUDING SPATIAL DEPENDENCE BOTH IN FEEDBACK EFFECTS AND IN NEUTPON DENSITY. THE RFSULTS ARE SUMMARIZED IN A MANNER SIMILAR TO POINT-KINETICS CODES, AND SPATIAL DISTRIBUTIONS ARE ALSO GIVEN. GRAPHICAL SUMMARIFS OF THF SIGNIFICANT VARIABLES AND SPATIAL DISTRIBUTIONS ARE GIVEN. IN THE IBM36O VERSINN, EITHER THE NEUTRON YIELD FROM FISSION OR THE THICKNESS OF A SPECIFIEO ZONE CAN BE CHANGED AS AN INDEPFNDENT FUNCTION OF TIME AS SPECIFIED BY THE USER. THIS PROVIDES TWO WAYS OF ALLOWING EXPLICIT REACTIVITY VARIATION WITH TIME.

310 GAKIN

THF MULTIGROUP, 1-DIMENSIONAL, TIME-DEPENDENT DIFFUSION THEORY EQUATIONS ARF SOLVED IN SLAB, CYLINDR ICAL OR SPHERICAL GEOMETRY WITH DELAYED NEUTRONS TAKEN INTO ACCOUNT. AN ARBITRARY SCATTERING MATPIX IS ALLOWED, TOGETHER WITH A PIECE-WISF, LINEAR, TIME-DEPFNDENT, INHOMOGENEOUS SOURCE TERM. FEEDBACK IS AVAILABLE FPOM TIME-DEPENDENT CROSS SECTION CHANGES AND BUILDUP IN XENON. THF TIME INTEGRATION IS OIVIDED INTO TIME ZONES WITH UNIQUE FEFDBACK AND SOURCE DATA FOR EACH ZONE. 
SPACE-TIME KINETICS, COUPLED NFUTRONICS-HYDRODYNAMICSTHERMCDYNAMICS, ANO EXCURSION SIMULATIONS

33० TWIGL/TWIGGLE

TWIGL SOLVES THE TWO-DIMFNSICNAL, TWO-GROUP, SPACF-TIME NEUTRON DIFFUSION EQUATIONS IN RECTANGULAR OR CYLINCRICAL GECMETRY IN THE PRESENCE OF TEMPERATURE FEEDBACK. THE NEUTRUN DIFFUSION AND DFLAYED PRECURSOR EQUATIONS ARE DIFFERENCED IN P.TTH SPACE AND TIME. THE THERMAL-HYDRAULIC DESCRIPTION IS BASFD ON A NO-BOILING, ONE-PASS MODEL FORMULATED IN TERMS OF REgIONWISE-AVERAGED CNULANT AND FUEL METAL TEMPERATURES.

352 RAUMZEIT

RAUMZEIT SOLVES SYSTEMS DF ONE-DI MENSIONAL, TIME-DEPENDENT, MUL TIGROUP DIFFUSION-TYPE EQUATIONS USING EITHER OF TWI TREATMENTS OF THE TIME DEPENDENCE, FINITE DIFFERENCING CP. THE TIME-INTEGRATED APPROACH ISEE REFERENCE 21.

370 GAKIT

GAKIT SOLVES THE MULTIGROUP, ONE-DIMENSIONAL, TIME-DEPENDENT DIFFUSION THEORY KINETICS FQUATIONS INCLUDING DELAYED NEUTRON EFFECTS AND TEMPERATURE FEEDRACK BASED ON TWO-DIMENSIONAL HEAT TRANSFER. CALCULATIONS. FDR THE ONEDIMENSIONAL MULTIGPDUP KINETICS EQUATIONS AN ARBITRARY SCATTEPINC; MATRIX AND ARBITRARY FISSION TRANSFER ARF ALLOWED, AND PLANE, CYLINDRICAL, OR SPHEFICAL GEOMETRY MIGHT BE USED. A PIECEWISE LINEAR TIME-DEPENDFNT INHOMOGENEDUS SNURCE CAN BE SPECIFIFD. FEEDBACK IS AVAILABLE FRTM XENON BUILDUP AND TEMPERATURE DEPENDENCE OF CROSS SECTIONS. THE HEAT TRANSFER CALCULATION IS PFPFORMED FOF TWO-DIMENSIONAL R- 2 FUEL ELEMENT MODELS ASSUMING PREDETFRMINED AXIAL PCWER SHAPE FUNCTIONS AND TIME-DEPENDENT POWER AMPLITUDES OBTAINED FROM THE ONE-DIMENSIONAL KINETICS CALCULATICNS. FOR THE FUEL ELEMENTS AVERAGF FUEL AND MODERATOR TEMPERATURES ARE CALCULATED WHICH DETERMINE, BASED ON TABLES, THE TFMPERATURE-DEPENDENT CPOSS SECTIONS. TRANSIENTS MAY BE INTRODUCED BY STEP CHANGES OF CROSS SFCTIONS, BY PIECEWISE LINEAR TIMEDEPENDENT CROSS SECTIONS (ROD WITHDRAWAL ACCIDENTS), BY STEP CHANGES DF THE FLOW RATES OR BY STEP CHANGES OF THE COOLANT INLET TEMPERATURES.

371 NOWIG

NOWIG IS A PROGRAM FOR SOLVING THE CNE-DIMENSIONAL TWO-GROUP NEUTRON DIFFUSION AND DELAYFD PRFCURSOR EQUATIONS USING A SHAPE-SPECIFIED POINT KINETICS APPROXIMATION. FEEDBACK DUE TO CHANGES IN THE FUEL METAL TFMPERATURE AND COCLANT DENSITY IS ACCDUNTED FOR RY USING A MODEL WHICH IS IDENTICAL WITH THAT USED IN THE WIGL2 (ACC ABSTRACT 274 ) PROGRAM. 
G. RADICLOGICAL SAFETY, HAZAR C ANU ACCIDENT ANALYSIS

47 CLOUD

THE CLQUD PROGRAM CALCULATES

THE FXTERNAL GAMMA-RAY DCSE RATE AND TOTAL INTEGRATED DOSE RESULTING FROM THE CONTINUCUS RFLEASE OF RADIUACTIVE MATERIALS TO THE ATMUSPHERF.

172 AISITE2/R 153

AISITF2 IS LARGELY BASED ON METHODS PRDPOSED BY THE AEC IN TIO-14844 BUT DIFFERS IN CERTAIN CF THE ASSUMPTIONS AND MODELS. THE CODE AUTOMATICALLY VARIES ANY ONE OF 46 PARAMETERS SUCH AS REACTOR POWER, BUILDING LEAK RATE, ICDINF CLEAN-UP RATF, AND HALOGEN FILTER EFFICIENCY, COMPUTING THE EXCLUSION AREA, AND LOW POPULATION ROUNOARY ZONES AS FUNCTIONS DF THAT PARAMETER. THE FDIT INCLUDES DOSE VS. DISTANCE DATA, FRACTIONAL CONTRIBUTION RY ISOTOPE GROUP TO THE INHALATION DOSE, AND CRITICAL DISTANCES PROVIDING BUTH PRINTED AND GRAPHICAL DATA. THREE MODELS ARE AVAILABLE FOR FISSION PRODUCT RELEASE WITH UP TO 4 LEVFLS IIF CONTAINMENT.

196 C.URIE/DOSF/THUNDEPHFAD

CURIE CALCULATES THE FISSION PRODUCT INVFNTORY PRCDUCED IN A REACTOR DURING CONSTANT POWER UPERATION AND RELEASES DIFFERFNT PERCENTAGES OF THE NOBLE GASES, HALOGENS, AND PARTICULATES TO THE ATMOSPHERE AT REACTOR SHUTDOWN. DOSF CALCULATES THE TOTAL DOSE TO 13 INTERNAL BODY ORGANS RESULTING FPOM INHALATICN OF THE PASSING RADIOACTIVE CLOUD. THUNDFRHEAD CALCULATFS THE EXTFRNAL CLOUD GAMMA EXPOSURF DOSE FROM THE RFLFASED FISSION PRCDUCTS.

2CO SATURATED BLCWCOWN2

CALCULATION DF LOCAL

PRESSURES, MASS FLOW RATFS, FLUID QUALITIES, SPECIFIC VOLUMES, TEMPERATURES AND LOCAL HEAT TRANSFER COEFFICIENTS AT WETTED WALLS, DURING BLDWCUWN OF THE REACTOR PRIMARY COOLANT LDOP.

228 PRECON

THE PURPOSE OF THE PPOGRAM IS

TO DETERMINE, FDR A GAS-COCLFU REACTDR, THE CONTAINMENT PRESSURE AS A FUNCTION OF TIME, AFTER RUPTURES HAVE BFEN ASSUMED TO DCCUR IN THE PRIMAPY SYSTEM OF IN CONJUNCTION WITH STEAM GENERATOR RUPTUPES.

229 ELBOWN

DFFLECTIUNS, RESTRAINT FORCES AND STRESSES ARE [ETERMINEL IN A FUEL FLEMENT SUBJFCTED TO ASYNMETRIC. PCWEF GFNEFATICN, CIRCUMFERENTIALLY NON-UNIFORM COCLANT TFMDCRATUPE DISTRIEUTICN, ANU ASYMMETRIC FAST NEIJTRON FLUX DAMATF. 
261 GADOSE/DOSFT

THE gadOSE PROGRAM CALCULATFS

RADIOACTIVITY AND DNSES RESULTING FROM INSTANTANEOUS ACCIDENTAL RELEASE OF ACTIVITY WHILE THE COMPANION PROGRAM DOSET INCLUDES THE EFFECTS DF A TIMF-DEPENDENT ACCIDENTAL FISSION PRODUCT RELEASE FOR THF HTGR TYPE OF PLANT. GIVEN AN INITIAL FISSION PRODUCT INVENTORY RELEASED INTO A REACTCP VESSEL OR CONTAINMENT VOLUME, THE QUANTITY OF EACH ISOTOPE IS CALCULATED AT A NUMBER OF TIMES AT A NUMBER OF LOCATIONS IIN THE CONTAINMENT, CONTAINMENT RECIRCULATING CLEANUP FILTERS, LEAK COLLECTOR, PLANT EXHAUST FILTERS AND IN THE ATMOSPHERE AT A NUMREP OF DISTANCES FROM THE PLANT). EACH DECAY CHAIN IS CALCULATED SEPARATELY CONSIDERING BUILDUP AND DECAY OF EACH ISOTOPE. RADIOLOGICAL DOSES ARE CALCULATED FOR ANY THREE BODY ORGANS AND THF WHOLE BODY BASED ON METEOROLOGICAL AND PHYSIDLOGICAL INPUT PARAMETERS. FALLOUT AND RAINOUT ARE INCLUDED.

265 RSAC RSAC GENERATES A FISSION PRODUCT INVENTORY FROM A GIVEN SET OF RFACTOR OPERATING CONDITIONS ANC THEN COMPUTES THE EXTERNAL GAMMA DOSE, THE DEPOSITION GAMMA DOSE, AND/OR. THF INHALATION-INGESTION DOSE TO CRITICAL BODY ORGANS AS A RESULT OF EXPOSURE TO THESE FISSION PRDDUCTS. PROGRAM DUTPUT INCLUNES REACTOR OPERATING HISTORY, FISSION PRODUCT INVENTORY, DOSAGES, AND INGESTICN PAPAMETERS.

268 TRANS-FUGUE 1 SINGLE CHANNEL, TWO-PHASE FLOW, AND HEAT TPANSFER CODE FOR ANALYSIS OF POSTULATED REACTOR INCIDENTS INVDLVING BOILING. THE CODE IS RASED ON A HUMUGENEDUS HYDRODYNAMIC MODEL WHICH ASSUMFS EQUAL PHASE TFMPERATURES ANO VELOCITIES. IT ASSUMES VAPOR GENERATION TO BE HEAT TRANSFER LIMITED ONLY, AND CALCULATES AXIAL DISTRIBUTION DF VELOCITY, VOID FRACTION, PRESSURE, COOLANT TEMPERATURE, AND FUEL TEMPERATURE. TRANSIENTS SIMULATING POWER EXCURSIONS, LDSS OF FLOW, LOSS OF PRESSURF AND CHANNEL PLUGGING CAN BE STUDIED. 

PRESSURE, VELUCITY, AND FORCE TRANSIENTS IN THE LIQUID FILLED PIPIAG NETWORKS. IT CAN RE APPLIFD TO MULTI-LOOP, COMPLFX PIPING NETHOPKS CONSISTING OF ANY NUMBER DF DEAD ENDS, ELBOWS, ORIFICES, MULTIPLE BRANCH TEFS, CHANGES OF FLOW PASSAGE CROSS SECTIONS, CHECK VALVES, PUMPS, PRESSURIZERS OR TANKS, AND EXIT VALVES. HYDRAUI IC LOSSES ARE CONSIDERED. TRANSIENTS CAN BF INITIATED EITHFE, BY CLCSURE DR RY OPENING OF DNF OR MORE EXIT VALVES IOR RY THF SYSTEM RUPTURE AT ONE OR MORF PLACESI, OR BY A PRESCRIBED CHANGF IN THE TANK (IRR PRESSURIZER) PRESSURE, OR BY THE PUMP PCWER FAILUPE. WHAM IS AN FXTENSION OF THE PROGRAM WATER-HAMMER. WATFR-HAMMER ANALYZFS HYDRAULIC TRANSIENTS IMPOSED BY THE SUDDEN DISCHAPCE DF LIQUID FPOM THE PRIMARY COOLANT LONP, RFFORE ANY GFNFRATION CF VAPOR HAS TAKEN PLACE. EFFECTS OF HYURAULIC LOSSES ARE NLGLECTEU, THE LOOP PRESSURIZFR IS ASSUMED TO REMAIN CONSTANT AT INITIAL PRESSURE AND THE PRESENCF OF A PUMP IS IGNORED. IT WAS DESIGNED FOR THE FARLY BLOWDOWN ANALYSIS FOR LOFT.

284 MOS55(ACT1)

THIS PROGRAM WILL PREDICT THE PRESSIIRE TRANSIENT IN THE CONTAINMENT VFSSEL AS A FUNCTION OF TIME AS A RESULT CF A MAJOP RUPTURE IN THE PRIMARY SYSTFM TF A PRESSURIZED WATFR REACTOR. MEANS ARE AVAILABLE FOR INTRODUCING WATER AND HEAT INTO THE CONTAINMENT VESSEL. THERE ARE ALSO PROVISIONS FOR SPECIFYING VARIOUS TYPES OF HEAT SINKS FOR ENERGY ABSORPTION. THE TEMPERATURE DISTRIBUTION IN THESE HEAT SINKS IS CALCULATFD AS A FUNCTION OF TIME. DISCHARGE RATES OF THE CONTAINMENT MAY AL SO BE DETFRMINFD AS A FUNCTION OF BOTH TIME AND THE INTERNAL PRESSURF. 


\section{CONTEMPT} PPEOICTS THE PRESSURF-TEMPCRATURE RESPONSE TOF A DRY WELL CONTAINMENT BUILDING TO A LISS-OF-CODLANT ACCIDFNT. THE CINTAINMENT VOLUNE IS SEPAPATED INTO A I IQUID REGION AND A VAPOR REGION. EACH RFGION IS ASSUMIN TO HAVF A UNIFORM TEMPERATURE BUT THE TEMPERATURE OF THE TWO RESITNS MAY BE DIFFERENT. THE CONTAINMENT BUILDING IS FEPRESENTED AS CONSISTING OF SEVERAL HEAT CONDUCTING STRUCTUFES WHOSE THERMAL PFHAVIOR CAN BE DESCRIBED BY THE ONE-DIMFNSIONAL MULTIPEGION HEAT CONDUCTION EQUATION. WATER AND ENERGY RATES FROM TISCHARGE OF COOLANT, THE BOILING OF RESIDUAL WATER BY RFACTOR DECAY HEAT, THE SUPERHEATING DF STEAM PASSING THRDUGH THE CORE, AND METAL-WATFR REACTIONS ARE ASSUMED AVAILABLE FROM PREVIDUS CALCULATICNS AND ARF INPUT DATA TO CONTEMPT. PRORRAM OUTPUT INCLUDES CONTAINMENT VOLUMF PRFSSURE ANIS TEMPERATURES, TEMPERATURE THROUGH BUILOINC STRUCTURES, AND THE AMOUNT OF WATER, VAPDR, AND ENFRGY IN THF CIINTAINMFNT VCLUMFS. THE PROGRAM ALSO CALCULATFS BUILDING LFAKAGE AND THE EFFECTS OF ENGINEERED SAFEGUARD DEVICES SUCH AS WATER SPRAY AND FAN COOLFR SYSTEMS.

328 NURLOC-1.J

NURLOC-1.0 PERFORMS CORE/PRESSURE VESSEL THERMAL ANALYSIS FOR A NUCLFAR REACTOR LOSS-OF-COOLANT ACCIDENT.

330 [CCSA 1

ECCSAI PREDICTS THE THFRMAL

ANC HYDRAULIC PERFORNANCE OF REACTOR CORE CHANNELS DURING, A LOSSOF-COOLANT ACCIDINT AND SUBSE ZUENT EMERGENCY CORE COOLING INJECTION.

366 CHEMLOC, 2

CHEMLOC2 IS USED TO COMPUTE THE EXTENT DF CORE HFATING AND METAL-STEAM REACTIDN FOLLOWING A HYPOTHETICAL LOSS-CF-COCLANT ACCIDENT, INCLUDING EMERGENCY CORECOOL ING FAILUPE, IN A WATFR-COOLED REACTDR. THE PROGRAM INCLUDES THE EFFECTS OF HEAT PRODUCTION BY DECAY HEATING IN THE FUEL AS WELL AS BY STFAM-METAL CHEMICAL REACTION, HEAT TRANSFER FROM THE CORE TO THE BOTTOM AND TOP GRID-SUPPORT PLATES AND TO THE WALL SURROUNDING THE CORE, AND METHCDS OF CALCULATING THE EFFFCTS OF CDRE MUVEMENT AND MATERIAL TRANSFER ON REACHING SLUMPING TEMPERATURE. 
G. pariglogical safety, hazARD avd aCCident analysis

369 RELAP2

RELAP2 CALCULATES FLOW, MASS

INVFNTORIES, TEMPEPATURES, PRESSURES, RFACTIVITIES, AND TRANSIENT PChEF FOK THE PRIMAPY SYSTEM DF A WATER REACTOP DURING A REACTIVITY OR A LOSS-OF-CUOLANT ACCIDENT. ALTHOUGH RETAINING THE SIMPLIFIF GELMETFY (THKEE VOLLMES PLUS A CORE RFGION) OF THE PREVIOUS RFLAP PRIGGRAM, MANY IMPRTVEMFNTS AND EXTENSIONS HAVE BEEN MADE. THF GEOMETRY CAN BE MADE TU APPROXIMATE EITHER A PRESSURIZED OR A BOILING WATER REACTOP SYSTEM. THF CORE IS TREATED AS A TWO-POINT MOTEL FOR POWFR GENERATION, HEAT TRANSFER, AND REACTIVITY FFFDBACKS AND AS A ONE-PCINT MODFL FOR THE REACTOR KINETICS, PRESSURE BALANCES, AND FLCM RALANCES. ALSO, PELAP2 CAN BE USED FOR REACTOR SYSTEM SATETY STUDIES INCLUDING LARGE REACTIVITY EXCURSICNS AS WELL AS THE LCSS-OF-COOLANT AND PUMP-FAILURE ACCIDFNTS. 
152 ARGUS (RE248)

THIS PROGRAM CALCULATES

TRANSIENT TFMPERATURES IN A CONCENTRIC, CYLINDRICAL CONFIGURAD TION. UP TO 25 CONCENTRIC REGIONS ARF ALLOWFD, EACH CONTAINING EITHER A STATIONARY (SOLIO GR NDNOFLOWING LIQUID) OR TURBULENTLY FLCWING (LIQUID OP GAS) NATERIAL. ANY STATIONARY REGION CAN HAVE SPATIAL- AND TIME-DEPENDENT HEAT GENERATION. TEMPERATURES ARE (ALCULATE:) AT NODE POINTS EQUALLY-SPACED WITHIN A REGION. FILM COEFFICIENTS ON FLDHING REGION BOUNDARIES ARE CALCULATED BY THE PRUGRAM. TIME-DEPENDENT COOLANT VELOCITIES ARE PERMITTED. THE HEAT SOURCE IS ASSUMED TO BE ANGULAR INDEPENDENT. AXIAL HEAT CONDUCTION IS NFGLECTFO, BUT AXIAL HEAT TRANSPORT DUE TO MATERIAL MOTICN IS CONSIDERED IN THE FLOWING REGIONS.

155 PTHI

TAINMFNT SHELL PRESSURE-TEMPERATURE HISTORY RESULTING FROM AQUEOUS COOLANT SYSTEM BLOWDNWN.
182 AXFLU

FROM A LATTICE OF FLUID CYLINDRICAL FUEL PINS TO COOLANT IN EITHEK SLUG OP FULLY-NEVELDPED LAMINAR FLOW. SOLUTION IS ANALYTIC AND CLDSED, FXCEPT FOR SATISFYING RDUNDARY CONDITIONS AT A FINITE, (BUT AREITRARY), NUMBER OF BDUNDARY POINTS.

183 AXTHRM

FER FROM A TRIANGULAF LATTICE OF CLAD SOLID CYLINDRICAL FUEL PIN TO COOLANI IN FITHER SLUG OR FULLY-DEVELOPED LAMINAR FLOW. SOLUTION IS ANALYTIC AND CLCSED, EXCEPT FOR SATISFYING BDUNDARY CONDIIICNS AT A FINITE, IBUT ARBITRARYI, NUMBER OF BDUNDARY POINTS.

199 HEATING2

HEATING2 IS A GENERALI ZED HEAT TRANSFER CODE CAPABLF OF SOLVING TRANSIENT AND/OR STEADY-STATE CRORDINATE SYSTEMS. THE SIMPLIFIED INPUT MAKES IT A VERY USEFUL CDOE FOR THOSE PROBLENS HAVING GERMETRICAL CONFIGURATIONS WHICH CAN BE DESCRIBED BY PARALLEL AND PERPENDICULAR. LINES OP PLANES, OR CONCENTRIC CIRCLES. THESE FITURES CAN BE BROKEN UP INTO A MAXIMUM OF 100 ONE-MATERIAL REGIONS WITH POSITION AND TIME-DEPENDENT VOLUMETRIC HEAT GENEFATION RATES. UP TO 40 MATERIALS WITH CONSTANT PROPERTIFS CAN BE DESCRIRED, AND THE INITIAL TEMPERATURES OF THESE REGIONS ARE POSITION-DEPFNDENT. THE BOUNDARIES OF THESE REGIONS CAN BE CONTACT, INSULATED, TIME-DEPENDENT TEMPERATURE CONTROLLED, DR FDRCED CONVECTION WITH A TIME-DEPENDENT SINK TFNPERATURE. ALSO A RADIATION BOUNDARY WITH A TIME-DEPENDENT SINK TEMPERATURE IS INCLUDFD. 
$2 C 5$ RLCOSTS

KINETICS C.ODE WITH A TWO-DIMENSIONAL HEAT TRANSFER CODE, AND IS APPLICABLE TU PRORLFMS FOR WHICH THE SPACE-INDEPENDENT FCRM IF THE REACTUR KINETICS EQUATIUN IS APPLICABLE.
24? RATH MESHER/RATH WANTTIN

THESE CODFS SOLVE THE TWO- AND THFEE-DIMENSIONAL HEAT CONCUCTION PROQLEM IN GENERAL GECMETRIES. TIME, TEMPERATURE, AND PCSITION-DEPFNDENT PHYSICAL PROPERTIES CAN BE USFD.

246 FLNW-MODEL

A MULTI-CHANNEL, TWO-

DIMENSIONAL, TWO-PHASE FLOW MDDEL, DESIGNEO TO COMPUTE THE AXIAL AND RADIAL COULANT DENSITY AND QUALITY PROFILES, THE AXIAL PRESSUR PROFILE AND THE WEIGHT FLOW DISTRIBUTION FOR AN OPEN MATRIX FLOW, ROILING WATEP REACTOF.

256 MANTA

MANTA IS A PRDGRAM WHICH PROVIDES A THERMAL-HYDRAULIC NODAL ANALYSIS IN THE STEADY STATE. IT WAS DFSIGNED TU ANALYZE FUEL ELEMFNT CONFIGURATION IN THE SUPERHEAT DFVELUPMENT PROGRAM. MANTA ANALYZES MIXING BFTWEFN CODLANT CHANNELS, ALLDWS FOR TEMPERATURE VARIANT CONDUCTIVITY IN ADMITTANCE CALCULATION, AND MULTIPLE STACKED SEGMENTS THROUGH THE FUFL REGION FOR A 7 ELEMENT CLUSTER ANALYSIS OVER A LENGTH DF UP TO 8 FEET. MANTA IS DFSIGNED FOQ SINGLF-PASS STEAM FLOW. THE FLOH DIRECTION IN THE COOLANT CHANNELS MAY BE EITHER UP OR DOWN, THEREBY PERMITTING THE ANALYSIS OF TWO-PASS AS WELL AS SINGLE-PASS FUEL ELFMENTS. MANTA ACCOUNTS FOR THE HEAT TRANSFFR AND PRESSURE DROD THAT MAY OCCUR BTTWEFN COMLANT CHANNELS DUE TO MIXING AS WELL AS TO THE CONVENTIUNAL HEAT TRANSFER AND PRESSURE DROP RELATIONSHIPS DUE TO FRICTION, TISCONTINUITIES, ACCELERATION, CONVECTION, CONUUCTION, AND RADIATION. MANTA ALLOWS FOR THE CALCULATION AT EACH NIUE DF THE MATERIAL PROPERTIES VISCOSITY, SPECIFIC HEAT, CONDLCTIVITY, AND SOECIFIC VOLUME TO CORRESPOND TO THE ACTUAL NODE TEMPERATURE BEING SOLVED FOR.

267 WIATER

WATER IS A SUBROUTINE USED TO EXTRACT THERMODYNAMIC AND TRANSPORT PROPERTIES OF LIQUID, VAPOR, AND SUPERCPITICAL WATER BY TABULAR INTERPILATION OVER THF RANGE OF STATES - 14.5 TO $14,50 C$ PSIA AND 32 TO 1472 DEGREFS F. THESE PFOPERIIES ARF SPECIFIC VOLUME, SPECIFIC ENTHALPY, DYNAMIC VISCOSITY, AND THFRMAL CCNOUCTIVITY, TABULATED FDR PRFSSURE AND TEMPFRATURE CONDITIDNS. 
272 FIGRO

FIGRO CALCULATES THE ONE-DIMENSIONAL STEADY-STATE TEMPERATURE DISTRIBUTION AND TOTAL FUEL SWELLING FOP METAL-CLAD, AXISYMMETRIC, BULK-DXIDE CYLINDRICAL FUEL ELEMENTS. THE FUEL PELLET MAY BE SOLID, ANNULAR, OR CONTAIN TWM RADIAL ZONES. OXIOE FUEL THERMAL CONDUCTIVITY IS A FUNCTION OF TEMPERATURE, DEPLETION, ANO POROSITY. FUEL SWELLING IS A FUNCTION DF TEMPERATURE, DEPLETICN, INTERNAL HYDROSTATIC PRESSURE, AND FISSIONING RATE. FITHER THE CLAD SURFACE FLUX OR THE TEMPERATURE AT THE INSIDE RADIUS OF THE FUEL MAY BE SPECIFIED AS A BOUNDARY CONDITION FOR THE HEAT R.CNDUCTION EQUATION. THERMAL EXPANSION OF THE FUEL AND CLADDING IS ACCOUNTED FOR.

286 HOT2

HOT2 IS A DIGITAL COMPUTER PRRGRAM TO SOLVE TWO-DIMENSIONAL PLANE AND AXIALLY SYMMETRIC STEADY-STATE AND TRANSIENT HEAT CCNDUCTION PROBLEMS WITH DIAGONAL BOUNDARIES AND INTFRFACES. MESH SPACING (AT MOST 5000 POINTS) IS COMPLETELY VARIABLE. AS MANY AS 99 REGIONS ARE PERMITTED IN URDER TO DESCRIBE SPATIAL VARIATIONS IN MATERIAL PROPERTIES, HEAT GENERATION RATES, AND BOUNDARY CONDITIONS. THE HEAT GENERATION RATE AND ROUNDARY CONDITIONS MAY VARY WITH TIME.

$294 \mathrm{MO899/ \textrm {HOH }}$

BY MAKING CALLS ON A SURROUTINE CALLED HOH, MO899 EDITS THERMODYNAMIC AND TRANSPORT PROPERTIES OF WATER OVER THE RANGE 14.5 TO 2538 PSIA AND UP TO 608 DEGREES FAHRENHEIT BELOW' SATURATION AND 932 DEGREES FAHRENHFIT ABCVE SATURATION.

299 LION LION IS A DIGITAL COMPUTER PROGRAM WHICH WILL SOLVE THREE-DIMENSIONAL TRANSIENT AND STEADYSTATE TEMPERATURE DISTRIBUTION PROBLEMS. THE INPUT CONSISTS OF GEOMETRY, PHYSICAL PRDPERTIES, BOUNDARY CONDITIONS, INTERNAL HEAT GENERATION FATES, AND CDCLANT FLOW RATES AS A FUNCTION OF TIME. IN ADDITION TO SOLVING PROBLEMS OF HEAT CONDUCTION IN A STRUCTURF. LION CAN HANDLE FORCED CONVECTION, FREE CONVECTION, AND RADIATION OR A COMBINATION OF THESE AT THE SURFACE OF THE STRUCTURE. THE OUTPUT CONSISTS OF COMPLETE NODAL TEMPERATURE DISTRIBUTIONS ALONG WITH SURFACE FLUXES AND HEAT TRANSFER COEFFICIENTS. AN CPTION IS INCLUDED IN THE PROGRAM FCR DETERMINING THE MEAN TEMPERATURE IN ANY SPECIFIED SECTION OF THE STRUCTURE. 
331 MC219(FLOT1)

FLOTI WILL PREDICT THE STEADYSTATE FLOW AND THE FLOW TRANSIENT DUE TO THE SUBSEQUENT LNSS OF POWER TU ALL PUMPS AND TERMINATE THE TRANSIENT AT A SPECIFIED TIME OR IT WILL PREDICT THF FLOW TRANSIENT IN WHICH ONLY SOME OF THE PUMPS ARE LOST. THIS LATTER TRANSIENT MAY BE TERMINATED BY A MAXIMUM TRANSIENT TIMF OR BY CHECK VALVE CLOSURES IN ALL LOOPS IN WHICH PUMPING POWER IS LOST. IN THE LATTER FVENT, THE PROGRAM WILL PREDICT THE SUBSEQUENT STEADY-STATE FLOW DISTRIRUTION.

346 THTE THTE ITRANSIENT HEAT TRANSFER VERSION EI PROVIDES A SOLUTION CAPABILITY FOR LARGE COMPLEX, THREE-DIMENSIONAL TRANSIENT AND STEADY-STATE HEAT TRANSFER PROBLEMS WHICH CAN INCLUDF CONDUCTION, CONVECTION, AND RADIATION WITH THE CPTION TO COMPUTE FLUID FLOW RATES ON A ONE-DIMENSIONAL BASIS.

348 TOPS

SIMULATION OF PRESSUPIZER DYNAMICS OF THE FIRST LAW OF THERMODYNAMICS MASS TRANSFER LAWS WITH EMPIRICALLY DETERMINED COEFFICIENTS. THE PROGRAM IS USEFUL IN STUDYING THE THERMODYNAMIC PATHS OF PRESSURIZER TRANSIENTS AND IS CONVENIENT TO USE AS A DESIGN TOOL.

349 TOODEE

THE TOODEE PROGRAM CALCULATES TFMPERATURES AT THE CENTER POINTS OF A TWO-DIMENSIONAL ARRAY IN $X-Y, R-Z$, OR R-THETA GEOMETRY. THE MESH IN THIS ARRAY MAY BE VAR I ARLY-SPACED. AVERAGED MATERIAL CONSTANTS ARE USED WHICH MAY BE SPATIAL AND TEMPERATURE DEPENDENT. PROVISION IS MADE IN THE PRCGRAM FOP MATERIAL PHASE CHANGES. CHANNELS FOR FORCED FLOW COOLANT MAY BE INCLUDED AT EXTERIOR BOUNDARIES. IN ADDITION TO THE TEMPERATURE ARRAY, PROGRAM DUTPUT INCLUDES SURFACE TEMPERATURES AND HEAT FLUXFS.

382 RAPP

RAPP COMPUTES THF RELATIONSHIP AMONG MASS FLOW, PRESSURE, AND PIPING RESISTANCE (K-FACTOR) FOR HIGH VELOCITY FLOW TF A TWO-PHASE MIXTURE OF STEAM AND WATER. THE SOURCE FLUID MAY BE SUBCODLED OR SATURATED WATER, SATURATED STEAM. OR A MIXTURE OF STEAM AND WATER. THE DOWNSTREAM PRESSURE MUST BE BELTW THE SATURATICN PRESSURE OF THE SOURCE FLUID. SPECIFIC APPLICATIONS INCLUDE PRESSURIZER SURGE LINE PRESSURE DROP AND PRESSURE DISTRIBUIION DOWNSTREAM OF A RELIEF VALVE. 
I. DEFCRMATION AND STRESS DISTRIBUTICN COMPUTATIONS,

STRUCTURAL ANALYSIS AND ENGINEERING DESIGN STUDIES

48 FUGUE

THE FUGUE PROGRAM COMPUTES

STEADY-STATE WALL AND RULK FLUID TEMPERATURE, VOID FRACTION, AND LOCAL PRESSURE IN LIOUID-COOLED CLOSED CHANNELS IN WHICH THE HEATING RATE IS SPECIFIFD. THE REQUIRED RELATIONSHIPS ARE EXPRESSED IN GENERAL, NON-DIMEASIONAL FORM AND COMBINED IN AN INTERNALLY CONSISTFNT MANNER TO ALLOW PREDICTIONS FOR A VARIETY OF CODLANTS AND SPECIFIED OPERATING CONDITIONS.

80 SOR 2

SOR2 SOLVES FOR THE FORCES, STPESSES, DEFLECTIONS, AND STRAINS IN THIN SHELLS OF REVOLUTION. THE SHELLS MAY BE GENERAL SURFACFS OF REVILUTION WITH VARIABLE THITKNESSES AND ELASTIC MODULII. THIS INCLUDES THE MORE FAMILIAR FRRMS - THE CIRCIJLAR FLAT PLATE, CONE, CYLINDER, SPHERE, ELLIPSE, AND TORII WITH CIRCULAR CR ELLIPTICAL CROSS SECTIONS, FDR WHICH A SIMPLIFIED INPUT IS USED. THF AXISYMMETRIC LOADINGS CONSIDERED INCLUDE ARBITRARY CISTRIBUTIONS OF NORMAL, TANGENTIAL AND MOMENT SURFACE LOADINGS, AS WELL AS EDGE FORCES AND DEFLECTIONS. THE EFFECTS OF PADIAL AND AXIAL TEMPERATURE DISTRIBUTIONS, CENTRIFUGAL LOADING DUE TO ROTATICN ABOUT THE AXIS AND VIBRATION ARE INCLUDED. THE ADDITIONAL EFFECTS GF MISALIGNMENT, LINE LOADS, AND ELASTIC SUPPORTS AT THE SHELL INTERSECTIONS ARE CONSIDERED.

109 4RESTRAINT PIPE STRESS CDDE THIS PROGRAM EVALUATES A FOUR RESTRAINT PIPING SYSTEM DESIGNED FOR HIGH TEMPERATURE OPERATION.

112 CROCK

CROCK SELECTS THE MINIMUM WEIGHT DESIGN FOR A SPACE POWER PLANT IN WHICH THE WASTE CYCLE HEAT IS RADIATED DIRECTLY TO SPACE FROM THE CONDENSER. IT ACCOUNTS FOR HEAT TRANSFER, FLUID FLOW, METEOROID PROTECTION, AND THE GFOMETRIC PRDPERTIES OF A RADIATOR-CONDENSER.

114 SHOCK

SHOCK SELECTS THE MINIMUM WEIGHT DESIGN FOP A HFAT-REJECTIDN SYSTEM FOR A SPACE POWER PLANT IN WHICH THE SENSIRLE HEAT LOST FROM A SINGLE-PHASE FLUID IS RADIATED TO SPACE. IT ACC NUNTS FDR HEAT TRANSFER, FLUID FLOW, METE- * ORCID PROTECTION AND FADIATOR GEOMETRY.

187 CENTRIFUGAL PUMP IMPELLER DES THIS SYSTEM HAS BEEN DEVELOPED FOR THE DESIGN AND DEVELOPMENT OF HIGH SPEED TURBOMACHINERY FOR PUMPING HIGH IEMPERATURE LIQUID METALS. AFTER INITIALING THE ANALYSIS AND DESIGN EFFORT BY ESTABLISHING THE PUMP CONDITIONS OF SERVICE THE CODES ARE USED TO DEFINE THE PUMP IMPELLER DESIGN. IN ALL PROGRAMS, REAL FLUID EFFECTS ARE NOT CONSIDERED. THE MACHINING CODE PRODUCES A PAPER TAPE FOR USE IN THE ACTUAL FABRICATION DF THE IMPELLER. 
I. DEFTRMATION AND STRESS DISTRIBUTION COMPUTATIONS, STRUCTURAL ANALYSIS AND ENGINEFRING DFSIGN STUDIFS

190 WOPEXPRT, WEIGHT OPTIMIZATION THE PURPOSE DF THE CODE IS TO CHONSE THF LIGHTEST REACTIR RESULTING FROM ALL POSSIBLE COMBINATIONS OVER THE RANGE DF REACTOR INDEPENDENT VARIABLES SPECIFIED. THE ENGINFFRING CALCULATIONS FOR EACH REACTOR DESIGN ARE RASFD DN A LIQUID-COOLED CYLINDRICAL REACTOR HAVING PIN-TYPE FUEL FLEMENTS. RFACTOR CONTROL IS ASSUMED TO BE EFFECTED BY MIVARLE SIDE REFLECTORS SURROUNDING THE CORE. NFCESSARY PHYSICS DATA IS INPUT IN THE FORM CF SECOND-DEGREE EQUATIONS AS A FUNCTION OF THF INDEPENDENT VARIABLES.

232 GAZELLES

DETERMINATION OF GAS-COOLED

FAST REACTOR CORE PROPIRTICNS REQUIRED TO SATISFY SPECIFIED DESIGN CONSTRAINTS AND COMPUTATION OF RESULTING PERFORMANCE CHARACTERISTICS.

233 CORE

THE REACTOR CORE CONFIGURATION DESIGNED BY THE CORE PRDGRAM CONSISTS OF CYLINDRICAL FUFL ELEMENTS ARRANGEC DN AN EQUILATERAL PITCH SPACING WITH INTERNAL AND EXTERNA COCLING. THE FUEL FLEMENT IS COMPOSED OF THREF CONCENTRIC GRAPHIT RINGS, AN INTERNAL COOLANT CHANNEL, AND A SPINE. THF COOLANT CHANNEL IS FORMED RY THE SPINE AND INNER GRAPHITE RING. THE FUEL IS CONTAINED IN THE MIDDLE GRAPHITE RING. CORE WILL DETERMINE THE NUMBER OF FUEL ELEMFNTS DF A SPECIFIFD DIAMETER AND LENGTH REOUIRED TO SATISFY A GIVEN CENTRAL FUEL TEMPERATURE. IT ALSO ADJUSTS THE PITCH SPACING REQUIRED TO PRODUCE A DESIRED PRESSURE DROP AS WELL AS PROVIDING A SPECIFIED INTERNAL COOLING RATE.

244 CYCLOPS 1

CYCLOPSI IS A PROGRAM FOR THE ANALYSIS OF THERMODYNAMIC SYSTEMS. IT IS A GENERAL PURPOSE PROGRAM THAT PERFORMS A HEAT AND MASS BALANCE FOR THERMODYNAMIC SYSTEMS COMPOSED OF PUMPS, TURBINES, SEPARATORS, HEAT EXCHANGERS, COMPRESSORS AND FLON THROTTLING DEVICES. THESE COMPONENTS MAY BE CONNFCTED IN ANY DESIRED WAY. THE THERMODYNAMIC FLUIDS THAT MAY BE USFD ARE WATEP, AIR, NITROGEN, AND PARA-HYDROGEN.

250 SAFE-PCRS

SAFE-PCRS NUMER ICALLY DETERMINES THE STRESS AND STRAIN DISTRIBUTION WITHIN EITHER HOMOGENEOUS OR HETEROGENEOUS THICK-WALLED BODIES OF REVOLUTION. IT IS DESIGNED FOR THE ANALYSIS OF MULTI-MATERIAL AXISYMMETRIC COMPOSITE STFUCTURES SUCH AS REINFORCED AND/OR PRESTRESSED CONCRETE VESSELS. DEFCRMATIONS MUST BE WITHIN THE ELASTIC LIMIT OF THE MATERIALS CCNSIDERED AND ONLY RODIES GF REVOLUTION SUBJECTED TO AXISYMMETRIC LOADING CAN BE TPEATED. 
I. DEFORMATILN ANE, STRESS DISTRI BUTION COMPUTATIONS,

STPUCTURAL ANALYSIS AND FNGINEERING DESIGN STUDIES

251 SAFF-AXISYM

SAFE-AXISYM IS A PRDGRAM FCR THE ANALYSIS OF MULTI-MATERIAL AXISYMMETRIC COMPOSITE STPUCTUPES. IT IS DESIGNED FOP THE ANALYSIS OF HETEROGENEOUS STRUCTURES SUCH AS PEINFORCED AND/CR PRESTRESSED CONCRETE VESSELS. THE STRUCTURE IS ASSUMED TO BF LINEARLY ELASTIC, AND ONLY BODIES OF REVOLUTION SURJFCTED TO AXISYMMETRIC LOANING CAN BE IRFATED.

252 SAFE-PLANE

DIMENSIONAL STRUCTUPES CF ARBITRARY EITHER PLANE STRESS OR PLANE STRAIN MECHANICAL AND/OR THERMAL LCADS ARE PERMITTED.
253 SAFE-SHELL SAFF-SHELL IS USED TO DESIGN AND ANALYZE AXISYMMETRIC THIN SHELL STRUCTURES DF ARBITRARY GENERATRICES UNDER AXISYMMETRIC MFCHANICAL ANOIOR THERMAL LOADING CONOITIONS. THE INTERSECTION OF TWO OR MORE SHELLS CAN BF TREATED.

266 CYGRO2 CYGRO2 IS USED TO DETERMINE STRESSES AND STRAINS DURING STEADY-STATE AND TRANSIENT POWER OPERATION OF AN OXIDE-FUELED, METAL CLAD ROD-TYPE FUEL FLEMENT IN A PRESSURIZED FNVIRONMENT. MAJOR LOADING CONDITIONS INCLUDF FUEL SWELLING, FISSION GAS AND COOLANT PRESSURF, CLAD GROWTH AND DIFFERENTIAL THERMAL EXPANSION. THE APPLICATION FOR WHICH THE PROGPAM HAS RECN DEVELOPED IS ZIRCALOY TUBES CONTAINING BULK OXIDF FUEL. AXIAL AND AZIMUTHAL SYMMETRY OF TEMPERATURE AND STRFSSES IS ASSUMED.

28? SEALSHFLL2 (MO110) THF SFALSHELL2 PROGRAM DETERMINES STFESSES, STRAINS, DEFLECTIONS, AND REACTIONS IN A THICK SHELL UF REVOLUTICN WITH AXISYMMETRIC LOADING. THE LOADING CONSISTS LF A TEMPERATUPE DISTPIBUTION, INSIDE AND OUTSIDE PRESSURE DISTRIBUTIONS, AND CIRCUMFERENTIAL FORCES AND MOMENTS APPLIED TO THE MIDDLE SURFACE. THE SHELL IS LINFAR-ELASTIC WITH TENSILE, BENDING, ANO SHEAR STRAINS.

$283 \quad M 0552$

MO552 SOLVES THE TRANSIENT RESPONSE PRCBLEM OF LINEAR ELASTIC, LUMDED-MASS SYSTEMS SUBJECTED TO A UNIDIRECTIONAL FIIUNOAIICN: TRANSIENT THAT CAN BE EITHER A VELOCITY OR ACCELERATION TRANSIENT. NORMAL MODE THECRY IS USED AND THE INPUT TO THE PFCGPAM CONSISTS OF THE MODE SHAPES, FREQUFNCIES, AND FCUNDATICN TRANSIENT. FLEMENT EFFECTS ARE ALSO FVALUATED AS A FUNCTION OF TIME. MCDAL DAMPING COEFFICIENTS MAY BE SPECIFIED. 
I DEFCRMATION AND STRESS DISTRIBUTION COMPUTATIONS, STRUCTURAL ANALYSIS AND ENGINEERING DESIGN STUDIES

300 SAFE-CREEP

SAFE-CREEP PERFORMS A VISCOELASTIC ANALYSIS OF PLANE OR AXISYMMETRIC COMPOSITE CONCRETE STRUCTURES WITH AGE- AND TEMPERATURE-DEPENDENT CREEP DATA.

315 WIPFX

WIREX PRODUCES WIRING LISTS

CONTAINING ALL THE INFORMATION NORMALLY FOUND ON DFTAILED WIRING DRAWINGS. THESE LISTS ARE PRESENTED TO THE ELECTRICIANS AS A JOB BOOK CONTAINING INFORMATION IN THE DRDER IN WHICH IT IS REQUIRED FOP LOGICAL PROCEDUPE THROUGH A WIRING JOB. WIREX LISTS WERE USED EXTENSIVELY DURING INSTALLATION FOR THE UHTREX PROJECT.

\section{MC457 (PIPE)}

PIPE PERFORMS AN ELASTIC STRESS ANALYSIS OF A 3-DIMENSIONAL PIPING STRUCTURE WITH THERMAL STRESSES, REDUNDANT LOOPS, AND CONCENTRATED LOADS.

332 SAFE-30

SAFE-3D IS A FINITE ELEMFNT PROGRAM FUR THE THREE-DIMENSIONAL ELASTIC ANALYSIS OF HETERDGENFOUS COMPOSITE STRUCTURES. THE PRDGRAM USES THE FOLLOWING TYPES OF FINITE ELEMFNTS - $(1)$ TETRAHEDRAL ELEMENTS TO REPRESENT THE CONTINUUM, (2) TRIANGULAR PLANE STRESS MEMBRANE ELEMFNTS TO REPRESENT INNER LINER OR OUTER CASE, AND (3) UNIAXIAL TENSION-COMPRESSION ELEMENTS TO REPRESENT INTERNAL REINFORCEMENT. THE STRUCTURE CAN BE OF ARBITRARY GEOMETRY AND HAVE ANY DISTRIRUTION OF MATERIAL PROPERTIES, TEMPFRATURES, SURFACE LOADINGS, AND BOUNDARY CONDITIONS.

\section{STFM}

STEM CALCULATES AND PUNCHES OUT PARTIALLY-COUPLED MASS, STIFFNESS AND INTERNAL LOAD FUNCTION MATRICES FOR A STRUCTURAL SYSTEM OF BEAMS HAVING PRISMATIC SEGMFNTS. SHEAR DFFORMATION AND RGTATIONAL INERTIA ARE INCLUDED IN THE CALCULATIONS.

344 GEM

GEM IS INTENDED PRIMARILY TO PERFDRM VIBRATION STUDIES WITH THE CAPABILITY OF GENERATING INPUT FOR THE VEP (VIBRATION EIGENVALUE PROBLEM) ROUTINE AND PERFORMING ADOITIONAL OPERATIONS DN THF DUTPUT FROM THE SHO (SHOCK) SEGMENT. GIVEN A SYSTEM OF MASSES AND SPPINGS, THE VEP ROUTINE COMPUTES THE NATURAL FREQUENCIES OF THE VIBRATING SYSTEM AS WELL AS THE MODE SHAPES FOR EACH FREQUENCY. GIVEN THE MDDE SHAPES, FREQUENCIES, AND MASSES OF A VIBRATING SYSTEM, THE SHO ROUTINE WILL COMPUTE THE DEFLECTIONS AND FORCES AT THE MASS PDINTS. 
STRUCTURAL ANALYSIS ANC ENGINEERING DESIGN STUDIES

353 SWFLL?

SWELL2 WAS DEVELDPED TO PROVIDF THF FULL-ELEMENT LIFETIME DATA REQUIRED FOR POWFR PLANT OPTIMIZATION STUDIES. THE PROGRAM COMMENCES BY CALCULATING RADIAL AND AXIAL TEMPERATURES IN A FUEL ELEMENT. THE FUEL WHICH IS HOTTER THAN THE EFFECTIVE-FISSION-GAS-RELEASE-TEMPERATURE IS CUNSIDERED TO RELEASE ITS FISSION GAS IMMEDIATELY TO A PLENUM, AND THE PRESSUPE OF ALL PLENUM GAS IS CALCULATED. THE PRESSURE DF THE GAS RETAINED FOR A WHILE IN THE COLOER FUEL IS ALSO CALCULATED. AT EACH AXIAL POSITION THE PLENUM PRESSURE IS COMPARED WITH THE PRESSURF EXERTED BY RETAINED FISSION GAS, AND THE LARGER OF THE TWD PRESSURES IS CCNSIDERED TO BE THE EFFECTIVE PRESSURE AS FAR AS CLADDING DAMAGE IS CONCERNED. THE CLADDING IS ASSUMED TO FAIL WHFN ITS CUMULATIVE DAMAGE EQUALS UNITY AT ANY AXIAL POSITION. DAMAGE COMPONENTS ARE PRIMARY CREFP, SECONDARY CREEP, RATCHETING GROWTH DUE TO THEPMAL CYCLING, FATIGUE DUE TO THERMAL CYCLING, AND STRAIN DUE TO INEXORABLE FUEL SWELLING. AT EACH STEP OF THE CALCULATIONS THE FUEL ELEMENT IS SUBJECTEN TO SEVERAL CONDITIONS OF ABNDRMAL OPERATION (OVERPOWER, FLOW COASTDOWN, ETC.) TO ENSURE THEY COULD NOT PRCDUCF ENDUGH ADDITIONAL DAMAGE TO CAUSE FAILURE AT THAT TIME.

\section{SUPORAN}

SUPORAN SOLVES FOR STEADYSTATE DEFORMATION AND STRENGTH CHARACTERISTICS OF A NUCLEAR REACTOR CCIRE SUPPORT STRUCTURE. THIS STRUCTURF IS ASSUMED TO BE MADE OF TWO CIRCULAR PLATFS WHICH ARE LOCATED ABOVE EACH UTHER AND ARE INTEPCONNECTED PEPPENDICULARLY WITH CONCENTRIC ROWS OF TUBULAR MEMBERS. THE GEOMFTRY OF THE STRUCTURE AND ITS LOADING (TRANSVERSE PRESSURE AND INTERNAL TEMPERATURE GRADIENTS) ARE ALL OF AXISYMMETRICAL NATURE.

365 BCW2

BOW2 IS USED TO CALCULATE

DEFLECTIONS OF CLNSELY-SPACED PARALLEL BEAMS, EACH WITH LIMITEDPIVOT SUPPORT AT ONE FND, POSSIRLE BEAM INTERACTIONS AT THE OTHER END AND AT ONE INTERMEDIATE POSITION, ASSUMING AN ARBITRARY TEMPERATURE DISTRIBUTION.

378 TUBE

TUBE SOLVES FOR THE STRESSES DUE TO PRFSSURE AND TIMPERATURE IN A U-TUBE TYPE HEAT EXCHANGER. SPECIFICALLY, IT HANOLES A CONFIGURATION CONSISTING OF A SPHER ICAL HEAD, PRIMARY TRANSITION CYLINDER, AND SECONDARY CYLINDER. THE TRANSITION CYLINDERS MAY BE CONICAL AND TAPERED IN THICKNESS, BUT THE REMAINING SHELLS ARE OF UNIFORM THICKNESS. THE SPHERICAL HFAD AND THE TRANSITION CYLINDERS MAY BE OMITTED FROM A PROBLFM. SYMMETRIC AND PLANE COMPCSITE STRUCTURES. 
I. DEFCPMATION AND STRESS DISTRIBUTION COMPUTATIONS, STRUCTURAL ANALYSIS AND ENGINFERING DESIGN STUDIES

383 MO266

MO266 COMPUTES THE DYNAMIC

SHOCK FURCES AND MODAL FREQUENCIES ACTING ON A LUMPED MASS, LINEAR ELASTIC MODEL OF A STRUCTURE SUBJECTED TO SHOCK SPECTRUM INPUTS. THE MOOEL FMPLOYFD IS A COLLECTION OF LUMPED MASSES CONNECTED BY WFICHTLESS FLEXIRLF EIEMFNTS. IF THF ORIGINAL STRUCTURE IS NOT STATICALLY DETERMINATE, PEDUNDANT FORCES MUST BE INTRODUCED TO ENSURE A PRIMARY STRUT TURE THAT IS. 
45 GRACE 1

GRACE1 IS A MULTIGRDUP, MULTIREGION, GAMMA-RAY ATTENUATION PROGRAM DESIGNED PR IMARILY FOR COMPUTING GAMMA-RAY HEATING AND GAMMA-RAY DOSE RATES IN MULTIREGICN FINITE OR SEMI-INFINITE SLAB SHIELDS. A DIFFERENT BUILDUP FACTOP MAY RE SPECIFIED FOR EACH SOURCE REGION CONSIDERED.

$46 \quad G=\triangle C E 2$

GRACE2 IS A MULTIGROUP, MULTIREGION, GAMMA-RAY ATTENUATION PROGRAM TO COMPUTE THE TOTAL DOSE RATE OR HEAT GENERATION RATE FROM FITHER A SPHERICAL OR A CYLINDRICAL SOURCE. THE SOURCE, WHICH MAY BE LOCATFD IN FITHFR THE CENTRAL REGION OF THE SYSTEM OR IN A CONCENTRIC SHELL REGION SUPRCUNOING IT, MAY BE UNIFORM, EXPONENTIAL, OR HAVE A POLYNOMIAL VARIATIDN IN THE RADIAL DIRECTION. IN THE CASE OF CYLINDRICAL GFOMETRY, IT MAY ALSO HAVE A POLYNOMIAL VARIATION IN THF AXIAL DIRFCTION.

\section{FARSE-1A}

THE PROGRAM COMPUTES THE NEUTRCN LEAKAGE FR'TM A SHIELD ANNULUUS. THE REMOVAL CROSS SECTIONS INCORPORATE MULTISCATTFRING EFFECTS. DNSE DEPOSIT AT THE TARGET MESH IS THEN DETERMINED FRCN THE ANGULAR DISTRIBUTION GF THE LEAKAGE NEUTRONS, INTEGRATED OVER THE SHIELD SURFACE.

110 SCARF?

SCARF 2 EVALUATFS THE FIRSTCRDER APPROXIMATION CF THE FAST NEUTRUN CURRENT AT THF PAY LOAD SURFACE DUE TO NEUTRONS WHICH SCATTER FROM THE RADIATCR FINS. IT USES SNAP GFOMETRY ANO IS A CONPLEMENTARY PROGRAM TC FARSE.

111 SCAR.1

SCAR 1 PERFORMS SINGLE SCATTER RAY TRACING AND EVALLATES SCATTERING FRDM A RING. IT IS COMPLEMENTAPY TO FARSE. 
123 LIPREC.AN 1

LIPRECANI IS A TWC-DIMFV-

SIONAL MONTE CARLO PROGRAM TO COMPUTF THE PENETPATION AND ENERGY DEPOSITION OF NEUTRONS IN PURE HYDROGENOUS MEDIA. THE CODE OFFERS THREE POSSIBLE GFCMETRIES, I. E., CONICAL, CYLINDRICAL AND UNEDIMFNSICNAL INFINITE SLAB GECMETRY (THIS LATTER OPTION TO THE EXTENT THAT AN INFINITE SLAB MAY BE APPROXIMATED BY A CYLINDER. OF LARGE RADIUSI. THE CODE MAY BF USEO WITH A MONO-DIRECTIONAL POINT DR BEAM SOURCE AND IS MODIFIED EASILY TO HANDLE ANGULAR DISTRIBUTIONS. ISOTRMPIC SCATTERING IN THE CENTER OF MASS SYSTEM IS ASSUMED. THE FOLLOWING RESULTS ARE TABULATED WITH EACH SUMMARY -

(A) ENERGY DEPOSITION DISTRIRUTION,

(P) PARTICLE DEPCSITION DISTRIBUTION,

(C) PAPTICLF LFAKAGE FRACTION,

(D) PARTICLF ABSURPTION FRACTION,

(F) THE FRACTICN CIF PARTICLES REACHING THE CUTOFF ENFRGY WHICH HAVE NFITHER LEAKED NDR HAVE BEEN ABSORBED,

(F) THE AVERACE ENERGY PER PARTICLE LEAKING FROM THE SYSTEM,

(G) THE AVERAGE ENERGY PER PARTICLE REMAINING IN THE SYSTEM AS HEAT GENFRATION,

(H) THE AVEPACE NUMBER CF COLLISIONS PER HISTORY,

(I) THE TOTAL NUMBER OF HISTCRIES CURRENTLY BEING SUMMARIZED,

(J) THE AVEPAGF ENERGY DEPOSIT PER HISTORY THROUGH ABSORPTION,

(K) THE AVERAGE FNERGY OF PARTICLES ABSORBED.

141 RATRAP

THE RATRAP PROGRAM COMPUTES

THE DOSE RATE AT SPECIFIED SPATIAL POINTS AROUT A SYSTEM OF SNAP GEOMETRY.

142 MORTIMER.

MORTIMER COMPUTES THE DOSE RATE AT SPECIFIEN SPATIAL POINTS ABOUT A SYSTEM DF SNAP GEOMETRY.

143 MAC

MAC PERFORMS SLAB GEOMETRY, MULTIGRTUP NEUTRON AND GAMMA RAY PENETRATION ANALYSIS FOR A MULTIREGION REACTOR SHIELD. THE CODE CALCULATES THE FOLLOWING INFORMATION AS A FUNCTION DF DISTANCE THROUGH A REACTOR SHIELD ASSEMBLY NEUTRON FLUXES FOR UP TO 35 ENERGY GROUPS,

NEUTRON DOSE RATES,

THE APPRCXIMATE NEUTRON SPECTRUM, GAMMA RAY FLUXES FOR 7 ENERGY GROUPS,

TOTAL GAMMA DOSE RATE, WITH A BREAKDOWN OF IHE CONTRIBUTION FRCM SOURCES IN EACH REACTOR AND SHIELD REGION,

THE APPROXIMATE GAMMA RAY SPECTRUM. 
197 SHOE

THE SHDE CODE MAKES USE OF THF METHCD OF STEEPFST DESCENT TO FIND THE DIMENSIONS OF A MINIMUMWEIGHT, THREE-LAYER SHIELD IN SPHERICAL GEOMETRY. THE WEIGHT MINIIMIZATION IS CARRIED OUT SUBJECT TO THE CONSTRAINING CONDITION OF a CONSTANT DOSE RATE AT SCME SELECTED POINT OUTSIDE THE SHIELD.

259 MUSCAT

MUSCAT COMPUTES THE INCIDENT SCATTERFD NEUTRON CUREENTS AS A FUNCTION OF POSITION WITHIN (1) THE CAVITY FORMED BY TWO TRUNCATED CONCENTRIC SPHERES, (2) THE CAVITY BETWEEN TWO CONCENTRIC CIRCULAR CYLINDERS, OR (3) A CYLINDRICAL CAVITY.

343 MO756(LETO)

LETD WILL SOLVE THE GAMMA RAY TRANSPORT AND ENEPGY DEPOSITION PRORLEM IN ONE-DIMENSIONAL LAMINAR SLAB GEOMETRY. THE ENFRGY GROUP SCHEME IS EMPLOYED TO ACCDUNT FOR PHOTCN ENERGY DFGRADATION. AN ARBITRARY EXTERNAL SPATIAL ISOTROPIC SOURCE MAY HE SPECIFIED WITH AN ARBITRARY ENERGY SPECTRUM. THE BDUNDARY CUNDITIONS MAY BE (A) FREE BOUNDARIES WITH ARBITRARY INCIDENT, (B) SYMMETPY ON THE LEFT ARBITRARY INCIDENT ON THE RIGHT, AND (C) SYMMETRY ON BOTH ENDS. 
273 THREDES

CATICNS PROGRAMMING SYSTEM NFCESSARY MODULES TO PFRFOPM PARAMETRIC DESIGN STUDIES OF THERMAL REACTORS INCLUDING THE THEFMAL CELL HOMOGENIZATION IBAM - ACC ABSTRACT 108), THE FAST SPECTRUM CALCULATION (FORM - ACC ABSTRACT 51). REACTOR DIFFUSICN THECRY (FOG - ACC ABSTRACT 28), AND ZERDDIMENSIONAL BURNUP IKINDLE) CALCULATIONS. THESE MODULES CAN BE USED IN CONJUNCTICN WITH ONE ANOTHER OR INDIVIDUALLY. 
189 SNC FOR DSN AND TDC.

\author{
CALCULATION DF SN CONSTANTS
}

193 CSP2A

FORWARD AND ADJOINT MACROSCOPIC MIXTURE CROSS SECTIONS FOR SN TYPE CODES. THE $1 O D$ GROUP MICRISCDPIC CROSS SECTIONS ARE TAKEN FROM THE CROSS SECTION TAPE WRITTEN BY THE CODE CSP1. THE DUTPUT OF CSP2A IS IN THE FCRM OF TWD TAPES, ONE CONTAINING THE FORWARD AND THE OTHER THE ADJOINT MACROSCOPIC CROSS SECTIONS. THE CROSS SECTIONS ARE ALSO PRINTED, IF DESIRED.

$104 \quad C S P 1$

THIS CODE PREPARFS 100 GROUP MICROSCOPIC CROSS SECTICNS FOR SN TYPE REACTOR CODES, USING THE GAM2 NUCLEAR DATA TAPE FOR THE CROSS SECTION DATA FOR THE FIRST 99 GROUPS. THE DATA FOR GRMUP 100 IS PART OF THE PUNCHED CARD INPUT. THE 100 GROUP SN CROSS SECTIONS, PREPARED BY THE CODE, ARE WRITTEN ON TAPE AND PRINTED, IF DESIRED. THE CRCSS SECTIONS ARE FMR THE ISOTRIPIC OPTION OF THF SN CODFS. THE DIAGONAL TRANSPORT APPROXIMATION HAS BEEN USED IN CALCULATING THE TRANSPORT AND IN-GROUP SCATTERING CROSS SECTIONS. THE CORRECTION TERM USED TO CALCULATE THESF TWO CROSS SFCTIONS IS SIMPLY $1 / 3$ OF THE PI SCATTERING CROSS SECTICN. THE NUMBER OF DUT-OF-GROUP SCATTERING TERMS IS OPTIONAL. WHEN LESS THAN THE NUMBER APPEARING ON THE GAM2 TAPE ARE REQUESTEC, THE REMAINING TERMS, FOR A GIVEN SDURCF GROUP, ARE SUMMED AND ADDED TN THE LAST DOWN-SCATTERING, TERM SAVED. WHEN CROSS SFCTIONS ARE LISTED IN THE SN FORMAT, IT IS POSSIBLE THAT CNE OR MORF INTERMEDIATE DOWN-SCATTERING TERMS WILL BE ZERO. WHEN THIS SITUATION ARISES, THE CODE WILL REPLACE THESE INTERMEDIATF ZFROS WITH THF QUANTITY $1.0 * 10 * *(-20)$.

\section{GAVER}

GAVER CALCULATES GRDUP AVERAGFD CROSS SECTIONS FROM POINTWISE CROSS SECTION DATA FOR THE GAM2 99 FINE-GROUP LIRRARY. THE INPUT DATA ARE USED TO DBTAIN A SET OF INTERPOLATED CROSS SECTIONS, WHERE 20 INTERPOLATED CROSS SFCTIONS ARE OBTAINEC FOR EACH FINE GRDUP. WHERE INPUT DATA DO NOT COVER THE FULL PANGE OF A FINE GROUP, THE GROUP-AVERAGED CROSS SECTION IS SET TO ZFRR.

$234 D P C$

DPC PREPARES INPUT DATA

FOR TWO-DIMENSIONAL NEUTRONIC CALCULATIONS FROM ENGINEERING DATA. A GENERAL DESCRIPTION OF REGIONS, IN TFRMS OF MULTIPLF SUBREGIONS, ALLOWS FOR EXPLICIT CCNSIDERATION OF DETAILED STRUCTURAL FORMS . DURING THE TRANSFCRMATION OF DATA, GENERAL THERMAL EXPANSIONS ARE. INCLUDED. ALSO, CONSIDFRARLE DATA CHECKING AND EVALUATION ARE PERFORNED. COMBINED WITH THE. FLEXIBLE NARRATIVE INPUT, THESF FEATURES MAKE THE CONE USEFUL IN THE PREPARATION OF ERRDR-FREE INPUT FOP COMDLEX PRCRLEMS. 


$$
296 \text { GRDWRK }
$$

GRDWRK GENERATES AS PUNCHED

DUTPUT THE BASIC FINITE ELEMENT REFERENCF GRID WORK FOR THE SAFE CODES. THIS GENERATED GRID CONSISTS OF TRIANGULAR ELEMENTS AND NOCES, UNIAXIAL ELFMFNTS, SUCH AS REINFORCEMENT BARS, TENDONS, AND ANCHORS, AND BIAXIAL MEMBRANES, SUCH AS ANY THIN SHELL OR LINER. THE PUNCHED CUTPUT SFRVE AS DIRECT INPUT DATA TO THE SAFE CODES.

345 GAND

TICNS NEEDED FOR IN FAST REACTORS FORMAT.
GAND PREPARES THE CROSS SECDETAILED COMPUTATIONS OF NEUTRON ENERGY SPECTRA FRIM A FILE OF RASIC NUCLEAR DATA IN THE ENDF/B
$373 \quad B L 47$ DESIGNED FOR PLANE STPUCTURFS THAT ARE TO UNDERGD STRFSS ANALYSIS. POINTS AND LINES ARE INPUT IN VARIOUS PARAMETRIC FDRMS, AND CURVED SEGMENTS ARE DRAWN BFTWEEN GIVEN POINTS ALONG THE GIVEN LINES. THE PROGRAM MAY BF USTD AS A DRAFTING TDOL TO CONSTRUCT ENGINEERING DRAWINGS. BL47 USES THREE POINTS DN A STRAIGHT LINE SEGMENT TO DBTAIN DIMENSIONS FOR SEALSHFLL2 (ACC ABSTRACT 282 ) INPUT DATA. 
159 MOMUS

MOMUS IS THE PROGRAM USED TO

CONSTRUCT AND MAINTAIN THE NEUTRON CROSS SECTION MASTER TAPE

DEVELCPED UNDER THE ATOMICS INTERNATIONAL AUTOMATED CROSS SECTION

PROGRAM. THE LIBRARY CONTAINS 21 ELEMENTS WITH DATA FOR 11

PARAMETERS IN THE RANGE 0.001 EV TO 10 MEV. MOMUS WILL PERFORM

THE FCLLOWING TASKS -

(A) MAKE THE BINAPY MASTER TAPE FROM CARDS,

(B) LIST SELECTED ELEMFNTS,

(C) UPDATE - ADD, CORRECT AND REPLACE ANY DATA,

(D) MAKE A SHORT TAPE CONTAINING SELECTED ELEMENTS,

(E) PROVIDE GRAPHICAL DISPLAY OF SELECTED DATA, AND

(F) PUNCH MICPOSCIPIC DATA.

181 XLIBIT

USING THE ANL STANDARD

CROSS SECTION DATA CARDS AS INPUT, THE PROGRAM CAN PERFORM THE FOLLCWING DPERATIDNS -

(A) PREPARE A LIBRARY TAPE CONSISTING OF THE CROSS SECTION DATA FOR SETS OF MATERIALS, INCLUDING A DIRECTDRY GIVING THE SETS ON THE TAPE AND THE MATERIALS IN EACH SET,

(B) GIVEN AN EXISTING LIBRARY TAPE, THE PROGRAM CAN PREPARE A DUPLICATE TAPE OR A MODIFIED TAPE, THE MODIFICATIONS CCNSISTING OF THE ADDITION AND DELETION OF SETS, THE ADOITION AND DELETION OF MATERIALS WITHIN A SET, AND THE RE-ORDER ING DF THE SETS ON THE TAPE,

(C) ANY OF THE DATA ON A LIBRARY TAPE MAY BE PRINTED. AND THE PROGRAM WILL PUNCH THE CROSS SECTION DATA CARDS THAT WERE USED TO PLACE ANY OF THE MATERIALS OR SETS ON THE TAPE WITH ALTERED SET AND MATERIAL NAMES IF DESIRED.

206 UNPACK

UNPACK RETRIEVES NEUTRON

CROSS SECTION DATA AND RELATED INFORMATION FROM A SCISRS (BROOKHAVEN NATIONAL LABORATORY) DATA TAPE. THE FORMAT AND STRUCTURE OF THE SCISRS TAPE IS DESCRIBED IN BNL-883 BY FRIEDMAN AND PLATT, JULY 1964.

236 DFSR

DATA FILE SERVICE RDUTINES (DFSR) ARE USED TO STORE, DISTRIBUTE, AND CHECK THE DATA ON THE EVALUATED NUCLEAR DATA FILE (ENDF). THERE ARE 6 ROUTINES DFSR 1 - STORES DATA ON MASTER LIBRARY TAPES. DFSR 2 - PRDCESSES REQUESTS FOR DATA BY FINDING THE APPRDPRIATE DATA ON THE MASTER TAPES AND COPYING THEM ONTO THE REQUESTCRS TAPE.

DFSR 3 - CORRECTS DATA ON THE MASTER TAPES.

DFSR 4 - COPIES/PRINTS/PUNCHES SELECTED DATA FROM THE MASTER TAPES.

DFSR5 - PRINTS LIST OF DATA RECENTLY ADDED TO MASTER TAPES AND PREPARES A CROSS-REFERENCE LIST OF ALL DATA ON THE MASTER TAPES.

DFSR 6 - MAKES COPIFS AND CHECKS THE MASTER TAPES. 
271 CLIP

CLIP IS THE CROSS SECTION

LI BRARY PREPARATION AND MAINTENANCE PROGRAM FOR FORM AND THREDES.

350 ETOE

ETOE IENDF/B TO MC* $* 2$ DATA

CCNVERSIONI ACCEPTS CROSS SECTIDN DATA FROM A MODE 2 ENDF/B TAPE (SEF REFERENCE 3) AND PREPARES THE BINARY CROSS SECTION AND LEGENDRE POLYNOMIAL TAPF FOR THE MC $* 2$ CODE WRITTEN BY ARGONNF NATIONAL LABTRATORY.

351 ECSIL

ECSIL IEXPERIMENTAL CROSS SECTION INFIJRMATION LIBRARYI IS A SYSTEM FOR THE STORAGE, RETRIEVAL, AND DISPLAY OF EXPERIMENTAL NEUTRON DATA. THE HEART OF THE ENTIRE SYSTEM IS THC COLLECTION OF DESIGNATORS USED TO IDENTIFY THE TYPE DF NEUTRON DATA, E.G., WHETHER THF MEASUREMENT IS A FISSION CROSS SECTICN, AN ANGULAR DISTRIBUTION FOR EMERGENT NON-ELASTIC NEUTRONS BETWEEN TWO NEUTRON ENERGIFS, ETC. THERE ARE THREE DICTIONARIES USED FOR INPUT TO THF DATA FILE - ONE FOR THE REACTION-TYPE DESIGNATOR, ONE FOR THE STATUS OF THE DATA, AND ONE TO FLAG THE PROGRAM TO PERFORM CERTAIN CONVFRSICNS. EXPERIMFNTAL NEUTRON DATA ARE, IN GENERAL, COMPOSEO OF TWO INTERDEPENDENT, BUT LOGICALLY SEPARABLE PARTS, THE BIBLIOGRAPHIC INFORMATION AND THE ACTUAL EXPERIMENTAL VALUES. THE REFEPENCE ACCESSION NUMBER, WHICH IS ASSIGNED TO A REFERENCE AND ITS ASSOCIATED SET OF DATA AS THEY ARE ACQUIRED, SERVFS AS A LINK BETWEEN THE BIBLIDGRAPHIC AND THE EXPERIMENTAL DATA FILES. AFTER A REFFRENCE ACCFSSION NUMBER IS ASSIGNED TO A NEW REFERENCE, THE FCLLOWING INFORMATION IS ENTERED INTO THE BIBLIOGRAPHIC FILE - THE COMPLETE RIBLIOGRAPHIC CITATION, THE LABORATOPY WHERE THE MEASUREMENT WAS PERFORMED, A BRIEF DESCRIPTION DF THE EXPERIMENTAL TECHNIQUE, CORRECTIONS THAT HAVE BEEN MADE TO THF RESULTS, AND NORMALIZATIONS, IF ANY. IN ADDITION, ANY CHANGES MADE TO THE DATA IRENDRMALIZATIONS TO BETTER STANDAROS, CORRECTIONS, ETC.I ARE RECORDED HERE. SUPPLEMENTARY REFERENCES ARE CARRIED ALONG AS SEE ALSOS.

375 SCORE? TRON CROSS SECTION EVALUATION SYSTEM.

SCORE IS AN INTERACTIVE NEU- 
384 CHECKER/CRECT/CAMMET/PLOTFB/ THIS PACKAGE OF FIVE PROGRAMS IS DES IGNED FOR PROCESSING ENDF/B IEVALUATED NUCLEAR DATA FILE VERSION BI TAPES.

CHECKER CHECKS THAT THE ENDF/B TAPES ARE IN PROPER FORMAT AND ALL FIELDS ARE WITHIN SPECIFIED LIMITS, RATHER THAN THE PHYSICS OF THE MATA LIBRARY. ANGULAR DISTRIBUTIONS RECONSTRUCTED FROM LEGENDRE COEFFICIENTS ARE EVERYWHERE POSITIVE.

CRECT PRIVIDES A MEANS OF CORRECTING ASSEMBLED DATA IN A TAPE BY INSERTION AND DELETION OF DATA.

CAMMET SELECTIVELY MERGES DATA FROM ONE OR TWO ENTF/B LIBRARY TAPES ONTO A FINAL TAPE. THE MODE (BCO OR BINARY) AND ARRANGEMFNT (STANDARD OR ALTEPNATEI MAY BE CHANGED DURING THIS PROCESS. PLOTFB PROCESSES ENDF/B LIBRARY TAPES WHICH CONTAIN DATA EMBEDDED WITHIN A NECFSSARY LIBRARY STRUCTURE IN ORDEP TO PRTDUCE COMPREHENSIVE LISTINGS AND/OR PLOTS. THE LISTINGS AND/OR PLOTS CONTAIN AN EXTENSIVE AMCUNT OF INFORMATION RELATED TO THF DATA, SUCH AS TEMPERATURF DEPENDENCE, PHYSICAL UNITS OF THE DATA, INTEPPOLATION LAWS FOR THE DATA. CRYPTIC TITLES DEFINING THE REACTION TYPE, ETC.

SLAVE3 PROVIDES MODULAR SUBROUTINES WHICH CAN BF ASSEMBLED TO RETRIEVE AND PROCESS ENDF/B DATA FOR A SPECIFIC PROBLEM. 
133 WED

THIS PROGRAM EDITS THE MAGNFTIC TAPE PRODUCED BY W-DSN CALCULATING REACTION RATES BY ENERGY AND BY VOLUME WITH TCTALS. IT CAN ALSO PRODUCE REACTION RATES FOR FED-IN CROSS SFCTIONS.

207 CROSSPLOT/CROSSPLOT DATA TAPE AUTOMATIC PLOTS ARE GENERATED FROM NEUTRON CROSS SECTION DATA.

210 DTX

THE DTX CODE CALCULATES

EFFECTIVE MACROSCOPIC, HOMOGENEOUS, GROUP CROSS SECTIONS WHICH ARE SPACE-AVERAGED OVER THE FLUXES AND CURRENTS PRE-CALCULATED IN A ONE-DIMENSIONAL NEUTRON TRANSPORT CODE SUCH AS DTK OR DSN. ISOTROPIC AND ANISOTROPIC CROSS SECTIONS MAY BE INCLUDED.

239 CPS

CPS PROVIDES A GRAPHICAL MEANS CF COMPARING EXPERIMENTAL CROSS SECTION VALUES OBTAINED FROM THE SCISRS LIBRARY TAPE WITH AN OPTION TO INCLUDE READING IN NEW EXPER IMENTAL OR CALCULATED VALUES. 
154 CROC 90

THE CROC9O CODE WAS DEVELOPED FOP USE IN THE DATA REDUCTION DF OUT-OF-PILE FLUID FLOW EXPEPIMENTS ON THF ML-1 FUFL ELEMENTS. THE CODE IS SPECIFICALLY DESIGNED TO EVALUATE FRICTION FACTORS, ENTRANCE AND EXIT COEFFICIENTS, AND ORIFICE CALIBRATIONS FROM HYORODYNAMIC DATA OBIAINED FROM SINGLE PHASE EXPERIMENTAL FLUID FLOW TESTS IN AXIAL FLOW DUCTS.

164 BUPPI

THE PROGRAM CALCULATES ABSOLUTE TOTAL EFFICIFNCY FOR MONOENERGETIC GAMMA RAY INTERACTIONS IN CYLINDR ICAL SCINTILLATION DETECTORS. THE ABSOLUTE TOTAL EFFICIENCY IS DEFINED AS THE FRACTION OF SOURCE GAMMAS WHICH INTERACT AT LEAST CNCE WITH THE CRYSTAL DETECTOR. CALCULATIONS ARE MADE FOR THE POINT ISOTROPIC SGURCE LOCATED ALONG THE AXIS OF SYMMETRY FOR SOLID CYLINDRICAL CRYSIALS, WITH OR WITHOUT A COAXIAL CYLINDRICAL WELL.

165 BURP? THE PROGRAM CALCULATES THE ABSOLUTE TOTAL EFFICIENCY FOR MONOENERGETIC GAMMA RAYS INTERACTING IN CYLINDRICAL SCINTILLATION DETECTORS. THE ABSOLUTE TOTAL EFFICIENCY IS DEFINED AS THE FRACTION OF SOURCE GAMMAS WHICH INTERACT AT LEAST ONCE WITH THE CRYSTAL DETECTOR. CALCULATIONS ARE MADE FOR HOMOGENEOUS, ISOTROPIC CIRCULAR DISK OR CYLINDRICAL VOLUME SOURCES. SOURCES MUST BE SYMMETRICAL WITH THE AXIS OF SYMMETRY FOR SOLID CYLINDRICAL CRYSTALS, WITH OR WITHOUT A COAXIAL CYLINDRICAL WELL. SOURCE ABSORPTION AND SCATTERING MAY BE INCLUDED FOR VOLUME SOURCES.

166 BURP3

THE PROGRAM CALCULATES ARSOLUTE TOTAL FFFICIENCY FCR MONOENERGETIC GAMMA RAY INTERACTIONS IN CYLINDRICAL SCINTILLATION DETFCTORS. THE ABSOLUTE TOTAL EFFICIENCY IS DEF INED AS THE FRACTION OF SOURCE GAMMAS WHICH INTERACT AT LEAST ONCE WITH THE CRYSTAL DETECTOR. CALCULATIONS ARE MADE FOR POINT ISOTROPIC SOURCES LOCATED BOTH ON AND OFF THE AXIS OF SYMMETRY FOR SOL ID CYLINORICAL CRYSTALS, WITH OR WITHOUT A COAXIAL CYLINDRICAL WELL. THE EFFICIENCIES FOR POINIS LOCATED AT SPECIFIED RADIAL OFF-AXIS POSITIONS, FOR A SINGLE AXIAL SOURCE-CRYSTAL DISTANCE, ARE NORMALIZED TO THE DN-AXIS EFFICIENCY FOR THE SAME AXIAL DISTANCE. THE ABSDLUTE EFFICIENCY FOR THE ON-AXIS POINT IS GIVEN. 
169 BURP4

BURP4 CALCULATES THE PHOTOFRACTION FOR MONOENERGETIC GAMMA RAYS INTERACTING IN SOLID CYLINDR ICAL SCINTILLATION DETECTORS. PHOTOFRACTION IS DEFINFD AS THE FRACTION OF INTERACTING SOURCE GAMMAS THAT ARE TOTALLY ABSORBED (INCLUDING SECONDAPIES) IN THE CRYSTAL. ISOTROPIC SOURCE GEOMETRIES ALLOWED ARE ISCTROPIC POINTS ION OR OFF-AXISI, DISKS, CYLINDRICAL VOLUMES. ALLOWED MONODIRECTIONAL SOURCES, NORMAL TO CRYSTAL FACE, ARE NARROW BEAM COLLIMATED TO CRYSTAL AXIS, BROAD REAM IILUMINATING ENTIRE CRYSTAL FACE, AND COLLIMATED BEAM OF ANY SPECIFIED DIAMETER.

170 BURP5

BURP5 CALCULATES THE PHOTOFRACTION FOR MONOENERGETIC GAMMA RAYS INTERACTING IN WELL-TYPE CYLINDRICAL SCINTILLATION DETECTORS. PHOTOFRACTIDN IS DFFINED AS THE FRACTION OF INTERACTING SOURCE GAMMAS THAT ARE TOTALLY ABSORBED (INCLUDING SECONDARIES) IN THE CRYSTAL. ISOTROPIC SOURCE GEOMETRIES ALLOWED ARE ISOTRDPIC POINTS ION OR OFF-AXISI, DISKS, CYLINDRICAL VOLUMES. ALSO ALLOWS NARROW MONODIRECTIONAL BEAM COLLIMATED TO CRYSTAL AXIS, INCIDENT NORMAL TO WELL ROTTOM.

248 COINC ICOMPUTER CODE FOR REDU COINCIDENCE COUNTING DATA ARE TREATED TO CBTAIN SPECIFIC DISINTEGRATION RATES, CHANNEL EFFICIENCIES ANO COUNT RATES, WEIGHTED MEANS, AND ALL ASSOCIATED STANDARD ERRORS. CORRECTIONS ARE MADE FOR UNEQUAL DEADTIME LOSS IN EACH CHANNEL, COINCIDENCE RESOLVING TIME LOSSES, DECAY DURING COUNTING, DECAY FROM A REFERENCE TIME, AND BACKGROUND IN EACH OF THE THREE CHANNELS. INPUT VARIABLES INCLUDE SAMPLE IDENTIFICATION, START TIME FOR COUNTING, SAMPLE REFERENCE TIME, COUNTING INTERVAL, TOTAL NUMBER OF COUNTS IN TWO SINGLE CHANNFLS AND ONE COINCIDENCE CHANNEL, AND NORMALIZING SAMPLE VOLUME. INPUT PARAMETERS CONSIST OF DEADTIMES OF EACH SINGLE CHANNEL, COINCIDENCE RESOLVING TIME FOR ALL THRFE CHANNELS, DFCAY CONSTANT, BACKGROUND COUNT RATE FOR ALL THREF CHANNELS, AND STANDARD ERRORS FOR EACH OF THE ABOVE PARAMETERS. OPTIONAL INPUT ALLOWS DATE, GROUP CLASSIFICATION, AND A 3-DIGIT USER CODE. DUTPUT CONTAINS CORRECTED SINGLE CHANNEL, COINCIDENCE, AND DISINTEGRATION RATES REFERRED TD START OF COUNT, SPECIFIC DISINTEGRATICN RATE (COUNTS/SECOND/UNIT VOLUME OR WEIGHT) REFERRED TO REFERENCE TIME, WEIGHTED MEAN AND ERROR DF ANY NUMBER OF PROBLEMS IN A GROUP, EFFICIENCIES OF THE TWO INDEPENDENT DETECTOR CHANNELS, DATE, SUMMARY OF BACKGROUND VALUES USED, IDENTIFICATION NUMBER, COUNT START TIME, AND UPPER AND LOWER LIMIT (ONE STANDARD DEVIATICNI OF EACH OF THE COMPUTED QUANTITIES. 
258 EXPN

EXPN ANALYZFS PULSED NEUTRON

DATA USING THE GARELIS-RUSSEL TECHNIQUE (REFERENCE 1). BASICALLY THE CNDE CONPUTES THE PROMPT DECAY CONSTANT, ALPHA, AND THE PARAMETER (K*BETA/L) FROM EXPERIMENTAL DATA, WHICH IS DIRECTLY EXTRACTED FROM A TIME ANALYZER STORAGE MEMORY AND READ ONTD A PUNCHED PAPER TAPE. THE ALPHA-DETERMINATION PART OF THE CODE WAS ORIGINALLY OBTAINED UNDER THE NAME EXPLICIT FROM KNOLLS ATOMIC POWER LABORATORY BUT HAS SINCE BEEN MODIFIED. THE CODE PROVIDES OPTIONS FOR A PRE-RURST OR A POST-BURST BACKGROUND ANALYSIS. THAT IS, THE PARAMETERS ALPHA AND (K*BETA/L) ARE OBTAINEN USING A BACKGROUND MEASURED PRIOR TO THE BURST OR MEASURED AFTER THE BURST.

311 BURNUP

BURNUP CORRELATES HEAVY ELEMENT ISOTOPIC ANALYSIS WITH FISSION PRODUCT NEOOYMIUM, URANIUM, AND PLUTONIUM CONCENTRATIONS IN AN IRRADIATED URANIUM FUEL FOR CALCULATIGN OF BURNUP (ATOM PER CENT FISSION AND MWD/MT). REACTDR PARAMETERS, INCLUDING EFFECTIVE NEUTRON ABSORPTION CROSS SECTIONS FOR ALL URANIUM AND PLUTONIUM ISOTOPES, CAPTURE-TO-FISSION RATIOS FOR U235, PU239, AND PU241, A TWC-GROUP DESCRIPTIMN OF THE NEUTRON SPECTRUM, THE AVERAGE NEUTRON TEMPERATURE, THE REACTOR FAST FISSION FACTOR, AND THE DISTRIBUTION OF THE SOURCES OF FISSION AMONG THE FISSIONABLE NUCLIDES ARE COMPUTED FROM THE EXPERIMENTAL DATA OBTAINED FROM THE MASS SPECTROMETRIC ANALYSIS DF URANIUM, PLUTONIUM, AND NEODYMIUM.

333 TOAD

ANALYZE GAMMA RAY SPECTRA.
TOAD IS USED TO PROCESS AND 
P. gENERAL MATHEMATICAL AND COMPUTING SYSTEM RUUTINES

43 CURFIT

CURFIT IS A COMPOSITE PROGRAM FOR FITTING EXPERIMENTAL DATA POINTS WITH DIFFERENT TYPES OF COMMON ANALYTIC CURVES. THERE ARE AT PRESENT FIVE FITS AVAILABLE -

(1) PCLYNOMIAL $Y=$ SUMMATION OVER I OF AII)*(X**(I)

(2) EXPONENTIAL $Y=A * \operatorname{EXP}(B X)$

(3) $\operatorname{COSINE} Y=A * \operatorname{COS}(B(X+C))$

(4) SERIES Or CURICS $Y=A(J)+B(J) * X+C(J) *(X * 2)+D(J) *(X * * 3)$

(5) FOURIER SERIES

62 LOS ALAMOS LEAST SQUAR,ES

THIS PROGRAM PERFORMS LEAST SQUARES FITTING OF LINEAR OP NONLINFAR FUNCTIONS IN SEVERAL INDEPFNOENT VARIABLES. THE PRQGRAM WILL DETERMINE AN ESTIMATE OF A IN THE FUNCTION $Y=F(X, A)$ RY MINIMIZING THE SUM OF SQUARES. IN THE FUNCTION, $X$ IS A VECTOR OF ORSERVED VARIARLES AND A IS A VECTCR OF PARAMETERS TO BE DETERMINED. IN THIS CONTFXT, A LINEAR FUNCTION IS ONE WHOSE PARTIAL DERIVATIVES WITH RESPECT TO THE ELEMENTS OF A ARE ALL INDEPENDENT OF A. A NONLINEAR FUNCTION HAS AT LEAST ONE NF THE [LEMENTS OF A APPEARING IN AT LEAST ONE OF THESE PARTIAL DERIVATIVES.

186 LAGI/LAG2

LAG IS A SINGLE PASS LOAD

AND GO ASSEMBLER DESIGNED TC: ACCEPT IBM7090 FLOCO II INSTRUCTIONS.

321 EXPALS

THIS PROGRAM FITS BY LEAST SQUARES A FUNCTION WHICH IS A LINEAR COMBINATION OF REAL EXPONENTIAL DECAY FUNCTIONS. THE FUNCTION IS

$Y(K)=$ SUMMATION CVVER J DF A(J) * EXP(-LAMBDA $(J) * K)$. VALUES OF THE INDEPENDENT VARIABLE (K) AND THE DEPENDENT VARIABLE Y (K) ARE SPECIFIED AS INPUT DATA. WEIGHTS MAY BE SPECIFIED AS INPUT INFORMATION OR SET BY THF PROGRAM $(W(K)=1 / Y(K))$.

324 FP.ANTIC

FRANTIC IS DESIGNED TO PROCESS RAW COUNTING DATA AND TO FIT IN THE LEAST SQUARES SENSE THESE DATA TO THE MULTIPLE EXPONENTIAL GROWTH AND DECAY EQUATIONS. THE PRDGRAN CAN BE USED FOR SUMS OF EXPINENTIALS WITH POSITIVE, NEGATIVE, OR ZERO FXPONENTS AND POSITIVF DR NEGATIVE COEFFICIFNTS.

\section{DAFT1}

DAFTI IS A PROGRAM FOR

WEIGHTED LEAST SOUARES FITTING OF 0.0253 EV NEUTRON DATA FOR FISSILE NUCLIDES. THE PROGRAM ALSO CARRIES DUT COMPUTATIONS RELEVANT TO DISCERNING OVERALL GOCDNESS OF FIT, PARTICULARLY DEVIANT DATA, AND DATA WHCSE IMPRDVFMENT WOULD LEAD TO LARGE REDUCTIONS IN ERROR OF EACH FITTED PARAMETER. 
364 SNEQ CODES, SNAP AND EQPLT, WHICH HAVE BEEN MERGED DUE TO THEIR COMMON USE OF THE SLIP COMPILER. SNAP INTERPRETS AND SOLVES PSEUDOFURTRAN INPUT EQUATIONS REPRESENTING NONL INEAR ALGEBRAIC SYSTEMS. EDPLT INTERPRETS PSEUDO-FORTRAN INPUT EQUATIONS AND CALCULATES AND PLOTS MULTIPLE CURVES TN A SINGLE GRAPH. EQPLT IS USEFUL FOR PARAMETER STUDIES. 
356 GAF/GAR DATA TAPES USED IN GG A BENCHMARK STUDY OF ZPR-I II ASSEMBLY 48 USING ENDF/B CROSS SECTIONS WAS UNDERTAKEN TO IDENTIFY POSSIRLE CROSS SECTICN DISCREPANCIES IN THE MICROSCOPIC ENDF/B DATA. THIS WORK WAS DONE FOR THE CSEWG TESTING SUBCOMMITTEE AS PART OF THEIR PHASE I DATA TESTING. THIS PACKAGE CONTAINS THE CROSS SECTION DATA GENERATED FOR THIS STUDY IN THE FRRM OF THE ULIRA-FINE GROUP CROSS SECTIONS OF THE MATERIALS OF ZPR-III ASSFMBLY 48 IN THE FORMAT OF THE GGA GAF/GAR PROGRAM DATA TAPES. 
VII. KWIC Index 


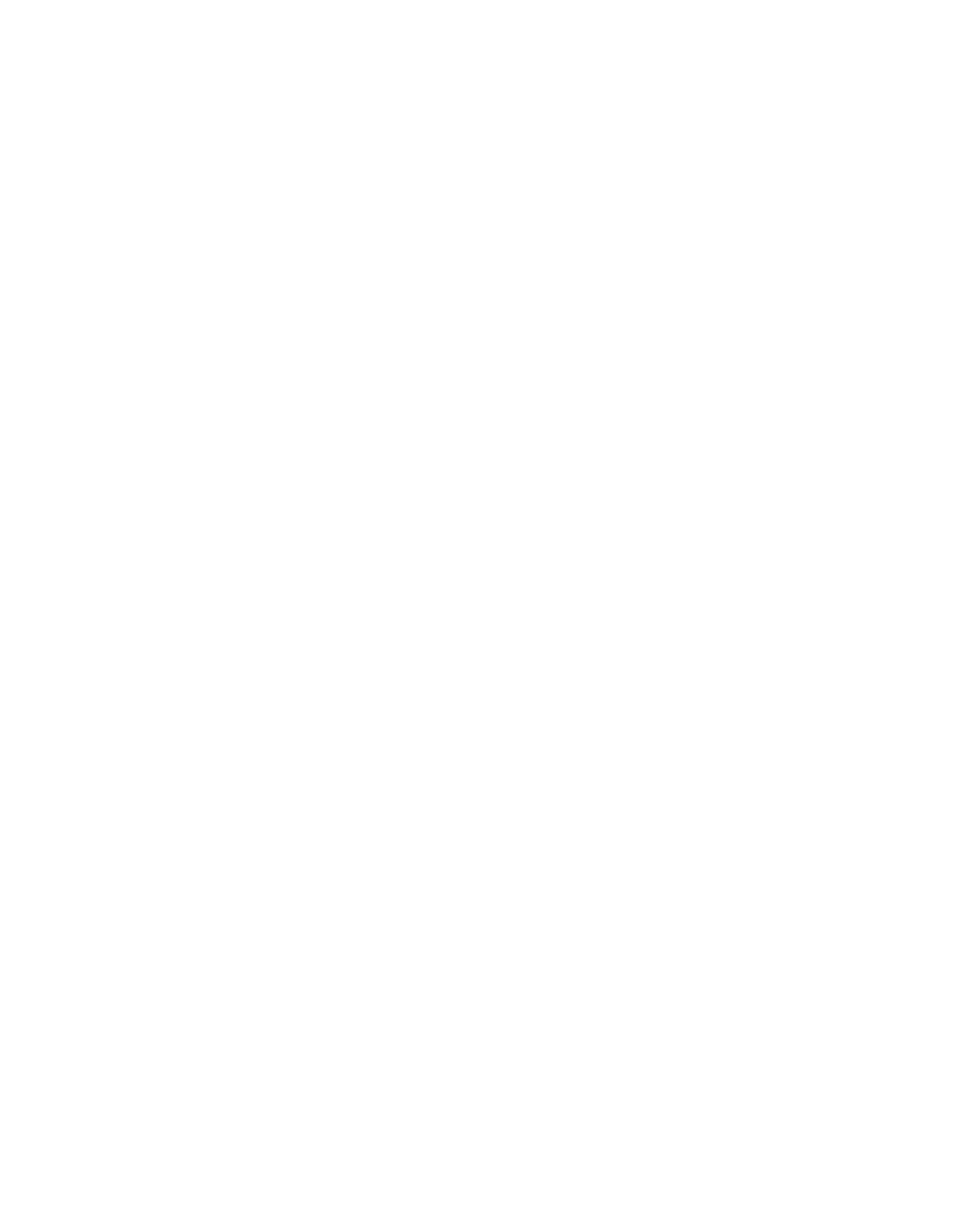


AAEC $360 \mathrm{~F}+\mathrm{BAL}$ RS $P$ T C\$ CRAM, 1-D AND 2-D MULTI-GP DIFFUSION PROGRAM ABSORPTION REMOVAL X-SECS BAPL 6600 F4 RS XT B\$ M0807, 2-D OIFFUSION ABSORPTITN, CELL ANL 3603 F36 RSBP XT B\$ RABBLE,WLIB,FLAT, RESONANCE ACCIDFNT ANALYSIS BAPL 6600 F4 RS P XT G\$ FLASH2, LDSS-OF-COMLANT ACCIDENT ANALYSIS PPCO 7040 F+MAP RS P T G\$ CONTFMPT, LOSS-OF-COOLANT ACCIDENT ANALYSIS RADL 6600 F4 RS P XT G\$ MO555, ACTI, LOSS-OF-COOLANT ACCIDENT ANALYSIS DOSE CALC GSA 1108 F4 RS T G\$ GADOSE,DOSET, HTGR ACTIVITY DIST STUDY GGA 7044 F4 RS P D\$ RAD2, HTGR FISSION PRODUCT ACT1, LOSS-DF-COOLANT ACCIDENT ANALYSIS BAPL $6600 \mathrm{~F} 4$ RS P XT G\$ MO555, AER $360 \mathrm{~F} 4$ S $\mathrm{P}$ B\$ WELWING, MATERIAL BUCKLING CYL FUEL ELEMENTS AEB $360 \mathrm{~F} 4$ RS L T C\$FIRE5, 1-D AGE-DIFFUSION SLAB CYLINDER SPHERF AEB $360 \mathrm{~F} 4$ RS $\mathrm{P}$ FE AIREK3, SPACE-INDEPENDENT KINETICS W/FEEDBACK AEB $360 \mathrm{~F} 4$ RS P E\$ RLAST, REACTOR KINETICS TEMPERATURF DIST STUDY AEG $7090 \mathrm{F2}$ RS AGC 7090 FLOCO RSBP AGC 7090 F2 RS P AGC 7090 F2 RS P $\triangle G C \quad 709 C F 2$ AGC $709 \mathrm{~F} 2$ AGC 7090 F2 RS P RSB B\$ DANCOFF JR, MODFRATOR SPACE CHORD DIST FUNCT C\$2DXY, 2-D MULTI-GP SN APPROXIMATION XY GEOM B\$ BOUNCE, FLUX DIST IN MULTI-PIN FUEL ELEMENT O\$ CROC9O, ML-1 FLUID FLOW EXPERIMENT ANALYSIS

$T$ B $\$$ AGN-SIGMA, CALC OF MULTI-GP TRANSFER MATRICES RSBPLXT BS AGN-GAM, FAST SPECTRUM MULTI-GD CONSTANT CALC AGE-DIFFUSION SLAR CYLINDER SPHERE AEB 360 F4 RS L T C\$FIRE5, $1-D$ AGN-GAM, FAST SPECTPUM MULTI-GP CONSTANT CALC AGC $7090 \mathrm{F2}$ RSRPLXT B \$ AGN-SIGMA, CALC OF MULTI-GP TRANSFER MATRICES AGC 7090 F2 RS P T B $\$$ AI 36C F+BAL RS L T M\$ SCORE2, SCISRS ENDF/B GRAPHIC X-SEC EVALUATION AI $360 \mathrm{~F}+\mathrm{BAL}$ RS $P$ T E\$ AIROS2A, SIMULATION OF REACTOR DYNAMICS

A I

A I

$\begin{array}{ll}360 & F 4 \\ 36 C & F 4\end{array}$

RS $P$ T F\$ TSN, SPATIALLY-DEPENDENT REACTOR KINETICS

RS P

T G\$ AISITEZ, PARAMETRIC SITE REQUIREMENT STUDY

$360 \quad F 4$

RS P XT

T $\$$ HWDCR-SAFF, 2-D MONTF CARLO CELL CALCULATION

103

R280

281

R295

297

R 284

261

231

R 284

362

$360 \quad F 4$

$360 \quad F 4$

RS PLXT B\$ AILMOE, X-SECTION CALC ELASTIC SCAT RESINANCES

$360 \quad F 4$

RSB L T MS CLIP, FORM OR THREDES LIBRARY UTILITY ROUTINE

$360 \quad F 4$

RSBP TK\$ THRFDES, 1-D FEW-GP DIFFUSION DESIGN SYSTEM

RSBP XT D\$ SIZZLE, I-D MULTIGROUP DIFFUSION DEPLETION

$360 \mathrm{F4}$

RSBPLXT C\$ ANISN, 1-D MULTI-GP DISCRETE ORDINATE CALC

$360 F 4$

RSB

$7090 \mathrm{~F}+\mathrm{FAP} R$

$7090 \mathrm{~F}+F A P$ RS

$X T C$

$\$$ CAESAR4, LIBLST, 1-D MULTI-GP DIFFUSION + LIA

A I

A I

AI

7090 F+FAP RS

$T$ I $\$$ 4RESTRAINT PIPE STRESS, MAXIMUM MOMENT CALC

$L T$ B\$ QUICKIE, INFINITE MEDIUM SPECTRUM X-SECTIONS

7000 F+FAP RS

L T C\$ FAIM, I-D MULTI-GP DIFFUSION SLAB CYL SPHERE

$L$ T C\$ ULCER, 1-D MULTI-GP DIFFUSION SLAB CYL SPHERE

7090 F+FAP RS PL T R\$ TFMPEST2, THERMAL NEUTRON SPECTRUM X-SECTIONS

A I

$7090 \mathrm{~F}+F A P$ RS

RS

7090 F2 RS

C.\$ AIMG, 1-D MULTI-GP DIFFUSION SLAB CYL SPHERE

BS S4 CYL CELL CODE, 1-D 1-GP S4 APPROXIMATION

C\$ PERT, 1-D PERTUPBATION FOR AIM AND FOG CODES

E\$ AIRFK3, SPACE-INDEPFNDENT KINETICS W/FEEDBACK

$7090 \mathrm{F2} \quad \mathrm{RS}$

E\$ SNAPKIN5/5A, 1-REGION KINETICS SNAP GEOMETRY

$7090 \mathrm{F2}$ RS

IS CROCK, SPACE POWER PLANT DESIGN OPTIMIZATION

7090 F2 RS

I\$ FUGUE, STEADY-STATE TEMPERATURE VOID FRACTION

I\$ SHOCK, SPACE POWER PLANT DESIGN OPTIMIZATION

$7090 \mathrm{F2}$

R S

J\$ FARSE IA, DOSE RATE FROM SNAP SHIELD LEAKAGE

$\begin{array}{lll}7090 & F 2 & R S \\ 7090 & F 2 & R S\end{array}$

J\& MORTIMFR, DOSE RATE CALCULATION SNAP GEOMETRY

J\$ SCARF2, SCATTER FROM RADIATDR FINS SNAP GEOM

709 C F 2

RS

J\$ SCAR 1, SCATTER FROM A RING SNAP GEOMETRY

$7090 \quad F 2$

RS

$7090 \mathrm{F2}$

$7090 \quad F 2$

$7090 \mathrm{F2}$

RS

L T D

\$ SIZZLE, I-D MULTIGROUP DIFFUSION DEPLETIDN

RS $p$ B \$ BAM, $54 \mathrm{CYL}$ CELL CODE AND TEMPEST COMBINATION

RS $P$

$7090 \mathrm{~F} 2$

$7090 \mathrm{~F} 2$

RS P

RS $P$

B\$ SAIL, 1-D 1-GP SN APPROXIMATION SLAB GEOMETRY

D\$ AIMFIRE, URANIUM FUEL CYCLE COST ANALYSIS

G\$ CLLUD, GAMMA-RAY DOSE RATE FROM A CLOUD

$7090 \mathrm{~F} 2$

RS P

RS $P$

J\$ GRACE 1, GAMMA-RAY ATTENUATION SLAB GEOMETRY

J\$ GRACE2, GAMMA-RAY ATTENUATION CYL SPHERE GEOM

121

363

150

18

237

154

243

153

204

9

204

243

375

326

309

172

307

147

271

273

58

151

270

109

119

120

118 
AI 7094 F+FAP RS P T G\$ AISITE2, PARAMFTRIC SITE REQUIRFMENT STUDY

AI 7004 F+FAP RS PL T B\$ AILMOE, X-SFCTION CALC ELASTIC SCAT RESONANCFS

AI $7094 \mathrm{FHFAP}$ RS PL T A\$ GRAVE, GROUP-AVFRAGING $X-S E C T I O N S$ PARAMETERS

AI 7094 F+FAP RS PL T B\$ TYCHE3, MONTF CARLO SLNWING-DNWN DFNSITY CALC

AI $7094 \mathrm{~F}+F A P$ RS PL T G\$ CURIE,DDSE, THUNDERHEAD, EXTERNAL IINTERNAL DOSE

AI 7094 F+MAP RS $P$ A\$ CHAD, LEGFNDRE COFF CALC FOR ANGULAR OIST DATA

AI 7094 F+MAP RS $P$ T E\$ AIROS, SPACE-INDEPENDENT KINETICS W/FEEDBACK

AI 7094 F+MAP RS DLXT A\$ TRIX1, RESONANCE INTEGRAL X-SECTION CALC

AI $7094 \mathrm{F2}$ RS P H\$ FLOW-MODEL, MULTI-CHANNEL 2-D 2-PHASE FLOW

AI $7094 \mathrm{FZ}$ RS P J\$ SHOF, SHIELD WEIGHT OPTIMIZATION DOSE CALC

AI $7094 \mathrm{~F} 2$ RS P TAS PPLUS, NON-SPHFRICAL DPTICAL MODEL X-SECTIONS

AI $7094 \mathrm{~F} ?$ RS P T G\$ TRANS-FUGUFI, TRANSIENT FLOW AND HEAT TRANSFER

AI $7 C 94 \quad F 2$ PS P T H\$ HEATING2, TRANSIENT STEADY-STATF HEAT TRANSFFR

AI $7094 \mathrm{F2}$

AI $7094 \quad \mathrm{FL}_{4}$

RS PL $T$ I\$ CYCLOPSI, THFRMODYNAMIC CYCLE ANALYSIS

AILMDE, X-SECTION CALC ELASTIC SCAT RESONANCES AI 360 F4 RS PLXT B \$ AILMOF, X-SECTION CALC ELASTIC SCAT RESONANCES AI 7094 F+FAP RS PL T B $\$$ AIM AND FIG CIIDES AI 7 COOF2 RS C\$ PFRT, 1-D PERTURBATIDNFIR AIM AND FIG CODES BHSC 360 F4 RS P C\$ PERT, 1-D PERTURBATIONFOR AIM AND FOG CODES CDC $16 C 4$ F63 RS AIMFIRE, UPANIUM FUEL CYCLE COST ANALYSIS AIMG, I-D MULTI-GP DIFFUSION SLAB CYL SPHERE AIMG, 1-D MULTI-GP TIFFUSION SLAR CYL SPHERE AIRFK3, SPACF-INDEPENDENT KINFTICS W/FEFNBACK AIREK3, SPACE-INDEPENDFNT KINETICS W/FEEDBACK AIREK3, SPACE-INDEPENDENT KINETICS W/FEEDBACK AIROS, SPACF-INDEPENDENT KINETICS W/FEFDBACK AIROSZA, SIMULATION OF REACTOR DYNAMICS AISITE2, PARAMETRIC SITE REQUIREMENT STUDY AISITE2, PARAMETRIC SITE REOUIRFMFNT STUDY

C $\$$ PERT, 1-D PERTURBATION FOR

$\begin{array}{llll}\text { PERT, } 1-D & \text { PERTURBATION FOR } & 30 \\ \text { AI } 7090 & \text { F2 RS P } & \end{array}$ AI 7090 F+FAP RS PL T C $\$ 29$ CDC 1604 F63 RS PL T C \$ 29 $A E B \quad 360 F 4 \quad$ RS $P$ E \$ 121 AI $7090 \mathrm{F2}$ RS $\quad$ F $\$ 121$ CDC 1604 F63 RS P E \$ 121 AI 7094 F+MAP RS P TE \$ 163 AI $360 \mathrm{FtAAL}$ RS P TE \$ 326 AI $360 \mathrm{FA} \quad$ RS P T G \$ 172 AI 7094 F+FAP RS P T G \$ 172 ALGEBRAIC FON SOLN CURVE PLIT KAPL $6600 \mathrm{~F}+A S C$ RS P T P\$ SNEQ, NONLINEAR R364 ANALYZER GAMMA-RAY SPECTRA GGA 1109 F4 RS P T O\$ TOAD, PROCFSSING OF 333 ANGULAR DIST GGA $7044 \mathrm{~F} 4$ RS P $X$ A\$ LEGCOEF3, LEGFNDRE COEF CALCFOR 217 ANGULAR DIST DATA AI 7094 F+MAP RS P A\& CHAD, LEGENDRE CNEF CALC FOR 215 ANISN, 1-D MULTI-GP DISCRFTE TRNINATE CALC AI ANL 360 F4 RS P F TWIGGLF, 2-D 2-GP SPACE-TIME DIFFUSION

ANL $360 \mathrm{F4}$ RS P T C\$ DTF4, 1-D MULTI-GP DISCRETE ORDINATE PROGRAM ANL 360 F4 RS P T $\$$ TWTTRAN, 2-D MULTI-GP TRANSPORT CODE X-Y GEOM

ANL $\quad 360 \quad F 4$ ANL $\quad 360 \quad F 4$

ANL $1604 \quad F 63$

ANL $3600 \quad F 36$

ANL 3600 F 36

ANL $3600 \quad F 36$

ANL $3600 \quad F 36$

ANL $3600 \quad F 36$

$\triangle N L \quad 3600 \quad F 36$

ANL $3600 \quad F 36$

ANL $3600 \quad F 36$

ANL $360 C \quad F 36$

ANL $3600 \quad F 36$

ANL $3600 \quad F 4$

ANL $3600 \mathrm{F63}$

ANL $3600 \quad F 63$

ANL $3600 \quad F 63$

ANL $3600 \quad F 63$

ANL 3600 FE3

ANL 3600 F63

ANL $3600 \quad F 63$

ANL $3600 \quad F 63$

ANL $3600 \quad F 63$

ANL $3600 \quad F 63$

ANL 3600 F63

ANL $3600 \quad F 63$
RS $P$ T F\$ SASIA, FAST REACTOR POWER AND FLOW TRANSIENTS RS P XT F\$ FORE2, FAST REACTOR EXCURSION CALCULATIONS

RS P H\$ MOR99,HOH, STEAM TABLES 14.5-2538 PSIA

SBP I\$ BOW2, DFFLECTION CALCULATION PARALLEL BEAMS RS P T BS MC \$? ENDF MULTIGROUP X-SECTION CALCULATION RS $P$ T C\$ SNARG-1D, 1-D MULTI-GP DISCRETE ORDINATE CALC RS $P$ I I\$ SUPOPAN, REACTOR CORE SUPPORT STRESS ANALYSIS RS P XT C MACHI, 1-D MULTI-GP DIFFUSION SLAB CYL SPHERE RSBP $\triangle$ \$ ISH-MASH, RESONANCF INTEGRAL CALC HOMOGENENUS RSRP G\$ CHEMLOC 2, CORE HEATING CLADDING-STFAM REACTION RSBP I\$ SWELL2, FUEL ELEMENT LIFETIME ANALYSIS $R S B P X T$ R\$ RABBLE,WLIB,FLAT, RFSONANCE ABSORPTIDN, CELL RSBP $X T$ B\$ RIFF-RAFF, RESONANCF INTEGRAL CALC 2-REG CELL RSBP T D\$2DB, 2-D MULTIGROUP DIFFUSION AND DFPLETION RS LXT BS GAMI, FAST NEUTRON SPECTRUM X-SFCTION CALC RSBP A\$ NEARREX, COMPOUND NUCLEUS $X$-SECTION CALC RSBP ES R101, SPACE-INDEPENDENT KINETICS KEX OPTIONS RSB ${ }^{\circ}$ E\$ R 102, SPACE-INDFPENDENT INVERSE KINETICS CALC RSBP RSBP T A\$ 2 PLUS, NON-SPHERICAL OPTICAL MODEL X-SFCTIONS RSBP T ES TRAFICORPORATION, TRANSFER FUNCTION SYNTHESIS RSRP T G\$ R153, PARAMETRIC SITE REQUIREMENT STUDY RSBP T H\$ ARGUS, TRANSIENT TEMPERATURE CALC CYLINDER RSBP T MS XLIBIT, X-SECTION LIBRARY UTILITY ROUTINE RSBP XT B\$ THERMOS(ANL), THERMAL SPECTRUM X-SECTION CALC RSBPL T J\$ MAC, SHIFLD DESIGN MULTIGROUP SLAB GEOMETRY
$? 15$

208

246

197

268

198

309

147

147

30

9

9

338

209

358

400

174

R. 294

365

355

788

357

262

214

366

353

281

213

325

33

171

255

168

248

254

135

172

152

181

184

143 
ANL $6600 \mathrm{~F} 4$ RS $P$ T F\$ SASIA, FAST REACTOR POWER AND FLOW TRANSIENTS 400 ANL 1, THEPMAL SPECTRUM X-SECTION CALC ANL 3600 F63 RSBP XT B\$ THERMOSI 184 ANNULAR VIID X-SECTION CALCULATION GEC $625 \mathrm{F4}$ RS P B\$ AVIID, 276 APDA 3600 ASAF4 RS P T M\$ FTOF, ENDF/B TO MC * 2 DATA CONVERSION APDA 7094 F2 RS P F WEAK EXPLOSION, COUPLED NEUTRON-HYDRODYNAMICS 145 APDA $7094 F_{4}$ DS P F MARS, 2-D EXCURSION CALCULATION R-Z GEOMETRY 293 APO 635 F4 RS P D RAPFU, FUEL CYCLE PARAMETERS FAST BREFDERS 372 ARES2, RESINANCE INTEGRAL X-SECTION CALC $\quad$ AI $7090 \mathrm{F2}$ RS PL T A \$ 89 ARES2, RESONANCE INTFGRAL X-SECTION CALC $\quad$ CDC 1604 F63 RS PL T A 59 ARGUS, TRANSIENT TEMPERATURE CALC CYLINDER ANL $3600 \mathrm{~F} 63$ RSRP T H \$ 152 ASAF4 RS P T M\$ ETME, ENDF/B TO MC *2 DATA CONVFRSION APDA $3600 \quad 350$ ASSAULT, 2-D MULTI-GP DIFFUS ION DEPLETION CODE ORNL 7090 F+FAP RS P $T$ D $\$ 240$ ASSEMRLER FOR FLICOR INSTRUCTION SET PW 1604 F+CDP RS P T P\$LAG, 186 ASSEMRLY 48 GAFGAR ENDF/B DATA TAPES GGA 1108 BIN R L T Z\$ 2PR-III 356 ATTENUATINN CYL SPHERE GENM AI $7090 \mathrm{~F} 2$ RS P J\$ GRACE2, GAMMA-RAY 46 ATTENUATION CYL SPHFRF GEOM CDC 1604 F63 RS P J\$ GRACE2, GAMMA-RAY 46 ATTENUATION SLAB GEOMETRY AI 7090 F2 RS P J\$ GRACE1, GAMMA-RAY 45 ATTENUATION SLAB GEOMETRY CDC 1604 F63 RS P J\$ GRACE1, GAMMA-RAY 45 AVERAGE X-SFC CALC BNL $56 \cap 0$ F4 RS P A AVERAGE, UNRESOLVEO RFGION 376 AVERAGE $X$-SEC CALC BNL $7094 \mathrm{~F} 4$ RS P A $\$$ AVERAGE, UNRESOLVED REGION 376 AVERAGE, UNRESOLVED REGITN AVERAGE X-SEC CALC BNL $6600 \mathrm{~F} 4$ RS P A 376 AVERAGE, UNRESOLVED REGION AVERAGE X-SEC CALC BNL 7094 F4 RS P $A$ \$ 376 AVERAGING GGA $7044 \mathrm{~F} 4$ RS P L GAVER, ENERGY INTERVAL X-5ECTION 218 AVOID, ANNULAP VOID X-SECTION CALCULATION GEC 625 F4 RS P $B$ B 276

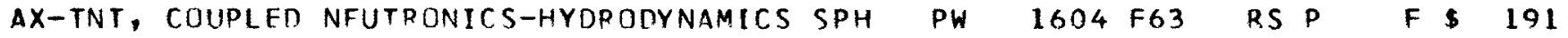
AXFLU, HEAT TRANSFER MOLTEN FUEL TUBF BUNDLES LASL 7094 F2 RSBP H $\$ 182$ AXISYM LOAD BAPL 660 O F4 RS P XT I\$ SEALSHELL2, SHELL STRESS ANALYSIS R282 AXISYMMITRIC LITAD GGA $7044 \mathrm{~F} 4$ RS P T I\$ SAFE-PCRS, STRESS ANALYSIS 250 AXISYMMETRIC LOAD GGA $7044 \mathrm{~F}_{4}$ RS $P$ T I\$ SAFE-AXISYM, STRFSS ANALYSIS 251 AXISYMMETRIC STRESS ANALYSIS GGA 1108 F4 RS P I\$ SAFE-2D, PLANE + 379 AXTHRM, HEAT TRANSFFR SOLID FUEL TURE BUNDLES LASL $7094 \mathrm{FZ} \quad$ RSBP $\quad H \$ 183$ AX1, CDUPLFD NEUTRONICS-HYDRODYNAMICS SPHEPE CDC 3600 F63 RSBP $F \quad \$ 102$ B-W MULTI-LEVEL CONVOLUTION PPCO $7040 \mathrm{~F} 4$ RS P A\$ COMBCO, COMBINED B-W RESONANCE DATA GGA 7044 F4 RS $P$ A\$ FASDOP, X-SFCTIONS FROM $B-W$ RESONANCE PARAMETERS WANL $7094 \mathrm{~F} 2$ RS $P$ A\$ EXT, X-SECTINNS FRDM B-W X-SEC CALC BNL 6600 F4 RS P A SIGPLOT, RESOLVED MULTILEVEL $B-W X-S E C$ CALC BNL $7094 F 4$ RS P A\$ SIGPLOT, RESILVED MULTILFVEL BAM, S4 CYL CELL CODE AND TEMPFST COMBINATION AI $7090 \mathrm{~F}$ ? RS P B \$ BAPL $6600 \mathrm{~F}+A S C$ RS $P$ XT D\$ DDQ7, 1,? OR 3-D FEW-GP DIFFUSION DEPLETION BAPL $660 C F+C O M$ RS $P X T$ I\$ GAPL3, INELASTIC LARGE DEFLECTION STRFSS STUDY BAPL $6600 \mathrm{~F} 4$ RS XT B\$ M0807, 2-0 DIFFUSIDN ABSORPTION REMOVAL X-SECS BAPL 660 C F4 BAPL $6600 \quad F 4$ BAPL $6600 \quad F 4$ BAPL 6600 F4 BAPL $6600 \quad F 4$ BAPL $6600 \mathrm{~F} 4$ BAPL. $6600 \mathrm{F4}$ BAPL $6600 \quad F 4$ BAPL $6600 \quad F 4$ BAPL $6600 \quad F 4$ BAPL $6600 \quad F 4$ BAPL $6600 \quad F 4$ BAPL $6600 \quad F 4$ BAPL 6600 F4 BAPL $6600 \quad F 4$ BAPL 6600 F4 BAPL $6600 \quad F 4$ BAPL $6600 \quad F 4$ BAPL $6600 \quad F 4$ BAPL 6600 F4 BAPL $6600 \quad F 4$ BAPL $6600 \quad \mathrm{~F} 4$ BAPL $6600 \quad F 4$

RS XT C\$ M0648, 1-D SLAB TRANSPORT WITH SLOWING DOWN RS XT H\$ WATER, STEAM TABLES 14.5-14,50OPSIA 32-4720EGF RS $X T$ I\$ CYGRO2, STRESS ANALYSIS CYL FUEL ELEMENT RS $P$ DS CINDFR, MO102, POINT DEPLFTION FISSION PRODUCT RS $P$ T O\$ JITER, FLUCTUATION EXPERIMENT ANALYSIS RS $P$ XT A\$ PUN1, UNRESOIVFD RESONANCE INTEGRALS X-SECS RS $P$ XT AS SUMOR, S-WAVE NEUTRDN X-SECTION CALCULATION RS $P X T$ B RESQ2, RESQO, DBF1, RESONANCE INTEGRAL HEX CFLL RS $P X T$ C\$ PEZI, FEW-GP DISCRETE ORDINATFS SLAB GEOMETRY RS $P$ XT F\$ NOWIG, 1-D 2-GP KINETICS TEMPERATURE FEEDBACK RS $P$ XT F\$ TWIGL, 2-D 2-GP SPACE-TIME DIFFUSION FEEDBACK RS $P X T$ F\$ WIGL2, 1-D 2-GP SPACF-TIME DIFFUSION 3-GEDM RS $P X T$ G\$ FLASH2, LOSS-OF-CODLANT ACCIDENT ANALYSIS RS $P X T G \$$ M0555,ACTI, LOSS-OF-COOLANT ACCIDENT ANALYSIS RS $P$ XT H\$ FIGRO, LSBR FUEL SWELLING TEMPERATURE STUDY RS $P X T$ H\$ FLOT1, MO219, PWR FLOW TRANSIENT ANALYSIS RS $P X T H \$$ HOT2, 2-D TRANSIENT HEAT CONDUCTION PROGRAM RS P XT H\$ MO899, HOH, STEAM TABLES 14.5-2538 DSIA RS $P X T$ H\$ TOPS, TRANSIENT THERMODYNAMICS OF PRESSURIZERS RS $P X T H \$$ WASP, WATER AND STEAM THERMOOYNAMIC PROPERTIES RS $P X T$ I\$ M0266, LINEAR ELASTIC STRUCTURAL DYNAMICS RS $P X T$ I\$ M0457,PIPE, ELASTIC STRESS OF PIPING SYSTEM RS P XT I\$ MO552, DYNAMIC ANALYSIS LINEAR ELASTIC SYSTEMS
203

216 238 377 377 108 R275 R 397 R280 R342 Q 267 R266

313

R394

R359 R. 399 R285 R398 R371 R338 R274 R295 R234 P 772 R331 R286 R 294 R348 R396 R383 R 329 R283 
$\begin{array}{lrl}\text { BAPL } & 6600 & F 4 \\ \text { BAPL } & 6600 & F 4 \\ \text { BAPL } & 6600 & F 4 \\ \text { BAPL } & 6600 & F 4 \\ \text { BC } & 625 & F 4 \\ \text { BC } & 625 & F 4 \\ \text { BC } & 625 & F 4 \\ \text { BC } & 625 & F 4 \\ \text { BCL } & 6400 & F 4 \\ \text { BCL } & 6400 & F 4\end{array}$

RS $P$ XT I\$ SEALSHELL2, SHELL STRESS ANALYSIS AXISYM LOAD

RS $D X T$ J\$ MO756,LETO, 1-D SLAB GAMMA-RAY TRANSPORT

RS $P X T$ L\$ BL47, DRAFTING TOOL TO PLOT PLANE STRUCTURFS

RS $P X T$ P DAFTI, LEAST SQUARES FIT FISSILE NUCLIDE DATA

RS T C\$ EXTERMINATOP 2, 2-D MULTI-GP DIFFUSION PROGRAM

RS T C\$FDG, 1-D FEW-GP DIFFUSION SLAB CYLINDER SPHERE

RS $P$ T CS DTF4, $1-n$ MULTI-GP DISCRETE ORDINATE PROGRAM

RS $P X T$ R\$ GAMTEC2, MULTI-GP CONSTANT CALC O TO 10 MEV

RS $P$ T G\$ ECCSAL, LOSS-OF-CODLANT + EMERGENCY COOL ING

RS $P$ T G\$ NURLOC-1.C, LOSS-OF-CDOLANT THERMAL ANALYSIS

BEAMS ANL

$3600 \mathrm{F36}$ SPD

I\$ BOW2, DFFLECTION CALCULATION PARALLEL

BEAMS KAPL 6600 F4 RS P I\$ STEM. MATRIX GENERATION FOR A SYSTEM OF

BE21, FEW-GP DISCPETF DRDINATES SLAB GEOMETRY BAPL 6600 F 4 RS P XT $\$$

BHSC $360 \mathrm{~F} 4$ RS $P$ C\$ PERT, 1-D PERTURBATION FOR AIM AND FOG CODES

BHSC $360 F 4$ QS P T CS FAIMUS, 1-D MULTI-GP DIFFUSION SLAB CYL SPHERE 120

BHSC $360 \mathrm{~F} 4$ RS PI T B\$ TEMPEST2, THERMAL NEUTRON SPECTRUM X-SECTIDNS

BIN R L T Z\$ ZPR-III ASSEMPLY 48 GAFGAR ENDF/B DATA TAPES GGA 1108 356

BISYN, 2-D MULTI-GP DIFFUSION SYNTHESIS CALC NED $635 \% 4 \quad$ RS PL T C \$ 287

BLAST, REACTOR KINETICS TFMDERATURF DIST STUDY AEB 360 F $\quad$ RS P F 363

BLOOST5, DIINT-KINETICS WITH 2-D HEAT TRANSFER GGA 7044 F4 $\quad$ RS $T$ H $\$ 205$

BLOOST6, COMBINES KINETICS 2-D HEAT TRANSFER GGA 1108 F4 RS P I F $\$ 303$

BLOWDOWN - EXCURSION ANALYSIS INC 7044 F4 RS P T G\$ RELAP2, REACTOR 369

BLOWDOWN ANALYSIS LOFT KE 7094 F+MAP RSRP T G\$ SATURATED BLDWDOWN2, 200

BLOWDOWN ANALYSIS LMFT UGA $360 \mathrm{~F} 4$ RS P G\$ WATFR-HAMMER, LIQUID 278

BLOWDOWN PRESSURE TEMPERATURE HISTORY KE $7094 \mathrm{~F} 2$ RSBP T H\$ PTHI, 155

BLOWDOWN2, BLOWDOWN ANALYSIS LOFT KE 7094 F+MAP RSBP T G\$ SATURATFD 20O

BL47, DRAFTING TONL TO PLOT PLANE STRUCTURFS BAPL 6600 F4 RS P XT L $\$$ R373

BNL 6600 F4 RS P A\$ AVERAGF, UNRESTLVED REGION AVERAGF X-SEC CALC 376

BNL 6600 F4 RS $P$ A\$ SIGPLOT, RFSOLVED MULTILEVEL B-W X-SEC CALC

BNL $6600 \Gamma 4$ RS $P$ T F\$ NOAH, 1-D DNE-GP SPACE-TIME DIFFUSION FFEDBACK 405

BNL 7090 F+FAP RS $D$ T M\$ DFSR, DATA FILE SFRVICE ROUTINES ENDF TAPES 236

BNL $7094 \mathrm{~F} 4$ RS $P$ A\$ $\triangle V F R A G E$, UNRESOLVED REGION AVERAGF X-SEC CALC 376

BNL 7094 F4 RS P A\$ SIGPLNT, RFSOLVED MULTILEVEL B-W X-SEC CALC

BNL-DP $360 \mathrm{~F} 4$ RS PLXT B\$ HAMMER, CRITICAL EXPERIMENT ANALYSIS SYSTEM ?T7

BNL-DP 7090 F2 RS PLXT P.\$ HAMMER, CRITICAL EXPERIMENT ANALYSIS SYSTEM 277

BNW $1107 \mathrm{F4}$ RS P T C\$HFN, 1-D MULTI-GP DIFFUSION SLAB CYL SPHERF

BNW 1107 F4 RS DL T B\$ GAMTEC2. MULTI-GP CONSTANT CALC O TO 10 MEV

BNW $11 C 8$ F4 RS P C\$ PFRT4, 2-D PERTURBATION XY RZ RTHETA GEOMETRY

BNW $1108 \mathrm{~F} 4$ RS $P$ T B\$ FCC4, FUNDAMENTAL MODE FAST REACTOR X-SEC CALC

BNW $1108 \quad F 4$

BNW $1108 \quad F 4$

RS $P$ T D\$ 2DE, 2-D MULTIGPOUP DIFFUSION AND DEPLETION

BNW $110 R \quad F 5$ RS $P X T P \& 1 D X, 1-D$ DIFFUSION FAST $X$-SECTION GENERATIDN

BNW 7C9O F+FAP RSBPL T D\$ ISOGFN, RADIDNUCLIDE GENERATION AND DECAY

BNW 7090 FLOCO

BNW $7090 \mathrm{F2}$

$R S O L T$

B\$ GAMTEC2, MULTI-GP CONSTANT CALC 0 TO $10 \mathrm{MEV}$

RSBP T C\$ GE-HAPO-S13, 1-D MULTI-GP DOURLE SN APPROX

RSBPL T J* MAC, SHIELD DESIGN MULTIGROUP SLAB GENMETRY

BNWL 1108 F4 RS $P$ T B\$ ETOX, MULTIGRDUP CONSTANTS FROM ENDF/B FOR IDX BODIES GSA $1108 \mathrm{~F} 4$ RS D I\$ SAFE-PLANE, PLANE STRESS ANALYSIS, 2-D BOUNCF, FLUX DIST IN MULTI-PIN FUEL ELFMENT AGC 7090 F2 RS P B \$ BOW2, DEFLECTION CALCULATION PARALLEL BEAMS ANL 3600 F36 SBP I $\$$ BREEDFRS APD 635 r4 RS P D\$RAPFU, FUFL CYCLF PARAMETERS FAST BUCKLING CYL FUEL ELFMFNTS AFB $360 \mathrm{~F} 4$ S $P$ BS WFLWING. MATERIAL BUNDLES LASL $7094 \quad \% 2$ DSPP H\$ AXFLU, HFAT TRANSFER MOLTEN FUFL TURE BUNDLFS LASL $7094 \mathrm{FZ}$ RSRP H\$ AXTHRM, HFAT TRANSFER SOLID FUEL TUBE BURNUP ANALYSIS GEV 635 F4 RS P T O\$ BURNUP, HEAVY ELEMENT ISOTOPIC BURNUP CYL IATTICE WAPD 7C94 F+MAP RS PLXT B\$ LASER, SPECTRUM CALC WITH BURNUP PCWFR DISTRIRUTION SEAPCH GGA 1108 F4 RS P T C\$ GASP7, 1-D BURNUP RZ GEOMETRY GGA 7090 F+FAP RSBP T DS DDR, 2-D FEW-GP DIFFUSIDN BURNUP, HFAVY ELEMENT ISOTOPIC BURNUP ANALYSIS GEV 635 F4 RS P T 0 \$ BURP1, DFTECTOP EFFICIFNCY POINT SNURCE BURP2, DETECTOR EFFICIFNCY DISK SOURCE BURP3, DETECTOR EFFICIENCY POINT SOURCE BURP4, GAMMA-RAY PHOTOFRACTION SOLID CRYSTAL BURP5, GAMMA-RAY PHOTOFPACTION WELL CRYSTAL

UM 7090 MAD

UM 7090 MAD

UM 7090 MAD

UM 7090 MAD

UM 7090 MAD

RSB

RSB

RSB

$0 \$$

$0 \$$

$0 \$$

RSB

RSB

0

$0 \$$

BW $200 C$ F4 RS AS STRIP, RESOLVED RFSONANCE INTEGRAL CALCULATION
$R 282$

185

304

306

325

374

367

185

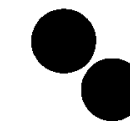

75

143

388

252

237

365

372

362

182

183

311

249

319

99

311

164

165

166

169

170

305 
CAESAR4,LIRLST, 1-D MULTI-GP DIFFUSION + LIB AI 360 F4 RSBPLXT C \$ CAVITY GEDM GGA $1108 \mathrm{~F} 4$ RS P T J\$ MUSCAT, VIEW FACTOR SHIFLDING CODE COC 1604 F63 RS C\$ PERT, 1-D PERTURBATINN FOR AIM AND FIG CODES

CDC 1604 F63 RS L T DS SIZZLE, I-D MULTIGROUP DIFFUSION DFPLFTION

CDC 1604 F63 RS P A\$ HAFEVER, HAUSER-FESHBACH INELASTIC SCATTERING

CDC 1604 F63 RS D B SAIL, 1-D 1-GP SN APPROXIMATION SLAB GEOMETRY

CDC 1604 F63 RS P R S4 CYL CELL CODE, 1-D 1-GP S4 APPROXIMATION

CDC 1604 F63 RS P F AIRFK3, SPACE-INDEPENDENT KINFTICS W/FEEDBACK

CDC $1604 \mp 63$

CDC $1604 \quad F 63$

RS $P$

G\$ CLOUD, GAMMA-RAY DOSE RATE FROM A CLTUD

RS P JS GRACE I, GAMMA-RAY ATTENUATION SLAB GEOMETRY

CDC 1604 FG3

RS P

CDC $1604 F_{63}$

RS $D T C \$$ EQUIPOISF3A, 2-D 2-GP DIFFUSION CYLINDER SLAB

CDC 1604 F63

RS $P$ T C\$ FOG, 1-D FEW-GP DIFFUSION SLAB CYLINDER SPHERE

CDC $1604 \mathrm{~F} 63$

RS P T C\$ WHIRLAWAY, 3-D 2-GROUP DIFFUSION XYZ GEOMETRY

CDC $1604 F_{63}$

CDC $1604 F_{63}$

RS $P$ T C\$ ?OGRAND, 2-D FEW-GROUP DIFFUSION SLAB CYLINDER

RS PL T A\$ ARES2, RESONANCE INTEGRAL X-SFCTION CALC

CDC 1604 F63

RS PL T BS FORM, FAST NEUTRON SPECTRUM X-SFCTION CALC

$\begin{array}{lll}C D C & 1604 & F 63 \\ C D C & 1604 & F 63\end{array}$

RS DL T B\$ TEMPEST2. THFRMAL NEUTRON SPECTRUM X-SECTINNS

CDC $1604 \quad F 63$

RS PL T C\$ AIMG, 1-D MULTI-GP DIFFUSION SLAR CYL SPHERE

RS PLXT BS GAMI, FAST NEUTRON SPECTRUM X-SECTION CALC

CDC 1604 F63

RS PLXT

CS FAIM, 1-D MULTI-GP DIFFUSION SLAB CYL SPHERE

RSBP

F\$ AXI, COUPLFD NEUTRONICS-HYDRDOYNAMICS SPHERE

CDC 3600 F63

RSBP

$T C$ C\$ FLARE, 3-D REACTIVITY AND POWER DISTRIBUTION

CELL $\triangle N L \quad 3600 F 36$ RSRP XT B\$ RABRLE,WLIB, FLAT, RESONANCE ABSORPTION,

CELL ANL 3600 F36 RSBP XT B\$ RIFF-RAFF, RESONANCE INTEGRAL CALC 2-REG

CELL RAPL $6600 \mathrm{~F} 4$ RS $P$ XT B\$ RESQ2, RESQO, DBF1, RESONANCF INTFGRAL HEX

CELL CALCULATION AI 360 F4 RS P XT B\$HWOCR-SAFF, 2-D MONTE CARLO

CELL CONE AND TEMPEST COMBINATION AI $7090 \mathrm{~F} 2$ RS P B\$ BAM, S4 CYL

CELL CODE, I-D I-GP S4 APPROXIMATION AI $7090 \mathrm{~F} 2$ RS BS S4 CYL

CELL CODE, I-D I-GP S4 APPRIXIMATION CDC 1604 F63 RS P BS S4 CYL

CENTRIFUGAL PUMP IMPELLER DESIGN STUDY PW $1604 \mathrm{~F} 63$ RS P T I\$PIP.

CHAD. LEGENDRE COEF CAIC FDR ANGULAR DIST DATA AI 7094 F+MAP RS P A

CHAIN ANALYSIS ORNL 1604 F63 RS P DS ISOCRUNCH, REACTION DECAY

CHAIN ANALYSIS DRNL $7090 \mathrm{~F} 2$ RS P D\$ ISOCRUNCH, REACTIDN DECAY

CHAIN EQUATIONS ORNL 7090 F2 RSRP D\$ NUCY, SOLUTIDN OF NUCLIDE

CHECKFR, CRECT, DAMMET, PLOTFB,SLAV3, ENDF/B PROC NCSC $6600 \mathrm{~F} 4$ RS T $\$$

CHEMLOC2, CORE HEATING CLADDING-STEAM REACTION ANL 3600 F36 RSBP G \$

CHORD DIST FUNCT AEG $7090 \mathrm{~F} 2$ RS BS DANCOFF JR, MODERATOR SPACE

CINCAS, NUCLEAR FUEL CYCLE COST AND ECONOMICS COMM $360 \mathrm{~F} 4$ RS P T $\$$

CINDER, MO102, POINT DEPLETION FISSION PRODUCT BAPL 6600 F4 $\quad$ RS P

CITATION, 1,2,3-D DIFFUSION DEPLETION MULTIGP ORNL $360 \mathrm{F4} \quad \mathrm{RS} P \mathrm{PT} \quad \$$

CLADDING-STEAM REACTIINN ANL 3600 F36 RSBP

CLIP, FORM OR THREDES LIBRARY UTILITY ROUTINE

$\begin{array}{llcllll}\text { CLOUD } & \text { AI } & 7090 \text { F2 } & \text { RS P } & \text { G\$ CLOUD, } \\ \text { CLOUD } & \text { CDC } & 1604 \text { F63 } & \text { RS P } & \text { G } \$ \text { CLOUD, } \\ \text { CLOUD } & \text { DP } & 360 \text { F4 } & \text { RS P } & \text { G\$ CLOUD, }\end{array}$

DP 360 F4 RS P

CLOUD, GAMMA-RAY DOSE RATE FROM A CLOUD

CLOUD, GAMMA-RAY DOSE RATE FROM A CLOUD

CLOUD, GAMMA-RAY DOSE RATE FROM A CLOUD

CMPXMAT, TRANSFER FUNCTION EVALUATION

G\$ CHEMLOC2, CORE HEATING

AI $360 \mathrm{FH}$ RSB L T M \$

gamMa-RAY DOSE RATE FROM a

gamma-ray dose rate from a

gAMMA-RAY DNSE RATE FROM A

AI 7090 F2 RS P G

CDC 1604 F63 RS P $G \$$

DP 360 F4 RS P

PH 1604 F63 RS P E $\$$

CODILLI, LEAST SQUARES ANALYSIS RESONANCE DATA UILL 360 F4 RS P A $\$$

COEF CALC GGA 7044 F4 RS P T C\$ TEMCD, 1-D FEW-GP DIFFUSIDN TEMP

COEF CALC FOR ANGULAR DIST GGA 7044 F4 RS P $X$ A\$ LEGCOEF3, LEGENDRE

COEF CALC FOR ANGULAR DIST DATA AI 7094 F+MAP RS $P$ A\$ CHAD, LEGENDRE

COEFFICIENT CALCULATION GGA 1108 F4 RS P T CS TEMCOT. TEMPERATURE

COEFFICIFNTS LRL 7090 F+FAP RS P T B\$ SOPHISTI/2/5, MULTI-GP TRANSFER

COHBE, COHERENT INELASTIC SCATTERING LAW CALC GGA 1108 F4 RS $P$ A $\$$ COHERENT INELASTIC SCATTEPING LAW CALC GGA $1108 \mathrm{F4}$ RS $P$ AS CDHBE, COINC, COINCIDENCE COUNTING DATA REDUCTION ANL 3600 F63 RSBP 0 \$ COINCIDENCE CDUNTING DATA REDUCTION ANL 3600 F63 RSAP D\$CDINC, COLLISION PROBABILITIES MC ORNL 360 F+BAL RS P T BS RAFFLE, IST FLIGHT COLLISION PROBABILITIES MC ORNL 7090 F+FAP RS P T B\$ RAFFLE, IST FLIGHT COMBCO, COMBINED B-W MULTI-LEVEL CONVOLUTION PPCO 7040 F4 RSPA COMM $360 \mathrm{~F} 4$ RS P T DS CINCAS, NUCLEAR FUEL CYCLE CDST AND ECONOMICS 
COMPLEX GAMMA-RAY SPECTRA KSUN 360 F4 RS P OS CORGAM, UNFOLDING OF COMPOSITF STRUCTURE STRESS STUDY GGA 1108 F4 RS P $T$ IS SAFE-3D, 3-D COMPOUND NUCLEUS X-SECTION TALC ANL 3600 F63 RSRP A\$ NFARREX, COMPUTER-PRODUCED WIRING LISTS UHTREX LASL $7090 \mathrm{F2}$ RS P IS WIREX, CONCRETE GGA 1108 F4 RS P IS SAFE-CRFFP, VISCOELASTIC ANALYSIS CONDUCTION PPCO 7044 F+MAP RS P T H\$ TOODEE, 2-D TIMF-DEDENDENT HEAT CONDUCTION LUMPED MASS LASL 7030 F4 RS T HS RATH, 2- DR 3-D HFAT CONDUCTION LUMPED MASS LASL 7094 FAP RS P T HS RATH, 2- OR 3-D HEAT CONDUCTION PROGRAM BAPL $6500 \mathrm{~F} 4$ RS P XT HS HOT2, 2-D TRANSIENT HEAT CONEC, COUPLED NEUTRUNICS-HYDR DDYNAMICS SPHERE LRL $7090 \mathrm{~F} 2$ RS P F CONFIGURATION FUEL TEMPERATURE CODE GGA $7044 \mathrm{~F} 4$ RS I\$ CORF, CORE CONSTANT CALC AGC $7090 \mathrm{~F} 2$ RSRPLXT B\$ AGN-GAM. FAST SPFCTRUM MULTI-GP CONSTANT CALC FROM TOR OUTPUT DATA LASL $6600 \mathrm{~F} 4$ RS P T BS GLEN, GRDUP CONSTANT CALC 0 TO $10 \mathrm{MEV}$ BC $625 \mathrm{~F} 4$ RS P XT B\$ GAMTFC2, MULTI-GP CONSTANT CALC O TO $10 \mathrm{MEV}$ BNW $1107 \mathrm{~F} 4$ RS PL T B\$ GAMTEC2, MULTI-GP CONSTANT CALC O TO 10 MFV RNW 7090 F+FAP RS PL $T$ BS GAMTEC2, MULTI-GP CONSTANTS ORNL $360 \mathrm{~F} 4$ DS PLXT BS XSDRN, DISCRETE ORDINATF MULTIGRDUP CONSTANTS FOR DSN TDC PW $1604 \mathrm{FG} 3$ RS P L\$ SNC, CALCULATION OF SN CONSTANTS FROM ENDF/B FOR $10 X$ BNWL 1108 F4 RS P T BS ETOX, MULTIGROUP CONTAINMENT PRESSURE POST RUPTURE GGA 7044 F4 RS XT GS PRECDN, HTGR CONTEMPT, LOSS-OF-CDOLANT ACCIDENT ANALYSIS PPCO $7040 \mathrm{~F}+$ MAP RS P $T$ G $\$$ CONVERSION APDA 3600 ASAF4 RS P T M\$ ETOE. ENDF/B TO MC $2 * 2$ DATA CONVOLUTION PPCO $7040 \mathrm{~F} 4$ RS P AS COMBCO, COMBINED B-W MULTI-LFVFL COOLING RCL $6400 \mathrm{~F} 4$ RS P T GS ECCSA1, LOSS-OF-COOLANT + EMERGFNCY CORE CONFIGURATIINN FUEL TEMPERATURE CODE GGA $7044 \mathrm{~F} 4$ RS I\$ CORE, CORE HEATING CLADOING-STEAM REACTION ANL 3600 F36 RSBP GS CHEMLOC 2 , CORE SUPPCRT STRESS ANALYSIS ANL $3600 \mathrm{~F} 36$ RS P T I\$ SUPORAN, REACTOR CORE THERMAL DESIGN STUDY Gr, 7044 F4 RS D I\$ GAZELLES, GAS-COOLED CORE, CORE CINFIGURATION FUEL TFMPERATURE CODE GGA $7044 \mathrm{~F} 4$ RS I \$ CORGAM, UNFOLDING OF COMPLEX GAMMA-RAY SPECTRA KSUN 360 F4 RS P 0 \% COST ANALYSIS AI $7090 \mathrm{~F} 2$ RS P D\& AIMFIRE, URANIUM FUEL CYCLF COST ANN ECONOMICS COMM $360 \mathrm{~F} 4$ RS P T D CINCAS, NUCLEAR FUEL CYCLE COSTS ORNL $1604 \mathrm{FG} 3$ RS P O\$ POWERCN, NUCLEAR STATION ELECTRICITY COSTS GGA 7044 F4 RS P T D\$ STMGFN, STFAM GENERATOR DESIGN CRITFRIA COSTS PERFORMANCE DATA KE $7090 \mathrm{~F} 2$ RSAP DS NPRFCCP, FUEL CYCLE COSTS PERFDRMANCE STUDY GGA $7044 \mathrm{~F} 4$ RS P D WAMPUM, FUEL CYCLE COUNTING DATA REDUCTION ANL $3600 \mathrm{FG} 3$ RSPP O\$ COINC, COINCIDENCE COUPLED NEUTRON-HYDRODYNAMICS APDA $7094 \mathrm{~F} 2$ RS P FE WEAK EXPLOSIMN, COUPLED NFUTRONICS-HYDRODYNAMICS CONE AGC $7090 \mathrm{F2}$ RSB F\$ HATCHET, COUPLED NEUTRONICS-HYORDDYNAMICS SPH PW 1604 F63 RS P F\$ AX-TNT, COUPLED NEUTRONICS-HYRRODYNAMICS SPHERE CDC $3600 \mathrm{~F} 63$ RSBP F\$ $A \times 1$, COUPLED NEUTRONICS-HYDRODYNAMICS SPHERE LRL $7090 \mathrm{F2}$ RS P FE CONEC, COUPLED-CHANNEL X-SFC EVALUATION DRNL $1604 \mathrm{~F} 63$ RS P T AS JUPITOR1, CPS, SC4020 PLOTS FROM SCISRS X-SECTION TAPES WANL 7094 F2 RSB T N CRAM, 1-D AND 2-D MULTI-GP DIFFUSION PROGRAM AAEC $360 \mathrm{~F}+B A L$ RS P $T C \$$ CRAM, 1-D AND 2-D MULTI-GP DIFFUSION PROGRAM UK-R $7090 \mathrm{~F}+F A P$ RSBPL $T$ C CRECT, DAMMET, PLOTFR, SLAV3, ENDF/B PROC NCSC 6600 F4 RS T M\$CHECKFR, CRITERIA COSTS GGA 7044 F4 RS $P$ T D\$ STMGEN, STEAM GENERATOR DESIGN CRITICAL EXPERIMENT ANALYSIS SYSTEM BNL-DP $360 F 4$ RS PLXT B\$ HAMMER, CRITICAL EXPERIMFNT ANALYSIS SYSTFM BNL-DP 7090 F2 RS PLXT B\$ HAMMER, CROCK, SPACF POWER DLANT DESIGN OPTIMIZATION AI $7090 \mathrm{~F} 2$ RS I CROC9O, ML-1, FLUID FLOW EXPERIMENT ANALYSIS AGC $7090 \mathrm{FZ}$ RS P 0 \$ CROSS SECTIONS LASL $6600 \mathrm{FA}$ RS P N\$ LARCA, FLUX-WEIGHTING DF DTF4
CROSSPLOT, SC 4020 PLOTS FROM X-SECTION TAPES GGA 7044F4 RSBP T N

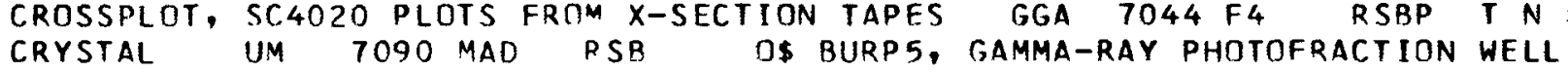
CRYSTAL UM 7090 MAD RSB OS BURP4, GAMMA-RAY PHOTOFRACTION SOLID CRYSTALLINF MATERIALS LASL 6600 F4 RS P T AS TOR, THERMAL SCATTERING CRYSTALLINF SCATTERING KERNEL CALC GGA $7090 \mathrm{F2}$ RS T AS SUMMIT, CSP1. SN X-SECTION LIBRARY TAPE PREPARATION PW 1604 F63 RS L 194 CSP2A, SN X-SECTION LIBRARY TAPE PREPARATION PW 1604 F63 RS 193 CURFIT, CURVE FITTING EXPERIMENTAL DATA POINTS KAPL $6600 \mathrm{~F}+A S C$ RS P $T$ P $\$$ CURIE, DOSF, THUNDERHEAD, EXTFRNAL +INTERNAL DOSE AI 7094 F+FAP RS PL T G\$196 CURVE FITTING LASL $7094 \mathrm{~F} 4$ RS T P\$ LASL LEAST SQUARES, GENERAL 62 CURVE FITTING EXPERIMFNTAL DATA POINTS KAPL $6600 \mathrm{~F}+A S C$ RS P T PS CURFIT, R 43 
CURVE PLOT KAPL $6600 \mathrm{~F}+A S C$ RS $P$ T P\$ SNEN, NONLINEAR ALGEBRAIC EQN STLN CURVES LRL $7094 \mathrm{FZ}$ RS P P\$ EXPALS, LEAST SQUARES EXPONENTIAL DECAY CYCLE ANALYSIS AI 7094 F2 RS PL $T$ IS CYCLOPSI, THERMODYNAMIC CYCLF ANALYSIS DAPTIAL DEFUEL GGA 7044 F4 RS P T D\$GARGOYLE, FUEL CYCLE ANALYSIS W/REFUELIN,, GGA 7044 F4 RS P T D\$ REVISFD-GAD, FUEL CYCLE CALCUIATION GGA 1108 F4 S S D\$ GAFFE, EQUILIBRIUM FUFL CYCLF COST ANALYSIS AI $7090 \mathrm{~F} 2$ RS P DS AIMFIRE, URANIUM FUEL CYCLE COST AND ECONOMICS CIMM 360 F4 RS P T D\$ CINCAS, NUCLEAR FUEL CYCLE COSTS PERFDPMANCF DATA KE $7090 \mathrm{~F} 2$ RSBP D\$ NPRFCCP, FUFL CYCLE COSTS PERFDRMANCE STUDY GGA $7044 \mathrm{~F} 4$ RS P D\$ WAMPUM. FUEL CYCLF PAPAMFTERS FAST BREENERS APO 635 F4 RS P N\$ RADFU, FUEL CYCLOPS1, THERMODYNAMIC CYCLE ANALYSIS CYGRO2, STRESS ANALYSIS CYL FUEL ELEMFNT CYL TRNL 7090 F2 RS P T C\$EQUIPOISE3, 2-D 2-GROUP DIFFUSION SLAB CYL CELL CODE AND TTMPFST COMRINATION AI 7090 F2 RS P B\$ BAM, S4 CYL CELL CODE, 1-D 1-GP 54 APPROXIMATION AI 7090 F2 RS BS CYL CELL CODE, 1-П 1-GP S4 APPROXIMATION CYL FUEL ELEMENT BAPL $6600 \mathrm{~F} 4$ RS XT I\$ CYGRD2, STRFSS ANALYSIS CYL FUEL ELEMENTS B\$ WELWING, MATERIAL BUCKLING CYL LATTICE WAPD 7094 F+MAP RS PLXT BS LASER, SPECTRUM CALC WITH RURNUP CYL PW 1604 F63 PS T C\$2DXYL, 3-D MULTI-GP FLUX SYNTHESIS PROGRAM CYL SPHFRE BNW 1107 F4 RS P T C\$ HFN, 1-D MULTI-GP DIFFUSION SLAB CYL SPHFRE AI 7090 F+FAP RS L T C\$ FAIM, 1-D MULTI-GP DIFFUSION SLAB CYL SPHERE AI 7090 F+FAP RS PL T C\$ AIMG, 1-D MULTI-GP DIFFUSION SLAB CYL SPHFRE CDC $16 \cap 4$ FG3 RS PL T C\$ AIM6, 1-D MULTI-GP DIFFUSION SLAB CYL SPHERF CDC 1604 F63 RS PLXT C\$ FAIM, 1-D MULTI-GP DIFFUSIDN SLAB CYL SPHFRE AI 7090 F+FAP RS L T C\$ ULCER, 1-D MULTI-GP DIFFUSION SLAB CYL SPHERE ANL 3600 F36 RS P XT C\$ MACHI, 1-D MULTI-GP DIFFUSIDN SLAB CYL SPHERE PURD 650C F4 RS PLXT C\$ MACHL, 1-D MULTI-GP DIFFUSION SLAB CYL SPHEPE PW 1604 LAGI RS P C\$MGDSN, 1-D MULTI-GP SN APPROX SLAB CYL SPHERF UK-W $7090 \mathrm{~F} 2$ RS P T CS W-DSN, 1-D MULTI-GP SN APPROX SLAB CYL SPHERE BHSC $360 \mathrm{~F} 4$ PS P T C\$ FAIMOS, 1-D MULTI-GP DIFFUSION SLAR CYL SPHEPE GFOM AI 7090 F2 RS P J\$ GRACE2, GAMMA-RAY ATTFNUATION CYL SPHERE GEOM CDC 1604 FG3 RS P J\$ GRACE2, GAMMA-RAY ATTENUATION CYLINDER ANL $3600 \mathrm{~F} 63$ RSBP T H\$ ARGUS, TRANSIENT TEMPERATURE CALC CYLINDER. PPCO $7040 \quad F 4$ CYLINDER PPCD $7090 \mathrm{~F} 2$ CYLINDFR CDC $1604 \$ 63$ RS P T C\$2OGRAND, 2-D FEW-GROUP DIFFUSION SLAB CYLINDER ORNL 7090 F2 RS P T C $\$ 20 G R A N D, 2-D$ FEW-GROUP DIFFUSION SLAB CYLINDER SLAB CDC 1604 F63 RS P T C\$ EDUIPOISE3A, 2-D 2-GP DIFFUSINN CYLINDER SLAB DRNL $7090 \mathrm{~F} 2$ RS P T C\$ EQUIPOISE3A, 2-D 2-GP DIFFUSION CYLINDER SPHERE AEB 360 F4 PS L T CS FIRE5, 1-D AGE-DIFFUSION SLAB CYLINDER SPHERE AI 7090 F2 RS P T C\$ FOG, 1-D FEH-GP DIFFUSION SLAB CYLINDER SPHERE BC $625 \mathrm{~F} 4$ RS T C\$ FOG, 1-D FEW-GP DIFFUSION SLAB CYLINDER SPHERE CDC 1604 F63 RS $P$ T C\$ FDG, 1-D FEW-GP DIFFUSION SLAB DAC $7090 \mathrm{~F} 2$ RSBP J\$LIPRECANL, MC NEUTRON PENETRATION CALCULATION DAFT1, LEAST SQUAPES FIT FISSILE NUCLIDE DATA BAPL $6600 F 4$ RS P XT $P$ DAMMET, PLOTFB, SLAV3, ENDF/B PROC NCSC 6600 F4 RS T MS CHFCKEP, CRECT, DANCOFF JR, MODERATOR SPACF CHORD DIST FUNCT AEG $7090 \mathrm{~F} 2$ RS B DATA GGA 7044 F4 RS P A\$ FASDOP, X-SECTIONS FROM B-W RESDNANCE DATA KE $7090 \mathrm{F2}$ PSBP D\$ NPRFCCP, FUEL CYCLE COSTS PERFORMANCE DATA NED $635 \mathrm{~F} 4$ RS P TT O\$ EXPN, ANALYSIS OF PULSEN NEUTRON SOURCE DATA BAPL $6600 \mathrm{~F} 4$ RS P XT P\$ DAFT1, LEAST SQUARES FIT FISSILE NUCLIDE DATA AI 7094 F+MAP RS P AS CHAD, LEGENDRF COEF CALC FOR ANGULAR DIST DATA CONVERSION APDA 3600 ASAF4 RS P T M\$ETDE, FNDF/B TO MC * 2 DATA FILE SFRVICE ROUTINFS FNDF TAPES BNL $7090 \mathrm{~F}+F A P$ RS P T M\$ DFSR, DATA LASL $6600 \mathrm{~F} 4$ RS P T B\$ GLEN, GROUP CONSTANT CALC FDOM TOR NUTPUT DATA LIBRARY LRL $7094 \mathrm{~F} 2$ RS PL T M\$ ECSIL, EXPFRIMENTAL NEUTRON DATA POINTS KAPL $6600 \mathrm{~F}+$ ASC RS P T P\$ CURFIT, CURVE FITTING EXPERIMENTAL DATA PREPARATION FOR 2-D DESIGN PROGRAMS LASL $7090 \mathrm{~F} ?$ RS P T LS DPC. DATA PROC DP 360 F4 RS P T A\$ FLANGE2, ENDF/B THERMAL SCATTERING DATA REDUCTION ANL 3600 F63 RSRP O\$ COINC, COINCIDENCE COUNTING DATA SYSTEM KAPL $6600 \mathrm{~F}+C C M$ RSB T M\$ DATATRAN, MODULAR PROGRAMMING AND DATA TAPES GGA 1108 BIN $R$ L T Z\$ ZPR-III ASSEMBLY 48 GAFGAR ENDF/B

R 364 321

244

260

223

302

55

354

146

224

372

244

39

108

53

53

R 266

362

249

192

241

120

29

29

120

118

262

262

211

132

120

46

46

152

148

148

40

40

87

87

9

28

28

28

123

P 327

384

150

216

146

258

R327

215

350

236

361

351

R 43

234

368

248

R 386

356 
DATA UILL 360 F4 RS P A\$ COOILLI, LEAST SQUARES ANALYSIS RESONANCE 347 DATATRAN UTILITY MODULES, $2-0+3-0$ PLOTTING KAPL $6600 F+A S C R S P$ T P $\$ 407$ DATATRAN 2-0 GFOMETRY INPUT, PRFPARATION, EDIT KAPL 6600 F+ASC RS P T L $\$$ R406 DATATRAN, MODULAR PROGRAMMING AND DATA SYSTFM KAPL $6600 F+C O M R S B$ T M $\$$ R36 DBF 1. RFSINANCE INTEGRAL HEX CEIL BAPL 66 CO F4 RS P XT B\$ RESQ2,RESQO, R285 DDB, 2-D FEW-GP DIFFUSION RURNUP RZ GFOMETRY GGA 7090 F+FAP RSPP T $D$ \$ 99 DECAY BNW $1108 F 5$ PSBPL T DS ISOGFN, RADIONUCLIDE GENERATIDN AND NECAY CHAIN ANALYSIS ORNL 1604 FG3 RS P DS ISTCRUNCH, REACTION DECAY CHAIN ANALYSIS ORNL $7090 \mathrm{~F} 2$ RS P DS ISOCRUNCH, REACTION DECAY CURVES LRL $7004 \mathrm{~F} 2$ RS $P$ P\$ FXPALS, LEAST SQUARES EXPONENTIAL DECAY DRNL $1604 \mathrm{FG} 3$ QS P D ISOTOPFS, MAXIMUM YIELD FROM REACTION OR DEFLECTION CALCULATION PARALLEL BFAMS ANL 3600 F36 SBP I\$ BOW?, DEFLECTICN STRESS STUDY RAPL $6600 F+C O M$ RS P XT I\$ GAPL3, INELASTIC LARGE DENSITY CALC AI 7094 FHFAP PS PL T R\$ TYCHE3, MONTE CARLD SLDWING-DNWN DFPLETION $\quad$ AI $360 \mathrm{~F} 4$ RSPP XT DS SIZZLE, 1-D MULTIGROUP DIFFUSION DEPLETION AI $707 C$ FP PS I T D\$SIZZLE, 1-D MULTICPOUP DIFFUSION DEPLETION CDC 1604 F63 RS L T D\$SIZILF, 1-D MULTIGROUP DIFFUSION DEPLETION DEPLETION LASL $7030 \mathrm{F4}$ RS $P$ T D\$ DTF-BURN, 1-0 MULTI-SP DTF4 WITH ANL 3600 T4 PSBP T DE 2DR, 2-D MULIIGROUP DIFFUSION AND DEPLETION BAPL 6600 F+AST RS P XT D\$ PDQ7, 1.2 OR 3-D FFW-SP DIFFUSION DEPLETIOR.

DEPLETION DEPLETION DEPLFTION DEPLETION

DEPLE TION BNW 1108 F4 RS $P$ T D\$ 2DB, 2-D MULTIGROUP DIFFUSION $A N D$ IRM $360 \mathrm{~F}+\mathrm{RAL}$ RS $P$ T D\$ PDQ5, 2-D FEW-GROUP DIFFUSION AND IBM $360 \mathrm{~F} 4$ RS $P$ T D PDQ7, 1,2 OR 3-D FEW-GP DIFFUSION LASL 660ก F4 RS P T D\$ 7DR, 7-D MULTIGROUP DIFFUSION AND WAPD $36, \cap$ F4 RS PLXT B\$ LEOPARD, SPECTRA CALCIILATION WITH DEPLETIIN COODE TRNL 7090 F+FAP RS $P$ T D\$ ASSAULT, 2-D MULTI-GP DIFFUSION DEPLETICN FISSION PRINUCT RAPL $6600 \mathrm{~F} 4$ RS P D\$ CINDFR, MOIO2, POINT DEPLETION GGA 11 OR F4 PS P T DS FEVERT, 1-D MULTIGROUP DIFFUSION AND DEPLETIOA, GGA 1108 F4 RS P T D\$GAUGE, ?-D FEW-GP HEX GEDM DIFFUSION DEPLFTION MULTIGP DRNL $360 \mathrm{FA}$ PS P XT K\$ CITATION, 1, 2, 3-D DIFFUSION DEPLETION PRDGPAM GGA 7090 F? RSB T DS FEVER, $1-D$ FEW-GP DIFFUSION DESIGN CFITERIA COSTS GGA 7044 F4 RS P T D\$ STMGEN, STEAM GENERATOR DESIGN MULTISROUP SLAB GFOMETRY ANL 3600 F63 RSBPL T JS MAC, SHIELD DESIGN MULTIGROUP SLAR GFOMFTRY BNW 7090 F2 RSBPL T J\$ MAC, SHIFLD DESIGN CPTIMIZATION AI 7090 F2 RS I\$ CROCK, SPACE POWER PLANT DESIGN OPTIMIZATION AI $7000 \mathrm{FZ}$ RS I\$ SHOCK, SPACE POWER PLANT DESIGN PRCGRAMS LASL 7090 F2 PS P T L\$ DPC, DATA PREPARATIDN FDR 2-D DESIGN STUDY PW 1604 F63 PS P T I\$ PIP, CENTRIFUGAL PUMP IMPELLFR DESIGN STUDY GGA 7044 F4 RS $P$ I\$ FAZELLES, GAS-COOLED CORE THFRMAL DESIGN SYSTEM AI 360 F4 RSBP TK\$ THREDES, 1-D FEW-GP DIFFUSION DETECTOR EFFICIFNCY DISK SOURCF UM 7090 MAN RSB OS BUPP2, DETECTOR EFFICIENCY POINT SMURCE UM 7090 MAD RSB DETECTIR EFFICIENCY PIINT SOURCF UM 7090 MAD RSB OS BURP3, DFSP, DATA FILE SFRVICF RTUTINES FNDF TAPES BNL 7090 F+FAP RSP T M DIFFUSION ANL $36 C$ F4 RS P F\$ TWIGGLE, 2-D 2-GP SPACF-TIME DIFFUSION UMCR 360 F4 RS P T C\$VARI-QUIR, TIME-DEP 2-D MULTI-GP DIFFUSION WANL 6600 F4 RS P T C\$ VARI-QUIR, TIME-DEP 2-D MULTI-GP DIFFUSION + LIB AI 3GCF4 RSBPLXT C\$ CAESAR4,LIBLST, 1-D MULTI-GP DIFFUSION ABSIRPTION REMTVAL X-SECS BAPL 6600 F4 RS XT R\$ MO807, 2-0 DIFFUSION AND DEPLETION ANL $3600 \mathrm{~F} 4 \quad$ RSRP T D\$2DB, 2-D MULTIGRDUP DIFFUSION AND DEPLETION RNW 1108 F4 RS P T D\$2DB, 2-D MULTIGROUP DIFFUSION AND DEPLETION IBM 360 F+BAL RS P T D\$ PDQ5, 2-D FEW-GROUP DIFFUSITIN AND DEPLETION LASL $6600 \mathrm{F4}$ RS P T D\$2DR, 2-D MULTIGROUP DIFFUSION AND DEPLETION GGA 1108 F4 RS P T D\$ FEVERT, 1-D MULTIGRDUP DIFFUSIUN BUPNUP RZ GFOMFTRY GGA 7090 F+FAP RSAP T D\$ DDB, 2-D FEW-GP DIFFUSION CALC KAPL GROC F4 RS P F\$ RAUMZEIT, 1-D TIMF-DFPENDENT DIFFUSION CALC HFX-7 MFSH GGA 1108 F4 RS P T C\$ GATT, 3-D FEW-GP DIFFUSION CYLINDFR SLAB CDC 1604 F63 RS P T C\$ EQUIPOISE 3A, 2-D 2-GP DIFFUSIDN CYLINDER SLAB DRNL 7090 F2 RS P T C\$EQUIPOISE3A, 2-D ?-GP DIFFUSION DEPLETION AI 360 F4 RSBP XT D\$ SIZZLF, 1-D MULTIGRDUP DIFFUSION DEPLETION AI 7090 F2 RS L T DS SIZZLF, 1-D MULTIGROUP DIFFUSION DFPLETION DIFFUSION DEPLETION

149

58

58

R 352

380

87 
DIFFUSION DEPLFTION

IRM $360 \mathrm{FH}^{4}$

RS $P$

$T$ D\$ PDQT, 1,2 DR 3-n FEW-G,P

DIFFUSION DFPLFTION

RS $P$

$T$ DS

RELOAD-FEVER, 1-D FEW-GP

DIFFUSION DFPLFTION CIDF ORNL 7090 F+FAP RS P T D\$ ASSAULT, 2-D MULTI-GP DIFFUSION DFPLETION GGA 1108 F4 RS P T D\$ GAUGE, 2-D FFW-GP HEX GEOM DIFFUSINN DFPLETION MILLTIGP ORNL $360 \mathrm{~F} 4$ QS P XT K\$ CITATION, 1, 2, 3-D DIFFUSION DEPLFTION PROGRAM GGA $7090 \mathrm{~F} 2$ RSB T DS FEVER, 1-D FEW-GP DIFFUSIITN DESIGN SYSTEM AI $360 \mathrm{~F} 4$ RSBP T K\$ THREDES, 1-D FEW-GP DIFFUSION FAST X-SECTION GENERATION BNW 1108 F4 RS $P$ XT R\$ 1DX, 1-D DIFFUSINN FEEDRACK BAPL B600 F4 RS P XT F\$ TWIGL, 2-0 2-GP SPACE-TIME DIFFUSION FFEDBACK BNL $6600 \mathrm{~F} 4$ RS P T F\$ NOAH, 1-D ONF-GP SPACE-TIME DIFFUSION GGA 1108 F4 PS P T F\$ GAKIN, 1-D MULTIGROUP TIMF-DEPENDENT DIFFUSIIN POWER DIST SEAPCH GGA $7044 \mathrm{~F} 4$ RS P T C\$ GASP2, 1-D FEW-GP DIFFUSION PROGRAM AAEC $360 \mathrm{~F}+R A L$ RS P T C\$ CRAM, I-D AND 2-D MULTI-GP DIFFUSION PROGRAM NRNL 7000 F+FAP RS P T C\$ EXTERMINATDR, 2-D MULTI-GP DIFFUSION PRTGRAM UK-R 7090 F+FAP RSBPL T C\$ CRAM, 1-D AND 2-D MULTI-GP DIFFUSIDN PRQGRAM $B C \quad 625 \mathrm{~F} 4$ RS T C\$ EXTERMINATOR2, 2-D MULTI-GP DIFFUSIINN PRIGRAM ORVL $360 \mathrm{~F} 4$ RS $P$ T CS EXTERMINATOR 2, D-D MULTI-GP DIFFUSION SLAB CYL OPNL 7090 F2 RS P T C\$ EQUIPOISE3, 2-D 2-GRDUP DIFFUSION SLAB CYL SPHERE BNW 1107 F4 RS P T C $\$$ HFN, 1-D MULTI-GP DIFFUSION SLAB CYL SPHFRF AI 7090 F+FAP RS L T CS FAIM, 1-D MULTI-GD DIFFUSION SLAR CYL SPHFRF AI 7090 F+FAP RS PL T C\$ AIMG, 1-D MULTI-GP DIFFUSION SLAB CYL SPHFRF COC 1604 F63 RS PL T C\$ AIMG, 1-D MULTI-GP DIFFUSION SLAB CYL SPHERE CDC 1604 F63 RS PLXT C\$ FAIM, 1-D MULTI-GP DIFFUSION SLAB CYL SPHERF AI 7090 F+FAP RS L T C ULCER, 1-D MULTI-GP DIFFUSION SLAB CYL SPHERF ANL $36 C 0$ F36 RS D XT C\$ MACHI, 1-D MULTI-GP DIFFUSION SLAB CYL SPHFRE PURD 6500 F4 RS PLXT C\$ MACHI, 1-D MULTI-GP DIFFUSION SLAB CYL SPHERE RHSC $360 F_{4}$ RS P T C\$ FAIMOS, 1-D MULTI-GP DIFFUSION SLAB CYLINDFP CDC 1604 F63 RS P T C\$ 2OGRAND, 2-D FEW-GROUP DIFFUSIINN SLAB CYLINDFR ORNL $7090 \mathrm{~F} 2$ RS P T C\$ 2OGRAND, 2-D FFW-GROUP DIFFUSINN SLAR CYLINDER SDHERE AI $7090 \mathrm{~F}$ ? RS $P$ T C\$ FOG, 1-D FEW-C,P DIFFUSINN SLAB CYLINIER SPHERE RC 625 F4 RS T C\$ FOG, 1-D FFW-GP DIFFUSICN SLAB CYLINDER SPHFRE CDR 1604 F63 PS P T CS FOG, I-D FEW-GP DIFFUSION SYNTHESIS CALC NED $635 \mathrm{~F} 4$ RS PL T C\$ BISYN, 2-D MULTI-GP DIFFUSION TEMP COEF CALC GGA $7044 F 4$ RS $P$ T C\$ TEMCO, 1-D FFW-GP DIFFUSION TRIANGULAR MESH GGA $1109 \mathrm{~F}+B A L$ RS $P$ T C\$GAMTRI, 2-D MULTIGP DIFFUSION XY RZ GEOMETPY GGA 1108 F+BAL RS P T C\$ GAMBLE5, 2-D MULTI-GP DIFFUSION XY R7 GFOMETRY GGA 7044 F+MAP RSBP T C\$ GAMBLF4, 2-D MULTI-GP DIFFUSION XY RZ RTH WANL 7094 F4 RS P XT C\$ VARI-QUIR3, ?-D MULTI-GP DIFFUSION XYZ GEDMETRY CDC 1604 F63 RS P T C\$ WHIRLAWAY, 3-D 2-GRTUP DIFFUSION XYZ GEOMFTRY MRNL $7090 \mathrm{~F}$ ? RS P T C\$WHIRLAWAY, 3-D 2-GRDUP DIFFUSION 3-GFOM RADL $6600 \mathrm{~F} 4$ RS P XT F\$ WIGL2, 1-D 2-GP SPACE-TIME DIFFUSION 3-GEMM GGA 1108 F4 RS P T F WIGL2, 1-D 2-GP SPACF-TIME DISCRETE ORDINATE CALC AI 7090 F2 RS PLXT C\$ DTF2, 1-D MULTI-GP DISCRETE ORDINATE CALC AI $360 \mathrm{~F} 4$ RSRPLXT C\$ ANISN, 1-D MULTI-GP DISCRETE RRDINATE CALC UNC 1604 F63 RS PL T C\$ DTF, 1-D MULTIGROUP DISCRETF ORDINATE CALT ANL 3600 F36 RS P T C\$ SNARG-10, 1-D MULTI-GP DISCRETE ORDINATE CDDE UNC-LASL 1604 F63 RS C\$2DF, 2-D MULTI-GP DISCRETE TRDINATE MULTIGROUP CONSTANTS ORNL $360 \mathrm{~F} 4$ RS PLXT B\$ XSDRN, DISCRETF ORDINATE PRחGRAM ANL $360 \mathrm{~F} 4$ RS P T CS DTF4, 1-D MULTI-GP DISCRETF TRDINATE PROGRAM BC 625 F4 RS P T C\$ DTF4, 1-D MULTI-GP DISCRETE ORDINATE PROGRAM LASL $6600 \mathrm{~F} 4$ RS P T CS DTF4, 1-D MULTI-GP DISCRETE ORDINATE PROGRAM LASL 7030 F4 RS P T C\$ DTF4, 1-D MULTI-GP DISCRFTE ORDINATE PROGRAM LER 7094 F4 RS $P$ T C DTF4, 1-D MULTI-T,P DISCRETE CRDINATE PROGRAM LER $7090 \mathrm{~F}+M A P$ RS P T CS TDSN, 2-D MULTIGROUP DISCRETF ORDINATES SLAR GFOMETPY BAPL 6600 F4 RS P XT C\$ RE2I, FEW-GP DISCRETE-FLEMENT ANALYSIS THIN SHFLLS MIT $360 \mathrm{~F} 4$ RS P T IS SABOR4, DISK SOURCE UM 7090 MAD RSB DOCUMENT INFORMATION SYSTFM KAPL $6600 \mathrm{~F}$ DOPIE, RESOLVED RESONANCF X-SECTION CALC DOPPLEQ EFFECTS NED $2000 \mathrm{~F} 2$ RS P

IS BURP2, DETECTOR EFFICIENCY $R$ B T M\$ TIGIR2, MODULAR NFD $2000 F 2$ RS P A \$ B\$ SPARTA, SPATIALLY-AVERAGFD DOSE AI 7094 F+FAP RS PL T G\$ CURIE, DOSE, THUNDERHEAD, EXTERNAL+INTFRNAL DOSE CALC AI 7094 F2 RS P J\$ SHOE, SHIELD WEIGHT OPTIMIZATION DOSE CALC GGA $1108 \mathrm{~F} 4$ RS T G\$ GADOSE, DOSFT, HTGR ACCIDENT ANALYSIS DOSE RATF CALCULATION SNAP GFOMETRY AI 7090 F2 RS P JS RATRAP, 
DOSE RATE CALCULATION SNAP GEOMETRY AI $7090 \mathrm{~F}$

DOSE RATE FROM A TLOUD

DOSE RATE FROM A CLCUD

$\begin{array}{lrll}\text { AI } & 7090 & F 2 & \text { RS P } \\ \text { CDC } & 1604 & F 63 & \text { RS P } \\ \text { DP } & 360 & F 4 & \text { RS P }\end{array}$

DOSE RATE FROM A CLOUD

AI $7090 \mathrm{~F} 2$

RS

J\$ MORT IMER,

G\$ CLNUD, GAMMA-RAY

G\$ CLOUD, GAMMA-RAY

G\$ CLNUD, GAMMA-RAY

RS J\$ FARSEIA.

DOSE, THUNDERHEAD, EXTERNAL+INTFRNAL DOSE AI $7094 \mathrm{~F}+F A P$ RS PL T G\$ CURIE,

DOSET, HTGR ACCIDFNT ANALYSIS DDSE CALC GGA 1108 F4 RS T G\$ GADOSE,

DOUBLE SN APPROX BNW 7C90 FLOCO RSBP T C\$ GE-HAPD-S13, 1-D MULTI-GP

DOUBLE SN APPROX SLAB GFOM PPCO 7090 F2 RS D C\$ MIST, I-D FEW-GP SN

DP $360 \mathrm{~F} 4$ RS P G\$ CLOUD, GAMMA-RAY DOSE RATE FRDM A CLOUD

DP $360 \mathrm{~F} 4$ RS D T A\$ FLANGE2, ENDF/A THFRMAL SCATTERING DATA PRIC

DPC, DATA PREPARATION FOR ?-D DESIGN PROGRAMS LASL $7090 \mathrm{~F} 2$ RS P TL $\$ 234$ DRAFTING TORL TO PLOT PLANE STRUCTURES $8 A P L 6600 \mathrm{F4}$ RS P XT L\$ BL47, R373 DSN NUTPUT PW 1604 LAGI RS $P$ N\$ DTX, EFFECTIVE X-SECTION CALC FROM 210 DSN TDC DW 1604 F63 RS P L\$SNC, CALCULATION OF SN CONSTANTS FOR 189 DTF-BURA, 1-D MULTI-GP DTF4 WITH DEPLETION LASL 7030 F4 RS P T D $\$ 269$ DTF, 1-D MULTIGROUP DI SCRETE ORDINATE CALC DTF2, 1 -D MULTI-GP DISCRFTF ORDINATE CALC DTF4 CROSS SECTIONS LASL 6600 F4 RS P DTF4 WITH DFPLETINN LASL 7030 F4 RS $P$ UNC 1604 F63 RS PL T C $\$ 144$ AI 7090 F2 RS PLXT C \$ 151 N\$ LARCA, FLUX-WEIGHTING OF 409 $T$ D\$ DTF-BURN, 1-D MULTI-GP 269 DTF4, 1-D MULTI-GP DISCRETE ORDINATF PROGRAM ANL 360 F $\quad$ RS P T C \$ 209 DTF4, 1-D MULTI-GP DISCRETE ORDINATE PRIGRAM BC 625 F4 $\quad$ RS P J C \$ 209 DTF4, 1-D MULTI-GP NISCPCTE ORDINATE PROGRAM LASL 6600 F4 $\quad$ RS P T C \$ 209 DTF4, 1-ก MULTI-GP DISCRETE ORDINATF PROGRAM LASL 7030 F4 $\quad$ RS P T C \$ 209 DTF4, I-D MULTI-GP DISCRFTE ORDINATE PROGRAM LER 7094 F4 $\quad$ RS P T C \$ 209 DTX, EFFECTIVE X-SFCTION CALC FROM DSN DUTPUT PW 1604 LAG1 RS P N \$ 210 DYNAMIC ANALYSIS LINEAR ELASTIC SYSTEMS BAPL $6600 \mathrm{F4}$ RS P XT IS MO552, R283 DYNAMICS AI $\quad 360 \mathrm{~F}+\mathrm{BAL}$ RS P T E\$ AIRTS2A, SIMULATION OF REACTOR 326 DYNAMICS BAPL 6600 F4 RS P XT I\$ M0266, LINEAR ELASTIC STRUCTURAL R383 ECCSAI, LOSS-OF-CDOLANT + FMERGENCY COOLING BCL $6400 F 4$ RSP T G $\$ 330$ ECONOMICS COMM $360 \mathrm{~F} 4$ RS P T D\$ CINCAS, NUCLEAR FUEL CYCLE COST AND 354 ECSIL, EXPERIMENTAL NEUTRON DATA LIRRARY LRL $7094 \mathrm{F2}$ RS PL T M 535 EDIT KAPL $6600 F+A S C$ RS P T L\$ DATATRAN 2-D GEOMETRY INPUT, PRFPARATIDN, R4O6 EDIT REACTION PATES UK-W 7090 F2 RS N\$WED, W-DSN OUTPUT TAPE EFFECTIVF X-SECTION CALC FROM DSN DUTPUT PW $1604 \mathrm{LAGI}$ PS P N\$ OTX, EFFICIFNCY DISK SOURCF UM 7090 MAD RSB DS BURP2, DETECTOR EFFICIENCY POINT SOURCE UM TO90 MAD RSB O O\$ BURPI, DFTECTOR EFFICIENCY POINT SOURCE UM 7090 MAD RSB OD OURP3, DETFCTOR EIGENVALUF PRORLEM FOR VIRRATING SYSTEMS KAPL 6600 F4 RS P T IS GEM, ELASTIC SCAT RESONANCES AI 360 F4 RS PLXT B\$ AILMOE, X-SECTION CALC ELASTIC SCAT RESONANCES AI 7094 F+FAP RS PL T B\$ AILMOE, X-SECTION CALC ELASTIC SCAT X-SECTIDNS HEX LATTICE GGA 1109 F4 RS BS HEXSCAT, ELASTIC SCATTERING PHASE-SHIFT ANALYSIS DRNL 1604 F63 RS P A\$PEGGY, ELASTIC STRESS OF PIPING, SYSTEM BAPL 6600 F4 RS P XT I\$ M0457, PIPF, ELASTIC STRUCTURAL DYNAMICS BAPL 6600 F4 RS P XT I\$ MO266, LINEAR ELASTIC SYSTEMS BAPL 6600 F4 RS P XT I\$ M0552, DYNAMIC ANALYSIS LINEAR ELBOW, FUEL ELEMENT STRESS ANALYSIS STUDY GGA 7044 F4 RS P T G $\$$ ELECTRICITY COSTS ORNL 1604 F63 RS P DS POWERCO, NUCLEAR STATIDN EMERGENCY COOLING BCL 6400 F4 RS P T G\$ ECCSAI, LOSS-OF-CODLANT + ENDF MULTIGROUP X-SECTION CALCULATION ANL $3600 \mathrm{~F} 36$ RS P T B\$MC*\$2, ENDF TAPES BNL 7090 F+FAP RS $P$ T M\$ DFSR, DATA FILE SERVICE ROUTINFS ENDF/B DATA TAPES GGA $1108 \mathrm{BIN} R$ L T Z\$ ZPR-III ASSEMBLY 4R GAFGAR ENDF/B FOR $1 D X$ BNWL 1108 F4 RS P T B\$ ETOX, MULTIGROUP CONSTANTS FROM ENDF/B GRAPHIC X-SEC FVALUATION AI 360 F+RAL RS L T M\$ SCORE2, SCISRS ENDF/B PRDC NCSC 6600 F4 RS T MS CHECKFR,CPECT, DAMMET, PLOTFB, SLAV3, ENDF/B THERMAL SCATTERING DATA PROC DP $360 \mathrm{F4}$ RS P T A\$ FLANGE2, FNDF/B TO MC *2 DATA CONVFRSION ENERGY INTFRVAL X-SECTION AVERAGING APDA 3600 ASAF 4 RS P T MS ETOE, GGA 7044 F4 RS P L GAVER, EPITHERMAL X-SECTIONS NED 635 F4 RS P T BS REAX, RESOLVED RESONANCE EPITHERMOS, SPECTRUM AND X-SECTICN CALCULATION GEV 7094 F+FAP RS P T 8 \$ 201 EQN SOLN CURVE PLOT KAPL 6600 F+ASC RS P T P\$ SNEQ, NONLINEAR ALGEBRAIC R364 EQUILIBRIUM FUEL CYCLE CALCULATION GGA 1108 F4 5 S T D\$GAFFE, 302 EQUIPOISE3, 2-D 2-GROUP DIFFUSION SLAB CYL TRNL 7090 F $\quad$ RS P T C \$ 39 EQUIPOISF3A, 2-D 2-GP DIFFUSION CYLINDER SLAB CDC 1604 F63 RS P T C \$ 87 
EQUIPOISE3A, 2-D 2-GP DIFFUSION CYLINDER SLAB ORNL 7090 F2 RS P T C \$ ETOF, ENDF/B TC MT* 2 DATA CONVERSION APDA 3600 ASAF4 RS P $T M$ ETOX, MULTIGROUP CONSTANTS FROM ENDF/B FOR 1 DX BNWL 1108 F4 RS P T $B$ \$ EXCHANGER STRESS ANALYSIS KAPL $6600 \mathrm{~F} 4$ R.S P I\$ TURF, U-TUBE HEAT EXCUPSION ANALYSIS INC $7044 \mathrm{~F} 4$ RS P T G\$ RFLAP2, REACTOR BLOWDOWN EXCURSION CALCULATION R-Z GFOMETRY APDA $7094 \mathrm{~F} 4$ RS P FS MARS, 2-D EXCURSION CALCULATIONS NEN $2000 \mathrm{~F} 4$ RS P T F\$ FDRE, FAST REACTOR EXCURSION CALCULATIONS ANL 360 F4 RS P XT F\$ FORE2, FAST REACTOR EXCURSIION CALCULATIONS NED 635 F4 RS P XT FS FORE2. FAST REACTOR EXPALS, LEAST SQUARFS EXPTNENTIAL DECAY CURVES LRL $7094 \mathrm{~F} 2$ RS P P \$ EXPERIMENT $\triangle N A L Y S I S \quad B A P L 66 T 0 \mathrm{~F} 4$ EXPERIMENT ANALYSIS AGC. $7090 \mathrm{~F} 2$ PS P RS P T OS JITER, FLUCTUATION EXPERIMENT ANALYSIS SYSTEM BNL-DP 360 F4 RS PLXT BS HAMMER, CRITICAL EXPER IMENT ANALYSIS SYSTFM BNL-DP $7090 \quad \mathrm{~F} 2$ RS PLXT R\$ HAMMER, CRITICAL EXPEPIMFNTAL DATA POINTS KAPL $6600 \mathrm{~F}+A S C$ RS P T P\$ CURFIT, CURVE FITTING EXPERIMFNTAL NEUTRON DATA LIBRARY LRL 7094 F2 RS PL T M\$ ECSIL, EXPLOSION, COUPLED NEUTRON-HYDRODYNAMICS APDA $7094 \mathrm{~F} 2$ RS P F\$ WEAK EXPN, ANALYSIS OF PULSED NEUTRON SOURCF DATA NED $635 \mathrm{~F} 4 \quad$ RS $P$ T $0 \$$ EXPONENTIAL DECAY CUPVES LRL $7094 \mathrm{~F} 2$ RS P P\$ EXPALS, LEAST SQUARES EXPONENTIALS MIT $7090 \mathrm{~F} 2$ PS P PS FRANTIC, LEAST SQUARES FIT SUM OF EXT, X-SECTIONS FROM B-W RESONANCE PARAMETERS EXTERMINATOR, 2-D MULTI-GP DIFFUSION PROGRAM EXTERMINATOR2, 2-D MULTI-GP DIFFUSION PROGRAM WANL $7094 \mathrm{~F}$ ? RS P A $\$$ ORNL 7090 F+FAP RS P T C \$ $B C \quad 625 \mathrm{FH}_{4}$ RS TC \$ EXTERMINATOR2, 2-D MULTI-GP DIFFUSION PRDGRAM ORNL $360 \mathrm{~F} 4 \quad$ RS P $T C \$$ EXTERNAL + INTERNAL DOSF AI 7094 F+FAP RS PL $T$ G\$ CURIE, DOSF, THUNDERHEAD, F+ASC RS P T H\$ LION, 3-1) TFMPERATURE DISTRIBUTION PROGRAM KAPL G600 $F+A S C$ RS $P$ T L\$ DATATRAN 2-D GEOMETRY INPUT, PREPARATION, EDIT KAPL 6600 $F+A S C$ RS $P$ T P\$ CUPFIT, CURVE FITTING EXPERIMENTAL DATA POINTS KAPL 6600 $F+A S C$ RS $P$ T P\$ DATATRAN UTILITY MODULES, ?-D + 3-D PLDTTING KAPL 6600 $F+A S C$ RS $P$ T P\$ SNEQ, NINLINEAR ALGEBRAIC EQN SOLN CURVE PLOT $F+A S C$ RS $P$ XT D\$ PDQ7, 1,2 OR 3-D FEW-GP DIFFUSION DEPLETION KAPL 6600 BAPL 6600 $F+B A L$
$F+B S L L$
$F S P$ $F+B A L$ RS $P$ T C $\$$ CRAM, 1-D AND 2-D MULTI-GP DIFFUSIDN DROGRAM F+BAL RS $P$ T C\$ GAMRLE5, 2-D MULTI-GP DIFFUSION XY RZ GEOMETRY

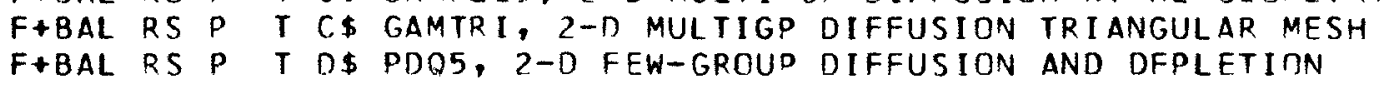

$F+B A L$ RS $P$ T E\$ AIROS?A, SIMULATION OF REACTOR DYNAMICS

$F+C D P$ RS $P$ T P\$ LAG, ASSEMRLER FOR FLOCO2 INSTRUCTION SET AI $\quad 360$ ORNL 360 $\triangle A F C \quad 360$ GGA 1108 GGA 1108 IAM $\quad 360$ AI $\quad 360$

$F+C D P$ RS $P$ XT B\$ FMC-N,FMC-G, MC NEUTRON, GAMMA-RAY HISTORIES

$F+C O M$ RS $P$ XT I\$ GAPL3, INFLASTIC LARGE DEFLECTION STRESS STUNY $F+C O M$ RSB $T$ M DATATRAN, MODULAR PROGRAMMING AND DATA SYSTEM F+FAP RS $T$ I\$ 4RESTRAINT PIPE STRESS, MAXIMUM MOMENT CALC

F+FAP RS $F+F A P$ RS F+FAP RS $L T$ B $\$$ QUICKIE, INFINITE MEDIUM SPECTRUM X-SECTIONS F+FAP RS L T C.S FAIM, 1-D MULTI-GP DIFFUSION SLAB CYL SPHERE $L$ T C \& ULCFR, 1-D MULTI-GP DIFFUSION SLAB CYL SPHFRF LT M\$ MOMUS, X-SECTION LIBRARY UTILITY PROGRAM PW 1604 PW 1604 BAPL 6600 KAPL 6600 AI 7090 AI 7090 A I 7090 AI $\quad 7090$ F+FAP RS $P$ T B\$ EPITHERMOS, SPECTRUM AND X-SECTION CALCULATION GEV 7094 F+FAP RS P T BS RAFFLE, IST FLIGHT COLLISION PROBABILITIFS MC F+FAP RS P T B\$ SOPHISTI/2/5, MULTI-GP TRANSFER COEFFICIENTS F+FAP RS D T CS EXTERMINATOR, 2-D MULTI-GP DIFFUSION PRDGRAM F+FAP RS P T DS ASSAULT, 2-D MULTI-GP DIFFUSION DEPLETINN CODE F+FAP RS $P$ T G\$ AISITE2, PARAMETRIC SITE REQUIREMENT STUDY F+FAP RS D T MS DFSR, DATA FILE SERVICF RDUTINES ENDF TAPES F+FAP RS PL T BS AILMOE, X-SECTION CALC ELASTIC SCAT RESONANCES F+FAP RS PL T B\$ GAMTEC2, MULTI-GP CONSTANT CALC 0 TO 10 MEV F+FAP RS PL T B GRAVE, GROUP-AVERAGING X-SECTIONS PARAMETERS F+FAP RS PL T BS TEMPEST2, THERMAL NEUTRON SPECTRUM X-SECTIONS F+FAP RS PL T B\$ TYCHE3, MONTE CARLO SLOWING-DOWN DENSITY CALC F+FAP RS PL T C\$ AIMG, 1-D MULTI-GP DIFFUSION SLAB CYL SPHERE F+FAP RS PL T G\$ CURIE, DOSE, THUNDERHEAD, EXTERNAL + INTERNAL DOSE F+FAP RSB F+FAP RSB $T$ A\$ TUZ, UNRESDLVED REGION RFSONANCE INTEGRAL CALC F+FAP RSBP

$T$ A ZUT, RESOLVED REGION RESONANCE INTEGRAL CALC $T$ DS DDB, 2-D FEW-GP DIFFUSION BURNUP RZ GEOMETRY

ORNL 7090 LRL 7090 ORNL 7090 ORNL 7090 AI $\quad 7094$ BNL 7090 AI 7094 BNW 7090 AI 7094 AI 7090 AI $\quad 7094$ A I 7090 7094 $\begin{array}{ll}\text { GGA } & 7090 \\ \text { GGA } & 7090\end{array}$ GGA 7090 
F+FAP RSBPL T C\$ CRAM, 1-D AND 2-D MULTI-GP DIFFUSION PROGRAM UK-R 7090

$\begin{array}{lll}F+M A P & R S P & P\end{array}$

F+MAP RS $P$ T B\$ GAROL, RESONANCE OVERLAP AND LATTICE EFFECTS GGA 7044

F+MAP RS P T C\$ TDSN, 2-D MULTIGROUP DISCRETE ORDINATE PROGRAM LER 7090 312

F+MAP RS $P$ T DS OPUS, POWER PLANT PERFCRMANCE AND PRICE STUDY GGA 7044226

F+MAP RS P T E AIROS, SPACE-INDEPENDENT KINETICS W/FEEDBACK AI $7094 \quad 163$

F+MAP RS P T G\$ CONTFMPT, LOSS-OF-CDOLANT ACCIDENT ANALYSIS PPCO 7040297

F+MAP RS P T G\$ RSAC, RAOINLMGICAL SAFETY ANALYSIS PROGRAM PPCO $7040 \quad 265$

F+MAP RS D T H\$ TONDFE, 2-D TIME-DFPENDENT HEAT CONDUCTION $\quad$ PPCO 7044349

F+MAP RS PLXT A T TRIXI, RFSONANCE INTEGRAL X-SECTION CALC $\quad$ AI $7094 \quad 208$

F+MAP RS PLXT B\$ LASER, SPFCTRUM CALC WITH BURNUP CYL LATTICE WAPD 70942249

F+MAP RSBP M\$ UNPACK, RFTRIEVAL FROM SCISRS X-SECTION TAPE GGA 7044206

F+MAP RSRP T C\$ GAMBLE4, 2-D MULTI-GP DIFFUSION XY RZ GEOMEIRY GGA 7044222

F+MAP RSBP T GS SATURATFD BLOWDOWN?, BLOWDOWN ANALYSIS LOFT KE 7094200

FACTOR SHIELOING CODE CAVITY GEOM GGA 1108 F4 RS P T J\$ MUSCAT, VIEW 259

FAIM, 1-D MULTI-GP DIFFUSINN SLAB CYL SPHERE AI $7090 \mathrm{~F}+F A P R S$ L T $\$ 120$

FAIM, 1-D MULTI-GP DIFFUSION SLAB CYL SPHERE CDC 1604 F63 RS PLXT C \$ 120

FAIMOS, 1-D MULTI-GP JIFFIISION SLAB CYL SPHFRE BHSC $360 \mathrm{~F} 4$ RS P T C \$ 120

FAP RS $P$ T H\$ RATH, 2- OR 3-D HEAT CONDUCTINN LUMPED MASS LASL 7094242

FARSEIA, DOSF PATE FRUM SNAP SHIELD LEAKAGE AI $7090 \mathrm{F2}$ RS 30

FASDDP, X-SECTIDNS FROM B-W RESONANCE DATA GGA 7044 F4 RS P A \$ 216

FAST BREEDERS APO $635 \mathrm{~F} 4$ RS P DS RAPFU, FUEL CYCLF PARAMETERS 372

FAST NEUTPON SPECTRUM X-SECTION CALC AI 7090 F2 RS PL T B\$ FORM, 51

FAST NFUTRON SPECTRUM X-SFCTION CALC ANL 3600 F63 RS LXT A\$ GAM1, 33

FAST NEUTRON SPECTRUM $X-S E C T I O N$ CALC

FAST NEUTRON SPECTRUM X-SECTION CALC

FAST NFUTRON SPECTRUM $X-S F C T I O N$ CALC

FAST REACTOR EXCURSION CALCULATIONS

FAST REACTOR EXCURSION CALCULATIONS

FAST REACTOR FXCURSION CALCULATIONS

FAST REACTOP POWER AND FLOW TRANSIENTS

FAST RFACTIR POWER AND FLTW TRANSIENTS

FAST REACTOR X-SEC CALC BNW 1108 F4

FAST SPECTRUM MULTI-GP CDNSTANT CALC

FAST THERMAL SPECTRA GGA 1108 F 4

FAST THERMAL SPECTRA GGA $6600 \mathrm{~F} 4$

CDC 1604 FO3

CDC 1604 F63

GGA $7090 \mathrm{~F}$ ?

NED $2000 \mathrm{FH}_{4}$

ANL $\quad 360 \mathrm{F4}$

NED $\quad 635 \quad F 4$

ANL $\quad 360 \mathrm{F4}$

ANL $6600 \mathrm{F4}$

RS $P T$ BS FCC4, FUNDAMENTAL MODE RS PL T R\$ FORM, RS PLXT B\$ GAM1, RS PLXT R\$ GAM1, RS $P$ T F\$ FORE, RS P XT FS FORE?, RS P XT F\$ FORE2, RS P T F\$ SASIA. AGC $7090 \mathrm{~F} 2$ RSBPLXT B\$ AGN-GAM, RS PLXT B\$ GGC4. MULTI-GP X-SECTIONS RS L T B\$ GGC4, MULTI-GP X-SECTIONS FAST X-SFCTION GENERATION BNW 1108 F4 RS $P$ XT B\$ $10 X, 1-D$ DIFFUSION FATIGUF KAPL $6600 \mathrm{~F} 4$ RS I\$ SORSDR, PRESSURE VFSSEL STRESS AND FCC4, FUNDAMENTAL MODE FAST REACTOR X-SEC CALC BNW 1108 F4 RS P T B $\$$ FEEDBACK BAPL $6600 \mathrm{~F} 4$ RS $P$ XT F\$ NOWIG, 1-D 2-GP KINETICS TEMPFRATURE FEEDBACK BAPL $6600 \mathrm{~F} 4$ RS $P$ XT F\$ TWIGL, 2-D 2-GP SPACE-TIME DIFFUSION FEEDRACK BNL 6600 F4 RS P T F\$NOAH, 1-D DNE-GP SPACE-TIME DIFFUSION FEEDBACK GGA 1108 F4 RS P T F\$ GAKIT, 1-D MULTIGP KINETICS WITH TEMP FEVER, 1-D FEW-GP DIFFUSINN DEPLETION PROGRAM GGA 7090 F2 RSA T D \$ FEVER 7, 1-D MULTIGRDUP DIFFUSION AND DEPLETIDN GGA 1108 F $R S P$ T $\$$ FEW-GP DIFFUSION BURNIJP RZ GEOMETRY GGA 7090 F+FAP RSBP T DS DDB, 2-D FEW-GP DIFFUSION CALC HEX-Z MESH GGA 1108 F4 RS P T C\$ GATT, 3-D FEW-GP DIFFUSION DEPLETION BAPL $6600 F+A S C$ RS P XT D\$PDO7, 1, 2 OR 3-D FEW-GP DIFFUSION DFPLFTION FEW-GP DIFFUSION DEPLETION IBM $360 \mathrm{FH}$ RS P T D\$ PDQT, 1,2 OR 3-D GGA 7044 F4 RS P T D\$ RELDAD-FEVER, 1-D FEH-GP DIFFUSION DEPLETION PROGRAM GGA 7090 F2 RSB T DSFFVFR, 1-D FEW-GP DIFFUSION DESIGN SYSTEM AI 360 F4 RSBP T K\$ THREDES, 1-D FEW-GP DIFFUSION POWFP DIST SEARCH GGA 7044 F4 RS P T C\$GASP2, 1-D FEW-GP DIFFUSION SLAB CYLINDER SPHERE AI 7090 F2 RS P T C\$FOG, $1-D$ FEW-GP DIFFUSION SLAB CYLINDER SPHERE BC $625 \mathrm{~F} 4 \quad$ RS $T$ C\$FOG: $1-D$ FEW-GP DIFFUSION SLAB CYLINDER SPHERE CDC 1604 F63 RS P T C\$FMG, 1-D FEW-GP DIFFUSION TEMP COEF CALC GGA $7 C 44$ F4 RS P T C\$ TEMCO, 1-D FEW-GP DISCRETE ORDINATES SLAB GEOMETRY BAPL 6600 F4 RS P XT C\$BE21, $\begin{array}{lllll}\text { FEW-GP HEX GEOM DIFFUSION DEPLETION GGA } & 1108 & \mathrm{~F} 4 \\ \text { FEW-GP SN APPROXIMATION CYLINDER } & \text { PPCO } & 7040 & \mathrm{~F} 4\end{array}$ FEW-GP SN APPROXIMATION CYLINDER PPCO $7090 \mathrm{~F} 2$ FEW-GP SN DOUBLE SN APPRAX SLAB GEOM PPCO 7090 F2 FEW-GP S4 APPROXIMATION RZ GEOMETRY LRL 709 F2 $\begin{array}{lll}\text { RS } P \text { RS } & P \text { T D } \$ \text { GAUGE. 2-D }\end{array}$ RS $P$ T C\$ TOPIC: $1-0$ RS $P$ T C\$ TOPIC, 1-D RS $P$ CS MIST, 1-D RS COS FIRN, 2-D 
FEH-GROUP DIFFUSICN AND DFPLETION IRM $360 \mathrm{~F}+B A L$ RS P T D\$ PDQ5, 2-D FEW-GROUP DIFFUSION SLAB CYLINDFR CDC 1604 F63 RS P T C\$ 2OGRAND, 2-D FEW-GROUP DIFFUSION SLAB CYLINDER ORNL 7090 F? RS P T C\$ 2OGRAND, 2-D FIGRO, LSRR FUEL SWELLING TEMPERATURE STUDY BAPL 6600 F4 RS P XTH $\$$ R2T2 FILE SERVICF RDUTINES ENTF TAPES BNL 7090 F+FAP RS P T MS DFSR, DATA 236 FINEL, FINTTE-FLEMENT STUNY 2,3-D STRUCTURES KAPL 6600 F4 RS $\mathrm{P}$ I $\$$ R404 FINITE-ELEMENT STUDY 2,3-0 STRUCTURES KAPL 6600 F4 RS P X I\$FINEL, R404 FINS SNAP GEOM AI 7090 F2 RS JS SCARF2, SCATTER FROM RADIATMR IIO FIRE5, 1-D AGE-DIFFUSION SLAB CYLINDER SPHERE AEB $360 F 4 \quad$ RS L T $\$$ \% FIRN, 2-D FEW-GP 54 ADPROXIMATION RZ GEMMETRY LRL 709 F2 RS FISSILE NUCLIDE DATA BAPL 6600 F4 RS P XT P\$ DAFTI, LEAST SQUARES FIT R327 FISSILE NUCLIDE X-SFCTION EVALUATION ORNL 7090 F4 RSBP A\$ MUFFLF, 373 FISSION PRDDUCT BADL 6600 F4 RS P D\$ CINDER, MO1O2, POINT DEPLETION 313 FISSION PRODUCT ACTIVITY DIST STUDY GRA 7044 F4 RS P D\$ RAD2, HTGR 231 FISSION PRODUCT RELEASF GGA 1108 F4 RS P DS FREVAPG, HTGR METALLIC 30I FIT FISSILE NUCLIDE DATA BADL 6600 F4 RS P XT P\$ DAFTI, LEAST SQUARES R3?7 FIT SUM OF EXPONENTIALS MIT $7090 \mathrm{~F} 2$ RS P PS FRANTIC, LEAST SQUARFS 324 FITIING LASL 7094 F4 RS T P\$ LASL LEAST SOUARES, GENERAL CURVE FITTING EXPFRIMENTAL DATA POINTS KAPL 6600 F+ASC RS P T P\$ CURFIT, CURVE R 43 FLAC, STEADY-STATE FLOW, PRFSSURE DISTRIBUTION GGA 1108 F5 RS P H \$ 395 FLANGE1, SCATTERING LAW X-SECTION CALCULATION GGA 1108 F5 RS P A 247 FLANGE1, SCATTERING LAW X-SECTION CALCULATION GGA 7044 F4 RS FLANGF2, ENDF/B THERMAL SCATTERING DATA PRDC DP 360 F4 PSP TA $\$ 368$ FLARE, 3-T RFACTIVITY AND POWER DISTRIBUTION COC 3600 F63 RSBP T C \$ 167 FLARE, 3-D PEACTIVITY AND PIWER DISTRIBUTION NED $635 \% 4 \quad$ RS P T C $\$ 167$ FLASH2, LOSS-OF-CODLANT ACCIDFNT ANALYSIS BAPL 6600 F4 RS P XT G $\$$ R?95 FLAT, RESONANCE ABSORPTION, CELL ANL 3600 F36 RSBP XT B\$ RABBLE, WLIB, 281 FLIGHT COLLISION PROBABILITIES MC ORNL 360 F+BAL RS P T RS RAFFLE, $1 S T$ TS2 FLIGHT C,CLLISION PRDBABILITIES MC ORNL 7090 F+FAP RS P T RS RAFFLE, IST FLOCO RS P B\$ MCS, MONTF CARLO NEUTRON PENETRATION STUDY FLOCO RS P B\$ ZOT, GROUP-COLLAPSING OF MULTI-GP X-SECTIONS LASL TO9O FLOCO RSRP C\$ 2DXY, 2-D MULTI-GP SN APPROXIMATION XY GFOM AGC TO9O FLOCO RSBP T C\$ GE-HAPD-S13, 1-D MULTI-GP DOUBLE SN APPROX FLOCO2 INSTRUCTION SET PW $1604 \mathrm{~F}+\mathrm{CDP} R S P$ T $P$ LAG. ASSEMBLER FOR FLOT1,MO219, PWR FLOW TRANSIENT ANALYSIS BAPL 6600 F4 RS P XT H FLOW AI 7094 F2 RS P H\$ FLOW-MODFL, MULTI-CHANNEL 2-D 2-PHASE FLOW AND HEAT TRANSFER AI $7094 \mathrm{~F} 2$ RS P T G\$ TRANS-FUGUEI, TRANSIENT FLOW EXPERIMENT ANALYSIS AGC 7090 F2 RS P O\$ CROC 90 , ML-1 FLUID FLOW STUNY STEAM-WATER MIX KAPL 6600 F4 RS P H\$ RAPP, HIGH-VELOCITY FLOW TRANSIENT ANALYSIS BAPL 6600 F4 RS P XT H\$ FLOT1,MO219, PWR FLOW TRANSIFNTS ANL 360 F4 RS P T F\$ SASIA, FAST REACTOR PDWER AND FLOW TRANSIENTS ANL $6600 F 4$ RS P T F\$SASIA, FAST REACTOR POWER AND FLOW-MONEL. MUL TI-CHANNEL 2-D 2-PHASE FLOW AI 7094 F2 RS P H FLOW, PRESSURE DISTRIBUTINN GGA 1108 F5 RS P H\$ FLAC, STFADY-STATE FLUCTUATION EXPERIMFNT ANALYSIS BAPL 6600 F4 RS P T O\$ JITER, FLUID FLOW EXPERIMENT ANALYSIS AGC 7090 F? RS P O\$ CROC90, ML-1 FLUX DIST IN MULTI-PIN FUEL ELEMENT AGC 7000 F2 RS P B\$BONCF, FLUX INPUT PW 1604 F63 RS CS TDP, 2-D PERTURBATION TDC OR 2DXY FLUX SYNTHESIS PRTGRAM CYL PW 1604 F63 RS T C\$2DXYL, 3-D MULTI-C,P FLUX-WEIGHTING, OF DTF4 CROSS SECTIONS LASL 6600 F4 RS P N\$ LARCA, FLUX, $X$-SEC CALC ORNL 360 F4 RS P D\$ ISOSEARCH, ISDTOPE DRODUCTION FLUX, $X$-SEC CALC ORNL $1604 F 63$ PS $P$ D\$ ISOSFARCH, ISOTOPE PRODUCTION FMA $7090 \mathrm{~F} 2$ RSBP $X$ C\$ HERESY1, LATTICE PARAMETERS HETEROGFNEOUS CALC FMC-G, MC NEUTRON, GAMMA-RAY HISTORIES PW 1604 F+CDP RS P XT B\$ FMC-N, FMC-N, MONTE CARLO CALC NEUTRON HISTDRIES GGA $7044 F 4$ RS P T R FMC-N, FMC-G, MC NEUTRON, SAMMA-RAY HISTORIFS PW 1604 F+CDP RS P XT R $\$$ FOG CODES AI $7090 \mathrm{~F} 2$ RS C\$ PERT, 1-D PERTURBATION FOR AIM AND FOG CODES BHSC 360 F4 RS P CS PERT, 1-D PERTURBATION FIR AIM AND FOG CODES CDC 1604 F63 RS C\$ PERT, 1-D PERTURBATION FOR AIM AND FOG, 1-D FEW-GP DIFFUSION SLAB CYLINDER SPHFRE AI $7090 \mathrm{F2}$ RS P T C. $\$$ FOG, 1-D FEW-GP DIFFUSINN SLAB CYLINDER SPHERE BC FOG, 1-D FEW-GP DIFFUSION SLAB CYLINDER SPHERE CDC FORE, FAST REACTOR EXCURSION CALCULATIONS FORE2, FAST REACTIR EXCURSIIN CALCULATIONS NED $2000 \mathrm{Fu}_{4}$ ANL $360 \quad F 4$
$625 \mathrm{~F} 4$ RS T C \$ 28 $1604 F 63$ RS P $T$ C \$ 28 RS P TF\$ $\$ 174$ RS P XTF\$ 174 
FORE2, FAST REACTOR EXCURSION CALCULATIONS FORM OR THREDES LIBRARY UTILITY ROUTINE AI FORM, FAST NEUTRON SPECTRUM X-SECTIINN CALC FORM, FAST NEUTRDN SPECTRUM X-SFCTION CALC FORTRAN TDC, 2-D MULTI-GP SN APPROXIMATION RZ FRANTIC, LFAST SQUARES FIT SUN CF EXPONENT IALS MIT FREVAP6, HTGR MFTALLIC FISSION PRCDUCT RELEASF GGA FUEL CYCLF ANALYSIS PAPTIAL REFUEL GGA $7044 \quad \mathrm{~F} 4$ FUEL CYCLE ANALYSIS W/REFUELING GGA $7044 \mathrm{~F} 4$ FUEL CYCLE CALCULATION GGA $1108 \mathrm{~F} 4 \quad \mathrm{~S}$ FUEL CYCLE COSTS PERFORMANCF DATA KE $7090 \mathrm{F2}$ RSBP D\$ NPRFCCP. FUEL CYCLE COSTS PERFORMAVCE STUDY FUEL CYCLE PARAMETERS FAST RREEDERS FUEL FLEMENT RAPL $6600 \mathrm{F4}$ RS FUEL ELEMENT AGC 7090 F2 RS $P$

FUEL ELFMENT LIFETIME ANALYSIS

FUEL ELEMENT STRESS ANALYSIS STUDY

FUEL ELFMENTS AEB $360 \quad$ F4 $\quad S P$

FUEL SWELLING TEMPERATURF STUDY

FUEL TEMPERATURE CODE G,GA $7044 \quad F 4$

FUEL TUBF BUNDLFS LASL $7004 \mathrm{~F} 2$ RSBP $P$ B\$ WELWING, MATERIAL BUCKLING CYL
BAPL 6600 F4 RS P XT H\$ FIGRO, LSRR GGA $7044 F 4$ RS P D\$ WAMPUM, APO $635 \mathrm{F4}$ RS P D\$RAPFU, XT I \$ CYGRO2, STRFSS ANALYSIS CYL B\$ BOUNCE, FLUX DIST IN MULTI-PIN ANL $3600 \mathrm{~F} 36$ RSBP I\$ SWELL? GGA 7044 F4 RS P T G\$ FLROW, RS I\$ COORE, CORE CONFI GURATION FUEL TURE SUNDLES LASL 7094 F2 RSBP H\$ AXFLU, HEAT TRANSFER MOLTEN H\$ AXTHRM, HFAT TRANSFER SOLID FUGUE, STEAOY-STATE TFMPERATURE VOID FRACTION AI TO9OF2 RS FUNDAMENTAL MODE FAST REACTRR X-SEC CALC BNW 1108 F4 RS P T BS FCC4, F2 RS A LYNNF, WOODS-SAXON POTENT IAL SHAPE CALCULATION ORNL 7090 F2 RS F2 RS $F 2$ RS F2 RS $F 2$ PS F2 RS $F 2$ DS

\section{B\$ DANTOFF JR, MODFRATOR SPACF CHORD DIST FUNCT}

R\$ $\$ 4$ CYL CFLI CODE, 1-D 1-GP S4 APPROXIMATION

C\$ FIPN, 2-D FEW-GP S4 APPROXIMATION RZ GEOMETRY

C\$ PERT, I-D PERTURBATION FOR AIM AND FOG CODFS

E\$ AIREK3, SPACE-INDEPENDENT KINETICS W/FEEDRACK

E\$ SNAPKIN5/5A, 1-REGION KINETICS SNAP GEOMETRY

I \$ CROCK, SPACE POWER PLANT DESIGN OPTIMIZATION

I F FUGUF, STFADY-STATE TEMPERATURF VOID FRACTION

I\$ SHMCK, SDAEE PDWER PLANT DESIGN OPTIMIZATION

J\$ FARSEIA, DNSE RATE FRDM SNAP SHIELD LEAKAGE

J\$ MORTIMER, DOSE RATE CALCULATION SNAP GFOMETRY

J\$ SCARF?, SCATTER FROM RADIATOR FINS SNAP GEOM

J\$ SCAR1, SCATTER FROM A RING SNAP GEOMFTRY

NS WED, W-DSN NUTPUT TAPE [DIT REACTION RATES

T A\$ SUMMIT, CFYSTALLINE SCATTERING KERNEL CALC

L D SI TZLE, 1-D MULTIGROUP DIFFUSION DEPLETION

A\$ DOPIE, RESTLVED RESONANCE X-SFCTIDN CALC

A\$ FXT, X-SECTIONS FROM B-W RESONANCE PARAMETERS

A\$ RAPTURF, PESCNANCF INTEGRAL X-SECTION CALC

P\$ BAM, S4 CYL CELL CDDE AND TEMPEST COMBINATION

B\$ BDUNCE, FLUX DIST IN MULTI-PIN FUEL ELEMFNT

B\$ SATL, 1-П 1-GP SN APPRTXIMATION SLAB GEOMETRY

B\$ SPARTA, SPATIALLY-AVFRAGED DOPPLER EFFECTS

C \$ MIST, 1-D FEW-GP SN DNUBLE SN APPROX SLAB GEOM

DS AIMFIRE, URANIUM FUFL CYCLE COST ANALYSISI

D\& ISOCRUNCH, RFACTION DECAY CHAIN ANALYSIS

F\$ CONEC, COUPLFD NEUTRONICS-HYDRODYNAMICS SPHERE

F\$ WEAK EXPLOSION, COUPLED NEUTRON-HYDRODYNAMICS

G\$ CLOUD, GAMMA-RAY DOSF RATE FROM A CLOUD

H\$ FLOW-MODFL, MULTI-CHANNFL 2-D 2-PHASE FLDW

I \$ WIREX, CIMPUTER-PRDDUCED WIRING LISTS UHTREX

J\$ GRACEI, GAMMA-RAY ATTENUATION SLAB GEOMETRY

I\$ GRACE2, GAMMA-RAY ATTENUATION CYL SPHERE GEOM

J\$ RATRAP, DOSE PATE CALCULATION SNAP GEOMETRY

J\$ SHDE, SHIELD WEIGHT OPTIMIZATION DOSE CALC

O\$ CROCOO, ML-1 FLUID FLOW EXPERIMENT ANALYSIS

P EXPALS, LEAST SQUARES EXPONFNTIAL DECAY CURVES

AFG 7090

AI 7090

LRL 709

AI 7090

AI 7090

AI 7090

AI 7090

AI 7090

A I

A I

7090

AI 7090

AI 7090

AI 7090

UK-W 7000

GGA 7090

AI 7090

NED 2000

WANL 7094

NFD 2000

AI 7090

AGC 7090

AI 7090

NED 2000

PPCO 7090

AI 7090

ORNL 7090

LRL 7090

APDA 7094

AI 7090

AI 7094

LASL 7090

AI 7090

A I

7090

AI 7090

AI 7094

AGC $\quad 7090$

RS $P$ 


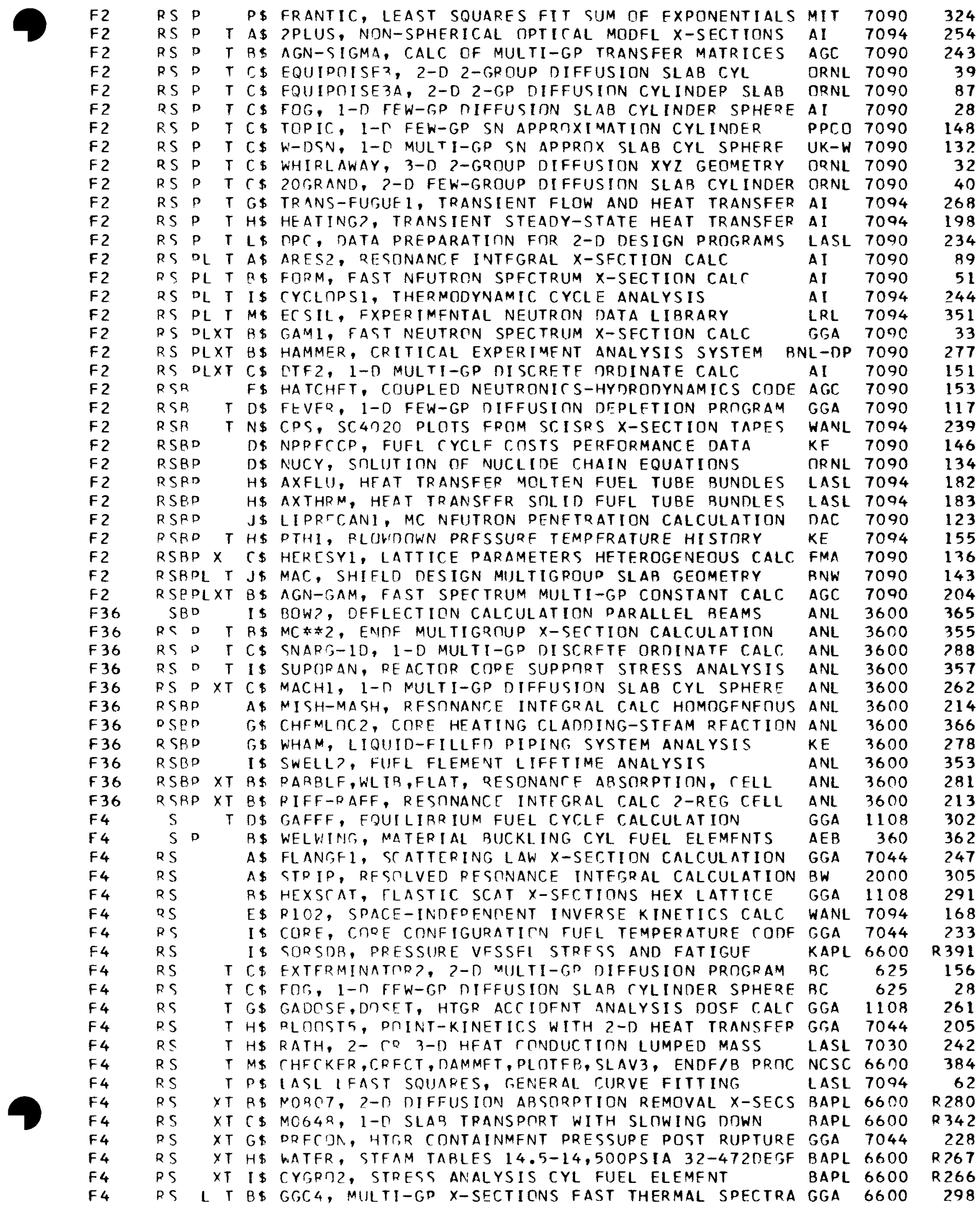




\begin{tabular}{|c|c|c|c|c|c|c|c|c|}
\hline F 4 & & $\mathbf{L}$ & $\mathrm{T}$ & $C \$$ & FIRE5, 1-D AGE-DIFFUSION SLAB CYLINDER SPHERE & $A F B$ & 360 & \\
\hline F4 & RS & $\begin{array}{l}p \\
p\end{array}$ & & $\begin{array}{l}\text { A\$ } \\
\text { A\$ }\end{array}$ & 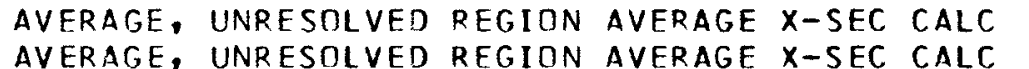 & $\begin{array}{l}\text { BNL } \\
\text { BNL }\end{array}$ & & $\begin{array}{l}376 \\
376\end{array}$ \\
\hline $\begin{array}{l}4 \\
4\end{array}$ & S & p & & A\$ & ODILLI, LEAST SQUARES ANALYSIS RESONANCF DATA & $\begin{array}{l}\text { BNL } \\
\text { UIL }\end{array}$ & $\begin{array}{l}094 \\
360\end{array}$ & 376 \\
\hline 4 & & $p$ & & As & OMBCO, COMBINED B-W MULTI-LEVEL CONVNLUTION & PPCD & & \\
\hline 4 & $\mathrm{~s}$ & p & & A\$ & X-SECTIONS FROM B-W RESONANCE DATA & GGA & 704 & 16 \\
\hline$=4$ & S & $P$ & & $A \$$ & GAKER, INFLASTIC SCAT X-SECTION CALC MODERATOR & GGA & 108 & 89 \\
\hline$=4$ & $\mathrm{~s}$ & $\mathbf{P}$ & & A\$ & GANDY, UNRESOLVED RESONANCE X-SECTION CALC & GGA & & 341 \\
\hline$=4$ & RS & $\mathbf{P}$ & & AS & ASKET, THERMAL SCATTERING LAW CALCULATION & GGA & 28 & 263 \\
\hline F4 & RS & $\mathbf{p}$ & & $A \$$ & PSEUDO, STATISTICAL RESONANCE PARAMETER CALC & GGA & 1108 & $29 ?$ \\
\hline F4 & $\mathrm{S}$ & $\mathbf{P}$ & & A\$ & IGPLOT, RESOLVEO MULTILEVEL R-W X-SEC CALC & BNL & 6600 & 377 \\
\hline 4 & & $\mathbf{P}$ & & A\$ & SIGPLOT, RESOLVED MULTILEVEL B-W X-SEC CALC & & & \\
\hline F 4 & RS & $\mathbf{p}$ & & B\$ & AVOID, ANNULAR VOID X-SFCTION CALCULATION & GEC. & 625 & 276 \\
\hline F4 & RS & $\mathbf{P}$ & & B\$ & GAMMA-P, PRODUCTION X-SECTIONS FOR GAMMA-RAYS & GFC & 7004 & 235 \\
\hline 4 & & $\mathrm{P}$ & & $C \$$ & PERT, 1-D PERTURBATION FOR AIM AND FOG CODES & & 360 & 30 \\
\hline 4 & $\mathrm{~S}$ & $\mathbf{p}$ & & C\$ & PERT4, 2-D PERTURBATION XY RZ RTHETA GEOMFTRY & BNW & 1108 & 304 \\
\hline F 4 & RS & $\mathbf{P}$ & & $D \$$ & CINDER, MO102, POINT DEPLETION FISSION PRODUCT & BAPL & 6600 & 313 \\
\hline 4 & & $\mathbf{P}$ & & D\$ & FREVAPG, HTGR METALLIC FISSION PRODUCT RELEASF & Ge & & \\
\hline 4 & $\mathrm{~s}$ & $\mathbf{P}$ & & D\$ & ISOSEARCH, ISOTOPE PRODUCTION FLUX, X-SEC CALC & ORNL & 360 & 322 \\
\hline 4 & RS & P & & D\$ & RAD2, HTGR FISSION PRODUCT ACTIVITY DIST STUDY & GGA & 7044 & 231 \\
\hline 4 & RS & $\mathbf{P}$ & & D\$ & RAPFU, FUEL CYCLF PARAMETERS FAST BREEDERS & APO & 635 & 372 \\
\hline 4 & $\mathrm{~s}$ & $\mathrm{p}$ & & D\$ & WAMPUM, FUEL CYCLE COSTS PERFORMANCE STUDY & GGA & & \\
\hline 4 & & $\mathbf{P}$ & & E\$ & AIREK3, SPACE-INDEPENDENT KINETICS W/FEEDBACK & & & 2 \\
\hline$=4$ & RS & p & & E\$ & RLAST, REACTOR KINETICS TEMPERATURE DIST STUDY & $A E B$ & & 363 \\
\hline F4 & S & $\mathrm{p}$ & & $E \$$ & GAPOTKIN, SPACE-INDEPENDENT REACTOR KINETICS & GGA & 110 & 317 \\
\hline $\mathbf{F} 4$ & & $\mathrm{p}$ & & E\$ & GASA, STABILITY ANALYSIS REACTOR KINETICS EQNS & GGA & & \\
\hline F4 & RS & $\mathbf{P}$ & & E\$ & SPACE-INDEPENDENT KINETICS KEX RPIIONS & WANL & & 255 \\
\hline F4 & RS & $\mathrm{P}$ & & $F \$$ & MARS, 2-D EXCURSION CALCULATION R-Z GEOMETRY & APDA & 7094 & 293 \\
\hline F4 & $\mathrm{S}$ & $\mathbf{p}$ & & F $\$$ & JMZEIT, I-D TIME-DEPENDENT DIFFUSION CALC & PL & & 352 \\
\hline F4 & & $\mathbf{P}$ & & F\$ & STINT 3, SINGLE-CHANNEL SPACE-TIME SYNTHE & & & \\
\hline $\mathbf{F 4}$ & RS & $\mathbf{P}$ & & $F \$$ & TWIGGLE, 2-D 2-GP SPACE-TIME DIFFUSION & ANL & 360 & 338 \\
\hline$=4$ & $\mathrm{~S}$ & $p$ & & G\$ & CLDUD, GAMMA-RAY DOSF RATE FROM A CLOUD & & 0 & 47 \\
\hline F4 & & $\mathbf{P}$ & & G\$ & WATER-HAMMER, LIQUID BLOWDOWN ANALYSIS LOFT & & & 278 \\
\hline $\mathbf{F} 4$ & RS & $\mathbf{P}$ & & H\$ & RAPP, HIGH-VELOCITY FLOW STUDY STEAM-WATER MIX & KAPL & & 382 \\
\hline $\mathbf{F 4}$ & RS & $P$ & & I \$ & GAZELLES, GAS-COOLED CORE THERMAL DES IGN STUNY & GGA & 7044 & 232 \\
\hline F4 & & $\mathbf{p}$ & & Is & AFE-CREEP, VISCOELASTIC ANALYSIS CONCRETE & & & 300 \\
\hline $\mathbf{F} 4$ & & $\mathbf{P}$ & & I \$ & PLANE STRESS ANALYSIS, 2-0 BODIES & & & \\
\hline F4 & RS & $\mathbf{P}$ & & I \$ & SAFE-SHELL, STRESS ANALYSIS THIN SHELLS & GGA & & 253 \\
\hline F4 & RS & P & & I\$ & SAFE-2D, PLANE + AXISYMMETRIC, STRESS ANALYSIS & GGA & 08 & 379 \\
\hline 4 & & 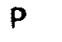 & & I & EM, MATRIX GENERATION FOR A SYSTEM OF BEAMS & & & \\
\hline$=4$ & & $\mathbf{P}$ & & I\$ & TUBE, U-TUBE HEAT EXCHANGER STRESS ANALYSIS & PL & & R 37 \\
\hline $\mathbf{F 4}$ & RS & $\mathbf{P}$ & & L\$ & GAVER, ENERGY INTERVAL X-SECTION AVERAGING & GGA & 44 & 218 \\
\hline F4 & & $\mathbf{p}$ & & L\$ & GRDWRK, GRID GENFRATION FOR SAFE PROGRAMS & & & 296 \\
\hline $\mathbf{F 4}$ & & $\mathbf{P}$ & & NS & A, FLUX-WEIGHTING OF DTF4 CROSS SECTIO & & & 409 \\
\hline F4 & RS & $\mathbf{P}$ & & $0 \$$ & CORGAM, UNFOLDING OF COMPLEX GAMMA-RAY SPECTRA & KSUN & 360 & 390 \\
\hline $\mathbf{F} 4$ & & $\mathbf{P}$ & $T$ & $\$$ & FLANGE2, ENDF/B THERMAL SCATTERING DATA PROC & D & & 368 \\
\hline$: 4$ & & P & & & ASI, ANALYSIS OF RESONANCE ME & & & \\
\hline$=4$ & & $\mathbf{P}$ & & & TOR, THERMAL SCATTERING CRYSTALLINE MATERIALS & & & 360 \\
\hline F4 & & $\mathbf{P}$ & $\mathrm{T}$ & B\$ & ETOX, MULTIGROUP CONSTANTS FROM ENDF/B FOR $1 D X$ & BNHL & & 388 \\
\hline 4 & & & & s & 4, FUNDAMENTAL MODE FAST REACTOR X-SEC CALC & & & 306 \\
\hline $\mathbf{F} 4$ & & P & $\mathbf{T}$ & & MC-N, MONTE CARLO CALC NEUTRON HISTORIES & & & \\
\hline F4 & & p & $\mathbf{T}$ & B & GAROL, RESONANCE OVFRLAP AND LATTICE EFFECTS & LER & & 219 \\
\hline $\mathbf{F 4}$ & & $\mathbf{P}$ & I & $\$$ & , GROUP CONSTANT CALC FROM & SL & & 61 \\
\hline $\mathbf{F 4}$ & & $\mathbf{P}$ & & & REAX, RESOLVEO RESONANCE EPITHERMAL X-SECTIONS & & & \\
\hline F4 & & $p$ & $\mathbf{T}$ & C & DTF4, 1-D MULTI-GP DISCRETE ORDINATE PROGRAM & AN & & 09 \\
\hline F4 & & $\mathbf{P}$ & $\mathbf{T}$ & & DIF4, 1-D MULTI-GP DISCRETE RRDINATE & B & & 209 \\
\hline 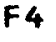 & & $\mathrm{P}$ & & C\$ & DTF4, 1-D MULTI-GP DISCRETE MRDINATE PROGRAM & & & 09 \\
\hline F4 & & P & $\mathbf{T}$ & C\$ $\$$ & DTF4, 1-D MULTI-GP DISCRETE ORDINATE PROGRAM & & & 209 \\
\hline F4 & & $\mathbf{P}$ & $\mathbf{T}$ & $\operatorname{cs}$ & DIF 4, 1-D MULTI-GP DISCRETE ORDINATE PROGRAM & & & \\
\hline F4 & & $\mathbf{P}$ & $\mathrm{T}$ & c\$ & EXTERMINATOR $2,2-D$ MULTI-GP DIFFUSION PROGRAM & & & 56 \\
\hline F4 & & $P$ & $\mathbf{T}$ & C\$ & FAIMOS, 1-D MULTI-GP DIFFUSION SLAB CYL SPHERE & & & 20 \\
\hline F4 & & $\mathbf{P}$ & T & C\$ & FLARF, 3-D REACTIVITY AND POWFR DISTRIBUTION & NE & & \\
\hline F4 & & $\mathbf{P}$ & $\mathrm{T}$ & Cs & GASP2, 1-D FEW-GP DIFFUSION POWER DIST SEARCH & GE & & \\
\hline F4 & R S & P & $T$ & c\$ $\$$ & POWER OISTRIBUTION SEARCH & GGA & 1108 & 319 \\
\hline
\end{tabular}




\begin{tabular}{|c|c|c|c|c|c|c|c|c|}
\hline $\begin{array}{l}F 4 \\
F 4\end{array}$ & S & & $\begin{array}{l}T \\
T\end{array}$ & $\begin{array}{l}C \$ \\
C \$\end{array}$ & $\begin{array}{l}\text { GATT, 3-D FEW-GP DIFFUSION CALC HEX-Z MESH } \\
\text { HFN, 1-D MULTI-GP DIFFUSION SLAB CYL SPHERE }\end{array}$ & $\begin{array}{l}\text { GGA } \\
\text { BNH }\end{array}$ & $\begin{array}{l}1108 \\
1107\end{array}$ & $\begin{array}{l}380 \\
241\end{array}$ \\
\hline$F_{4}$ & & $p$ & $\boldsymbol{T}$ & Cs & TEMCO, 1-D FEW-GP DIFFUSION TEMP COEF CALC & GGA & 7044 & 225 \\
\hline F4 & RS & $r$ & $\mathbf{T}$ & $C \$$ & TEMPFRATURE COEFFICIENT CALCULATION & GGA & 108 & 320 \\
\hline $\mathbf{F 4}$ & $\mathrm{S}$ & & $T$ & $C \$$ & TOPIC, 1-D FEW-GP SN APPROXIMATION CYLINDER & PPCD & 7040 & \\
\hline F4 & & $\mathbf{P}$ & $\mathrm{T}$ & C\$ & TWOTRAN, 2-D MULTI-GP TRANSPORT CODE X-Y GEOM & NL & & \\
\hline $\mathbf{F 4}$ & S & & $\mathbf{T}$ & C\$ & TWOTRAN, 2-D MULTI-GP & ASL & 1108 & 358 \\
\hline F4 & RS & $\mathbf{P}$ & $\mathbf{T}$ & C\$ & VARI-QUIR, TIME-DEP 2-D MULTI-GP DIFFUSION & UMCC & 360 & 212 \\
\hline $\mathbf{F} 4$ & S & & $\mathbf{T}$ & $C \$$ & VAR I-QUIR, TIME-DEP 2-D MULTI-GP DIFFUSION & HANL & 300 & \\
\hline $\mathbf{F} 4$ & S & $\mathbf{P}$ & $\mathbf{T}$ & $0 \$$ & CINCAS, NUCLEAR FUEL CYCLE COST AND ECONOMICS & COMM & 360 & \\
\hline $\mathbf{F 4}$ & RS & $\mathbf{P}$ & $\mathbf{T}$ & D\$ & DTF-BURN, 1-D MULTI-GP DTF4 WITH DEPLETION & LASL & 7030 & 269 \\
\hline $\mathbf{F} \mathbf{4}$ & $\mathrm{S}$ & $P$ & $T$ & $D \$$ & FEVERT, 1-D MULTIGROUP DIFFUSION AND DEPLETION & GGA & 108 & 18 \\
\hline F 4 & & & $\mathbf{T}$ & $D \$$ & GARGOYLE, FUEL CYCLE ANALYSIS PARTIAL REFUEL & GGA & & \\
\hline F4 & as & $\mathbf{p}$ & $\mathbf{T}$ & D. $\$$ & GAUGE, 2-D FEW-GP HEX GEOM DIFFUSION DEPLETION & GGA & 1108 & 339 \\
\hline F4 & RS & $P$ & $T$ & D\$ & PDQ7, 1,? OR 3-D FEW-GP DIFFUSION DEPLETION & I BM & 360 & 275 \\
\hline F4 & S & & $T$ & D\$ & RELOAD-FEVFR, 1-D FEW-GP DIFFUSION DEPLETION & GA & 344 & \\
\hline F4 & 25 & $P$ & $\mathbf{T}$ & D\$ & REVISED-GAD, FUEL CYCLE ANALYSIS W/REFUE & GA & & \\
\hline $\mathbf{F} 4$ & RS & $p$ & $\mathbf{T}$ & $0 \$$ & STMGEN, STEAM GENERATOR DESIGN CRITERIA COSTS & GGA & 7044 & 227 \\
\hline $\mathbf{F} 4$ & & & $T$ & D\$ & 209, 2-D MULTIGROUP DIFFUSION AND DEPLETION & BNW & & \\
\hline $\mathbf{F} 4$ & $\mathbf{S}$ & $\mathbf{P}$ & $\mathrm{T}$ & $0 \$$ & $20 B, 2-n$ MULTIGROUP DIFFUSION AND DEPLETION & LASL & & 325 \\
\hline $\mathbf{F} 4$ & RS & $P$ & $\mathbf{T}$ & E\$ & BLOOST6, COMBINED KINETICS 2-0 HEAT TRANSFER & GGA & 1108 & 303 \\
\hline $\mathbf{F} 4$ & & & $\mathrm{~T}$ & & FORE, FAST REACTOR EXCURSION CALCULATIONS & NED & & \\
\hline $\mathbf{F 4}$ & $\mathrm{S}$ & $P$ & $\mathbf{T}$ & F\$ & GAKIN, 1-D MULTIGRDUP TIME-DEPFNDENT DIFFUSION & GGA & & 310 \\
\hline F4 & 25 & $p$ & $\mathbf{T}$ & F\$ & 1-D MULTIGP KINETICS WITH TEMP FEEDBACK & GGA & & 370 \\
\hline $\mathbf{F} 4$ & 3 & & $T$ & F\$ & NOAH, 1-D ONE-GP SPACE-TIME OIFFUSION FEEDBACK & BNL & 6600 & 405 \\
\hline $\mathbf{F 4}$ & & 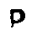 & $\mathbf{T}$ & $\mathbf{F} \$$ & SASIA, FAST REACTOR POWER AND FLOW TRANSIENTS & ANL & & 400 \\
\hline $\mathbf{F} 4$ & 25 & $p$ & $\mathrm{~T}$ & $F \$$ & SASIA, FAST REACTOR POWFR AND FLOW TRANSIENTS & ANL & & 400 \\
\hline F4 & 3 & $p$ & $T$ & F\$ & TSN, SPATIALLY-DEPENDENT REACTOR KINETICS & A I & 360 & 309 \\
\hline $\mathbf{F} 4$ & $\mathbf{S}$ & $\mathbf{P}$ & $\mathrm{T}$ & F\$ & TSN, SPATIALLY-DEPENDENT REACTOR KINETICS & & & 309 \\
\hline $\mathbf{F} \mathbf{4}$ & is & & $\mathbf{T}$ & F\$ & WIGL2, 1-D 2-GP SPACE-TIME DIFFUSION 3-GEOM & GGA & & 274 \\
\hline F4 & 0 & $p$ & $\mathbf{T}$ & G\$ & AISITE2, PARAMETRIC SITE REQUIREMENT STUDY & & 360 & 172 \\
\hline F4 & & $P$ & $\mathrm{~T}$ & G\$ & ECCSA1, LOSS-OF-COOLANT + EMERGENCY COOL & $\mathrm{BCL}$ & 6400 & 330 \\
\hline $\mathbf{F} 4$ & & & $\mathbf{T}$ & G\$ & ELBOW, FUEL ELEMENT STRESS ANALYSIS STUDY & G & & \\
\hline F4 & & & $\mathbf{T}$ & G\$ & NURLOC-1.0, LOSS-OF-COMLANT THERMAL ANALYSIS & $\mathrm{BCL}$ & 6400 & 328 \\
\hline $\mathbf{F} \mathbf{4}$ & & $r$ & $\mathbf{T}$ & G\$ & RELAP2, REACTOR BLOWDOWN - EXCURSION ANALYSIS & INC & 7044 & 369 \\
\hline $\mathbf{F} 4$ & & & $\mathrm{~T}$ & H\$ & MANTA, STEADY-STATE THERMAL-HYDRAULIC ANALYSIS & NED & & \\
\hline $\mathbf{F} \mathbf{4}$ & 25 & $\mathbf{p}$ & $\mathrm{T}$ & Is & GEM, EIGENVALUE PROBLEM FDR VIBRATING SYSTEMS & KAPL & 6600 & 344 \\
\hline $\mathbf{F} 4$ & RS & $P$ & $\mathbf{T}$ & I\$ & SABOR 4, DISCRETE-ELEMENT ANALYSIS THIN SHELLS & MIT & 360 & R402 \\
\hline F4 & & & $\mathrm{T}$ & I\$ & SAFE-AXISYM, STRESS ANALYSIS AXISYMMETRIC LOAD & GGI & & 251 \\
\hline $\mathbf{F 4}$ & & $p$ & $\mathbf{T}$ & I\$ & SAFE-PCRS, STRESS ANALYSIS AXI SYMMETRIC LOAD & GGA & & 250 \\
\hline F4 & RS & 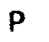 & $T$ & I\$ & SAFE-3D, 3-D COMPOSITE STRUCTURE STRESS STUDY & GGA & 1108 & 332 \\
\hline F4 & & & $\mathbf{T}$ & I\$ & SOR2, STRESS ANALYSIS SHELLS OF REVDLUTION & APL & & R 80 \\
\hline F4 & & P & $\mathbf{T}$ & J\$ & MUSCAT, VIEW FACTOR SHIELDING CODE CAVITY GEOM & & & \\
\hline $\mathbf{F} \mathbf{4}$ & 25 & $P$ & $\mathbf{T}$ & LS & GAND, GAFGAR X-SECTION LIBRARY PREPARATION & GGA & 1108 & 345 \\
\hline $\mathbf{F 4}$ & S & $\boldsymbol{p}$ & $\mathrm{T}$ & 0 s & BURNUP, HEAVY ELEMENT ISOTOPIC BURNUP ANALYSIS & GEV & & 311 \\
\hline & & & $\mathbf{T}$ & $0 \$$ & EXPN, ANALYSIS OF PULSED NEUTRON SOURCE DATA & & & 258 \\
\hline$F_{4}$ & & $\mathbf{p}$ & $\mathbf{T}$ & $0 \$$ & JITER, FLUCTUATION EXPERIMENT ANALYSIS & BAPL & & \\
\hline F4 & P 5 & $\mathbf{P}$ & $\mathbf{T}$ & $0 \$$ & TOAD, PROCESSING OF ANALYZER GAMMA-RAY SPECTRA & GGA & & 333 \\
\hline F4 & 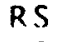 & $\mathbf{P}$ & $x$ & As & BE, COHERENT INELASTIC SCATTERING LAW CALC & GGA & & 385 \\
\hline F4 & & $\mathbf{P}$ & $x$ & As & LEGCOEF 3, LEGENDRE COEF CALC FOR ANGULAR DIST & & & \\
\hline F4 & RS & $\mathbf{p}$ & $x$ & I\$ & FINEL, FINITE-ELEMENT STUDY 2,3-D STRUCTURES & KAPL & 6600 & R 404 \\
\hline $\mathbf{F} 4$ & RS & $\mathbf{p}$ & XT & A \$ & PUN1, UNRFSOLVED RESONANCE INTEGRALS X-SECS & BAPL & & R359 \\
\hline $\mathbf{F} 4$ & & p & $\mathrm{XT}$ & A \$ & SUMOR, S-WAVE NEUTRON X-SECTION CALCULATION & PL & & 399 \\
\hline F4 & & $\mathbf{P}$ & XT & $B \$$ & GAF,GAR, SPECTRA AND GROUP-AVERAGED X-SEC CALC & GGA & & 316 \\
\hline F4 & RS & $\mathbf{P}$ & XT & B\$ & MULTI-GP CONSTANT CALC 0 TO 10 MEV & B & & 18 \\
\hline$F$ & $\mathbf{R}$ & $\mathbf{p}$ & $\mathrm{XT}$ & BS & HWOCR-SAFE, 2-D MONTE CARLO CELL CALCULATION & & & 307 \\
\hline F4 & $\mathbf{R}$ & $\mathbf{P}$ & $\mathrm{x}$ & B & RESQ2,RESQO,DBF 1, RESONANCE INTEGRAL HEX CELL & & & 2285 \\
\hline F & RS & $\mathbf{P}$ & $\mathbf{X T}$ & BS & 1-D DIFFUSION FAST $X$-SECTION GENERATION & BN & 1108 & 374 \\
\hline $\mathbf{F} 4$ & & $\boldsymbol{p}$ & XT & $C \$$ & E21, FFW-GP DISCRETE ORDINATES SLAB GEOMETRY & BAPL & & R398 \\
\hline F & $\mathbf{R}$ & $\mathbf{P}$ & XT & C\$ & VARI-QUIR3, 2-D MULTI-GP DIFFUSION XY RZ RTH & HANL & & 264 \\
\hline $\mathbf{F} 4$ & RS & $\mathbf{P}$ & XT & F\$ & FORE2, FAST REACTOR EXCURSION CALCULATIONS & Al & & 17 \\
\hline F4 & & $\mathbf{P}$ & $\mathbf{X T}$ & F \$ & FAST REACTOR EXCURSION CALCULATIONS & & & 174 \\
\hline F4 & $R$ & $\mathbf{P}$ & $\mathrm{XT}$ & F\$ & 1-D 2-GP KINETICS TEMPERATURE FEEDBACK & BAPL & & \\
\hline $\mathbf{F} 4$ & RS & $\mathbf{P}$ & XT & F\$ & TWIGL, 2-D 2-GP SPACE-TIME DIFFUSION FEEDBACK & BAPL & 6600 & R 338 \\
\hline
\end{tabular}


F6 3

F6 3

F 63

F 63

F 63

F 63

F 63

F63

F 63

F 63

F 63

F 63

F 63

F 63

F63

F63

F63

F 63
RS P XT F\$ WIGL2, 1-n 2-GP SPACE-TIME DIFFUSION 3-GEOM RS P XT G\$ FLASHZ, LOSS-OF-COOLANT ACCIDENT ANALYSIS RS $P X T$ G\$ MO555,ACT1, LOSS-OF-COOLANT ACCIDENT ANALYSIS RS $P X T$ H\$ FIGRO, LSBR FUFL SWELLING TFMPERATURE STUNY RS $P$ XT HS FLOTI, MO219, PWR FLOW TRANSIENT ANALYSIS RS $P$ XT H\$ HOT2, 2-D TRANSIENT HEAT CONDUCTION PROGRAM RS P XT H\$ MO899,HOH, STEAM TABLES 14.5-2538 PSIA

RS $P$ XT H\$ TOPS, TPANSIENT THERMOOYNAMICS OF PRESSURIZERS RS $P X T$ H\$ WASP, WATFP AND STFAM THFPMODYNAMIC PROPERTIES RS P XT I\$ MO266, LINEAR ELASTIC STPUCTUIRAL DYNAMICS RS $P X T$ I\$ MO457, PIPF, FLASTIC STRFSS OF PIPING SYSTEM RS $P X T$ I\$ MO552, DYNAMIC ANALYSIS LINEAR ELASTIC SYSTEMS RS P XT I\$ SEALSHFLL 2 , SHELL STRESS ANALYSIS AXISYM LDAD RS $P X T$ J\$ MOT56,LETR, 1-D SLAB GAMMA-RAY TRANSPORT RS $P$ XT K\$ CITATION, 1,2,3-D IIFFUSION DEPLETION MULTIGP RS $P X T$ L BL 47 , DRAFTING TOOL TO PLOT PLANF STRUCTURES RS P XT P\$ DAFTI, LFAST SDUARES FIT FISSILE NUCLIDE DATA RS PL T B\$ GAMTEC2, MULTI-GP CONSTANT CALC O TO 10 MEV RS PL T B\$ TEMPFST2, THEPMAL NEUTRON SPFCTRUM $X$-SFCTIONS RS PL T C\$ BISYN, 2-D MULTI-GP DIFFUSION SYNTHESIS CALC RS PLXT B\$ AILMOF, X-SFCTION CALC ELASTIC SCAT RESINANCES RS PLXT B\$ GGC4, MULTI-GP X-SFCTIONS FAST THERMAL SPECTPA RS PLXT B\$ HAMMER, CPITICAL EXPERIMENT ANALYSIS SYSTFM BNL RS PLXT B\$ LEOPARD, SPECTRA CALCULATION WITH DFPLETION RS PLXT B\$ XSDRN, DISCRETE ORDINATE MULTIGROUP CONSTANTS RS PLXT C\$ MATHI, 1-D MULTI-GP DIFFUSION SLAB CYL SPHERE RSB L T M\$ CLIP, FORM OR THREDES LIBRARY UTILITY ROUTINF R SEP RSBP RSBP A\$ MUFFLE, FISSILE NUCLIDE X-SFCTION EVALUATION $T K \$$ THPFDFS, 1-D FEW-GD DIFFUSION DESIGN SYSTEM RSBP T N\$ CROSSPLOT, SC 4020 PLOTS FROM X-SECTION TAPFS RSRP XT D\$ SIZZLE, 1-D MULTIGROUP DIFFUSIINN DEPLFTION RSBPLXT C\$ ANISN, I-n MULTI-GP DISCRETE ORDINATE CALC RSBPLXT C\$ CAESAR4,LIRLST, 1-П MULTI-SP DIFFUSION + LIB RSBPLXT D\$ NAP, NFUTRLIN-INDUCED GAMMA-RAY RADIOACIIVITY RS P RS P RS $P$ A\$ FLANGE L, SCATTERING LAW X-SFCTION CALCULATION H\$ FLAC, STFADY-STATF FLOW, PRESSURE DISTRIBUTION T HS TAC2N, STEADY-STATE AND TPANSIENT TEMP CALC RSBDL T DS ISOGFN, RAIIONUCLIDE GENERATION AND DECAY RS PS RS

RS RS RS RS RS RS RS P RS P RS $P$ RS $P$ RS $p$ RS $P$ RS P RS P RS P RS P RS P RS $P$ RS $P$ RS P RS $P$ RS P
C $\$$ PERT, 1-D PERTURRATION FOR AIM AND FOG CONFS

C\$ TDP, 2-I PERTURBATION TDC OR 2DXY FLUX INPUT C\$ 2DF, 2-D MULTI-GP DISCRETF ORDINATE CODE UNC-L I\$ WOPEXPRT, REACTOR WEIGHT DPTIMIZATION STUDY I\$CSP1, SN X-SECTION LIRRARY TAPE PREPARATION L\$ CSP2A, SN Y-SFCTION LIBRARY TAPE PRFPARATICN

T C\$ 2DXYL, 3-C MULTI-GP FLUX SYNTHFSIS PROGRAM CYL $L T$ D\$ SIZZLF, 1-D MULTIGQDUP DIFFUSION DEPLETION LXT B\$ GAMI. FAST NFUTRON SPECTRUM X-SECTION CALC A\$ HAFFVER, HAUSER-FFSHBACH INELASTIC SCATTERING A\& PEGGY, ELASTIC SCATTERING PHASF-SHIFT ANALYSIS A\$ RAMFS, PARTICLE WAVE FUNCTION RADIAL INTFGRALS B \$ SAIL, 1-D 1-GP SN APPROXIMATIIN SLAB GEOMFTRY B\$ S4 CYL CELL CODE, 1-D 1-GP S4 APPROXIMATION D\$ ISOCRUNCH, REACTION DECAY CHAIN ANALYSIS D\$ ISOSFARCH, ISOTOPE PRODUCTION FLUX, X-SFC CALC D\$ ISOTOPES, MAXIMUM YIELD FROM REACTION OR DFCAY D\$ POWERCO, NUCLEAR STATION ELFCTRICITY COSTS E\$ AIREK3, SPACE-INDEPENDENT KINFTICS W/FFEDBACK E\& CMPXMAT, TRANSFER FUNCTION FVALUATION F\$ AX-TNT, COUPLFD NEUTRONICS-HYDRODYNAMICS SPH G CLOUD, GAMMA-RAY DOSF RATE FROM A CLOUO H\$ MOBO9, HOH, STEAM TABLES 14.5-2538 PSIA J\$ GRACF1, GAMMA-RAY ATTENUATION SLAB GFOMETRY J\$ GRACE2, GAMMA-RAY ATTENUATION CYL SPHFRE GFOM
BAPL 6600 BAPL 6600

RAPL 6600

RAPL 6600

BAPL 6600

RAPL $66 \cap 0$

BAPL 6600

BAPL 6600

BAPL 6600

BAPL $66 C 0$

BAPL 6600

BAPL 6600

BAPL 6600

BAPL 6600

DRNL 360

BAPL 6600

BAPL 6600

BNW 1107

BHSC 360

NED 635

AI $\quad 360$

GGA 1108

-DP 360

WAPD 360

ORNL 360

DURD $65 \cap 0$

AI $\quad 360$

ORNL T090

ANL 3600

AI 360

GGA 7044

A I $\quad 360$

A I 360

A I 360

IITR 7094

GGA 1108

GGA

GGA

BNW 1108

CDC 1604

PW 1604

SSL 1604

PW 1604

PW 1604

PW

$\mathrm{PW}$

1604

CDC 1604

ANL 3600

CDC 1604

ORNL 1604

ORNL 1604

CnO 1604

CDC 1604

ORNL 1604

DRNL $16 \cap 4$

ORNL 1604

ORNL 1604

CDC $\quad 1604$

PW 1604

PW $\quad 1604$

CDC 1604

ANL 1604

CDC 1604

CDC 1604
R 274 R 295 R 284 R 272

R331

R 286

R204

R 348

R396

R 383

R329

R283

R 282

R 343

387

R 373

R 327

185

50

287

147

298

277

279

393

262

271

323

325

273

207

58

151

270

314

247

395

408

367

30

199

173

190

194

193

192

58

33

14

334

335

52

53

180

322

179

340

121

188

191

47

R294

45

46 


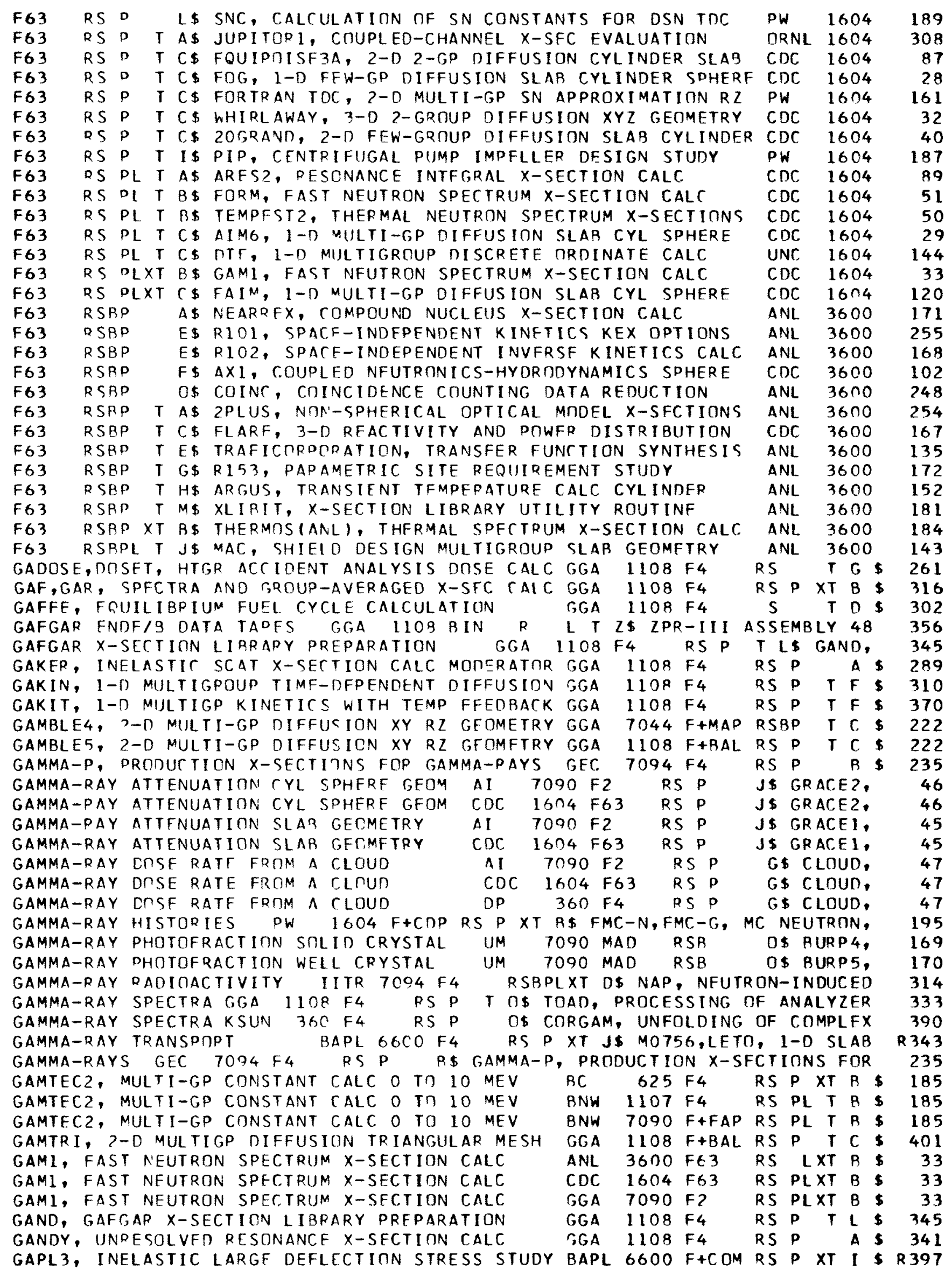


GAPOTKIN, SPACE-INDEPENDENT REACTOR KINETICS GGA 1108 F4 RS P E 317 GAR, SPFCTRA AND GROUP-AVEPAGED X-SEC CALC GGA 1108 F4 PS P XT B\$ GAF, 316 GARGOYLE, FUEL CYCLE ANALYSIS PARTIAL REFUEL GGA $7044 \quad F 4 \quad$ RS P I D \$ 260 GAROL, RESONANCE IVERLAP AND LATTICF EFFECTS GGA 7044 F+MAD RS P T B \$ 219 GAROL, RESONANCE OVFRLAP AND LATTICF EFFECTS LER 7094 F4 RSP TR $\$ 219$ GAS-CODLED CORE THFRMAL DESIGN STUDY RGA $7044 \mathrm{~F} 4$ RS P I\$ GAZELLF5, 232 GASA, STABILITY ANALYSIS RFACTOR KINETICS FQNS GGA 1108 F4 RS P GASKET, THERMAL SCATTERING, LAW CALCULATION GGA 1108 F4 RS P A $\$ 263$ GASP2, 1-D FEW-GP DIFFUSION PNWFR DIST SEARCH GGA 7044 F4 RS P T C $\$ 220$ GASP7, 1-D RURNUP POWFP DISTRIRUTINN SEARCH GGA 1108 F4 RS P T C \$ 319 GATT, 3-D FFW-GP DIFFUSION CALC HEX-Z MESH GGA 1108 F4 RS P T C \$ 380 GAUGE, 2-D FEW-GP HEX REOM DIFFUSION DEPLETION GGA 1108 F4 RS P T D \$ 339 GAVER, ENERGY INTFRVAL X-SECTION AVERAGING GGA 7044 F4 $\quad$ RS P L 218 GAZELLE5, GAS-COOLED CORE THERMAL DFSIGN STUDY GGA $7044 \quad F 4 \quad$ RS P I \$ 232 GE-HAPO-S13, 1-D MULTI-C,P MOURLF SN APPROX RNW 709O FLOCORSBP T C $\$ 75$ GEC $625 \mathrm{~F} 4$ RS P B\$ AVCID, ANNULAR VIID X-SECTION CALCULATION 276 GEC $635 \mathrm{~F}+\mathrm{GMP}$ RSBP T H\$ THTE, 3-D TRANSIENT HEAT TRANSFER PROGRAM 346 GEC 7094 F4 RS $P$ B\$ GAMMA-P, PRODUCTION X-SECTIONS FOR GAMMA-RAYS 235 GEM, EIGENVALUF PROBLEM FIP VIRRATING SYSTEMS KAPL 6600 F4 RS P I I \$ R344 GENERATOR DESIGN CRITERIA CTSTS GGA 7044 F4 RS P T DS STMGEN, STEAM 227 GEV $635 \mathrm{~F} 4$ RS P T O\$ RURNUP, HFAVY ELEMENT ISOTOPIC BURNUP ANALYSIS 311 GEV 7094 F+FAP RS P T $8 \$$ FPITHERMOS, SPECTRUM AND X-SECTION CALCULATION 201 GGA 1108 BIN R L T $I \$ 7 P R-I I I$ ASSEMBLY 49 GAFGAR ENDF/B TATA TAPES

GGA 1108 F+BAL RS P T C\$ GAMBLF5, 2-D MULTI-GP DIFFUSION XY RI GEOMETRY 222 356 GGA $1108 \mathrm{FHRAL}$ RS $P$ T C\$ GAMTRI, 2-D MULTIGP DIFFUSION TRIANGULAR MESH 40I

GGA 1108 F4 S T D\$ GAFFF, EQUILIBRIUM FUFL CYCLE CALCULATION

GGA 1108 F4 RS B\$ HEXSCAT, ELASTIC SCAT X-SECTIONS HEX LATTICE

GGA 1108 F4 RS T G\$ GADNSE, DOSFT, HTGR ACCIDENT ANALYSIS DOSF CALC

291

GGA $1108 \quad F 4$

GGA $1108 \quad F 4$

RS P

GGA $1108 \quad F 4$

RS P

A\$ GAKER, INELASTIC SCAT X-SECTION CALC MONERATRR

261

789

GGA $1108 \quad F 4$

RSP

A\$ GANDY, UNRESOLVED RESONANCF X-SECTION CALC

RS P

A\$ GASKET, THFRMAL SCATTERING LAW CALCULATION

A\$ PSFUDO, STATISTICAL RESONANCE PARAMFTER CALC

GGA 1108 F4

RS $P$

D\$ FREVAPG, HTGP METALLIC FISSION PRODUCT RELEASE

RS $p$

ES GAPOTKIN, SPACE-INDEPENDENT REACTOR KINETICS

GGA 1108 F4

RS $P$

F\$ GASA, STABILITY ANALYSIS REACTOR KINETICS EQNS

RS $P$

I \$ SAFF-CPEEP, VISCOFLASTIC ANALYSIS CONCRETE

RS P

I\$ SAFE-PLANE, PLANE STRESS ANALYSIS, 2-D BODIFS

GGA $1108 \quad F_{4}$

RS $P$

I\$ SAFF-SHFLL, STRESS ANALYSIS THIN SHELLS

RS $P$

GGA 1108 F4

GGA $1108 \quad F 4$

GGA 1108 F4

RS $P$

I \$ SAFF-2D, PLANE + AXISYMMETRIC STRESS ANALYSIS

LS GRDWRK, GRID GENERATION FOR SAFE PRIGRAMS

RS $P$ T AS TACASI, ANALYSIS OF RESONANCE MEASURFMENTS

GGA $1108 \quad F 4$

RS P

T C

GASPT, 1-D BURNUP PNWER DISTRIBUTION SEARCH

341

263

292

301

317

290

300

252

253

379

296

RS $P$ T CS GATT, 3-D FEW-GP DIFFUSION CALC HEX-Z MESH

RS $P$ T C\$ TEMCOT, TEMPERATURE COEFFICIENT CALCULATION

GGA $1108 \quad F 4$

GGA $1108 \quad F 4$

GGA $1108 \quad F 4$

GGA $1108 \quad F 4$

GGA $1108 \quad F 4$

GGA $1108 \quad F 4$

RS $P$ T DS FEVERT, 1-D MULTIGROUP DIFFUSION AND DEPLETION

RS $P$ T DS GAUGE, 2-D FFW-GP HEX GEOM DIFFUSION DEPLETION

RS $P$ T F\$ RLOOST6, COMBINFD KINETICS ?-D HEAT TRANSFER

RS $P$ T FS GAKIN, 1-D MULTIGRDUP TIME-DEPENDENT DIFFUSION

410

319

380

320

318

339

303

RS P TF\$ GAKIT, 1-D MULTIGP KINETICS WITH TEMP FEEDRACK

310

RS $P$ T F\$ WIGL2, 1-D 2-GP SPACE-TIME DIFFUSION 3-GEOM

RS P T I\$ SAFE-3D, 3-D COMPOSITF STRUCTURE STRFSS STUDY

370

GGA $1108 \quad F 4$

GGA $1108 \quad F 4$

GGA $1108 \quad F 4$

GGA $1108 \quad F 4$

GGA 1108 F4

GGA $1108 \mathrm{~F} 4$

GGA $1108 \mathrm{~F} 4$

GGA 1108 F4

GGA 1108 F5

RS $P$ T JS MUSCAT, VIEW FACTOR SHIELDING CODE CAVITY GEMM

RS $P$ T L\$ GAND, GAFGAR X-SECTION LIBRARY PPEPARATION

RS $P$ T OS TOAD, PRICESSING DF ANALYZER GAMMA-RAY SPECTRA

$R S P X$ A\$ COHBF, COHERENT INFLASTIC SCATTERING LAW CALC

RS $P X T$ BS GAF, GAR, SPECTRA ANN GROUP-AVERAGED X-SEC CALC

RS PLXT RS GGC4, MULTI-GP X-SECTIONS FAST THERMAL SPER,TRA

RS $P$ AF FLANGEI, SCATTERING LAW X-SECTION CALCULATION

GGA 1108 F5

GGA 1108 F5

$R S P$

H\$ FLAC, STEATY-STATE FLDW, PRESSURE DISTRIBUTION

GGA 6600 F4

RS $P$ TH\$ TAC2D, STFADY-STATE AND TRANSIENT TEMP CALC

GGA $7044 F+M A P$

RS L T B\$ GGC 4, MULTI-GP X-SECTIONS FAST THERMAL SPFCTRA

R 274

332

259

345

333

385

316

298

247

395

408

298

219

GGA $7044 \mathrm{~F}+\mathrm{MAP}$ RS $P$ T DS OPUS, POWFR PLANT PERFORMANCE AND PRICE STUDY

226

GGA 7044 F+MAP RSBP

M\$ UNPACK, RETRIEVAL FROM SCISRS X-SFCTION TADE

206 


$\begin{array}{lll}\text { GGA } & 7044 & F+M A P \\ \text { GGA } & 7044 & \text { F } 4 \\ \text { GGA } & 7044 & F 4 \\ \text { GGA } & 7044 & F 4 \\ \text { GGA } & 7044 & F 4 \\ \text { GGA } & 7044 & F 4 \\ \text { GGA } & 7044 & F 4 \\ \text { GGA } & 7044 & F 4 \\ \text { GGA } & 7044 & F 4 \\ \text { GGA } & 7044 & F 4 \\ \text { GGA } & 7044 & F 4 \\ \text { GGA } & 7044 & F 4 \\ \text { GGA } & 7044 & F 4 \\ \text { GGA } & 7044 & F 4 \\ \text { GGA } & 7044 & F 4 \\ \text { GGA } & 7044 & F 4 \\ \text { GGA } & 7044 & F 4 \\ \text { GGA } & 7044 & F 4 \\ \text { GGA } & 7044 & F 4 \\ \text { GGA } & 7044 & F 4 \\ \text { GGA } & 7044 & F 4 \\ \text { GGA } & 7044 & F 4 \\ \text { GGA } & 7090 & F+F A P \\ \text { GGA } & 7090 & F+F A P \\ \text { GGA } & 7090 & F+F A P \\ \text { GGA } & 7090 & F 2 \\ \text { GGA } & 7090 & F ? \\ \text { GGA } & 7090 & F 2 \\ \text { GGC } & \text { MUL }\end{array}$

SBP

RS

QS

RS

RS

RS $P$

RS $P$

RS P

RS P

RS $P$

RS P

RS D

RS P

RS P

RS $p$

RS P

$R S P$

RS P

RS $P$

RS $P X$

RSBP

RSB

$R S B$

RSBP

$R S$

RS
D. $P$

$T$ C\$ GAMRLE4, 2-D MULTI-GP DIFFUSION XY RZ GEOMFTRY A\$ FLANGEI, SCATTERING LAW X-SECTION CALCULATION

I\$ CORE, CORF CONFIGURATION FUFL TEMPERATURE CODE

$T H \$$ RLOCST5, POINT-KINFTICS WITH 2-D HFAT TRANSFER

XT GS PRECON, HTGR CONTAINMENT PRESSURF POST RUPTURE A\$ TASMOP, $X$-SECTIONS FROM B-W RESONANCF DATA DE RADZ, HTRR FISSION PRODUCT ACTIVITY DIST STUDY D\$ WAMPUM, FUEL CYCLE COSTS PERFORMANCE STUDY

I \$ GAZELLE5, GAS-CDOLFD CORE THERMAL DFSIGN STUDY L\$ GAVFR, ENERGY INTERVAL X-SECTION AVERAGING

$T$ F $F M C-N$, MONTE CARLO CALC NEUTRON HISTORIES

T C\$ GASP2, 1-D FFW-GP DIFFUSION POWFR DIST SEARCH

T C TEMCD, 1-D FEW-GP DIFFUSION TEMP COFF CALC

$T$ D\$ GARGOYLE, FUEL CYCLF ANALYSIS PARTIAL REFUEL

$T$ D\& RELOAD-FFVER, I-D FEW-GP DIFFUSION DEPLFTION

$T$ DS FFVISED-GAD, FUEL CYCLE ANALYSIS W/REFUELING

T D\$ STMGFN, STEAM GFNERATOR DESIGN CRITERIA COSTS

T I FLROW, FUFL FLEMENT STRESS ANALYSIS STIJOY

$T$ IS SAFE-AXISYM, STDFSS ANALYSIS AXISYMMETRIC LOAD

$T$ SAFE-PCRS, STRESS ANALYSIS AXISYMMETRIC LOAD

AS LFGCOEF3, LEGENDRE CCEF CALC FDR ANGULAR DIST

$T$ T CRTSSPLDT, SC4O20 DLOTS FROM X-SFCTIIN TAPES

$T$ A TUZ, UNRESOLVED REGION RESINANCE INTFGRAL CALC

$T \triangle \$$ ZUT, PFSOLVFD REGITN RFSONANCE INTEGRAL CALC

$T$ T DDE, 2-D FEW-GP DIFFUSION BURNUP R? GEOMETRY

T A\$ SUMMIT, CRYSTALLINE SCATTERING KERNFL CALC

GGC4, MULTI-GP X-SECTIINNS FAST THERMAL SPECTRA GGA 1108 F4

GGC4, MULTI-GP X-SECTINNS FAST THERMAL SPECTRA GGA $6600 \% 4$

GLEN, T,PQUP CONSTANT CALC FPOM TOR OUTPUT DATA LASL 6600 F4

GRACE 1, GAMMA-PAY ATTENUATION SLAB GFOMFTRY AI 7090 F?

GRACF 1, GAMMA-RAY ATTINUATION SLAB GEOMFTRY

GRACF2, RIAMMA-RAY ATTFNUATICN CYL SPHFRF GFOM

GRACF2, GAMMA-RAY ATTENUATION CYL SPHERE GFOM

GRAPHIC X-SFC EVALUATION AI

36C F+BAL RS

GRAVE, GRIUP-AVERAGING X-SECTIONS PARAMFTERS

GRDWRK, GRID GENFPATI NN FOP SAFF PRIGRAMS

GRID GENFPATION FOP SAFE PRIGPAMS

GRA 1108 F4 RS P

$T$ M\$ SCORE2, SCISRS ENDF/B

AI 7094 F+FAP RS PL T B \$ GGA 1108 F4 RS P L GROUP CONSTANT CALC FROM TIR OUIPUT DATA LASL $6600 F 4$ RS P L GRDWRK, GROUP-AVEPAC,ED X-SFC CALC GGA 1108 F4 RS P XT B\$ GAF, GAR, SPECTRA AND GROUP-AVERAGING X-SECTIONS PARAMFTFRS AI $7094 \mathrm{FHFAP} R S$ PL T B\$ GRAVE, GROUP-COLLAPSING OF NULTI-GP X-SFCTIONS LASL 7C9O FLOCD RS P HAFEVER, HAUSER-FTSHRACH INFLASTIC SCATTERING CDC $1604 \quad F 63$ HAMMER, CRITICAL FXPFRIMFNT ANALYSIS SYSTFM BNL-DP $360 F 4$ HAMMER, CPITICAL FXPEQIMFNT ANALYSIS SYSTFM BNL-DP 7090 F2 HATCHET, COUPLFD AEUTRONICS-HYDPMDYNAMICS CDDE AGC 7090 F2 HAUSER-TFSHRACH INELASTIC STATTERING CDC 1604 F63 RS D HEAT CONDUCTION PDCO 7C44 F+MAP PS P THS TOODEF, 2-D TIME-DEPENDFNT HEAT CONDUTTION LUMPED MASS IASL 7030 F4 RS T H\$ RATH, 2- OR 3-D HEAT CONDUCTINN LUMPED MASS LASL 7004 FAP RS P T H\$ RATH, 2- DR 3-D HEAT CONOUCTION PROGRIM PAPL $66 C O F 4$ RS P XT H\$ HOT2, 2-D TRANSIENT HEAT EXTHANGFP STRESS ANALYSIS KAPL 6600 F4 RS P I\$ TUBE, U-TURF HEAT TRANSFFR GGA 1109 F4 RS $P$ T F\$ BLONST6, COMAINED KINFTICS ?-D HEAT TRANSFFQ AI $7074 \mathrm{~F} ?$ RS $P$ T GS TRANS-FUGUEI, TRANSIFNT FLOW AND HEAT TRANSFFR AI $7094 \mathrm{~F} 2$ RS $P$ T H\$ HFATING2, TRANSIFNT STFADY-STATE HEAT TRANSFFQ GGA $7044 \mathrm{~F} 4$ RS T H\$ BLODST5, POINT-KINFTICS WITH 2-D HEAT TRANSFFR MOLTEN FUFL TUBE BUNDLES LASL $7094 \mathrm{~F} 2$ RSBD H\$ AXFLU, HEAT TRANSFER PRDGRAM GFC 635 F+GMP RSRP T H\$ THTE, 3-D TRANSIFNT HEAT TRAN!SFFR SOLID FUEL TURE BUNDLFS LASL $7094 \mathrm{F2}$ RSBP H\$ AXTHRM, HEATING CLADDING-STFAM REACTINN ANI 3600 F36 RSBP G\$ CHFMLOC?, CORRE HEATING2, TRANSIENT STEADY-STATF HFAT TRANSFFR AI $7094 \mathrm{~F} 2$ HEAVY ELFMENT ISTTOPIC RURNIIP ANALYSIS GFV $635 \mathrm{~F} 4$ RS P HERESY1, LATTICE PARAMETFRS HETEROGFNEOUS CALC FMA 7090 F2
222

247

233

205

278

216

231

224

232

218

195

220

225

260

221

223

227

229

251

750

217

207

42

41

99

56

33

117

298

299

361

45

45

46

46

375

162

296

296

361

316

162

113

14

277

277

153

14

349

242

242

R $>86$

R 378

303

268

198

205

182

346

183

366

198

311

136 
HETEROGENEDUS CALC FMA $7090 \mathrm{~F} 2$ RSBP $X$ C\$ HERESY1, LATTICE PARAMETERS HEX CELL BAPL $6600 \mathrm{~F} 4$ RS $P$ XT B\$ RFSQ2, RFSQO,DBFI, RFSONANCE INTEGRAL HEX GEOM DIFFUSION DEPLETION GGA 1108 F4 RS P T D\$ GAUGE, 2-D FEW-GP HEX LATTICF GGA 1108 F4 PS B\$ HEXSCAT, ELASTIC SCAT X-SECTIONS HEX-Z MESH GGA 1108 F4 RS P T C\$ GATT, 3-D FEW-GP DIFFUSION CALC HEXSCAT, ELASTIC SCAT X-SECTIONS HFX LATTICE GGA 1108 F4 RS HFN, 1-D MULTI-GP DIFFUSION SLAB CYL SPHERF BNW 1107 F4 RS P T C \$ 241 HIGH-VELOCITY FLOW STUDY STEAM-WATER MIX KAPL 6600 F4 RS P H\$ RAPP, R3B2 HISTORIES GGA $7044 \mathrm{~F} 4$ RS P T BS FMC-N, MONTE CARLO CALC NEUTRON I95 HISTORIES PW $1604 \mathrm{~F}+\mathrm{CDP} R S P \times T$ B\$ FMC-N,FMC-G, MC NEUTRON, GAMMA-RAY 195 HISTORY KE $7094 \mathrm{~F} 2$ RSBP T H\$ PTHI, BLNWDOWN PRFSSURE TEMPERATURE 155 HOH, STEAM TABLES $14.5-2538$ PSIA ANL 1604 F63 RS P H\$MO899, R294 HOH, STFAM TABLES 14.5-2538 PSIA BAPL 6600 F4 RS P XT HS MO899, R294 HOMOGENEDUS ANL 3600 F36 RSAP A\$ MISH-MASH, RESONANCE INTEGRAL CALC 214 HOT2, 2-D TRANSIENT HEAT CONDUCTION PROGRAM BAPL 6600 F4 RS P XT H $\$$ R286 HTGR ACCIDENT ANALYSIS DOSE CALC GGA 1108 F4 RS T G\$ GADOSE,DOSFT, 261 HTGR CONTAINMENT PRESSURE POST RUPTURE GGA $7044 \mathrm{F4}$ RS XT GS PRECON, 228 HTGR FISSION PRODUCT ACTIVITY DIST STUDY GGA 7044 F4 RS P P\$ RAD2, 231 HTGR METALLIC FISSIDN PRODUCT RELEASE GGA 1108 F4 RS P DS FRFVAPG. 301 HWOCR-SAFE, 2-D MONTE CARLN CELL CALCULATION AI 360 F4 RS P XT B $\$ 307$ IBM $360 \mathrm{~F}+\mathrm{BAL} R S P$ T D\$ PDQ5, 2-D FEW-GROUP DIFFUSION AND DEPLFTION R336 IBM $360 \mathrm{F4}$ RS P T D\$ PDQ7, 1,2 OR 3-D FEW-GP DIFFUSION DEPLETION R275 1 ITR 7094 F4 RSBPLXT D\$ NAP, NEUTRON-INDUCED GAMMA-RAY RADIOACTIVITY IMPELLER DESIGN STUDY PW 1604 F63 RS P T I\$ PIP, CFNTRIFUGAL PUMP INC 7044 F4 RS P T G\$ RELAP2, REACTOR BLDWDOWN - FXCURSION ANALYSIS

INELASTIC LARGE DEFLECTION STRESS STUDY BAPL $6600 \mathrm{~F}+\mathrm{COM} R S \mathrm{P} X \mathrm{I}$ IS GAPL 3 . INELASTIC SCAT X-SECTION CALC MODERATOR GGA 1108 F4 RS P AS GAKER. INELASTIC SCATTERING CDC 1604 F63 RS P A\$ HAFEVFR, HAIISER-FESHRACH INELASTIC SCATTERING LAW CALC GGA 1108 F4 RS $P$ AS COHAE, COHERENT INFINITE MEDIUM SPECTRUM X-SECTIONS AI 7090 F+FAP RS L T B\$ QUICKIE. INFDRMATION SYSTEM KAPL $6600 \mathrm{~F}$ R B T MS TIGIR2, MODULAR DOCUMENT INPUT PW 1604 F63 RS C\$ TDP, 2-D PERTURBATION TDC DR 2DXY FLUX INPUT, PREPARATION, EDIT KAPL 6600 F+ASC RS P T L\$ DATATRAN 2-D GFOMETRY INSTRUCTION SET PW 1604 F+CDP RS P T P\$ LAG, ASSEMBLER FOR FLOCO2 INTERVAL X-SECTION AVFRAGING GGA 7044 F4 RS P L\$ GAVFR, ENERGY INVERSE KINETICS CALC ANL 3600 F63 RSBP F\$ RIO?, SPACE-INDEPENDFNT INVERSE KINETICS CALC WANL 7094 F4 RS ISOCRUNCH, REACTION DECAY CHAIN ANALYSIS ISOCRUNCH, REACTION DECAY CHAIN ANALYSIS I SOGEN, RADIONUCLIDE GENERATION AND DECAY ISOSEARCH. ISOTOPE PRODUCTION FLUX, $X$-SFC ISOSEARCH, ISOTOPE PRODUCTION FLUX, $X-S E C$ ISOTOPE PRODUCTION FLUX, $X$-SFC CALC ORNL CAL, ORNL 1604 F63 F\$ R102, SPACE-INDFPENDENT $\begin{array}{lllll}\text { ORNL } 1604 & F 63 & \text { RS P } & \text { D } \$ \\ \text { ORNL } 7090 & \text { F2 } & \text { RS P } & \text { D } \$\end{array}$ BNW 1108 F5 RSPPL T D $\$$

187

369

R397

289

14

385

119

R403

199

R406

186

218

168

168

180

180

367

322

322

322 ISOTOPE PRODUCTION FLUX, X-SEC CALC ORNL 1604 F63 RS P OS ISOSEARCH, 322 ISOTOPES, MAXIMUM YIELD FROM REACTION OR DECAY ORNL 1604 F63 RS P ISOTOPIC BURNUP ANALYSIS GEV 635 F4 RS P T OS BURNUP, HEAVY ELFMFNT 311 JITER, FLUCTUATION EXPERIMENT ANALYSIS BAPL $6600 F 4$ RS P T $\$$ R394 JUPITOR1. COUPLED-CHANNEL X-SEC EVALUATION ORNL 1604 F63 RS P T A $\$ 308$ KAPL $6600 \mathrm{~F}$ R B T M\$ TIGIR2, MODULAR DOCUMENT INFDRMATINN SYSTEM R4O3 KAPL $6600 \mathrm{FHASC} R S \mathrm{P} T \mathrm{H}$ LIDN, 3-D TEMPERATURE DISTRIBUTINN PROGRAM R2903 KAPL 6600 F+ASC RS P T L\$ DATATRAN 2-D GEOMETRY INPUT, PREPARATION, EDIT KAPL $6600 F+A S C$ RS P T P\$CURFIT, CURVE FITTING EXPERIMENTAL DATA POINTS KAPL 6600 F+ASC RS P T P\$ DATATRAN UTILITY MODULES, 2-D + 3-D PLOTTING KAPL $6600 F+A S C$ RS P T P\$ SNEQ, NONLINEAR ALGFBRAIC EQN SOLN CURVE PLOT KAPL $6600 \mathrm{~F}+$ COM RSB T MS DATATRAN, MODULAR PROGRAMMING AND DATA SYSTEM KAPL $6600 \quad F 4$ RS KAPL 6600 F4 KAPL $6600 \quad F 4$ KAPL $6600 \quad F 4$ KAPL $6600 \quad F 4$ KAPL $6600 \quad F 4$ KAPL $6600 \quad F 4$ KAPL $6600 \quad F 4$ KAPL $6600 \quad F 4$ I\$ SORSDB, PRESSURE VESSEL STRESS AND FATIGUE $\begin{array}{lll}\text { RS } P & F \$ \text { RAUMZEIT, I-D TIME-DEPENDENT DIFFUSION CALC } \\ \text { RS } P & \text { F\$ STINT3, SINGLE-CHANNEL SPACE-TIMF SYNTHESIS }\end{array}$ RS P H\$ RAPP, HIGH-VELOCITY FLOH STUDY STEAM-WATER MIX RS $P$ I\$ STEM, MATRIX GENERATION FOR A SYSTEM OF BEAMS RS $P$ I\$ TUBE, U-TUBE HEAT EXCHANGER STRESS ANALYSIS RS $P$ I I\$ GEM, EIGENVALUE PROBLEM FOR VIBRATING SYSTFMS RS $P$ I \$ SOR2, STRESS ANALYSIS SHELLS OF REVDLUTION $R S P X$ I\$ FINEL, FINITE-ELEMFNT STUDY 2,3-D STRUCTURFS

R406 R 43 R407 R 364 R3B6 R 391 R.352 R389 R 382 R 337 R 378 R 344 R 80 R404 
KE $3600 \quad F 36 \quad$ RSBP

KE $7090 \mathrm{F2}$ RSBP

KE 7094 F+MAP RSBP

KE $7094 \quad F 2$ RSBP

KERNEL CALC

KEX OPTIONS

KEX OPTIONS

KINETICS

KINETICS

KINETICS

KINETICS

KINETICS

KINETICS

KINETICS

KINETICS

KINETICS GGA 7090 F?
ANL 3600 F63 WANL $7094 \quad F 4$

AI $360 \quad F_{4}$

AI $7094 \quad F 4$

GGA $1108 \mathrm{FH}^{-}$RS P

6\$ WHAM, LIQUID-FILLFD PIPING SYSTEM ANALYSIS

D\$ NPRFCCP, FUEL CYCLF COSTS PERFORMANCF DATA

$T$ G\$ SATURATED BLOWDOWN2, BLOWDOWN ANALYSIS LOFT

T HS PTHI, BLOWDOWN PPESSURE TEMPERATUPE HISTORY RS T A\$ SUMMIT, CRYSTALLINE SCATTERING RSBP ES RIOI, SPACE-INDEPENDENT KINETICS RS P E\$RIOI, SPACE-INDFPENDENT KINETICS RS P T F\$ TSN, SPATIALLY-DEPENDFNT REACTOR RS P T F\$ TSN, SPATIALLY-DEPENDENT REACTOR 1108 F4 RS P E\$ GAPOTKIN, SPACE-INDEPFNDENT REACTOR CALC WANL $7094 F_{4}$ RS RS P EQNS GGA 1108 F4 KEX OPTIONS ANL 3600 F63 WANL $7094 \quad F 4$ AI 7090 F2 RS DTUDY AEB $360 \mathrm{~F}$ KINETICS TEMPERATURE FFEDBACK BAPL $6600 \quad \mathrm{~F} 4$ KINETICS W/FEEDBACK AI 7094 F+MAP RS $P$ KINETICS W/FEEDBACK AEB 360 F4 RS P KINETICS W/FEFDRACK AI 7090 F2 RS KINETICS W/FEEDBACK CDC 1604 F63 RS P KINETICS WITH TFMP FFEDBACK GGA 1108 F4 KINETICS 2-D HEAT TRANSFER GGA $1108 \mathrm{~F}_{4}$ E\$ R102, SPACE-INDEPENDFNT INVERSE E\$ GASA. STABILITY ANALYSIS RFACTOR RSBP E\$ RIOI, SPACE-INDEPENDENT E\$ RIOI, SPACE-INDEPENDENT
F\$ RIOI, SPACE-INDEPENDENT E\$ SNAPKIN5/5A, I-REGION RS $P$ E\$ BLAST, REACTOR RS P XT F\$ NOWIG, 1-D 2-GP $T$ E\$ AIROS, SPACE-INDEPENDENT E\$ AIREK3, SPACE-INDEPENDENT E\$ AIREK 3. SPACE-INDEPENDENT E\$ AIREK 3, SPACE-INDEPENDENT RS $P$ T F\$ GAKIT, 1-D MULTIGP RS $P$ T E\$ BLOOST6, COMBINED KSUN 360 F4 RS P OS CORGAM, UNFOLDING OF COMPLEX GAMMA-RAY SPECTRA LAG. ASSEMBLER FOR FLDCO2 INSTRUCTION SET PW 1604 F+CDP RS P T P \$ LAGI RS $P$ C\$ MGDSN, I-D MULTI-GP SN APPROX SLAB CYL SPHERE PW 1604 LAGI RS $P$ N\$ DTX, EFFECTIVE X-SECTION CALC FROM DSN OUTPUT PH 1604 LARCA, FLUX-WEIGHTING NF DTF 4 CROSS SECTIONS LASL 6600 F4 RS P N \$ LARGE DEFLECTION STRESS STUDY BAPL $6600 \mathrm{~F}+C O M$ RS P XT I\$ GAPL3, INELASTIC LASER, SPECTRUM CALC WITH BURNUP CYL LATTICE LASL LEAST SQUARES, GENERAL CURVE FITTING LASL 1108 F4 LASL $6600 \quad F 4$ RS P $T C S$ C\$ TWOTRAN, 2-D MULTI-GP TRANSPORT CODE $X-Y$ GEOM LASL $6600 \quad F 4$ LASL $6600 \quad F 4$ LASL 6600 F4 LASL 6600 F4 LASL $7030 \quad F 4$ RS $P$ RS P RS $p$ RS $P$ RS $p$ RS RS P RS P

LASL $7030 \quad F 4$

LASL 7090 FLOCO RS P LASL 7090 FLOCO RS P LASL 709C F2 RS P LASL 7000 F2 LASL 7094 FAP RS $P$ RSP LASL 7094 F2 LASL 7094 F2 LATTICE GGA 1108 F4 I A\$ TOR, THERMAL SCATTERING CRYSTALLINE MATFRIALS $T$ B\$ GLEN, GROUP CONSTANT CALC FROM TOR OUTPUT DATA I C\$ DTF4, 1-D MULTI-GP DISCRETE ORDINATE PROGRAM T D\$ 2DB, 2-D MULTIGROUP DIFFUSION AND DEPLETION T H\$ RATH, 2- OR 3-D HEAT CONDUCT ION LUMPED MASS T C\$ DTF 4,1 -D MULTI-GP DISCRETE ORDINATE PROGRAM T D\$ DTF-BURN, 1-D MULTI-GP DTF4 WITH DEPLETION B\$ MCS, MONTE CARLO NEUTRON PENETRATION STUDY B\$ ZOT, GROUP-COLLAPSING OF MULTI-GP X-SECTIONS I \$ WIREX, COMPUTER-PRODUCED WIRING LISTS UHTREX T L\$ DPC, DATA PREPARATION FOR 2-D DESIGN PROGRAMS $T$ H\$ RATH, 2- OR 3-D HEAT CONDUCTION LUMPED MASS H\$ AXFLU, HEAT TRANSFER MOLTEN FUEL TUBE BUNDLES H\$ AXTHRM, HEAT TRANSFER SOLID FUEL TUAE BUNDLES $T$ P\$ LASL LEAST SQUARES, GENERAL CURVE FITTING BS HEXSCAT, ELASTIC SCAT X-SECTIONS HEX LATTICE WAPD 7094 F+MAP RS PLXT BS LASFR, SPFCTRUM CALC WITH BURNUP CYL LATTICE FFFECTS GGA $7044 \mathrm{~F}+M A P$ RS $P$ T BS GARDL, RESONANCE OVERLAP AND LATTICE EFFECTS LEP $7004 \mathrm{~F} 4$ 'RS P T B\$ GAROL. RESONANCE NVERLAP AND LATTICE PARAMETERS HETEROGENEOUS CALC FMA $7090 \mathrm{~F} 2$ RSRP $X$ C\$ HERESYL. LEAKAGE AI $7090 \mathrm{~F} 2$ RS J\$ FARSEIA, DOSE RATE FRTM SNAP SHIELD LEAST SQUARFS ANALYSIS RESONANCE DATA UILL 360 F4 RS P AS CODILLI. LEAST SQUARFS EXPONENTIAL DTCAY CURVFS LRL $7094 \mathrm{F2}$ RS P P\$ EXPALS. LEAST SQUARES FIT FISSILE NUCLIDE DATA BAPL 6600 F4 PS PT P\$ DAFTI, LEAST SQUARFS FIT SUM OF EXPONFNTIALS MIT $7090 \mathrm{~F}$ ? RS LEAST SOUARFS, GENERAL CIJRVF FITTING LEGCOEF3, LEGENDRF COFF CALC FOR ANGULAR DIST GGA $7044 \mathrm{~F}_{4}$ LEGENDRE CDEF CALC FOR ANGULAR DIST GGA 7044 F4 $\quad$ RS $P$ LEGENDRE COEF CALC FOR ANGULAR DIST DATA AI LEOPARD, SPECTRA CALCULATION WITH DFPLETION $7094 F+M A P$ RS P WAPD $360 \quad F 4$ PS FRANTIC, $T$ P\$ LASL A\$ LEGCOEF 3 . A\$ CHAD, RS PLXT R RS $P X$ A 
LER $7090 \mathrm{~F}+M A P$ RS $P$ T $C \$$ TDSN, 2-0 MULTIGROUP DISCRFTE ORDINATF PROGRAM LER 7094 F4 4 RS $P$ T B\$ GAROL, RESONANCE OVERLAP AND LATTICE FFFECTS LER 7094 F4 RS P T C\$ DTF4, I-D MULTI-GP DISCRETE ORDINATF PROGRAM LETO, I-D SLAB GAMMA-RAY TPANSPIRT BAPL $6600 \mathrm{F4}$ RS P XT J\$ MOT56, LIB AI 360 F4 RSBPLXT C\$ CAFSAR4, LIBLST, 1-D MULTI-GP DIFFUSION + LIBLST, 1-D MULTI-GP DIFFUSION + LIB AI 360 F4 RSBPLXT C\$CAESAR4, LIBRARY LRL $7094 \mathrm{~F} ?$ RS PL T M\$ ECSIL, EXPERIMFNTAL NFUTRON DATA LIBRARY PREPARATION GGA 1108 F4 RS P T L\$ GAND, GAFGAR X-SECTION LIBRARY TAPE PREPARATION PW 1604 F63 RS L $\$$ CSPI, SN X-SECTION LIBRARY TAPE PREPARATION PW 1604 F63 RS L\$CSP2A, SN X-SECTION LIBRARY UTILITY PROGRAM AI 7094 F+FAP RS L T MS MOMUS, X-SECTINN LIBRARY UTILITY ROUTINF LIBRARY UTILITY ROUTINF LIFETIME ANALYSIS AI $360 \mathrm{~F} 4$ RSR L T M\$CLIP, FCRM OR THREDES ANL 3600 F63 RSRP T M\$ XLIBIT, X-SFCTION ANL 3600 F36 PSBP I\$ SWELL2, FUEL ELEMENT LINEAR ELASTIC STRUCTURAL DYNAMICS BAPL $6600 \mathrm{F4}$ RS P XT I\$ MO266, LINEAR FLASTIC SYSTEMS BAPL 6600 F4 RS P XT I\$ MO552, DYNAMIC ANALYSIS LION, 3-D TFMPERATURE DISTRIRUTI ON PROGRAM LIPRECANI, MC NFUTRON PENETRATION CALCULATION LIQUID BLIWDOWN ANALYSIS LCFT UGA
LIQUID-FILLED PIPING SYSTEM ANALYSIS LIQUID-FILLED PIPING SYSTEM ANALYSIS
LISTS UHTPFX LASL $7090 \mathrm{~F} 2$ $360 \quad F 4$ KAPL $6600 F+A S C$ RS P TH\$ DAC $7090 \mathrm{F2}$ RSPP J $\$$ RS P G\$ WATFR-HAMMER, KE 3600 F36 RSRP G\$ WHAM, I\$ WIRFX, COMPUTER-PRODUCED WIRING LOAD GGA 7044 F4 RS P T I\$ SAFE-PCRS, STRESS ANALYSIS AXISYMMETRIC LOAD BAPL $6600 \mathrm{~F} 4$ RS $P$ XT I \$ SEALSHELL2, SHFLL STRESS ANALYSIS AXISYM LOAD GGA $7044 \mathrm{~F} 4$ RS P T I\$ SAFF-AXISYM, STRESS ANALYSIS AXISYMMETRIC LOFT KE $7094 \mathrm{~F}+M A P$ RSBP T G\$ SATURATED BLOWDOWN?, RLOWDOWN ANALYSIS LOFT UGA $360 \mathrm{~F} 4$ RS $P$ G\$ WATFR-HAMMFR, LIQUIN BLOWDNWN ANALYSIS LOSS-OF-COOLANT + EMERGENCY COOL ING BCL 64חOF4 PS P T G\$ FCCSAI, LOSS-OF-COOLANT ACCIDENT ANALYSIS LOSS-OF-CROLANT ACCIDFNT ANALYSIS LOSS-OF-CONLANT ACC IDENIT ANALYSIS LOSS-OF-COOLANT THERMAL ANALYSIS BAPL 6600 F4 RS P XT G\$ FLASH?. PPCO 7040 F+MAP RS P T T,\$ CONTEMPT. BAPL $6600 \mathrm{F4}$ RS P XT G\$ MO555, ACT1, RCL $6400 F 4$ RS P T C\$ NURLOC-1. C. LRL 709 F2 RS C\$ FIRN, 2-D FEW-GP S4 APPROXIMATION RI GEOMFTRY LRL 7090 F+FAP RS $P$ T B\$ SOPHIST1/2/5, MULTI-GP TRANSFFR COEFFICIENTS

LRL $7090 \mathrm{~F} 2$ RS P F\$ CONEC, COUPLED NFUTRONICS-HYDPMDYNAMICS SPHEPE LRL $7094 \mathrm{~F} 2$ RS P P\$ EXPALS, LEAST SQUARFS EXPONFNTIAL DECAY CURVFS LRL $7094 \mathrm{F2}$ RS PL T MS FCSIL, EXPERIMENTAL NEUTRON DATA LIBRARY

LSBR FUEL SWELLING TEMPERATURE STUDY BAPL G6OOF4 RS P XT H\$FIGRT, LUMPED MASS LASL 7030 F4 RS TH\$ RATH, 2- OR 3-D HEAT CONDUCTION LUMPED MASS LASL 7094 FAP RS P T HS RATH, 2- OR 3-D HFAT CONDUCTION LYNNE, WOODS-SAXON POTFNTIAL SHAPE CALCULATION ORNL 7090 F2 RS A MAC, SHIFLD DESIGN MULTIGRTUP SLAB GFOMETRY ANL 3600 FG3 RSRPL T J \$ MAC, SHIELD DESIGN MULTIGPCUP SLAB GEOMETRY RNW TO9OF2 RSRPL T J \$ MACH1, 1-D MULTI-GP DIFFUSICN SLAB CYL SPHERF ANL 3600 F36 RS $P$ XT $\$$ MACHI, 1-D MULTI-GP DIFFUSICN SLAR CYL SPHERE PURD $6500 \quad F 4$ MAD RSB O\$ RURPI, OFTECTOR EFFICIENCY PDINT SOURCE MAD RSB D\$ RURP2, DETFCTOR EFFICIENCY DISK SDURCE MAD RSR O\& BUPP3. DETECTOR EFFICIENCY DIINT SOURCE MAD RSB O\$ BURP4, GAMMA-RAY PHOTOFRACTION SOLID CRYSTAL MAD RSB O\$ RURP5, GAMMA-RAY PHOTOFRACTION WELL CRYSTAL MANTA, STEADY-STATE THERMAL-HYDRAULIC ANALYSIS NED 635 F4 MARS, 2-D EXCURSION CALCULATICN R-Z GEDMETRY APDA $7094 \quad F 4$ MASS 2-O MASS LASL 7094 FAD RS P T HS RATH, 2- OR 3-D HEAT CONDUCTION LUMPFD MATERIAL RUCKLING CYL FUEL ELEMENTS AEB 330 F4 4 S P BS WFLWING. MATERIALS LASL $6600 F 4$ PS P T A\$ TOR, THERMAL SCATTFRING CRYSTALLINE MATRICES AGC 7090 F2 RS $P$ T B\$ AGN-SIGMA, CALC OF MULTI-GP TRANSFFR MATRIX GENFRATION FOR A SYSTEM TF BFAMS KAPL 6600 F4 RS P IS STEM. MAXIMUM MOMENT CALC AI 7090 F+FAP RS T I\$ $4 R E S T R A I N T$ PIPF STRFSS, MAXIMUM YIELO FROM REACTION OR DECAY ORNL 1604 F63 RS P OS ISTTOPES, MC ORNL $360 \mathrm{~F}+B A L$ RS P T B\$ RAFFLE, IST FLIGHT COLLISION PROAABILITIES MC ORNL 7090 F+FAP RS P T R\$ RAFFLE, IST FLIGHT COLLISICN PROBABILITIES MC NEUTRON PENETRATION CALCULATION DAC 7090 F2 RSRP J\$ LIPRECANI, MC NFUTRCN, GAMMA-RAY HISTORIES PW $1604 \mathrm{~F}+\mathrm{CDP}$ RS P XT P\$ FMC-N,FMC-G, $M C * 2$ DATA CONVFRSION
312

219

209

R 343

270

270

351

345

194

193

159

181

771

353

R 383

R2 83

R299

123

278

278

315

250

R28?

251

200

278

330

R 295

297

P 284

378

7

160

129

321

351

R 772

247

742

381

143

143

262

262

164

165

166

169

170

256

293

242

242

362

360

243

R 337

109

179

392

392

123

195

350 
MC* 2, FNDF MULTIGROUP X-SFCTION CALCULATION ANL 3600 F36 RS P T B 355 MCS, MONTE CARLO NEUTRON PENETRATION STUNY LASL 7090 FLOCO RS P $B$ \$ 202 MEASUREMENTS GGA 1108 F4 RS P T A\$ TACASI, ANALYSIS OF RESONANCE MEDIUM SPECTRUM X-SECTIONS AI 7090 F+FAP RS L T R\$ QUICKIE, INFINITE MESH GGA 1108 F4 RS P T C\$ GATT, 3-D FEW-GP DIFFUSION CALC HEX-Z MESH GGA 1108 F+BAL RS D T C\$ GAMTRI, 2-D MULTIGP DIFFUSION TRIANGULAR METALLIC FISSION PRONUCT RELEASE GGA 1108 F4 RS P D\$ FREVAPG, HTGR MGDSN, 1-D MULTI-GP SN APPROX SLAR CYL SPHERE PW 1604 LAGI RS P $C$ \$ MISH-MASH, RESONANCE INTEGRAL CALC HOMOGENFOUS ANL 3600 F36 RSBP A $\$$ MIST, 1-D FEW-GP SN DOUBLE SN ADPPDX SLAB GEOM PPCO 7090 F? RS P C MIT $36 C \mathrm{~F} 4$ RS P T I\$ SABOR4, DISCRETE-FLEMENT ANALYSIS THIN SHELLS MIT $7090 \mathrm{~F}$ ? RS P PS FRANTIC, LEAST SQUARES FIT SUM OF FXPONFNTIALS MIX KAPL $6600 F_{4}$ RS P HS RAPP, HIGH-VELDCITY FLOW STUNY STEAM-WATER ML-1 FLUID FLOW EXPFRIMENT ANALYSIS AGC $7090 \mathrm{~F} 2$ RS $D$ O\$ CROC90, MODE FAST RFACTOR X-SEC CALC RNW 1108 F4 RS P T A\$ FCC4, FUNDAMENTAL MODERATIR GGA $11 C 8$ F4 RS $P$ AS GAKER, INFLASTIC SCAT X-SFCTION CALC MODERATOR SPACE CHORO DIST FUNCT AEG $7090 \mathrm{~F} 2$ RS B\$ DANCOFF JR, MODULAR DOCUMENT INFORMATION SYSTEM KAPL $6600 \mathrm{~F}$ R B T M\$ TIGIRZ, MODULAR PROGRAMMING AND DATA SYSTEM KAPL $6600 \mathrm{~F}+$ COM RSB T MS DATATRAN, MODULES, 2-D + 3-0 PLOTTING KAPL $6600 F+A S C$ RS P T P\$ DATATRAN UTILITY MOLTEN FUEL TUBE RUNDLES LASL $7 C 94 \mathrm{~F} 2$ RSBP HS AXFLU. HEAT TRANSFER MOMENT CALC AI $709 C$ FTFAP RS T $1 \$$ 4RESTRAINT PIPE STRFSS, MAXIMUM MOMUS, X-SECTIDN LIBRARY UTILITY PROGRAM AI 7094 F+FAP RS L T M S MONTE CARLO CALC NEUTRON HISTORIFS GGA 7044 F4 RS P T B\$ FMC-N, MONTE CAPLO CELL CALCULATION AI 360 F4 RS P XT B\$ HWOCR-SAFE, 2-D MONTE CARLO NEUTRON PENETRATION STUDY LASL 7C9O FLOCO RS P B\$ MCS, MONTE CARLO SLOWING-DOWN DENSITY CALC AI 7094 F+FAP RS PL T BS TYCHE3. MORTIMER, DOSE RATE CALCULATION SNAP GEOMETRY AI $7090 \mathrm{~F} 2$ RS J MUFFLE, FISSILE NUCLIDE X-SECTION EVALUATION ORNL $7090 \mathrm{~F} 4$ RSBP A \$ MULTI-CHANNEL 2-D 2-PHASE FLOW AI $7094 \mathrm{~F} 2$ RS P HS FLNW-MODEL, MULTI-GP CONSTANT CALC AGC $7090 \mathrm{~F} 2$ RSBPLXT B\$ AGN-GAM, FAST SPECTRUM MULTI-GP CONSTANT CALC O TO $10 \mathrm{MEV}$ AC $625 \mathrm{~F} 4$ RS P XT B\$ GAMTEC2, MULTI-GP CONSTANT CALC O TO 10 MFV BNW 1107 F4 RS PL T R\$ GAMTFC2, MULTI-GP CONSTANT CALC O TO 10 MEV BNW 7090 F+FAP RS PL T B\$ GAMTEC2, MULTI-GD DIFFUSION UMCC $360 \mathrm{~F} 4$ RS P T C\$ VARI-QUIR, TIME-DEP 2-D MULTI-GP DIFFUSINN WANL 6600 F4 RS P T C\$ VARI-QUIR, TIME-DEP 2-D MULTI-GP DIFFUSION + LIB AI 360 F4 RSPPLXY C\$ CAESAR4,LIBLST, 1-D MULTI-GP DIFFUSION DEPLETION CODE DRNL 7090 F+FAP RS $P$ T D ASSAULT, 2-D MULTI-GP DIFFUSION PROGRAM AAEC $360 \mathrm{~F}+B A L$ RS $P$ T C\$ CRAM, 1-D AND 2-D MULTI-GP DIFFUSION PRCGRAM ORNL 7090 F+FAP RS P T CS EXTERMINATDR, 2-D MULTI-GP DIFFUSION PROGRAM UK-R 7090 F+FAP RSBPL T CS CRAM, 1-D AND 2-D MULTI-GP DIFFUSION PRIGRAM RC $625 \mathrm{~F} 4$ RS T C\$EXTFRMINATOR2, 2-D MULTI-GP DIFFUSION PROGRAM ORNL $360 \mathrm{~F} 4$ RS P T CS EXTERMINATIR2, 2-D MULTI-GP DIFFUSION SLAR CYL SPHERE RNW 1107 F4 RS P T C\$ HFN, 1-D MULTI-GP DIFFUSION SLAB CYL SPHERE AI 7090 F+FAP RS L T CS FAIM, 1-D MULTI-GP DIFFUSION SLAB CYL SPHERE AI 7090 F+FAP RS PL T C\$ AIMG, 1-D MULTI-GP DIFFUSION SIAR CYL SPHERE CDC $1604 \mathrm{~F} 63$ RS PL T C\$ AIMG, 1-D MULTI-GP DIFFUSION SLAR CYL SPHFRF CDC 1604 F63 RS PLXT CS FAIM, 1-D MULTI-GP DIFFUSION SLAR CYL SPHERF AI TO90 F+FAP RS L T C\$ULCER, 1-D MULTI-GP TIFFUSION SLAR CYL SPHFRF ANL 3600 F36 RS P XT C\$ MACHI, 1-D MULTI-GP DIFFUSION SLAR CYY SPHEPF PURD 6500 F4 RS PLXT CS MACH1, 1-D MULTI-GP DIFFUSION SLAB CYL SPHERE BHSC. 360 F4 RS P T CS FAIMOS, 1-D MULTI-GP DIFFUSIDN SYVTHFSIS CALC NED 635 F4 RS PL T C\$ BISYN, 2-D MULTI-GD DIFFUSION XY PZ GFOMETRY GGA 1108 F+RAL RS P T C\$ GAMBLE5, 2-D MULTI-GP DIFFUSION $X Y$ RZ SFOMETRY GGA 7044 F+MAP RSBP T CS GAMBLE4, 2-D MULTI-GP DIFFUSION XY RZ RTH WANL $7094 F 4$ RS P XT C\$ VARI-QUIR3, 2-D MULTI-GP DISCPETE OPNINATF TALC AI 7093 F2 RS PLXT C\$ DTF2, 1-D MULTI-GP DISCRETF DRDINATF CALC AI 360 F4 RSBPLXT C\$ ANISN, 1-0 MULTI-GP DISCRETE ORDINATF $T$ ALC ANL 3630 F36 RS P T C SNARG-1D, 1-D MULTI-GP DISCRETE DODINATE CODE UNR-LASL 1674 F63 RS CS 2DF, 2-D MULTI-GP DISCRETE CPDINATE PROGRAM ANL 360 F4 RS P T C\$ DTF4, 1-D MULTI-GP NISCPETF MRDINATF DRDGRAM BC 625 F4 RS P T C\$ DTF4, 1-D MULTI-GP TISCRETF ORDINATE PROGRAM MULTI-GP DISCPETE ORDINATE PRIGRAM LASL $6600 \quad \mathrm{~F} 4$ RS P T C\$ DTF4, 1-D LASL 7030 F4 RS P T C\$ DTF4, 1-D

410

119

380

401

301

211

214 59

R 402

324

R 382

154

306

289

150

$R 403$

R 386

R407

182

109

159 195 307 202

149

142 323 246 204 185 185 185 212

212

270

240

103

156

103

156

156

241

120

29

29

120

118

262

262

120

287

222

222

264

151

151

288

173 209 209 209 
MULTI-GP DISCRETE ORDINATE PROGRAM LER 7094 F4 RS P T C\$ DTF4, 1-D MULTI-GP DOUBLE SN APPROX BNW 7090 FLOCO RSBP T C\$ GE-HAPO-S13, 1-D MULTI-GP DTF4 WITH DEPLETION LASL 7030 F4 RS P T D\$ DTF-BURN, 1-D MULTI-GP FLUX SYNTHFSIS PRCGRAM CYL PW 1604 F63 RS T C\$ 2NXYL, 3-D MULTI-GP SN APPROX SLAR CYL SPHERE PW 1604 LAG1 RS P C\$ MGNSN, 1-D MULTI-GP SN APPRDX SLAB CYL SPHERE UK-W 7090 F2 RS P T C\$W-DSN, 1-D MULTI-GP SN APPROXIMATION RZ PW 1604 F63 RS P T CS FIRTRAN TDC, 2-0 MULTI-GP SN APPPOXIMATION XY GEOM AGC 7090 FLDCO RSBP C\$ 20XY, 2-D MULTI-GP TRANSFER COEFFICIFNTS LRL 7090 F+FAP RS P T B $\$$ SOPHISTI/2/5, MULTI-GP TRANSFFR MATRICLS AGC $7090 \mathrm{~F} 2$ RS P T BS AGN-SIGMA, CALC OF MULTI-GP TRANSPORT CODF $X-Y$ GEOM ANL $360 \mathrm{~F} 4$ RS $P$ T C TWOTRAN, 2-D MULTI-GP TRANSPORT CODE $X-Y$ GEOM LASL 1108 F4 RS P T CS TWOTRAN, 2-D MULTI-GP $X$-SECTIONS LASL 7090 FLOCO RS P B ZOT, GROUP-COLLAPSING OF MULTI-GP $X$-SECTIONS FAST THERMAL SPECTRA GGA 1108 F4 RS PLXT R\$ GGC4, MULTI-GP X-SECTIONS FAST THFPMAL SPECTRA GGA 6600 F4 RS L T R\$ GGC4, MULTI-LEVFL CONVOLUTION PPCO 7040 F4 RS P A\$ COMBCO, COMBINED B-W MULTI-PIN FUEL ELEMFNT AGC 7090 F2 RS P B BOUNCE, FLUX DIST IN MULTIGP DRNL $360 F 4$ RS P XT K\$ CITATION, 1,2,3-D DIFFUSION DEPLETION MULTIGP DIFFUSION TRIANGULAR MFSH GGA 1108 F+BAL RS P T C\$ GAMTRI, 2-D MULTIGP KINETICS WITH TEMP FEEDBACK GGA 1108 F4 RS P T F\$ GAKIT, 1-D MULTIGROUP CONSTANTS ORNL 360 F4 RS PLXT B\$ XSDRN, DISCRETE ORDINATE MULTIGROUP CONSTANTS FROM FNDF/B FOR 1 DX BNWL 1108 F4 RS P T B\$ ETDX, MULTIGRCUD DIFFUSION ANO DEPLETION ANL $3600 \mathrm{~F} 4$ RSBP TD\$2DB, ?-D MULTIGPOUP DIFFUSIOA AND REPLETION BNW 1108 F4 RS P T $\$ \$ 2 D B, 2-D$ MULTIGRDUP DIFFUSION AND DEPLETION LASL $6600 \mathrm{F4}$ RS P T D\$ 2DB, 2-0 MULTIGROUP DIFFUSION AND DEPLETION GRA 1108 F4 RS P T D FEVER7, 1-D MULTIGRTUP DIFFISSION DEPLETION AI 360 F4 RSBP XT DS SIZZLF, 1-D MULTIGRDUP DIFFUSION DFPLFTION $A I$ I $7090 \mathrm{~F} 2$ RS L T D\$SIZZLE, $1-D$ MULTIGROUP DIFFUSION DEPLFTION CDC 1604 F63 RS L T DS SIZZLE, 1-D MULTIGRTUP DISCRFTE DRDINATE CALC UNC $1604 \mathrm{~F} 63$ RS PL T CS DTF, 1-D MULTIGROUP DISCRETE IRIINATF PROGRAM LER 7090 F+MAP RS P T C\$ TISN, 2-D MULTIGROUP SLAB GFOMITRY ANL 3600 F63 RSBPL T J\$ MAC, SHIFLD DESIGN MULTIGRDUN SLAB GEOMETRY BNW 7090 F2 RSBPL T IS MAC, SHIFLD DESIGN MULTIGROUP TIME-DEPENDENT DIFFUSION GGA $1108 \mathrm{~F} 4$ RS P T F\$ GAKIN, 1-D MULTIGRCUP X-SECTION CALCULATION ANL 3600 F36 RS P T B\$ MC*2, ENDF MULTILEVFL B-W X-SEC CALC BNL 6500 F4 RS P A\$ SIGPLOT, RESOLVFD MULTILFVEL B-W X-SEC CALC BNL 7094 F4 RS P A\$ SIGPLOT, RESOLVFD MO102, POINT DEPLETION FISSION PRODUCT BAPL $6600 \mathrm{~F} 4$ RS P DS CINDER, 313 M0219, PWR FLOW TRANSIENT ANALYSIS BAPL $6600 \mathrm{~F} 4$ RS P XT HS FLOTI, R331 M0266, LINEAR ELASTIC STRUCTURAL DYNAMICS BAPL 6600 F4 RS P XT I R383 M0457,PIPE, ELASTIC STPESS OF PIPING SYSTEM BAPL 6600 F4 RS P XT I \$R329 M0552, DYNAMIC ANALYSIS LINFAR ELASTIC SYSTFMS BAPL $6600 \mathrm{~F} 4 \quad$ RS P XT I $\$$ R283 MO555, ACT1, LOSS-OF-CUOLANT ACCIDENT ANALYSIS BAPL $6600 \mathrm{~F} 4 \quad$ RS P XT G \$R284 M0648, 1-D SLAB TRANSPIRT WITH SLIWING DOWN RAPL $6600 \mathrm{~F} 4 \quad$ RS XT C $\$$ R342 M0756,LETO, 1-D SLAB GAMMA-PAY TRANSPMRT BAPL $6600 \mathrm{~F} 4 \quad$ RS P XT J\$R343 M0807, 2-D IIFFUSION ABSTRPTION REMDVAL X-SECS RAPL $6600 \mathrm{~F} 4 \quad$ RS XT B \$R280 MO899, HOH, STEAM TABLFS $14.5-2538$ PSIA $\quad$ ANL 1604 F63 RS P $H \$ R 294$ M0899. HOH, STEAM TARLES $14.5-2538$ PSIA $\quad$ BAPL $6600 \mathrm{~F} 4 \quad$ RS P XT H \$ R294 NAP, NEUTRON-INDUCED GAMMA-PAY RADIDACTIVITY IITR 7094 F4 RSBPLXT D \$ 314 NCSC 6600 F 4 RS T M\$ CHECKER. CRFCT, DAMMET, PLOTFB, SLAV3, ENDF/B PROC 384 NEARREX, COMPOUND NIJCLEUS X-SECTION CALC ANL $3600 \mathrm{~F} 63$ RSBP A \$ 171 NED $635 \mathrm{~F} 4$ RS $P$ T RS PFAX, RESOLVFD RESONANCE EPITHERMAL X-SECTIONS 257 NED 635 F4 RS P T C\$ FLARE, 3-D REACTIVITY AND PIWER DISTRIBUTION 167 NED $635 \mathrm{~F} 4$ RS $P$ T H\$ MANTA, STFADY-STATE THERMAL-HYDRAULIC ANALYSIS 756 NED 635 F4 RS P T OS FXPN, ANALYSIS OF PULSED NEUTRON SOURCE DATA 758 NED $635 \mathrm{~F}_{4}$ RS D XT F\$ FDRE2, FAST REATTOR FXCURSION CALCULATIONS 174 NED 635 F4 RS PL T C B RISYN, 2-D MULTI-GP DIFFUSIINN SYNTHFSIS CALC 287 NED $2000 \mathrm{~F} 2$ RS P A DOPIF, RFSTLVED RFSONANCE X-SFCTION CALC $\quad 177$ NED 2000 F2 RS $P$ A\$ RAPTURE, RESUNANCE INTEGRAL X-SECTION CALC 176 NED $2000 \mathrm{~F} ?$ RS $P$ RS SPARTA, SPATIALLY-AVFRAGED DOPDLER EFFECTS 178 NED 2000 F4 RS P T F\$ FORE, FAST RFACTOR EXCURSION CALCULATIONS 174 NEUTRON DATA LIBRARY LRL $7094 \mathrm{~F} 2$ RS PL T M\$ ECSIL, EXPERIMENTAL 351 NEUTRON HISTORIES COGA $7044 \mathrm{~F} 4$ RS P T BS FMC-N, MONTE CARLO CALC 
NEUTRON PENETRATION CALCULATION DAC $7090 \mathrm{~F} 2$ RSBP J\$ LIPRECANI, MC NEUTRON PENETRATION STUDY LASL 7090 FLOCO RS P BS MCS, MONTE CARLO NEUTRON SOURCE DATA NED $635 \mathrm{~F} 4$ RS P T O\$ EXPN, ANALYSIS OF PULSED NEUTRON SPECTRUM X-SECTION CALC AI $7090 \mathrm{~F} 2$ RS PL T BS FORM, FAST NEUTRON SPECTPUM $X$-SECTION CALC NEUTRON SPECTRUM $X-S E C T I O N$ CALC NEUTRON SPECTRUM $X-S E C T I O N$ CALC NEUTRON SPECTRUM $X$-SECTION CALC ANL 3600 F63 RS LXT B\$ GAMI, FAST CDC 1604 F63 RS PL T BS FORM, FAST CDC 1604 F63 RS PLXT B\$ GAMI, FAST GGA 7090 F2 RS PLXT B \$ GAML, FAST NEUTRON SPFCTRUM X-SFCTIONS AI 7090 F+FAP RS PL T B\$ TEMPEST2, THERMAL NEUTRON SPECTRUM X-SECTIONS BHSC $360 \mathrm{~F} 4$ RS PL T B\$ TEMPEST2, THERMAL NEUTRON SPECTRUM $X$-SECTIONS COC 1604 F63 RS PL T B\$ TEMPEST2, THERMAL NEUTRON X-SECTION CALCULATION BAPL 6600 F4 RS P XT AS SUMOR, S-WAVE NEUTRON-HYDRODYNAMICS APDA 7094 F2 PS P FS WEAK EXPLOSION, COUPLED NEUTRON-INDUCED GAMMA-RAY RADIOACTIVITY IITR 7094 F4 RSBPLXT D\$ NAP, NEUTRON, GAMMA-RAY HISTORIES PW 1604 F+CDP RS P XT B\$ FMC-N,FMC-G, MC NEUTRONICS-HYDRODYNAMICS CODE AGC $7090 \mathrm{F2}$ RSB F\$ HATCHET, COUPLED NEUTRONICS-HYDRODYNAMICS SPH PW $1604 \mathrm{~F} 63$ RS P F\$ AX-TNT, COUPLED NEUTRDNICS-HYDRODYNAMICS SPHERE CDC 3600 F63 RSBP F\$ AX1, COUPLED NEUTRONICS-HYDRODYNAMICS SPHERF LRL $7090 \mathrm{~F} 2$ RS $P$ F\$ CONEC, COUPLED NOAH, I-D ONE-GP SPACE-TIME DIFFUSION FEEDBACK BNL $6600 \mathrm{~F} 4 \quad$ RS $P$ T $F$ s NON-SPHERICAL OPTICAL MODEL X-SECTIONS AI $7094 \mathrm{F2}$ RS P T AS 2 PLUS, NON-SPHER ICAL OPTICAL MOOEL X-SECTIONS ANL 3600 F63 RSBP T A\$ 2 PLUS, NONLINFAR ALGEBRAIC ERN SOLN CURVE PLOT KAPL $6600 \mathrm{~F}+A S C$ RS P $T$ P\$ SNEQ, NOWIG, 1-D 2-GP KINETICS TEMPERATURE FEEDBACK BAPL 6600 F4 NPRFCCP, FUEL CYCLE COSTS PFRFORMANCE DATA KE $7090 \mathrm{F2}$ NUCLEAR FUEL CYCLE COST AND ECONOMICS COMM $360 \mathrm{~F} 4$ NUCLEAR STATION ELECTRICITY COSTS ORNL 1604 F63 NUCLEUS X-SECTION CALC NUCLIDE. CHAIN EQUATIONS ANL 3600 F63 RSBP RS P RS P XT F S RSBP XT O NUCLIDE DATA BAPL $6600 \quad F 4$ DRNL 7090 F? RSBP $T$ D\$ CINCAS, RS P DS POWERCD, A \$ NEARREX, COMPOUND D\$ NUCY, SOLUTION OF NUCLIDE X-SECTION EVALUATION ORNL $7090 \quad F 4$ NUCY, SOLUTION OF NUCLIDE CHAIN EQUATIONS NURLOC-1.0, LOSS-OF-COOLANT THERMAL ANALYSIS BCL $6400 \mathrm{~F} 4$ RS P T ONE-GP SPACE-TIME DIFFUSION FEEDBACK BNL $6600 \quad \mathrm{~F} 4$ RS P T F\$ NOAH, 1-D OPTICAL MODFL X-SECTIONS AI $7094 \mathrm{~F} 2$ RS P T AS 2PLUS, NON-SPHERICAL OPIICAL MODEL X-SECTIONS ANL 3600 F63 RSBP T AS 2PLUS, NON-SPHERICAL DPTIMIZATION AI $7090 \mathrm{~F}$ ? RS IS CROCK, SPACE POWFR PLANT DESIGN OPTIMIZATION AI 7096 F2 RS I\$ SHOCK, SPACE POWER PLANT DESIGN OPTIMIZATION DOSE CALC AI $7094 \mathrm{~F} 2$ RS P J\$ SHOE, SHIELD WEIGHT OPTIMIZATION STUDY PW 1604 F63 RS I\$ WOPEXPRT, REACTOR WEIGHT OPUS, POWER PLANT PERFORMANCF AND PRICE STUDY GGA $7044 \mathrm{~F}+M A P$ RS $P$ T $D$ \$ ORDINATE CALC AI $700 \mathrm{C} F 2$ RS PLXT C\$ DTF2, I-D MULTI-GP DISCRETE ORDINATE CALC AI $36 \mathrm{CF}_{4}$ RSBPLXT C\$ ANISN, 1-D MULTI-GP DISCRETE ORDINATE CALC UNC $1604 \mathrm{~F} 63$ RS PL T C\$ DIF, 1-D MULTIGRDUP DISCRETE ORDINATF CALC ANL $3600 \quad F 36$ RS P T C SNARG-1D, 1-D MULTI-GP DISCRETE ORDINATE CDDE UNC-LASL $16 C 4$ F63 RS CS 2DF, 2-D MULTI-GP DISCRETE ORDINATE MULTIGRDUP CONSTANTS ORNL $360 \mathrm{~F} 4$ RS PLXT $8 \$$ XSDRN, DISCRETE ORDINATF PROGRAM ANL $360 \mathrm{~F} 4$ RS P T C\$ DTF4, 1-D MULTI-GP DISCRETE ORDINATE PROGRAM BC $625 \mathrm{~F} 4$ RS P T C\$ DTF4, 1-D MULTI-GP DISCRETE DRDINATF PRDGRAM LASL $6600 \mathrm{~F} 4$ RS P T C\$ DTF4, 1-D MULTI-GP DISCRETE ORDINATE DRRGRAM LASL 703 C F4 RS P T C\$ DTF4, I-D MULTI-GP DISCRETE ORDINATE PROGRAM LEP 7094 F4 RS P T C\$ DTF4, 1-D MULTI-GP DISCRETE ORDINATE PROGRAM LER $7090 \mathrm{~F}+$ MAP RS P T C TDSN, 2-D MULTIGRDUP DISCRETE ORDINATFS SLAB GEOMFTRY BAPL $6600 \mathrm{~F} 4$ RS P XT C\$ BE21, FEW-GP DISCRETE ORNL 360 F+BAL RS P T R\$ RAFFLE, IST FLIGHT COLLISION PROBARILITIES MC ORNL $360 \mathrm{~F}_{4}$ RS $P$ D ISOSEARCH, ISOTOPE PRODUCTION FLUX, $X-S E C$ CALC ORNL 360 F4 ORNL 360 F4 ORNL $360 \quad F 4$ ORNL $1604 \quad F 63$ ORNL 1604 F63 ORNL 1604 F63 ORNL $16 C 4$ F63 RS $P$ C\$ FXTERMINATOR2, 2-D MULTI-GP DIFFUSION PROGRAM RS $P X T K \$$ C.ITATION, 1,2,3-D DIFFUSION DEPLETION MULTIGP RS PLXT R\$ XSDRN, DISCRETF ORDINATE MULTIGROUP CONSTANTS RS $P$ AS PEGGY, ELASTIC SCATTERING PHASE-SHIFT ANALYSIS RS $P$ A R RAMES, PARTICLE WAVE FUNCTION RADIAL INTEGRALS RS $P$ DS ISOCRUNCH, REACTION DECAY CHAIN ANALYSIS ORNL 1604 F63 RS P D\$ I SOSEARCH, ISOTOPE PRODUCTION FLUX, X-SEC CALC RS P D\$ ISOTOPES, MAXIMUM YIELD FROM REACTION DR DECAY

123

202

258

51

33

51 33 33 50 50 50 R399 145 314 195 153 191 102 129 405 254 254 R 364 R 371 146 354 340 171 134 R327 323 134 328 405 254 254 112 114 197 190 226 151 151 144 288 173 393 209 209 209 209 209 312 R398 
ORNL $16 \cap 4$ F63 RS P D\$ POWERCO, NUCLEAR STATION ELECTRICITY COSTS

ORNL 1604 F63 RS 9 T A\$ JUPITORI, COUPLED-CHANNEL X-SFC FVALUATION

ORNL 7090 F+FAP RS $P$ T B\& RAFFLE, IST FLIGHT COLLISION PROBABILITIES MC.

ORNL 7090 F+FAP RS D T C\$ FXTERMINATOR, 2-D MULTI-GP DIFFUSION PROGRAM

DRNL 7090 F+FAP RS $P$ T DS ASSAULT, 2-D MULTI-GP DIFFUSION DEPLETION CDDE

ORNL $7090 \mathrm{~F} 2$ RS A\$ I YNNE, WOODS-SAXON POTENTIAL SHAPE CALCULATION

ORNL $7090 \mathrm{FP}$

ORNL $7090 \quad F 2$

ORNL $7090 \quad F 2$

ORNL $7090 \mathrm{F2}$

ORNL $7090 \quad F 2$

ORNL $7090 \quad F 2$

ORNL $7090 \quad F 4$

RS D

D I STCRUNCH, REACTION DECAY CHAIN ANALYSIS

RS P T CS FQUIPOISE3, 2-D 2-GRDUP DIFFUSION SLAB CYL

RS $P$ T C\$ EQUIPCISE3A, 7-D 2-GP DIFFUSION CYLINDER SLAB

RS D T C\$ WHIRLAWAY, 3-D 2-GROUP DIFFUSIDN XYZ GEOMETRY

RS P T CE 2 CGPAND, 2-D FEW-GRDUP DIFFUSIDN SLAB CYLINDER

RSBP DS NUCY, SOLUTION OF NUCLIDE CHAIN EQUATIONS

RSBP A\& MUFFLE, FISSILE NUCLIDE X-SECTION FVALUATION

OUTPUT PW 1604 LAGI RS $D$ N\$ DTX. EFFFCTIVE X-SECTION CALC FROM DSN

OUTPUT IATA LASL 6600 F4 RS P T B\$ GLEN, GROUP CONSTANT CALC FROM TOR

OUTPUT TAPF EDIT REACTION RATES UK-W 7090 F2 RS WS WED. W-NSN

OVERLAP AND LATTICE EFFECTS GGA $7044 \mathrm{~F}+M A P$ PS P T B\$ GAROL, RESONANCE

OVERLAP AND LATTICE EFFECTS LER 7094 F4 RS P T B\$ GAROL, RFSONANCE

PARALLEL BFAMS ANL 3600 F36 SBP I\$ BNW2, DEFLECTION CALCULATION

PARTIAL RFFUEL GGA 7044 F4 RS P T DS GARGOYLE, FUEL CYCLE ANALYSIS

PARTICLE WAVE FUNCTION RADIAL INTEGRALS ORNL 1604 F63 RS P A\$ RAMES,

PDO5, 2-D FFW-GROUP DIFFUSION AND DFPLFTIDN IBM 36OF+BAL RS P I D R336

PDQ7, 1,2 CR 3-D FEW-GP DIFFUSION DEPLETION BAPL 6600 F+ASC RS P XT D $\$$ R275

PDQ7, 1,2 DR 3-D FEW-GP DIFFUSION DEPLETION IBM 360 F4 RS P T D $\$$ R275

PEGGY, ELASTIC SCATTERING PHASE-SHIFT ANALYSIS ORNL 1604 F63 RS P A $\$ 334$

PENETRATION CALCULATION DAC $7090 \mathrm{F2}$ RSBP J\$LIPRECANI, MC NEUTRON

PENETRATION STUDY LASL 7090 FLOCO RS P BS MCS, MONTE CARLO NEUTRON

PERFORMANCE AND PRICF STUDY GGA $7044 \mathrm{~F}+M A P$ RS $P$ T D\$ OPUS, POWER PLANT

PERFORMANCF DATA KE $7090 \mathrm{~F} 2$ RSBP D\$ NPRFCCP, FUFL CYCLE COSTS

PERFORMANCE STUDY GGA 7044 F4 RS P DS WAMPUM, FUEL CYCLE COSTS

PERT, 1-D PERTURBATION FOR AIM AND FRG CODES

PERT, $1-D$ PFRTURBATION FOR AIM AND FOG CODES

PERT, I- $\cap$ PFRTURBATION FOR AIM AND FOG CODES

AI $7090 \mathrm{F2}$

$\begin{array}{llllll}\text { BHSC } & 360 & F 4 & \text { RS P } & C & \text { C }\end{array}$

RS

$C$ s

PERTURBATION FOR AIM AND FOG CODES

PERTURRATION FOR AIM AND FOG CODES

PERTURBATION FOR AIM AND FOG CODES

AI 7090 F2 RS

BHSC $360 \mathrm{~F} 4$ RS P

CDC $1604 F_{63}$ RS

PERTURBATION TDC OR 2NXY FLUX INPUT PW 1604 F63 RS

PERTURBATION XY RZ RTHETA GEOMETRY BNW $1108 \mathrm{~F} 4$ RS $P$

PERT4, 2-D PFRTURRATION XY RZ PTHETA GEOMFTRY BNW 1108 F4

C\$ PERT, 1-D

C\$ PERT, 1-D

$C \$ P E R T, 1-D$

C\$ TDP, 2-D

C\$ PERT4, 2-D

123

202

226

146

224

PHASE-SHIFT ANALYSIS ORNL 1604 F63 RS $P$

PHOTOFRACTT ANALYSIS ORNL

PHOTOFRACIIONN SOLID CRYSTAL UM 7090 MAD RSB O\$ BURP4, GAMMA-RAY

PHOTOFRACTION WELL CRYSTAL UM 7090 MAD RSB OS RURP5, GAMMA-RAY

PIP, CENTRIFUGAL PUMP IMPELLFR DESIGN STUDY PW 1604 F63 RS P TI \$ PIPE STRESS, MAXIMUM MOMENT CALC AI 7090 F+FAP RS T IS 4RESTRAINT PIPE, ELASTIC STRESS OF PIPING SYSTEM RAPL $6600 \mathrm{F4}$ RS P XT I\$MO457, PIPING SYSTEM BAPL 6600 F4 RS P XT I\$ M0457,PIPE, ELASTIC STRESS OFF PIPING SYSTEM ANALYSIS KE 3600 F36 RSBP G\$WHAM, LIQUID-FILLED PLANE + AXISYMMETRIC STRFSS ANALYSIS GGA 1108 F4 RS P I\$SAFE-2D, PLANE STRFSS ANALYSIS, 2-D BDDIES GGA 1108 F4 RS P I\$ SAFE-PLANE, PLANE STRUCTURES BAPL $66 C 0 F 4$ RS P XT L\$ RL47, DRAFTING TOOL TO PLOT PLANT DESIGN OPTIMIZATION AI $7090 \mathrm{F2}$ RS PLANT DESIGN OPTIMIZATION AI $7090 \mathrm{~F} 2$ RS I\$ SHOCK, SPACE POWER PLANT PERFORMANCE ANO PRICF STUDY GGA 7044 F+MAP RS P T D\$ OPUS, POWER PLOT KAPL $6600 \mathrm{~F}+\mathrm{ASC}$ RS $P$ T PS SNEQ, NONLINEAR ALGEBRAIC EQN SOLN CURVE PLOT PLANE STRUCTURES BAPL 6600 F4 RS P XT L\$BL47, DRAFTING TOOL TO PLOTFB, SLAV3, ENDF/B PROC NCSC 6600 F4 RS T M\$CHECKER,CRECT,DAMMET, PLOTS FROM SCISRS X-SECTION TAPES WANL $7094 \mathrm{~F} 2$ RSB T N\$ CPS, SC4O20 PLOTS FROM X-SECTION TAPFS GGA 7044 F4 RSBP T N\$ CROSSPLOT. SC4O2O PLOTIING KAPL $6600 \mathrm{~F}+\mathrm{ASC}$ RS P T P\$ DATATRAN UTILITY MODULES, 2-D $+3-D$ POINT DEPLETION FISSINN PRODUCT BAPL 6600 F4 RS P DS CINDER,MOIO2, POINT SOURCE UM 7090 MAD RSB OS BURPI, DETECTOR EFFICIENCY POINT SOURCE UM 7090 MAD RSB OS BURP3, DETECTOR EFFICIFNCY POINT-KINETICS WITH 2-D HFAT TRANSFER GGA 7044 F4 RS TS HLDOST, POINTS KAPL $6600 \mathrm{~F}+A S C$ RS $P$ T $\$$ CURFIT, CURVE FITTING EXPERIMENTAL DATA

30

30

30

30

30

30

199

304

304

334

169

170

187

109

R329

R329

278

379

252

R373

112

114

226

R 364

R373

384

239

207

R407

313

164

166

205

R 43 
POST RUPTURE GGA 7044 F4 RS XT GS PRFCON, HTGR CONTAINMENT PRESSURE POTENTIAL SHAPE CALCULATION ORNL $7090 \mathrm{~F} ?$ RS AS LYNNE, WODNS-SAXON POWER AND FLOW TRANSIENTS ANL 360 F4 RS P T F\$SASIA, FAST RFACTOR POWER AND FLOW TRANSIENTS ANL 6600 F4 RS P T F\$ SASIA, FAST RFACTOR POWER DIST SEARCH GGA 7044 F4 RS P T C\$ GASP2, 1-D FEW-GP DIFFUSION POWER DISTRIBUTION CDC 3600 F63 RSRP T C\$FLARE, 3-D REACTIVITY AND POWER DISTRIBUTION NED 635 F4 RS P T C\$ FLARE, 3-D REACTIVITY AND POWER DISTRIRUTION SEARCH GGA 1108 F4 RS P T C\$ GASP7, 1-D BURNUP POWER PLANT DESIGN DPTIMILATION AI 7090 F2 RS I\$ CROCK, SPACE POWER PLANT DESIGN DPTIMIZATION AI $7090 \mathrm{~F} 2$ RS I\$ SHDCK, SPACE POWER PLANT PERFORMANCE AND PRICE STUDY GGA $7044 \mathrm{~F}+\mathrm{MAP}$ RS P $T$ DS OPUS, POWERCO, NUCLFAR STATION FIECTRICITY COSTS ORNL 1604 F63 RS P D PPCO 7040 F +MAP RS P T G\$ CONTEMPT, LDSS-OF-COOLANT ACCIDENT ANALYSIS PPCO 7040 F+MAP RS P T G\$RSAC, RADIOLDGICAL SAFETY ANALYSIS PROGRAM PPCO $7040 \mathrm{~F} 4$ RS P A\$ COMBCO, COMBINFD A-W MULTI-LEVEL CINVOLUTION PPCO 7040 F4 RS P T C\$ TOPIC, 1-D FEW-GP SN APPROXIMATION CYLINDER PPCO 7044 F+MAP RS $P$ T H\$ TOODEE, 2-D TIME-DFPENDENT HEAT CONDUCTION PPCD 7090 F2 RS P C\$MIST, 1-D FEW-GP SN DOUBLE SN APPRחX SLAB GEOM PPCO 7090 F2 RS P T C\$ TOPIC, 1-D FEW-GP SN APPROXIMATION CYLINDER PRECON, HTGP CONTAINMENT PRESSURF POST RUPTURF GGA 7044 F4 RS XT G $\$$ PREPARATION GGA 1108 F4 RS P T L\$ GAND, GAFGAR X-SECTION LIBRARY PREPARATION PW 1604 F63 RS L\$CSPI, SN X-SECTION LIBRARY TAPE PREPARATION PW 1604 F63 RS L\$CSP2A, SN X-SECTION LIBRARY TAPE PREPARATION FOR 2-D DESIGN PROGRAMS LASL 7090 F2 RS P T L\$ DPC, DATA PREPARATION, EDIT KAPL 6600 F+ASC RS P T L\$ DATATRAN 2-D GEOMETRY INPUT, PRESSURE DISTRIBUTION GGA 1108 F5 RS P H\$ FLAC, STEADY-STATE FLOW, PRESSURE POST RUPTURE GGA 7044 F4 RS XT G\$ PRECON, HTGR CONTAINMENT PRESSURF TEMPERATURE HISTOPY KE 7094 F2 RSBP T H\$ PTH1, BLOWDOWN PRESSURE VESSEL STRESS AND FATIGUE KAPL $6600 \mathrm{F4}$ RS I\$ SORSDB, PRESSURILERS BAPL 6GCO F4 RS P XT H\$ TOPS, TRANSIENT THERMODYNAMICS DF PRICE STUDY GGA 7044 F+MAP RS P T D\$ DPUS, POWER PLANT PFRFORMANCE AND PROBABILITIES MC ORNL $360 \mathrm{~F}+B A L R S P$ T B\$ RAFFLE, IST FLIGHT COLLISION PROBABILITIES MC ORNL 7090 F+FAP RS P T R\$ RAFFLE, IST FLIGHT COLLISION PROC DP $360 \mathrm{FH}$ RS P T A\$ FLANGF2, ENDF/B THERMAL SCATTERING DATA PROC NCSC 6600 F4 RS T M\$ CHECKER,CRECT, DAMMET, PLOTFB, SLAV3, ENDF/B PROCESSING TF ANALYZER GAMMA-RAY SPECTRA GGA 1108 F4 RS P T DS TOAD, PROGRAMMING AND DATA SYSTEM KAPL $6600 \mathrm{~F}+\mathrm{COM}$ RSB T M\$ DATATRAN, MODULAR PROPERTIES BAPL $6600 \mathrm{~F} 4$ RS P XT H\$ WASP, WATER AND STEAM THERMODYNAMIC PSEUDD, STATISTICAL RESDNANCE PARAMETER CALC GGA 1108 F4 RS P A $\$$ PTHI, BLDWDNWN PRESSURE TEMPERATURE HISTMRY KE $7094 \quad F 2 \quad$ RSBP T H $\$$ PULSED NEUTRON SOURCF DATA NED $635 \mathrm{~F} 4$ RS P $T$ O\$ EXPN, ANALYSIS OF PUMP IMPELLER DESIGN STUDY PW 1604 F63 RS P I I\$PIP, CENTRIFUGAL PUN1, UNRESTLVED RESONANCF INTFGRALS X-SECS BAPL $6600 F 4$ RS P XT A PURD $6500 \mathrm{~F} 4$ RS PLXT C\$ MACH1, 1-D MULTI-GP DIFFUSION SLAB CYL SPHERF PW $1604 \mathrm{~F}+\mathrm{CDP}$ RS $P$ T P\$ LAG, ASSEMBLER FOR FLOCD2 INSTRUCTION SET PW $1604 F+C D P$ RS P XT R\$ FMC-N,FMC-G, MC NEUTRON, GAMMA-RAY HISTORIES PW 1604 F63 RS C\$ TDP, 2-D PERTURAATION TDC OR 2DXY FLUX INPUT PW 1604 F63 RS I\$ WOPEXPRT, REACTOR WEIGHT OPTIMIZATION STUDY PW $1604 \mathrm{F63}$ RS L\$ CSPI, SN X-SECTION LIBRARY TAPE PREPARATION PW 1604 F63 RS L\$CSP2A, SN X-SECTIDN LIBRARY TAPE PREPARATION PW $16 C 4$ F63 RS TC\$2DXYL, 3-D MULTI-GP FLUX SYNTHESIS PROGRAM CYL PW 1604 F63 RSP E\$ CMPXMAT. TRANSFER FUNCTION EVALUATION

PW 1604 F63 RS P F\$ AX-TNT; CDUPLFD NEUTRONICS-HYDRODYNAMICS SPH

PW 1604 FG3 RS $P$ L\$ SNC, CALCULATION OF SN CONSTANTS FIR DSN TDC

PW 1604 F63 RS P T CS FORTRAN TDC, 2-D MULTI-GP SN APPROXIMATION RZ

PW 1604 F63 RS P T I\$ PIP, CENTRIFUGAL PUMP IMPELLER DESIGN STUDY

PW 1604 LAGI RS P C\$ MGDSN, 1-D MULTI-GP SN APPRTX SLAB CYL SPHERE

PW 1604 LAGL RS P N\$ DTX. EFFECTIVE X-SECTION CALC FROM TSN OUTPUT PWR FLOW TRANSIENT ANALYSIS BAPL 6600 F4 PS P XT H\$ FLOTI, MO219, QUICKIE, INFINITE MEDIUM SPECTRUM X-SFCTIONS AI 7090 F+FAP RS L T B R-Z GEOMETRY APDA 7094 F4 RS P F\$ MARS, 2-D FXCURSION CALCULATION RABBLE, WLIR,FLAT, RESTNANCE ARSORPTION, CELL ANL 3600 F 36 RSBP XT B \$ RADIAL INTFGRALS ORNL 1604 F63 RS P A RAMES, PARTICLE WAVE FUNCTION RADIATOR FINS SNAP GEOM AI 709C F2 RS JS SCARF2, SCATTER FROM

228

381

400

400

220

167

167

319

112

114

226

340

297

265

203

148

349

59

148

228

345

194

193

234

R 406

395

228

155

R 391

R 348

226

392

392

368

384

333

R386

R 396

292

155

258

187

R359

262

186

195

199

190

194

193

192

188

191

189

161

187

211

210

R331

119

293

281

335

110 
RADIOACTIVITY IITR 7094 F4 RSPPLXT DS NAP, NEUTRON-INDUCFD GAMMA-RAY RADIOLOGICAL SAFETY ANALYSIS PROGRAM DPCD $7040 \mathrm{FHMAP} R S$ P T G\$ RSAC. RADIONUCLIDE GENFRATIIN AND DECAY RNW $1108 \mathrm{F5}$ RSBPL T D\$ ISOCEN, RAD2, HTGR FISSION PRDDUCT ACTIVITY RIST STUDY GGA 7044 F4 RSP RAFFLE, IST FLIGHT COLLISINN PRIBABILITIES MC ORNL 360 F+RALRSP TR $\$ 392$ RAFFLE, IST FLIGHT COLLISION PROBABILITIES MC MRNL 7090 F+FAP RS P T R \$ 392 RAMES, PAPTICLE WAVE FUNTTICN PADIAL INTFGRALS ORNL 1604 F63 RS P A 335 RAPFU, FUFL CYCLE PAPAMETFRS FAST RREEDERS APO 635 F4 $\quad$ RS P 0 \$ 372 RAPP, HIGH-VELOCITY FLOW STUDY STEAM-WATER MIX KAPL 6600 F4 RS P H $\quad$ R382 RAPTURE, RESINANCE INTEGRAL X-SECTION CALC NED $2000 \quad F 2 \quad$ RS P A 176 RATES UK-W 7090 F2 PS N\$ WED, W-DSN OUTPUT TAPE FOIT REACTION 133 RATH, 2- OR 3-D HEAT CONDURTION LUMPED MASS LASL 7030 F RS TH \$242 RATH, 2- IR 3-0 HFAT CONDUCTION LUMPFD MASS LASL 7094 FAP RS P TH $\$ 342$ RATRAP, DISE RATE CALCULATION SNAP GEOMFTRY AI $7090 \mathrm{F2} \quad \mathrm{RS} P \quad \mathrm{~J} \$ \mathbf{1 4 1}$ RAUMZEIT, 1-D TIMF-DEDENDFMT DIFFUSION CALC KAPL $6600 F 4$ RS P F $\$$ R352 REACTION ANL 3600 F36 RSAP G\$ CHEMLOC2, CORE HFATING CLADOING-STEAM 366 REACTIIN DECAY CHAIN ANALYSIS ORNL 1604 F63 RS P D\$ ISOCRUNCH. REACTION DFCAY CHAIN ANALYSIS REACTION OR DECAY ORNI 1604 F63 RS D DS ISOTOPES, MAXIMUM YIELD FROM REACTION RATES UK-W 7090 F? RS N\$ WED, W-DSN OUTPUT TAPE EDIT REACTIVITY AND PDWER DISTRIRUTION CDC $360 C$ F63 RSBP T C\$FLARE. 3-D REACTIVITY AND POWER DISTRIRUTIUN NED 635 F4 PS P T C\$FLARF. 3-D REAX, PESCLVFD RESONANCF FPITHERMAL X-SFCTIONS NFD 635 F4 RS P T $R$ REDUCTIDN ANL 3600 F63 RSAP O\$ COINC, COINCIDENCE COUNTING DATA REFUEL GGA $7044 \mathrm{~F} 4$ PS P T D\$ GAPGOYLF, FUFL CYCLE ANALYSIS PARTIAL RELAP2, RFACTOR RLOWDOWN - FXCURSION ANALYSIS INC 7044 F4 RS P T $\mathrm{T}$ \$ RELEASE GGA $1108 \mathrm{~F} 4$ RS P OS FREVAD6, HTRR METALLIC FISSION PRONUCT RELOAD-FEVER, 1-D FEW-G,D DITFUSINN DEPLETION GGA 7044 F4 RSP T D REMOVAL X-SFCS BAPL 66COF4 RS XT RD MOBOT, 2-D DIFFUSION ABSORPTION RESOLVED MULTILEVFL B-W X-SFC CALC ANL $6600 \mathrm{~F} 4$ RS P A\$ SIGPLOT, RESOLVED MULTILEVEL B-W X-SEC CALC BNL 7094 F4 RS P A\$ SIGPLOT, RESOLVFT RFGION RESUNANCF INTEGRAL CALC GGA 7090 F+FAP PSB T A\$ ZUT, RESOLVFD RFSONANCE EPITHERMAL X-SECTIONS NED $635 \mathrm{~F} 4 \quad$ RS P T R\$ RFAX, RESOLVED RESONANCE INTFGRAL CALCULATION BW 2000 F4 RS A\$STRIP, RESOLVED RESONANCE X-SECTION CALC. NED $2000 F 2$ RS P A\$ DOPIF, RESONANCE ARSORPTION, CELL ANL 3600 F36 RSRP XT B\$ RABRLF, WLIB, FLAT, RESONANCE DATA GGA $7044 \mathrm{~F} 4$ DS $p$ AS FASDOP, X-SFCTINNS FRDM B-W RESONANCE DATA UILL $36 C$ F4 RS P A\$ CONILLI, LEAST SOUARFS ANALYSIS RESONANCF EPITHERMAL X-SFCTIONS NED 635 F4 RS P T B\$ DEAX. RESTLVED RESONANCF INTEGRAL CALC GCA 7090 F+FAP PSB T A\$ ZUT, RFSOLVED REGION RESONANCE INTEGRAL CALC GGA 7090 F+FAP RSR T A\$ TUZ, UNRESOLVED REGION RESONANCE INTEGRAL CALC HOMTGENETUS ANL 3600 F36 RSBP A\$ MISH-MASH, RESONANCE INTEGRAL CALC 2-PFG CELL ANL 3600 F36 RSBP XT B\$ RIFF-RAFF, RESONANICE INTEGRAL CALCULATION BW $2 C O C$ F4 RS AS STRIP, RESDLVED RESONANCE INTFGRAL HEX CELL BAPL 6500 F4 RS P XT B\$ RESO2, RESOO, DBF1, RESONANCF INTEGRAL X-SECTIIN CALC AI 7090 F2 PS PL TA\$ ARFS2, RESONANCE INTFGRAL X-SECTICN CALC AI $7094 \mathrm{~F}+M A P$ RS PLXT AS TRIXI, RESONANCE INTEGRAL X-SFCTION CALC CDC $1604 \mathrm{~F} 63$ RS PL TASARFS2, RESONANTE INTEGRAL X-SECTION CALC NET $2000 \mathrm{~F} ?$ RS P AS RAPTURF. RESONANCE INTEGRALS X-SECS PAPL 6600 F4 RS P XT A\$ PUNI, IJNRESDLVED RESONANCE MFASUREMENTS GGA 1108 F4 RS P T AS TACASI, ANALYSIS TF RESONANCF DVERLAP AND LATTICE FFFFCTS GGA 7044 F+MAP RS P T BS GARTL. RESONANCE OVERLAD AND LATTICE EFFECTS LER $7094 F 4$ PS P T B\$GARDL, RESONANCE PARAMETEP CALC G,GA 1109 F4 RS P AS PSEUDO, STATISTICAL RESONANCE PARAMETERS WANL $7094 \mathrm{~F} 2$ RS $P$ AS EXT, X-SFCTIINS FROM R-W RESONANCE X-SECTION CALC NED $2000 F 2$ RS $P$ A\$ DOPIF, RESOLVFD RESONANCF X-SFCTION CALC GGA 1108 F4 RS P A\$ GANDY, UNRFSOLVED RESONANCES AI $36 \cap F 4$ RS PLXT B\$ AILMOE, X-SECTION CALC ELASTIC SCAT RESONANCES AI 7094 F+FAP PS PL T B\$ AILMNE, X-SECTION CALC FLASTIC SCAT RESOO.DRF I, RFSONANCF INTEGPAL HFX CFLL RAPL 66OOF4 RS D XT R\$RFSO2, R?85 RESQ2, RFSOD, DBF1, RESINANCE INTEGRAL HEX CELL BAPL 6600 F RS P $\mathrm{PT} \$$ R2B5 RETRIFVAL FROM SCISPS X-SECTION TAPE GGA 7044 F+MAP RSPP MS UNPACK, TO6 REVISED-GAD, FUFL CYCLE ANALYSIS W/REFUELING GGA $7044 F 4 \quad R S P$ T $\$ 223$ REVOLUTION KAPL GGOC F4 RS P T IS STR?, STRESS ANALYSIS SHELLS OF R BO 
RIFF-RAFF, RESONANCE INTEGRAL CALC 2-REG CELL ANL 3600 F36 RSBP XT B \$ 213 RING SNAP GEOMETRY AI $7090 \mathrm{F2}$ RS JS SCAR1, SCATTER FROM A RSAC, RADIOLOGICAL SAFETY ANALYSIS PROGRAM PPCO 7040 F+MAP RS P T G $\$$ RTH WANL 7094 F4 RS P XT C\$ VARI-QUIR3, 2-D MULTI-GP OIFFUSION XY RZ RTHETA GEOMETRY BNW 1108 F4 RS P C\$ PERT4, 2-D PERTURBATION XY RL RUPTURE GGA $7044 \mathrm{~F} 4$ RS XT G\$ PRECDN, HTGR CONTAINMENT PRESSURF POST RL PW 1604 F63 RS P T C\$ FORTRAN TOC, 2-D MULTI-GP SN APPROXIMATION RZ GEOMETRY GGA TO90 F+FAP RSBP T DS DOB, 2-0 FEH-GP DIFFUSION BURNUP RZ GEOMETRY LRL 709 F2 RS C\$ FIRN, 2-D FEH-GP S4 APPROXIMATION RZ GEOMETRY GGA 1108 F+BAL RS P T C\$ GAMBLE5, 2-D MULTI-GP DIFFUSION XY RZ GEOMETRY GGA 7044 F+MAP RSBP T C\$ GAMBLE4, 2-D MULTI-GP DIFFUSION XY RZ RTH WANL 7094 F4 RS $P$ XT C $\$$ VARI-QUIR3, 2-D MULTI-GP DIFFUSION XY RZ RTHETA GEOMETRY BNW 110 F F4 RS P C\$ PERT4, 2-D PERTURBATION XY R101, SPACE-INDEPENDENT KINETICS KEX OPTIONS ANL 3600 F63 RSBP E \$ R101, SPACE-INDEPENDENT KINETICS KEX OPTIONS R102, SPACE-INDFPENDENT INVERSE KINETICS CALC R 102, SPACE-INDEPENDENT INVERSE KINETICS CALC R153. PARAMETRIC SITE REQUIREMENT STUDY WANL $7094 F_{4}$ RS P E \$ ANL 3600 F63 RSBP E $\$$ WANL 7094 F4 RS E $\$ 168$ SABOR 4, DISCRETE-ELEMENT ANALYSIS THIN SHELLS MIT 360 F4 RS P TIS SAFE PRDGRAMS GGA 1108 F4 RS P L\$ GRDWRK, GRID GENERATION FOR SAFE-AXISYM, STRESS ANALYSIS AXISYMMETRIC LOAO GGA 7044 F4 RS P T I SAFE-CREEP, VISCOELASTIC ANALYSIS CONCRETE SAFE-PCRS, STRESS ANALYSIS AXISYMMETRIC LOAD SAFE-PLANF, PLANE STRESS ANALYSIS, 2-D BODIES SAFE-SHELL, STRESS ANALYSIS THIN SHELLS

SAFE-20, PLANE + AXISYMMETRIC STRESS ANALYSIS SAFE-3D, 3-D COMPOSITE STRUCTURE STRESS STUDY SAFETY ANALYSIS PROGRAM PPCO 7040 F+MAP RS SAIL, 1-D 1-GP SN APPROXIMATION SLAB GEOMETRY SAIL, 1-D 1-GP SN APPROXIMATION SLAB GEOMFTRY SASIA, FAST REACTOR POWER AND FLOW TRANSIENTS SASIA, FAST REACTOR POWER AND FLOW TRANSIENTS SATURATED BLOWDOWN2, BLOWDOWN ANALYSIS LOFT SCARF2, SCATTER FROM RADIATOR FINS SNAP GEOM SCAR1, SCATTER FROM A RING SNAP GEOMETRY GGA $1108 \mathrm{FA}$ GGA $7044 \quad F 4$ GGA $1108 \quad F 4$ GGA $1108 \quad F 4$ GGA $1108 \quad F 4$ GGA $1108 \mathrm{F4}$ $P T$ GS RSAC, RADIOLOGICAL AI 7090 F2 RS P B CDC 1604 F63 RS P B $\$$ ANL 360 F4 $\quad$ RS P TF $\$$ ANL $6600 \quad F 4$ RS P T F \$ KE 7094 F+MAP RSBP T G AI 7090 F2 RS J \$ AI $7090 \mathrm{F2}$ RS J

SCAT RESONANCES AI $360 \mathrm{~F} 4$ RS PLXT BS AILMOE, X-SECTION CALC ELASTIC SCAT RESONANCES AI 7094 F+FAP RS PL T B\$ AILMOE, $X-S E C T I O N$ CALC ELASTIC SCAT X-SECTION CALC MODERATOR GGA 1108 F4 RS P AS GAKER, INELASTIC SCAT X-SECTIONS HEX LATTICE GGA 1108 F4 RS HEXSCAT, ELASTIC SCATTER FROM A RING SNAP GEOMETRY AI 7090 F2 RS SCATTER FROM RADIATOR FINS SNAP GEOM AI 7090 F2 RS JS SCARF2, SCATTERING CDC 1604 F63 RS P A HAFEVER, HAUSER-FESHBACH INELASTIC SCATTERING CRYSTALLINE MATERIALS LASL 6600 F4 RS P T A\$ TOR, THERMAL SCATTERING DATA PROC DP 360 F4 RS P T A\$ FLANGE2, ENDF/B THERMAL SCATTERING KERNEL CALC GGA $7090 \mathrm{F2}$ RS T A\$SUMMIT, CRYSTALLINE SCATTERING LAW CALC GGA 1108 F4 RS $P$ AS COHBE, COHERENT INELASTIC SCATTERING LAW CALCULATION GGA 1108 F4 RS P A\$ GASKFT, THERMAL SCATTFRING LAW X-SECTION CALCULATION GGA 1108 F5 RS P A\$ FLANGE1, SCATTERING LAW X-SECTION CALCULATION GGA 7044 F4 RS A\$ FLANGEI, SCATTERING PHASE-SHIFT ANALYSIS ORNL 1604 F63 RS P A\$ PEGGY, ELASTIC SCISRS ENDF/B GRAPHIC X-SEC EVALUATION AI 360 F+BAL RS L T MS SCORE2, SCISRS X-SECTION TAPE GGA 7044 F+MAP RSBP MS UNPACK, RETRIEVAL FROM SCISRS X-SECTION TAPES HANL 7094 F2 RSB T NS CPS, SC4020 PLOTS FROM SCORE2, SCISRS ENDF/B GRAPHIC X-SEC EVALUATION AI 360 F+BAL RS L T M $\$$ SC4020 PLOTS FROM SCISRS X-SECTION TAPES WANL 7094 F2 RSB T N\$ CPS, SC 4020 PLDTS FROM X-SECTION TAPES GGA 7044 F4 RSBP T NS CRDSSPLOT. SEALSHELL2, SHELL STRESS ANALYSIS AXISYM LDAD BAPL $6600 F 4$ RS $P$ I $\$$ SEARCH GGA 1108 F4 RS P T CS GASPT, 1-D BURNUP POWER DISTRIBUTION SEARCH GGA $7044 F 4$ RS P T C\$ GASP2, 1-D FEW-GP DIFFUSION POWER DIST SECTIONS LASL 6600 F4 RS $P$ N\$ LARCA, FLUX-WEIGHTING DF DTF4 CROSS SERVICE RDUTINES ENDF TAPES BNL 7090 F+FAP RS $P$ T M\$ DFSR, DATA FILE SHAPE CALCULATION ORNL 7O9C F2 RS AS LYNNE, WOODS-SAXON POTENTIAL SHELL STRESS ANALYSIS AXISYM LOAD BAPL $6600 \mathrm{~F} 4$ RS P XT I\$ SEALSHELL2,

111 265 264 304 228

161 99 
SHELLS GGA 1108 F4 RS P IS SAFE-SHELL, STRESS ANALYSIS THIN SHELLS MIT 360 F4 RS P T I\$ SABNR4, OISCRETE-ELEMENT ANALYSIS THIN SHELLS OF RFVOLUTION KAPL 6600 F4 RS P T I\$SOR2, STRESS ANALYSIS SHIELD DESIGN MULTIGROUP SLAB GEOMETRY ANL $3600 \mathrm{~F} 63$ RSBPL T J\$MAC. SHIELD DESIGN MULTIGROUP SLAB GEOMETRY SHIELD LEAKAGE AI 7090 F2 RS SHIELD WEIGHT OPTIMIZATION DOSE CALC RNW 7090 F2 RSBPL T J\$ MAC, I\$ FARSEIA, DOSE RATE FROM SNAP SHIELDING CODE CAVITY GEOM GGA 1108 F4 RS P T J\$ MUSCAT, VIEW FACTOR SHOCK, SPACE POWER PLANT DESIGN OPTIMIZATION AI 7090 F2 RS I SHOE, SHIELD WEIGHT OPTIMIZATION DOSE CALC SIGPLOT, RESOLVED MULTILEVEL B-W X-SEC CALC SIGPLOT, RESOLVED MULTILEVEL $B-W X$-SEC CALC SIMULATION OF REACTOR DYNAMICS AI A I AI $7094 \mathrm{~F} 2$ RSP J $\$$ $\begin{array}{lllll}B N L & 6600 & F 4 & R S P & A \\ B N L & 7094 & F 4 & R S P & A\end{array}$ $360 F+B A L$ RS P TES AIRDS2A, SITE REQUIREMENT STUDY SITE REQUIREMENT STUDY SITE REQUIREMENT STUDY SIZZLE, 1-D MULTIGROUP DIFFUSION DFPLETION SIZZLE, 1-D MULTIGROUP DIFFUSION DEPLETION SIZZLE, 1-D MULTIGROUP DIFFUSION DEPLETION ANL 3600 F63 RSBP T G\$ R153, PARAMETRIC AI $360 \mathrm{~F} 4$ RS $P$ T GS AISITE2, PARAMETRIC

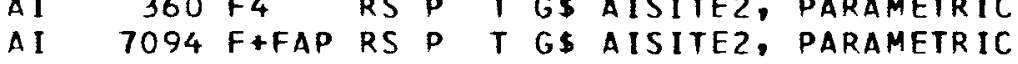
253

R402

R 80

143

143

91

197

259

114

197

377

377

326

R 389

172

172

172 SLAB ORNL $7090 \mathrm{~F} 2$ RS P T C\$EQUIPOISE3A, 2-D 2-GP DIFFUSION CYLINDER SLAB CYL ORNL $7090 \mathrm{~F} 2$ RS P T C\$ EQUIPOISE3, 2-D 2-GROUP DIFFUSION SLAB CYL SPHERE BNW 1107 F4 RS P T C\$ HFN, 1-D MULTI-GP DIFFUSION SLAB CYL SPHERE AI 7090 F+FAP RS L T C\$ FAIM, 1-D MULTI-GP NIFFUSION SLAB CYL SPHERE AI 7090 F+FAP RS PL T C\$ AIMG, 1-O MULTI-GP DIFFUSION SLAB CYL SPHERE CDC 1604 F63 RS PL T C\$ AIM6, 1-D MULTI-GP DIFFUSION SLAB CYL SPHERE CDC 1604 F63 RS PLXT C\$ FAIM, 1-D MULTI-GP DIFFUSION SLAB CYL SPHERE AI 7090 F+FAP RS L T C\$ULCER, 1-D MULTI-GP DIFFUSION SLAB CYL SPHERE ANL $3600 \mathrm{~F} 36$ RS P XT C\$ MACH1, 1-D MULTI-GP DIFFUSION SLAB CYL SPHERE PURD 6500 F4 RS PLXT C\$ MACHI, 1-D MULTI-GP DIFFUSION SLAB CYL SPHERE PW 1604 LAGI RS P CS MGDSN, I-D MULTI-GP SN APPROX SLAB CYL SPHERF UK-W 7090 F2 RS P T C\$ W-DSN, 1-D MULYI-GP SN APPROX SLAB CYL SPHERE BHSC 360 F4 RS P T C\$ FAIMOS, $1-0$ MULTI-GP DIFFUSION SLAB CYLINDER CDC 1604 F63 RS P T C\$2OGRAND, 2-D FFW-GROUP DIFFUSION SLAB CYLINDER ORNL 7090 F2 RS P T C\$2OGRAND, 2-D FEW-GRDUP DIFFUSION SLAB CYLINDER SPHERE AEB 360 F4 RS L T CS FIRE5, I-D ASE-DIFFUSION SLAB CYLINDER SPHERE AI 7090 F2 RS P T C\$ FOG, 1-D FFW-GP DIFFUSION SLAB CYLINDER SPHERF BC 625 F4 RS T C\$ FDG, 1-D FEW-GP DIFFUSION SLAB CYLINDER SPHERE CDC $1604 \mathrm{~F} 63$ RS P T C\$ FOG, 1-O FEW-GP DIFFUSION SLAB GAMMA-RAY TRANSPDRT SLAB GEOM PPCO $7090 \mathrm{~F} 2$ RS P C\$ MIST, 1-D FEW-GP SN DOUBLE SN APPROX SLAB GEOMETRY AI $7090 \mathrm{~F} 2$ RS 9 J\$ GRACE1, GAMMA-RAY ATTENUATION SLAB GEOMETRY ANL 3600 F63 RSBPL T J\$ MAC, SHIELD DESIGN MULTIGRDUP SLAB GEOMETRY RNW 7090 F? RSRPL T J\$ MAC, SHIELD DESIGN MULTIGROUP SLAB GEOMETRY CDC 1604 F63 RS P J\$ GRACE1, GAMMA-RAY ATTENUATION SLAB GEOMETRY AI 7090 F? RS P B\$ SAIL, 1-D 1-GP SN ADPROXIMATION SLAB GEOMFTRY BAPL 6600 F4 RS P XT C\$ RE21, FEW-GP DISCRETE ORDINATES SLAB GEOMETRY CDC 1604 F63 RS P BS SAIL, 1-D 1-GP SN APPROXIMATION SLAB TRANSPORT WITH SLOWING DOWN BAPL $6600 \mathrm{~F} 4$ RS XT C\$ MO648, 1-D SLAV3, ENDF/B PROC NCSC $6600 \mathrm{~F} 4$ RS T M\$ CHECKER,CRECT, DAMMET,PLDTFB SLOWING DOWN BAPL 6600 F4 RS XT C\$ M0648, 1-D SLAB TRANSPORT WITH SLOWING-DOWN DENSITY CALC AI 7094 F+FAP RS PL T BS TYCHE3, MONTF CARLO SN APPROX BNW 7090 FLOCO RSBP T C\$ GF-HAPD-S13, 1-D MULTI-GP DOUBLE SN APPROX SLAB CYL SPHERE PW 1604 LAGI RS P C\$ MGDSN, 1-D MULTI-GP SN APPROX SLAB CYL SPHERE UK-W 7090 F2 RS P T C\$ W-DSN, 1-D MULTI-GP SN APPROX SLAB GEOM PPCO 7090 F2 RS P CS MIST, 1-D FEW-GP SN DOUBLE SN APPROXIMATION CYLINDER PPCO 7040 F4 RS P T C\$ TDPIC, 1-D FEW-GP SN APPROXIMATION CYLINDEP PPCD $7090 \quad F 2$ SN APPROXIMATION RZ PW 1604 F63 RS P T C\$ FORTRAN TDC, 2-D MULTI-GP SN APPROXIMATION SLAB GEOMFTPY AI 7090 F2 RS P R\$SAIL. I-D I-GP SN APPROXIMATION SLAR GEOMETRY CDC 1604 F63 RS P B\$ SAIL, I-D 1-GP SN APPRDXIMATION XY GEOM AGC 7090 FLOCO RSRP C\$ 2DXY, 2-D MULTI-GP SN CONSTANTS FOR DSN TDC PW 1604 F63 RS P L\$SNC, CALCULATION OF 
SN DOUBLE SN APPROX SLAB GEOM PPCO 7090 F2 RS P C\$ MIST, 1-D FEH-GP

SN X-SECTION LIBRARY TAPF PREPARATION PW $1604 \mathrm{~F} 63$ RS LS CSP1, SN X-SECTION LIBRARY TAPE PREPARATION PW $1604 \mathrm{~F} 63$ RS LS CSP2A. SNAP GEOM AI $7090 \mathrm{~F} 2$ RS J\$ SCARF2, SCATTER FROM RADIATOR FINS SNAP GEOMETRY AI $7090 \mathrm{~F} 2$ RS J\$ SCARI, SCATTER FROM A RING SNAP GEOMETRY AI $7090 \mathrm{~F} 2$ RS P J\$ RATRAP, DOSE RATE CALCULATION SNAP GEOMFTRY AI $7090 \mathrm{~F} 2$ RS E\$ SNAPKIN5/5A, 1-REGION KINETICS SNAP GEOMFTRY AI $7090 \mathrm{F2}$ RS J\$ MORTIMER, DOSE RATE CALCULATION SNAP SHIELD LEAKAGE AI 7090 F2 RS SNAPKIN5/5A, 1-REGION KINETICS SNAP GEOMETRY SNARG-ID, 1-D MULTI-GP DISCRETF ORDINATE CALC. SNC, CALCULATION OF SN CONSTANTS FOR DSN TDC J\$ FARSEIA, DOSE RATE FROM AN $7090 \mathrm{~F} 2$ RS 3600 F 36 RS P T $\$ 122$ PW 1604 F63 RS P L \$ 189 SNEQ, NONLINEAR ALGEBRAIC EQN SOLN CURVE PLOT KAPL 6600 F+ASC RS P T P $\$$ R364 SOLID CRYSTAL UM 7090 MAD RSA OS BURP4, GAMMA-RAY PHOTOFRACTION SOLID FUEL TUBE BUNDLES LASL 7094 F2 RSBP H\$ AXTHRM, HEAT TRANSFER SOPHISTI/2/5, MULTI-GP TRANSFER COEFFICIENTS SORSDB, PRESSURE VESSEL STRESS AND FATIGUE SOR2, STRESS ANALYSIS SHFLLS OF REVOLUTION LRL 7090 FHFAP RS P T B $\$ 160$ KAPL 6600 F4 RS I \$R391 SOURCE UM 7090 MAD RSB O\$ RURP2, DETECTOR EFFICIENCY DISK SOURCE UM 7090 MAD RSB O\$ BURPI, DETECTOR EFFICIENCY POINT SOURCE UM 7090 MAD RSR O\$ BURP3, DETECIOR EFFICIENCY POINT SOURCE DATA NED $635 \mathrm{~F} 4$ RS P T O\$ EXPN, ANALYSIS OF PULSED NEUTRON SPACE CHORD DIST FUNCT AEG 7090 F2 RS B\$ DANCOFF JR, MODERATOR SPACE POWER PLANT DESIGN OPTIMIZATION AI $7090 \mathrm{~F} 2$ RS I\$CROCK, SPACE POWER PLANT DESIGN DPTIMIZATION AI $7090 \mathrm{F2}$ RS IS SHOCK, SPACE-INDEPFNDENT INVERSE KINETICS CALC ANL $3600 \mathrm{~F} 63$ RSBP E\$ R102, SPACE-INDEPENDENT INVERSE KINETICS CALC WANL 7094 F4 RS SPACE-INDEPFNDENT KINETICS KEX OPTIONS SPACE-INDEPENDENT KINETICS KEX OPTIONS SPACE-INDEPENDENT KINETICS W/FEEDBACK SPACE-INDEPENDENT KINETICS W/FEEDBACK SPACE-INDEPFNDENT KINFTICS W/FEFDBACK SPACE-INDEPENDENT KINEYICS W/FEEDBACK ANL $3600 \quad F_{63} 3$ RSBP WANL 7094 F4 RS P E\$ RIO1, E\$ RIOl, AI 7094 F+MAP RS P T ES AIROS, AEB $360 \mathrm{~F} 4$ RS P ES AIREK3, AI $7090 \mathrm{~F} 2$ RS ES AIREK3, $1604 F_{63}$ RS P ES AIREK3, SPACE-TIME DEF GGA 1108 F4 RS P E\$ GAPOTKIN, SPACE-TIME DIFFUSION FFEDBACK ANL 360 F4 RS P F\$ TWIGGLE, 2-D 2-GP SPACE-TIME DIFFUSION FEEDBACK BNL $6600 \mathrm{F4}$ SPACF-TIME DIFFUSION 3-GFOM BAPL $6600 \mathrm{~F} 4$ SPACE-TIMF DIFFUSION 3-GEOM GGA 1108 F4 SPACE-TIME SYNTHESIS KAPL $6600 F_{4}$ RS $P$ RS $P$ T F N NOAH, $1-D$ ONE-GP RS P XT FS WIGL2, 1-D 2-GP RS P T FS WIGL2, 1-D 2-GP F\$ STINT3, SINGLE-CHANNEL SPARTA, SPATIALLY-AVERAGED DOPPLER EFFECTS NED 2000 F2 RS P B \$ SPATIALLY-AVERAGED DOPPLER EFFECTS NED $2000 \mathrm{F2}$ RS P R\$ SPARTA, SPATIALLY-DEPENDENT RFACTIR KINETICS AI 360 F4 RS P T F\$ TSN, SPATIALLY-DEPENDENT REACTOR KINETICS AI 7094 F4 RS P T F\$ TSN, SPECTRA AND GROUP-AVERAGED X-SEC CALC GGA 1108 F4 RS P XT BS GAF,GAR, SPECTRA CALCULATION WITH DEPLETION WAPO 360 F4 RS PLXT BS LEDPARD, SPECTRA GGA $1108 \mathrm{~F}_{4}$ RS P T OS TOAD, PROCESSING OF ANALYZER GAMMA-RAY SPECTRA GGA 1108 F4 RS PLXT B\$ GGC4, MULTI-GP X-SECTIONS FAST THERMAL SPECTRA GTA $6600 \mathrm{~F} 4$ RS L T B\$ GGC4, MULTI-GP X-SECTIONS FAST THERMAL SPECTRA KSUN $360 \mathrm{~F} 4$ RS P O\$ CORGAM, UNFOLDING OF COMPLEX GAMMA-RAY SPECTRUM AND X-SECTION CALCULATION GEV 7094 F+FAP RS P T BS EPITHERMOS, SPECTRUM CALC WITH BURNUP CYL LATTICE WAPD 7094 F+MAP RS PLXT B\$ LASER, SPECTRUM MULTI-GP CONSTANT CALC AGC $7090 \mathrm{~F} 2$ RSBPLXT B\$ AGN-GAM, FAST SPECTRUM X-SECTION CALC AI 7090 F2 RS PL T B\$ FORM. FAST NEUTRON SPECTRUM X-SECTION CALC ANL 3600 F63 RS LXT BS GAMI, FAST NEUTRON SPECTRUM X-SECTION CALC CDC 1604 F63 RS PL T B\$ FORM, FAST NEUTRON SPECTRUM X-SECTION CALC CDC 1604 F63 RS PLXT B\$ GAMI, FAST NEUTRON SPECTRUM $X$-SECTION CALC GGA $7090 \mathrm{~F} 2$ RS PLXT B\$ GAMI, FAST NEUTRON SPECTRUM X-SECTION CALC ANL $3600 \mathrm{FG3}$ RSBP XT B\$ THERMOS (ANL), THERMAL SPECTRUM $X$-SECTIONS AI 7090 F+FAP RS L T B\$ QUICKIE, INFINITE MEDIUM SPECTRUM X-SECTIONS AI 7090 F+FAP RS PL $T$ B\$ TEMPEST2, THERMAL NEUTRON SPECTRUM $X$-SECTIONS BHSC $360 \mathrm{~F} 4$ RS PL T BS TEMPEST2, THERMAL NEUTRON SPECTRUM $X$-SECTIONS CDC 1604 F63 RS PL T BS TEMPEST2, THERMAL NEUTRDN SPH PW 1604 F63 RS P F\$ AX-TNT, COUPLED NEUTRONICS-HYDRODYNAMICS 
SPHERE BNW 1107 F4 RS P T C HFN, 1-D MULTI-GP DIFFUSION SLAB CYL SPHERE AI 7090 F+FAP RS L T C\$ FAIM, I-D MULTI-GP DIFFUSION SLAR CYL SPHERE AI 7090 F+FAP RS PL T C\$ AIMG, 1-D MULTI-GP DIFFUSION SLAB CYL SPHERE CDC $1604 \mathrm{FG} 3$ RS PL T C\$ AIM6, I-D MULII-GP DIFFUSION SLAB CYL SPHERE CDC 1604 F63 RS PLXT C\$ FAIM, 1-D MULTI-GP DIFFUSION SLAB CYL SPHERE CDC 3600 F63 RSBP F\$AX1, COUPLED NEUTRONICS-HYDRODYNAMICS SPHERE AEB $360 \mathrm{~F} 4$ RS L T $T$ FIRES, 1-D AGF-DIFFUSION SLAB CYLINDER SPHERE AI 7090 F+FAP RS L T C\$ ULCER, 1-D MULTI-GP DIFFUSION SLAB CYL SPHERE ANL 3600 F36 RS P XT C\$ MACHI, 1-D MULTI-GP DIFFUSIDN SLAB CYL SPHERE PURN 6500 F4 RS PLXT C\$ MACH1, 1-D MULTI-GP DIFFUSION SLAB CYL SPHERE PW 1604 LAGI RS P C\$ MGDSN, 1-D MULTI-GP SN APPRDX SLAB CYL SPHERE UK-W 7090 F2 RS P T C\$ W-DSN, 1-D MULTI-GP SN APPRDX SLAB CYL SPHERE AI $7090 \mathrm{F2}$ RS P T C\$FOG, 1-D FEW-GP DIFFUSION SLAB CYLINDER SPHERE BC $625 \mathrm{~F} 4$ RS T C\$FNG, 1-D FEH-GP DIFFUSION SLAB CYLINDER SPHERE BHSC 360 F4 RS P T C \$FAIMOS, 1-D MULTI-GP DIFFUSION SLAB CYL SPHERE CDC 1604 F63 RS P T C\$ FOG, 1-D FFH-GP DIFFUSION SLAB CYLINDER SPHERE GEOM AI $7090 \mathrm{~F} 2$ RS P J\$ GRACE2, GAMMA-RAY ATTENUATIDN CYL SPHERE GEOM CDC 1604 F63 RS P J\$ GRACE2, GAMMA-RAY ATTENUATION CYL SPHERE LRL $7090 \mathrm{~F} 2$ RS P F\$ CONEC, COUPLFD NEUTRONICS-HYDRODYNAMICS STABILITY ANALYSIS REACTOR KINETICS EQNS GGA 1108 F4 RS P ES GASA, STATION ELECTRICITY COSTS ORNL 1604 F63 RS P D\$ POWERCD. NUCLEAR STATISTICAL RESINANCF PARAMETER CALC GGA 1108 F4 RS P AS PSEUDO, STEADY-STATE AND TRANSIENT TEMP CALC GGA 1108 F5 RS P THSTAC2D, STEADY-STATE FLOW, PRESSURF DISTRIBUTION GGA $1108 \mathrm{F5}$ RS P H\$ FLAC, STEADY-STATE HEAT TRANSFER AI 7094 F2 RS P T H\$ HEATING2, TRANSIENT STEADY-STATE TEMPERATURE VOID FRACTION AI $7090 \mathrm{FZ}$ RS IS FUGUE, STEADY-STATE THERMAL-HYDRAULIC ANALYSIS NEO 635 F4 RS P T H\$ MANTA, STEAM GENFRATOR DESIGN CRITERIA COSTS GGA 7044 F4 RS P T D\$ STMGEN, STEAM TABLES 14.5-14,50OPSIA 32-4720EGF BAPL 6600 F4 RS XT H\$ WATER, STEAM TABLES $14.5-2538$ PSIA ANL 1604 F63 RS P H\$ MOR99.HOH. STEAM TABLES $14.5-2538$ PSIA BAPL 6600 F4 RS P XT H\$ MO899,HOH, STEAM THERMODYNAMIC PROPERTIES BAPL $6600 \mathrm{~F} 4$ RS $P$ XT H\$ WASP, WATER AND STEAM-WATER MIX KAPL 6600 F4 RS P H\$ RAPP, HIGH-VELOCITY FLOW STUDY STEM, MATRIX GENEPATION FOR A SYSTEM OF BFAMS KAPL 6600 F RS P I $\$$ STINT3, SINGLE-CHANNEL SPACE-TIMF SYNTHESIS KAPL 6600 F4 $\quad$ RS P $F$ STMGEN, STEAM GENERATDR DESIGN CRITERIA COSTS GGA 7044 F4 P RS P T D \$
STRESS ANALYSIS KAPL 6600 F4 RS P IUBE U-TURE HEAT EXCHANGER STRESS ANALYSIS ANL 3600 F36 RS P T I\$ SUPORAN, REACTOR CORE SUPPORT STRESS ANALYSIS GGA 1108 F4 RS P I\$ SAFE-2D, PLANE + AXISYMMETRIC STRESS ANALYSIS AXISYM LOAD BAPL 6600 F4 RS $P$ XT I\$ SEALSHFLL?, SHFLL STRESS ANALYSIS AXISYMMETRIC LOAD GGA 7044 F4 RS P T I\$ SAFE-PCRS, STRESS ANALYSIS AXISYMMETRIC LOAD GGA 7044 F4 RS P T I\$ SAFE-AXISYM, STRESS ANALYSIS CYL FUEL ELEMENT BAPL $6600 \mathrm{F4}$ RS XT I\$ CYGRT2, STRESS ANALYSIS SHELLS OF REVOLUTION KAPL 6600 F4 RS P T I\$ SOR2, STRESS ANALYSIS STUDY GGA 7044F4 RS P T G\$ ELBOW, FUEL ELEMFNT STRESS ANALYSIS THIN SHFLLS GGA 1109 F4 RS P I\$ SAFE-SHFLL, STRESS ANALYSIS, 2-D BODIES GGA 1108 F4 RS P I\$ SAFE-PLANE, PLANE STRESS AND FATIGUE KAPL 6600 F4 RS STRESS OF PIPING SYSTFM BAPL 6600 F4 RS P XT I\$ MO457,PIPE, FLASTIC STRESS STUOY GGA 1108 F4 RS P T I\$ SAFE-3D, 3-D COMPOSITE STRUCTURE STRESS STUDY BAPL $6600 \mathrm{~F}+\mathrm{COM}$ RS $P$ XT I\$ GAPL3, INELASTIC LARGE DEFLECTION STRESS, MAXIMUM MOMENT CALC, AI 7090 F+FAP RS T I\$ 4RESTRAINT PIPF STRIP, RESOLVED RESONANCE INTEGRAL CALCULATION RW 2000 F4 RS A STRUCTURAL DYNAMICS BAPL 6600 F4 RS P XT I\$MO266, LINEAR ELASTIC STRUCTURE STRESS STUDY GGA $110 R$ F4 RS P T I\$ SAFE-3D, 3-D COMPOSITE STRUCTURES RAPL 6600 F4 RS P XT L\$ BL47, DRAFTING TOOL TO PLOT PLANE STRUCTURES KAPL $6600 \mathrm{~F} 4$ RS $P \times$ I\$ FINEL, FINITE-FLFMFNT STUDY $2.3-D$ SUM OF EXPONFNTIALS MIT 7090 F2 RS $P$ SUMMIT, CRYSTALLINE SCATTERING KERNEL CALC SUMOR, S-WAVE NFUTRON X-SECTION CALCULATION SUPORAN, REACTOR CORE SUPPORT STRESS ANALYSIS SUPPORT STRESS ANALYSIS ANL 3600 F36 RS P SWELLING TEMPERATURF STUDY BAPL $6600 \mathrm{~F} 4$ SWELL2, FUEL ELEMENT LIFFTIME ANALYSIS
P\$ FRANTIC, LEAST SQUARES FIT 324 GGA $7090 \mathrm{F2}$ RS TA $\$ 56$ BAPL 6600 F4 RS P XT A \$ R399 $\triangle N L \quad 3600$ F36 RS P T I \$ 357 T I\$ SUPORAN, RFACTOR CORE 357 RS P XT HS FIGRD, LSBR FUEL R 272 ANL $3600 \quad F 36$ RSBP I \$353 56
102

118

262

262

211

132

28

120

28

46

46

129

290

292

408

395

256

227

R 267

R294

R 294

R396

R 382

R 337

227

R 378

357

379

R 282

250

251

$R 266$
$R \quad 80$

229

253

25?

R329

332

R397

109

R 383

332

R373

R 404 99
57 
SYNTHESIS

KAPL $6600 \mathrm{F4}$

RS $P$

F\$ STINT3, SINGLE-CHANNEL SPACE-TIME

SYNTHESIS

ANL 3600 F63

RSBP

$T$ E\$ TRAFICOR RS PL T CS

SYNTHESIS PROGRAM CYL PW 1604 F63 RS

S4 APPROXIMATION AI $7090 \mathrm{~F} 2$ RS

S4 APPROXIMATION CDC 1604 F63 RS P

S4 APPR OXIMATION RZ GEOMETRY LRL $709 \mathrm{FZ}$

54 CYL CELL CODE AND TEMPFST COMBINATION AI

S4 CYL CELL CODE, 1-D 1-GP S4 APPROXIMATION

S4 CYL CELL CODE, 1-D 1-GP S4 APPROXIMATION

TABLES $14.5-14,500 P$ SIA 32-4720EGF BAPL 6600 F4

TABLES $14.5-2538$ PSIA

ANL $1604 \quad F 63$

BAPL 6600 F4

TABLES $14.5-2538$ PSIA

TACASI, ANALYSIS OF RESONANCE MEASUREMENTS
TAC2D, STEADY-STATE AND TRANSIENT TEMP CALC

TAPE GGA 7044 F+MAP RSPP

TAPE EDIT REACTION RATES UK-W $7090 \mathrm{~F} 2$ RS N\$ WED, W-DSN DUTPUT

TAPE PREPARATION PW 1604 F63 RS L\$ CSPI, SN X-SECTION LIBRARY

TAPE PREPARATION PW 1604 F63 RS L\$ CSP2A, SN X-SECTION LIBRARY

TDC PW 1604 F63 RS P LS SNC, CALCULATION OF SN CONSTANTS FOR DSN

TDC OR 2DXY FLUX INPUT PW $1604 \mathrm{FG3}$ RS CS TDP, 2-D PERTURBATION

TDC, 2-D MULTI-GP SN APPROXIMATION RZ PW 1604 F63 RS P T C\$ FORTRAN

TDP, 2-D PERTURBATION TDC OR 2DXY FLUX INPUT PW 1604 F63 RS

TDSN, 2-D MUL TIGROUP DISCRETE ORDINATE PROGRAM LER 7090 F+MAP RS P $T$ C $s$

TEMCO, 1-D FEW-GP DIFFUSIDN TEMP COEF CALC GGA 7044 F4 RS P T C \$

TEMCO7, TEMPERATURE COEFFICIENT CALCULATION GGA 1108 F4 RS P T C \$

TEMP CALC GGA 1108 F5 RS P T H\$ TAC2D, STEADY-STATE AND TRANSIENT

TEMP COEF CALC GGA 7044 F4 RS P T C\$ TEMCD, 1-D FEW-GP DIFFUSION

TEMP FEEDBACK GGA 1108 F4 RS P T F\$ GAKIT, 1-D MULTIGP KINETICS WITH

TEMPERATURE CALC CYLINDER ANL $3600 \mathrm{~F} 63$ RSBP T H\$ ARGUS, TRANSIENT

TEMPERATURE CODE GGA $7044 \mathrm{~F} 4$ RS I\$ CORE, CORE CONFIGURATION FUEL

TEMPERATURE COEFFICIENT CALCULATION GGA 1108 F4 RS P T C\$ TEMCO7,

TEMPERATURE DIST STUDY AER $360 \mathrm{~F} 4$

TEMPERATURE DISTRIBUTION PROGRAM

TEMPERATURE FEEDBACK BAPL $6600 \quad F 4$

TEMPERATURE HISTORY KE $7094 \mathrm{~F} 2$

TEMPERATURE STUDY BAPL $6600 \mathrm{~F} 4$

TEMPERATURE VOID FRACTION AI $7090 \mathrm{~F} 2$ RS I\$ FUGUE, STEADY-STATE

TEMPEST COMBINATION AI $7090 \mathrm{~F} 2$ RS P $3 \$$ BAM, S4 CYL CELL CODE AND

TEMPEST2, THERMAL NEUTRON SPECTRUM X-SECTIONS AI 7090 F+FAP RS PL T B \$

TEMPEST2, THERMAL NEUTRON SPFCTRUM X-SECTIONS BHSC $360 \mathrm{~F} 4$ PS PL T B

TEMPEST2, THERMAL NEUTRON SPECTRUM X-SECTIONS CDC $1604 \mathrm{F63}$ RS PL $T$ B

THERMAL ANALYSIS BCL $6400 \mathrm{~F} 4$ RS $P$ T G\$ NURLOC-1.0, LOSS-OF-CDOLANT

THERMAL DESIGN STUDY GGA $7044 \mathrm{FH}$ RS P I\$ GAZELLE5, GAS-COOLED CORE

THERMAL NEUTRON SPECTRUM X-SECTIONS AI 7090 F+FAP RS PL T BS TEMPEST2,

THERMAL NEUTRON SPECTRUM X-SECTIONS BHSC 360 F4 RS PL T BS TEMPEST2,

THERMAL NEUTRON SPECTRUM X-SECTIONS CDC 1604 F63 RS PL T AS TEMPEST2,

THERMAL SCATTERING CRYSTALLINE MATERIALS LASL 6600 F4 RS P T A\$ TOR,

THERMAL SCATIERING DATA PROC DP $360 \mathrm{~F} 4$ RS P T A\$ FLANGE2, ENDF/B

THERMAL SCATTERING LAW CALCULATION GGA 1108 F4 RS P A\$ GASKET,

THERMAL SPECTRA GGA $1108 \mathrm{~F} 4$ RS PLXT B \$ GGC4, MULTI-GP X-SECTIONS FAST

THERMAL SPECTRA GGA 6600 F4 RS L T B\$ GGC4, MULTI-GP X-SECTIONS FAST

THERMAL SPECTRUM X-SECTION CALC ANL 3600 F63 RSBP XT B\$ THERMOSIANLI, THERMAL-HYDRAULIC ANALYSIS NED 635 F4 RS P T H\$ MANTA, STEADY-STATE THERMODYNAMIC CYCLE ANALYSIS AI $7094 \mathrm{~F} 2$ RS PL T IS CYCLOPSI, THERMODYNAMIC PROPERTIES BAPL 6600 F4 RS P XT HS WASP, WATER AND STEAM THERMODYNAMICS OF PRESSURIZERS BAPL 6600 F4 RS P XT H\$ TOPS, TRANSIFNT THERMOS(ANL), THERMAL SPECTRUM X-SECTIDN CALC ANL 3600 F63 RSBP XT B \$ THIN SHELLS GGA 1108 F4 RS P I\$ SAFE-SHELL, STRESS ANALYSIS THIN SHELLS MIT $360 \mathrm{~F} 4$ RS P T I\$ SABOR4, DISCRETE-ELEMENT ANALYSIS THREDES LIBRARY UTILITY ROUTINE AI $360 \mathrm{~F} 4$ RSB L T M\$ CLIP, FORM OR THREDES, 1-D FEW-GP DIFFUSION DESIGN SYSTFM AI $360 \mathrm{~F} 4$ RSAP T K \$ THTE, 3-D TPANSIENT HEAT TRANSFER PRDGRAM GEC $635 \mathrm{~F}+G M P$ RSRP $T$ H THUNDERHEAD, EXTERNAL+INTEPNAL DOSE AI 7094 F+FAP RS PL T G\$ CURIE, DOSE,

R389

135

287

192

53

53

108

53

53

R267

R294

R294

410

408

206

133

194

193

189

199

161

199

312

225

320

408

225

370

152

233

320

363

R299

R371

155

R 272

48

108

50

50

50

328

232

50

50

50

360

368

263

298

298

184

256

244

R396

R348

184

253

R402

271

273

346

196 
TIGIR2, MODULAR DOCUMENT INFORMATION SYSTEM KAPL $6600 F \quad$ R B T M $\$$ R403 TIME-DEP 2-D MULTI-GP DIFFUSION UMCC 360 F4 RS P T C\$ VARI-QUIR, 212 TIME-DEP 2-D MULTI-GP DIFFUSION WANL 6600 F4 RS P T C\$VARI-QUIR, 212 TIME-DEPENDENT DIFFUSION CALC KAPL 6600 F 4 RS P F RAUMZEIT, I-D R352 TIME-DEPENDENT DIFFUSION GGA 1108 F4 RS P T F\$ GAKIN, 1-D MULTIGROUP 310 TIME-DEPENDENT HEAT CONDUCTION PPCO 7044 F+MAP RS P T H\$ TOODFE, 2-D 349 TOAD, PROCESSING OF ANALYZER GAMMA-RAY SPECTRA GGA 1108 F4 RS P T 0 \$ 333 TOODEE, 2-D TIME-DEPENDENT HEAT CONDUCTION PPCO 7044 F+MAP RS P T H $\$ 349$ TOOL TO PLOT PLANE STRUCTURES BAPL 6600 F4 RS P XT L\$ BL47, DRAFTING R373 TOPIC, 1-D FEW-GP SN APPROXIMATION CYLINDER PPCD 7040 F4 TS P T $\$$ I48 TOPIC, 1-D FEW-GP SN APPROXIMATION CYLINDER PPCO 7090 F2 RS P T C $\$ 148$ TOPS, TRANSIENT THERMODYNAMICS OF PRESSURIZERS BAPL 6600 F $\quad$ RS P XT H $\$$ R48 TOR OUTPUT DATA LASL 6600 F4 RS P T B\$ GLEN, GROUP CONSTANT CALC FRDM 361 TOR, THERMAL SCATTERING CRYSTALLINE MATERIALS LASL 6600 F4 RS P T A $\$ 360$ TRAFICORPORATION, TRANSFER FUNCTION SYNTHESIS ANL 3600 F63 RSBP T E $\$ 135$ TRANS-FUGUE1, TRANSIENT FLOW AND HEAT TRANSFER AI $7094 \quad F 2 \quad$ RS P T G $\$ 268$ TRANSFER GGA 1108 F4 RS P T F\$ BLODST6, COMBINED KINETICS 2-D HEAT 303 TRANSFER AI $7094 \mathrm{~F} 2$ RS P T G\$ TRANS-FUGUE1, TRANSIENT FLOW AND HEAT 268 TRANSFER AI 7094 F2 RS P T H\$ HEATING2, TRANSIENT STEADY-STATE HEAT TRANSFER COEFFICIENTS LRL $7090 \mathrm{~F}+F A P$ RS P T B\$ SOPHISTI/2/5, MULTI-GP TRANSFER FUNCTION EVALUATION $\quad$ PW 1604 F63 RS P E\$CMPXMAT, TRANSFER FUNCTION SYNTHESIS ANL 3600 F63 RSBP T E\$ TRAFICDRPORATION, TRANSFER GGA 7044 F4 RS T H\$ BLDOST5, PDINT-KINETICS WITH 2-D HEAT TRANSFER MATRICES AGC 7090 F2 RS P T B\$ AGN-SIGMA, CALC OF MULTI-GP TRANSFER MOLTEN FUEL TUBE BUNDLES LASL 7094 F2 RSBP H\$ AXFLU, HEAT TRANSFER PROGRAM GEC 635 F+GMP RSBP T HS THTE, 3-D TRANSIENT HEAT TRANSFER SOLID FUEL TUBE BUNDLES LASL 7094 F2 RSBP H\$ AXTHRM, HEAT TRANSIENT ANALYSIS BAPL 6600 F4 RS P XT H\$FLOT1, MO219, PWR FLDW TRANSIENT FLOW AND HEAT TRANSFER AI 7094 F2 RS P T G\$ TRANS-FUGUEI, TRANSIENT HEAT CONDUCTION PROGRAM BAPL 6600 F4 RS P XT H\$ HOT2, 2-D TRANSIENT HEAT TRANSFER PROGRAM GEC 635 F+GMP RSBP T H\$ THTE, 3-D TRANSIENT STEADY-STATE HFAT TRANSFER AI 7094 F2 RS P T H\$ HEATING2, TRANSIENT TEMP CALC GGA 1108 F5 RS P T H\$ TAC2D, STEADY-STATEAND TRANSIENT TEMPERATURF CALC CYLINDER ANL $3600 \mathrm{FG} 3$ PSBP T H\$ ARGUS, TRANSIENT THERMODYNAMICS OF PRESSURIZERS BAPL $6600 \mathrm{~F} 4$ RS P XT H\$ TOPS, TRANSIENTS ANL $360 \mathrm{~F} 4$ RS $P$ T F\$SASIA, FAST REACTOR POWFR AND FLDW TRANSIENTS ANL 6600 F4 RS P T F\$ SASIA, FAST REACTOR POWER AND FLDW TRANSPORT BAPL 6600 F4 RS P XT J\$ MOT56.LETO, I-D SLAB GAMMA-RAY TRANSPORT CODE $X-Y$ GEOM ANL 360 F4 RS P T C\$ TWOTRAN, 2-D MULTI-GP TRANSPORT CODE X-Y GEOM LASL 1108 F4 RS P T C\$ TWOTRAN, 2-D MULTI-GP TRANSPORT WITH SLOWING DOWN BAPL $6600 \mathrm{~F} 4$ RS XT C\$MO648, 1-D SLAB TRIANGULAR MESH GGA 1109 F+BAL RS P T CS GAMTRI, 2-D MULTIGP DIFFUSION TRIX1. RESONANCE INTEGRAL X-SECTION CALC AI 7094 F+MAP RS PLXT A \$ TSN, SPATIALLY-DEPENDENT REACTOR KINETICS $\quad$ AI 360 F4 RS P TF \$ TSN, SPATIALLY-DEPENDENT REACTOR KINETICS AI 7094 F4 RS P TF $\$$ TUBE BUNDLES LASL $7094 \mathrm{FZ}$ RSBP H\$ AXFLU, HEAT TRANSFER MOLTFN FUFL TUBE BUNDLES LASL $7094 \mathrm{~F} 2$ RSBP H\$ AXTHRM, HEAT TRANSFER SOLID FUFL TUBE, U-TUBE HEAT EXCHANGER STRESS ANALYSIS KAPL 6600 F4 RS P I $\$$ R378 TUZ. UNRESOLVED REGION RESONANCE INTEGRAL CALC GGA 7090 F+FAP RSB T A $\$ 42$ TWIGGLE, 2-D 2-GP SPACE-TIME DIFFUSION $\quad$ ANL 360 F4 RS P F $\$$ R338 TWIGL, 2-D 2-GP SPACE-TIME DIFFUSION FEEDBACK BAPL 6600 F4 RS P XT F $\$$ R338 TWOTRAN, 2-D MULTI-GP TRANSPORT CODE X-Y GEOM ANL 360 F4 RS P T C \$ 358 TWOTRAN, 2-D MULTI-GP TRANSPORT CODE X-Y GEOM LASL 1108 F4 TYCHE3, MDNTE CARLO SLOWING-DOWN DENSITY CALC AI 7094 F+FAP RS PL T $\$$ S 149 U-TUBE HEAT EXCHANGER STRESS ANALYSIS KAPL $6600 \mathrm{~F} 4$ RS P I\$ TUBF, R378 UGA $360 \mathrm{~F} 4$ RSP G\& WATER-HAMMER, LIQUID BLOWDOWN ANALYSIS LOFT UHTREX LASL $7090 \mathrm{~F} 2$ RS $P$ IS WIREX, COMPUTER-PRODUCED WIRING LISTS UILL $360 \mathrm{~F} 4$ RS P A\$ CODILLI, LEAST SQUARES ANALYSIS RESONANCE DATA UK-R 7090 F+FAP RSBPL T C\$ CRAM, 1-D AND 2-D MULII-GP DIFFUSION PRDGRAM UK-W 7090 F2 RS N\$ WED, W-DSN OUTPUT TAPE EDIT REACTION RATES UK-W $7090 \mathrm{~F} 2$ RS P T C\$ W-DSN, 1-D MULTI-GP SN APPROX SLAB CYL SPHERE ULCER, 1-D MULTI-GP DIFFUSION SLAR CYL SPHFRE AI 7090 F+FAP RS LT C \$ UM 7090 MAD RSB O\$ BURPI, DETECTOR EFFICIENCY POINT SOURCE UM 7090 MAD RSB O\$ RURP2, DETECTOR FFFICIENCY DISK SOURCE 

WATER-HAMMFR, LIQUIN BLOWDIWN ANALYSIS LOFT UGA 360 F4 RS P G $\$ 278$ WATER, STEAM TABLES 14.5-14,500PSIA 32-472DEGF BAPL 6600 F4 RS XT H \$ R267 WAVE FUNCTION RADIAL INTEGRALS ORNL 1604 F63 RS P A\$ RAMES, PARTICLE 335 WEAK EXPLOSION, COUPLED NFUTPON-HYDRODYNAMICS APDA $7094 F 2$ RS P F 145 WED, W-DSN OUTPUT TAPF EDIT REACTION RATES UK-W 7090 F2 RS WEIGHT OPTIMIZATION DOSE CALC AI 7094 F? RS $P$ J\$SHOE, SHIELD 197 WEIGHT OPTIMIZATICN STUDY PW 1604 F63 RS IS WOPFXPRT, REACTOR I90 WELL CRYSTAL UM 7090 MAD RSB O\$ BURP5, GAMMA-RAY PHOTOFRACTION I7O WELWING, MATERIAL BUCKLING CYL FUEL ELEMFNTS AEB 360 F4 $\quad S \quad P \quad 8 \quad 362$ WHAM, LIQUID-FILLFD PIPING SYSTEM ANALYSIS $\quad$ KF 3600 F36 RSAP G 278 WHIRLAWAY, 3-D 2-GRNUP DIFFUSION XYZ GEOMETRY CDC 1604 F63 RS P TC \$ 32 WHIRLAWAY, 3-D 2-GROUP DIFFUSION XYZ GEOMFTRY ORNL 7090 F2 $\quad$ RS P T C \$ 32 WIGL2, 1-D 2-GP SPACE-TIME NIFFUSINN 3-GEOM BAPL 6600 F4 RS P XT F $\$ 274$ WIGL2, 1-D 2-GP SPACE-TIME DIFFUSION 3-GEOM GGA 1108 F4 RSP TF \$R274 WIREX, COMPUTER-PRODUCFD WIRING LISTS UHTREX LASL 7090F? RS P I \$ WIRING LISTS UHTREX LASL $7090 \mathrm{FZ}$ RS $P$ IS WIREX, COMPUTFR-PRODUCED 315 WLIB,FLAT, RESONANCE ABSORPTION, CELL ANL 360C F36 RSBP XT B\$RABBLE, WOODS-SAXON POTENTIAL SHAPE CALCULATION ORNL TO9OF2 RS AYNE, WOPEXPRT, REACTOR WEIGHT OPTIMIZATIDN STUDY PW 1604 F63 RS I $X$-SEC CALC BNL $6600 F 4$ RSP A\$ SIGPLOT, RESOLVFN MULTILEVEL B-W $X$-SEC CALC BNL 7094 F4 RS $P$ A\$ SIGPLOT, RESOLVFD MULTILEVEL B-W $X$-SEC CALC BNL $6600 \mathrm{~F} 4$ RS $P$ A\$ AVERAGE, UNRESOLVED REGION AVERAGE $X$-SEC CALC BNL 7094 F4 RS P A\$ AVFRAGE, UNRESDLVED REGIDN AVERAGE $X$-SEC CALC BNW 1108 F4 RS P T B\$ FCC4, FUNDAMENTAL MODE FAST REACTOR

315

281

381 190 377 377 376 376 306 
$X$-SEC CALC GGA $1108 \quad F 4$ $X$-SEC CALC ORNL $360 \quad F 4$ $X$-SEC CALC ORNL $1604 \quad F 63$ $X$-SEC EVALUATION $X$-SEC FVALUATION AI $X$-SECS BAPL $6600 \mathrm{~F} 4$ $X$-SECS BAPL $6600 \quad F 4$ $X$-SECTION AVERAGING $X$-SECTION CALC $X$-SECTION CALC $X$-SECTION CALC $X$-SECTION CALC $X$-SECTION CALC $X$-SECTION C,ALC $X$-SECTION CALC $X$-SECTION CALC $X$-SECTION CALC $X$-SECTION CALC. $X$-SECTION CALC $X$-SECTION CALC $X$-SECTION CALC $X$-SECTION CALC $X$-SECTION CALC $X$-SECTION CALC RS ORNL 1604 F63 $360 F+B A L$ RS RS XT R\$ MO807, 2-D DIFFUSION ABSORPTION REMOVAL GGA 7044 F4 RS P LS GAVER, ENERGY INTERVAL AI $7090 \mathrm{~F} 2$ RS PL T AS ARES2, RESONANCE INTETRAL AI $7 C 94$ F+MAP RS PLXT AS TRIXI, RESONANCE INTEGRAL ANL 3600 F63 RSBP A\$ NEARREX, COMPOUND NUCLEUS CDC 1604 F63 RS PL T A $\$$ ARES2, RESONANCE INTEGRAL NED 2000 F2 RS $P$ AS DOPIE, RESOLVED RESONANCE AI $7090 \mathrm{~F} 2$ RS PL T RS FORM, FAST NEUTRON SPECTRUM ANL 3600 F63 RS LXT R\$ GAM1. FAST NEUTRON SPECTRUM CDC 1604 F63 RS PL T B\$ FORM, FAST NEUTRON SPFCTRUM CDC 1604 F63 RS PLXT RS GAMI, FAST NEUTRON SPECTRUM GGA 1108 F4 RS P A GANDY, UNRFSOLVED RFSONANCE GGA TOSO F2 RS PLXT BS GAMI, FAST NEUTRON SPECTRUM NED 20 CO F2 RS P AS RAPTURE, RESONANCF INTEGRAL ANL 3600 F63 RSBP XT BS THERMOS(ANL), THERMAL SPECTRUM ELASTIC SCAT RESONANCES AI $360 \mathrm{~F} 4$ RS PLXT BS AILMOE, ELASTIC SCAT RESONANCFS AI 7094 F+FAP RS PL T B\$ AILMOF, $X$-SECTION CALC MODERATOR GGA $1108 F_{4}$ RS P AS GAKER, INFLASTIC SCAT $X$-SECTION CALCULATION GEC $625 \mathrm{~F} 4$ RS P BS AVOID, ANNULAR VOID X-SECTION CALCULATION $X$-SECTION CALCULATION $X$-SECTION CALCULATION $X$-SECTION CALCULATION BAPL 6600 F4 ANL 3600 F 36 GGA 1108 F5 GGA 7044 F4 RS P XT AS SUMOR, S-WAVE NEUTRON RS P T B\$ MC * 2, ENDF MULTIGROUP RS P A\$ FLANGEI, SCATTFRING LAW RS AS FLANGEI, SCATTERING LAW $X$-SECTION CALCULATION GEV 7094 F+FAP RS $P$ T B\$ EPITHERMOS, SPECTRUM AND $X$-SECTION EVALUATION ORNL $7090 \mathrm{~F} 4$ RSBP AS MUFFLE, FISSILF NUCLIDE $X$-SECTION GENERATION BNW 1108 F4 RS P XT B\$ 1DX, 1-D DIFFUSION FAST $X$-SECTION LIBRARY PREPARATION GGA $1108 \mathrm{~F} 4$ RS P T L $\$$ GAND, GAFGAR $X$-SECTION LIBRARY TAPE PREPARATION PW $1604 \mathrm{~F} 63$ RS LS CSPI, SN $X$-SECTION LIBRARY TAPE PREPARATION PW 1604 F63 RS LS CSP2A, SN $X$-SECTION LIBRARY UTILITY PROGRAM AI 7094 F+FAP RS LT M\$ MOMUS, $X$-SECTION LIBRARY UTILITY ROUTINE ANL $3600 \mathrm{~F} 63$ RSBP T M\$ XLIBIT, $X$-SECTION TAPE GGA 7044 F+MAP RSAP M\$ UNPACK, RETRIEVAL FROM SCISRS $X$-SECTION TAPES GGA $7044 \mathrm{~F} 4$ RSBP T NS CROSSPLOT, SC 4020 PLDTS FROM $X$-SECTION TAPES WANL 7094 F2 RSB T N\$CPS, SC4020 PLOTS FROM SCISRS $X$-SECTIONS AI 7090 F+FAP RS L T B\$ QUICKIE, INFINITE MEDIUM SPECTRUM $X$-SECTIONS LASL 7090 FLOCO RS $P$ B\$ $20 T$, GROUP-COLLAPSING OF MULTI-GP $X$-SECTIONS AI 7090 F+FAP RS PL $T$ B\$ TEMPEST2, THERMAL NFUTRON SPECTRUM $X$-SECTIONS AI 7094 F2 RS P T A\$ 2PLUS, NON-SPHERICAL OPTICAL MODEL $X$-SECTIONS ANL 3600 F63 RSBP T A\$ 2PLUS, NON-SPHERICAL DPTICAL MODEL $X$-SECTIONS BHSC $360 \mathrm{~F} 4$ RS PL T B\$ TEMPEST2, THERMAL NEUTRON SPECTRUM $X$-SECTIONS CDC 1604 F63 RS PL T B\$ TEMPEST2, THERMAL NEUTRON SPECTRUM $X$-SECTIONS FAST THERMAL SPECTRA GGA 1108 F4 RS PLXT B\$ GGC4, MULTI-GP $X$-SECTIONS FAST THERMAL SPECTRA GGA 6600 F4 RS L T B\$ GGC4, MULTI-GP $X$-SECTIONS FOR GAMMA-RAYS GFC 7094 F4 RS P B GAMMA-P, PRDDUCTION $X$-SECTIONS FROM B-W RESONANCE DATA GGA 7044 F4 RS P AS FASDOP, $X$-SFCTIONS FROM B-W RESONANCE PARAMETEPS WANL $7094 \mathrm{~F} 2$ RS P AS EXT, $X$-SECTIONS HEX LATTICE GGA 1108 F4 RS B\$ HEXSCAT, ELASTIC SCAT $X$-SECTIONS NED $635 \mathrm{~F}_{4}$ RS P T BS REAX, RESOLVED RESONANCE EPITHERMAL $X$-SECTIONS PARAMETFRS AI 7094 F+FAP RS PL $T$ BS GRAVE, GROUP-AVERAGING $X-Y$ GEOM ANL 360 F4 RS P T C\$ TWOTRAN, 2-D MULTI-GD TRANSPORT CODE $X-Y$ GEOM LASL 1108 F4 RS $P$ T C $\$$ TWOTRAN, 2-D MULTI-GP TRANSPORT CODE $X L I B I T, X$-SFCTION LIRRARY UTILITY RDUTINF ANL $3600 \mathrm{~F} 63$ RSRP T $M$ s $X$ SORN, OISCRETF OROINATE MULTIGROUP CONSTANTS ORNL 360 F4 RS PLXT $B$ \$ $X Y$ GEOM AGC 7090 FLOCO RSBP C\$ 2DXY, 2-D MULTI-GP SN APPROXIMATION $X Y$ RZ GEOMETRY GGA 1108 F+RAL RS P T C\$ GAMBLE5, 2-D MULTI-GP DIFFUSION $X Y$ RZ GEOMETRY GGA 7044 F+MAP RSBP T C\$ GAMBLF4, 2-D MULTI-GP DIFFUSION XY RZ RTH WANL 7094 F4 RS P XT C\$ VARI-QUIR3, 2-D MULTI-T,P DIFFUSION
316

322

322

308

375

R359

$R>80$

218

89

208

171

89

177

51

33

51

33

341

33

176

184

147

147

210

289

276

R399

355

247

247

201

323

374

345

194

193

159

181

206

207

239

119

113

50

254

254

50

50

298

298

235

216

238

291

257

162

358

358

181

393

18

222

222

264 
XY RZ RTHFTA GEOMETRY BNW 1108 F4 RS P C\$ PERT4, 2-D PERTURBATION XYZ GEOMFTRY CDC 1604 F63 RS P T C\$ WHIRLAWAY, 3-D 2-GRDUP DIFFUSION XYZ GEOMETRY ORNL 7090 F2 RS P T C\$ WHIRLAWAY, 3-D 2-GROUP DIFFUSION YIELD FROM REACTION OR DECAY ORNL 1604 F63 RS P D ISOTDPES, MAXIMUM ZOT, GROUP-COLLAPSING OF MULTI-GP X-SECTIONS ZPR-III ASSEMBLY 48 GAFGAR ENDF/B DATA TAPES ZUT, RESOLVED REGION RESONANCE INTEGRAL CALC 1-D AGE-DIFFUSION SLAB CYLINDER SPHERF $A E B$ LASL 7090 FLDCO RS P B \$ GGA 1108 BIN R L T Z GGA 7090 F+FAP RSB TA 1-D AND 2-D MULTI-GP DIFFUSION PROGRAM 1-D AND 2-D MULTI-GP DIFFUSION PROGRAM 1-D BURNUP POWER DISTRIBUTION SEARCH 1-D DIFFUSION FAST X-SECTION GENERATION BNW $1108 \mathrm{~F} 4$ RS P XT BS IDX, $360 \mathrm{~F} 4$ RS L T CS FIRE5, UK-R 7090 F+FAP RSBPL T C\$ CRAM, GGA $1108 \mathrm{FH}_{4}$ RS P T C\$ GASP7, 1-D FEW-GP DIFFUSION DEPLETION PROGRAM GGA $7090 \mathrm{F2}$ RSB T D\$FEVER, 1-D FEW-GP DIFFUSION DESIGN SYSTEM AI $360 \mathrm{F4}$ RSBP T K\$ THREDES, 1-D FEW-GP DIFFUSION POWER DIST SEARCH GGA 7044 F4 RS P T C\$ GASP2, 1-D FEW-GP DIFFUSION SLAB CYLINDER SPHERE AI $7090 \mathrm{~F} 2$ RS P T C\$FOG. 1-D FEW-GP DIFFUSION SLAB TYYLINDER SPHERE BC $625 \mathrm{F4}$ RS T C\$FOG, 1-D FEW-GP DIFFUSION SLAB CYLINDER SPHERE CDC $1604 \mathrm{FG3}$ RS P T C\$FOG, 1-D FEW-GP DIFFUSION TEMP COEF CALC GGA 7044 F4 RS P T C\$ TEMCO, 1-D FEW-GP SN APPROXIMATION CYLINDER PPCO 7040 F4 PS P T CS TOPIC. 1-D FFW-GP SN APPROXIMATINN CYLINDER PPCO 7090 F2 RS P TCS TOPIC, 1-D FEW-GP SN DOUBLE SN APPROX SLAB GEOM PPCO $7090 \mathrm{FZ}$ RS P C\$ MIST, 1-D MULTI-GP DIFFUSION + LIB AI 360 F4 RSBPLXT C\$ CAESAR4,LIBLST, 1-D MULT I-GP DIFFUSION SLAB CYL SPHERE BNW 1107 F4 RS P T C\$ HFN, 1-D MULTI-GP DIFFUSION SLAB CYL SPHERE AI 7090 F+FAP RS L T C\$FAIM, 1-D MULTI-GP DIFFUSION SLAB CYL SPHERE 1-D MULTI-GP DIFFUSION SLAB CYL SPHERE 1-D MULTI-GP DIFFUSION SLAB CYL SPHFRE 1-D MULTI-GP DIFFUSION SLAB CYL SPHERE 1-D MULTI-GP DIFFUSION SLAB CYL SPHERE 1-D MULTI-GP DIFFUSION SLAB CYL SPHERE AI 7090 F+FAP RS PL T C\$ AIMG, CDC $1604 \mathrm{F6} 3$ RS PL T C\$ AIM6, CDC 1604 F63 RS PLXT C\$ FAIM, AI 7090 F+FAP RS LT C\$ ULCER, ANL 3600 F36 RS P XT C\$ MACHI, PURD 6500 F4 RS PLXT CS MACHI, 1-D MULTI-GP DIFFUSION SLAB CYL SPHFRE BHSC $360 \mathrm{F4}$ 1-D MULTI-GP DISCRETE DRDINATE CALC 1-D MULTI-GP DI SCRETE TRDINATE CALC 1-D MULTI-GP DISCRETE ORDINATE CALC ANL 1-D MULTI-GP DISCRETE ORDINATE PRDGRAM 1-D MUL TI-GP DISCRETF ORDINATE PROGRAM 1-D MULTI-GP DISCRETE ORDINATE PRCGRAM 1-D MULTI-GP DISCRETE ORDINATE PROGRAM 1-D MULTI-GP DISCRETE ORDINATE PROGRAM

$\begin{array}{lll}A I & 7090 \mathrm{F2}\end{array}$
RS P T CS FAIMOS, RS PLXT CS DTF2, RSBPLXT C\$ ANISN, $3600 F 36$ RS P T C\$ SNARG-1D, ANL $360 \mathrm{F4}$ RS $P$ T C\$ DTF4, BC $\quad 625 \mathrm{~F} 4$ RS P T C\$ DTF4, LASL 6600 F4 RS P T C\$ DTF4. LASL 7030 F4 RS P T C\$ DTF4, LER 7094 F4 RSP T C\$ DTF4, 1-D MULTI-GP DOUBLE SN APPROX BNW 7090 FLOCO RSBP T C\$ GE-HAPD-SI3, 1-D MULTI-CP DTF4 WITH DEPLETION LASL 7030 F4 RS P T D\$ DTF-BURN, 1-D MULTI-GP SN APPROX SLAB CYL SPHERE PW 1604 LAGI RS P CS MGDSN, 1-D MULTI-GP SN APPROX SLAB CYL SPHERE UK-W 7090 F2 RS P T CS W-DSN, 1-D MULTIGP KINETICS WITH TEMP FEEDBACK GGA 1108 F4 RS P T F\$ GAKIT. 1-D MULTIGROUP DIFFUSION AND DEPLETION GGA 1108 F4 1-D MULTIGROUP DIFFUSION DEPLETION 1-D MULTIGRTUP DIFFUSION DEPLETION 1-D MULTIGROUP DIFFUSION DEPLFTION 1-D MULTIGRTUP DISCRETE ORDINATE CALC AI $360 \quad F 4$ AI $7090 \quad F 2$ CDC $1604 \mathrm{FG}_{3} \mathrm{RS} \mathrm{L}$ UNC $1604 \mathrm{~F}_{63}$ RS PL T C\$ DTF, 1-D MULTISROUP TIME-DEPENDENT DIFFUSION GGA 1108 F4 PS P T F\$ GAKIN, 1-D ONE-GP SPACE-TIME DIFFUSION FEEDBACK BNL $6600 \mathrm{~F} 4$ 1-D PERTUPBATION FOR AIM AND FOG CODES 1-D PFRTURBATION FOR AIM AND FOG CODES 1-D PERTURBATION FOR AIM AND FOG CODES I-D SLAR GAMMA-RAY TRANSPORT AI 7090 F2 BHSC $360 \quad F_{4}$ CDC $1604 \mathrm{FG}_{3}$ I-D SLAB TRANSPORT WITH SLOWING DOWN BAPL $6600 \quad F 4$ BAPL $6600 F 4$ RS $P$ RS $P$ T FS NOAH, RS C\$ PERT, RS P C\$ PERT, RS C\$ PERT, 1-D TIME-DEPFNOENT DIFFUSION CALC KAPL 6600 F4 RS P F\$ RAUMZEIT, 1-D 1-GP SN APPRDXIMATION SLAB GEOMETRY AI $7090 \mathrm{~F} 2$ RS P B\$ SAIL, 1-D 1-GP SN APPROXIMATION SLAB GFOMFTRY CDC 1604 F63 RS P B\$ SAIL, 1-D 1-GP S4 APPRDXIMATION AI 7090 F2 RS 1-D 1-GP S4 APPROXIMATION CDC 1604 F63 RS P B\$ S4 CYL CELL CODE, 1-D 2-GP KINETICS TEMPERATURE FFEDBACK BAPL 6600 F4 RS P XTF\$ NOWIG,
304

32 32 179 113 356 41

220

28 28 28 225 148 148 59 270 241 120 29 29 120 118 262 262 120 151 151 288 209 209 209 209 209 75 269 211 132 370 318 
1-D 2-GP SPACE-TIME DIFFUSIUN 3-GEOM

BAPL $6600 \quad F 4$ GGA $1108 \quad F 4$ 1-GP SN APPROXIMATION SLAR GEOMFTRY 1-GP SN APPROXIMATION SLAB GEOMETRY CDC 1-GP S4 APPROXIMATION AI 7000 F2 RS B\$ S4 CYL CELL CDDE, 1-D 1-GP 54 APPROXIMATION CDP 1604 F63 RS P $B \$$ S4 CYL CELL CODE, 1-D

RS P XT F\$ WIGL2, RS P T F\$ WIGL2, RS P B\$ SAIL, I-D RS P B \$ SAIL, 1-D 1-REGION KINETICS SNAP GEOMFTRY AI 7090 F2 RS F 2 SNAPKIN5/5A, 1DX BNWL 1108 F4 RS $P$ T B\$ ETOX, MULTIGROUP CONSTANTS FROM ENDF/B FOR 1DX, 1-D DIFFUSION FAST X-SECTION GENERATION BNW 1108 F4 IST FLIGHT COLLISION PROBABILITIES MC ORNL 360 F+BAL RS P T AS RAFFLE, $1 S T$ FLIGHT COLLISION PROBAEILITIES MC ORNL 7090 F+FAP RS P T B\$RAFFLF, $10 \mathrm{MEV} \quad \mathrm{AC} \quad 625 \mathrm{~F} 4$ RS P XT B\$GAMTEC2, MULTI-GP CONSTANT CALC O TO $10 \mathrm{MEV}$ ANW $1107 \mathrm{~F} 4$ RS PL T B\$ GAMTEC2, MULTI-GP CONSTANT CALC O TO 10 MEV BNW 7090 F+FAP RS PL T B\$ GAMTEC2, MULTI-GP CONSTANT CALC O TO $1107 \mathrm{FA}$ RS $P$ T C\$ HFN, 1-D MULTI-GP DIFFUSION SLAB CYL SPHERE BNW

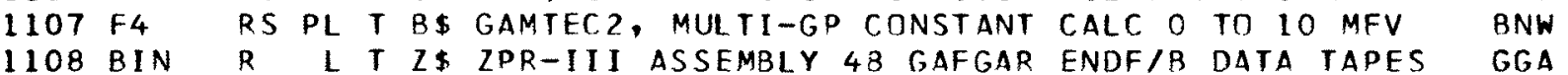
1108 F+BAL RS P T C $\$$ GAMBLE5, 2-D MULTI-GP DIFFUSION XY RZ GEOMETRY GGA $1108 F+B A L$ RS $P$ T C\$ GAMTRI, 2-D MULTIGP DIFFUSION TRIANGULAR MESH GGA $1108 \mathrm{~F}_{4} \quad \mathrm{~S}$ $1108 F_{4} \quad R S$ $1108 \quad F 4$ $1108 F 4$ $1108 \mathrm{~F} 4$ $1108 \quad F 4$ $1108 F 4$ $1108 F 4$ $1108 F 4$ $1108 F 4$ $1108 \mathrm{FA}$ $1108 \mathrm{FA}$ $1108 \mathrm{~F} 4$ $1108 \mathrm{~F} 4$ $1108 \mathrm{~F} 4$ $1108 \mathrm{~F} 4$ $1108 \quad F 4$ $1108 \mathrm{FG}$ $1108 \quad F 4$ $1108 \mathrm{F4}$ $1108 \quad F 4$ $1108 \mathrm{~F} 4$ $1108 F 4$ $1108 F 4$ $1108 F 4$ $1108 F 4$ $1108 \mathrm{~F} 4$ $1108 \mathrm{F4}$ $1108 \quad F 4$ $1108 \quad F 4$ $1108 F_{4}$ $1108 F 4$ $1108 \mathrm{~F} 4$ $1108 \quad F 4$ $1108 \mathrm{F4}$ $1108 \quad F 4$ $1108 \quad F 4$ $1108 \quad F 4$ $1108 \mathrm{F5}$ $1108 \mathrm{~F} 5$ $1108 F 5$ 1108 F 5

$T$ D\$ GAFFE, EQUILIBPIUM FUEL CYCLE CALCULATION

\$ HEXSCAT, ELASTIC SCAT X-SECTIONS HEX LATTICE GGA

RS

RS P

RS $P$

RS $P$

RS P

RS $P$

RS $P$

RS P

RS $P$

RS P

RS $P$

RS $P$

PS P

RS $P$

RS $P$

RS $P$

RS P

RS P

RS $p$

RS $P$

RS P

RS $P$

RS $P$

RS $P$

RS $P$

R S $P$

RS $P$

RS $P$

RS $p$

RS $P$

RS $p$

RS $P$

RS $p$

RS $P X T \quad P S$

RS $P X T$ B

RS PLXT

RS $P$

RS $P$

RS $p$

PSBPL T D\$ ISOGEN, RADIONUCLIDE GFNERATION AND DECAY BNW

G\$ GADOSE, DOSET, HTGR ACCINENT ANALYSIS DOSE CALC GGA

A\$ GANDY, UNRESOLVER RESONANCE X-SFCTION CALC GGA

A\$ GASKET, THERMAL SCATTERING LAW CALCULATION GGA

A\$ PSEUDO, STATISTICAL RESONANCE PARAMETFR CALC GGA

C\$ PERT4, 2-D PERTURBATION XY RZ RTHETA GEOMETRY BNW

D\$ FREVAP6, HTGR METALLIC FISSION PRDDUCT RELEASE GGA

E\$ GAPOTKIN, SPACE-INDEPENDENT REACTOR KINETICS GGA

E\$ GASA, STABILITY ANALYSIS REACTOR KINETICS FONS GGA

I \$ SAFE-CREEP, VISCOELASTIC ANALYSIS CONCRETE

I \$ SAFE-PLANE, PLANE STRESS ANALYSIS, 2-D BODIES

I \$ SAFE-SHELL, STRESS ANALYSIS THIN SHELLS

I \$ SAFE-2D, PLANF + AXISYMMETRIC STRESS ANALYSIS

L\$ GRDWRK, GRID GENERATION FOR SAFE PROGRAMS

$T$ A\$ TACASI, ANALYSIS OF RESNNANCE MEASUREMENTS

GGA

GGA

GGA

GGA

GGA

GGA

$T$ B\$ ETOX, MULTIGROUP CONSTANTS FROM ENDF/R FOR IDX BNWL

T R\$ FCC4, FUNDAMENTAL MODE FAST REACTOR X-SFC CALC BNW

$T$ C\$ GASPT, 1-D BURNUP POWER DISTRIBUT ION SEARCH GGA

T C\$ GATT, 3-D FEW-GP DIFFUSION CALC HEX-Z MESH GGA

T C\$ TEMCOT, TEMPERATURE COEFFICIENT CALCULATION

GGA

C\$ TWOTRAN, 2-D MULTI-GP TRANSPORT CODE $X-Y$ GEOM LASL

I DS FEVFR7, 1-D MULTIGROUP DIFFUSION AND DEPLETION GGA

T D\$ GAUGE, 2-D FFW-GP HEX GEOM DIFFUSION DEPLETION GGA

T D\$ 2DB, 2-D MULTIGROUP DIFFUSION AND DEPLETION RNW

$T$ E\$ BLOOST6, COMBINED KINETICS 2-D HEAT TRANSFER GGA

$T$ F $\$$ GAKIN, 1-D MULTIGROUP TIME-DEPENDFNT DIFFUSION GGA

TF\$ GAKIT, 1-D MULTIGP KINETICS WITH TFMP FEEDBACK GGA

T F\$ WIGL2, 1-D 2-GP SPACF-TIME DIFFUSION 3-GEOM GGA

$T$ I\$ SAFF-3D, 3-D COMPOSITE STRUCTURE STRFSS STUDY GGA

J\$ MUSCAT, VIEW FACTOR SHIELDING CODE CAVITY GEOM GGA

$T$ L\$ GAND, GAFGAR X-SECTION LIRRARY PREPARATION

GGA

O\$ TOAD, PROCESSING OF ANALYZER GAMMA-RAY SPECTRA GGA

\$ COHAE, COHERENT INELASTIC SCATTERING LAW CALC GGA

- GAF,GAR, SPECTRA AND GROUP-AVERAGED X-SFC CALC GGA

\$ IDX, 1-D DIFFUSION FAST X-SECTION GFNERATION

BNW

$\$$ GGC4, MULTI-GP X-SECTIONS FAST THERMAL SPECTRA GGA

A\$ FLANGE 1, SCATTERING LAW X-SECTION CALCULATION GGA

H* FLAC, STEADY-STATE FLOW, PRESSURE DISTRIBUTION GGA 14.5-14,50OPSIA 32-472DEGT BAPL 660 F4 RS XT H\$ WATER, STEAM TABLES $14.5-2538$ PSIA $14.5-2538$ PSIA ANL $1604 F 63$ BAPL $6600 \mathrm{F4}$
R 274

R 774

52

52

53

53

122

388

374

392

392

185

185

185

241

185

356

222

401

302

291

261

289

341

263

292

304

301

317

290

300

252

253

379

296

410

388

306

319

380

320

358

318

339

325

303

310

370

R274

332

259

345

333

395

316

374

298

247

395

408

367

R267

R?94

R294 


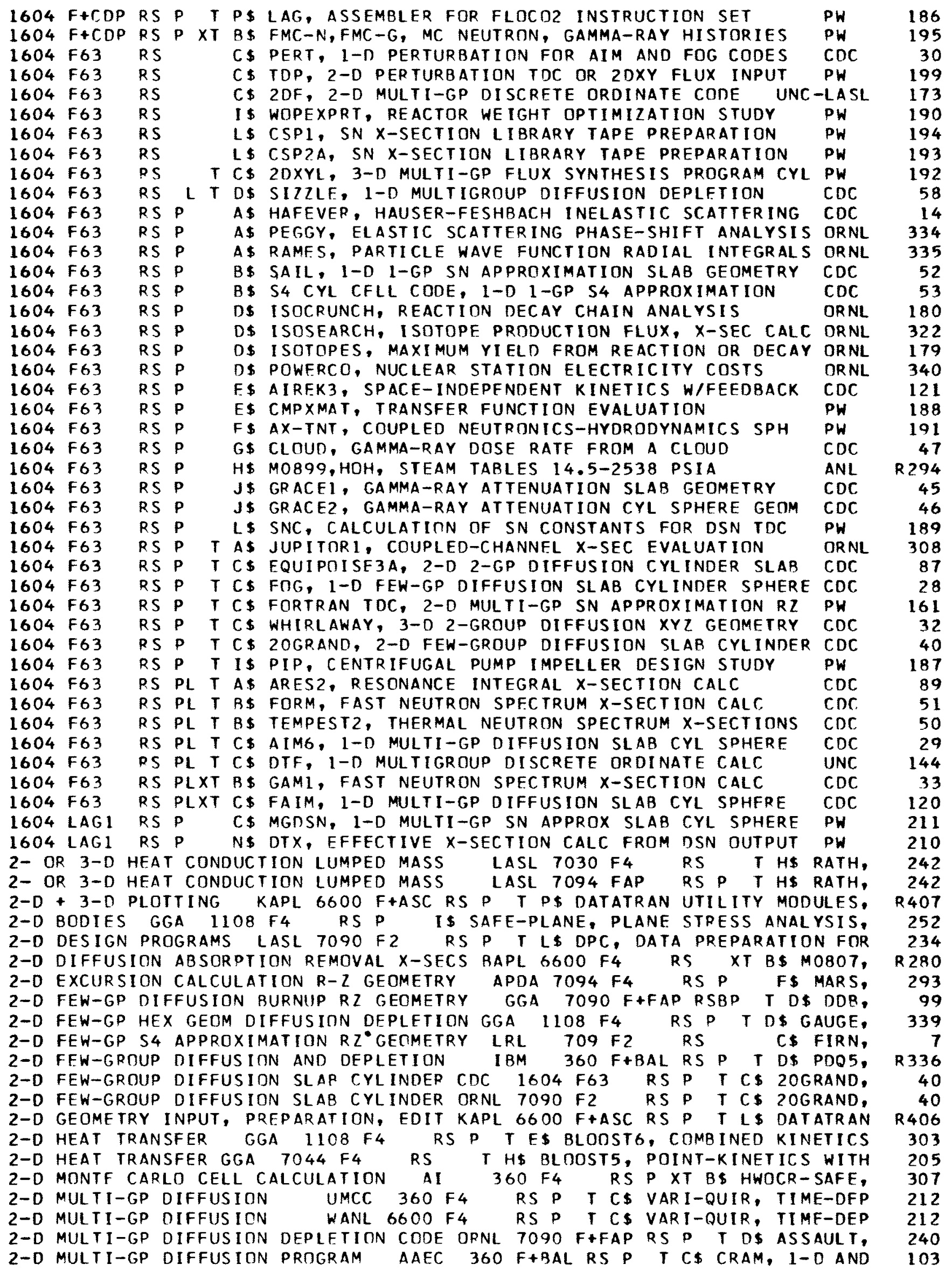


2-D MULTI-GP DIFFUSION PROGRAM 2-D MULTI-GP DIFFUSION PROGRAM 2-D MULTI-GP DIFFUS ION PROGRAM 2-D MULTI-GP DIFFUSION PROGRAM ORNL 7090 F+FAP RS P T C\$ EXTERMINATOR, UK-R 7090 F+FAP RSBPL T C\$ CRAM, 1-D AND BC $625 \mathrm{~F} 4$ RS T C\$ EXTERMINATDR2, ORNL $360 \mathrm{~F} 4$ RS $P$ T C\$ EXTERMINATOR2, 2-D MULTI-GP DIFFUSION SYNTHESIS CALC NED 635 F4 RS PL T CS BISYN, 2-D MULTI-GP DIFFUSION XY RZ GEDMETRY GGA 1108 F+BAL RS P $T$ CS GAMBLE5, 2-D MULT I-GP DIFFUSION XY RZ GEOMETRY GGA 7044 F+MAP RSBP $T$ C\$ GAMBLE4, 2-D MULTI-GP DIFFUSION XY RZ RTH WANL 7094 F4 RS P XT C\$ VARI-OUIR3, 2-D MULTI-GP DISCRETE ORDINATE CODE UNC-LASL $1604 \mathrm{~F} 63$ RS C\$2DF, 2-D MULTI-GP SN APPRDXIMATION RZ PW $1604 \mathrm{FG3}$ RS P T CS FORTRAN TDC, 2-D MULTI-GP SN APPROXIMATION XY GEOM AGC 7090 FLDCO RSBP C\$ 2DXY, 2-D MULTI-GP TRANSPORT CODE $X-Y$ GEOM ANL $360 \mathrm{~F} 4$ RS P T C\$ TWOTRAN, 2-D MULTI-GP TRANSPORT CODE $X-Y$ GEOM LASL 1108 F4 RS P T C\$ THOTRAN, 2-D MULTIGP DIFFUSION TRIANGULAR MESH GGA $1108 \mathrm{~F}+B A L$ RS $P$ T C\$ GAMTRI, 2-D MULTIGROUP DIFFUSION AND DEPLETION ANL $3600 \mathrm{~F} 4 \quad$ RSBP T D\$2DB, 2-D MULTIGROUP DIFFUSION AND DEPLETION BNW 1108 F4 RS P T D 2DB, 2-D MULTIGROUP DIFFUSION AND DEPLETION LASL 6600 F4 RS $P$ T DS $20 B$, 2-D MULTIGROUP DISCRETE TRDINATE PROGRAM LER $7090 \mathrm{~F}+M A P$ RS P T C\$ TDSN, 2-D PERTURBATION TDC OR 2DXY FLUX INPUT PW $1604 \mathrm{F63}$ RS C\$TDP, 2-D PERTURBATION XY RZ RTHFTA GEOMETRY BNW 1108 F4 RS P C PERT4, 2-D TIME-DEPENDENT HEAT CONDUCTION 2-D TRANSIENT HEAT CONDUCTION PROGRAM 2-D 2-GP DIFFUSION CYLINDER SLAR CDC PPCO 7044 F+MAP RS P T HS TOONEE, BAPL 6600 F4 RS P XT HS HOT2, 2-D 2-GP DIFFUSION CYLINDER SLAB ORNL $7090 \mathrm{~F} 2$ RS $P$ T CS EQUIPOISE3A, 2-D 2-GP SPACE-TIME DIFFUSION ANL 360 F4 RS P F\$ TWIGGLE, 2-D 2-GP SPACE-TIME DIFFUSION FEEDBACK BAPL 6600 F4 RS P XT F\$ TWIGL, 2-D 2-GROUP DIFFUSION SLAB CYL ORNL $7090 \mathrm{F2}$ RS $P$ T CS EQUIPOISE3, 2-D 2-PHASE FLOW AI $7094 \mathrm{~F} 2$ RS P HS FLOW-MDDEL, MULTI-CHANNEL 2-GP DIFFUSION CYLINDER SLAB CDC 1604 F63 RS P T C\$ EOUIPOISE3A, 2-D 2-GP DIFFUSION CYLINDER SLAB ORNL $7090 \mathrm{F2}$ RS P T C\$ EQUIPOISE3A, 2-D 2-GP KINETICS TEMPERATURE FFEDBACK BAPL $6600 \mathrm{~F} 4$ RS P XT F\$ NOWIG, I-D 2-GP SPACE-TIME DIFFUSINN ANL $360 \mathrm{~F} 4$ RS P F TWIGGLE, 2-D 2-GP SPACE-TIME DIFFUSION FFEDBACK BAPL 6600 F4 RS P XT FS THIGL, 2-D 2-GP SPACE-TIME DIFFUSION 3-GEOM 2-GP SPACE-TIME DIFFUSION 3-GEOM 2-GROUP DIFFUSION SLAR CYL BAPL 6600 F4 GGA 1108 F4 RS P XT FS WIGL2, 1-D RS P T F\$ WIGL2, 1-D 2-GROUP DIFFUSION XYZ GEOMETRY CDC 1604 F63 RS P T C\$ WHIRLAWAY, 3-D 2-GROUP DIFFUSION XYZ GEOMETRY ORNL $7090 \mathrm{F2}$ RS P T C\$ WHIRLAWAY, 3-D 2-PHASE FLOW AI $7094 \mathrm{~F} 2$ RS P H\$ FLOW-MDDEL, MULTI-CHANNEL 2-D 2-REG CELL ANL $3600 \mathrm{~F} 36$ RSBP XT BS RIFF-RAFF, RESDNANCE INTEGRAL CALC 2DB, 2-D MULTIGROUP DIFFUSION AND DEPLETION ANL $3600 \mathrm{~F} 4 \quad$ RSBP $T$ D $\$$ 2DB, 2-D MULTIGROUP DIFFUSION AND DEPLETION BNW $1108 \mathrm{~F} 4 \quad$ RS P $T$ D 2DB, 2-D MULTIGROUP DIFFUSION AND DEPLETION LASL $6600 \mathrm{~F} 4 \quad$ RS $P$ T $D \$$ 2DF, 2-D MULTI-GP DISCRETE DRDINATE CODE UNC-LASL 1604 F63 RS $C \$$ 2DXY FLUX INPUT PW 1604 F63 RS CS TDP, 2-D PERTURBATION TDC OR 2DXY, 2-D MULTI-GP SN APPROXIMATION XY GEOM AGC 7090 FLOCO RSBP $C$, 2DXYL, 3-D MULTI-GP FLUX SYNTHESIS PROGRAM CYL PH $1604 \mathrm{F63}$ RS T C $\$$ 2PLUS, NON-SPHERICAL OPTICAL MODEL X-SECTIONS AI $7094 \mathrm{~F} 2$ 2PLUS, NON-SPHERICAL OPTICAL MODEL X-SECTIONS ANL 3600 F63 20GRAND, 2-D FEW-GRDUP DIFFUSION SLAB CYLINDER CDC 1604 F63 20GRAND, 2-D FEW-GROUP DIFFUSION SLAB CYLINDER ORNL 7090 F2 $2000 \mathrm{~F} 2$ RS $P$ A\$ DOPIE, RESOLVED RESONANCE X-SECTION CALC $2000 \mathrm{~F} 2$ $2000 \mathrm{~F} 2$ RS P RS P $2000 \mathrm{~F} 4$ RS $2000 \mathrm{~F} 4$ RS P A\$ RAPTURE, RESONANCE INTEGRAL X-SECTION CAL BS SPARTA, SPATIALLY-AVERAGFD DOPPLER EFFECTS A\& STRIP, RESOL VED RESONANCE INTEGRAL CALCULATION RS P T A RSBP $T$ T A RS $P$ T C RS P $T$ C $\$$ NED NED NED 3-D COMPOSITE STRUCTURE STRFSS STUDY GGA $1108 \mathrm{~F} 4$ RS $P$ T IS SAFE-3D, 3-D DIFFUSION DEPLETION MULTIGP ORNL 360 F4 RS P XT K\$ CITATION, 1, 2 , 3-D FEW-GP DIFFUSION CALC HEX-Z MESH GGA 1108 F4 RS P T C\$ GATT, 3-D FEW-GP DIFFUSION DEPLETION BAPL $6600 \mathrm{~F}+A S C$ RS $P$ XT D\$ PDQ7, 1,2 OR 3-D FEW-GP DIFFUSION DEPLETION IBM $360 \mathrm{~F} 4$ RS $P$ T DS PDQ7, 1,2 OR 3-D HEAT CONDUCTION LUMPED MASS LASL $7030 \mathrm{~F} 4$ RS T HS RATH, 2- OR 3-D HEAT CONDUCTION LUMPFD MASS LASL 7094 FAP RS P T H\$ RATH, 2- OR 3-D MULTI-GP FLUX SYNTHESIS PROGRAM CYL PW 1604 F63 RS T CS 2 DXYL,
156

103

156

156

287

222

222

264

173

161

18

358

358

401

325

325

325

312

199

304

349

R286

87

87

R 338

R 338

39

246

87

87

R371

R338

R338

R274

R274

39

32

32

246

213

325

325

325

173

199

18

192

254

254

40

40

177

176

178

305

174

332

387

380

R275

R275

242

242

192 
3-D PLOTTING KAPL 6600 F+ASC PS P T P\$ DATATRAN UTILITY MODULFS, 2-D + 3-D REACTIVITY AND POWER DISTRIBUTION CDC 3600 F63 RSBP T CS FLARE, 3-D REACTIVITY AND POWFR DISTRIBUTION NED 635 F4 RS P $T$ C\$FLARE, 3-D STRUCTURES KAPL $6600 \mathrm{~F} 4$ RS $P \times$ I\$ FINEL, FINITE-ELEMENT STUDY 2 , 3-D TEMPERATURE DISTRISUTION PROGRAM KAPL $6600 \mathrm{~F}+A S C$ RS P T H\$LION, 3-D TRANSIENT HEAT TRANSFER PROGRAM 3-D 2-GROUP DIFFUSION XY7 GFOMETRY 3-D 2-GROUP DIFFUSION XYZ GFOMETRY ORNL 7090 F2 RS P T C\$ WHIRLAWAY, 3-GEOM BAPL 6600 F4 RS P XT F\$ WIGL2, 1-D 2-GP SPACE-TIME DIFFUSION 3-GEOM GGA 1108 F4 RS P T F\$ WIGL2, 1-D 2-GP SPACE-TIME DIFFUSION 32-472DEGF BAPL $6600 \mathrm{~F} 4$ PS XT H\$ WATER, STEAM TARLES 14.5-14,50OPSIA $360 \mathrm{~F}+B A L$ RS $L T M \$ S C O R E 2$, SCISRS ENDF/B GRAPHIC X-SFC EVALUATION AI $360 F+B A L$ RS $P$ T B\$ RAFFLE, IST FLIGHT COLLISION PROBABILITIES MC DRNL $360 \mathrm{~F}+B A L$ RS $P$ T C\$ CRAM, 1-D AND 2-D MULTI-GP DIFFUSION PROGRAM AAEC $360 \mathrm{~F}+B A L$ RS $P$ T D\$ PDQ5, 2-D FEW-GR IUP DIFFUSION AND DEPLETION $360 \mathrm{~F}+B A L$ RS $P$ T E\$ AIROS2A, SIMULATION OF REACTOR DYNAMICS

$360 F 4$ $360 \mathrm{~F} 4$

$360 \quad F 4$

$360 \quad F 4$

$360 \quad F 4$

$360 \quad F 4$

$360 \quad F 4$

$360 \mathrm{~F} 4$

360 F 4

$360 \mathrm{~F} 4$

$360 \quad F 4$

$360 \quad F 4$

$360 \quad F 4$

$360 \mathrm{~F} 4$

360 F4

360 F4

$360 F 4$

360 F4

$360 \mathrm{~F} 4$

$360 F 4$

$360 \mathrm{FA}$

360 F4

360 F4

$360 \mathrm{FA}$

360 F4

$360 \quad F 4$

$360 \quad F 4$

360 F4

$360 \quad F 4$

$360 \mathrm{~F} 4$

360 F 4

$360 F 4$

$360 \mathrm{~F} 4$

$360 \quad F 4$

$360 \mathrm{FA}$

360 F4 $S P$

BS WELWING, MATERIAL BUCKL ING CYL FUEL ELEMENTS

IBM

AI

AEB

RS L T

$T$ CS

RS P

C\$ FIRES, 1-D AGE-DIFFUSION SLAB CYLINDER SPHERE

RS $P$

RS $P$

RS P

RS $P$

RS $P$

RS P

RS P

RS P

RS $P$

PS $P$

RS P

C\$ PFRT, I-D PERTURBATION FDR AIM AND FOG CODES

D\$ ISISEARCH, ISOTOPF PRODUCTION FLUX, X-SFC CALC

E \& AIREK3, SPACE-INDEPENDENT KINETICS W/FEEDBACK

ES BLAST, REACTOR KINETICS TEMPERATURE DIST STUDY

F\$ TWIGGLE, 2-D 2-GP SPACE-TIME DIFFUSIDN

G\$ CLOUD, GAMMA-RAY DOSE RATE FROM A CLOUD

G\$ WATER-HAMMER, LIQUID BLOWDOWN ANALYSIS LDFT

O\$ COPGAM, UNFOLDING OF COMPLEX GAMMA-RAY SPECTRA

T AS FLANGEZ, ENDF/B THERMAL SCATTERING DATA PROC

RS $P$

RS $P$

$T C$

DTF4

MULTI

C\$ EXTERMINATOR2, 2-D MULTI-GP DIFFUSION PROGRAM

RS $P$

$T C$

FAIMOS, 1-D MULTI-GP DIFFUSION SLAB CYL SPHERF

RS P

WOTRAN, $2-D$ MULTI-GP TRANSPORT CODF X-Y GEOM

$T$ C\$ VAPI-QUIR, TIME-DEP 2-D MULTI-GP DIFFUSION

RS $P$

$T$

CINCAS, NUCLEAR FUEL CYCLE COST AND ECONOMICS

RS P

T $F$

$\$$ PDQ7, 1,

$2 \pi$

R 3-

FE

RSP

$T F$

$T S N$

IA. FAST REACTOR POWER AND FLOW TRANSIENTS

RS P

T $G$

AISITE2, PARAMETRIC SITF REQUIREMENT STUDY

RS $P$ T I\$ SABOR4, DISCRETE-ELEMENT ANALYSIS THIN SHELLS

RS P XT B\$ HWOCR-SAFF, 2-D MONTE CARLO CELL CALCULATION

RS $P X T$ FS FORE2, FAST REACTOR EXCURSION CALCULATIONS

RS P XT K\$ CITATION, 1,2,3-D DIFFUSION DEPLETION MULTIGP

RS PL T B TFMPEST2, THERMAL NEUTRON SPECTRUM X-SECTIONS

RS PLXT B\$ AILMOE, X-SECTION CALC ELASTIC SCAT RESONANCES

RS PLXT BS HAMMER, CRITICAL EXPERIMENT ANALYSIS SYSTEM BNL

RS PLXT B\$ LEOPARD, SPECTRA CALCULATION WITH DEPLETION

RS PLXT B\$ XSDRN, DISCRETE ORDINATE MULTIGROUP CONSTANTS

RSB L T MS CLIP, FORM OR THREDES LIBRARY UTILITY ROUTINE

RSBP T K\$ THREDES, 1-D FEW-GP DIFFUSION DESIGN SYSTEM

RSBP XT DS SIZZLE, I-D MULTIGROUP DIFFUSION DEPLETION

RSBPLXT C\$ ANISN, 1-D MULTI-GP DISCRFTE ORDINATE CALC

RSBPLXT C\$ CAESAR4, LIBLST, 1-D MULTI-G,P DIFFUSION + LIB

3600 ASAF 4 RS P

$3600 F 36$

$3600 F 36$

$3600 F 36$

$3600 \quad F 36$

$3600 \mathrm{~F} 36$

$3600 F 36$

$3600 F 36$

$3600 F 36$

$3600 F 36$

$3600 F 36$

3600 F36
SBP

RS P

RS P

RS $P$

RS $P$

RSBP

RSBP

R SBP

R SBP

RSBP $X$

$T M \$$

I\$ BOW2, DEFLFCTION CALCULATION PARALLEL BFAMS

$T$ B $\$ M C * 2$, ENDF MULTIGROUP X-SECTION CALCULATION

T C\$ SNARG-1D, 1-0 MULTI-GP DISCRETE ORDINATE CALC

$T$ I \$ SUPTRAN, REACTOR CORF SUPPORT STRESS ANALYSIS

$\times T C$

MACHI, 1-D MULTI-GP DIFFUSION SLAR CYL SPHERE

A\$ MISH-MASH, RESONANCE INTFGRAL CALC HOMOGENENUS

G\$ CHEMLOC2, CORE HEATING CLADDING-STEAM REACTIDN

G\$ WHAM, LIQUID-FILLED PIPING SYSTEM ANALYSIS

I\$ SWELL?, FUEL ELEMENT LIFETIME ANALYSIS

RIFF-RAFF, RESONANCE INTEGRAL CALC 2-REG CELL
AFB

UILL

BHSC

ORNL

AEB

$A E B$

ANL

DP

UGA

KSUN

DP

ANL

ORNL

BHSC

ANL

UMC C

COMM

IBM

ANL

AI

AI

MIT

AI

ANL

ORNL

BHSC

AI

L-DP

WAPD

ORNL

AI

AI

A I

AI

AI

APDA

ANL

ANL

ANL

ANL

ANL

ANL

ANL

KE

ANL

ANL

ANL
R407

167

167

R404

R299

346

32

32

R274

R274

R 267

375

392

103

R336

326

362

347

30

322

121

363

R 338

47

278

390

368

209

156

120

358

212

354

R275

400

309

172

R402

307

174

387

50

147

277

279

393

271

273

58

151

270

350

365

355

288

357

262

214

366

278

353

281

213 
$6600 \mathrm{F4}$ $6600 \mathrm{~F} 4$ $6600 \mathrm{~F} 4$ $6600 \mathrm{F4}$ $6600 \mathrm{F4}$ $6600 \mathrm{~F} 4$ $6600 F 4$ $6600 \mathrm{~F} 4$ $6600 \mathrm{FH}$ $6600 \mathrm{F4}$ $6600 \quad F 4$ $6600 \mathrm{F4}$ $6600 \mathrm{~F} 4$ $6600 \mathrm{~F} 4$ $6600 \mathrm{F4}$ $6600 \mathrm{F4}$ $6600 F_{4}$ $6600 \mathrm{~F} 4$ $6600 \mathrm{F4}$ $6600 \mathrm{FA}$ $6600 \mathrm{F4}$ $6600 \mathrm{FA}$ $6600 F 4$ $6600 F 4$ $6600 \quad F 4$ $6600 \mathrm{~F} 4$ $6600 F 4$ $6600 \mathrm{F4}$ $7030 \mathrm{~F} 4$ $7030 \mathrm{~F} 4$ $7030 \mathrm{~F} 4$ $7040 \mathrm{~F}+$ MAP $7040 \mathrm{~F}+M A P$ $7040 \mathrm{~F} 4$ RS $P$ $7040 F 4$ RS $P$ $7044 F+M A P$ RS P $7044 F+M A P$ RS $P$ $7044 F+M A P$ RS $P$ $7044 F+M A P$ RSBP $7044 F+M A P$ RSBP $7044 F 4$ RS $7044 F 4 \quad$ RS $7044 F 4$ RS $7044 F 4$ $7044 F 4$ $7044 F 4$ $7044 \mathrm{~F} 4$ $7044 F 4$ $7044 F 4$ $7044 F 4$ $7044 F 4$ $7044 F 4$ $7044 F 4$ $7044 F 4$ $7044 F 4$ $7044 F 4$ $7044 F 4$ $7044 \quad F 4$ $7044 \quad F 4$ $7044 \Gamma 4$ $7044 F 4$ $7044 F 4$ $709 \mathrm{~F} 2$ $7090 \mathrm{~F}+F A P$ RS

RS $P$

RS $P$

RS $p$

RS $p$

RS $P$

RS $P$

RS $P$

RS $P$

RS $p$

RS $P$

RS P RS
RS $P$ T D\$ 20B, 2-D MULTIGROUP DIFFUSION AND DEPLFTION LASL

RS $P$ T F\$ NOAH, I-D ONE-GP SPACE-TIME DIFFUSION FEEDBACK BNL

RS $P$ T F SASIA, FAST REACTOR POWER AND FLOW TRANSIENTS

RS $P$ T I\$ GFM. FIGENVALUE PROBLEM FOR VIBRATING SYSTEMS

RS $P$ T I \$ SOR2, STRESS ANALYSIS SHELLS OF REVOLUTION

RS $P$ T O\$ JITER, FLUCTUATION EXPERIMENT ANALYSIS

RS $P X$ I\$ FINEL, FINITE-FLEMENT STUDY 2.3-D STRUCTURES

RS $P X T$ AS PUNI, UNRESOLVFD RESONANCE INTEGRALS $X$-SECS

RS $P X T$ AS SUMOR, S-WAVE NEUTRON X-SECTION CALCULATION

RS $P X T$ B\$ RESQ2, RESQO,DBF1, RESONANCE INTEGRAL HEX CELL

RS P XT C \$ BE21, FEW-GP DISCRETE ORDINATES SLAB GEOMETRY

RS $P X T$ F NOWIG, 1-0 2-GP KINETICS TEMPERATURE FEEDBACK

RS $P$ XT F\$ TWIGL, 2-D 2-GP SPACF-TIMF DIFFUSION FEEDBACK

RS $P X T$ F\$ WIGL2, 1-D 2-GP SPACE-TIME DIFFUSION 3-GEDM

RS $P X T$ G\$ FLASHZ, LOSS-DF-CONLANT ACCIDENT ANALYSIS

RS $P X T$ G \$ MO555,ACT1, LOSS-OF-COOLANT ACCIDENT ANALYSIS

RS $P X T$ HS FIGRD, ISBR FUEL SWELLING TEMPERATURF STUDY

RS $P X T$ HS FLOT1, MO219, PWR FLNW TRANSIENT ANALYSIS

RS $P X T$ H\$ HOT2, 2-D TRANSIENT HEAT CONDUCTION PROGRAM

RS $P$ XT H\$ MO899, HOH, STFAM TABLES 14.5-2538 PSIA

RS $P X T$ I\$ MO457, DIPE, ELASTIC STRESS OF PIPING SYSTEM

RS $P X T$ I\$ MO552, DYNAMIC ANALYSIS LINEAR ELASTIC SYSTEMS

RS $P X T$ I\$ SEALSHELL2, SHELL STRESS ANALYSIS AXISYM LOAD

RS P XT J\$ MO756, LETO, I-D SLAB GAMMA-RAY TRANSPORT

RS $P X T$ L\$ BL47, DRAFTING TOOL TO PLOT PLANE STRUCTURES

RS $P X T$ P DAFTI, LEAST SQUARFS FIT FISSILE NUCLIDF DATA

RS T H\$ RATH, 2- OR 3-D HFAT CONDUCTION LUMPED MASS

RS P T C\$ DTF4, 1-D MULTI-GP DISCRETE ORDINATE PRTGRAM

RS $P$ T D\$ DTF-BURN, 1-D MULTI-GP DTF4 WITH DEPLFTIDN

$T$ G\$ CONTFMPT, LOSS-OF-CODLANT ACCIDENT ANALYSIS

$T$ GS RSAC, RADIOLOGICAL SAFETY ANALYSIS PROGRAM

A\$ COMBCO, COMBINED B-W MULTI-LEVEL CONVOLUTION

$T$ C\$ TOPIC, 1-D FEW-GP SN APPROXIMATION CYLINDER

$T$ B\$ GAPOL, RESONANCE OVERLAP AND LATTICE EFFECTS

$T$ D\$ OPUS, POWER PLANT PERFIRMANCE AND PRICE STUDY

$T$ H\$ TOODEE, 2-D TIME-DEPENDENT HEAT CONDUCTION

M\$ UNPACK, RETRIEVAL FROM SCISRS X-SECTION TAPE

ANL

KAPL

KAPL

BAPL

KAPL

$B A P L$

$B A P L$

BAPL

BAPL

$B A P L$

BAPL

$B A P L$

BAPL

BAPL

BAPL

BAPL

BAPL

$B A P L$

BAPL

BAPL

$B A P L$

BAPL

BAPL

BAPL

BAPL

BAPL

LASL

LASL

LASL

PPCO

PPCO

PPCO

PPCO

GGA

GGA

PPCO

$T$ C\$ GAMBLE4, 2-D MULTI-GP DIFFUSION XY RZ GEOMETRY GGA

A\$ FLANGE 1, SCATTER ING LAW X-SECTION CALCULATION GGA

I \$ CORF, CORE CONFIGURATION FUEL TEMPERATURE CIDE GGA

T H\$ BLOOST5, POINT-KINETICS WITH 2-D HEAT TRANSFER GGA

$X T$ G\$ PRECIN, HTGR CUNTAINMFNT PRESSURE POST RUPTURE GGA

PS P

RS P

RS P

RS $P$

$P S P X$ A\$ LEGCOEF3, LEGENDRE COEF CALC FOR ANGULAR DIST

RSBP

A\$ FASDIP, X-SECTIONS FROM R-W RFSONANCF DATA

D\$ RAD2, HTGR FISSION PRODUCT ACTIVITY DIST STUDY

DS WAMPUM, FUEL CYCLE COSTS PERFORMANCE STUDY

GGA

L\$ GAVER, ENERGY INTFRVAL X-SECTION AVFRAGING

GGA

GGA

$T$ C\$ GASD2, 1-D FEW-GP DIFFUSION POWER DIST SFARCH GGA

T C\$ TENCT, 1-D FEW-GP DIFFUSION TEMP CNEF CALC

T DS GARGTYLE, FUEL CYCLE ANALYSIS PARTIAL REFUEL

$T$ D\$ RELOAD-FFVER, 1-D FFH-GP DIFFUSION DFPLETION

GGA

GGA

GGA

GGA

$T$ D REVISED-GAD, FUEL CYCLE ANALYSIS W/R.FFUELING
$T$ DS STMFFN, STFAM GENERATOR DESIGN CRITERIA COSTS

GGA

GGA

$T$ G\$ RELAP?, REACTOR BLOWDOWN - EXCURSION ANALYSIS INC

$T$ I\$ SAFE-AXISYM, STRESS ANALYSIS AXISYMMETRIC LOAD GGA

$T$ I\$ SAFF-PCRS, STRESS ANALYSIS AXISYMMETRIC LOAD GGA

$T$ N\$ CROSSPLOT, SC4020 PLOTS FROM X-SECTION TAPFS

C\$ FIRN, 2-D FEW-GP S4 APPROXIMATION RZ GEOMETRY

GGA

GGA

LRL

$T$ I\$ $\$ R E S T R A I N T$ PIPE STRFSS, MAXIMUM MOMENT CALC AI

325

405

400

R 344

R 80

R394

R404

R359

R399

R285

R 398

R371

R338

R274

R 295

R284

R272

R331

R286

R294

R348

R396

R329

R283

R282

R343

R373

R327

242

209

269

297

265

203

148

219

226

349

206

222

247

233

205

228

216

231

224

232

218

195

220

225

260

221

223

227

229

369

251

250

217

207 
7090 F+FAP RS L T BS QUICKIE, INFINITE MEOIUM SPECTRUM X-SECTIONS 7090 F+FAP RS L T C\$ FAIM, I-D MULTI-GP DIFFUSION SLAB CYL SPHERE 7090 F+FAP RS L T CS ULCER, 1-D MULTI-GP DIFFUSION SLAB CYL SPHERE 7090 F+FAP RS $P$ T B\$ RAFFLE, 1ST FLIGHT COLLISION PROBARILITIES MC 7090 F+FAP RS $P$ T B $\$$ SOPHIST1/2/5, MULTI-GP TRANSFER CDEFFICIENTS 7090 F+FAP RS $P$ T C\$ EXTERMINATOR, 2-D MULTI-GP DIFFUSION PROGRAM 7090 F+FAP RS P T DS ASSAULT, 2-D MULTI-GP DIFFUSION DEPLETION CODE 7090 F+FAP RS P T M\$ DFSR, DATA FILE SFRVICE ROUTINES ENDF TAPES 7090 F+FAP RS PL T B\$ GAMTEC2, MULTI-GP CONSTANT CALC O TO 10 MEV

A I

A I

A I

ORNL

LRL

ORNL

OR NL

BNL

BNW

AI

A I

7090 F+FAP RS PL

7090 F+FAP RSB

7090 F+FAP RSB

7090 F+FAP RSBP

7090 F+FAP RSBPL

$7090 F+M A P$ RS $P$

7090 FLOCO RS P

7090 FLOCO RS P

7090 FLOCO RSBP

7090 FLOCO RSBP

7090 F2 RS

7090 F2 RS

$7090 \mathrm{~F} 2$ RS

$7090 \mathrm{~F} 2$ RS

$7090 \mathrm{~F} 2$ RS

7090 F2 RS

$7090 \mathrm{~F} 2$ RS

$7090 \mathrm{~F} 2$ RS

$7090 \mathrm{~F} 2$

$7090 \mathrm{~F} 2$

$7090 \mathrm{~F} 2$

$7090 \mathrm{~F} 2$

$7090 \mathrm{~F} 2$

$7090 \mathrm{~F} 2$

$7090 \mathrm{~F} 2$

$7090 \mathrm{~F} 2$

$7090 \mathrm{~F} 2$

$7090 \mathrm{~F} 2$

$7090 \mathrm{~F} 2$

$7090 \mathrm{~F} 2$

$7090 \mathrm{~F} 2$

7090 F2

$7090 \mathrm{~F} 2$

$7090 \mathrm{~F} 2$

$7090 \mathrm{~F} 2$

$7090 \mathrm{~F} 2$

$7090 \mathrm{~F} 2$

7090 F2

7090 F2

$7090 \mathrm{~F} 2$

$7090 \mathrm{~F} 2$

7090 F2

$7090 \mathrm{~F} 2$

$7090 \mathrm{~F} 2$

$7090 \mathrm{~F} 2$

$7090 \mathrm{~F} 2$

$7090 \mathrm{F2}$

$7090 \mathrm{~F} 2$

$7090 \mathrm{~F} 2$

$7090 \mathrm{~F} 2$

$7090 \mathrm{~F} 2$

$7090 \mathrm{~F} 2$

$7090 \mathrm{~F} 2$

$7090 \mathrm{~F} 2$

$T$ B \$ TEMPEST2, THERMAL NEUTRON SPECTRUM X-SECTIONS

T C\$ AIMG, 1-D MULTI-GP DIFFUSION SLAB CYL SPHERE

$T$ A $\$$ TUZ, UNRESOLVED REGION RESONANCE INTEGRAL CALC
$T$ A\$ ZUT, RESOLVED REGION RESONANCE INTEGRAL CALC

$T$ D\$ DDB, 2-D FEW-GP DIFFUSION RURNUP RZ GEOMETRY

$T$ C\$ CRAM, 1-D AND 2-D MULTI-GP DIFFUS ION PRIGRAM

$T$ C\$ TDSN, 2-D MULTIGROUP DISCRETE ORDINATE PROGRAM

B\$ MCS, MONTE CARLO NEUTRON PENETRATION STUDY

B\$ ZOT, GROUP-COLLAPSING OF MULTI-GP X-SECTIONS

C\$ $2 D X Y, 2-D$ MULTI-GP SN APPROXIMATION XY GEOM

$T$ C\$ GE-HAPO-S13, 1-D MULTI-GP DOUBLE SN APPROX

A\$ LYNNE, WOODS-SAXON POTENTIAL SHAPE CALCULATION

B\$ DANCOFF JR, MODERATOR SPACE CHORD DIST FUNCT

B\$ S4 CYL CELL CODE, 1-D 1-GP S4 APPROXIMATION

C\$ PERT, 1-D PERTURBATION FOR AIM AND FIG CODES

E \$ AIREK3, SPACE-INDEPENDENT KINETICS W/FEEDBACK

E\$ SNAPKIN5/5A, 1-REGION KINETICS SNAP GEOMETRY

I \$ CROCK, SPACE POWER PLANT DESIGN OPTIMIZATION

I\$ FUGUE, STEADY-STATE TEMPERATURE VIID FRACTION

I \$ SHOCK, SPACE POWER PLANT DESIGN OPTIMIZATION

J\$ FARSEIA, DOSE RATE FROM SNAP SHIELD LEAKAGE

J\$ MORTIMER, DOSE RATE CAL CULATION SNAP GEOMETRY

J\$ SCARF2, SCATTER FROM RADIATOR FINS SNAP GEOM

J\$ SCARI, SCATTER FROM A RING SNAP GEOMETRY

N\$ WED, W-DSN OUTPUT TAPE EDIT REACTION RATES

$T$ AS SUMMIT, CRYSTALLINE SCATTERING KERNEL CALC
$T$ DS SIZZLE, 1-D MULTIGROUP DIFFUSION DEPLETION

RS

RS

$L T$ DS

RS $P$

RS $P$

RS $P$

RS $P$

RS $P$

RS $P$

RS $P$

RS $p$

RS $p$

RS $P$

RS $P$

RS $P$

RS $P$

RS $P$

RS P

RS $P$

RS $P$

RS $P$

RS $P$

RS $p$

RS $P$

Bs

BS BAM, S4 CYL CELL CODE AND TEMPEST COMBINATION

B\$ SAIL, 1-D 1-GP SN APPROXIMATION SLAB GEOMETRY

C\$ MIST, 1-D FEW-GP SN DOUBLE SN APPROX SLAR GEOM

D\$ AIMFIRE, URANIUM FUEL CYCLE COST ANALYSIS

DS ISOCRUNCH, REACTION DECAY CHAIN ANALYSIS

F\$ CONEC, COUPLED NEUTRONICS-HYDRODYNAMICS SPHERE

G\$ CLOUD, GAMMA-RAY DOSE RATE FROM A CLOUD

I \$ WIREX, COMPUTER-PRODUCED WIRING LISTS UHTREX

J\$ GRACE1, GAMMA-RAY ATTENUATION SLAB GEOMETRY

J\$ GRACE2, GAMMA-RAY ATTENUATION CYL SPHERE GEOM

J\$ RATRAP, DOSE RATE CALCULATION SNAP GEOMETRY

OS CROC 90, ML-1 FLUID FLOW EXPERIMENT ANALYSIS

P\$ FRANTIC, LEAST SQUARES FIT SUM DF EXPONENTIALS

$T$ B\$ AGN-SIGMA. CALC DF MULTI-GP TRANSFER MATRICES

T C\$ EQUIPOISE3, 2-D 2-GROUP DIFFUSION SLAB CYL

GGA

GGA

GGA

UK $-R$

LER

LASL 202

LASL 113

AGC $\quad 18$

BNW $\quad 75$

DRNL

AEG 150

AI $\quad 53$

AI 30

A I

A I

A I

A I

A I

A I

AI

A I

AI

UK $-H$

GGA

A I

AI

AGC $\quad 237$

AI

PPCO

A I

ORNL

121

122

112

48

114

91

142

110

111

133

56

58

52

59

55

LRL

129

$\begin{array}{ll}A I & 47\end{array}$

LASL $\quad 315$

AI $\quad 45$

AI $\quad 46$

AI $\quad 141$

AGC $\quad 154$

MIT 324

AGC $\quad 243$

ORNL $\quad 39$

ORNL $\quad 87$

C\$ EQUIPOISE3A, 2-D 2-GP DIFFUSION CYLINDER SLAB

T C\$ FOG, 1-D FEH-GP DIFFUSION SLAB CYLINDER SPHERE AI

T C\$ TOPIC, L-D FEW-GP SN APPROXIMATION CYLINDER

PPCO

28

148

132

RS P T C\$ 2OGRAND, 2-D FEW-GROUP DIFFUSION SLAB CYLINDER

RS $P$ T L DPC, DATA PREPARATION FDR 2-D DESIGN PROGRAMS

RS PL T A ARES2, RESONANCE INTEGRAL X-SECTION CALC

RS PL T B\$ FORM, FAST NEUTRON SPECTRUM X-SECTION CALC

RS PLXT B\$ GAMI, FAST NEUTRON SPECTRUM X-SECTION CALC

RS PLXT B\$ HAMMER, CRITICAL EXPERIMENT ANALYSIS SYSTEM

RS PLXT C\$ DTF2, 1-D MULTI-GP DISCRETE ORDINATE CALC

BN

NL-DP

AI

ORNL

LASL

A I

AI

32

40

234

89

51

33

277

151 


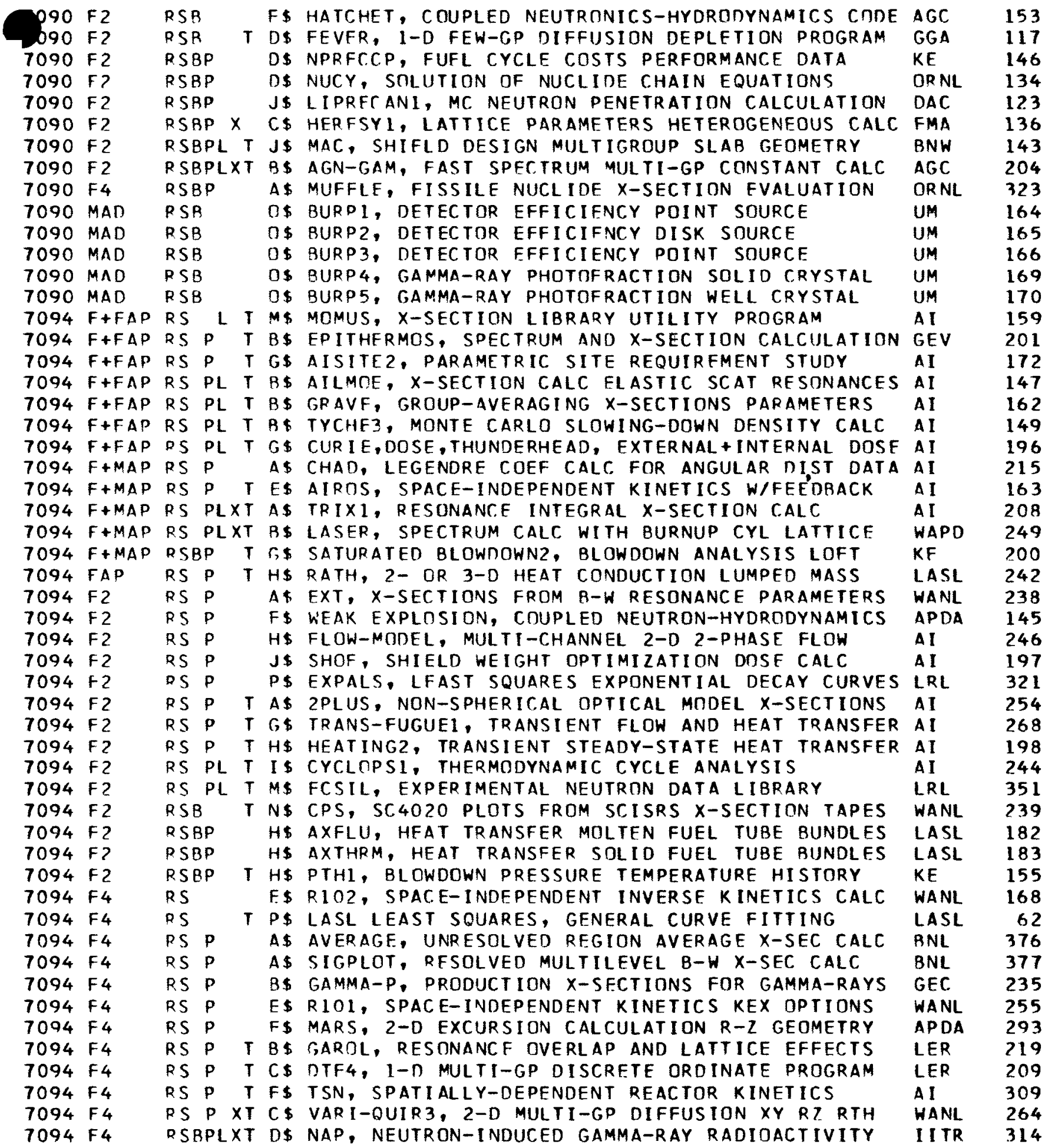


812

P 


\section{REFERENCES}

1. Radkowsky, A., and R. Brodsky, A Bibliography of Available Digital Computer Codes for Nuclear Reactor Problems, AECU-3078 (Oct 1955).

2. Nuclear Codes Group Newsletters, No. 1 (Sept. 25, 1956); No. 2 (Dec. 1, 1956); No. 3 (March 1, 1957); No. 4 (June 1, 1957); No. 5 (Sept. 1, 1957); No. 6 (Dec. 1, 1957); No. 7 (June 1, 1958); No. 8 (Dec. 8, 1958); No. 9 (Sept. 1, 1959); No. 10 (Dec. 1, 1959); AEC Computing and Applied Mathematics Center, Institute of Mathematical Sciences, New York University, New York, N. Y.

3. Nather, V., and W. Sangren, Reactor Code Abstracts, Commun. Assoc. Computing Mach. 2(1) (Jan 1959).

4. Nather, V., and W. Sangren, Reactor Code Abstracts, Commun. Assoc. Computing Mach. 3(1) (Jan 1960).

5. Argonne Code Center, Reactor Code Abstracts, Distribution 1-12 (1961April 24, 1967).

6. American Nuclear Society Standard ANS-STD.2-1967, A Code of Good Practices for the Documentation of Digital Computer Programs.

7. European Atomic Energy Community, EURATOM-Thesaurus, EUR 500.e (Second Edition) (1966). 